
Universidade de São Paulo - Faculdade de Arquitetura e Urbanismo

Programa de Pós-Graduação

ISIS SALVIANO ROVERSO SOARES

Análise do desempenho aplicada à preservação predial: O caso do Edifício Vila Penteado

Dissertação de Mestrado 

ISIS SALVIANO ROVERSO SOARES

\title{
Análise do desempenho aplicada à preservação predial: O caso do Edifício Vila Penteado
}

\author{
Dissertação de Mestrado
}

\begin{abstract}
Dissertação apresentada ao Programa de Pós Graduação em Arquitetura e Urbanismo da Faculdade de Arquitetura e Urbanismo da Universidade de São Paulo, para obtenção do título de Mestre em Arquitetura e Urbanismo.

Área de Concentração: Tecnologia da Arquitetura Orientadora: Prof ${ }^{\underline{a}}$ Dr $^{\text {a }}$ Claudia Terezinha de Andrade Oliveira
\end{abstract}


AUTORIZO A REPRODUÇÃO E DIVULGAÇÃO TOTAL OU PARCIAL DESTE TRABALHO, POR QUALQUER MEIO CONVENCIONAL OU ELETRÔNICO, PARA FINS DE ESTUDO E PESQUISA, DESDE QUE CITADA A FONTE.

E-MAIL AUTORA: isis@isisroverso.arq.br

E-MAIL ORIENTADORA: ctao@usp.br

Soares, Isis Salviano Roverso

S676a Análise do desempenho aplicada à preservação predial: o caso do Edifício Vila Penteado / Isis Salviano Roverso Soares - São Paulo, 2012. 389 p. : il.

Dissertação (Mestrado - Área de Concentração: Tecnologia da Arquitetura) - FAUUSP.

Orientadora: Claudia Terezinha de Andrade Oliveira

1.Patrimônio arquitetônico 2. Preservação 3.Conservação 4.Restauração 5.Manutenção 6.Análise de desempenho 7.Vila Penteado I.Título

CDU 72.025.3 


\title{
FOLHA DE APROVAÇÃO
}

\author{
Isis Salviano Roverso Soares
}

Análise do desempenho aplicada à preservação predial:

O caso do Edifício Vila Penteado

\begin{abstract}
Dissertação apresentada ao Programa de Pós Graduação em Arquitetura e Urbanismo da Faculdade de Arquitetura e Urbanismo da Universidade de São Paulo, para obtenção do título de Mestre em Arquitetura e Urbanismo.

Área de Concentração: Tecnologia da Arquitetura Linha de Pesquisa: Tecnologia da Construção Orientadora: Prof ${ }^{a}$ Dr $^{\text {a }}$ Claudia Terezinha de Andrade Oliveira
\end{abstract}

Aprovado em:

Banca Examinadora:

$\operatorname{Prof} .\left(^{\mathrm{a}}\right) \operatorname{Dr} .\left(^{\mathrm{a}}\right)$

Instituição:

Assinatura:

Prof. $\left({ }^{\mathrm{a}}\right) \operatorname{Dr} .\left(^{\mathrm{a}}\right)$

Instituição:

Assinatura:

Prof. $\left({ }^{a}\right)$ Dr. $\left({ }^{a}\right)$

Instituição:

Assinatura: 

Aos meus queridos pais e irmã que sempre me incentivaram e apoiaram.

E ao meu amado esposo, que está ao meu lado em todos os momentos. 



\section{AGRADECIMENTOS}

Algumas pessoas cruzaram meu caminho nesse processo do mestrado e deixaram marcas. Marcas de aprendizado que fizeram com que esse trabalho fosse ainda mais gratificante.

Agradeço a minha orientadora, Profa - Claudia Terezinha de Andrade Oliveira, que desde as primeiras aulas na disciplina "Análise do Desempenho Técnico-Construtivo e da Qualidade de Edifícios" demonstrou grande capacidade técnica, aprofundamento didático e intenso apoio. Claudia, você é uma dessas raras pessoas que provocam a admiração dos que a cercam. Sua objetividade e clareza me auxiliaram tremendamente em todo o processo.

Preciso agradecer às valiosas contribuições das professoras da banca de qualificação, Prof ${ }^{a}$ Beatriz Mugayar Kühl e Prof ${ }^{\underline{a}}$ Helena Ayoub Silva, que, com muita sabedoria e conhecimento técnico, trouxeram informações e incentivo para o fechamento da dissertação.

Agradeço também aos professores que dedicaram seu tempo em conversas dentro e fora das salas de aula: Prof $\stackrel{-}{-}$ Maria Lucia Bressan Pinheiro, Prof. João Roberto Leme Simões, Prof ${ }^{a}$ Érica Yukiko Yoshioka, Prof. Julio Roberto Katinsky, Prof. Luiz Américo de Souza Munari, Prof. Artur Simões Rozenstraten, Prof. Silvio Soares Macedo, Prof ${ }^{a}$ Monica Junqueira de Camargo, Prof. Reginaldo Luiz Nunes Ronconi, Prof. Carlos Egidio Alonso e Prof $^{a}$ Sheila Walbe Ornstein. Vocês contribuíram com suas experiências ao longo de todo o curso, orientando, apoiando e até mesmo discordando. Suas falas estão registradas como preciosos ensinos.

Agradeço aos funcionários das bibliotecas da Graduação e da Pós Graduação da FAUUSP e, especialmente, a Arq $^{\text {a }}$ Eunice Bruno do Grupo Executivo de Gestão dos Espaços Físicos (GEEF). Agradeço ainda a todos os amigos e colegas, companheiros de pós-graduação. Amigos de sala de aula e de cafés, obrigada por suas conversas enriquecedoras.

À minha querida tia Rute Salviano Almeida e minha amada mãe Raquel Pereira Salviano Roverso, pelo incentivo constante e revisão do trabalho. Agradeço ao meu pai José Carlos Roverso, por me fazer acreditar desde cedo que posso seguir em frente e à minha irmã Carla Salviano Roverso, pelo companheirismo e amizade inigualável. Agradeço ao meu amado esposo Arthur Vilas Boas Soares, pelo apoio incondicional e suporte a todo instante, e a minha nova família Soares, por tudo o que são e representam em minha vida.

Por fim, e ainda mais importante, agradeço a Deus por permitir tudo isso. Agradeço pela vida. 

"Para bem restaurar, é necessário amar e entender o monumento, seja estátua, quadro ou edifício, sobre o qual se trabalha... Ora, que séculos souberam amar e entender as belezas do passado? E nós, hoje, em que medida sabemos amá-las e entendê-las?" (BOITO, 1884). 



\section{RESUMO}

O objetivo desse trabalho é propor diretrizes, que fundamentem a operacionalização da manutenção predial, destinadas ao patrimônio arquitetônico, com base na abordagem de desempenho. Visando contribuir com reflexões acerca da preservação de bens históricos, adota-se como objeto o edifício Vila Penteado, construído em 1903, e que permanece hoje como um dos raros exemplos paulistas do art nouveau.

A pesquisa parte do aprofundamento do estudo da análise de desempenho técnicoconstrutivo das edificações, ponderada pelos princípios do campo disciplinar do restauro existentes hoje no Brasil. Os aspectos projetuais e construtivos originais, bem como as intervenções mais significativas realizadas e projetadas para a Vila Penteado, ao longo da sua história, foram analisados. O estado atual de conservação do edifício foi caracterizado com base na análise integrada dos sistemas da edificação: terrapleno, fundação, estrutura, cobertura, vedos, vãos, paramentos, pavimentos, instalações eletromecânicas e hidrossanitárias.

A manutenção predial, já conhecida e bem conceituada, tanto no campo da análise de desempenho de edificações, quanto no campo do restauro, é destacada como elemento central e afirmada como um conjunto de ações programadas para a salvaguarda do patrimônio arquitetônico, permitindo a continuidade das condições satisfatórias relacionadas à segurança, habitabilidade e funcionalidade.

São identificados os principais desafios e dificuldades para a implementação de um programa de manutenção contínua: falta da cultura da manutenção programada e do seu projeto específico; distanciamento das ações de intervenção prática em relação aos estudos pormenorizados do edifício; escassez de recursos financeiros para contratação de serviços; falta de valorização do orçamento necessário à manutenção predial, por parte da administração pública e indisponibilidade de mão-de-obra qualificada no mercado brasileiro.

São propostas diretrizes para operacionalização da manutenção rotineira, aplicáveis a edifícios com restrições ao uso e ocupação, levando em consideração o nível de desempenho esperado para os sistemas da edificação, a alocação de recursos, a necessidade de registros e documentação das obras e continuidade das ações implementadas.

Palavras chave: Patrimônio Arquitetônico; Preservação; Conservação; Restauração; Manutenção; Análise de Desempenho; Vila Penteado. 



\section{ABSTRACT}

The main objective of this study is to propose guidelines to support the maintenance operationalization for buildings of architectural heritage based on the performance approach. To contribute to discussions about the preservation of historical assets, the Vila Penteado building will be used as the case study, built in 1903, it remains until today as one of rare example of art nouveau in São Paulo.

The research starts on the deep study of the analyze of performance technicalconstructive of buildings, weighted by the disciplinary principles of restoration field existing today in Brazil. The projective aspects and original constructive, as well as the most significant interventions performed and projected for Vila Penteado along its history were analyzed. The current conservation state of the building was characterized based on the integrated analyze of the edification systems: embankment, foundation, structure, coverage, walls, vain, facings, floors and electromechanical and hydro-sanitary installations.

The building maintenance, already known and well conceptualized both in the field of performance analyzes of buildings as in the field of restoration, it is highlighted as the central element and confirmed as a set of actions planned for the architectural heritage protection, allowing the continuity of the satisfactory conditions regarding to the security, ability and functionality.

Are identified the key challenges and difficulties to implement a continued maintenance program: lack of culture of scheduled maintenance and of its specific project, detachment of practical intervention actions regarding to the detailed studies of the building, lack of financial resources to hire services, lack of the correct budget required for the building maintenance by the public administration and the lack of qualified labor in the Brazilian market.

Are proposed the guidelines for the operationalization of the maintenance routine applicable for buildings with use and occupancy restrictions, taking into account the level of expected performance for the building systems, the resources allocation, the necessities of records and

Keywords:; Architectural Heritage; Preservation; Conservation; Restoration; Maintenance; Performance Analysis; Vila Penteado. 



\section{LISTA DE IMAGENS}

Figura 1 - Sabiá no chafariz da Vila Penteado 35

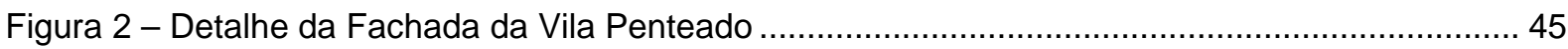

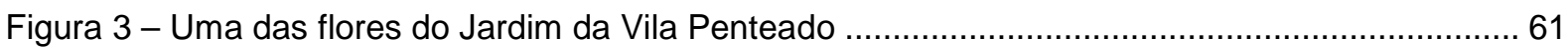

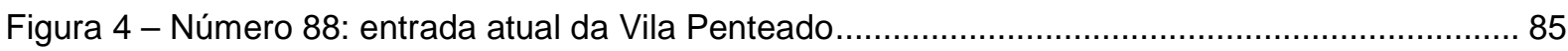

Figura 5 - Trecho do desenho da Fachada Posterior, com destaque para a volumetria do chafariz .. 88

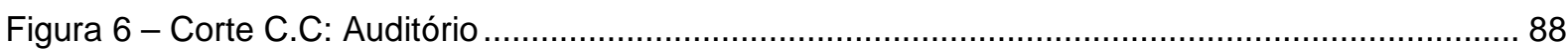

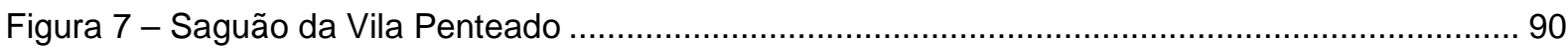

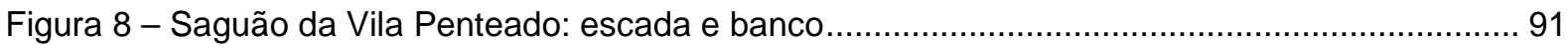

Figura 9 - Vila Penteado, Perspectiva. Aquarela. Arquiteto Carlos Ekman ......................................... 93

Figura 10 - Antônio Álvares Penteado rodeado por sua família ....................................................... 94

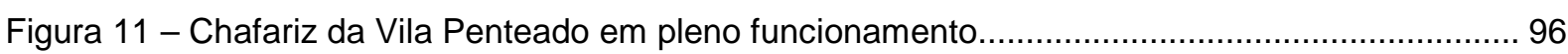

Figura 12 - Fotos externas do Teatro Real Dramático de Estocolmo, projeto do arquiteto sueco Fredrik Lilljekvist, contemporâneo ao arquiteto Carlos Ekman ......................................... 99

Figura 13 - Foto noturna da entrada e foto interna do Teatro Real Dramático de Estocolmo: uma das primeiras obras ao estilo Art Nouveau.......................................................... 99

Figura 14 - Residência de Carlos Ekman, na Rua Veridiana, 398................................................ 100

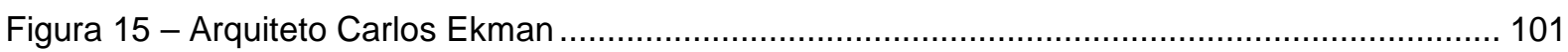

Figura 16 - Vista externa do Teatro São José, no Viaduto do Chá................................................ 101

Figura 17 - Vistas internas do Teatro São José, no Viaduto do Chá ................................................ 102

Figura 18 - 'Vila Antonieta', residência na Avenida Higienópolis. Projeto e construção de

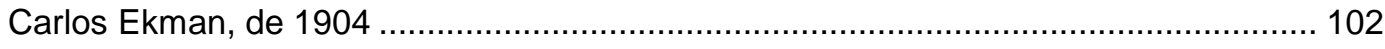

Figura 19 - À esquerda: o lote colonial. À direita: o palacete isolado no lote .................................... 108

Figura 20 - Abertura do Bairro de Higienópolis, em 1898, sob a denominação de Boulevards

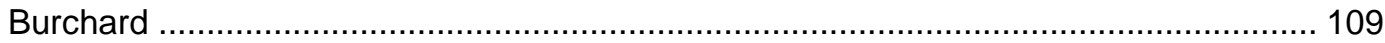

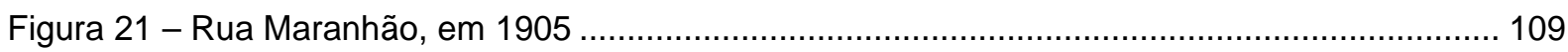

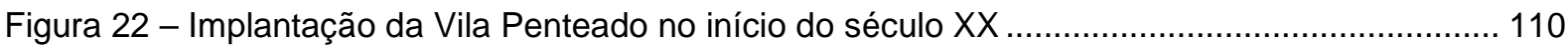

Figura 23 - Foto da Vila Penteado no início do século XX. Disposição original dos edifícios e

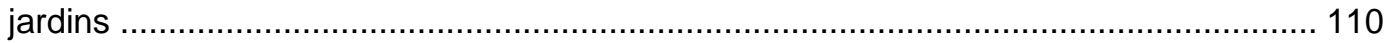

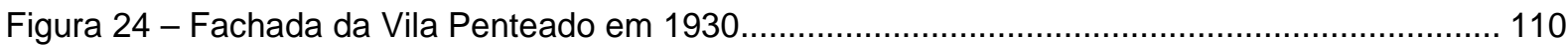

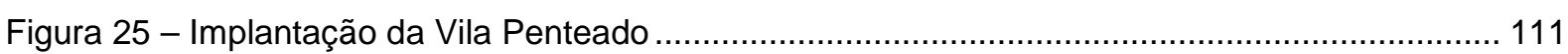

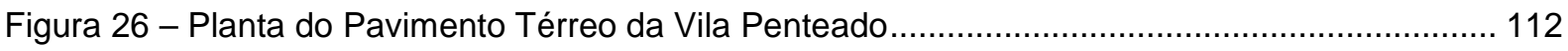

Figura 27 - Planta do Pavimento Térreo da Vila Penteado, de autoria de Carlos Ekman, de 1902, localizada no Arquivo Histórico Municipal "Washington Luís" ....................................... 113

Figura 28 - Planta do Pavimento Superior da Vila Penteado, de autoria de Carlos Ekman, de 1902, localizada no Arquivo Histórico Municipal "Washington Luís"......................... 114

Figura 29 - Modificação espacial documentada: ampliação do $2^{\circ}$ pavimento em 1906 .................... 115

Figura 30 - Vila Penteado fotografada nos primeiros anos do século XIX (imagem anterior à ampliação de 1906) e fachada lateral antes e depois da ampliação ... 
Figura 31 - Vista lateral do palacete antes da reforma de ampliação do segundo pavimento

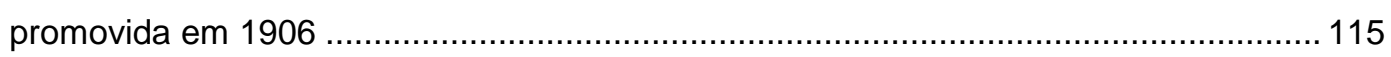

Figura 32 - Foto e Mapa: implantação da Vila Penteado com Barracões Anexos.............................. 118

Figura 33 - Fotos da Vila Penteado com Barracões Anexos....................................................... 118

Figura 34 - Fotos da Vila Penteado com Barracões Anexos......................................................... 119

Figura 35 - Fotos dos ambientes internos da Vila Penteado no período da graduação ..................... 121

Figura 36 - Fotos dos ambientes internos da Vila Penteado no período da graduação ..................... 121

Figura 37 - Foto das antigas salas Luis XV e Maria Antonieta, no período da graduação foram usadas como salas de aula e, hoje, como auditório .................................................. 122

Figura 38 - Fotos dos antigos dormitórios, usados como sala de contabilidade e sala de aula no período da graduação e, hoje, como secretaria ......................................................... 122

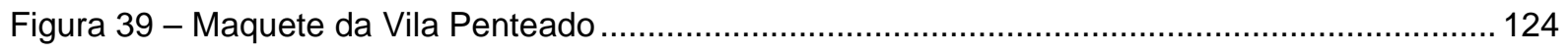

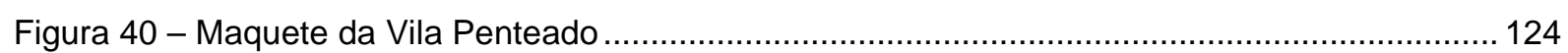

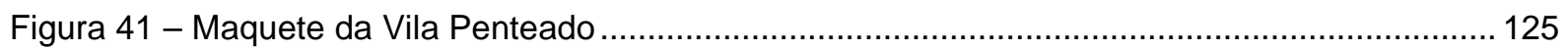

Figura 42 - Mapa de Forros x Planta Atual = Esclarecimentos sobre a planta construída em 1903.128

Figura 43 - Quadro original de luz e força guardado no porão da Vila Penteado .............................. 129

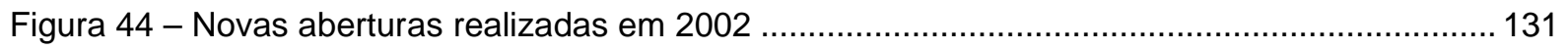

Figura 45 - Alinhamento das novas aberturas realizadas em 2002 ................................................ 132

Figura 46 - Foto aérea do entorno do lote do edifício Vila Penteado ............................................... 135

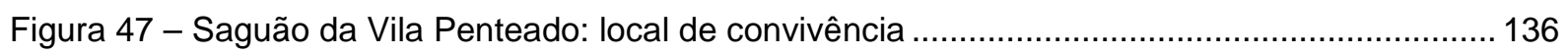

Figura 48 - Planta da Vila Penteado com indicação dos principais eixos estruturais ........................ 137

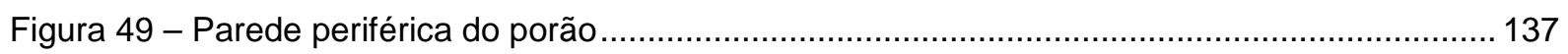

Figura 50 - Corte Transversal parcial da Vila Penteado, com destaque para e espessura das

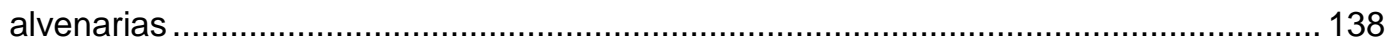

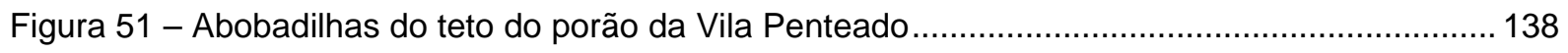

Figura 52 - Abobadilhas do teto do porão, estruturando o piso do saguão principal, localizado no pavimento térreo

Figura 53 - Corte Transversal parcial da Vila Penteado, com destaque para o emprego de arcos e abobadilhas estruturais

Figura 54 - Saguão da Vila Penteado: destaque para o conjunto de arcos que acompanham o perímetro da área.

Figura 55 - Área interna e externa do corredor lateral: destaque para os arcos que auxiliam a estrutura e complementam a ornamentação art nouveau ............................................. 140

Figura 56 - Detalhe do mosaico: montagem artesanal de tesselas irregulares ................................. 141

Figura 57 - Corrimão metálico da escadaria interna lateral da Vila Penteado ................................... 141

Figura 58 - Desenho do corrimão metálico da escadaria interna lateral da Vila Penteado ............... 142

Figura 59 - Detalhe do ornamento interno do Saguão da Vila Penteado........................................... 142

Figura 60 - Banco sob a escada do Saguão: destaque para o detalhe em forma de ramo de café

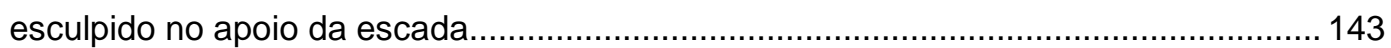

Figura 61 - Guarda-corpo em madeira da escada próxima a biblioteca ......................................... 144 
Figura 62 - Cadeiras antes do restauro. 146

Figura 63 - Cadeiras após o restauro feito pela empresa Reformaflex ......................................... 146

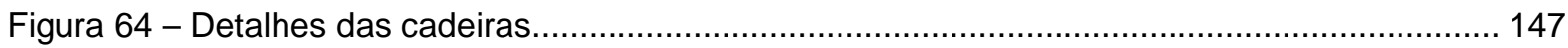

Figura 65 - Foto da Vila Penteado com destaque para os planos da cobertura............................... 152

Figura 66 - Vista geral da estrutura da Cobertura da Vila Penteado, Ala Lateral............................. 152

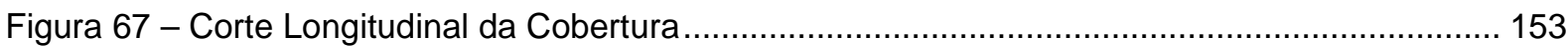

Figura 68 - Planta esquemática da Cobertura - Restauro das Lâminas de Cobre .......................... 157

Figura 69 - Foto da Cobertura em Obras- Restauro das Lâminas de Cobre .................................... 157

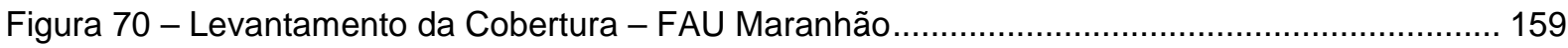

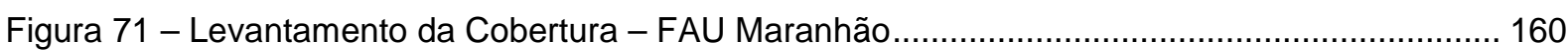

Figura 72 - Escoramento do forro do mezanino da Vila Penteado ................................................ 165

Figura 73 - Abertura do piso para intervenção no forro do Pavimento Térreo …................................ 166

Figura 74 - Fasquias de juçara com a primeira camada de resina acrílica ....................................... 166

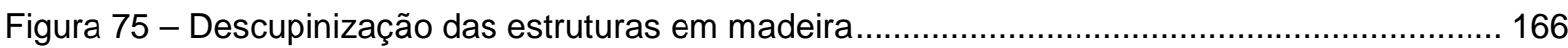

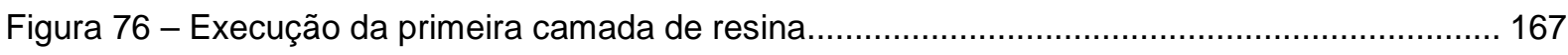

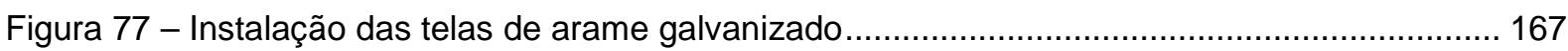

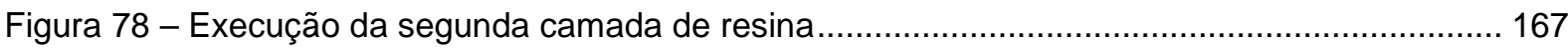

Figura 79 - Equipe de estagiários do Canteiro de Restauro do CPC-USP durante a restauração das pinturas murais do saguão principal em 1993

Figura 80 - Simulação computadorizada com base em dados de prospecção de superfície arquitetônica

Figura 81 - Cômodos antes do restauro

Figura 82 - Mapa de Forros x Planta atual = esclarecimentos sobre a planta construída em 1903.. 172

Figura 83 - Modificação espacial documentada: ampliação do $2^{\circ}$ pavimento em 1906. 172

Figura 84 - Mapeamento dos pontos de sondagem e decapagem realizadas para identificação de pinturas artísticas nas paredes para planejamento de futuros restauros

Figura 85 - Exemplo de camadas ornamentadas nas paredes da Saleta Superior I, correspondentes ao segundo e terceiro ciclo ornamental da casa.... 173

Figura 86 - Modelo de pintura mural identificada com decapagem . 174

Figura 87 - As lacunas de cor dos murais foram reintegradas por meio do método da seleção cromática (trattegio) 174

Figura 88 - Estado de conservação do barramento representando plantas de café..... 175

Figura 89 - Após consolidação das partes integras, as áreas de lacuna foram niveladas e preparadas para a reintegração cromática

Figura 90 - Vista geral do Saguão antes das intervenções de restauro ......................................... 176

Figura 91 - Saguão da Vila Penteado antes e depois do restauro .............................................. 176

Figura 92 - A parede da porta de acesso à sala de vistas após a conclusão do restauro ................. 176

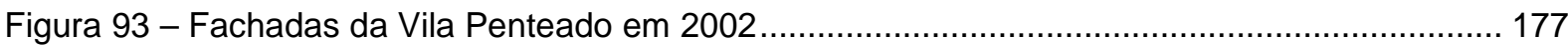

Figura 94 - Estudos de prospecção orientados pela CPC .............................................................. 178

Figura 95 - Teste de cor nas Fachadas da Vila Penteado ......................................................... 178 


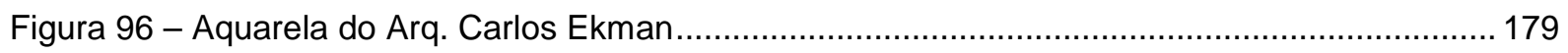

Figura 97 - Desenhos dos ornatos das fachadas da Vila Penteado .............................................. 180

Figura 98 - Desenhos dos ornatos das fachadas da Vila Penteado .............................................. 181

Figura 99 - Desenhos dos ornatos das fachadas da Vila Penteado ................................................ 182

Figura 100 - Exemplo de Ficha de Inventário: Metais (ficha de registro dos elementos

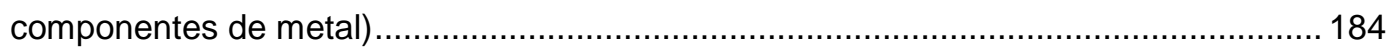

Figura 101 - Serralheria (metal) e madeira. Detalhe do sistema de encaixe do gradil que compõe uma das portas de entrada do palacete... 184

Figura 102 - Metal. Foto e desenho do sistema de montagem de ferragem de janela da ala

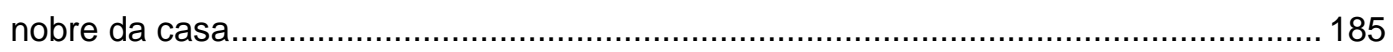

Figura 103 - Desenho técnico detalhado de uma das janelas da Vila Penteado................................. 185

Figura 104 - Foto de prospecção de pintura de folhas internas .......................................................... 185

Figura 105 - Foto de prospecção de pintura de folhas externas ....................................................... 186

Figura 106 - Foto do trabalho de recuperação das esquadrias externas............................................ 186

Figura 107 - Foto do trabalho de recuperação dos peitoris das esquadrias externas ....................... 187

Figura 108 - Instalação, emendas e conexões em situação de risco ............................................... 189

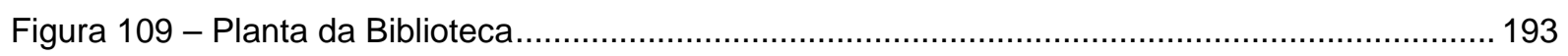

Figura 110 - Mesa de jantar retomou seu lugar na sala................................................................... 194

Figura 111 - As distâncias entre as prateleiras foram projetadas para livros de diversas

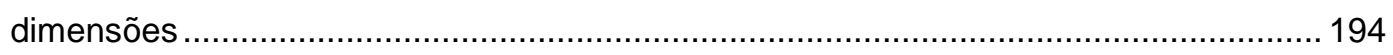

Figura 112 - Fixação das prateleiras nas paredes liberou o piso da carga dos livros ........................ 195

Figura 113 - Sala do acervo de teses, com mesa para consulta ....................................................... 195

Figura 114 - Local contemplativo e de reflexão: o espaço fechado do alpendre recebeu duas

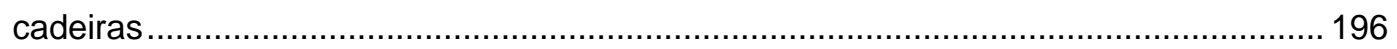

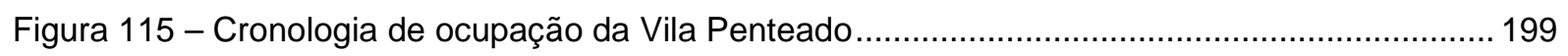

Figura 116 - Cronologia de ocupação do prédio FAU Maranhão RESIDENCIAL.............................. 199

Figura 117 - Cronologia de ocupação do prédio FAU Maranhão GRADUAÇÃO .............................. 200

Figura 118 - Cronologia de ocupação do prédio FAU Maranhão PÓS GRADUAÇÃO........................ 200

Figura 119 - Implantação do Edifício Vila Penteado .................................................................... 202

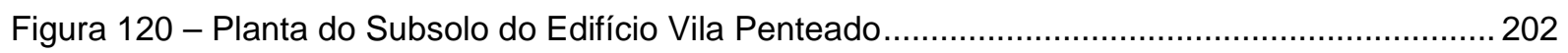

Figura 121 - Planta do Pavimento Térreo do Edifício Vila Penteado ................................................ 203

Figura 122 - Planta do Pavimento Superior do Edifício Vila Penteado ................................................203

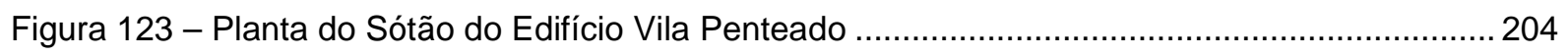

Figura 124 - Planta da Cobertura do Edifício Vila Penteado................................................................ 204

Figura 125 - Corte Transversal do Edifício Vila Penteado .................................................................. 205

Figura 126 - Corte Longitudinal do Edifício Vila Penteado ............................................................ 205

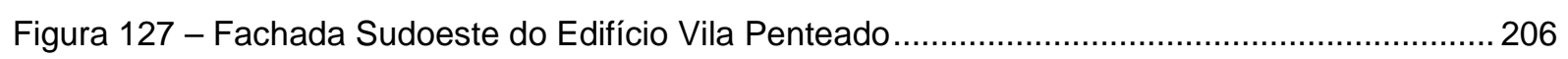

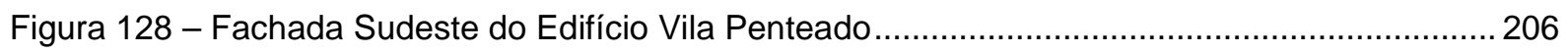

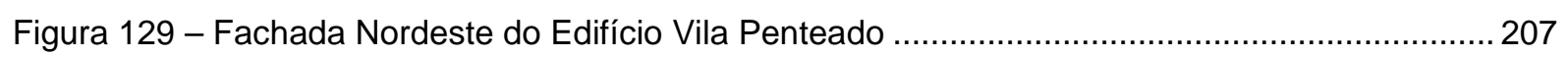

Figura 130 - Fachada Noroeste do Edifício Vila Penteado ........................................................... 207 
Figura 131 - Planta da Sala dos Espelhos - Sala de Conferências Prof. Anhaia Mello,

Edifício Vila Penteado.

Figura 132 - Corte AA da Sala dos Espelhos - Sala de Conferências Prof. Anhaia Mello,

Edifício Vila Penteado.

Figura 133 - Corte BB da Sala dos Espelhos - Sala de Conferências Prof. Anhaia Mello,

Edifício Vila Penteado.

Figura 134 - Corte CC da Sala dos Espelhos - Sala de Conferências Prof. Anhaia Mello,

Edifício Vila Penteado. 209

Figura 135 - Detalhe do Corte CC da Sala dos Espelhos - Sala de Conferências Prof. Anhaia Mello,

Edifício Vila Penteado. 209

Figura 136 - Corte DD da Sala dos Espelhos - Sala de Conferências Prof. Anhaia Mello,

Edifício Vila Penteado 210

Figura 137 - Levantamento Arquitetura - FAU Maranhão (CPG) 210

Figura 138 - Planta do Pav. Térreo (localização do sanitário masculino a reformar) ........................ 212

Figura 139 - Planta do Sanitário Masculino a reformar................................................................... 213

Figura 140 - Planta do Pav. Térreo (localização do sanitário a reformar) ......................................... 215

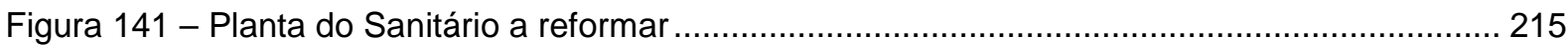

Figura 142 - Planta do Pav. Térreo (localização do sanitário acessível a reformar) ......................... 216

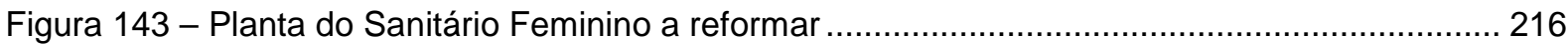

Figura 144 - Planta do Pav. Superior (localização do sanitário masculino a reformar) ..................... 217

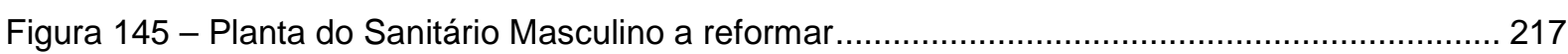

Figura 146 - Planta do Pav. Superior (localização do sanitário feminino a reformar)........................ 218

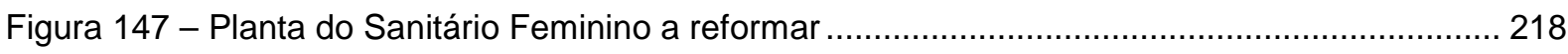

Figura 148 - Implantação com Estudo Preliminar do Projeto de Paisagismo..................................... 219

Figura 149 - Elevação Frontal da Vila Penteado, Estudo Preliminar do Projeto de Paisagismo....... 220

Figura 150 - Perspectiva, Estudo Preliminar do Projeto de Paisagismo.............................................. 220

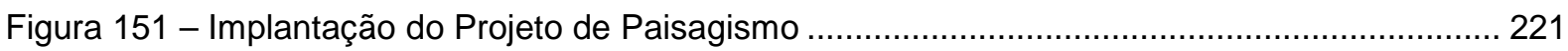

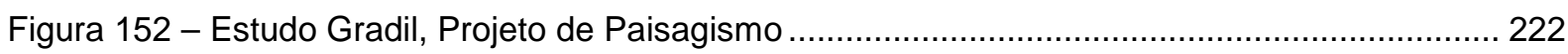

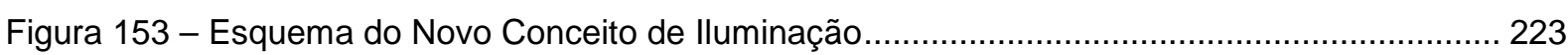

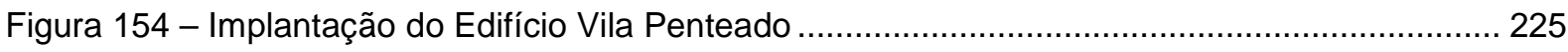

Figura 155 - Planta do Subsolo (Porão) do Edifício Vila Penteado ................................................. 226

Figura 156 - Planta do Pavimento Térreo do Edifício Vila Penteado .................................................. 227

Figura 157 - Planta do Pavimento Superior do Edifício Vila Penteado .............................................. 228

Figura 158 - Planta da Cobertura do Edifício Vila Penteado ........................................................... 229

Figura 159 - Trecho da Planta de Forro do Pavimento Térreo da Vila Penteado.............................. 231

Figura 160 - Fotos da decoração dos forros da Sala dos Espelhos da Vila Penteado....................... 231

Figura 161 - Trecho da Planta do Pavimento Térreo do Edifício Vila Penteado ................................. 231

Figura 162 - Trecho da Planta do Pavimento Térreo do Edifício Vila Penteado ............................... 232

Figura 163 - Trecho da Planta do Pavimento Térreo do Edifício Vila Penteado ................................ 232 
Figura 164 - Saguão de Acesso, Pavimento Superior (junto à escada principal): simulação dos arcos recuperados e decorados com guirlandas do século passado.............................235

Figura 165 - Planta da Cobertura do Edifício Vila Penteado ......................................................... 236

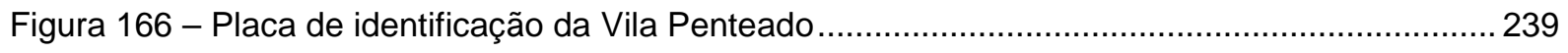

Figura 167 - Planta do Porão do Edifício Vila Penteado .................................................................... 242

Figura 168 - Planta do Pavimento Térreo do Edifício Vila Penteado ............................................... 243

Figura 169 - Planta do Pavimento Superior do Edifício Vila Penteado ............................................. 244

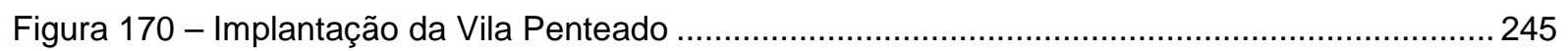

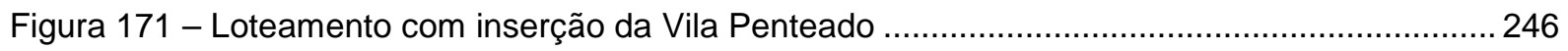

Figura 172 - Vila Penteado cercada por prédios altos em 1992 ...................................................... 246

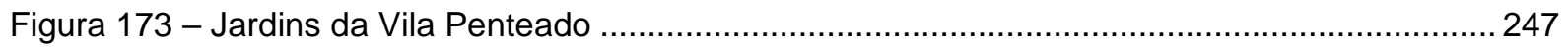

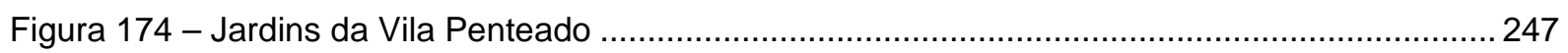

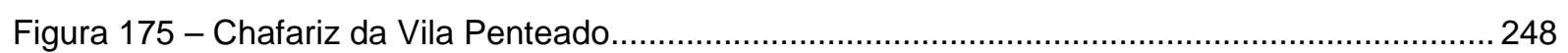

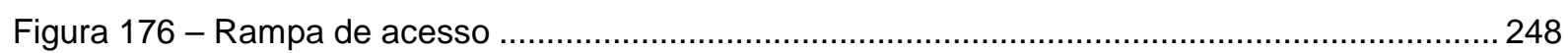

Figura 177 - À esquerda, foto do porão da década de 1970 e, à direita, foto atual da mesma área. 249

Figura 178 - Comparação da foto da década de 1970 com a situação atual: estrutura estável........ 249

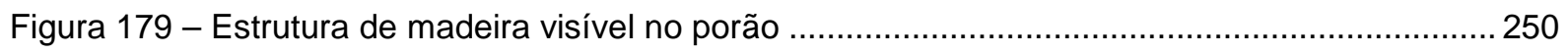

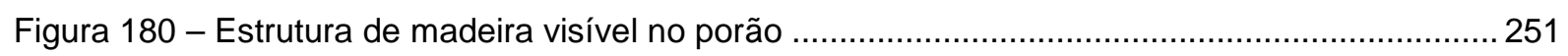

Figura 181 - Estrutura de madeira visível e abertura vedada no porão …………............................ 251

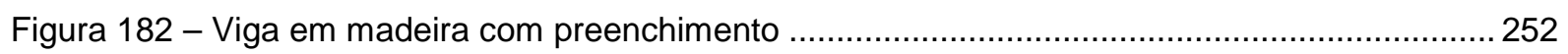

Figura 183 - Vigas de madeira cortadas para passagem dos eletrodutos da biblioteca .................... 252

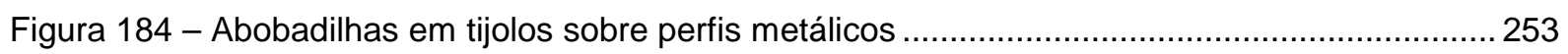

Figura 185 - Cobertura da Vila Penteado: telhamento em cobre e ardósia ...................................... 254

Figura 186 - Cobertura da Vila Penteado: sem beirais e com ornamentos metálicos .......................255

Figura 187 - Cobertura da Vila Penteado: águas em telhas de pedra ardósia ................................... 255

Figura 188 - Cobertura da Vila Penteado: água em chapas de cobre ............................................ 255

Figura 189 - Cobertura da Vila Penteado: água sobre mezanino em chapas de cobre (local com vazamento que provou o desmoronamento de parte do forro em estuque) .................. 256

Figura 190 - Cobertura da Vila Penteado: chapas de compensado, impermeabilizadas, fixas sobre

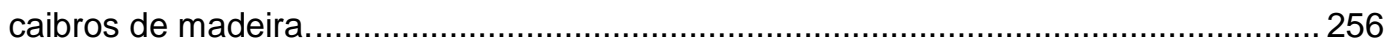

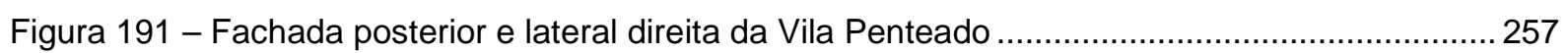

Figura 192 - Fachada posterior e lateral esquerda da Vila Penteado ............................................... 257

Figura 193 - Fachada lateral esquerda da Vila Penteado .......................................................... 258

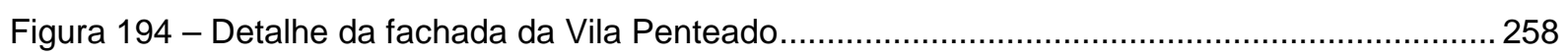

Figura 195 - Divisórias em alvenaria dividindo das áreas internas dos banheiros (S46 e

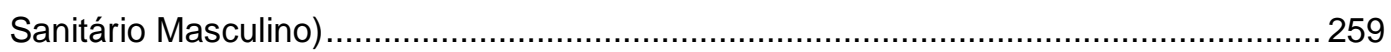

Figura 196 - Divisória leve da Sala 44 e da Secretaria (entre S71 e S73) .......................................... 259

Figura 197 - Janela da Sala 73 (Secretaria) e janela da Sala dos Espelhos: perda de material de fixação dos vidros provocado pelo ressecamento da massa ....................................2 261 
Figura 198 - Peitoril da Janela da Sala 44: falha da pintura e consequente degradação da madeira provocada por incidência solar contínua sem proteção

Figura 199 - Porta de Entrada (acesso à portaria): a área de suporte da dobradiça está comprometida, o que causa, inclusive, insegurança no caso de uma tentativa de arrombamento.

Figura 200 - Porta de acesso ao terraço da Sala 52: base da folha veneziana está se desprendendo.....

Figura 201 - Janela da Sala 77: moldura da folha veneziana danificada com aleta solta 263

Figura 202 - Janela da Sala 75 (Banheiro Feminino): faltam aletas e a parte superior da moldura da folha veneziana.

Figura 203 - Porta do terraço esquerdo da Secretaria, Sala 74: as peças de madeira da parte inferior da porta se soltaram

Figura 204 - Janela da Sala 71 (Diretoria): tanto a parte superior quanto a parte inferior da folha veneziana apresenta aletas faltando e ainda danos na moldura da folha

Figura 205 - Porta do banheiro feminino que, por falta de ajustes, permanecia constantemente semi aberta

Figura 206 - Porta improvisada do sanitário masculino, em segundo plano, com dimensões reduzidas que permitiam a visualização interna do sanitário a partir da portaria 265

Figura 207 - Nova porta do banheiro masculino, vista externa e interna 266

Figura 208 - Porta dupla instalada na área dos lavatórios 266

Figura 209 - Portão de entrada 267

Figura 210 - Muro de divisa com a calçada: gradil metálico ornamentado 267

Figura 211 - Grade da porta de acesso da fachada posterior e vista externa da porta de acesso lateral (corredor S16) 268

Figura 212 - Grade da porta de acesso lateral (corredor S16) e da janela do porão 268

Figura 213 - Vista interna e externa da grade da janela do porão 268

Figura 214 - Maçaneta da Vila Penteado 269

Figura 215 - Maçaneta e dobradiça da porta da Sala 12 e puxador da porta externa ...................... 269

Figura 216 - Tranqueta e maçanetas 270

Figura 217 - Maçaneta substituída da Saleta S70 270

Figura 218 - Guarda-corpo: base metálica ornamentada e pega em madeira com acabamento em pintura 271

Figura 219 - Trechos do guarda-corpo próximo à fachada frontal ................................................ 272

Figura 220 - Finalização do corrimão das escadas próximas à fachada posterior ............................. 272

Figura 221 - Trecho do guarda-corpo do mezanino. 272

Figura 222 - Pinturas murais do Saguão: à esquerda, "Glorificação da Indústria", pintura de Carlo De Servi e, à direita, "A indústria do século XVI ao XVIII, pintura de Oscar Pereira da Silva

Figura 223 - Pinturas murais do Saguão e detalhe em relevo 274

Figura 224 - Pinturas murais do Saguão 
Figura 225 - Paramento e detalhe do corredor S16.....

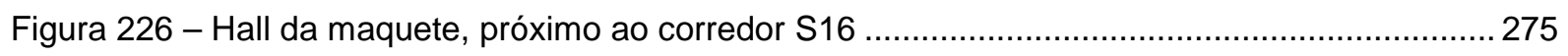

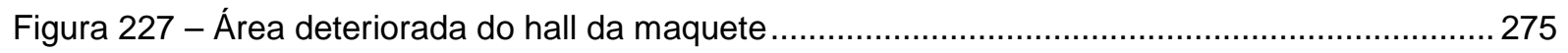

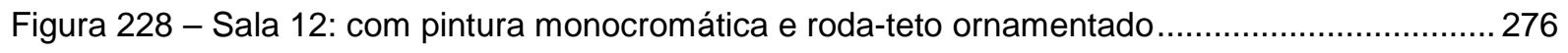

Figura 229 - Sala 12: com pintura monocromática em duas tonalidades ........................................ 276

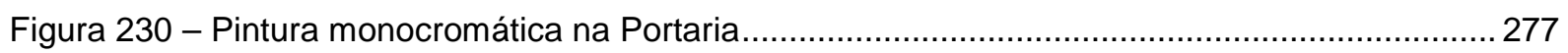

Figura 231 - Acabamentos da Biblioteca após intervenção de 2002 ............................................ 277

Figura 232 - Acabamentos da Biblioteca após intervenção de 2002 .................................................. 278

Figura 233 - Sala dos Espelhos: pintura monocromática e trechos destacados para análise

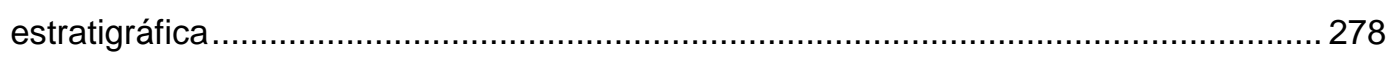

Figura 234 - Salas de aula (Sala 58 e 61) com pintura monocromática em duas tonalidades.......... 279

Figura 235 - Análise estratigráfica realizada no corredor S57 e na Sala 68 ...................................... 279

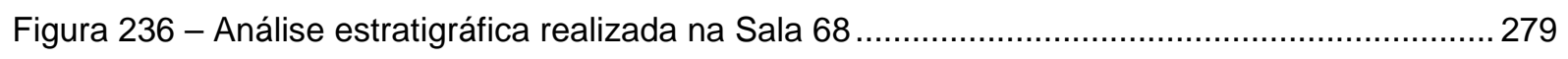

Figura 237 - Paredes azulejadas dos banheiros: WC Feminino S75 e S46 ..................................... 280

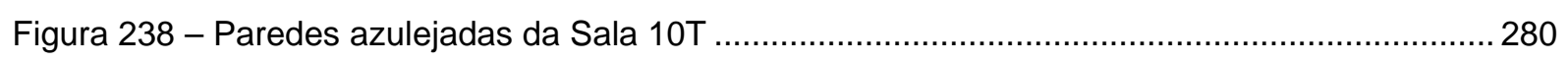

Figura 239 - Sala 10T: paredes com acabamento deteriorado - descascamento............................. 281

Figura 240 - Porão: paredes com acabamento deteriorado - desagregamento de material.............. 281

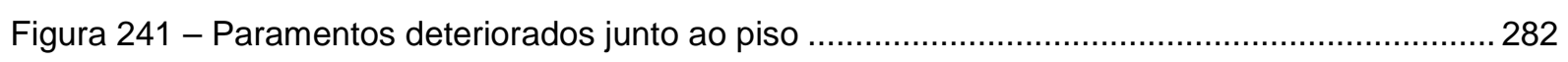

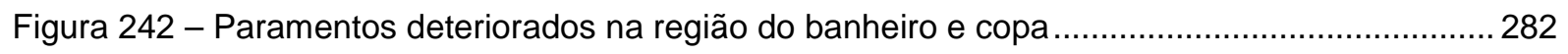

Figura 243 - Área deteriorada próxima à cobertura em cobre que protege o terraço da entrada

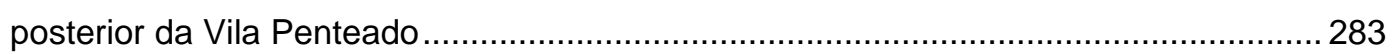

Figura 244 - À esquerda, área deteriorada no topo do edifício e, à direta, sob o balcão .................... 283

Figura 245 - Área do terraço posterior da Vila Penteado, pavimento térreo ....................................... 284

Figura 246 - Detalhe de uma das paredes da área do terraço posterior da Vila Penteado,

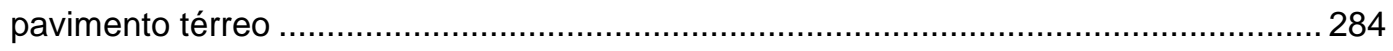

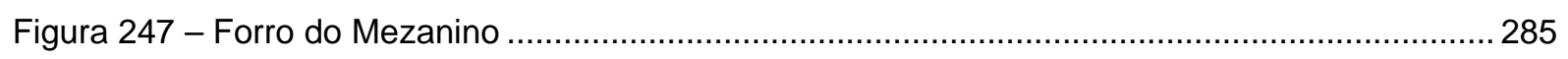

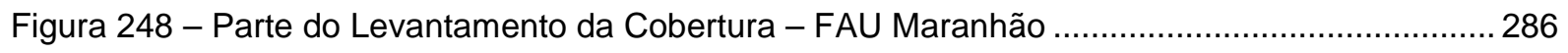

Figura 249 - Fotografias do Levantamento da Cobertura - FAU Maranhão....................................... 286

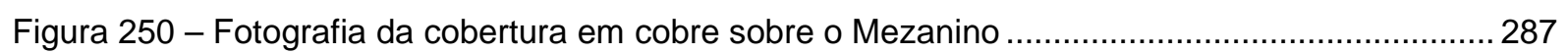

Figura 251 - Forro do Mezanino: área que apresentava vazamento devido à falha na solda da

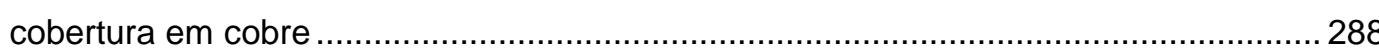

Figura 252 - Forro do Mezanino: área que apresentava vazamento devido à falha na solda da cobertura em cobre

Figura 253 - Forro do corredor em frente à Sala 65: vazamento constante no período de chuvas, sendo que acima do forro há um balde que contém parte desse vazamento ................. 289

Figura 254 - Forro do WC Feminino S46, Pavimento Superior ...................................................... 289

Figura 255 - Forro da Sala dos Espelhos: vazamento recente ..................................................... 290

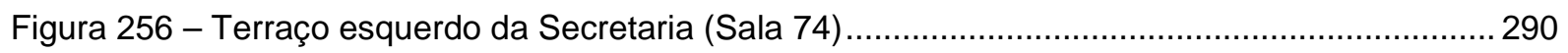

Figura 257 - Forro em madeira da Sala 44: descascamento ........................................................ 290 
Figura 258 - Descascamento dos paramentos da Copa: situação que provoca falta de higiene

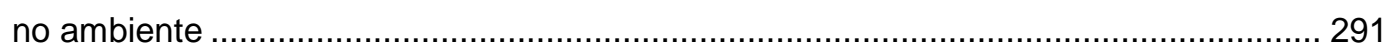

Figura 259 - Forro em estuque com pintura mural da Sala 25 - Biblioteca..................................... 291

Figura 260 - Forro em estuque com pintura mural da Sala dos Livros e das Teses - Biblioteca ..... 292

Figura 261 - Forro em estuque com pintura mural da Sala 37 da Biblioteca.................................... 292

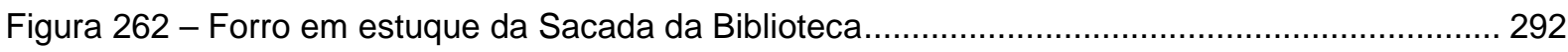

Figura 263 - Forro em estuque com pintura mural da Sala dos Leques da Biblioteca ...................... 293

Figura 264 - Forro em réguas de madeira da Biblioteca.................................................................. 293

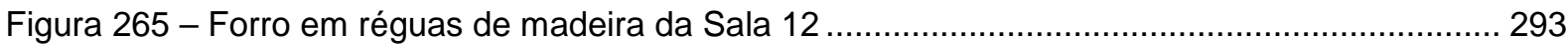

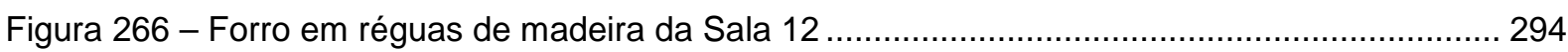

Figura 267 - Forro em réguas de madeira da Portaria e forro em estuque com pintura mural da

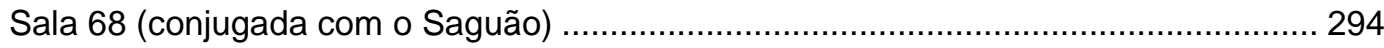

Figura 268 - Forro restaurado do Corredor S16 (em frente à Sala 12) ........................................... 294

Figura 269 - Forro em madeira ripada da escada de acesso ao porão ............................................. 295

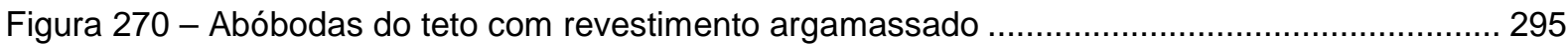

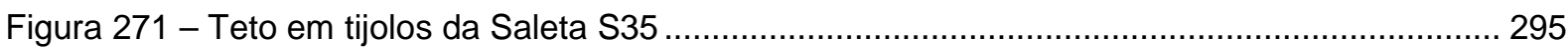

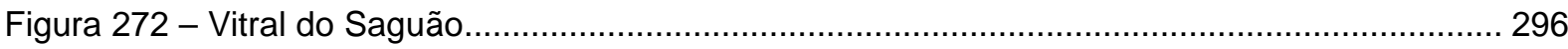

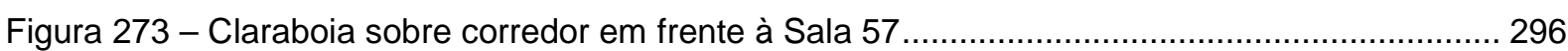

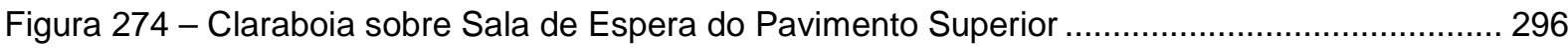

Figura 275 - Alçapões de acesso ao sótão - Hall S70 e Corredor S65............................................ 297

Figura 276 - Alçapões de acesso ao sótão - Sala 44 e WC Feminino S46 ...................................... 297

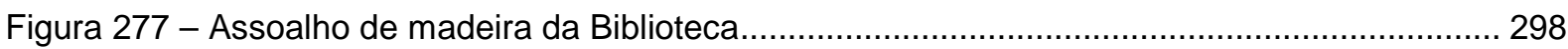

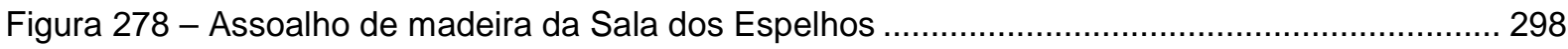

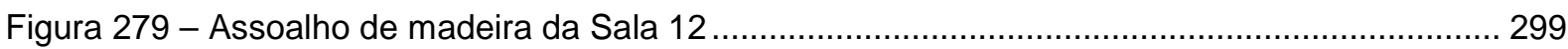

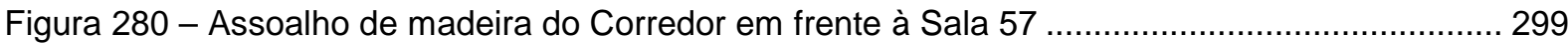

Figura 281 - Assoalho de madeira do Corredor S65 e da Sala da Diretoria S71 ........................... 299

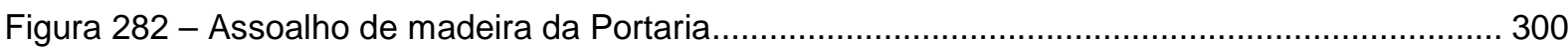

Figura 283 - Área de inspeção no assoalho de madeira da Portaria .................................................. 300

Figura 284 - Área intermediária entre o assoalho de madeira da Portaria e o mosaico do Saguão. 301

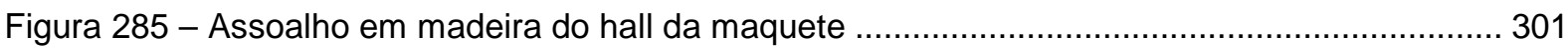

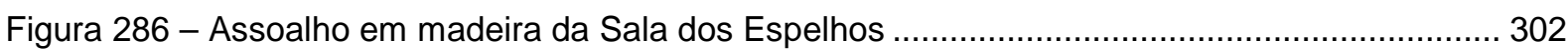

Figura 287 - Assoalho em madeira do Mezanino, sob a área do forro em estuque que ruiu ............ 302

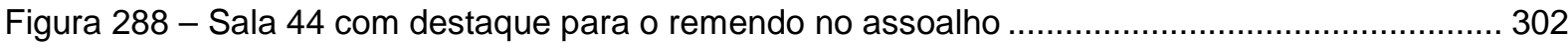

Figura 289 - À esquerda, degraus da Sala 44 e, à direita, degraus do Laboratório de Informática .. 303

Figura 290 - Escada em madeira que interliga o Saguão ao pavimento superior .............................. 303

Figura 291 - Escada em madeira que interliga o Saguão ao pavimento superior ............................. 304

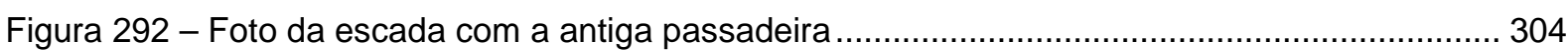

Figura 293 - escada principal: marcas dos suportes da antiga passadeira ................................... 305

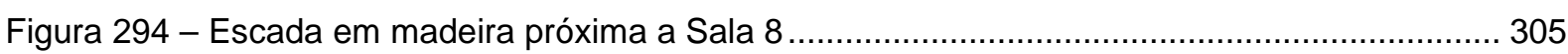

Figura 295 - Escada que interliga o pavimento térreo com o superior, próxima à Biblioteca............. 305 
Figura 296 - Piso em mosaico do acesso principal (em frente à portaria) …................................... 306

Figura 297 - Piso em mosaico do Saguão (área em frente ao acesso posterior) ............................... 306

Figura 298 - Piso em mosaico do Saguão (área próxima à escada principal) ................................... 306

Figura 299 - Piso em mosaico da entrada lateral (hall próximo à Sala 12) ........................................ 307

Figura 300 - Trecho do piso em mosaico - piso próximo à portaria ................................................. 307

Figura 301 - Desenho do trecho do piso em mosaico - piso próximo à portaria ................................ 308

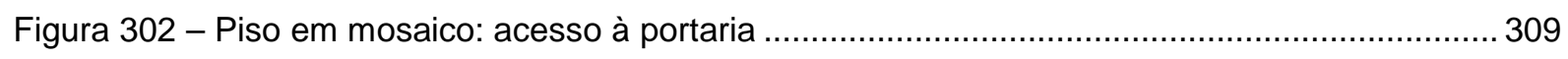

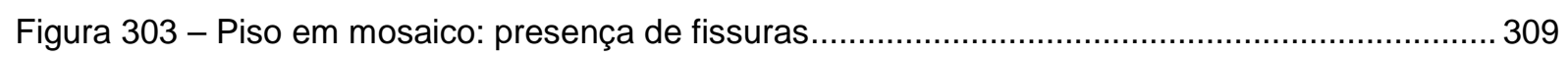

Figura 304 - Observação sobre rompimentos no mosaico............................................................ 310

Figura 305 - Piso em mosaico da área de acesso posterior: áreas claras próximas as linha de tesselas de cor amarela apresenta peças faltando ...................................................... 311

Figura 306 - Piso em mosaico com tesselas faltando (escada de acesso em frente à portaria) ........ 311

Figura 307 - Piso em mosaico da área do chafariz com destaque para o corte preciso das

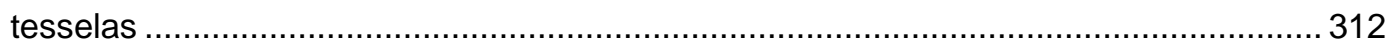

Figura 308 - Piso em mosaico da área do chafariz: algumas tesselas já se soltaram ...................... 312

Figura 309 - Piso em mármore da escada de acesso a entrada lateral............................................. 313

Figura 310 - Escada em mármore: acesso posterior da Vila Penteado .............................................. 313

Figura 311 - Piso em mármore, entre assoalho e granilite, na Sala S37 da Biblioteca ...................... 313

Figura 312 - Pisos externos da Vila Penteado: irregularidades na superfície..................................... 314

Figura 313 - Piso externo da Vila Penteado: empoçamento de águas pluviais .................................. 314

Figura 314 - Pisos externos da Vila Penteado: pavimentação em pedra e em concreto .................... 315

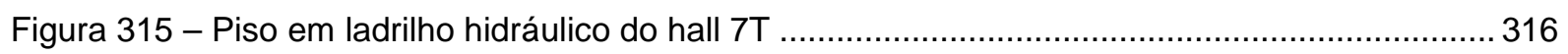

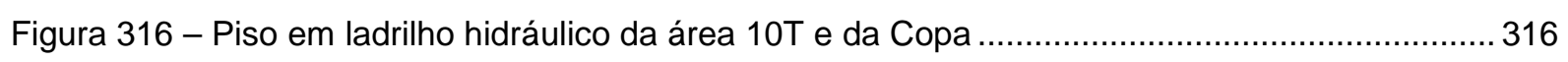

Figura 317 - Piso em ladrilho hidráulico do corredor conjugado a área 10T, terminando na soleira da Sala da Zeladoria (Sala 13T) e na soleira da Sala do Almoxarifado (Sala 10T) ....... 316

Figura 318 - Piso em ladrilho hidráulico do corredor conjugado a área 10T e da saleta S78B (saleta interligada com o Laboratório de Informática).................................................. 317

Figura 319 - Piso em ladrilho hidráulico do hall externo de acesso às áreas de serviço 10T ........... 317

Figura 320 - Piso com revestimento em peças cerâmicas da Sala 8 ............................................. 318

Figura 321 - Detalhe do piso com revestimento em peças cerâmicas da Sala 8 .............................. 319

Figura 322 - Piso com revestimento em peças cerâmicas do terraço do Laboratório de Informática

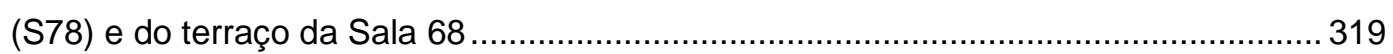

Figura 323 - Piso com revestimento em peças cerâmicas do terraço da Secretaria (S74) e do

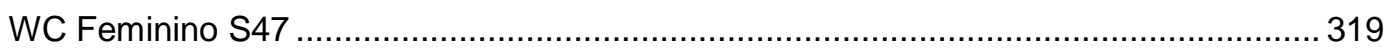

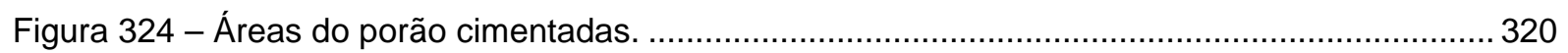

Figura 325 - Escada de acesso à área SUB-10 (Depósito) em cimento queimado........................... 320

Figura 326 - Piso com revestimento em tijolos maciços da área de acesso a sala SUB-1 ............... 321

Figura 327 - Piso com revestimento em tijolos maciços da área SUB-10 do porão ........................... 321

Figura 328 - Luminária instalada no hall de acesso a área de consulta da Biblioteca ........................ 322

Figura 329 - Novos eletrodutos instalados para atender a Biblioteca........................................... 323 
Figura 330 - Teto do porão com novos eletrodutos instalados para atender a Biblioteca

Figura 331 - Cabos expostos no Corredor S77 (trajetos sem suportes ou protetores) e Sala da Diretoria (cabos soltos pelo piso) 324

Figura 332 - Sala de Espera e Saguão: falha dos terminais das instalações elétricas ...................... 324

Figura 333 - Instalações elétricas da área externa da Vila Penteado.............................................. 325

Figura 334 - Falhas nas cúpulas dos postes de iluminação dos jardins .......................................... 325

Figura 335 - Quadro de entrada de luz e força, instalado na sala SUB-2 do porão .......................... 326

Figura 336 - Trajeto de encaminhamento dos cabos a partir do quadro de entrada de luz e força.. 326

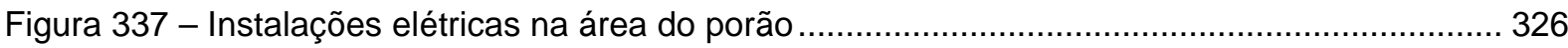

Figura 338 - Instalações elétricas na área do porão: caixas de passagem inadequadas ................. 327

Figura 339 - Instalações elétricas na área do porão: trajetos desorganizados, com eletrodutos

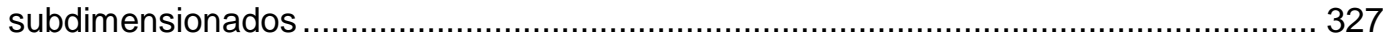

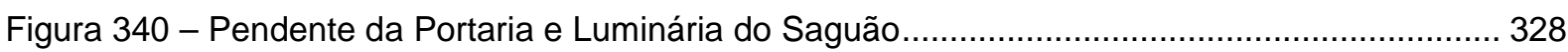

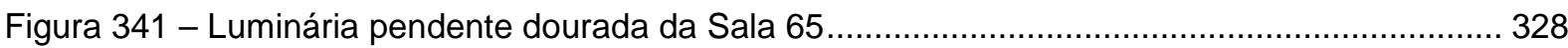

Figura 342 - Cúpulas e suportes ornamentados de diversas luminárias .......................................... 328

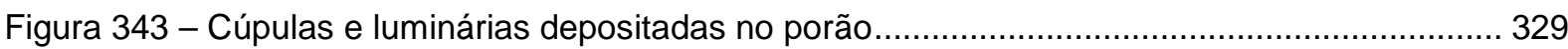

Figura 344 - Porta do Laboratório de Informática com aviso "Laboratório interditado por tempo indeterminado"

Figura 345 - Fotos do quadro geral, existente no porão, com novos disjuntores ligados ao novo circuito de alimentação do Laboratório de Informática................................................. 330

Figura 346 - Foto da saída dos cabos alimentadores por traz do quadro geral ................................ 330

Figura 347 - Trajeto feito pelo porão dos novos cabos em eletroduto aparente .............................. 331

Figura 348 - Caixa existente sob a escada do porão com novos cabos para alimentação do Laboratório de Informática..

Figura 349 - Caixa existente no pavimento térreo ao lado da sala 08: serviu de passagem para os novos cabos de alimentação do Laboratório de Informática ..................................... 331

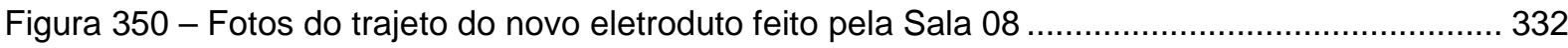

Figura 351 - Foto com passagem do eletroduto pela saleta conjugada a Sala 08 ........................... 332

Figura 352 - Novo quadro elétrico instalado na saleta conjugada ao Laboratório de Informática (essa saleta fica sobre a Sala 03)

Figura 353 - Novo quadro elétrico para alimentação das tomadas do Laboratório de Informática ... 333

Figura 354 - A partir do novo quadro, a alimentação da nova régua de tomadas foi distribuída

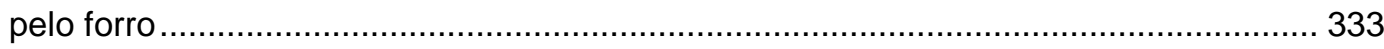

Figura 355 - Alimentação da nova régua de instalações elétricas.................................................. 333

Figura 356 - Nova régua com tomadas para o Laboratório de Informática ........................................ 334

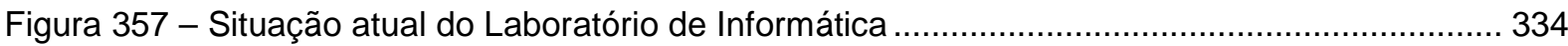

Figura 358 - Foto do Sanitário Masculino no Pavimento Térreo: destaque para a falta de duas

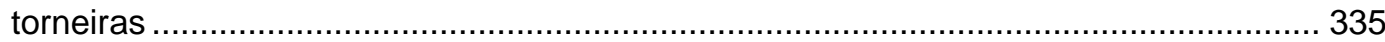

Figura 359 - Caixa d'água e tubulações na área do sótão da Vila Penteado...................................... 336

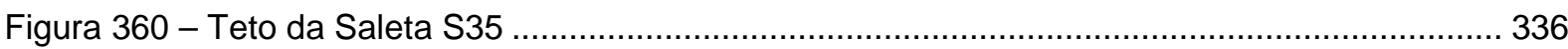




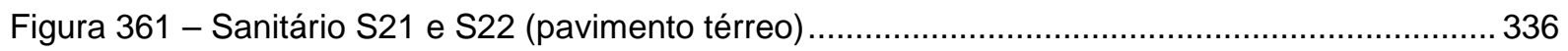

Figura 362 - Sanitário feminino (S75): aviso na válvula de descarga, indicando falha....................... 337

Figura 363 - Sanitários S45, S46 e S47 (pavimento superior) ................................................... 337

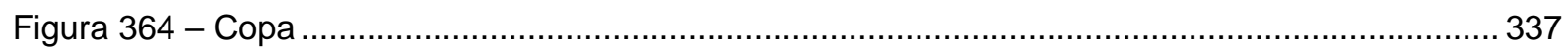

Figura 365 - Banheiro usado pelas funcionárias da Vila Penteado, em frente à área 10T................ 338

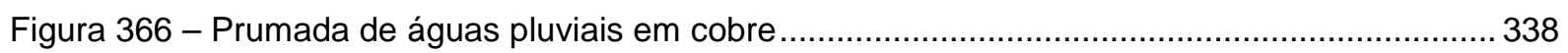

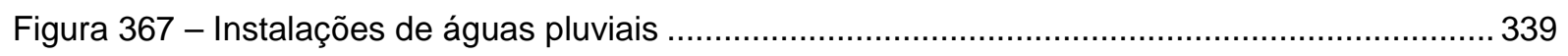

Figura 368 - Saída de águas pluviais em direção ao piso externo ..................................................... 339

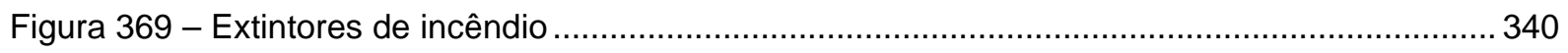

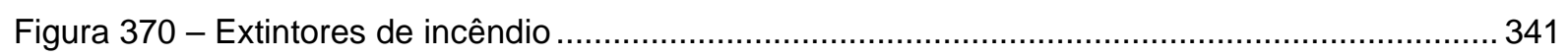

Figura 371 - Área do Porão com exceto de material combustível ...................................................... 341

Figura 372 - Área do Porão com exceto de material combustível ..................................................... 342

Figura 373 - Saleta 2, conjugada a Sala 8 e, à direita, Saleta 3 , também anexa a Sala 8 ................ 342

Figura 374 - Saleta 3, anexa a Sala 8 e Saleta S78b, conjugada ao Laboratório de Informática ...... 343

Figura 375 - Área SUB-1 do porão: equipamento obsoleto sem uso em primeiro plano e, abaixo

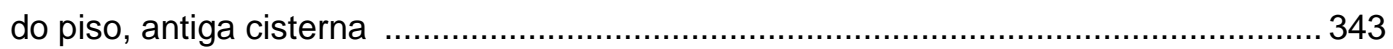

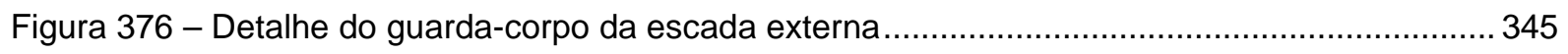

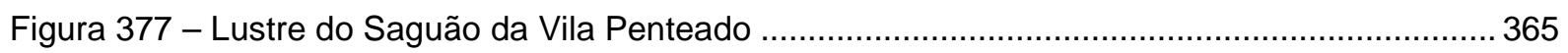

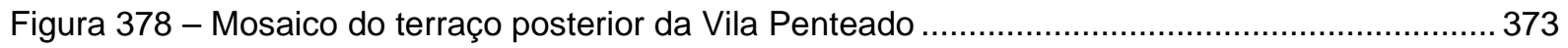

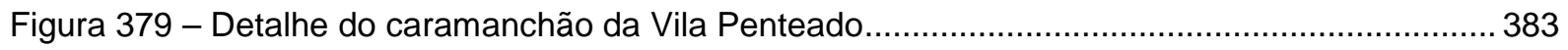




\section{LISTA DE TABELAS}

Tabela 1 - Requisitos básicos da norma de desempenho - Resumo................................................. 51

Tabela 2 - Tipos de madeira empregados nos elementos construtivos do edifício Vila Penteado. .. 145

Tabela 3 - Tabela de Pisos/ Revestimentos/ Divisórias (Sanitário Masculino a reformar no

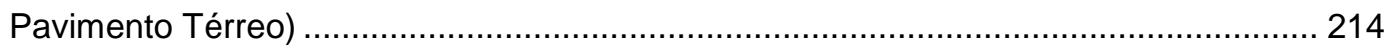

Tabela 4 - Tabela de Louças/ Metais (Sanitário Masculino a reformar no Pavimento Térreo) ......... 214

Tabela 5 - Tabela de Acessórios (Sanitário Masculino a reformar no Pavimento Térreo) ................. 214

Tabela 6 - Tabela de Prioridades das Obras de Restauro da Vila Penteado ...................................... 361

Tabela 7 - Lista de processos e protocolos consultados na FAUUSP............................................. 389 



\section{LISTA DE ABREVIATURAS E SIGLAS}

ABNT

CAEC FAU

CAPES

COESF

CONDEPHAAT

CONPRESP

CPC USP

CPC USP

CPG

CREA

CREA-SP

CUASO

DOP

DPS

FUNDUSP

FUPAM

FAPESP

FAUUSP

GEEF

GFAU

GEGRAN

IAB

ICOMOS
Associação Brasileira de Normas Técnicas

Comissão de Atividades Extra Curriculares da FAU

Coordenação de Aperfeiçoamento de Pessoal de Nível Superior Coordenadoria do Espaço Físico da USP

Conselho de Defesa do Patrimônio Histórico, Arqueológico, Artístico e Turístico

Conselho Municipal de Preservação do Patrimônio Histórico, Cultural e Ambiental da Cidade de São Paulo

Comissão de Patrimônio Cultural da Universidade de São Paulo (de 1986 a 2002)

Centro de Preservação Cultural da Universidade de São Paulo (desde 2002)

Comissão de Pós Graduação

Conselho Regional de Engenharia, Arquitetura e Agronomia

Conselho Regional de Engenharia, Arquitetura e Agronomia do

Estado de São Paulo

Cidade Universitária Armando de Salles Oliveira

Departamento de Obras Públicas de São Paulo

Dispositivo de Proteção Contra Surtos Atmosféricos

Fundo de Construções da USP

Fundação para a Pesquisa Ambiental

Fundação de Amparo à Pesquisa no Estado de São Paulo

Faculdade de Arquitetura e Urbanismo da Universidade de São Paulo

Grupo Executivo de Gestão dos Espaços Físicos

Grêmio Estudantil da Faculdade Arquitetura e Urbanismo

Grupo Executivo da Grande São Paulo

Instituto dos Arquitetos do Brasil

International Council on Monuments and Sites (Conselho Internacional de Monumentos e Sítios) 
IBAPE/SP Instituto Brasileiro de Avaliações e Perícias de Engenharia de São Paulo

IPT Instituto de Pesquisas Tecnológicas

IPHAN Instituto do Patrimônio Histórico e Artístico Nacional

ISO International Organization for Standardzation (Organização Internacional de Normalização)

MIS Museu da Imagem e do Som

NBR Norma Brasileira

NUTAU USP Núcleo de Pesquisa em Tecnologia da Arquitetura e Urbanismo da Universidade de São Paulo

SAR Associação Nacional dos Arquitetos Suecos

SPDA Sistema de Proteção Contra Descargas Atmosféricas

SPHAN Serviço do Patrimônio Histórico e Artístico Nacional

UNESCO United Nations Educational, Scientific and Cultural Organization (Organização das Nações Unidas para a Educação, a Ciência e a Cultura)

USP Universidade de São Paulo 


\section{SUMÁRIO}

INTRODUÇÃO

\section{CAPÍTULO 1:}

A Análise de Desempenho Técnico-Construtivo e da Qualidade dos Edifícios 45

1. A Análise de Desempenho Técnico-Construtivo e da Qualidade dos Edifícios ...........47

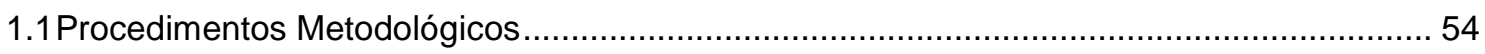

1.2A Análise de Desempenho como Ferramenta para Sistematização da Manutenção ............56

\section{CAPÍTULO 2:}

A Análise do Desempenho Técnico-Construtivo Aplicada à Preservação Patrimonial 61

2. A Análise do Desempenho Técnico-Construtivo Aplicada à Preservação Patrimonial 63

2.1Bases Históricas 65

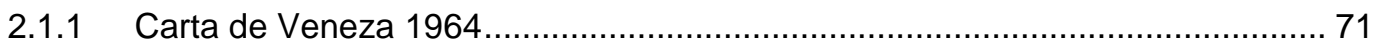

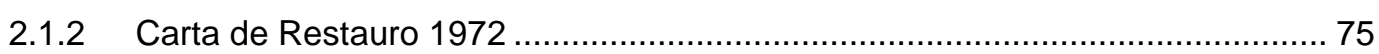

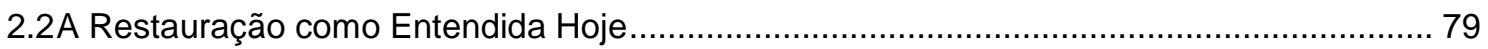

2.3A Análise do Desempenho Aplicada à Restauração e a Preservação Patrimonial ............... 81

2.4Considerações sobre a Preservação Patrimonial................................................................ 84

\section{CAPÍTULO 3:}

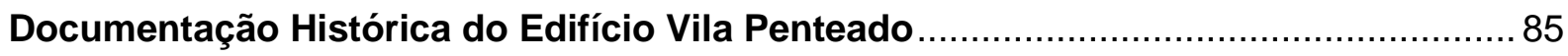

3. Documentação Histórica do Edifício Vila Penteado .................................................. 87

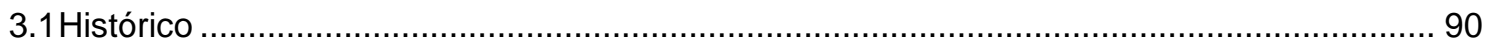

3.1.1 O Proprietário: Conde Antonio Álvares Penteado .......................................... 93

3.1.2 O Arquiteto: Carlos Ekman ....................................................................... 97

3.1.3 O Estilo Arquitetônico: Art Nouveau ………….......................................... 105

3.1.4 O Edifício: Vila Penteado........................................................................ 108

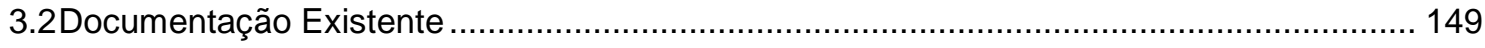

3.2.1 Documentos sobre a Cobertura ……………...................................... 151

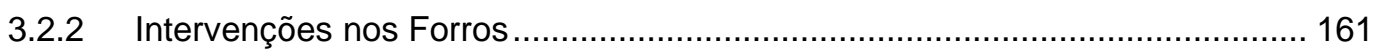

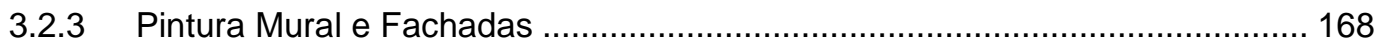

3.2.4 Levantamento e Recuperação das Esquadrias .......................................... 184

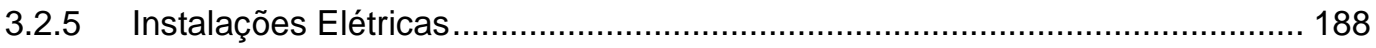

3.2.6 Intervenção na Área da Biblioteca.......................................................... 192

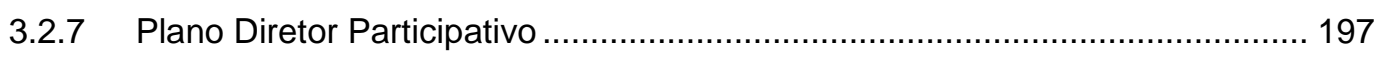


3.3Levantamento Cadastral

3.3.1 Elementos Gráficos: Bases Digitais....................................................... 201

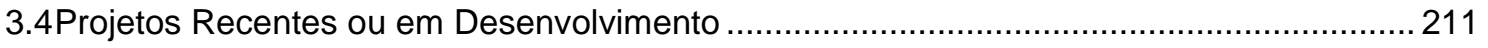

3.4.1 Projeto de Reforma dos Sanitários ................................................... 212

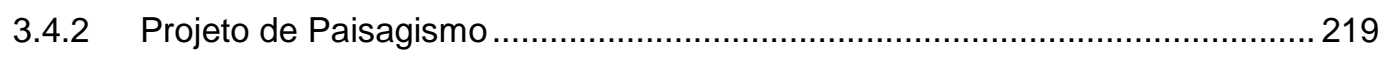

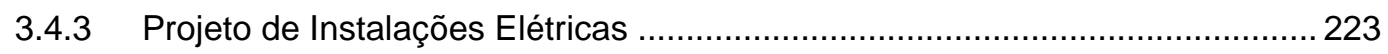

\section{CAPÍTULO 4:}

Análise de Desempenho dos Sistemas do Edifício Vila Penteado..............................239

4. Análise de Desempenho dos Sistemas do Edifício Vila Penteado .............................241

4.1Documentação Fotográfica e Análise dos Sistemas .............................................. 241

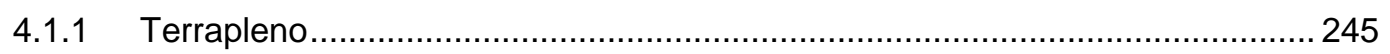

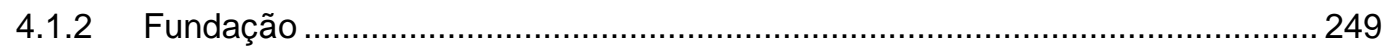

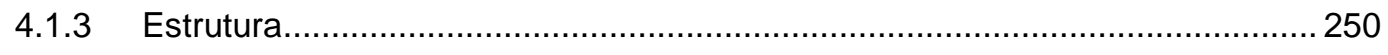

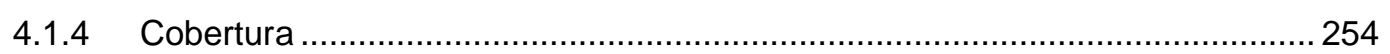

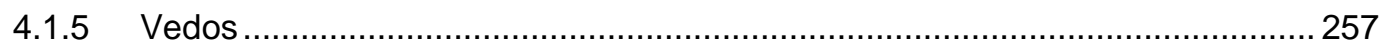

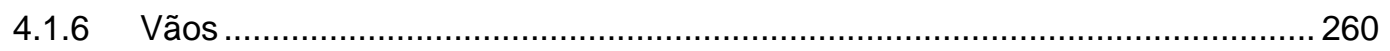

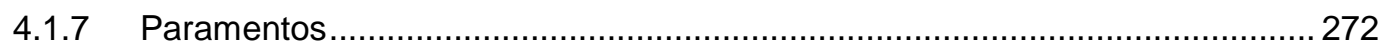

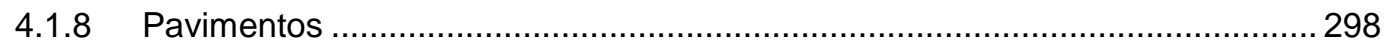

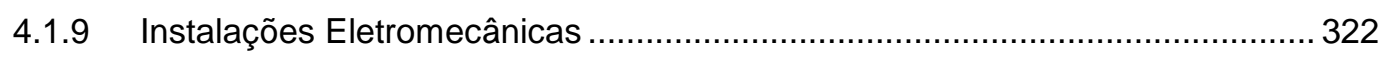

4.1.10 Instalações Hidrossanitárias ....................................................... 335

\section{CAPÍTULO 5:}

Diretrizes e Operacionalização da Manutenção e Conservação Predial .......................345

5. Diretrizes e Operacionalização da Manutenção e Conservação Predial ....................347

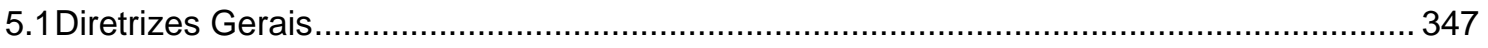

5.1.1 Preservação como Finalidade Institucional ......................................... 348

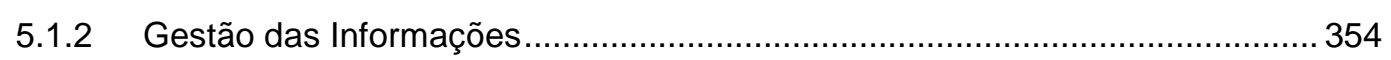

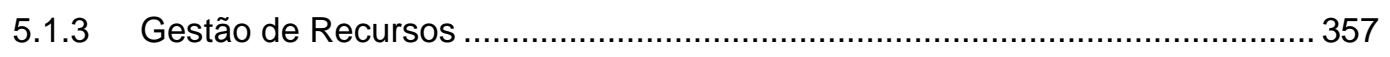

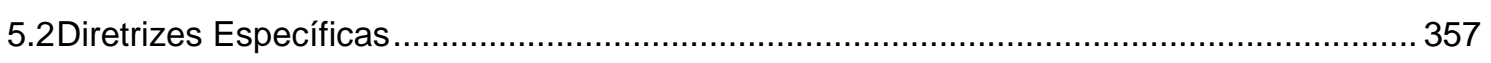

5.2.1 Frequência de inspeções e ações de manutenção ...................................... 358

5.2.2 Períodos de efetivação das ações de manutenção..................................... 360

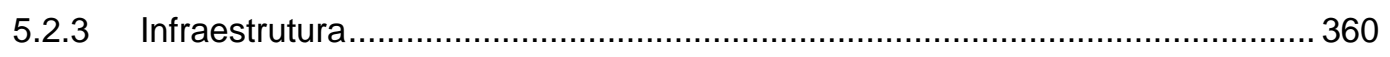

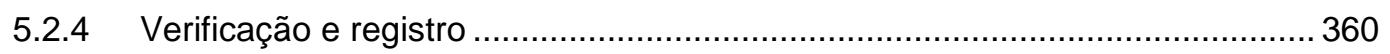

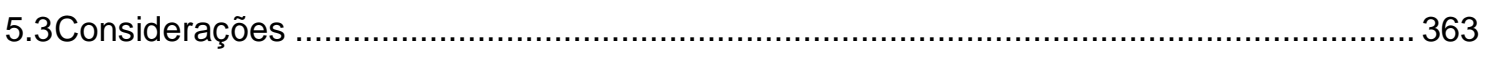

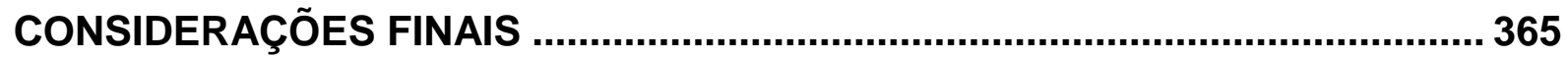




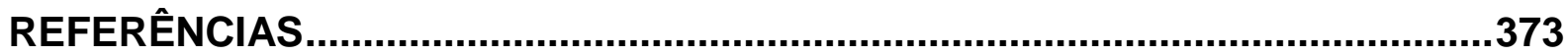

ANEXO 



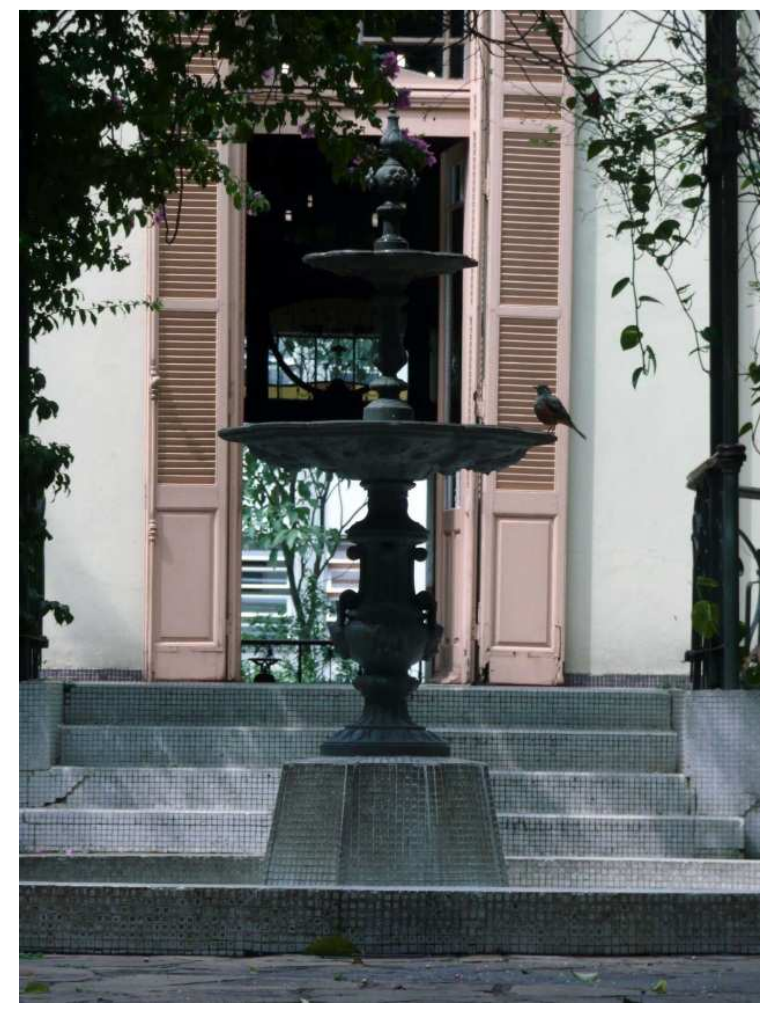

Figura 1 - Sabiá no chafariz da Vila Penteado Foto: Isis Roverso, dezembro de 2010. 



\title{
INTRODUÇÃO
}

A falta de coordenação entre as ações práticas e a teoria do restauro, leva o patrimônio arquitetônico a uma situação de risco: se por um lado o conhecimento não é traduzido em ações, por outro, as intervenções realizadas, por vezes, estão desprovidas de estrutura teórica própria do campo disciplinar do restauro. Como bem expõe Kühl:

\begin{abstract}
É possível verificar, em intervenções ou propostas de atuação em bens de interesse histórico e artístico, a falta de fundamentos culturais. Enorme contradição, pois, por um lado, esses edifícios são escolhidos por serem 'bens culturais', como forma também de valorizar a imagem de uma instituição ou de legitimar uma dada iniciativa; por outro lado, são os aspectos histórico-artísticos, memoriais e simbólicos da edificação que passam ao largo das questões projetuais. Ou seja, esses exemplares são eleitos por terem interesse histórico, mas as intervenções desprezam os valores culturais que motivaram sua tutela. Prevalecem questões funcionais - com uma destinação predeterminada que orienta a intervenção -, ou ainda políticas, midiáticas e de exploração visando lucros. ${ }^{1}$
\end{abstract}

As ações projetuais devem ser construídas sobre um embasamento teórico consistente, que resgate as características singulares da obra e ainda estabeleça as condições práticas da intervenção.

A situação atual do patrimônio histórico brasileiro revela a falta desse alicerce teórico nos projetos de intervenção e, nos raros casos onde há a reflexão teórica, essa não atinge as ações práticas das restaurações.

Além da dissociação entre teoria e prática, pesquisas também têm destacado, há algum tempo, outro fato relevante na preservação do patrimônio histórico: as intervenções emergenciais caracterizadas pelo improviso e desprovidas da visão sistêmica da edificação. Tirello apresenta um exemplo desse quadro no depoimento "Redescobrindo e Restaurando as Pinturas Murais dos Edifícios da USP":

[...] devido a pouca tradição na conservação do patrimônio histórico cultural, no Brasil, as restaurações de edifícios e obras de arte, frequentemente, se caracterizam pela improvisação, e, o que é pior, costumam ser promovidas quando esses bens já se encontram em avançado estado de degradação. No caso dos edifícios, a situação se agrava. As intervenções quase sempre se reduzem as "reformas" emergenciais que priorizam as consolidações estruturais deixando fora do projeto a restauração dos metais, dos estuques, das madeiras e pinturas antigas originais. Os elementos

\footnotetext{
1 KÜHL, Beatriz Mugayar. Preservação do Patrimônio Arquitetônico da Industrialização -
} Problemas teóricos de restauro. Cotia: Ateliê / FAPESP, 2009, p.220. 
componentes dessas arquiteturas, que distinguem e caracterizam os estilos, quando danificados costumam, nesse tipo de intervenção assistemática, ser substituídos por modelos "similares" que terminam por transformar o edifício em um híbrido arquitetônico, distanciado de sua própria história e natureza. São ações que ao longo dos anos vêm contribuindo para a descaracterização de muitos prédios históricos de São Paulo, construídos no final do século XIX e início do século XX. ${ }^{2}$

A problemática, que envolve a falta de articulação entre teoria e prática e a improvisação nas intervenções em edifícios tombados, pode ser atenuada com a sistematização da manutenção preventiva, planejada a partir da reflexão teórica e realizada de forma contínua.

A manutenção preventiva se compreendida como meio de mitigar a ação do tempo, minimizando a descaracterização, bem como as alterações no estado físico da edificação e suas consequências, possibilita a materialização de um dos princípios básicos do restauro, ou seja, a mínima intervenção.

A questão da manutenção contínua não é algo novo, a Carta de Veneza (1964) traz a seguinte informação no seu artigo quarto: "a conservação dos monumentos exige, antes de tudo, manutenção permanente". 3

Apesar do reconhecimento conceitual da importância da manutenção, a sua falta é um problema central para a eficácia da preservação de obras relevantes.

Por se tratar de um conjunto de atividades cujo objetivo é eliminar ou tratar a causa do problema antes da sua manifestação plena, evitando a obsolescência precoce ou falhas em longo prazo, os resultados da manutenção preventiva não são facilmente perceptíveis, considerando que não se observam alterações de grande impacto no estado aparente da edificação.

A dificuldade de implantação de um programa de manutenção preventiva não é exclusividade da gestão do uso de edifícios históricos. Para edifícios não passíveis de tombamento, o programa de manutenção, igualmente, não é valorizado.

Pesquisadores apontam que o exercício das atividades técnicas relativas à manutenção não desperta muito interesse, tampouco traz tanto prestígio aos

2 TIRELLO, Regina A.. Depoimento: Redescobrindo e Restaurando as Pinturas Murais dos Edifícios da USP. Comissão de Patrimônio Cultural da USP (LOURENÇO, Maria Cecília França; et al org.). Bens Imóveis tombados ou em processo de tombamento da USP. São Paulo: EDUSP, IMESP, CPC, 1999, v. 1, p. 202.

${ }^{3}$ Carta de Veneza, Revista do Patrimônio Histórico e Artístico Nacional, 1987, n. 22, p. 106-107. 
profissionais atuantes na área como as grandes obras de restauração (ALLAN, 2012; DANN; CANTELL, $2007^{4}$ apud FORSTER; KAYAN, 2009).

Outros motivos que contribuem para a não valorização dessas atividades giram em torno da insuficiência de recursos de recursos humanos e financeiros alocados para esse fim, sobretudo nos casos onde o edifício é público. A situação é agravada pela lentidão dos processos e pela falta de estudos detalhados que possibilitam o provisionamento das verbas necessárias e o planejamento em médio e longo prazo. Soma-se a isso a dificuldade de realizar vistorias nos edifícios e também a dificuldade de identificar, nos vários segmentos de mercado, mão-deobra, materiais, componentes específicos para a manutenção desses edifícios históricos.

As razões que embasam a manutenção em edifícios tombados devem ter, como principal objetivo, a preservação de seu valor cultural, assegurando sua integridade e a de seus usuários.

Quando atributos vinculados à segurança e à funcionalidade (que garantem a integridade da edificação e dos usuários) podem ser aferidos objetivamente, em termos de significância aos atributos culturais e estéticos (de valor inerente ao patrimônio arquitetônico) a manutenção passa a ser reconhecida como ação contínua e essencial.

Toda ação de intervenção em monumentos históricos ${ }^{5}$ deve ser destinada a preservação e aqui o termo preservação abrange uma variedade de ações, tais como: documentação, registros, inventários, leis específicas, que visam à salvaguarda do monumento histórico, incluindo as ações de intervenção com graus distintos de abrangência: manutenção, conservação e restauro.

\footnotetext{
${ }^{4}$ Dann, N. and Cantell, T. Maintenance in conservation. In: FORSYTH, M. (Ed.). Understanding Historic Building. Oxford: Blackwell. 2007, p. 185-198.

${ }^{5} \mathrm{O}$ termo "monumento histórico" deve ser esclarecido "...por 'monumento histórico', não se deve entender obra grandiosa de valor artístico e histórico excepcional (como foi frequente no século XIX), mas, sim, como propõem variados autores da atualidade, qualquer artefato que adquiriu significação cultural com o tempo, - algo mais relacionado ao seu sentido etimológico e às propostas de Riegl." Kühl (2010, p.301).
} 


\section{A. JUSTIFICATIVA}

O campo disciplinar do restauro tem por objetivo estudar a preservação de bens culturais, com métodos e referenciais teóricos próprios. Esses estudos trazem implicações práticas, que vão desde a documentação do patrimônio até a execução de intervenções planejadas, segundo critérios e requisitos específicos do campo disciplinar, aplicadas às especificidades do patrimônio estudado. Esse trabalho de análise requer reflexão crítica, profissionais interdisciplinares e criatividade projetual.

Já a análise de desempenho é usada, na construção civil, para expressar o comportamento de um produto (edifício ou ambiente construído), quando em uso. A metodologia da análise de desempenho foi desenvolvida com o objetivo de orientar e condicionar o projeto, de modo a garantir que o edifício cumpra satisfatoriamente as funções para os quais foi produzido, quando submetido a determinadas condições de uso $^{6}$. A prática desses conceitos capacita 0 arquiteto para uma abordagem mais sistêmica do processo de projeto, cuja eficácia se verifica na fase de uso, operação e manutenção do edifício. Por essa razão, a análise de desempenho, feita nos edifícios em uso, tem se mostrado particularmente interessante, porque identifica patologias construtivas $^{7} \mathrm{e}$ as correlaciona ao não atendimento das necessidades e expectativas dos usuários $^{8}$. Isso possibilita a avaliação do comportamento das soluções construtivas, componentes e instalações e permite propostas de intervenções, de modo a restabelecer as condições de segurança, habitabilidade e funcionalidade do edifício. Mesmo que praticada de forma pontual e discreta, a análise permite a visão integrada do edifício e a detecção mantém a correlação entre o comportamento do todo (edifício) e de suas partes (subsistemas).

No contexto do desempenho, a manutenção predial tem sido reconhecida como um novo requisito de desempenho a ser considerado, desde as fases iniciais

${ }^{6}$ GIBSON, E. J. (Coord.) Working with the performance approach in building. INTERNATIONAL COUNCIL FOR RESEARCH AND INNOVATION IN BUILDING AND CONSTRUCTION - CIB, Rotterdam, Netherlands, 1982. (CIB State of Art Report no 64, Working Commission W60).

${ }^{7}$ Patologia construtiva nesse contexto é compreendida como o estudo das falhas construtivas em sistemas do edifício, suas origens e consequências.

${ }^{8}$ As necessidades e expectativas dos usuários definem as condições que devem ser atendidas por um edifício para um fim específico. Os requisitos e critérios de desempenho definem os termos qualitativos e quantitativos, respectivamente para que essas condições sejam atendidas, conforme as normas ISO6241 (INTERNATIONAL ORGANIZATION FOR STANDARDZATION, 1984) e NBR15.575-1; ASSOCIAÇÃO BRASILEIRA DE NORMAS TÉCNICAS, 2008). 
de um projeto, cuja importância foi destacada na recente divulgação da norma brasileira sobre o desempenho de edifícios (ASSOCIAÇÃO BRASILEIRA DE NORMAS TÉCNICAS, 2008). Manutenção predial e industrial é o ramo da engenharia voltado para a conservação, operação e segurança das edificações residenciais, comerciais ou industriais. Dependendo da complexidade do edifício, a atividade é exercida por empresas especializadas, por meio de programas específicos, de acordo com a necessidade de cada infraestrutura. O resultado é a valorização constante do patrimônio, a garantia da funcionalidade de suas instalações e a segurança dos que nelas habitam, trabalham ou circulam.

Aproximando as necessidades relativas à preservação do patrimônio arquitetônico, com as vantagens da análise do desempenho de edifícios em uso, é possível estabelecer diretrizes, para a operacionalização das ações de intervenção em edifício de interesse histórico e cultural. $O$ processo de análise combinada e ponderada, entre o campo do conhecimento do restauro e do desempenho, permite a sistematização e priorização das intervenções, culminando na organização das ações projetuais, provisionamento de recursos humanos, técnicos e financeiros, para a criação de planos de manutenção permanente.

A partir do entendimento, de que a preservação do patrimônio arquitetônico é facilitada através da manutenção permanente, e que as intervenções de grande porte, não raras vezes, contribuem para o empobrecimento e descaracterização da obra, é que a busca por requisitos, que validem a sistematização da manutenção de edifícios tombados, é justificada.

Entretanto, esses requisitos não devem ser aplicados de forma direta a trabalhos de manutenção preventiva de edifícios diversos sem a devida reflexão. Os requisitos devem ser usados como ferramentas, que poderão nortear a análise dos estudos da obra em questão, sendo que esses estudos deverão conter o entendimento e reconhecimento da obra, respeitando o princípio de que cada caso de preservação é um caso singular e, portanto, deve ser analisado na íntegra, antes que as ações de preservação e manutenção sejam aplicadas, evitando dessa forma possíveis enganos de gramática da arquitetura, de entendimento da técnica e de priorização nas soluções aplicadas. 


\section{B. OBJETIVO E OBJETO}

O objetivo desse trabalho é propor diretrizes, que fundamentem a operacionalização da manutenção predial, destinadas ao patrimônio arquitetônico com base na abordagem do desempenho.

O objeto escolhido, para desenvolvimento desse trabalho, é o edifício Vila Penteado e sua escolha justifica-se devido sua relevância: construído em 1903, permanece hoje como um dos raros exemplos paulistas do art nouveau. Foi tombado pelo Conselho de Defesa do Patrimônio Histórico, Arqueológico, Artístico e Turístico (CONDEPHAAT), em 1978, e pelo Conselho Municipal de Preservação do Patrimônio Histórico, Cultural e Ambiental da Cidade de São Paulo (CONPRESP), em 1991, como exemplo de obra arquitetônica, patrimônio histórico e cultural. A sua representatividade, técnicas e materiais empregados, além de apresentar mais de cem anos de uso, o torna objeto ideal para análise e discussão das questões de preservação e da qualidade do desempenho predial.

\section{MÉTODO}

O trabalho inicia-se conceituando os campos disciplinares da análise de desempenho técnico-construtivo e da preservação do patrimônio arquitetônico. Desenvolve-se com o estudo de caso e apresenta os resultados encontrados.

É realizada a revisão do atual estado da arte da análise de desempenho em edifícios, aplicada ao estudo de edifícios em uso. A revisão bibliográfica também engloba conceitos e princípios do campo da preservação existentes hoje no Brasil, e as estratégias e desafios atuais na conservação de edifícios de valor histórico.

Os princípios e conceitos do campo disciplinar da preservação do patrimônio arquitetônico são usados para ponderar os requisitos e critérios da análise de desempenho de edifícios, a fim de que essa abordagem do desempenho possa ser aplicada à análise de obras arquitetônicas de interesse histórico, cultural, estético e científico.

O levantamento documental e das intervenções realizadas até o momento na Vila Penteado foram feitos para o conhecimento do edifício.

Na sequência foi realizada a análise do desempenho técnico-construtivo da Vila Penteado. A abrangência e os procedimentos metodológicos da análise de 
desempenho são apresentados em detalhes no Capítulo 1, por fazerem parte da fundamentação teórica deste trabalho.

As principais intervenções na edificação e formas de ação são sistematizadas a partir do histórico do edifício e do seu estado atual de conservação.

As diretrizes para a manutenção da edificação são apresentadas com base no equilíbrio intencional de ações que permitam a salvaguarda do monumento e o uso adequado que garanta a segurança dos usuários.

\section{ESTRUTURA DOS CAPÍTULOS DA DISSERTAÇÃO}

O trabalho inicia-se com a Introdução, seguido de uma estrutura de cinco capítulos e encerra-se com as Referências.

O Capítulo 1, intitulado "A Análise de Desempenho Técnico-Construtivo e da Qualidade dos Edifícios", procura estabelecer o campo da análise de desempenho, com seus procedimentos metodológicos próprios. Estudos recentes são apresentados de forma sucinta e objetiva, visando o entendimento das potencialidades que a análise traz. A análise qualificada visa ponderar os resultados obtidos, facilitando o diagnóstico e a priorização das ações de manutenção programada e corretiva.

O Capítulo 2, sob tema "A Análise de Desempenho Técnico-Construtivo Aplicada a Preservação Patrimonial", levanta os princípios que norteiam o campo da preservação hoje no Brasil; para tanto, um breve histórico é apresentado, com destaque para o conteúdo que alicerça as bases teóricas contemporâneas. O segundo capítulo encerra-se com a união entre o campo disciplinar da análise de desempenho técnico-construtivo e a preservação, trazendo diretrizes aplicáveis a edifícios históricos.

Já o Capítulo 3, "Documentação Histórica do Edifício Vila Penteado", permitiu o aprofundamento dos estudos do edifício Vila Penteado, no estado atual e das suas origens. A intenção foi de agregar o maior conjunto de informações possível, visando desdobramentos em futuros trabalhos dessa instituição.

O Capítulo 4, intitulado "Análise de Desempenho dos Sistemas do Edifício Vila Penteado", traz o registro atual do estado dos sistemas da Vila Penteado, através de levantamento fotográfico e ponderações circunstanciadas. Por meio do entendimento do passado histórico e das ações de intervenção ocorridas no edifício, 
a atual situação de alguns sistemas pode ser compreendida. Esse capítulo, assim como o anterior, tem por objetivo contribuir para a fundamentação do futuro projeto de restauração e manutenção.

Por fim, o Capítulo 5, intitulado "Diretrizes e Operacionalização da Manutenção e Conservação Predial destinada a Bens Tombados", organiza os resultados obtidos da análise de desempenho técnico-construtivo, ponderada pela preservação, e traduz os mesmos em diretrizes abrangentes, que podem ser usadas na operacionalização da manutenção rotineira do edifício.

As Considerações Finais são apresentadas, identificando os principais desafios e dificuldades para a implementação de um programa de manutenção contínua. Em seguida, são registradas as Referências. 


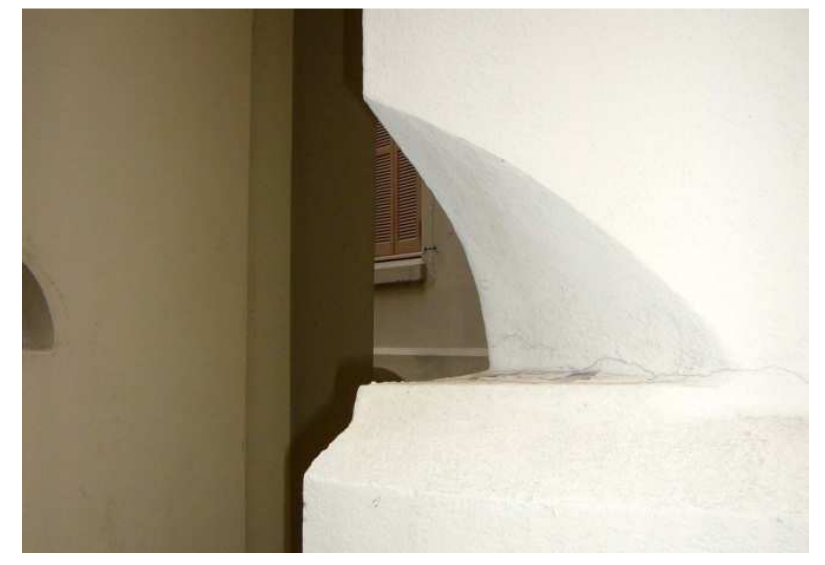

Figura 2 - Detalhe da Fachada da Vila Penteado Foto: Isis Roverso, abril de 2011.

CAPÍTULO 1:

A ANÁLISE DE DESEMPENHO TÉCNICO-CONSTRUTIVO E DA QUALIDADE DOS EDIFÍCIOS 



\section{A ANÁLISE DE DESEMPENHO TÉCNICO-CONSTRUTIVO E DA QUALIDADE DOS EDIFÍCIOS}

A intenção expressa no primeiro capítulo é estabelecer o campo da análise de desempenho técnico-construtivo e da qualidade dos edifícios, com seus procedimentos metodológicos próprios, visando seu uso como ferramenta de sistematização do diagnóstico, que possibilita a priorização das ações de manutenção rotineira, programada e não planejada ${ }^{9}$.

O conceito de desempenho pode ser estabelecido através do entendimento do comportamento de um produto em uso, sendo que sua análise e avaliação são possíveis através de parâmetros pré-estabelecidos, fruto de requisitos e critérios específicos. Segundo a norma brasileira, NBR 15.575-1 $(2008)^{10}$, o termo desempenho pode ser definido como "comportamento em uso de um edifício e de seus sistemas", sendo que a degradação é conceituada exatamente como "a redução do desempenho devido à atuação de um e de vários agentes de degradação", onde agente de degradação é "tudo aquilo que, agindo sobre um sistema, contribui para reduzir seu desempenho". Os agentes de degradação podem ser: ambientais (radiação, temperatura, água, constituintes do ar e poluentes, gelo/ degelo e vento); biológicos (roedores, fungos, bactérias, etc.); carregamento (deformação lenta, fadiga, água e seus derivados e cargas de uso); possíveis incompatibilidades (químicas e físicas) e, por fim, os próprios fatores de uso provocam a degradação do edifício.

A metodologia da análise de desempenho foi desenvolvida com a finalidade de orientar e condicionar o projeto, de modo a garantir que o edifício cumpra satisfatoriamente as funções para os quais foi produzido, quando submetido a determinadas condições de uso (GIBSON, 1982), sendo que a análise de desempenho, quando realizada em edifícios em uso traz informações que,

${ }^{9}$ Conforme NBR 5674 (1999), a manutenção pode ser rotineira (tratando de serviços simples que, assim que identificados, podem e devem ser realizados), programada (organizada a partir da vida útil dos elementos e dos relatórios de vistoria periódica) e não planejada (caracteriza-se pelos serviços que não constam das rotinas, incluindo os emergenciais). A manutenção programada pode ser denominada como preventiva e a manutenção não planejada pode ainda ser chamada de emergencial ou corretiva.

${ }^{10}$ ASSOCIAÇÃO BRASILEIRA DE NORMAS TÉCNICAS - ABNT. Edifícios habitacionais de até cinco pavimentos - Desempenho. Parte 1: Requisitos gerais. NBR 15.575-1. Rio de Janeiro: ABNT, 2008. 
organizadas, auxiliam no projeto de manutenção programada, objetivando a preservação do edifício, segurança dos usuários e pleno atendimento das atividades desenvolvidas no mesmo.

A análise de desempenho de edifícios, tanto propicia o entendimento da situação específica do edifício em questão, quanto traz elementos que auxiliam o estudo de outros edifícios. A análise é útil ainda para rever problemas evidenciados no período de uso das edificações, o que pode realimentar as discussões para futuros projetos de edificações de tipologia semelhante.

Ainda, segundo NBR 15.575-1 (2008), as especificações de desempenho são definidas como:

Conjunto de requisitos e critérios de desempenho estabelecido para o edifício ou seus sistemas. As especificações de desempenho são uma expressão das funções exigidas do edifício ou de seus sistemas e que correspondem a um uso claramente definido.

A relação entre o uso e o desempenho esperado é relevante para a análise, em função das alterações de parâmetros dos requisitos e critérios de desempenho. Ou seja, o uso do edifício irá trazer parâmetros que, associados à verificação dos riscos existentes, promovem maior rigor na avaliação dos critérios de desempenho.

Cabe ressaltar que os critérios de desempenho referem-se aos atributos esperados de um edifício avaliados de forma quantitativa ou facilmente mensuráveis por meio de premissas de projetos, enquanto que os requisitos de desempenho referem-se às condições esperadas de um edifício e de seus sistemas, expressos de forma qualitativa, sendo que ambos visam atender às exigências dos usuários.

Sobre as exigências dos usuários, a NBR 15.575-1 (2008) as organiza em três grupos, sendo eles:

- Segurança: segurança estrutural; segurança contra o fogo; segurança no uso e na operação.

- Habitabilidade: estanqueidade; conforto térmico; conforto acústico; conforto lumínico; saúde, higiene e qualidade do ar; funcionalidade e acessibilidade; conforto tátil e antropodinâmico. 
- Sustentabilidade: durabilidade ${ }^{11}$; manutenabilidade ${ }^{12}$; impacto ambiental.

Baseado nessa lista de exigências ou necessidades do usuário é possível extrair uma extensa lista de requisitos de desempenho, cada qual com seus critérios específicos, o que dificulta a análise de desempenho técnico-construtivo de edifícios, devido à falta de objetividade. Dessa forma, é importante limitar os requisitos e critérios, em função do uso da edificação em análise. $O$ uso aqui se torna base para análise, tanto que a norma brasileira de desempenho, na sua primeira versão de 2008 (ABNT NBR 15.575:2008) ${ }^{13}$, trata apenas de edifícios habitacionais de até cinco pavimentos, mesmo assim, a conceituação trabalhada na norma tem ampla abrangência e pode ser usada como base para a interpretação dos requisitos de desempenho de outras tipologias funcionais de edificações.

De forma sintética, a reportagem "Vale o desempenho: Nova norma deve ser um marco na construção, mas o atendimento requer mecanismos de gestão da qualidade de projetos e execução, além de rigor nas compras", por Luciana Tamaki para a Revista Téchne (maio, 2010) apresenta a tabela intitulada "Requisitos básicos da norma de desempenho - Resumo" (ver Tabela 1).

A NBR 15.575 define três níveis de desempenho: Mínimo (M), Intermediário (I) e Superior (S), sendo que todos os requisitos devem ser atendidos, ao menos, no nível mínimo.

11 Durabilidade, conforme a NBR 15.575-1 (ASSOCIAÇÃO BRASILEIRA DE NORMAS TÉCNICAS, 2008), é a capacidade do edifício ou de seus sistemas de desempenhar suas funções, ao longo do tempo e sob condições de uso e manutenção especificadas, até um estado limite de utilização.

12 Manutenabilidade refere-se ao grau de facilidade de um sistema, elemento ou componente em ser mantido ou recolocado no estado no qual pode executar suas funções requeridas, sob condições de uso especificadas, quando a manutenção é executada sobre condições determinadas, procedimentos e meios prescritos, conforme NBR 15.575-1 (2008). Note-se que, tanto a definição de durabilidade, quanto a de manutenabilidade, contemplam a necessidade da manutenção efetiva.

${ }^{13}$ A norma brasileira NBR 15.575, Associação Brasileira de Normas Técnicas, encontra-se em revisão, devendo ter, alguns de seus trechos, nova redação. A previsão é a de que a Norma de Desempenho revisada passará a ser exigida a partir de março de 2013. 


\section{Requisitos Básicos da Norma de Desempenho - Resumo}

$\begin{array}{lll}\text { Desempenho } & \square \text { projeto deve prever que os estados limites de serviço não causem } \\ \text { Estrutura } & \begin{array}{l}\text { O } \\ \text { prejuízos a outros elementos de construção. O manual do proprietário deve } \\ \text { conter informações acerca de sobrecargas. }\end{array}\end{array}$
Os conceitos se dirigem para a baixa probabilidade de incêndio, alta

Segurança contra incêndio

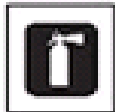

\section{Segurança no Uso} e na Operação

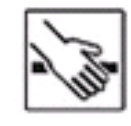
probabilidade de os usuários sobreviverem sem sofrer qualquer tipo de injúria, e reduzida extensão de danos à propriedade e vizinhança imediata ao local de origem do incêndio. A maior parte dos critérios segue normas prescritivas já existentes, e os métodos de avaliação, em sua maioria, baseiam-se em análise de projeto.

Os sistemas não devem apresentar rupturas, instabilizações, partes cortantes ou perfurantes, deformações ou defeitos acima dos limites especificados nas demais partes da Norma. Sobre segurança das instalações, deve-se evitar a ocorrência a ferimentos aos usuários, atendendo-se às normas prescritas pertinentes.

Os requisitos e métodos de avaliação estão especificados em cada parte pertinente da Norma, Fontes de umidade externa, por exemplo, aparecem nas partes de Pisos Internos, Vedações e Coberturas. Sobre fontes de umidade internas à edificação, a Norma determina que devem ser verificados em projeto os detalhes pertinentes que assegurem a estanqueidade, como as vinculações entre instalações de água, esgoto e caixas d'água com estrutura, piso e paredes.

Desempenho
Térmico 棌离

Ambientes de permanência prolongada (sala, dormitório) devem apresentar condições melhores que a externa, ou seja, temperatura igual ou inferior à externa, no verão.

Os limites sonoros e o método de avaliação de fontes externas de ruído são

Desempenho

Acústico

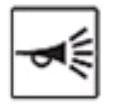

apontados em norma correspondente (NBR 10.152). Sobre isolação acústica entre ambientes internos, cada parte da norma especifica os critérios e métodos de avaliação para cada sistema.

A Norma trata tanto da iluminação natural como da artificial. O iluminamento

Desempenho

Luminoso

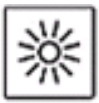
geral mínimo para luz natural deve ser de pelo menos 60 lux, e, para luz artificial, pelo menos 100 lux ou 50 lux em corredores, escadarias e garagens.

A Norma indica os prazos de Vida Útil de Projeto (VUP) e orienta para os prazos de garantia. Um mesmo sistema (ou elemento, componente,

Durabilidade e Manutenibilidade (5) instalação) tem prazos de garantia variados quanto a ocorrências diferentes. Para revestimentos de paredes, por exemplo, a garantia indicada é de três anos para estanqueidade das fachadas e dois anos para ocorrência de fissuras.

As exigências de salubridade são estabelecidas por regulamento da Anvisa

Saúde, Higiene e Qualidade do $\mathrm{Ar}$ (Agência Nacional de Vigilância Sanitária). No geral, deve-se evitar a proliferação de micro-organismos e limitar os poluentes na atmosfera interna de acordo com as normas e resoluções da Anvisa. 


\begin{tabular}{|c|c|}
\hline $\begin{array}{l}\text { Funcionabilidade e } \\
\text { Acessibilidade }\end{array}$ & $\begin{array}{l}\text { A norma define as medidas mínimas de mobiliário e espaço de circulação. } \\
\text { Sobre a adequação a portadores de deficiência, a Norma enuncia que deve- } \\
\text { se seguir os critérios da ABNT NBR 9.050. No caso de ampliação da } \\
\text { unidade habitacional, o incorporador, ou construtor deve incluir no Manual } \\
\text { de Uso e Manutenção do usuário os detalhes construtivos necessários, de } \\
\text { forma que a construção ampliada mantenha pelo menos os mesmo níveis } \\
\text { de desempenho que a construção original. }\end{array}$ \\
\hline $\begin{array}{l}\text { Conforto Tátil e } \\
\text { Antropodinâmico }\end{array}$ & $\begin{array}{l}\text { As partes da edificação não devem apresentar rugosidades, contundências } \\
\text { ou outras irregularidades que possam prejudicar o caminhar, apoiar, limpar, } \\
\text { brincar e demais atividades normais. Quanto a dispositivos de manobra, } \\
\text { como portas, janelas, torneiras, a força necessária para seu acionamento } \\
\text { não deve exceder } 10 \mathrm{~N} \text { e seu torque não deve exceder } 20 \mathrm{Nm} \text {. }\end{array}$ \\
\hline $\begin{array}{l}\text { Adequação } \\
\text { Ambiental }\end{array}$ & $\begin{array}{l}\text { De forma geral, os empreendimentos devem ser projetados e construídos } \\
\text { visando ao mínimo de interferência no meio. Devem ser considerados riscos } \\
\text { de desconfinamento de solo, enchentes, erosão, entre outros. Deve-se } \\
\text { privilegiar a utilização de materiais que causem menor impacto ambiental, } \\
\text { madeiras certificadas, implementar sistema de gestão de resíduos, } \\
\text { possibilitar o reuso da água, minimizar o consumo de energia, entre outras } \\
\text { recomendações. }\end{array}$ \\
\hline
\end{tabular}

Tabela 1 - Requisitos básicos da norma de desempenho - resumo.

Fonte: Reportagem "Vale o desempenho", por Luciana Tamaki, para a Revista Téchne, maio de 2010, edição 158.

Tratando da conceituação do campo disciplinar a que o desempenho das edificações pertence, cabe ressaltar as diferenças entre a análise e a avaliação do mesmo. A análise do desempenho é aplicável às edificações e se refere à apreciação ou crítica dos sistemas do edifício em estudo, feitas a partir de vistoria, com a detecção de falhas, reconhecimento dos atuais padrões de uso e das reais condições do entorno, ou seja, a edificação é examinada sistemicamente, porém, do ponto de visto qualitativo quanto ao atendimento das necessidades dos usuários. Já a avaliação do desempenho determina se as soluções de projeto atendem objetivamente aos critérios e níveis de desempenho, aos padrões de uso e às condições do entorno, previamente conhecidos. Trabalha com dados mensuráveis, definidos por normas técnicas, de métodos e procedimentos de cálculo, dimensionamento ou de ensaios, com resultados confiáveis e verificáveis por terceiros.

Para esse trabalho, a análise foi julgada como de maior interesse por apresentar a qualificação de valores, especialmente porque permite incorporar a verificação dos riscos e a priorização das ações. 
Uma das contribuições significativas da análise de desempenho é a visão sistêmica aplicada ao entendimento da edificação. A visão da edificação como um sistema, empresta conceitos da Teoria Geral dos Sistemas (BERTALANFFY, 2006) ${ }^{14}$, onde é possível compreender o todo (sistema) a partir do entendimento de cada uma de suas partes (elementos) e da relação que essas partes guardam entre si. A edificação aqui pode ser vista como um sistema que, segundo Bertalanffy, é definido por três características principais: (a) cada sistema existe dentro de outro sistema maior; (b) por consequência, todo o sistema é aberto e mantem uma troca contínua com os sistemas contíguos e com o entorno; (c) as funções do sistema dependem da sua estrutura.

Da primeira característica decorre que a edificação é composta por outros sistemas que, para efeito prático na arquitetura, são definidos em um total de dez:

- Terrapleno: terreno ou substrato onde a edificação é implantada, incluindo as condições de escoamento das águas pluviais, paisagismo, circulação e acesso ao edifício);

- Fundação: infra e mesoestrutura;

- Estrutura: supraestrutura;

- Cobertura: estrutura de suporte, revestimento (telhas, placas) e elementos de drenagem;

- Vedos: abrangendo as vedações verticais internas e externas (paredes) e horizontais (forros);

- Vãos: esquadrias (portas e janelas) externas e internas;

- Paramentos: condicionamento das superfícies, revestimentos de vedos verticais e horizontais, pinturas de vedos e de caixilhos;

- Pavimentos: base e revestimento dos pisos;

- Instalações eletromecânicas: instalações elétricas, telefônicas, antenas, dados, bombas de recalque ou drenagem, equipamentos para transporte vertical e para condicionamento térmico dos ambientes internos;

- Instalações hidrossanitárias: instalações de água fria e quente, esgoto, águas pluviais, prevenção e combate a incêndio e gás combustível e fluídos diversos, para edifícios com usos específicos.

\footnotetext{
${ }^{14}$ A Teoria Geral dos Sistemas surgiu a partir dos trabalhos de Ludwig von Bertalanffy publicados entre 1950 e 1968. Esta corrente, à qual pertenciam outros estudiosos na época, propõe teorias e formulações conceituais aplicáveis à realidade em vários campos disciplinares.
} 
A segunda característica reforça a importância do conhecimento das relações entre os sistemas da edificação, bem como das condições do local de implantação (intemperismo, fatores de degradação comentados anteriormente e as próprias ações antrópicas, ou seja, as ações do usuário).

A terceira característica ressalta o significado do conhecimento da estrutura de cada sistema (estrutura, cobertura etc) para a análise do desempenho da edificação, ou seja, do seu comportamento em uso. 


\subsection{PROCEDIMENTOS METODOLÓGICOS}

Os procedimentos metodológicos, aqui descritos, resultam da aplicação dos princípios da norma ISO $6.241(1984)^{15}$, dos conceitos da norma de desempenho nacional ABNT NBR15.575 (2008) e do trabalho de Simões (2004).

O método da análise do desempenho contempla etapas que auxiliam 0 entendimento global do edifício.

A análise é iniciada com o detalhamento objetivo da edificação com a elaboração da sua ficha técnica, contendo as informações relevantes sobre os projetos e as condições de execução da obra. Na ficha técnica são registrados os autores e responsáveis pelos projetos, pela execução e fiscalização das obras, sua localização, área construída, uso inicial e alterações de uso, quando for o caso, situações legais relativas ao loteamento, zoneamento, uso e ocupação do solo, além das informações específicas julgadas relevantes para o edifício em estudo.

Após o registro da ficha técnica, aspectos históricos são pesquisados e registrados. As condições que motivaram a construção do edifício, bem como a filosofia dos projetos do mesmo e sua representatividade no período histórico são relacionados. Da motivação inicial do projeto até o uso atual, as modificações e alterações significativas devem ser registradas, especialmente as alterações de uso.

As características físicas do edifício também compõem a análise sistêmica. A análise das características físicas inicia-se com o entendimento do partido arquitetônico e do programa de necessidades, como também das condições finais do projeto de arquitetura e das condições de seu detalhamento. Os aspectos formais e funcionais, como o número de pavimentos e as necessidades expressas dos espaços e ambientes, devem ser registrados. A escolha dos materiais e técnicas construtivas, o relato das intervenções relevantes, assim como a frequência ou não das ações rotineiras de cuidados com o edifício deve ser relatado.

A análise de desempenho relaciona as características técnicas dos materiais, técnicas e tecnologias utilizadas nos sistemas do edifício. É feito o levantamento das falhas do edifício que afetam o usuário, direta ou indiretamente. O levantamento é

15 international ORganization fOR StANDARDZATION (ISO) ISO6241. Performance standards in buildings: principles for their preparation and factors to be considered. London: ISO, 1984. 
realizado através de vistorias técnicas ao edifício, levantamento fotográfico e entrevistas com as pessoas que administram e zelam pelo patrimônio em análise. Esse levantamento deve ser feito, preferencialmente, por profissionais habilitados e capacitados na prática de projetos, execução e acompanhamento de obras, de forma sistemática, visando trazer resultados confiáveis.

Após o levantamento das falhas, é necessário organizar toda informação técnica coletada, visando verificar a qualidade desses sistemas em relação às necessidades e exigências dos usuários e requisitos de desempenho.

A organização dos dados permite ainda a reflexão sobre a origem das falhas, verificando se as mesmas foram originadas por deficiências ou inadequações do projeto, problemas na execução da obra, qualidade dos materiais ou ainda falta de manutenção programada. Esses resultados são de interesse específico para a realimentação dos processos de projeto, obra ou mesmo de manutenção predial.

A partir dos resultados obtidos é possível determinar os itens críticos que interferem no desempenho de cada sistema do edifício, indicando quais os reflexos, positivos ou negativos, que cada falha resulta nos requisitos de desempenho (ver Tabela 1). Dependendo da significância e gravidade dos reflexos é possível estabelecer as prioridades para as ações de intervenção imediata, como também organizar as ações de manutenção preventiva. 


\subsection{A ANÁLISE DE DESEMPENHO COMO FERRAMENTA PARA SISTEMATIZAÇÃO DA MANUTENÇÃO}

A prática do método da análise do desempenho capacita o arquiteto para uma abordagem sistêmica do processo de construção predial, o que deve resultar no uso dessas ferramentas para os estudos de novos projetos.

Além de realimentar as discussões de projeto, a análise de desempenho visa fornecer elementos que permitam a organização das ações de manutenção predial, visto ser essa uma prática, por vezes, negligenciada.

O programa de manutenção deveria ser traçado durante os estudos dos projetos, tornando-se uma diretriz para as definições dos materiais e técnicas empregados nos sistemas. Entretanto, as ações de manutenção, principalmente nos edifícios públicos, ainda têm caráter corretivo e de grande abrangência, deixando de se tornar uma ação de manutenção para se enquadrar como reformas, ou pequenas reformas. Mas essa é uma situação que tende a mudanças, como é comentado na introdução da norma NBR 5674 (1999) ${ }^{16}$ :

\footnotetext{
A manutenção de edificações é um tema cuja importância tem crescido no setor da construção civil, superando, gradualmente, a cultura de se pensar o processo de construção limitado até o momento quando a edificação é entregue e entra em uso.
}

A manutenção programada visa manter as condições de desempenho dos sistemas do edifício, devendo ser elaborada para essa finalidade, não podendo contar com ações desconectadas, pontuais e inconsequentes. A sistematização da manutenção mantém a visão global do edifício, permitindo que as ações sejam comprometidas com o entendimento do patrimônio.

A NBR 5674 (1999) chama a atenção para verdades relacionadas ao valor das edificações:

É inviável sob o ponto de vista econômico e inaceitável sob o ponto de vista ambiental considerar as edificações como produtos descartáveis, passíveis da simples substituição por novas construções quando seu desempenho atinge níveis inferiores ao exigido pelos seus usuários. Isto exige que se

${ }^{16}$ ASSOCIAÇÃO BRASILEIRA DE NORMAS TÉCNICAS - ABNT. Manutenção de edificações Procedimento. NBR 5674. Rio de Janeiro: ABNT. 6p. 1999. 
tenha em conta a manutenção das edificações existentes, e mesmo as novas edificações construídas, tão logo colocadas em uso, agregam-se ao estoque de edificações a ser mantido em condições adequadas para atender as exigências dos seus usuários.

Quando o edifício possui, além dos valores econômicos e ambientais, os valores culturais, éticos e científicos, torna-se ainda mais relevante a necessidade da programação da manutenção predial, visando a preservação do patrimônio.

O sistema de manutenção deve considerar as características do edifício ou do complexo de edificações em análise. Segundo a NBR 5674 (1999), as características relevantes são: o uso, tamanho e complexidade funcional das edificações, número e dispersão geográfica, relações especiais de vizinhança e implicações de entorno. Sendo que esse sistema de manutenção deve ser guiado por diretrizes que definam:
a) padrões de operação que assegurem a preservação do desempenho e do valor das edificações ao longo do tempo;
b) fluxo de informações entre os diversos intervenientes do sistema, incluindo instrumentos para comunicação com o proprietário e os usuários; e
c) atribuições, responsabilidades e autonomia de decisão dos intervenientes. (NBR 5674, 1999).

Os padrões de operação são estabelecidos considerando-se o desempenho mínimo aceitável, o prazo entre a observação da falha e a realização da manutenção, as condições aplicáveis pela legislação vigente e as condições econômicas disponíveis para manter o edifício, sendo que deve ser facilitada e organizada tanto a comunicação entre os responsáveis pelas ações, como os limites entre as responsabilidades.

O sistema de manutenção deve ser organizado de forma a operar em três diferentes instâncias: manutenção rotineira, manutenção programada e manutenção não planejada.

A manutenção rotineira deve contar com material e pessoal permanente à disposição no imóvel, trata-se de serviços simples que, assim que identificados, podem e devem ser realizados. O limite da manutenção rotineira deve ser préestabelecido e suas diretrizes devem ser absolutamente claras, inclusive o pessoal disponível para essas atividades de manutenção rotineira devem receber treinamento adequado, observando as normas específicas de segurança do trabalho. 
A manutenção programada leva em conta a durabilidade dos materiais e sistemas. É programada a partir da vida útil dos elementos e dos relatórios de vistoria periódica. Os serviços são contratados e o material necessário deve ser orçado com antecedência, visando sua compra e entrega, de acordo com o planejamento da execução dos serviços de manutenção.

A manutenção não planejada caracteriza-se pelos serviços não programados e que não constam das rotinas. Está incluso nesse item os serviços emergenciais, que visam manter o uso seguro das edificações. Com a implantação do sistema de manutenção, é desejável que a manutenção não planejada seja, se não eliminada, reduzida ao mínimo possível, visto que gera custos e mobilizações não esperadas, que, por vezes, não contam com o tempo necessário para as pesquisas que motivam a contratação e compra ideal para a realização dos serviços.

O sistema de manutenção deve ser organizado sobre uma estrutura documental, ou seja, além de contar com uma base de dados, o sistema deve ser alimentado com relatórios de vistorias rotineiras e registros dos serviços executados.

7.2 A estrutura de documentação e registros deve conter:

a) manual de operação, uso e manutenção das edificações, incluindo desenhos arquitetônicos e de engenharia, projetos de sistemas de segurança e proteção das edificações, memoriais de cálculo, memoriais descritivos e especificações como construído e suas atualizações por intervenções posteriores;

b) registro de serviços de manutenção realizados, classificados pela natureza ou componente da edificação, contendo a documentação da tomada de preços, propostas técnicas e relatórios de fiscalização da execução, que demonstrem custos e tempo de execução de cada serviço;

c) registro de reclamações e solicitações dos usuários;

d) relatórios das inspeções;

e) acervo de normas e procedimentos padronizados para serviços de manutenção;

f) programas de manutenção para as edificações e seus equipamentos, com destaque para os aspectos relativos à higiene, saúde e segurança dos usuários. (NBR 5674, 1999).

Os relatórios devem seguir modelos definidos de forma a facilitar o registro, a documentação e a recuperação das informações. Dessa forma, o registro do problema observado não permanece como uma informação estática, antes tem seu direcionamente determinado, onde a situação já é avaliada: se deve ser tratada como manutenção emergencial ou se está dentro dos parâmetros do programa de manutenção planejada. 
A implantação de um sistema de manutenção inicia-se com o seu projeto. De forma ideal, o projeto de manutenção deve ser elaborado juntamente com o projeto arquitetônico e os demais projetos do edifício. Entretanto, a manutenção ainda não é considerada um dos projetos complementares, então, o projeto de manutenção pode ser feito com o edifício em uso. Para tanto, a análise de desempenho técnicoconstrutivo e da qualidade do edifício torna-se uma ferramenta de grande auxílio, visto que contém a análise sistêmica do edifício, com registros do seu histórico, características físicas, etc.; conta ainda com a análise de desempenho em contrapartida com a qualidade das construções, onde as falhas construtivas são relacionadas e organizadas; e, por fim, trabalha a análise das necessidades e exigências dos usuários e requisitos de desempenho, qualificando os dados relacionados, o que confere uma excelente base para o traçado das diretrizes de manutenção planejada.

É importante salientar que o sistema de operacionalização da manutenção predial é traçado a partir do projeto de manutenção, que conta com os registros textuais e gráficos, como qualquer outro projeto predial. A partir do entendimento da vida útil de projeto e vida útil residual, torna-se possível projetar as ações de manutenção. A vida útil de projeto refere-se ao período de tempo, estimado em projeto, onde os componentes ou sistemas construtivos atendem a todos os critérios de desempenho previstos na norma. Sendo ser imprescindível que os mesmos sejam aplicados, utilizados e mantidos de acordo com as especificações do fornecedor e que as condições de exposição inicial permaneçam. A vida útil residual representa o período, após a vida útil de projeto, onde o elemento apresenta decréscimo continuado do desempenho, em função do uso e do envelhecimento natural. Na vida útil residual são necessárias ações de manutenções e, por vezes, ações de reformas mais abrangentes, visando manter níveis adequados de conforto, segurança, saúde e higiene.

O maior ganho do sistema de manutenção é a garantia do desempenho do edifício, além da otimização dos recursos financeiros e humanos empenhados. 



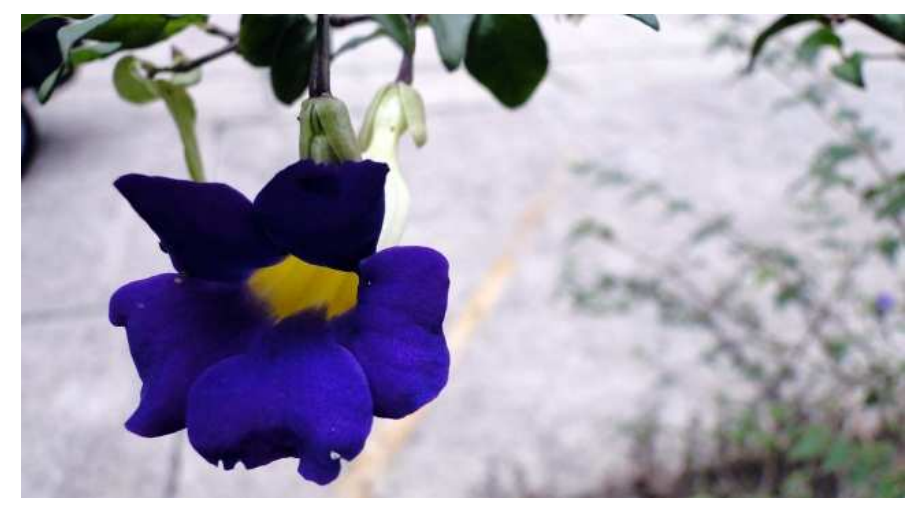

Figura 3 - Uma das flores do Jardim da Vila Penteado Foto: Isis Roverso, agosto de 2011.

CAPÍTULO 2: 



\title{
2. A ANÁLISE DO DESEMPENHO TÉCNICO-CONSTRUTIVO APLICADA À PRESERVAÇÃO PATRIMONIAL
}

\author{
Base Teórica para Diretrizes e Operacionalização da Manutenção \\ Predial Destinada ao Patrimônio Arquitetônico
}

Ao fundamentar a base teórica dos campos disciplinares do restauro, da avaliação de desempenho técnico-construtivo e da qualidade de edifícios, é possível obter critérios e requisitos que congregam valores dos dois campos do conhecimento, permitindo traçar diretrizes para a operacionalização da manutenção predial destinada ao patrimônio arquitetônico.

Esse segundo capítulo dessa dissertação discorre sobre os princípios que fundamentam o campo da preservação e restauro hoje no Brasil; relatando aspectos históricos de forma pontual, através de alguns nomes que construíram a história da preservação.

Dentre as cartas, convenções, recomendações e tratados elaborados pelo o International Council on Monuments and Sites (ICOMOS; Conselho Internacional de Monumentos e Sítios), órgão criado em 1965 e acolhido como consultor e de colaboração, pela Organização das Nações Unidas para a Educação, a Ciência e a Cultura (UNESCO), é destacada a Carta de Veneza (fruto do II Congresso Internacional de Arquitetos e de Técnicos de Monumentos Históricos, realizado em Veneza de 25 a 31 de maio de 1964) e, de divulgação do Ministério da Instrução Pública da Itália, é selecionada a Carta de Restauro (1972). Esses documentos são aqui apresentados por permanecerem atuais e refletirem as intenções de reuniões científicas internacionais, trazendo reais contribuições para a análise das questões referentes à preservação do patrimônio arquitetônico.

A Carta de Veneza não é normativa e sim indicativa e é um documento internacional, de princípios gerais sobre a teoria crítica do restauro, sendo considerado o documento-base do ICOMOS. Nenhuma outra carta foi feita ou aprovada para substituir a Carta de Veneza, porque seus princípios continuam perfeitamente válidos para o trato atual de obras de interesse para a preservação. Após a Carta de Veneza foram formulados outros documentos com o intuito de integrar e aprofundar os conceitos já apresentados na Carta de Veneza. Esses documentos são as seguintes cartas, adotadas pela Assembléia geral do ICOMOS: 
Carta dos jardins históricos (Carta de Florença), 1981; Carta internacional para a salvaguarda de cidades históricas (Carta de Washington), 1987; Carta internacional do patrimônio arqueológico, 1990; Carta internacional sobre a proteção e gestão do patrimônio cultural subaquático, 1996; Carta internacional do turismo cultural, 1999; Princípios a seguir para a conservação de estruturas históricas de madeira, 1999; Carta do patrimônio construído vernacular, 1999; Carta de princípios para a análise, conservação e restauração de estruturas do patrimônio arquitetônico, 2003; Carta para a preservação e a conservação-restauração de pinturas murais, 2003; Carta dos itinerários culturais, 2008; Carta para a interpretação e a apresentação de sítios culturais patrimoniais, $2008^{17}$.

Já a Carta de Restauro é a interpretação normativa dos princípios da Carta de Veneza e se aplicam à Itália, mas como se trata de uma interpretação conceituada, o seu estudo é relevante e apresenta uma leitura direcionada.

O conteúdo da Carta de Veneza, que traz informações baseadas no conceito de "restauro crítico" e da Teoria Brandiana, e o conteúdo da Carta do Restauro são comentados amplamente, sendo que alguns conceitos podem ser destacados, tais como o fato de que a restauração é um ato de cultura além de ser um ato crítico e criativo; o que colabora para a eficácia da análise de desempenho dirigida a preservação patrimonial; afinal, estabelecendo uma atitude crítica e reflexiva, o método de análise do desempenho de edifícios pode ser avaliado segundo as bases do campo disciplinar do restauro.

${ }^{17}$ Lista de documentos disponível em <http://www.international.icomos.org/chartes.htm>, consultada em 19 dez. 2011. 


\subsection{BASES HISTÓRICAS}

O campo da preservação abrange diversas ações, que vão desde os registros documentais dos monumentos até as ações práticas de intervenção, sendo que essas ações incorporaram a escala da manutenção, da conservação e do restauro, como apontados pela Carta de Veneza.

O texto "Restauração hoje: método, projeto e criatividade", de Beatriz Kühl, baseado na Carta de Veneza, traz esclarecimentos precisos. Preservação, no Brasil, é o termo mais abrangente, que abarca métodos e procedimentos de intervenção nos bens, incluindo a manutenção, a conservação e a restauração. Já a manutenção designa as ações cotidianas e periódicas, que tem por objetivo resolver os problemas assim que surgem. Na manutenção os trabalhos devem ser feitos por analogia, optando por formas e materiais iguais ou semelhantes aos originais. A conservação implica em manutenção permanente e objetiva manter o estado existente do monumento histórico. Já a restauração adquire um caráter excepcional, designando intervenção de maior envergadura, onde se deve operar através da distinguibilidade.

Apesar das definições citadas e amparadas por documentos de validade internacional, dependendo do país de origem, os conceitos se desencontram, e tratando especificamente do Brasil, é possível citar definições equivocadas em documentos legais:

RESTAURO OU RESTAURAÇÃO: recuperação de edificação tombada ou preservada, de modo a restituir-lhe as características originais. ${ }^{18}$

O que é restauração? A restauração é um conjunto de atividades que visa a restabelecer o estado original ou próximo deste e anterior aos danos decorrentes da ação do tempo, ou do próprio homem em intervenções que descaracterizam um bem imóvel ou móvel. A restauração visa a garantir a permanência de um testemunho físico e real de época passada para gerações futuras. Os processos de restauração são orientados por posturas consolidadas em cartas patrimoniais. ${ }^{19}$

${ }^{18}$ BRASIL. Lei № 11.228, de 25 de junho de 1992. Dispõe sobre as regras gerais e específicas a serem obedecidas no projeto, licenciamento, execução, manutenção e utilização de obras e edificações, dentro dos limites dos imóveis revoga a Lei no 8.266, de 20 de junho de 1975, com as alterações adotadas por leis posteriores, e dá outras providências. Regulamentada pelo DM 32.329/92

${ }^{19}$ GHIRARDELLO, Nilson; SPISSO, Beatriz (Coord.). CARTILHA Patrimônio histórico: como e por que preservar. Bauru: Canal 6, 2008. 
Como definições atuais podem ainda trazer conceitos como "retorno ao original"? Desde quando é possível retornar ao passado, ou melhor, estabelecer precisamente a configuração original de uma obra? E o valor de antigo? As marcas de envelhecimento configuram-se num problema ou conferem valor à obra?

A trajetória da preservação ainda tem diversas questões a enfrentar, mas em retrospecto é verificável um longo processo histórico, iniciando-se no renascimento italiano. Esse processo já passou por um amadurecimento de pelo menos cinco séculos. No século $\mathrm{XV}$, houve o início de indícios de mudança de atuação em relação à restauração das obras arquitetônicas relevantes. No final do século XVIII, a restauração consolida-se como ação cultural. Conceitos como: "não induzir o observador ao engano", são apresentados no campo da arqueologia. O século XIX presenciou experiências sistemáticas de intervenções práticas, como formulações teóricas e legislativas e sistematização do conhecimento. Aqui é possível citar Eugène Emmanuel Viollet-le-Duc (francês, 1814-1879), que deu grande importância aos estudos pormenorizados do edifício e Camillo Boito (italiano, 1836-1914), que dizia não aceitar "nem acréscimos, nem supressões" e ainda considerava possível certas incongruências em função da disciplina da restauração não ser um assunto finalizado.

Viollet-le-Duc consolidou suas teorias sobre a restauração no que se conhece como "restauração estilística", que prega a busca da unidade estilística e formal, idealizando um modelo de "pureza" formal. Na "restauração estilística" o restaurador tinha a liberdade de efetuar completamentos ou reparos de acordo com a sua interpretação da obra como original. Viollet-le-Duc concebeu um sistema teórico ideal que relacionava os elementos da forma, estrutura e função, buscando a lógica da concepção do projeto e proporcionou a formação de um modelo base para seus projetos de intervenção e restauração. Justificava dizendo que: "restaurar um edifício não é mantê-lo, repará-lo ou refazê-lo, é restabelecê-lo em um estado que pode não ter existido nunca em um dado momento" (VIOLLET-LE-DUC, 2000, p.29). Não raramente como resultado, a intervenção gerava obras diferentes da original, onde a alteração, tanto formal como nos materiais empregados, era uma constante.

Hoje o legado que Viollet-le-Duc deixou refere-se ao primor da documentação das obras, principalmente em relação à metodologia de projeto, com a apresentação da importância dos levantamentos detalhados do edifício e atuação baseada em 
circunstâncias particulares a cada projeto. Como teórico teve muito a contribuir, apesar de que na prática o resultado mostrou-se equivocado.

No século XIX, houve na Itália um verdadeiro campo de teste: idéias antagônicas conviviam num mesmo período e, para contrapor os ideais de Viollet-leDuc, temos os de Ruskin. John Ruskin (inglês, 1818-1900) pensava de maneira oposta a Viollet-le-Duc, visto que acreditava ser necessário manter as marcas do tempo. "A restauração é a destruição do edifício, é como tentar ressuscitar os mortos. É melhor manter uma ruína do que restaurá-la" (RUSKIN). A melhor forma de destruir um monumento é restaurá-lo, segundo pensava Ruskin. A restauração leva a adulteração da história.

Sintetizando aspectos da teoria de Viollet-le-Duc e Ruskin, o texto "Os restauradores", apresentado na Conferência feita na Exposição de Turim, em 1884, identifica e diferencia os termos "restauração" e "conservação", dando um sentido de confronto entre ambos. Contudo, em relação a obras arquitetônicas, Boito discorda de Ruskin e Viollet-le-Duc: do primeiro, por não aceitar a morte certa dos monumentos e do segundo, por considerar as alterações e complementações como ações arbitrárias.

No final do século XIX, o conceito de "não induzir o observador ao engano" foi apresentado à arquitetura.

Baseado nos postulados de Boito, Gustavo Giovannoni (italiano, 1873-1947) marcou o restauro da primeira metade do século XX, foi um dos precursores do restauro científico e da necessidade de preservar as cidades históricas. No mesmo período, Alois Riegl (austríaco, 1858-1905), propõe o inventário e classificação como formas de auxílio à preservação e não apenas ao tombamento. Riegl questiona o valor artístico das obras, dizendo que é passível de mudança de acordo com o momento histórico, então, analisa as obras de acordo com o valor de antigo (mínimo de sessenta anos).

No século XX, a restauração constitui-se como campo disciplinar autônomo a partir do texto de Riegl, "O culto moderno dos monumentos" (1903). Nesse texto Riegl estabelece os princípios para a preservação histórica, com base nos valores dos monumentos, sendo eles: valor de antiguidade, valor histórico, valor de rememoração intencional, valor de uso, valor de arte relativo e valor de novidade.

Em 1916, o texto panfletário "Catecismo da Preservação de Monumentos", de Max Dvořák (austríaco nascido tcheco, 1874-1921), de leitura acessível, caráter 
informativo e abrangente, leva questões e reflexões sobre o patrimônio histórico as pessoas comuns. Como contribuição a área de preservação, Dvořák desenvolve o conceito de relação do monumento com seu entorno e dá base às discussões sobre conjuntos patrimoniais e suas relações com a paisagem.

Nos anos de 1940, alguns textos de grande relevância, que se mantêm atuais, são escritos por Cesare Brandi, Roberto Pane, Renato Bonelli e Paul Philippot.

Cesare Brandi (italiano, 1906-1988), em A Teoria da Restauração (1963), texto fundamental sobre restauração, defende o caráter multidisciplinar do restauro, visando eliminar as arbitrariedades e ainda conceitua a restauração como atividade filológica em ato (1954): "a restauração constitui o momento metodológico de reconhecimento da obra de arte, na sua consistência física e na sua dúplice polaridade: estética e histórica, com vistas à sua transmissão para o futuro". ${ }^{20}$

Sobre a teoria de Brandi, alguns conceitos, que se traduzem em princípios teórico-metodológicos, são estabelecidos: a distinguibilidade, a reversibilidade (que para a arquitetura é mais coerente o termo retrabalhabilidade), mínima intervenção e compatibilidade dos materiais. Sobre a substituição do termo reversibilidade por retrabalhabilidade, na arquitetura é mais coerente permitir ou facilitar futuras intervenções do que pensar em reverter ações, ou seja, as obras de preservação não devem "engessar" o monumento histórico, devem antes permitir a continuidade das ações que mantém seu estado de conservação. Esclarecendo, com a objetividade de Kühl (2011):

A ação deve ter em vista alguns princípios, pensados de forma concomitante e não excludente: Distinguibilidade: pois a restauração (que é vinculada às ciências históricas), não propõe o tempo como reversível e não pode induzir o observador ao engano de confundir a intervenção ou eventuais acréscimos com o que existia anteriormente, além de dever documentar a si própria; Reversibilidade, que mais recentemente tem sido enunciada, de modo mais preciso, como "re-trabalhabilidade", pois a restauração não deve impedir, tem, antes, de facilitar qualquer intervenção futura e, portanto, não pode alterar a obra em sua substância, devendo-se inserir com propriedade e de modo respeitoso em relação ao preexistente, de forma a não impedir ou inviabilizar intervenções futuras que se façam necessárias; Mínima intervenção: pois não se pode desnaturar o documento histórico nem a obra como imagem figurada, respeitando suas estratificações; Compatibilidade de técnicas e materiais, pois é necessário levar em conta a consistência física da obra, com a aplicação de técnicas

${ }^{20}$ BRANDI, Cesare. A Teoria da Restauração. Cotia: Ateliê Editorial, 2004, p.30. 
compatíveis, que não sejam nocivas e que tenham eficácia comprovada através de muitos anos de experiência. ${ }^{21}$

Hoje há discussões sobre a aplicabilidade da teoria de Brandi às obras arquitetônicas, entretanto, essa é uma afirmação infundada.

\footnotetext{
Se estivesse superado, significaria que os conceitos presentes nas formulações de Brandi não mais podem ser repensados para as circunstâncias atuais, tornando-se inoperantes - algo que a reflexão teórica e a atuação prática, hoje, negam (KÜHL, 2009, p.98).
}

O entendimento do restauro, segundo Brandi, articula teoria e prática de intervenções, preservando a obra e seus aspectos de conformação e documento histórico. É esse o conceito também adotado pela vertente "crítico-conservativa", que prega a conservação de forma prudente, intervindo na obra de forma criativa e respeitosa, com fundamentos no juízo histórico-crítico.

Atualmente na Itália, país que guarda um longo período de análise e reflexão sobre a preservação, é possível verificar três segmentos de pensamento, sendo eles: "crítico-conservativo e criativo", como denomina Carbonara, ou "posição central", nas palavras de Gaetano Miarelli Mariani; "pura-conservação" ou "conservação integral", que privilegia as questões históricas e condena as ações de conservação e restauração; e seu oposto "manutenção-repristinação" ou "hipermanutenção", que propõe o cuidado intensivo da obra, através de manutenções ou integrações constantes. ${ }^{22}$

No caso brasileiro, o início do século XX vê demolições e transformações de obras significativas por todo o país. Com a justificativa de abertura de avenidas para o progresso, ou ainda de alterar o estilo das fachadas para o eclético, que se adequava aos novos padrões, diversas atrocidades foram cometidas com legítimas construções históricas. E as intervenções arbitrárias não foram exclusivas dos primeiros anos de 1900, hoje ainda vemos exemplos claros da falta de análise e entendimento do significado do patrimônio arquitetônico, falta de adequação com as técnicas e falta de percepção da gramática arquitetônica. Caminhamos em estudos,

${ }^{21}$ KÜHL, Beatriz Mugayar. Seminário de Estudos sobre Restauração Arquitetônica: "Técnicas Analíticas e de Diognóstico de Bens Culturais: Experiências Italianas Recentes". Revista do programa de pós-graduação em arquitetura e urbanismo da FAUUSP. São Paulo: FAUUSP, 2011, n. 29, p. 198-224.

22 KÜHL, Beatriz Mugayar. Preservação do Patrimônio Arquitetônico da Industrialização. Problemas teóricos de restauro. Cotia: Ateliê/ FAPESP, 2009, p.81 a 100. 
mas a teoria ainda se vê distante da prática, falta critérios para as intervenções ou, nas palavras de Beatriz Kühl (2009, p.100), "quando se analisam os principais escritos sobre preservação no Brasil, constata-se que raramente os problemas de critérios de intervenção são abordados."

A preservação pode ser definida como um ato de cultura e deve ser ditada por aspectos estéticos, históricos, memoriais e simbólicos. Dentre os documentos de referência existentes, é necessário destacar as cartas patrimoniais, entretanto, cabem algumas considerações: as cartas patrimoniais são fruto da discussão de um determinado momento e tem um papel claro que é indicativo, oferecendo orientações gerais. Sua importância é indiscutível, mas dentre as várias cartas há inclusive incoerências e até contradições. É de suma importância entender o período histórico e as circunstâncias que levaram a redação das cartas e só então entender que elas não podem e não devem ser colocadas num mesmo plano. As cartas não devem ser usadas para justificar ações, elas devem orientar a reflexão teórica e crítica que propicie o debate dos aspectos teórico-metodológicos e técnicooperacionais da restauração, a fim de que os projetos de preservação sejam munidos do seu princípio imutável, que é a salvaguarda do monumento histórico.

Dentre as cartas, a Carta de Veneza (1964) e a Carta de Restauro (1972) devem ser destacadas. A Carta de Veneza é selecionada aqui por ser um documento internacional e, portanto, indicativo, que carrega orientações mantidas atualmente pelo ICOMOS e como o CPC (órgão da USP responsável pelo patrimônio da mesma) é membro do ICOMOS, as ações nos edifícios da USP devem ser guiadas pela Carta de Veneza, o que indica que os estudos voltados ao Palacete Vila Penteado, imóvel de propriedade da Faculdade de Arquitetura e Urbanismo da Universidade de São Paulo (FAUUSP) e estudo de caso dessa dissertação, devem ser norteados pela mesma. A Carta de Restauro deve ser destacada por apresentar conteúdo normativo e ser coerente com a Carta de Veneza. 


\subsubsection{CARTA DE VENEZA 1964}

A Carta de Veneza foi redigida em maio de 1964, como resultado do II Congresso Internacional de Arquitetos e Técnicos dos Monumentos Históricos, ICOMOS - Conselho Internacional de Monumentos e Sítios. Trata-se de uma carta internacional sobre conservação e restauração de monumentos e sítios.

A Carta de Veneza traz informações que reforçam o conceito de "restauro crítico" e da Teoria Brandiana. Inicia-se trazendo o conceito de "testemunhos vivos" para as obras monumentais, o que significa que esses estão presentes na vida das pessoas e estão relacionados, de alguma forma, tanto às pessoas, como ao sítio e à cidade. Essa carta, assim como as demais cartas internacionais, traz parâmetros formulados no âmbito internacional, possuindo caráter indicativo, dessa forma, cabe a cada país aplicar as suas indicações, conforme legislação e cultura próprias, formulando normas e instrumentos específicos.

A Carta de Veneza baseia-se na Carta de Atenas (1931), no sentido de the conferir o valor devido e a partir dela reexaminar os princípios estabelecidos para se obter um aprofundamento. Segundo a Carta de Veneza, conservação e preservação fazem parte do mesmo processo crítico, diferindo em quantidades, gradação e intensidade, sendo que os princípios fundamentais propostos na Carta devem guiar todas as intervenções.

Os dois primeiros artigos da Carta de Veneza tratam de definições. No artigo primeiro fica claro que a noção de monumento histórico abrange não apenas a obra isolada, como também o sítio e o entorno. A significação não está depositada na grandiosidade da obra e sim em seu valor cultural.

$O$ artigo segundo esclarece que a restauração e conservação constituem um campo disciplinar, que contem processos metodológicos próprios e que contam com todos os campos do saber capazes de contribuir de alguma forma para o entendimento.

O terceiro artigo trabalha a finalidade da conservação e restauração dos monumentos: "visam a salvaguardar tanto a obra de arte quanto o testemunho histórico."23

A questão da conservação é tratada do artigo quarto ao artigo oitavo e traz colocações importantes. A primeira delas encontra-se no artigo quarto: "a

\footnotetext{
${ }^{23}$ Carta de Veneza, Revista do Patrimônio Histórico e Artístico Nacional, 1987, n. 22, p. 106-107.
} 
conservação dos monumentos exige, antes de tudo, manutenção permanente". ${ }^{24} \mathrm{~A}$ falta de manutenção preventiva acaba por deixar a obra num estado onde grandes intervenções são necessárias e as questões de originalidade da obra começam a ser de fato um problema. Com um programa de manutenção eficaz, a manutenção ordinária não passaria de rotina, com a procrastinação dos cuidados básicos com a obra, as complicações na intervenção são aumentadas de forma exponencial. A manutenção de monumentos também faz parte do processo de preservação e como tal deve ser embasada numa análise crítica, que englobe as questões gerais da obra. Entendendo a questão da manutenção, é possível perceber que a mesma é deixada de lado por falta de critérios que a conduza de forma clara, ou seja, a manutenção ordinária é hoje deixada de lado pela falta de entendimento de como executá-la, respeitando os critérios da preservação. Nota-se a falta de instrumentos capazes de contribuir para as ações cotidianas de conservação, devido a quase inexistência de estudos para a confecção de manuais de operacionalização da manutenção programada.

O quinto artigo é um pouco polêmico, mas basta entender o sentido que é dado as afirmações:

A conservação dos monumentos é sempre favorecida por sua destinação a uma função útil à sociedade; tal destinação é, portanto, desejável, mas não pode nem deve alterar a disposição ou a decoração dos edifícios. É somente dentro destes limites que se deve conceber e se pode autorizar as modificações exigidas pela evolução dos usos e costumes. ${ }^{25}$

Aqui o entendimento não deve ser "engessar" e sim não "desnaturar". A idéia não é proibir as alterações e sim as desnaturações. E o limite da intervenção que promove a desnaturação não pode ser definido de forma global, não há limites precisos, porque não é uma ciência exata e sim humana. Cada caso deve ser analisado de forma única, através da busca do apoio no campo interdisciplinar, evitando arbitrariedades. É necessário entender que o uso é um meio para preservar e não uma finalidade em si.

O sexto artigo trata da preservação do sítio, do entorno e não apenas da obra. É um pouco mais abrangente do que a Carta de Atenas. O artigo sétimo apresenta a

\footnotetext{
${ }^{24}$ Carta de Veneza, Revista do Patrimônio Histórico e Artístico Nacional, 1987, n. 22, p. 106-107.

${ }^{25}$ Ibidem.
} 
relação clara das obras com o seu contexto. Não é possível deslocar uma obra sem perder sua relação com a história. A exceção se dá quando é a única alternativa para a salvaguarda da obra. O oitavo artigo se assemelha ao sétimo, mas faz referência a não separação entre os elementos artísticos, seja escultura, pintura ou decoração, e o monumento.

A partir do nono artigo até o décimo terceiro, o tema tratado é a restauração. No artigo nono, há o caráter da restauração:

\begin{abstract}
A restauração é uma operação que deve ter caráter excepcional. Tem por objetivo conservar e revelar os valores estéticos e históricos do monumento e fundamenta-se no respeito ao material original e aos documentos autênticos. (...) A restauração será sempre precedida e acompanhada de um estudo arqueológico e histórico do monumento. ${ }^{26}$
\end{abstract}

É necessário ressaltar os valores estéticos e históricos da matéria como transformada pelo tempo. O limite da restauração deve estar contido antes do início da hipótese, ou seja, não cabem suposições em substituição à documentação aprofundada. No artigo décimo, a Carta de Veneza mostra-se mais prudente com relação às novas técnicas usadas em intervenções, visto ser necessária a comprovação da eficácia das mesmas:

Quando as técnicas tradicionais se revelarem inadequadas, a consolidação do monumento pode ser assegurada com o emprego de todas as técnicas modernas de conservação e construção cuja eficácia tenha sido demonstrada por dados científicos e comprovada pela experiência. ${ }^{27}$

O artigo décimo primeiro demonstra respeito à estratificação do tempo e dá abertura a remoção de adições, se o que for retirado apresentar pouco interesse e o que é revelado mostrar "grande valor histórico, arqueológico, ou estético, e seu estado de conservação é considerado satisfatório." ${ }^{28} \mathrm{O}$ conjunto da obra com suas marcas temporais devem ser entendidos e não apenas a construção original.

Os artigos décimo segundo e décimo terceiro afirmam que as modificações devem respeitar o conjunto. Nas ações de consolidação ou pequenos acréscimos, é oportuno o uso das técnicas tradicionais. As ações de manutenção ordinária devem

\footnotetext{
${ }^{26}$ Carta de Veneza, Revista do Patrimônio Histórico e Artístico Nacional, 1987, n. 22, p. 106-107.

${ }^{27}$ Ibidem.

${ }^{28}$ Ibidem.
} 
ser feitas com técnica similar e não devem ser usados materiais distintos a fim de se manter intacta a leitura da obra. Já as ações de restauro devem apresentar a distinguibilidade, sem, no entanto, alterar o equilíbrio da composição e a relação da obra com o sítio.

O artigo décimo quarto trata dos sítios monumentais onde as questões relativas às obras também são aplicáveis aos sítios. É preciso além da salvaguarda de sua integridade, promover sua manutenção e valorização.

O artigo décimo quinto traz um conteúdo próprio às escavações. É oportuno ressaltar o valor das ruínas, que é histórico e, portanto, não cabem reconstruções. As ruínas devem receber intervenções no limite da recomposição de partes existentes que estejam desmembradas e, se houver algum elemento novo de integração, este deve ser reconhecível.

Os trabalhos de escavação devem ser executados de conformidade com padrões científicos e com a "Recomendação Definidora dos Princípios internacionais a serem aplicados em Matéria de Escavações Arqueológicas", adotada pela UNESCO em 1956. ${ }^{29}$

O último artigo expõe elementos sobre a documentação e publicação, reafirmando sua importância, tanto como elemento projetual, como elemento integrante da história, que deve ser depositado em órgão público e sempre que possível publicado, facilitando a pesquisa e o aprofundamento dos estudos dirigidos à área.

Em resumo, o conteúdo da Carta de Veneza é bem razoável: limita as arbitrariedades e abre as possibilidades de intervenções, a partir da análise pautada em método rigoroso. A necessidade da manutenção fica clara, sem cair em extremismos, onde a obra acabe sendo desnaturada pelo exagero das intervenções.

A Carta de Veneza é um instrumento que traz conteúdo adequado à reflexão. Os seus conceitos devem permear as ações projetuais, sobretudo as de caráter rotineiro, evitando-se assim a necessidade de intervenções de maior amplitude.

${ }^{29}$ Carta de Veneza, Revista do Patrimônio Histórico e Artístico Nacional, 1987, n. 22, p. 106-107. 


\title{
2.1.2 CARTA DE RESTAURO 1972
}

A Carta do Restauro foi divulgada em 06 de abril de 1972, pelo Ministério da Instrução Pública da Itália, através da circular número 117 e traz considerações relevantes que também se mantém atuais, apesar de, a partir de numerosos debates, resultarem numa nova carta: Carta 1987, della conservazione e del restauro.

Os princípios da Carta de 1972 continuam válidos, com alguns textos complementares e integrativos, pois o documento incluía, além de preceitos teóricos, alguns procedimentos técnicos considerados ultrapassados na atualidade. Autores como Cordaro, Carbonara e Basile, através de cuidadosa releitura da Carta de 1972, recomendam que se deva ater a seu cerne teórico e remeter a capítulos técnicos que tratem as questões técnicas e operacionais, a ser revistos e atualizados periodicamente. ${ }^{30}$

Os três primeiros artigos da Carta do Restauro englobam os elementos a que à carta se refere. Os elementos são citados de forma abrangente, tanto enquanto objetos, como em relação ao tempo: "todas as obras de arte de qualquer época, na acepção mais ampla". ${ }^{31}$

No artigo quarto há a definição de conservação e restauração:

\begin{abstract}
Entende-se por salvaguarda qualquer medida de conservação que não implique a intervenção direta sobre a obra; entende-se por restauração qualquer intervenção destinada a manter em funcionamento, a facilitar a leitura e a transmitir integralmente ao futuro as obras e os objetos definidos nos artigos precedentes. ${ }^{32}$
\end{abstract}

O quinto artigo pede a elaboração, por parte das superintendências de instituições responsáveis pela conservação do patrimônio, de um programa anual para os trabalhos de salvaguarda e restauração. A intenção é a de documentar e organizar os trabalhos, eliminando falhas e juízos equivocados.

30 KÜHL, Beatriz Mugayar. Preservação do Patrimônio Arquitetônico da Industrialização. Problemas teóricos de restauro. Cotia: Ateliê/ FAPESP, 2009, p.87.

${ }^{31}$ Carta do Restauro (1972), p.1. Disponível em: <http://portal.iphan.gov.br/portal/ montarDetalheConteudo.do?id=12430\&sigla=Legislacao\&retorno=detalheLegislacao >. Acesso em: 10 dez. 2010.

32 Ibidem, p. 1 e 2. 
Os artigos sexto e sétimo trazem restrições e possibilidades da forma de trabalho, visando o respeito à obra e às marcas do tempo, mantendo dessa forma a integridade histórica da obra.

O oitavo artigo trata da retrabalhabilidade das obras e o nono pondera o uso de técnicas e materiais novos nos procedimentos de restauração. $O$ artigo décimo trata das modificações necessárias ao meio ambiente em função da conservação da obra, que devem ser feitas somente quando indispensáveis e de forma discreta. $O$ décimo primeiro artigo remete aos métodos especificados nos anexos e o último artigo esclarece que, em caso de dúvidas, o ministro terá a decisão "a partir dos pareceres dos superintendentes ou chefes de instituições interessados, ouvido o Conselho Superior de Antigüidades e Belas Artes." ${ }^{33}$

Após os artigos, a Carta de Restauro apresenta quatro anexos específicos, sendo eles: Anexo A - Instruções para a salvaguarda e a restauração dos objetos arqueológicos; Anexo B - Instruções para os critérios das restaurações arquitetônicas; Anexo $\mathrm{C}$ - Instruções para a execução de restaurações pictóricas e escultóricas; Anexo D - Instruções para a tutela dos centros históricos.

Uma questão essencial para esse trabalho encontra-se no início do Anexo B:

No pressuposto de que as obras de manutenção realizadas no devido tempo asseguram longa vida aos monumentos, encarece-se o maior cuidado possível na vigilância contínua dos imóveis para a adoção de medidas de caráter preventivo, inclusive para evitar intervenções de maior amplitude. ${ }^{34}$

Sempre é preferível trabalhar com a manutenção preventiva a submeter à obra a uma intervenção brusca. A restauração de uma obra pode ser evitada e, com ela, diversas questões sobre originalidade, limite da desnaturação, entendimento da gramática da obra e seleção das técnicas e materiais apropriados, se a manutenção preventiva se mostrar eficaz. Como primeira grande diretriz que visa à continuidade do desempenho de edifícios preservados, é possível destacar a manutenção e conservação programadas.

\footnotetext{
${ }^{33}$ Carta do Restauro (1972), p.1. Disponível em:

<http://portal.iphan.gov.br/portal/montarDetalheConteudo.do?id=12430\&sigla=Legislacao\&retorno=det alheLegislacao>. Acesso em: 10 dez. 2010, p.4.

${ }^{34}$ Ibidem, p.8.
} 
No Anexo B, a questão da restrição ou alteração do uso surge como instrumento que tem por objetivo assegurar a salvaguarda dos monumentos. $\mathrm{O}$ uso deve ser limitado em função das características essenciais de conservação da obra, mas não deve ser inexistente, visto ser um instrumento adequado que garante a continuidade de vida ao monumento. Ainda sobre o uso, as alterações necessárias ao funcionamento do monumento não devem desnaturar suas características tipológicas, assim como sua organização estrutural.

Com vistas ao projeto de restauro de uma obra, é necessária a realização de análise detalhada sobre o monumento. Essa análise deve ser interdisciplinar e deve abranger a obra, o sítio e seu entorno.

\begin{abstract}
Parte integrante desse estudo serão pesquisas bibliográficas, iconográficas e arquivísticas, etc., para obter todos os dados históricos possíveis. O projeto se baseará em uma completa observação gráfica e fotográfica, interpretada também sob o aspecto metrológico dos traçados reguladores e dos sistemas proporcionais e compreenderá um cuidadoso estudo específico para a verificação das condições de estabilidade. ${ }^{35}$
\end{abstract}

As marcas do tempo devem ser distinguidas dos problemas de manutenção, evitando-se assim eliminar pátinas e outras características do envelhecimento da obra com o argumento da manutenção. Cabe ainda notar que nem todo processo de envelhecimento de materiais diversos promovem sua própria proteção. Muitas vezes o que é considerado marcas do tempo não passam de descuidos de manutenção mascarados, que vão pouco a pouco destruindo os sistemas do edifício. O limite entre a manutenção eficaz e o respeito ao envelhecimento natural da obra é tênue e delicado. Esse limite deve ser determinado para cada obra de forma singular, através da reflexão crítica teórica e do conhecimento técnico aprimorado.

No Anexo C, no subtítulo: Providências a serem efetuadas na execução da intervenção restauradora, os procedimentos de intervenção, inclusive limpeza, são detalhados. O Anexo $\mathrm{D}$, que trata da tutela dos centros históricos, relaciona os principais tipos de intervenção com referência a edifícios:

1. Saneamento estático e higiênico dos edifícios, que atende à manutenção de suas estruturas e a uma utilização equilibrada; essa intervenção se realizará em função das técnicas, das modalidades e das

\footnotetext{
${ }^{35}$ Carta do Restauro (1972), p.1. Disponível em: $<$ http://portal.iphan.gov.br/portal/montarDetalheConteudo.do?id=12430\&sigla=Legislacao\&retorno=det alheLegislacao>. Acesso em: 10 dez. 2010, p.9.
} 
advertências a que se referem as instruções procedentes para a realização de restaurações arquitetônicas. [...].

2. Renovação funcional dos elementos internos, que se há de permitir somente nos casos em que resultar indispensável para efeitos de manutenção em uso do edifício. [...]. ${ }^{36}$

Em ambos os casos é importante ressaltar o respeito à tipologia e aos sistemas construtivos do edifício, ficando limitadas as alterações que possam descaracterizar o mesmo.

Como instrumento de operacionalização dessas intervenções, é destacado:

- planos de desenvolvimento geral, que reestruturem as relações entre o centro histórico e o território e entre o centro histórico e a cidade em seu conjunto;

- planos parciais relativos à reestruturação do centro histórico em seus elementos mais significativos;

- planos de execução setorial, referentes a uma edificação ou a um conjunto de elementos reagrupáveis de forma orgânica. ${ }^{37}$

A Carta de Restauro apresenta diversos pontos semelhantes à Carta de Veneza, demonstrando coerência entre ambas. Também aprofunda alguns temas em seus anexos, tratando questões práticas como em um manual, que devem ser revistas a luz das técnicas e análise atuais. A necessidade de estudos abrangentes que promovam a reflexão sobre o edifício a ser preservado é evidente, assim como a necessidade de caminhar com esses estudos, gerando planos de trabalho que orientem tanto as ações de intervenção imediatas, como as ações de manutenção permanente.

36 Carta do Restauro (1972), p.1. Disponível em: <http://portal.iphan.gov.br/portal/ montarDetalheConteudo.do?id=12430\&sigla=Legislacao\&retorno=detalheLegislacao $>$. Acesso em: 10 dez. 2010, p.18.

${ }^{37}$ Ibidem. 


\subsection{A RESTAURAÇÃO COMO ENTENDIDA HOJE}

O campo da restauração já ponderou sobre diversas questões, sem chegar a um consenso, mas talvez não seja preciso convergir para um ponto em comum, visto que na diversidade há campo propício para a reflexão.

Entretanto, para esse trabalho, alguns conceitos podem ser definidos, tais como: a restauração é um ato de cultura, além de ser um ato crítico e criativo. É necessário estabelecer uma atitude crítica, uma hipótese crítica, "[...] o restauro é ato crítico, voltado ao reconhecimento da obra de arte (sem o que o restauro não é restauro) e necessário para superar a dialética das duas instâncias, a histórica e a

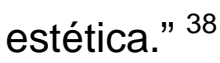

A restauração deve voltar-se à transmissão do bem para as próximas gerações. O restauro antes de se tornar uma questão técnica é um problema metodológico. Cada restauração deve ser analisada de modo singular, onde suas características e particularidades devem ser entendidas, inclusive sua trajetória ao longo do tempo. E com relação ao método, é necessário criar objetividade nas ações através do seu rigor, onde exista eficiência nos processos e afastamento das arbitrariedades.

Algumas diretrizes podem ser destacadas, com a análise dos ideais de Viollet-le-Duc, associada às falhas práticas de sua autoria: não se pode propor a intervenção em uma obra de interesse histórico baseada na visão exclusiva de um profissional. A interdisciplinariedade é algo almejado. Assim como não se pode presumir que as conclusões equacionadas, num determinado período, sejam absolutas. Cada tempo detém características e pensamentos próprios, que podem sofrer alterações com o entendimento da história gerada ao longo de anos.

É de extrema importância notar que a intervenção num bem histórico é pertinente ao momento e não será percebida da mesma forma em outro período histórico. A partir disso, o princípio da reversibilidade, ou melhor, retrabalhabilidade, pode ser introduzido. As intervenções de um dado momento histórico poderão ser questionadas e revistas em outro momento. Não que as intervenções deverão ser removidas ou refeitas, mas é importante haver a possibilidade de continuidade da

${ }^{38}$ CARBONARA, Giovanni. Brandi e a restauração arquitetônica hoje, Desígnio, 2006, n. 6, p. 35-47, p.36. 
análise da obra. Segundo Brandi, a restauração deve facilitar uma intervenção futura, não deve impedi-la. ${ }^{39}$

Outro princípio essencial é o da distinguibilidade. A restauração não propõe o tempo como reversível e, portanto, não é coerente tentar voltar às condições de uma obra como era originalmente. Não é cabível o retorno ao original porque o tempo, o espaço e principalmente as pessoas não voltam ao passado, não pertencem ao passado. E de fato como era essa obra? E qual é a sua essência? Seu valor está simplesmente na sua composição formal, como de origem, ou as marcas do tempo Ihe conferem valor? Qualquer intervenção deve se colocar como tal e não tentar se confundir com a matéria original, falseando a obra. A intervenção não pode induzir o observador ao engano e deve documentar a si própria, afinal, está se incorporando à obra histórica e dessa forma também faz parte da história.

Não se pode alterar a obra em sua substância. As intervenções devem ser inseridas com propriedade e de modo respeitoso. Cabe ressaltar que, nos processos de manutenção ordinária, os elementos a serem substituídos devem ser semelhantes ao original. A mínima intervenção também é um princípio essencial, porque a restauração não deve desnaturar o documento histórico, nem a obra como imagem figurada.

Há ainda o princípio da compatibilidade de técnicas e materiais, onde se deve levar em conta a consistência física do objeto, o tratamento com técnicas compatíveis e não prejudiciais a longo tempo para a obra. Como inserir técnicas e materiais novos, que tem seu comportamento ao longo dos anos incerto, em obras centenárias? É preciso ter a comprovação de sua eficácia, afinal, o patrimônio histórico não é um objeto ordinário, onde testes podem ser executados sem o comprometimento com os resultados.

${ }^{39}$ BRANDI, Cesare. A Teoria da Restauração. Cotia: Ateliê Editorial, 2004, p.48. 


\subsection{A ANÁLISE DO DESEMPENHO APLICADA À RESTAURAÇÃO E A PRESERVAÇÃO PATRIMONIAL}

A partir das questões levantadas, é possível traçar diretrizes de preservação patrimonial, que visam ponderar o método de avaliação de desempenho de edifícios.

Inicialmente, vale destacar que a obra, patrimônio histórico, condiciona a restauração e não o contrário, ou seja, por vezes será necessário determinar limitantes para o edifício, se essa limitação for imprescindível para sua salvaguarda.

Retomando algumas definições já registradas, desempenho é o "comportamento em uso de um produto, frente às condições de exposição" (NBR $15.575)^{40}$. O desempenho de edifícios refere-se às características ou capacidades de rendimento do seu conjunto, ou de suas partes, em especial quando comparados com metas, requisitos ou expectativas. Segundo o método de análise de desempenho, é necessário ter parâmetros (critérios e requisitos) ${ }^{41}$ que possibilitem avaliar o edifício em estudo. No caso de edifícios que fazem parte do patrimônio histórico arquitetônico, esses parâmetros precisam ser reavaliados segundo os critérios já vistos da preservação. A partir da revisão desses critérios e requisitos será possível aplicar o método de avaliação de desempenho a obras sem comprometer o seu reconhecimento.

A diretriz fundamental, para a revisão dos parâmetros, altera o sentido do desempenho, onde a plena funcionalidade do edifício deve ser substituída por sua salvaguarda, para tanto, torna-se necessária à classificação das falhas construtivas constatadas nas inspeções prediais. Essa classificação deve considerar o risco oferecido tanto aos usuários, quanto ao patrimônio.

O método de avaliação de desempenho de edifícios engloba: análise sistêmica; análise de desempenho em contrapartida com a qualidade das

\footnotetext{
${ }^{40}$ A norma ABNT NBR 15.575, constituída por seis partes, estabelece parâmetros que permitem avaliar o desempenho de edificações. A norma foi direcionada a edifícios residenciais de até cinco pavimentos, mas é hoje a referência para avaliação de outros tipos de edifício. A norma define responsabilidades dos agentes envolvidos e traz parâmetros de projeto e especificação.

41 Segundo ABNT NBR 15.575, Requisitos de desempenho: condições que expressam qualitativamente os atributos que o edifício e seus sistemas devem possuir, a fim de que possam satisfazer às exigências do usuário. Critérios de desempenho: especificações quantitativas dos requisitos de desempenho, expressos em termos de quantidades mensuráveis, a fim de que possam ser objetivamente determinados.
} 
construções; as necessidades e exigências dos usuários e requisitos de desempenho.

Trabalhando esse método em paralelo com os conceitos de preservação, uma segunda diretriz pode ser traçada: a análise sistêmica deve ser aprofundada nos aspectos históricos e documentais. Os levantamentos de campo e registros gráficos e fotográficos devem ser ampliados e detalhados. Ou seja, a documentação padrão para a análise de desempenho de edifícios não oferece subsídios para 0 reconhecimento da obra, entendimento da sua gramática e real respeito às marcas do tempo registradas nos materiais, portanto, a primeira etapa do processo, que é a análise sistêmica, torna-se indispensável e absolutamente relevante, para os casos de avaliação de bens arquitetônicos.

A questão da análise de desempenho em contrapartida com a qualidade das construções, também deve ser revista, porque a qualidade das obras preservadas não está em sua plena funcionalidade e boa relação custo-benefício de sua operacionalização. A qualidade dessas obras situa-se no seu valor histórico e cultural, portanto, para cada obra estudada deverá ser destacada sua essência a ser preservada.

As necessidades e exigências dos usuários e requisitos de desempenho deverão ser qualificadas. No caso do método de avaliação de desempenho, as necessidades e exigências dos usuários são exemplificadas pelos requisitos dos usuários, sendo eles: estabilidade; segurança contra fogo; segurança em uso; estanqueidade; higrotermia; pureza do ar; conforto acústico; conforto visual; conforto tátil; conforto antropodinâmico; higiene; conveniência de espaços; durabilidade e economia. É possível manter a avaliação com base nesses requisitos, sendo que cada item deverá ser qualificado e ponderado pelos conceitos da preservação.

Para o controle da avaliação de desempenho, o edifício é desmembrado em sistemas, sendo eles: terrapleno, fundação, estrutura, cobertura, vedos, vãos, paramentos, pavimentos, instalações eletromecânicas e instalações hidrossanitárias. No caso da avaliação ponderada pela preservação, a análise dos sistemas pode ser mantida, sendo que a avaliação final da obra deve tratar da mesma de forma global, para o seu significado não ser diluído ou fragmentado, revelando falhas ou arbitrariedades na avaliação.

Ainda, tratando sobre o método de avaliação de edifícios, reconhecer ou destinar a responsabilidade pelas ocorrências ao projeto, execução da obra, material 
ou manutenção, não é cabível. Isso se justifica pela falta de documentação dos projetos e situação em que foi feita a execução da obra, pelo fato de que muitas das obras históricas já terem seus materiais em uso por tempo superior a sua vida útil, estando em prolongada tentativa de se manter a vida residual e pelo fato de que a manutenção mostra-se precária, num número elevado de casos.

O reconhecimento das responsabilidades pelos problemas de uma obra é relevante, à medida que agrega conhecimento para a busca aprimorada de técnicas e materiais, revisão dos conceitos de projeto e sistematização das operações realizadas na execução da obra e no período de manutenção. No caso de bens patrimoniais, os objetivos maiores não estão na análise, que visa promover a revisão para novos projetos, e sim na análise que gera informação, para o entendimento da obra em questão e base teórica para análise e intervenção em outras obras preservadas. 


\subsection{CONSIDERAÇÕES SOBRE A PRESERVAÇÃO PATRIMONIAL}

Através do estudo dos conceitos da preservação e orientações vindas do campo da tecnologia, onde a avaliação de desempenho é apresentada como ferramenta de análise e diagnóstico de edifícios, uma diretriz mostra-se plena e irrevogável: é necessário buscar a manutenção continuada, evitando-se assim maiores intervenções nas obras.

Para a busca da manutenção programada, torna-se necessário um plano de ação, a partir da análise da obra, com o entendimento do seu significado e de suas características técnicas e formais, do sítio e entorno, dos agentes de degradação, do uso e ocupação da mesma, da verificação e probabilidade de ocorrência de riscos.

Em um projeto de manutenção, destinado a um edifício qualquer, as questões a serem respondidas são as seguintes: Como é possível realizar a manutenção? Como vai ocorrer a degradação? Quais são as consequências? Qual é a evolução das necessidades dos usuários? Em um projeto destinado a um edifício a ser preservado, apenas a última questão precisa ser alterada para: Qual é a evolução das necessidades do edifício?

A relação de proximidade entre a preservação patrimonial e as ações de manutenção são claras em diversos documentos pertinentes e normas, por exemplo, a Norma de Inspeção Predial IBAPE/SP $-2011^{42}$, destaca no seu texto introdutório:

A observação permanente das edificações, o espaço físico de maior relevância na vida do homem urbano, tanto pelo aspecto patrimonial quanto pelas questões relacionadas à segurança e ao conforto, conduz 0 observador ao conceito de preservação e, conseqüentemente, ao tema manutenção.

O projeto de manutenção visa minimizar e simplificar a manutenção, permitindo prolongar a vida e salvaguardar o patrimônio cultural.

\footnotetext{
${ }^{42}$ Instituto Brasileiro de Avaliações e Perícias de Engenharia de São Paulo (IBAPE/SP).
} 


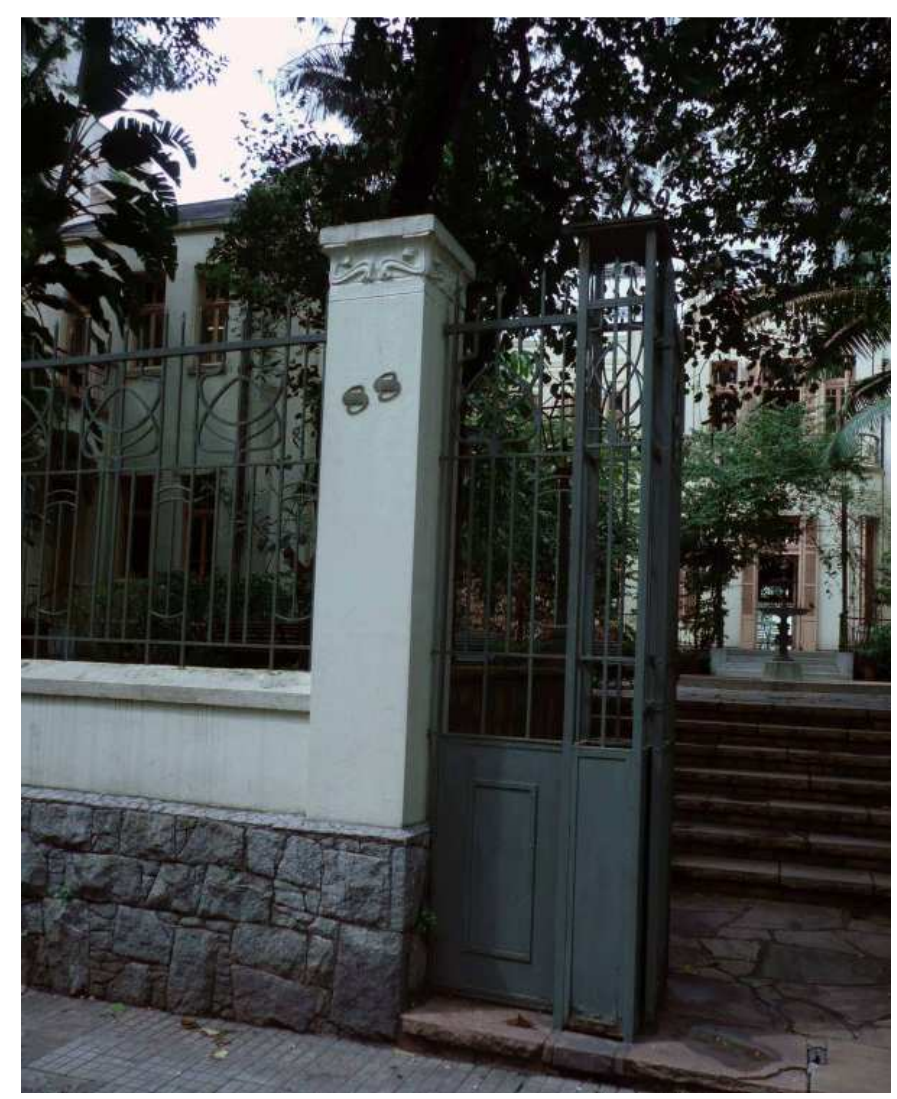

Figura 4 - Número 88: entrada atual da Vila Penteado Foto: Isis Roverso, dezembro de 2010. 



\section{DOCUMENTAÇÃO HISTÓRICA DO EDIFÍCIO VILA PENTEADO}

O terceiro capítulo aborda a pesquisa histórica, cronologia construtiva, levantamento cadastral, documentação gráfica e fotográfica, projetos e ações recentes, ocorridas no edifício Vila Penteado. Apresenta dados históricos e documentais, evidenciando décadas de intenso trabalho, orientações adotadas e decisões tomadas nesse período, como também falhas na continuidade das ações, o que dificulta a manutenção desse bem histórico e cultural.

Um trabalho que deve ser destacado é a publicação de 1976, "Exposição Vila Penteado", fruto do estudo coordenado pela pesquisadora Maria Cecília Naclério Homem Prado e Lucio Gomes Machado. No texto de apresentação dessa publicação, Nestor Goulart Reis Filho, expõe que esse trabalho resultou de dois projetos desenvolvidos na FAUUSP, no período de 1972 a 1976: o primeiro era a constituição de um grupo de profissionais para a realização de projetos culturais e o segundo projeto consistia na obtenção de documentação para compor o processo de tombamento do edifício Vila Penteado no CONDEPHAAT.

Boa parte dos documentos consultados está disponível nas bibliotecas da graduação e da pós-graduação da FAUUSP, sendo que o Setor de Projetos de Arquitetura da Biblioteca da Graduação contém desenhos e documentos importantes, inclusive alguns originais. Do Setor de Projetos é possível destacar os desenhos de levantamento da Vila Penteado, datados do ano de 1984, doados em 1987, pelo Prof. Carlos Lemos. Um trecho desses desenhos é apresentado na figura 5.

Há também estudos e projetos relacionados com a Vila Penteado, como o Projeto Executivo de 2002, que detalha um Anexo para Laboratórios de Restauração/Auditório, junto à divisa dos fundos do terreno da Rua Maranhão, 88, prevendo a ocupação do térreo e subsolo (na figura 6 contém um dos desenhos desse projeto). Ou ainda o Projeto Pré-executivo, de Arquitetura Paisagística (abr. 1996), coordenado pela Prof $^{a}$ Dr $^{a}$ Maria Assunção Ribeiro Franco, com a colaboração dos professores Dr. Silvio Soares Macedo e Wladimir Bartaglini, com desenho de Alessandra Benevides Granja. 


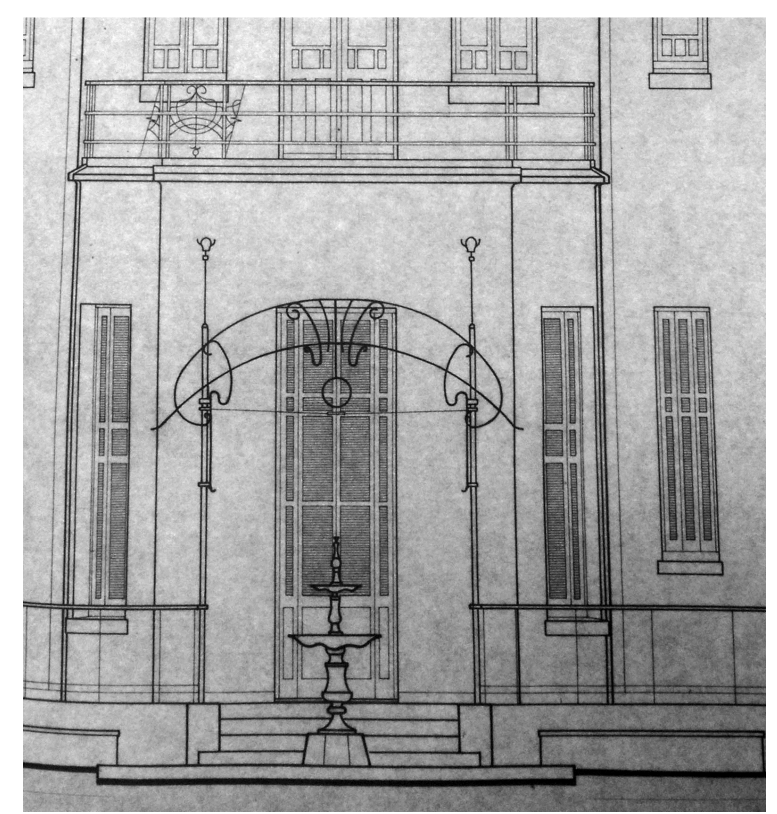

Figura 5 - Trecho do desenho da Fachada Posterior, com destaque para a volumetria do chafariz

Fonte: Projeto Vila Penteado, Rua Maranhão, 88, Fachada Posterior, Folha 07, Desenho Airton, data 16.10.84, escala 1:50, FAUUSP.

Doação Prof. Carlos Lemos, 1987, Seção de Patrimônio P23/257. Fl.10, Biblioteca da Faculdade de Arquitetura e Urbanismo - SP.

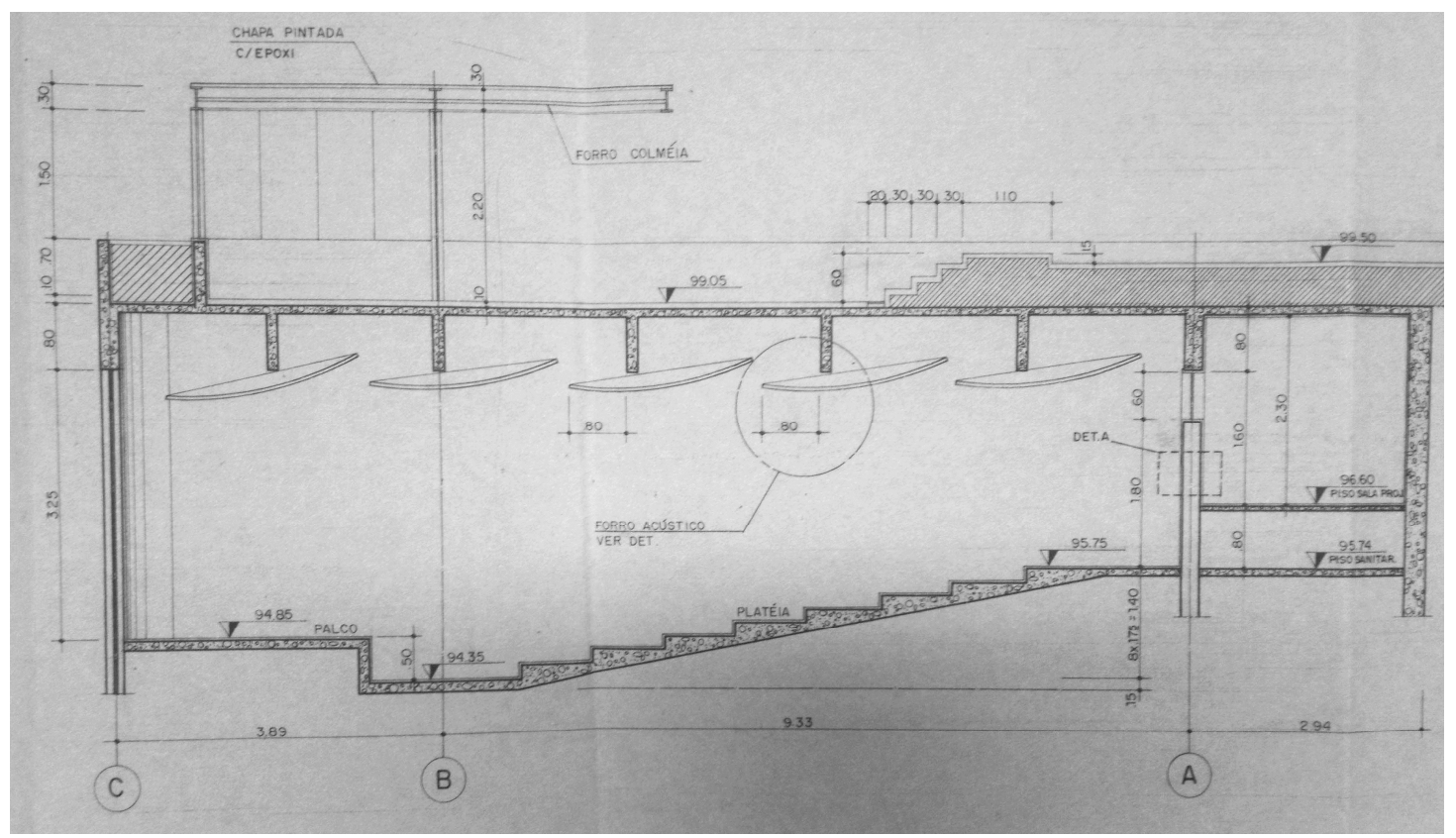

Figura 6 - Corte C.C: Auditório

Fonte: Vila Penteado, Anexo para Laboratórios de Restauração/ Auditório, Projeto Executivo - Arquitetura, Cortes C.C, D.D, E.E, F.F e Detalhes, Folha 06/09, data 03.08.02, escala 1:50, FAUUSP, Fundo de Construção da Universidade de São Paulo, João Walter Toscano Arquiteto Associados.

Outras informações fragmentadas foram reunidas, a partir da leitura de dissertações e teses de alunos da FAUUSP e da Escola Politécnica da USP. Com 
enfoques diversos, esses alunos desenvolveram seus trabalhos tendo como estudo de caso a Vila Penteado. Vale destacar os trabalhos de mestrado da engenheira Claudia Bastos do Nascimento, intitulado "Deterioração de forro em estuque reforçado com ripas vegetais: o caso da Vila Penteado - FAUUSP" (2002) e da arquiteta Silvana Serafino Cambiaghi, com o tema "Desenho universal: métodos e técnicas de ensino na graduação de arquitetos e urbanistas" (2004).

Há ainda documentos não publicados de grande valor, como os arquivos particulares da Prof ${ }^{a}$ Helena Ayoub Silva, onde detalhes dos relatórios de gestão, assim como cópias de tratativas durante as obras executadas puderam ser analisados, especialmente das obras ocorridas entre os anos de 2002 e 2003.

O Grupo Executivo Gestor os Espaços Físicos da FAUUSP (GEEF), conta também com uma grande quantidade de documentos, arquivos, projetos $\mathrm{e}$ desenhos, sendo que boa parte desse material está organizado em arquivos digitais separados por tema e data (ano). Essa organização digital pormenorizada iniciou-se em 2007; alguns arquivos com data anterior também estão disponíveis em formato digital, porém não catalogados (agrupados em pasta única designada "até 2006"). Os processos arquivados e em andamento que se encontram na FAUUSP e na Coordenadoria dos Espaços Físicos da USP (COESF) também puderam ser consultados, através de requerimento aprovado pela diretoria da FAUUSP. 


\subsection{HISTÓRICO}

O Edifício Vila Penteado carrega, não apenas vestígios do passado, como continua construindo sua história. De residência a faculdade de arquitetura, passou por algumas mudanças de layout, porém, mais que isso, não apenas sofreu as transformações da história, como marcou a história de diversas pessoas e da comunidade onde está inserido.

A sua representatividade é singular. Não há como não se surpreender ao entrar pelo seu saguão central e notar as suas dimensões e configurações. A escadaria imponente que abriga o banco introspectivo. A grande altura do salão que induz o olhar do observador aos detalhes do lustre central e do vitral superior. Os balcões e circulações que permitem enquadramentos únicos dos ambientes.

A leitura da gramática da Vila Penteado surpreende: enquanto que suas paredes trazem detalhes que a remetem a uma época passada, esses mesmos detalhes transformam os espaços em ambientes, ou seja, a relação provocada entre a arquitetura e o usuário tende a uma aproximação intimista, que surpreende 0 usuário mais sensível.

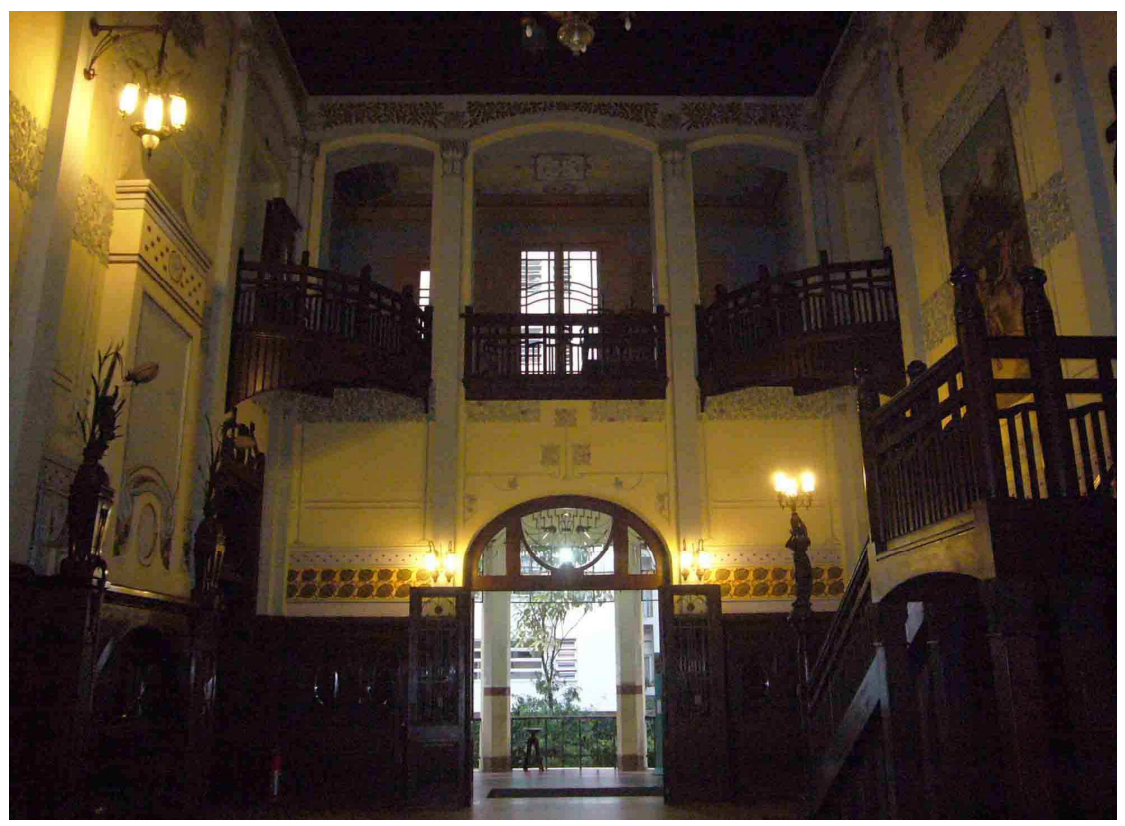

Figura 7 - Saguão da Vila Penteado Foto: Isis Roverso, abril de 2011. 

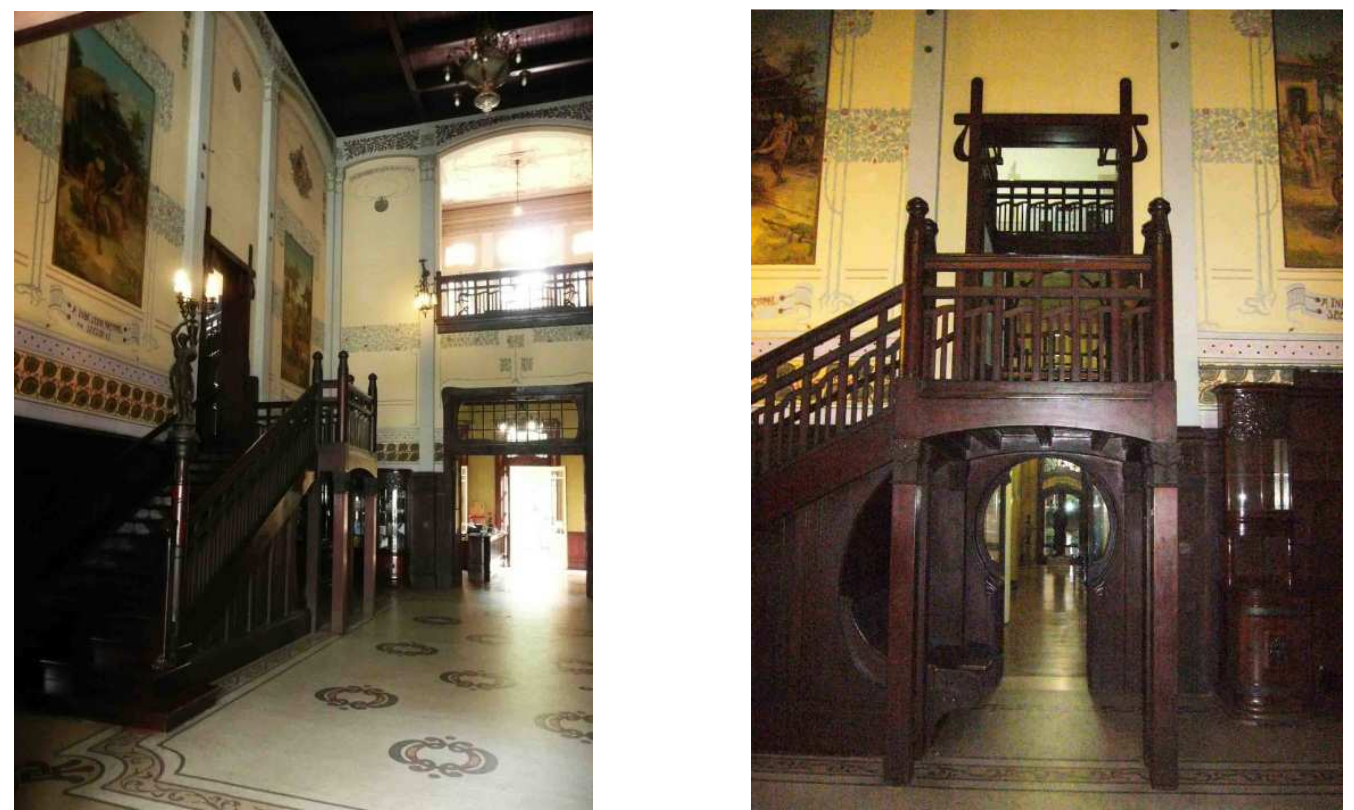

Figura 8 - Saguão da Vila Penteado: escada e banco

Fotos: Isis Roverso, dezembro de 2010 e abril de 2011.

O Edifício Vila Penteado apresenta características marcantes e singulares, reveladas em suas fachadas, pinturas murais e detalhes em metal e madeira. Esses e outros elementos diversos transformam o edifício em obra rara, marca de uma época e de conceitos próprios do estilo art nouveau.

\begin{abstract}
A imponente residência da rua Maranhão também agrega inovação e tradição e insere-se entre os bens culturais ressaltáveis da USP. Atrai, em primeiro lugar, pela materialidade, portando valor estético indiscutível e associado à presença de algumas soluções art-nouveau, tão bem analisadas pelo professor Flávio Motta em clássico estudo. O tema escolhido para decorar a Vila Penteado é simbólico e, em parte, centrado no café, embora hajam outras flores e folhagens. A par disso, o monograma 'AP', identificador do sobrenome familiar, impõe-se no piso da residência e no andar do visitante. (LOURENÇO, 2002).
\end{abstract}

Tanto o conjunto de detalhes, quanto a conformação total do edifício, devem ser registrados, propiciando inicialmente seu entendimento e a seguir permitindo estudos aprofundados que induzam as ações de preservação.

Se sua conformação arquitetônica é algo singular, o desgaste visível que ultrapassa os limites das marcas do tempo e demonstram falta de manutenção preventiva, não é um fato novo, nem tão pouco único. Diversas obras arquitetônicas públicas com valores históricos, culturais e éticos reconhecidos, sofrem com a falta de manutenção programada, o que evidencia o desequilíbrio entre a intenção de preservar a obra e as ações práticas realizadas. 
O Edifício Vila Penteado torna-se mais um exemplo no que diz respeito à falta de manutenção preventiva, mesmo em meio a diversos estudos e obras realizadas. A questão problemática consiste na falta de sistematização das ações, o que torna os resultados dos importantes trabalhos efetuados no edifício, algo fragmentado e, por vezes, ineficiente.

Por sua representatividade consagrada, pelo fato de ser um exemplar que sofre com o duelo entre a passagem do tempo e a falta de uma manutenção programada, e em função da fragmentação de informações e ações, é que o trabalho de documentação do Edifício Vila Penteado justifica-se. 


\subsubsection{O PROPRIETÁRIO: CONDE ANTONIO ÁLVARES PENTEADO}

O Edifício Vila Penteado foi construído entre os anos de 1902 e 1903, sendo que o seu projeto residencial foi apresentado para aprovação municipal em 4 de março de 1902. O projeto foi encomendado pelo Conde Antonio Álvares Penteado, fazendeiro de café e industrial, para o arquiteto sueco Carlos Ekman, formado pela Escola Politécnica de Estocolmo.

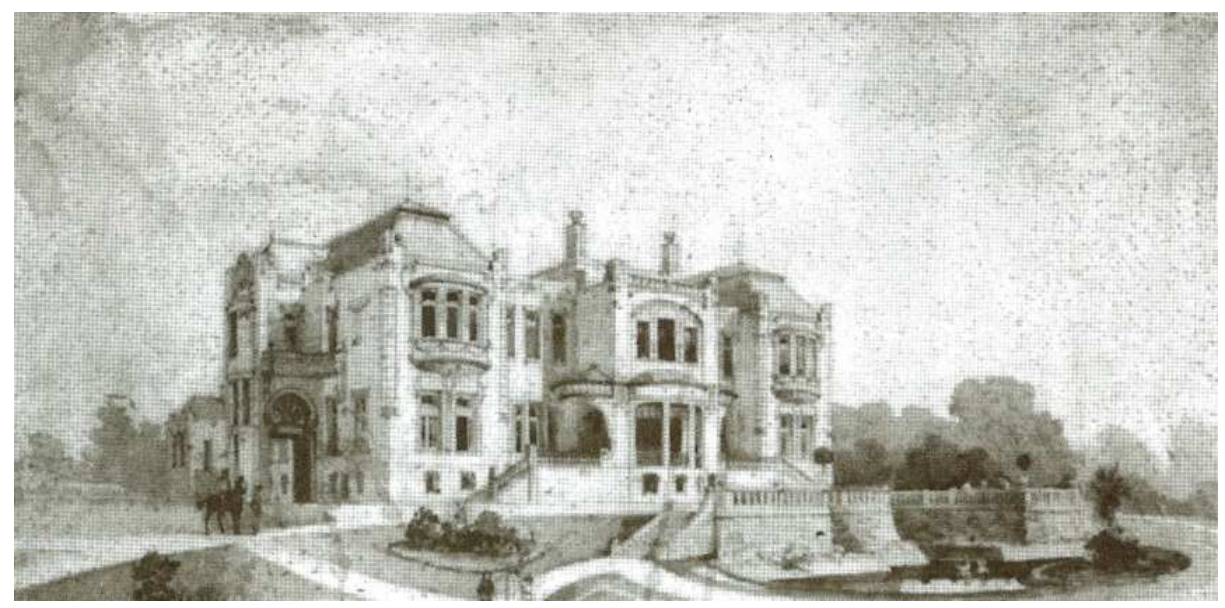

Figura 9 - Vila Penteado, Perspectiva. Aquarela. Arquiteto Carlos Ekman Fonte: Acervo da Biblioteca da FAUUSP (Vila Penteado: registros, p.13).

Antonio Álvares Leite Penteado (1852-1912) descendente de proprietários rurais, nasceu em Mogi Mirim, São Paulo. Chegou a ter setecentos e cinquenta mil pés de café e fundou duas importantes indústrias têxteis, em São Paulo, as Fábricas Santana em 1889 e Penteado, em 1898, no Brás. Em 1900, numa viagem à Europa, pode visitar a Grande Exposição Universal de Paris, onde conheceu um novo estilo, denominado art nouveau. Retornando ao Brasil, decidiu encomendar ao arquiteto Carlos Ekman uma casa com as características desse estilo que o surpreendeu. Em 1901, Carlos Ekman foi contratado para desenvolver o projeto, iniciando a execução da construção dessa residência em 1902.

Álvares Penteado nasceu numa família bem estruturada e iniciou logo cedo seus estudos:

Antonio Álvares Leite Penteado nasceu em Mogi Mirim, em 1852. Era filho de João Carlos Leite Penteado, juiz de direito naquela cidade, e de D. Maria Hygina Alves de Lima. Seu avô, Bernardo José Leite Penteado, fora abastado fazendeiro e gozava de grande prestígio na época em que viveu. Sua primeira esposa, D. Maria Ferreira Penteado, logo faleceu. De seu segundo casamento, com D. Ana Franco de Lacerda, filha dos Barões de 
Araras, teve cinco filhos: Silvio, Antonieta, Eglantina, Stella e Armando, nascidos nos últimos anos do Império. (HOMEM, 1976, p. 58)

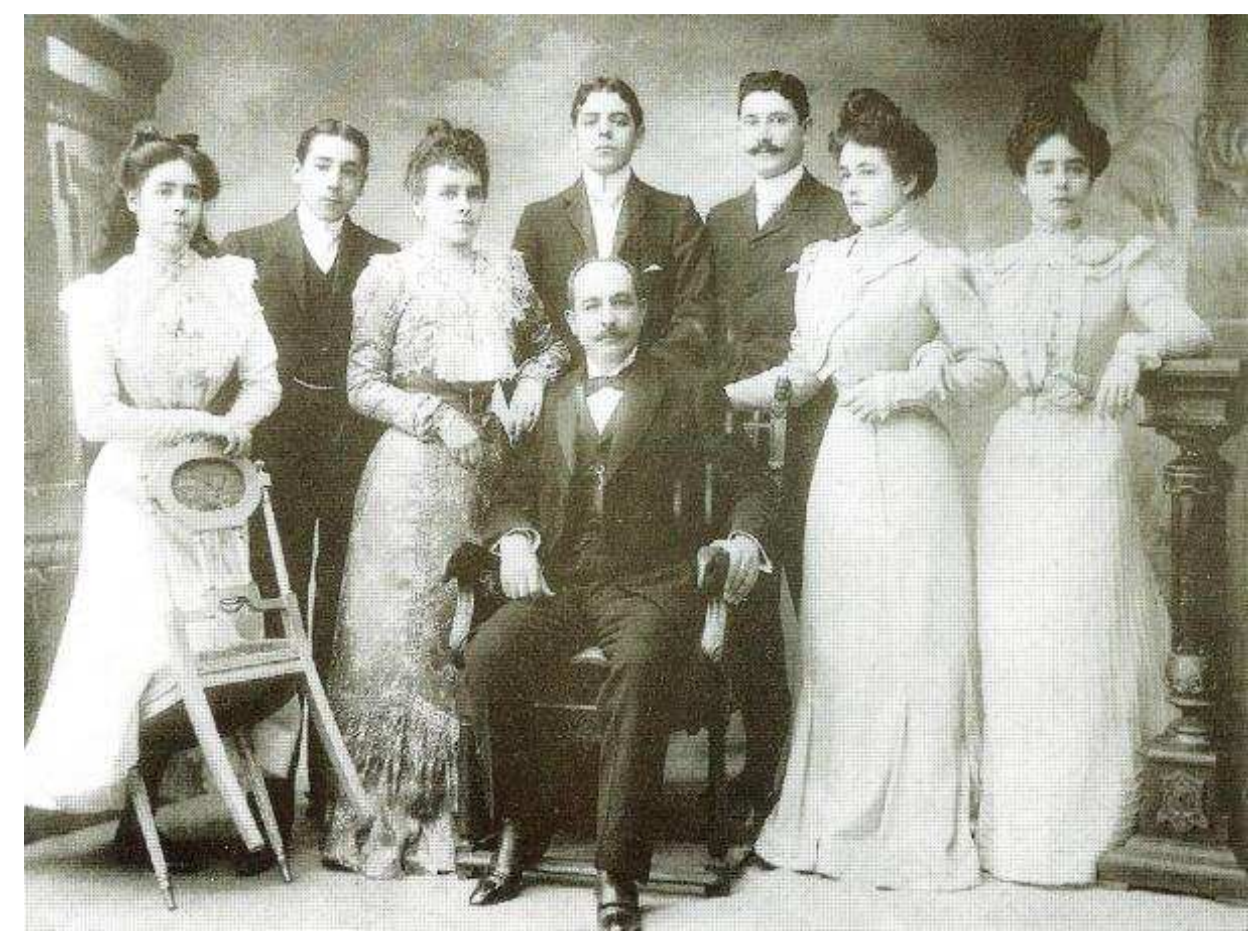

Figura 10 - Antônio Álvares Penteado rodeado por sua família Da esquerda para a direita: Stella e Armando (filhos), dona Ana (esposa), Silvio (filho), Caio Prado (genro), Antonieta e Eglantina (filhas).

Fonte: Arquivo da Biblioteca da FAUUSP.

Ainda jovem, com vinte e cinco anos, Álvares Penteado já elaborava projetos industriais, acreditando no progresso destinado ao Brasil e, de fato, veio a tornar-se um dos pioneiros da indústria nacional. Distinguiu-se, não apenas pelas realizações na área da agricultura e na área industrial, como também pela assistência social que passou a prestar aos operários. Cabe ressaltar que, em suas fazendas, o conde já empregava mão-de-obra assalariada, mesmo antes da promulgação da "Lei Aurea".

Também desenvolveu planos na área educacional, com a criação da escola de comercio em São Paulo, fundando, em 1902, a Escola Prática de Comercio, onde foi diretor honorário.

Possuía uma coleção de quadros, visto ser amante das artes plásticas e do teatro, aliás, mantinha na Rua Boa Vista o Teatro Santana (que, depois de demolido em 1912, foi substituído por novo teatro na Rua 24 de Maio).

Em fevereiro de 1952, motivado pelas comemorações do centenário de nascimento do conde Álvares Penteado, o jornal O Estado de São Paulo divulgou uma matéria que teve por início: 
Vem sendo comemorado nesta Capital com uma serie de cerimônias das quais participam varias instituições, dentre as quais a Escola de Comercio e a Faculdade de Ciências Econômicas da Fundação "Álvares Penteado", a Faculdade de Arquitetura e Urbanismo, a Federação das Indústrias e outras entidades econômicas, o centenário do nascimento do conde Antonio Álvares Leite Penteado, que, por seus empreendimentos, ligou seu nome ao desenvolvimento econômico do Estado, esclarecido lavrador que foi um dos pioneiros da indústria nacional. ${ }^{43}$

Nessa matéria fica clara a participação e influência de Álvares Penteado na história do desenvolvimento de São Paulo. A reportagem comenta ainda, aos sessenta anos de idade, as circunstâncias de sua morte:

Em viagem de recreio, partira, em fins de 1911, para a Europa, sendo, infelizmente, acometido na França por traiçoeira enfermidade que, meses depois, o abatia: faleceu em Paris a 25 de maio de 1912. Seu corpo foi transportado para São Paulo, sendo sepultado no cemitério do Santíssimo Sacramento, pois pertencia à Irmandade. Depois, seus restos mortais foram transladados para o cemitério da Consolação, onde repousam no jazigo da família. ${ }^{44}$

Após o falecimento de Álvares Penteado, a situação da família manteve-se na liderança econômica, devido as suas novas realizações, como bem comenta Maria Cecília Naclério Homem Prado, no texto "Uma família paulista” (Catálogo Exposição Vila Penteado, 1976, p.63):

[...] por volta de 1920, aquela aristocracia rural urbana, devido às crises sucessivas do café, encontrava-se arruinada e perdia seu 'status' social. A família Álvares Penteado manteve-se, porém, na liderança, por suas novas realizações na indústria e no comércio, assim como no campo das artes, do ensino, da construção urbana a até dos esportes, algumas devidas à iniciativa da Condessa D. Ana Álvares Penteado.

${ }^{43}$ O Estado de S. Paulo - Terça-feira, 5 de fevereiro de 1952.

44 Ibidem. 


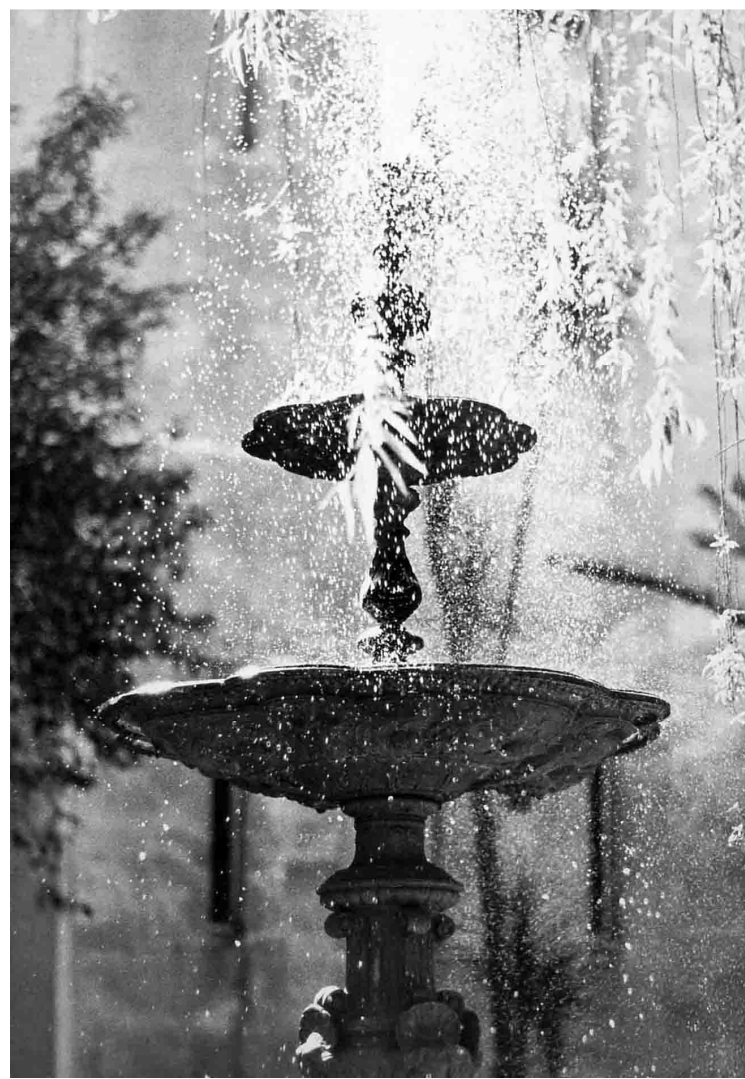

Figura 11 - Chafariz da Vila Penteado em pleno funcionamento Fonte: Foto pertencente ao Trabalho de Graduação Final "Vila Penteado: vida nova em velho prédio", de Alberto de Prado, 1979.

Álvares Penteado e seus descendentes deixaram um legado, e a Vila Penteado faz parte dessa história. 


\title{
3.1.2 O ARQUITETO: CARLOS EKMAN
}

Carlos Ekman, ou Carl Wilhelm Ekman, nasceu em Garvargatan, Estocolmo, Suécia, em 9 de janeiro de 1866 e veio a falecer em Santos, Brasil, em 1940. Era filho do construtor e arquiteto Pehr Johan Ekman, desenvolveu projetos ecléticos, mas se destaca na história da arquitetura brasileira por realizar um estilo novo, o art nouveau, tendo como principal exemplar a Vila Penteado.

$\mathrm{O}$ arquiteto sueco Carlos Ekman e o arquiteto francês Dubugras, foram quem desenvolveram, em São Paulo, nos anos de 1900, a vertente austríaca do Art Nouveau, a Sezession.

O sueco Carlos Ekman forma ao lado do francês Dubugras, entre os que trouxeram a São Paulo experiência mais valiosa. É nítida sua vinculação à corrente austríaca, como se adverte examinando a atual Escola de Comércio, no Largo de São Francisco, ou sabendo que consultava os exemplares do 'Wiener Neubaten Style der Sezession',45. (DAHER, 2002, p. 45).

Se Dubugras foi, por temperamento, um dos mais característicos representantes do 'art nouveau' entre nós, devemos a Carlos Ekman o fato de ter projetado um dos primeiros exemplares do gênero: a 'Vila Penteado', em 1902 [...]. (MOTTA, 1976, p.92).

As características, menos rebuscadas da sezession, denotam também traços do arquiteto que, mesmo projetando em outros estilos, evidenciava o controle e discrição dos detalhes ornamentais.

\begin{abstract}
Era um sueco que via com mais interesse o estilo 'Sezession' austríaco, ao 'art nouveau' francês ou o floreal italiano. O 'Sezession' foi um 'art nouveau' menos rebuscado e com maior preocupação estrutural. [...] A 'Vila', na sua aparência externa, demonstra essa tendência de Ekman para o discreto emprego dos arabescos e das formas florais. Apenas o 'hall' de entrada, central, é fartamente decorado com pinturas de De Servi, Oscar Pereira da Silva (pinturas glorificando a indústria) e ornatos de Paciulli. Lustres, estátuas, lareiras inglesas, muitos trabalhos de ferragem foram importados, inclusive a grande fonte do jardim. Na parte que coube excusivamente a Ekman, a volúpia do arabesco restringia-se. (MOTTA, 1976, p.92).
\end{abstract}

\footnotetext{
${ }^{45}$ Os catálogos 'Wiener Neubauten Style der Sezession' (Neubauten e não Neubaten como consta no texto de Luiz Carlos Daher) apresentavam exemplos fotográficos da arquitetura sezession e design de interiores, incluindo exemplo dos designers mais importantes da época. No Catálogo Exposição Vila Penteado, FAUUSP (1976), há reproduções de algumas páginas do álbum que pertenceu a Carlos Ekman.
} 
Segundo o texto "Ambiente Arquitetônico Sueco na Época do Arquiteto Carlos Ekman", de Ole Peter Reiter (Boletim Técnico número 2, 1993):

\begin{abstract}
Carlos Ekman cresceu durante um período de progresso e aumento populacional em Estocolmo e nas restantes cidades suecas. $\mathrm{O}$ ambiente da família de Carlos Ekman era um ambiente burguês [...].

Carlos Ekman começou seus estudos de arquitetura em Copenhague, capital da Dinamarca, no ano de 1882. Depois da morte de seu pai e da falência de sua firma, voltou para Estocolmo em 1884, onde terminou o curso, 1886. Em Copenhague foi contemporâneo de H. J. Holm, Ludvig Fenger e Martin Nyrop [...].

Quando Carlos Ekman voltou a Estocolmo foi companheiro de Fredrik Liljekvist, Ferdinand Broberg ${ }^{46}$ e Erik Lallerstedt. Liljekvist era o arquiteto do Teatro Dramático de Estocolmo, uma das primeiras construções Art Nouveau, construída de 1901 a 1908, com uma volumosa homogeneidade barroca e superfícies decorativamente trabalhadas. Nos ornamentos interiores usou motivos florais naturalistas. Erik Lallerstedt é conhecido pela influência anglo-saxônica na Art Nouveau, com fachadas muito modeladas, tetos altos e discretos padrões nas paredes.

Entre os contemporâneos de Carlos Ekman, Ferdinand Broberg é o mais conhecido arquiteto do Art Nouveau na Suécia, com suas composições assimétricas e formas de arcadas, ligadas a fachadas livremente criadas e ornamentadas. $\mathrm{O}$ ornamento naturalístico em relevo, que ele desenvolveu, tem ligações com Richardson e Sullivan (Estados Unidos), mas também com a ornamentação espanhola e moura. Broberg era o arquiteto da exposição de Estocolmo, de 1897, o que foi, na verdade, o ponto de partida para o Art Nouveau sueco. Tanto a arquitetura de Lallerstedt como Broberg têm ligação com a Vila Penteado de Carlos Ekman em São Paulo.
\end{abstract}

O Teatro Dramático Real de Estocolmo, The Royal Dramatic Theater ou Kungliga Dramatiska Teatern, citado no texto do Boletim Técnico número 2 (1993), é uma construção simétrica em estilo art nouveau, localizada em Nybroplan, de frente para o mar. Está em pleno funcionamento e recebeu, em 2011, cuidados de manutenção em suas fachadas. Os ornamentos dourados se destacam tanto nos exteriores, quanto nos interiores. O interior é tão grandioso quanto o exterior: paredes com acabamentos em ouro e em mármore, pinturas de teto realizadas por Julius Kronberg (pintor sueco, 1850-1921) e pinturas do átrio de Carl Larsson (pintor sueco, 1853-1919). Os relevos da fachada são de Christian Eriksson (artista e escultor sueco, 1858-1935) e as esculturas do pórtico de entrada de Carl Milles (escultor sueco, 1875-1955).

Segundo "The complete guide to Architecture in Stockholm", o Teatro Dramático Real é um dos poucos edifícios monumentais, em Estocolmo, desenhados em estilo art nouveau.

${ }^{46}$ A grafia correta seria Ferdinand Boberg, e não Broberg, como consta no texto do Boletim Técnico. 

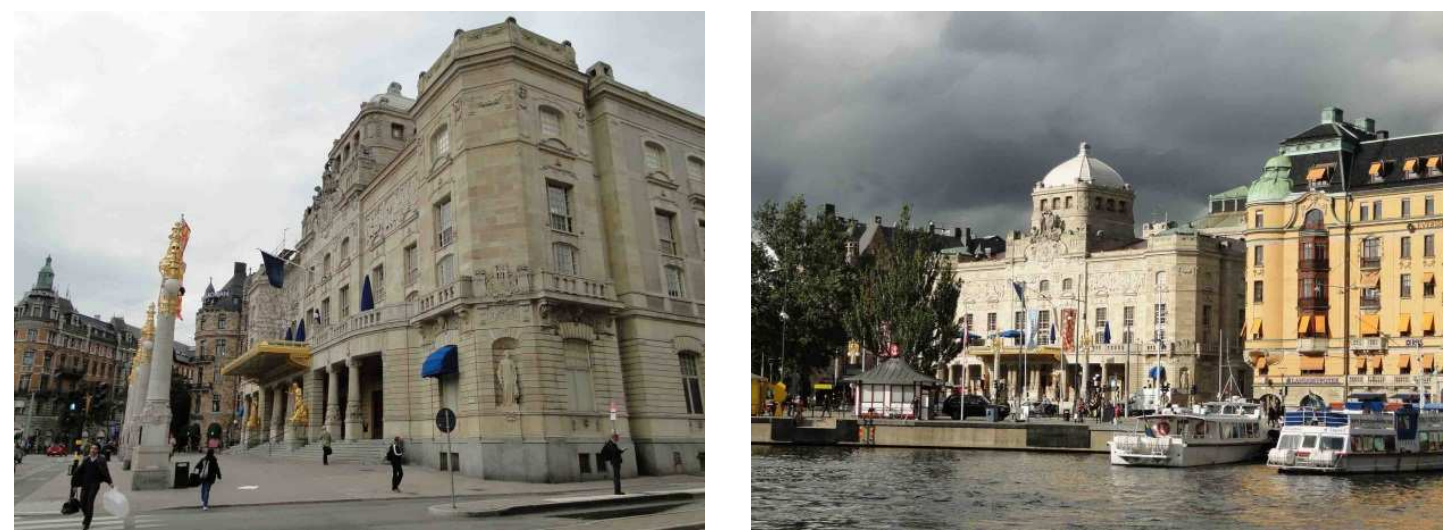

Figura 12 - Fotos externas do Teatro Real Dramático de Estocolmo, projeto do arquiteto sueco Fredrik Lilljekvist, contemporâneo ao arquiteto Carlos Ekman Fotos: Isis Roverso, setembro de 2011.
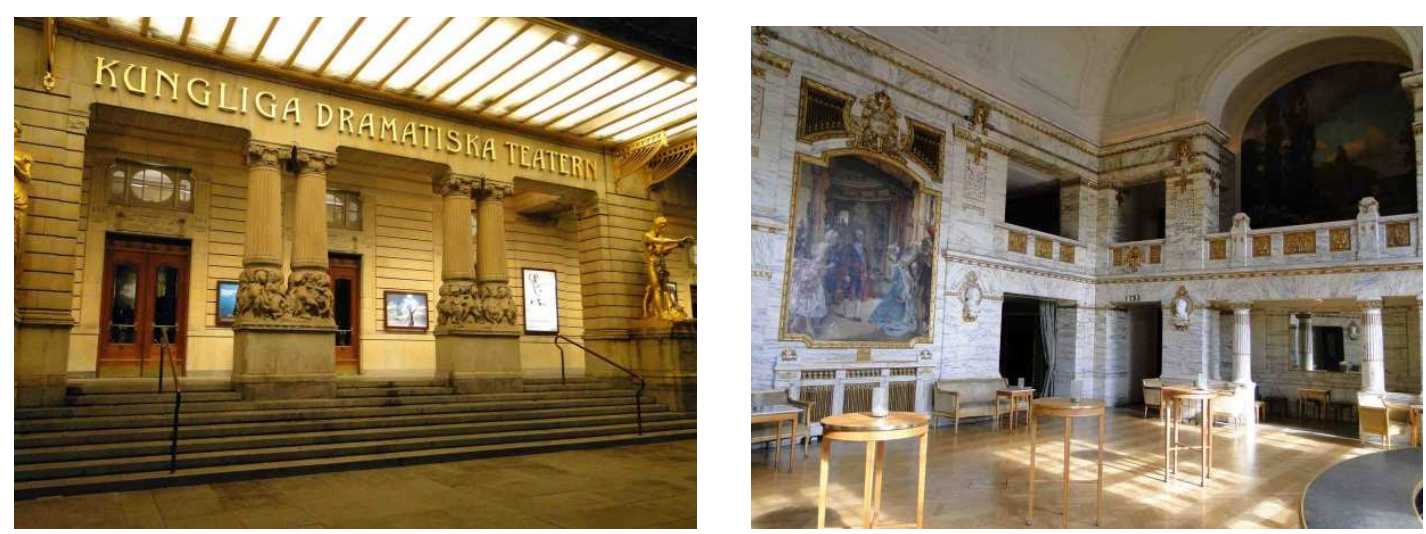

Figura 13 - Foto noturna da entrada e foto interna do Teatro Real Dramático de Estocolmo: uma das primeiras obras ao estilo Art Nouveau

Fotos: Isis Roverso, setembro de 2011.

Carlos Ekman apresentou inclinação às artes desde cedo: "Desde pequeno tive muito gosto pelo desenho e me matriculei na classe de principiantes, curso noturno, na Academia de Belas Artes". (EKMAN, 2002).

Aos 16 anos, Ekman foi enviado pelo seu pai para Copenhague, onde iniciou seus estudos na Tekniska Selskabo Skole, mas com o falecimento de seu pai, precisou retornar a Estocolmo, onde concluiu seus estudos na Escola Politécnica de Estocolmo, curso de Arquitetura e Ornamentação. Seus primeiros trabalhos foram de desenhista. Após ter trabalhado em Nova York, em Buenos Aires (1981) e no Rio de Janeiro (1893), veio para São Paulo, onde foi introduzido na profissão pelo 
arquiteto alemão August Fried. Casou-se em 1898, com dona Flora Jaguaribe Ekman, filha do médico, geógrafo e escritor Domingos José Nogueira Jaguaribe. ${ }^{47}$.

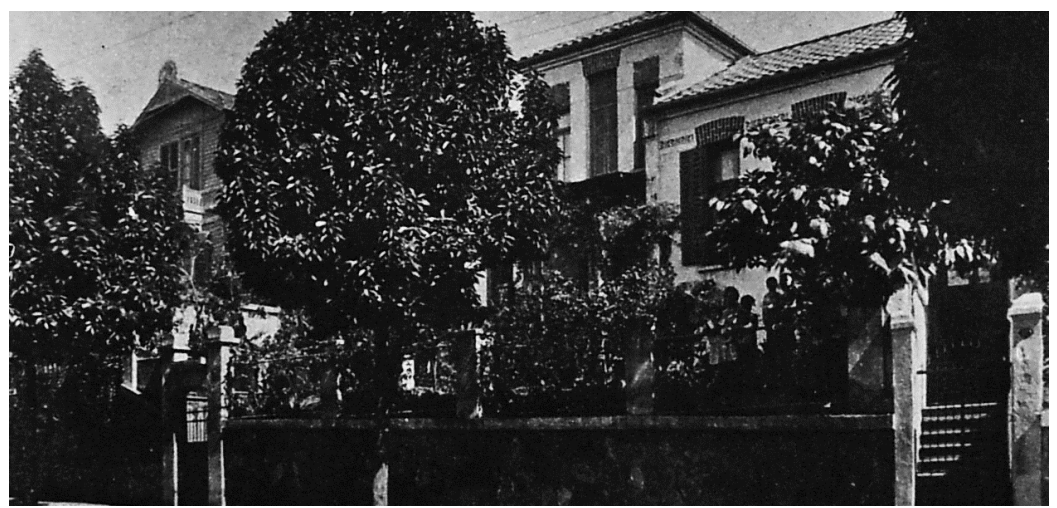

Figura 14 - Residência de Carlos Ekman, na Rua Veridiana, 398

Ao lado, o velho café, pré-fabricado pelo pai do arquiteto e importado da Suécia pelo Dr. Domingos Jaguaribe, posteriormente seu sogro. Desmontado, parte o chalé encontra-se em Campos do Jordão, abrigando o escritório do Loteamento 'Vale Encantado'.

Fonte: Catálogo “Exposição Vila Penteado”, FAUUSP, 1976.

Em seu depoimento "Recordações de Minha Vida" de 1937, publicado em "Exposição Vila Penteado" (1976), e também na Revista Pós, número especial, "Vila Penteado: 100 anos" (2002), Carlos Ekman relata a história de sua vida. Conta como foi sua infância ao lado de cinco irmãos: Gustavo, Hilda, Magnus, Anders e Anna. Comenta sobre as dificuldades que passou, especialmente após a falência e morte de seu pai, evidenciando um período difícil de sua trajetória:

Foi durante a viagem de Hull a Liverpool que sentia terrível aflição do isolamento. O coração parecia comprimido por uma mão de ferro. Não podia calcular qual seria meu destino. Se não encontrasse trabalho como desenhista seria necessário tomar qualquer coisa que se oferecesse. Lembrei-me dos poucos meses que trabalhei, por ordem do meu pai, como pedreiro. Tinha então 16 anos e para aproveitar o curto verão, trabalhava 12 horas por dia. As mãos ficavam com feridas e as costas doíam bastante. Os dias pareciam nunca acabar, porém, então tinha a cama, se não aguentasse mais. Agora, tudo parecia mais grave. ${ }^{48}$

47 Informações extraídas do texto de HOMEM, Maria Cecília Naclério. Vila Penteado: Carlos Ekman, um inovador na arquitetura paulista. Boletim Técnico de São Paulo, São Paulo, n. 10, p. 924, abr. 1993. Texto presente também na revista comemorativa Vila Penteado 100 anos, p.66 -77.

48 EKMAN, Carlos. Recordações de minha vida. Exposição Vila Penteado. Catálogo. São Paulo: FAUUSP, 1976, p.45. 
Mas, com muito trabalho e visão de oportunidades, Ekman desenvolveu diversos projetos, dentre eles o prédio Bamberg, de 1910, na Rua XV de Novembro, um dos primeiros da cidade a ter estrutura metálica. Desenvolveu o projeto para o Instituto Jaguaribe, em Campos do Jordão. Elaborou o projeto para o Externato Santa Cecília, em 1921, assim como o projeto de prédios na Rua Florêncio de Abreu, números 106 a 112, projetados e construídos por ele para João Alves de Lima, entre os anos de 1918 e 1919.

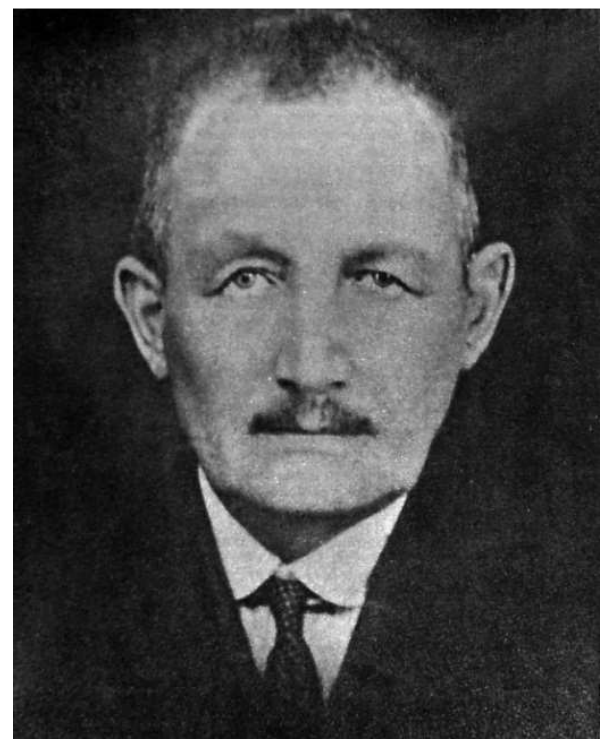

Figura 15 - Arquiteto Carlos Ekman

Fonte: Catálogo “Exposição Vila Penteado”, FAUUSP, 1976.

Carlos Ekman projetou também o Teatro São José, no Viaduto do Chá, propriedade de Estanislaw do Amaral Campos, construído por Regino Aragão.

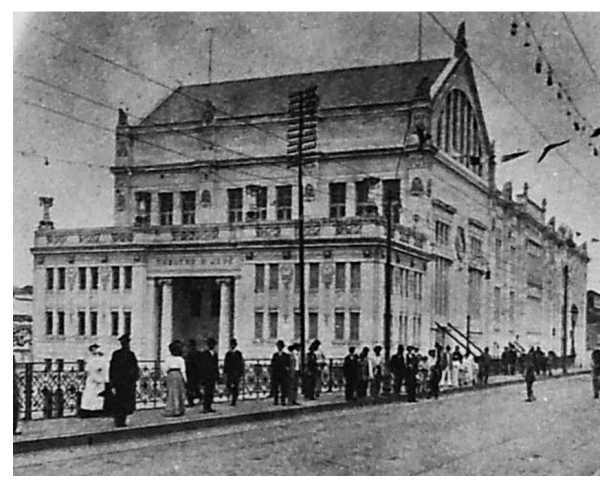

Figura 16 - Vista externa do Teatro São José, no Viaduto do Chá Fonte: Catálogo “Exposição Vila Penteado”, FAUUSP, 1976. 

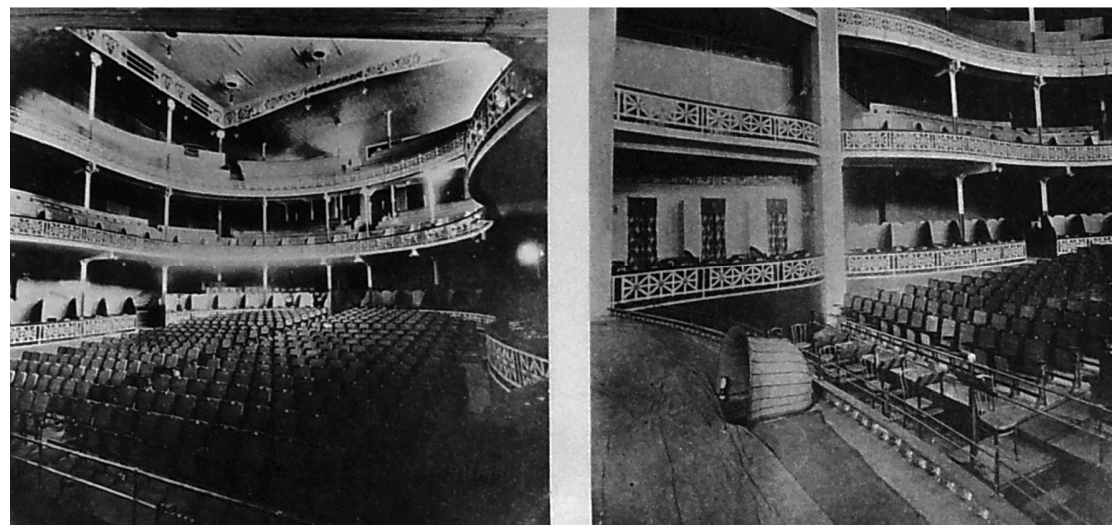

Figura 17 - Vistas internas do Teatro São José, no Viaduto do Chá Fonte: Catálogo “Exposição Vila Penteado”, FAUUSP, 1976.

Ekman projetou e construiu também outras residências, inclusive a 'Vila Antonieta'. Residência de Antonieta e Caio da Silva Prado, na Avenida Higienópolis, esquina com a Rua Sabará, em 1904.

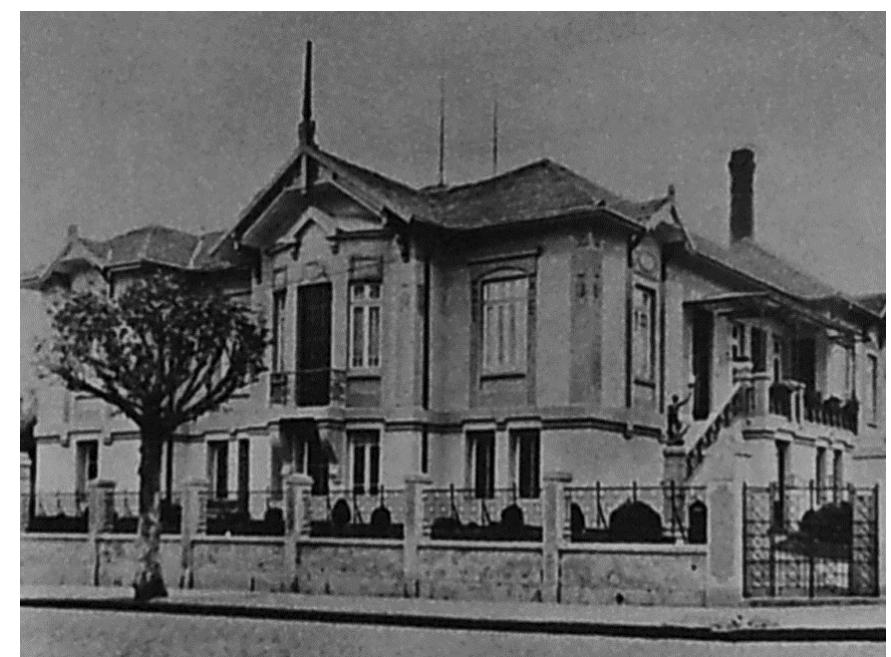

Figura 18 - 'Vila Antonieta', residência na Avenida Higienópolis. Projeto e construção de Carlos Ekman, de 1904

Fonte: Catálogo “Exposição Vila Penteado", FAUUSP, 1976.

Carlos Ekman nas palavras de Yves Bruand, 1971:

Ekman soube inspirar-se nas realizações europeias e nas alterações da época sem ser, porém, um imitador servil: a síntese feliz que conseguiu efetuar entre a simetria absoluta do estilo 'Sezession', e a audácia, a liberdade da invenção dos mestres belgas é a primeira prova da segurança de sua escolha, se seus dons de assimilação, de suas faculdades criativas. $^{49}$

49 HOMEM, Maria Cecília Naclério. (Coord), MACHADO, Lucio Gomes. Exposição Vila Penteado. Catálogo. São Paulo, FAUUSP, 135 p., 1976. 
Mas a obra de Ekman não obteve qualidade apenas na relação projetual e estética, o detalhamento de seus projetos e seu acompanhamento às obras fizeram com que as construções obtivessem alto rigor construtivo. $O$ relato de Domingo Ribeiro Jaguaribe Ekman (neto de Carlos Ekman) evidencia essa situação:

Em 1902 é contratado por Antonio Penteado para construir a vila, cujo projeto e construção esmerados lhe trouxeram várias obras no bairro de Higienópolis, alguns para a própria família Penteado.

[...]

Carlos Ekman era um arquiteto minucioso e executava suas obras com acabamento esmerado. Todos os seus clientes se tornaram amigos e grande parte voltou a requisitar seus serviços.

Alguns detalhes construtivos eram por ele executados manualmente. Em sua residência na rua Veridiana produziu os ornamentos em gesso sobre as portas, os vitrais com motivos escandinavos e esculpiu em madeira os montantes do corrimão das escadas. 0 mobiliário também foi executado conforme seu desenho.

As estruturas de madeira que construía eram bem dimensionadas. Sua casa de campo, em Osasco, é totalmente em alvenaria em meio-tijolo e não apresenta trincas. A orientação correta e o sistema de forro duplo garantem um excelente conforto térmico.

Inovou também na técnica de construir, como na reforma da residência do dr. João Alves de Lima, na avenida São Luís. O episódio me foi relatado recentemente por dona Heloísa Alves de Lima e Motta que, menina, assistiu à consulta de seu pai sobre as possibilidades de ampliação da casa em que residiam. Após examinar a construção existente, Carlos Ekman decidiu acrescer mais um pavimento sobre a excelente estrutura da construção original. Para tanto, levantou lentamente, sobre macacos, a estrutura do telhado e, concomitantemente, acresceu fiadas de alvenaria que abrigaram o segundo pavimento. Tal obra causara admiração dos passantes e resultou em uma relação amistosa e contrato para novas obras, inclusive os ainda existentes sobrados na rua Florêncio de Abreu, em que o desenho dos frontões sempre remete ao vizinho, em uma composição harmoniosa.

$\mathrm{Na}$ residência do dr. Fridjof Detthow, na rua Jaguaribe, utiliza o sistema enxaimel, com painéis em argamassa sobre telas de aço, vedando a estrutura portante em madeira. ${ }^{5}$

Esse esmero e cuidado do arquiteto podem, ainda hoje, ser vistos na Vila Penteado. A qualidade construtiva desse edifício deve-se a dedicação de Ekman, visto que se dedicou exclusivamente a essa obra, conforme acordo firmado com o proprietário: "Antonio Penteado, que tinha apreciado nosso projeto do teatro, me encarregou da Vila Penteado, com a condição de durante o primeiro ano não tomar outras obras e eu, com fome, tive de aceitar." (EKMAN, 2002).

${ }^{50}$ EKMAN, Domingos Ribeiro Jaguaribe. Vila Penteado: manuscrito inédito do arquiteto Carlos Ekman. Vila Penteado: 100 anos. Revista do programa de pós-graduação em arquitetura e urbanismo da FAUUSP - número especial. São Paulo: FAUUSP, 2002, p. 62. 
Por volta do ano de 1923, após a formatura de Sylvio em engenharia pelo Instituto Mackenzie, Carlos Ekman abre a firma "Carlos Ekman e Filho", com endereço a Rua São Bento, 59 (mesmo edifício que abrigava, entre outros, o escritório de Victor Dubugras). Carlos e Sylvio mantém a sociedade até 1934, quando Sylvio já atua de forma independente em Fortaleza. A partir desse momento, Carlos Ekman pode dedicar mais tempo à pintura: "Expõe, no Primeiro Salão Paulista de Belas Artes, em 1934. [...] Desse ano em diante produziu dezenas de aquarelas, com traço surpreendentemente firme". (EKMAN, 2002). O que demonstra que, mesmo com o passar dos anos, Carlos não perdeu a sensibilidade para 0 desenho e para as artes.

Carlos Ekman faleceu em 29 de julho de 1940, em Santos, devido a colapso cardíaco. 


\subsubsection{O ESTILO ARQUITETÔNICO: ART NOUVEAU}

A art nouveau, do francês "nova arte", determina o estilo artístico que se desenvolveu entre 1890 e a Primeira Guerra Mundial (1914-1918) na Europa e nos Estados Unidos, espalhando-se para o resto do mundo.

O termo art nouveau tem origem na galeria parisiense L'Art Nouveau, aberta em 1895, pelo comerciante de arte e colecionador Siegfried Bing, que teve o projeto de redecoração de sua casa apresentado na Exposição Universal de Paris de 1900, Art Nouveau Bing, conferindo visibilidade e reconhecimento internacional ao movimento art nouveau. Relaciona-se com os ideais da $2^{\underline{a}}$ Revolução Industrial, através da exploração de novos materiais, tais como o ferro, vidro e cimento. $\mathrm{O}$ art nouveau apresenta um estilo estético e artístico, marcado por linhas curvas, delicadas, irregulares e assimétricas. As obras arquitetônicas nesse estilo costumam apresentar mosaicos e pinturas parientais, valorizando o trabalho artesanal. $\mathrm{O}$ art nouveau surgiu como uma tendência arquitetônica inovadora, marcada por um estilo floreado, inspirado por formas orgânicas. É um estilo internacional que apresenta denominações variadas em diferentes países: na Alemanha, é chamado jugendstil, em referência à revista Die Jugend, 1896; na Itália, stile liberty; na Espanha, modernista; na Áustria, sezessionstil.

O estilo austríaco difere-se dos demais por apresentar as características do movimento sem exageros, sem se aproximar a caricatura. Luiz Carlos Daher, no texto "Aspectos da arquitetura no início do século XX", esclarece as características do estilo sezession:

A maior severidade da arquitetura da sezession austríaca, sua preferência
pelas formas simples, círculos, retângulos, refletem também nos interiores,
em uma época em que se pretendia a extensão da linguagem artística a
todo o ambiente urbano. E se explica, em parte, por sua proximidade com a
tradição acadêmica, principalmente pela influência de Otto Wagner,
arquiteto e professor da Academia de Arte Viena. [...] a escola austríaca,
incluindo Hoffman e Olbrich, é vista, malgrado seu nome dissidente -
sezession - como um esforço de ampliação da tradição, mais que ruptura.
(DAHER, 2002, p. 43).

No Brasil, o art nouveau teve seu período áureo entre 1900 e 1905, coincidente com o europeu, e a partir de 1920 se mesclou com outros estilos. 
O art nouveau representa pois para nós aquilo que não se representou para a Europa. Lá estava ligado às origens do liberalismo e do nacionalismo. Aqui, aportou como mercadoria exótica. Acompanhou a insegurança da nossa industrialização, nos primeiro anos da República. Acabou por sofrer completa revisão e se incorporou à nossa vida, dentro daquilo que Oswald de Andrade chamou à nossa 'capacidade antropofágica'. Foi, portanto, uma espécie de condimento do repasto indígena. (MOTTA, 1965).

A Vila Penteado destaca-se pela inovação estética, construída em sezession, modalidade austríaca do novo estilo. De composição equilibrada, o edifício apresenta volumes simétricos, em eixos visivelmente definidos. Os volumes principais ortogonais ganham movimento com os alpendres curvos dos acessos principais da residência e pela ornamentação curvilínea com motivos florais. Nas palavras de Luiz Carlos Daher "a Vila Penteado assegura várias relações desse tipo: fachada de movimentação discreta, mas contínua; simetria dos volumes principais [...]" (DAHER, 2002, p. 45).

Os detalhes arquitetônicos das fachadas também podem ser contemplados internamente, onde os ornamentos são ainda mais trabalhados.

\begin{abstract}
A Vila Penteado [...] é considerada um dos mais representativos exemplares de art nouveau em São Paulo. Projetada pelo arquiteto Carlos Ekman (1866 - 1940), em 1902, a residência segue o padrão menos rebuscado do estilo sezession austríaco. Na facha externa, nota-se o discreto emprego de arabescos e formas florais. No monumental hall de entrada, pinturas de Carlo de Servi (1871 -1947), Oscar Pereira da Silva (1867 -1939) e ornamentação de Paciulli. ${ }^{51}$
\end{abstract}

O projeto da Vila Penteado diferencia-se das demais residências de mesmo padrão por romper com a tendência neoclássica e, nas palavras de Carlos Lemos (2002, p.35), a Vila Penteado é destacada das demais construções do período, juntamente com as obras de Victor Dubugras:

Cremos que os melhores exemplos de verdadeiras residências estilo artnouveau em São Paulo foram os de Victor Dubugras e Carlos Ekman e, deste, sobrou solitária a casa dos Álvares Penteado. Casa refinada em tudo, absolutamente coerente em tudo, tanto no que diz respeito ao estilo, ao partido dentro do parque e à tradição paulista na organização do complexo habitacional, prevendo a horta, a cocheira, o grupo de paineiras evocativas da roça e o carvalho da Europa cultivada e, inclusive, a duplicidade dos ambientes de moradia, isto é, duas residências em uma só, permitindo que dois casais da mesma família coabitassem o mesmo prédio.

${ }^{51}$ Texto extraído da Enciclopédia Itaú Cultura Artes Visuais, atualizado em 04 set. 2008. Disponível em:<http://www.itaucultural.org.br/AplicExternas/enciclopedia_IC/index.cfm?fuseaction=termos_texto \&cd_verbete=909>. Acesso em: 26 jul. 2011. 
Poucos exemplares da arquitetura art nouveau sobreviveram à transformação da cidade de São Paulo, ocorrida nos anos 1950. A Vila Penteado é um desses raros edifícios remanescentes. 


\title{
3.1.4 O EDIFÍCIO: VILA PENTEADO
}

O programa da residência paulista sofreu alterações no final do século XVIII, onde as casas mais ricas e amplas contavam com o afastamento das divisas do lote e com a clara organização das funções dos ambientes, divididos nas zonas de estar, repouso e serviços.
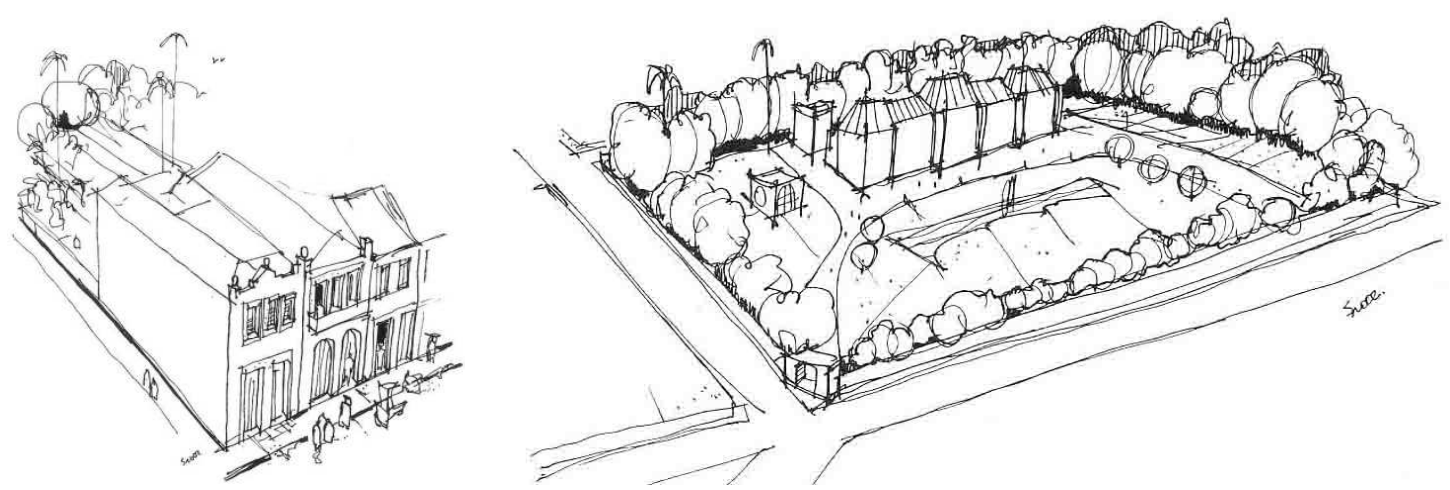

Figura 19 - À esquerda: o lote colonial. À direita: o palacete isolado no lote

Fonte: MACEDO, Silvio Soares. Vila Penteado: significados paisagísticos. Vila Penteado: 100 anos. Revista do programa de pós-graduação em arquitetura e urbanismo da FAUUSP - número especial. São Paulo: FAUUSP, 2002, p. 108. Desenhos: Silvio Soares Macedo.

O controle das circulações torna-se importante nessa tipologia, onde a entrada dá-se por hall, saguão ou vestíbulo.

\begin{abstract}
Nos palacetes do começo do século surgiu uma grande novidade a qual, ao que tudo indica, teria sido introduzida por Ekman. Por influência do artnouveau, recém-chegado à capital, os halls com pé-direito duplo cresceram e vieram ocupar a posição central dos edifícios, recebendo a escadaria um cuidado especial que Ihe conferia movimento e beleza. Estes grandes saguões eram iluminados por claraboias, em geral fechadas por caixilhos especialmente desenhados, com vidros ornamentados, e apareceram nas construções destinadas aos novos programas surgidos em decorrência da Revolução Industrial e da urbanização, tais como estações ferroviárias, teatros, palácios de exposições, museus, grandes hotéis, lojas de departamentos, etc. Em escala reduzida, naturalmente, foram inseridos em residências, a princípio, nas mais amplas e luxuosas.

É provável que a primeira residência a contar com esse recurso, em São Paulo, tivesse sido a Vila Penteado, conforme projeto e construção do referido arquiteto, em 1902, feitos para Antônio Álvares Penteado, fazendeiro de café e industrial de aniagens (HOMEM, M. C. N, 1993).
\end{abstract}

A Vila Penteado foi projetada em 1901, configurando-se um dos primeiros exemplares em estilo art nouveau, localiza-se no bairro de Higienópolis, em São Paulo, à Rua Maranhão, 88, seu endereço atual. O terreno do palacete Vila 
Penteado pertencia ao loteamento residencial da empresa Victor Nothman e Martinho Burchard.

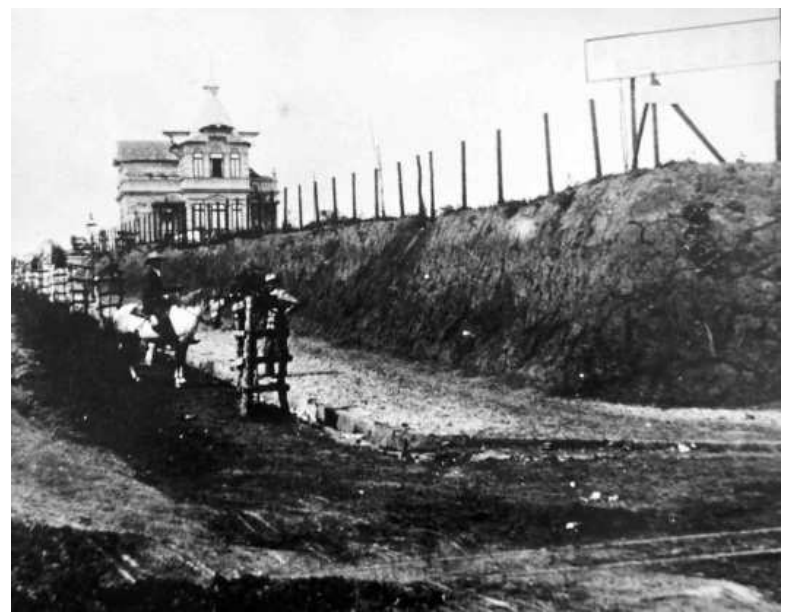

Figura 20 - Abertura do Bairro de Higienópolis, em 1898, sob a denominação de Boulevards Burchard

Na foto à esquerda: Martinho Burchard, sócio de Victor Nothman, aparece montado a cavalo, na Rua Itambé, em frente à quadra onde se construiria a Vila Penteado.

$\mathrm{Na}$ figura a direita: pôster de programa de lançamento de Higienópolis.

Fonte: Catálogo "Exposição Vila Penteado", FAUUSP, 1976 (imagem à esquerda) e MACEDO, 2002 (imagem à direita).

O industrial adquiriu o terreno da firma Victor Nothman e Martinho Burchard, que abriu e loteou o bairro em 1898, sob a denominação de Boulevards Burchard, em terras que haviam pertencido ao Barão de Ramalho. Comprou também um terreno no Pacaembu, ocupado atualmente pelas instalações da Fundação Armando Álvares Penteado, onde uma nascente iria garantir por meio de canalização, o abastecimento de água de sua residência, apesar de o bairro já ser provido de água, gás e rede de esgotos. (HOMEM, 1976, p.70).

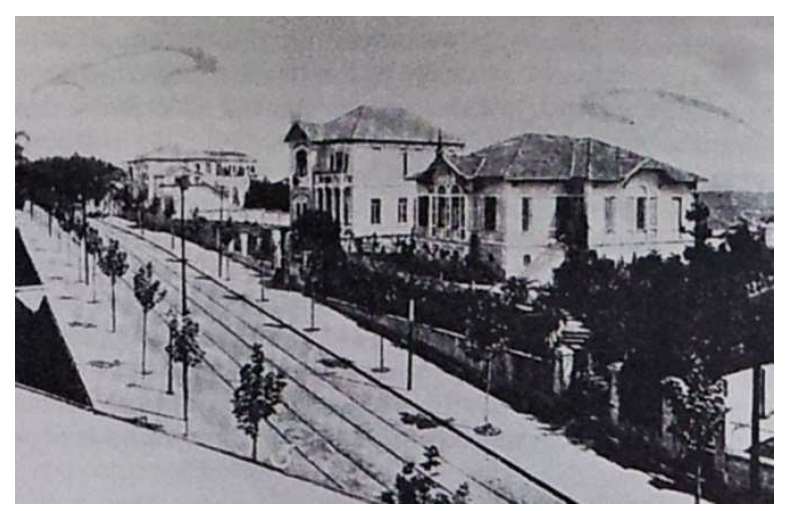

Figura 21 - Rua Maranhão, em 1905

Fonte: Catálogo "Exposição Vila Penteado", FAUUSP, 1976.

Quando de sua construção, o palacete estava contido num lote bem maior do que o existente hoje. Na época sua dimensão era de uma quadra inteira, 
contemplando cerca de $14.000 \mathrm{~m}^{2}$ de área, entre as ruas Itambé, Sabará e Maranhão, com entrada principal pela Avenida Higienópolis, o que permitia a ampla visualização da construção (ver figuras 22 e 23).

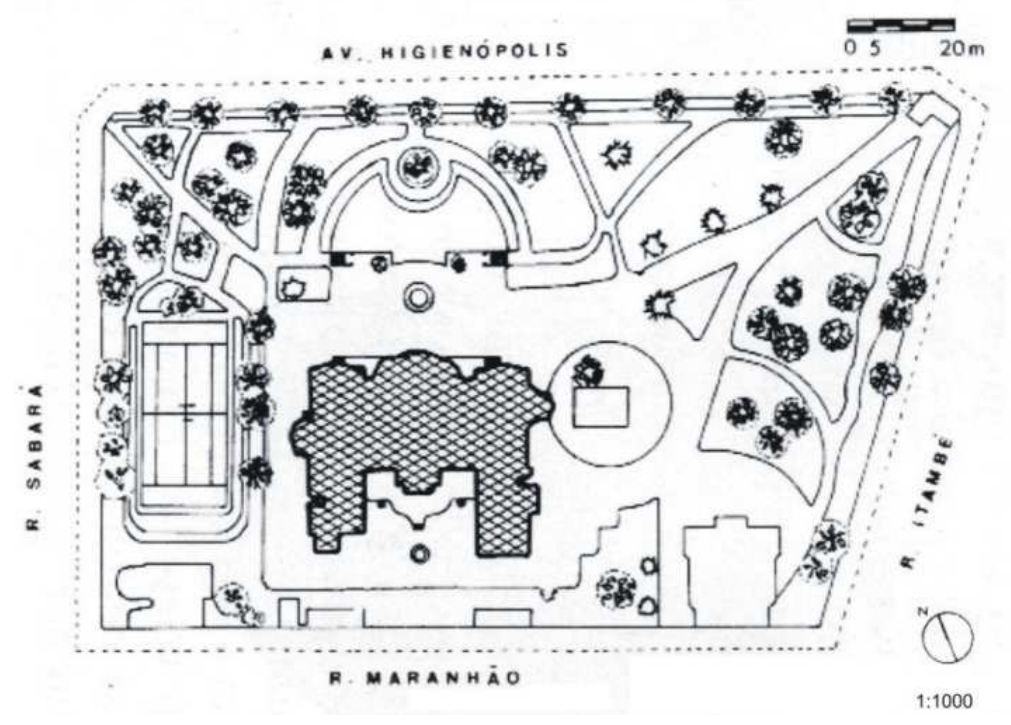

Figura 22 - Implantação da Vila Penteado no início do século XX Fonte: Revista Vila Penteado 100 anos, FAUUSP 2002.

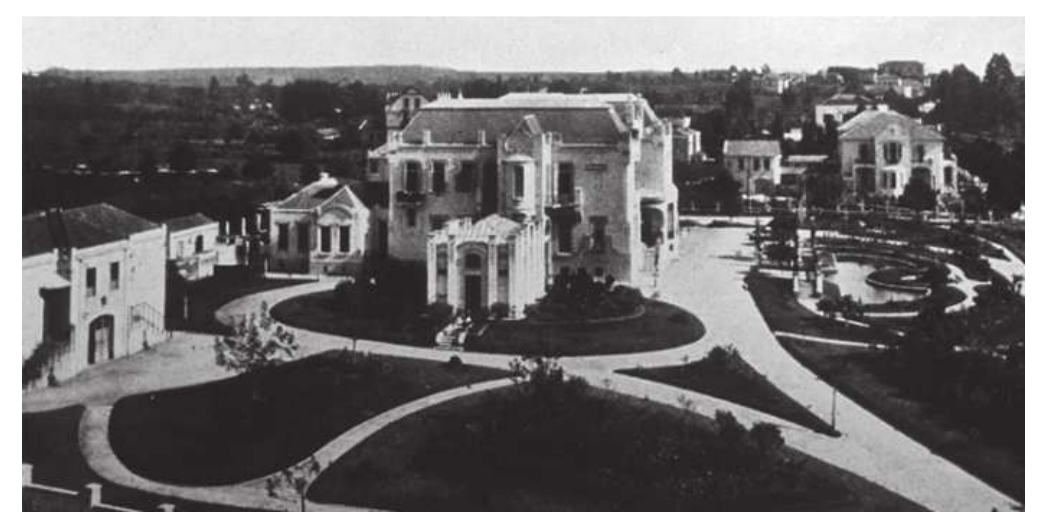

Figura 23 - Foto da Vila Penteado no início do século XX. Disposição original dos edifícios e jardins

Fonte: Painel de Pesquisa Histórica, 1aㅡ Etapa (1990 a 1992): estudo pormenorizado da arquitetura. Pesquisa Documental Arquivística/ Iconográfica. CPC USP. Arquivo FAUUSP, s/d.

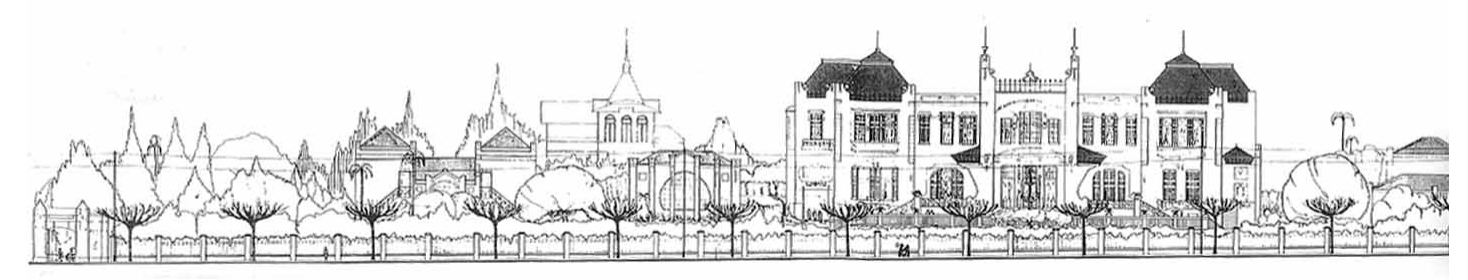

Figura 24 - Fachada da Vila Penteado em 1930

Fonte: MACEDO, 2002, p. 110. Desenho: Silvio Soares Macedo. 
Além da posição privilegiada em relação ao lote, a Vila Penteado era destacada por seu embasamento elevado e construção marcada frontalmente por um grande espelho d'água. Externamente havia, além do espelho d'água, quadra de tênis, estufa, horta, bosque, garagem, cocheira e dependências para os empregados.

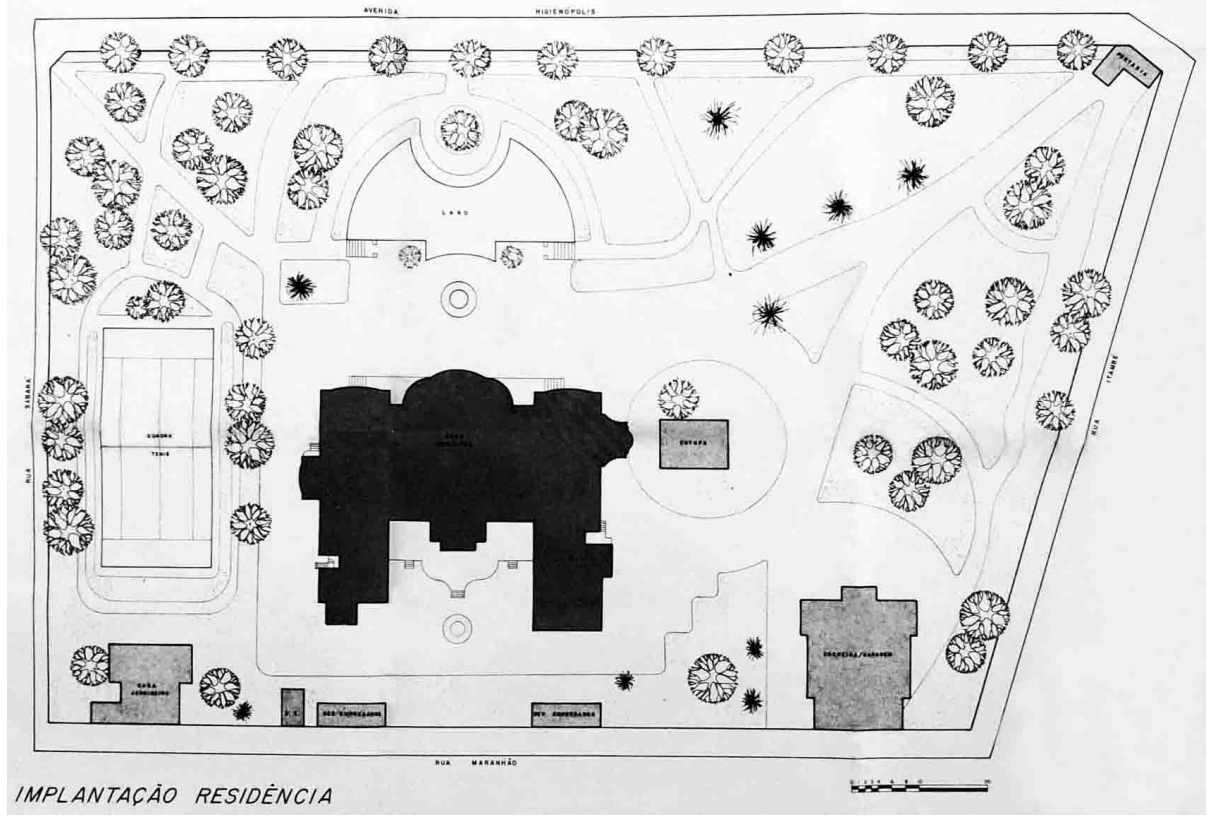

Figura 25 - Implantação da Vila Penteado

Fonte: Prancha de desenho integrante do Trabalho de Graduação Final de Alberto da S. Prado, intitulado "Vila Penteado - Vida nova em velho prédio", orientador Eduardo Kneese de Mello, Faculdade de Arquitetura e Urbanismo "Farias Brito", 1979.

A figura 25 apresenta a implantação da Vila Penteado, sendo que a construção maior, destacada em cor escura, refere-se ao casarão. Originalmente, a entrada principal para a residência dava-se pela Avenida Higienópolis (via posicionada acima no desenho) e atualmente a entrada é feita pela Rua Maranhão (rua indicada abaixo no desenho da figura 25).

Nesse desenho de implantação é possível ainda identificar, à esquerda, a quadra de tênis e, à direta, a estufa e a cocheira/ garagem (a cocheira/ garagem encontra-se junto ao limite do lote com a Rua Maranhão). Entre a Avenida Higienópolis e o casarão, é possível visualizar a área do lago.

Atravessava os jardins uma avenida que conduzia à entrada principal, toda ladeada de álamos, recém introduzidos em São Paulo, um lago artificial de linhas irregulares, ficava nos baixos do terreno e, em seu centro, de uma ilhota de forma redonda, erguiam-se um carvalho. Sobre a balaustrada, que acompanhava os contornos do lago, foram colocados vasos com flores e 
palmeiras. Uma quadra de tênis, paralela à R. Sabará, e, ao lado da casa, uma grande estufa, onde eram cultivadas flores e samambaias, completavam a parte de lazer dos jardins. Nos fundos do terreno, no alinhamento com a Rua Maranhão, foram construídas duas cocheiras, garagem e quartos para os jardineiros e cocheiro. As dependências do porteiro ficavam junto ao portão principal. (HOMEM, 1976, p.72).

A Avenida Higienópolis, apesar de não contar com calçamento, sendo recoberta por saibro, já contava com o serviço de bonde da Light, desde 1901.

O casarão foi projetado com uso residencial para abrigar duas importantes famílias paulistas: a do Conde Antônio Álvares Penteado e a de seu genro, Antônio Prado Junior, casado com Eglatina Álvares Penteado Prado. As duas casas, apesar de integradas, apresentam programas distintos e bem definidos. Na figura 26 é apresentada a planta do pavimento térreo, onde é possível observar as áreas específicas de cada moradia e perceber o ponto de interligação entre as mesmas, que se dava através de uma porta existente entre a Sala de Bilhar da residência do Conde (Casa A) e o pequeno hall próximo ao Salão da residência de Antônio Prado Junior (atual Biblioteca).

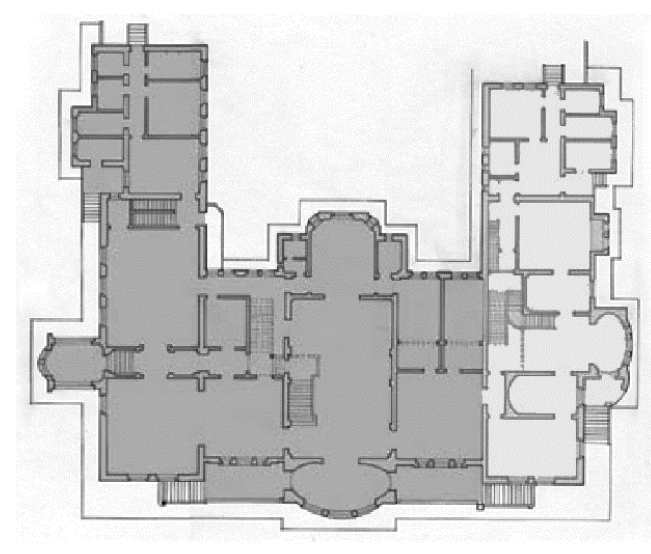

Casa A Conde Antônio Álvares Penteado

Casa B Antônio Prado Junior

Figura 26 - Planta do Pavimento Térreo da Vila Penteado Fonte: Painel de Pesquisa Histórica, 1르 Etapa (1990 a 1992): estudo pormenorizado da arquitetura. Pesquisa Documental Arquivística/ Iconográfica. Arquivo CPC USP.

A residência abrigou diversos moradores ao longo de sua história como residência. Inicialmente foi o lar do conde Álvares Penteado, de sua esposa Ana Lacerda, de três dos seus cinco filhos e de seu genro, Antonio Prado Junior. 
três de seus filhos: Silvio, Armando, ainda solteiros, e Eglatina, casada com Antonio Prado Jr. As duas outras filhas, Antonieta e Stella, moravam vizinhas. Antonieta, a mais velha das três, casara-se aos 15 anos com Caio Prado e veio morar no $\mathrm{n}^{\circ} 3$ da Av. Higienópolis, na chamada "Vila Antonieta". Doada por seus pais, a casa também foi projetada e construída por Carlos Ekman, em 1904. Nesse mesmo ano, Stella ficava noiva do irmão de Caio, Martinho Prado Neto, primos de Antonio Prado Jr., e se casaram pouco depois, indo residir ao lado de Antonieta.

Dessa forma, Antonio Álvares Penteado mantinha seus filhos, genros e netos ao seu redor. (HOMEM, 1976, p.72).

A figura 27 apresenta a planta do pavimento térreo e a figura 28, a planta do pavimento superior. O saguão principal, chamado de "hall", era o local de encontro da família, assim como na sala de bilhar.

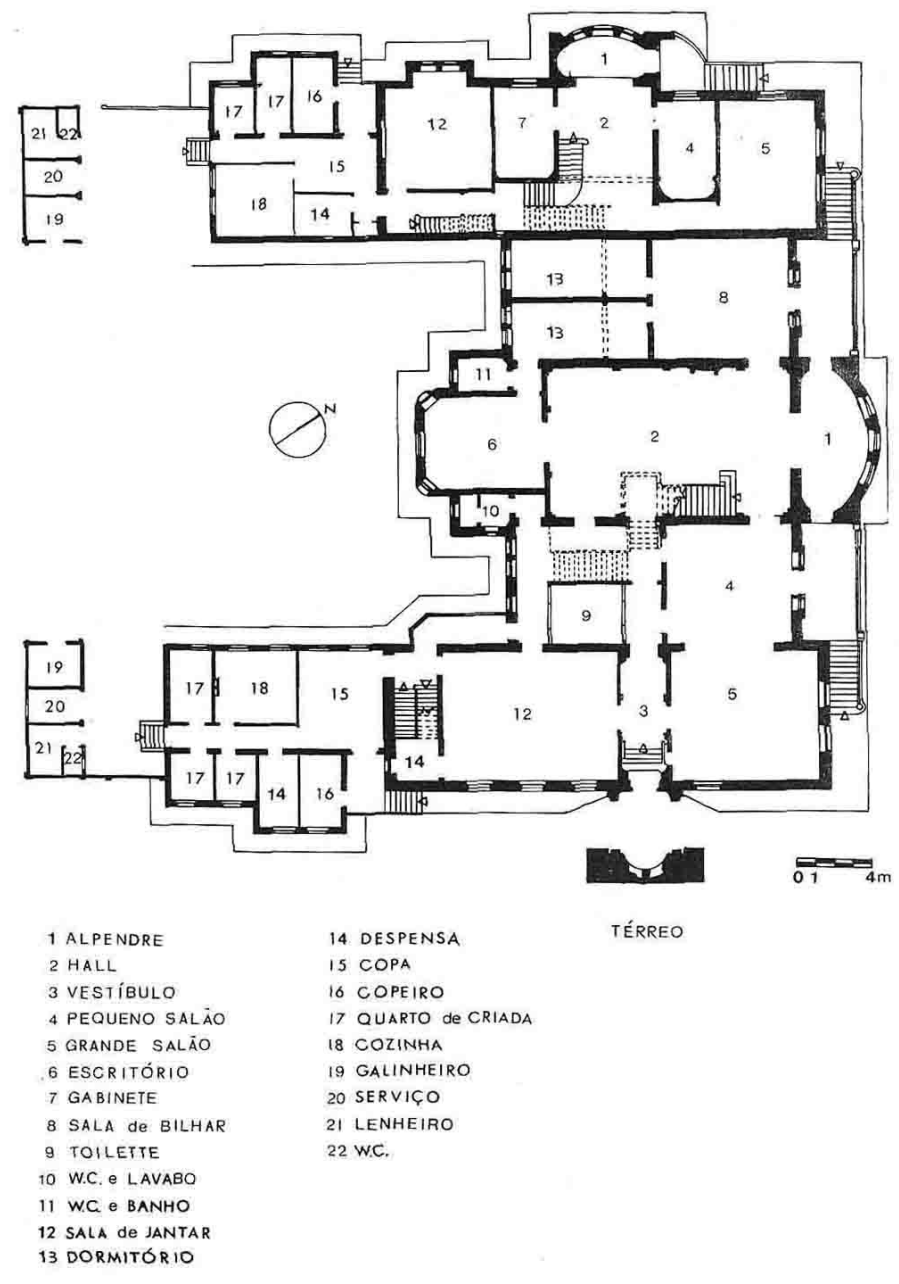

Figura 27 - Planta do Pavimento Térreo da Vila Penteado, de autoria de Carlos Ekman, de 1902, localizada no Arquivo Histórico Municipal "Washington Luís"

Fonte: Revista Vila Penteado 100 anos, FAUUSP 2002, p.74. 


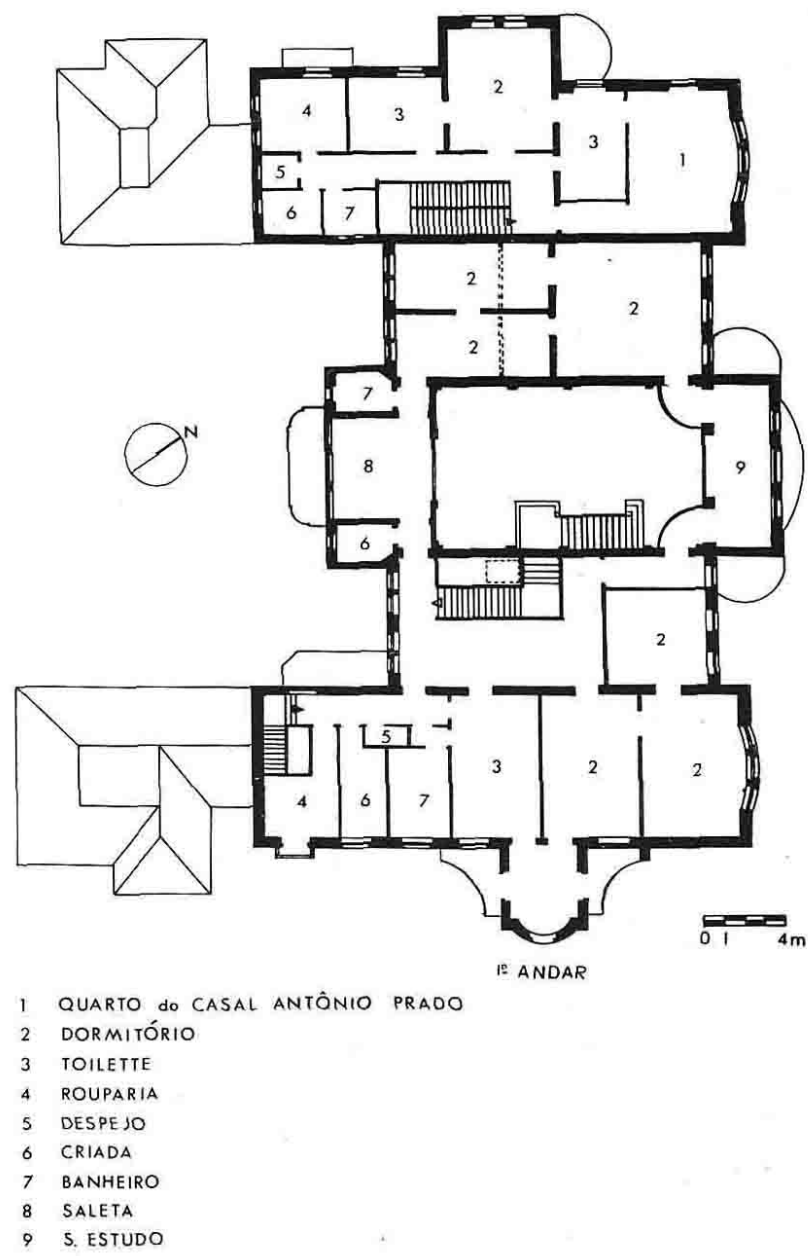

Figura 28 - Planta do Pavimento Superior da Vila Penteado, de autoria de Carlos Ekman, de 1902, localizada no Arquivo Histórico Municipal "Washington Luís" Fonte: Revista Vila Penteado 100 anos, FAUUSP 2002, p.74.

Ainda nos primeiros anos, após sua construção, a Vila Penteado sofreu alterações: originalmente as alas laterais da casa, onde funcionavam as áreas de serviço, eram térreas, só receberam o pavimento superior em 1906, segundo pesquisa histórica relatada pelo Programa Conservação e Restauração de Bens Arquitetônicos e Integrados, promovido pelo Centro de Preservação Cultural da Universidade de São Paulo (CPC USP) ${ }^{52}$. As áreas ampliadas podem ser visualizadas nas figuras 29,30 e 31 .

\footnotetext{
${ }^{52}$ Inventário Crítico 4/4, $1^{\text {a }}$. Etapa (1990 a 1992): estudo pormenorizado da arquitetura - mapeamento de forros, Painel 8, Vila Penteado. Arquivo CPC USP.
} 


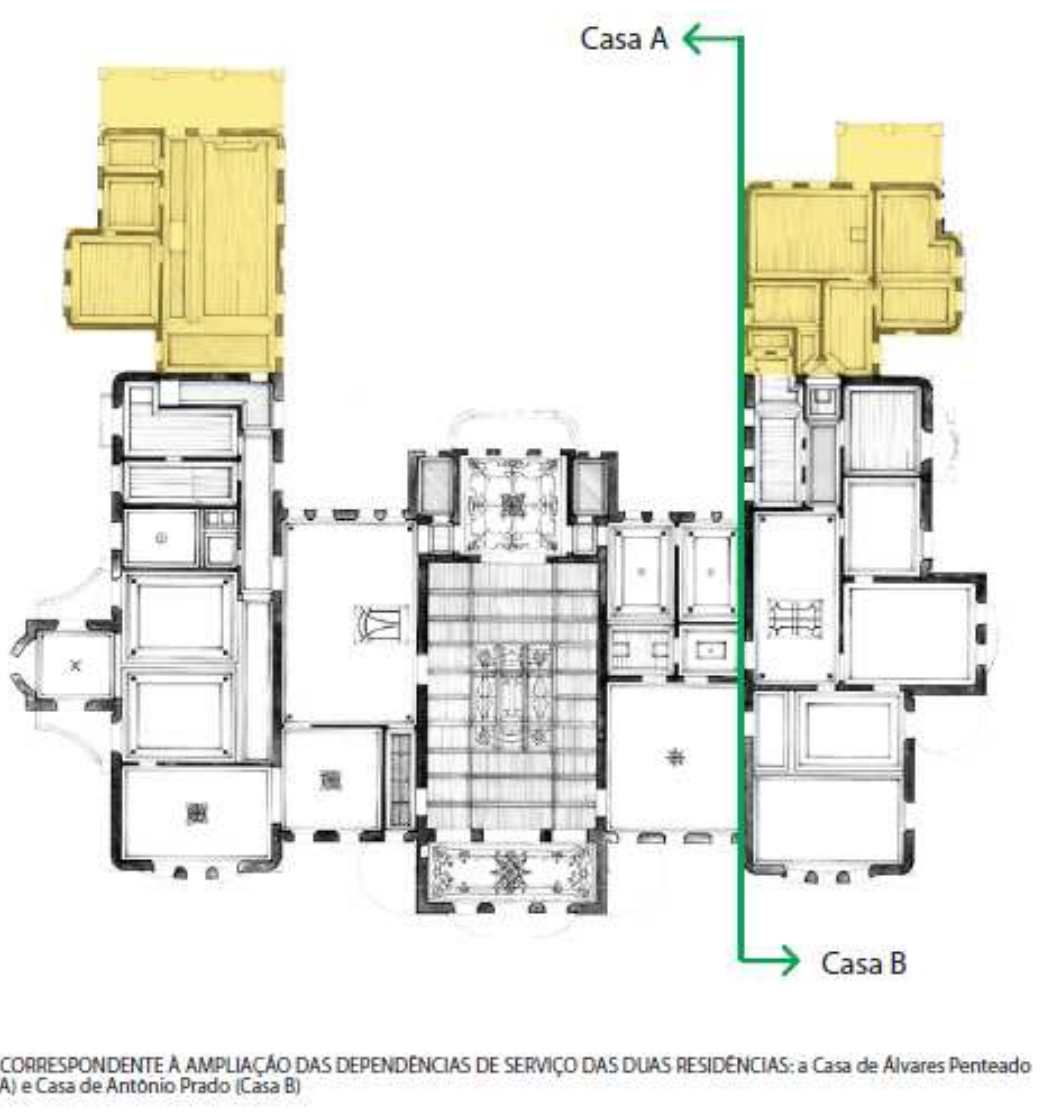

Figura 29 - Modificação espacial documentada: ampliação do 2 pavimento em 1906 Fonte: Inventário Crítico 4/4, ${ }^{\mathrm{a}}$. Etapa (1990 a 1992): estudo pormenorizado da arquitetura - mapeamento de forros, Painel 8, Vila Penteado. Arquivo CPC USP.
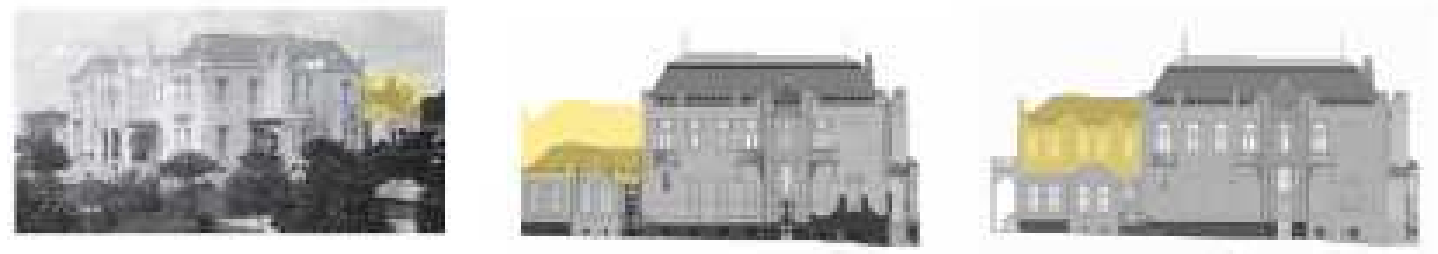

Figura 30 - Vila Penteado fotografada nos primeiros anos do século XIX (imagem anterior à ampliação de 1906) e fachada lateral antes e depois da ampliação Fonte: Arquivo FAUUSP, s/d.

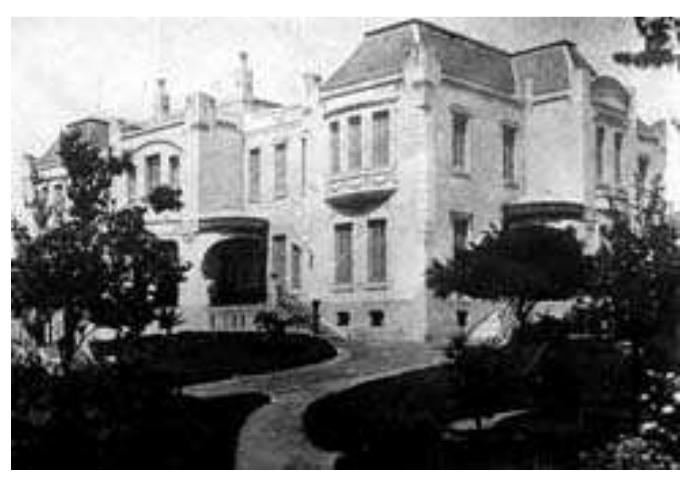

Figura 31 - Vista lateral do palacete antes da reforma de ampliação do segundo pavimento promovida em 1906

Fonte: Arquivo FAUUSP, s/d. 
Após a morte do conde Álvares Penteado, em 1912, a residência passou a ser propriedade de sua viúva, Ana de Lacerda, que veio a falecer em 1938, quando a Vila Penteado passou por herança aos filhos. Nesse período, a residência permaneceu fechada e o terreno ao redor da casa foi dividido entre os herdeiros. Em 1946, o edifício Vila Penteado foi doado por dois filhos do conde Álvares Penteado, Silvio Álvares Penteado e Armando Álvares Penteado, para a Universidade de São Paulo, tendo por uso a instalação de uma Faculdade de Arquitetura e Urbanismo.

A escritura de doação é clara quanto ao novo uso dado a Vila Penteado:

[...] a presente doação é feita, mediante as seguintes condições: $\left.1^{\circ}\right)$ o prédio ora doado destina-se à instalação de uma Faculdade de Arquitetura, devendo para ele ser transferido o Curso de Arquitetura ora existente na Escola Politécnica de São Paulo. Esta Faculdade passará a denominar-se 'Faculdade de Arquitetura e Urbanismo da Universidade de São Paulo'; 2º) Deverá figurar permanentemente como adendo à denominação dessa Faculdade em forma de sub-título, os seguintes dizeres: 'Instalada em 1947, no prédio da 'Vila Penteado' doado pelos irmãos Silvio e Armando Alvares Penteado'; tal sub-título será inscrito na fachada principal da Faculdade e bem assim nos diplomas e papeis oficiais; $3^{\circ}$ ) A Faculdade instituirá dois prêmios de primeiro e dois prêmios de segundo lugares, denominados 'Prêmio Silvio e Armando Alvares Penteado' a serem distribuídos anualmente aos quatro alunos que mais se houverem distinguido durante os Cursos de Arquitetura e Urbanismo - sendo que tais prêmios serão representados por duas medalhas de ouro e duas de prata, com a devida inscrição supra; 4ํ) A finalidade dessa Faculdade será, especialmente, proporcionar um Curso de Arquitetura e Artes complementares e um Curso de Urbanismo, consoante as normas geralmente adotadas em estabelecimentos congêneres dos centros mais adiantados na matéria - isto em substituição aos respectivos cursos existentes na Escola Politécnica de São Paulo; 5) Em virtude da doação ora feita à Universidade de São Paulo, a Faculdade de Arquitetura e Urbanismo gozará de todas as regalias outorgadas pelos seus Estatutos e Regulamentos; 6ํ) O imóvel não poderá ter outro destino especializado, a não ser o de suas finalidades acima definidas - podendo entretanto ser parcialmente ocupado a título provisório e precário, por outra dependência da Escola Politécnica de São Paulo, quando tal seja de absoluta necessidade - e isto pelo prazo máximo de dez anos - todavia; $7^{\circ}$ ) Quando a Faculdade de Arquitetura e Urbanismo, eventualmente, mas em prazo nunca inferior a vinte anos, venha a ser transferida para um edifício próprio na Cidade Universitária, os ora doadores, determinam que o prédio e respectivo terreno da 'Vila Penteado' ora doados, se destinem a uma Biblioteca Pública especializada em assuntos atinentes e afins com os objetivos da Faculdade de Arquitetura e Urbanismo, bem como com os da Escola Politécnica de São Paulo [...]. ${ }^{53}$

${ }^{53}$ Trecho da Escritura de doação da Vila Penteado, de 31 de outubro de 1946. Outorgantes: Silvio Alvares Penteado e outro. Outorgada: Universidade de São Paulo. Livro de Notas n 766 fls. $66 v^{\circ}$. Primeiro translado de escritura de doação. Carimbo do $4^{\circ}$ distribuidor $n^{\circ} 12766$. Documento incluso no processo 2007.1.1416.1.2 da FAUUSP, Secretaria de ensino superior do Estado de São Paulo, GR/2007/RUSP", Informações fornecidas a pedido SOBRE ESCRITURA E SUA DETERMINAÇÃO NA DOAÇÃO DO PRÉDIO DA FAUUSP - RUA MARANHÃO, 88. 
Quando da doação, a Vila Penteado estava inserida em terreno reduzido em relação a sua implantação original, tendo, conforme escritura de doação, as seguintes dimensões: $60 \mathrm{~m}$ de frente para a Rua Maranhão, $68 \mathrm{~m}$ referentes ao lado esquerdo, $60 \mathrm{~m}$ de fundo e $64,50 \mathrm{~m}$ referentes ao lado direito, somando $3.975 \mathrm{~m}^{2}$ de área.

O edifício Vila Penteado recebeu o curso de graduação da Faculdade de Arquitetura e Urbanismo, que começou a funcionar nessas instalações, com aproximadamente 50 alunos, a partir de 1948.

\begin{abstract}
Em meados dos anos de 1948, era finalmente criada a Faculdade de Arquitetura e Urbanismo de São Paulo. Aparentemente simples, a criação da nova Faculdade pela Lei $n^{\circ}$. 104, de 21 de junho de 1948, aprovada pela Assembleia Legislativa do Estado, era no entanto, o resultado de uma longa série de iniciativas, entendimentos e providências, que tiveram início anos atrás.

[...]

Foram principais protagonistas destes acontecimentos, o prof. Luiz Ignacio Romeiro de Anhaia Mello, do curso de Engenheiro Arquiteto da Escola Politécnica, reconhecido como fundador da Faculdade de Arquitetura e Urbanismo da Universidade de São Paulo, e os irmão Armando e Silvio Álvares Penteado, doadores do prédio da rua Maranhão, 88, para a sua instalação e funcionamento. Inegavelmente, L. I. R. de Anhaia Mello foi o articulador e esteve no centro de todo este processo. (BIRKHOLZ; NOGUEIRA, 1993). ${ }^{54}$
\end{abstract}

Naquele momento o Departamento de Obras Públicas de São Paulo (DOP) fez as obras necessárias para adaptação do edifício para o novo uso, onde, com exceção do saguão e das saletas, que se interligam com o saguão, as demais salas receberam pinturas uniformes. O pavimento superior do edifício foi transformado em salas de aula, seção de alunos e diretoria, sendo que o pavimento inferior abrigou, em seus salões, os ateliês de artes plásticas, pintura e escultura. Nesse momento os banheiros também sofreram intervenções, visando adequar as instalações ao novo uso. Sendo que "a ocupação do prédio foi comemorada com uma exposição em homenagem ao primeiro aniversário do $\mathrm{GFAU}^{55}$, em 5 de novembro de 1949, e a Mário de Andrade, na 2a Semana Nacional de Folclore" (NASCIMENTO, 2002, p. 144 e 145).

54 BIRKHOLZ, Lauro Bastos e NOGUEIRA, Brenno Cyrino Nogueira. A FAUUSP, sua Criação e Funcionamento na Vila Penteado. Sinopses Memória. São Paulo: Faculdade de Arquitetura e Urbanismo da Universidade de São Paulo, 1993, edição especial.

${ }^{55}$ Grêmio Estudantil da Faculdade de Arquitetura e Urbanismo (GFAU). 
Também foram construídos pavilhões de apoio, junto às divisas laterais e de fundo do terreno da Vila Penteado, visando suprir a necessidade de espaços para o funcionamento das atividades pertinentes ao curso de graduação em Arquitetura e Urbanismo. As fotos das figuras 32 a 34 apresentam trechos dos três barracões edificados.
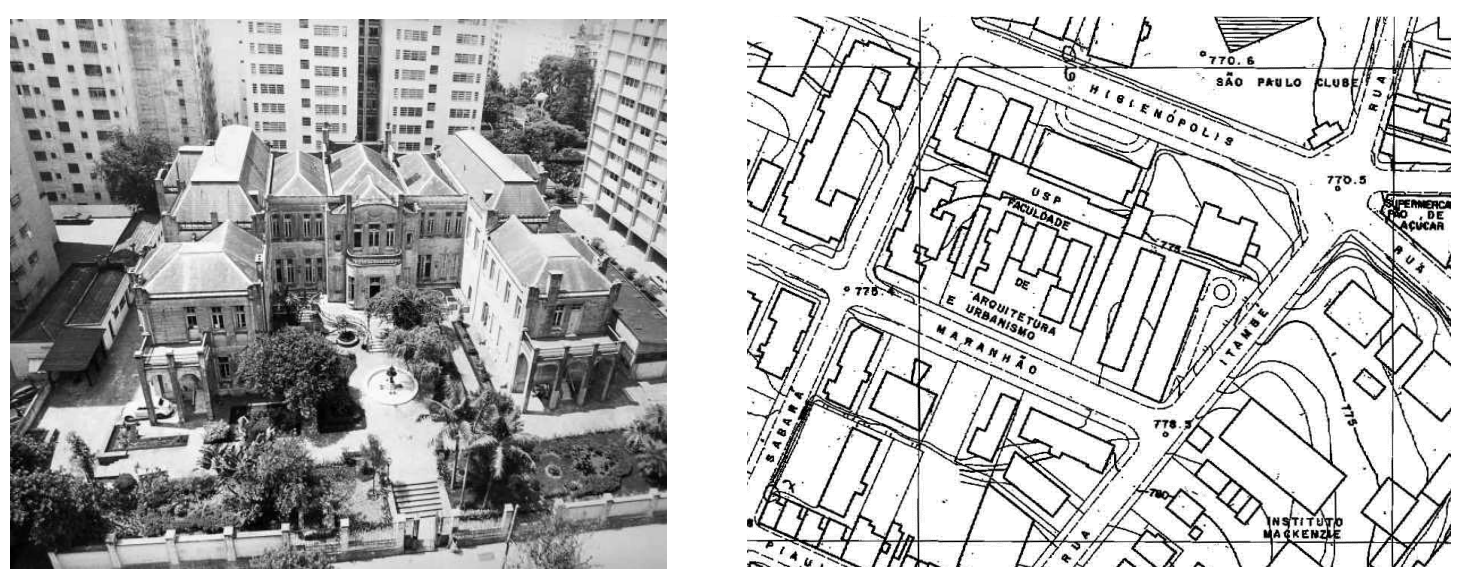

Figura 32 - Foto e Mapa: implantação da Vila Penteado com Barracões Anexos Fonte: Foto pertencente ao Trabalho de Graduação Final "Vila Penteado: vida nova em velho prédio", de Alberto de Prado, 1979. Mapa GEGRAN, atualizado com voo de 1974.
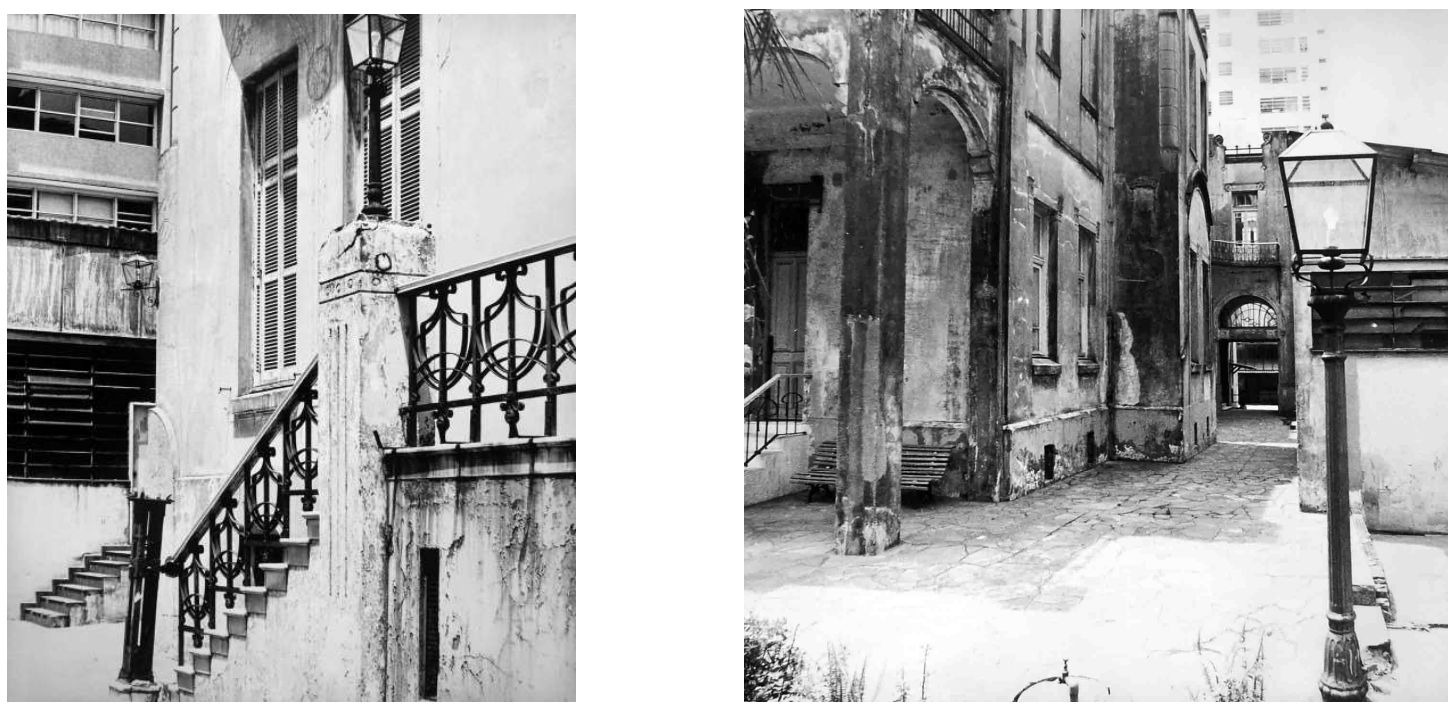

Figura 33 - Fotos da Vila Penteado com Barracões Anexos

Foto à esquerda, barracão anexo com $96 \mathrm{~m}^{2}$ de área construída (notar em primeiro plano o casarão Vila Penteado, em segundo plano o barracão anexo e ao fundo o edifício do terreno vizinho ao lote 88).

Foto à direita, o barracão localiza-se atrás do poste de iluminação. Esse pavilhão englobava $279 \mathrm{~m}^{2}$ de área construída.

Fonte: Fotos pertencentes ao Trabalho de Graduação Final "Vila Penteado: vida nova em velho prédio", de Alberto de Prado, 1979. 

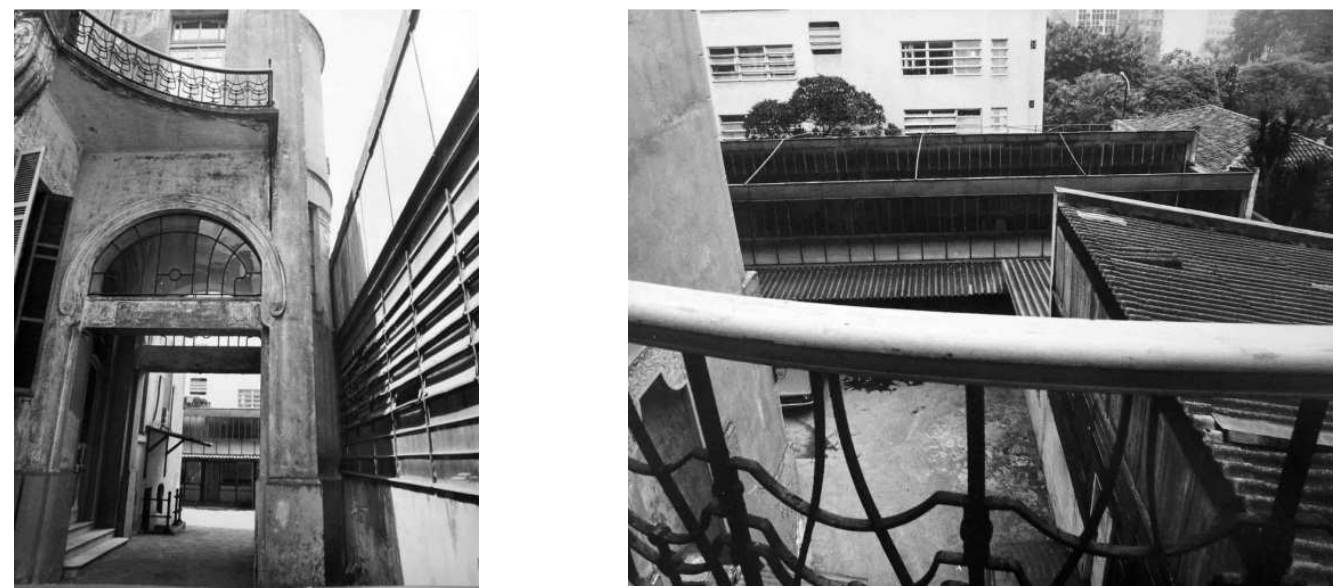

Figura 34 - Fotos da Vila Penteado com Barracões Anexos

Foto à esquerda, barracão anexo com $279 \mathrm{~m}^{2}$ de área construída em primeiro plano, e, ao fundo, barracão de $561 \mathrm{~m}^{2}$.

Foto à direita, vista, a partir do terraço do casarão Vila Penteado, dos barracões de $279 \mathrm{~m}^{2}$ e de $561 \mathrm{~m}^{2}$.

Fonte: Fotos pertencentes ao Trabalho de Graduação Final "Vila Penteado: vida nova em velho prédio", de Alberto de Prado, 1979.

Segundo o cadastro imobiliário (desenho M-519, escala 1:500, de 22/02/1972), o edifício Vila Penteado contém 2.206,42 $\mathrm{m}^{2}$ de área construída e os três barracões anexos contemplavam juntos cerca de $936 \mathrm{~m}^{2}$ de área construída, totalizando $3.142,42 \mathrm{~m}^{2}$ de área construída, em terreno de $3.975 \mathrm{~m}^{2}$ (de acordo com a escritura), tendo $832,58 \mathrm{~m}^{2}$ de área livre.

Mais tarde, o edifício sede da FAU na Cidade Universitária Armando de Salles Oliveira, de autoria do arquiteto João Batista Vilanova Artigas, foi edificado, e o curso de graduação foi transferido em 1969 (SIMÕES, 1993, p.9). Com a transferência do curso de graduação, a Vila Penteado passou por uma fase de abandono, permanecendo no casarão apenas o Centro de Pesquisa e Estudos Urbanísticos (NASCIMENTO, 2002, p.145).

Nesse período que foi mantido fechado, o edifício sofreu intensa deterioração:

Com o passar dos anos (período de 69 a 73), suas áreas físicas sofrem um degaste natural, motivado pela falta de manutenção e preservação compatíveis e necessárias, o que não acontecia anteriormente pela intensidade do seu uso, pois sua manutenção preventiva e corretiva se fazia sentir. (SIMÕES, 1993, p.9)

A dissertação de mestrado da engenheira Claudia Bastos do Nascimento (2002), evidencia a significativa deterioração do edifício Vila Penteado, durante os dois períodos de abandono pelos quais passou: 
[...] a edificação Vila Penteado passou por dois períodos de abandono, o primeiro após o falecimento da Condessa Ana e o segundo após a transferência do curso de graduação de arquitetura e urbanismo para a Cidade universitária. Esses períodos devem ter contribuído significativamente para o avanço da deterioração do prédio;

- foi verificada a presença de cupins de solo, comuns na região do bairro Higienópolis, em avaliação em 1989. Embora esta avaliação tenha resultado na indicação de medidas corretivas, não se encontraram registros da realização de descupinização, exceto para o madeiramento do telhado, 0 qual recebeu um tratamento químico [...] (NASCIMENTO, 2002, p.134 e 135).

Visando definir a nova ocupação do edifício Vila Penteado, a Congregação aprovou, em sessão de 26 de setembro de 1969, o Parecer emitido pela Comissão encarregada de estudar o destino a ser dado ao prédio Vila Penteado:

A Comissão, tendo em vista os itens $6^{\circ}$ e $7^{0}$ da Escritura de doação de 31 de outubro de 1946, propõe:

1. que o prédio permaneça sob a direção e responsabilidade da Faculdade de Arquitetura e Urbanismo;

2. que se programe a reconstituição de prédio com mobiliário e objetos da época, efetuando-se para tanto as pesquisas necessárias pelo Departamento de História da Faculdade de Arquitetura e Urbanismo e o respectivo orçamento para execução das obras;

3. que se objetive instalar-se no prédio reconstituído - monumento arquitetônico dos mais representativos do início do século - Biblioteca referente ao avanço tecnológico e à vida artística da cultura do café;

4. que, isto feito, as atividades da Faculdade de Arquitetura e Urbanismo, no seu prédio da 'Vila Penteado', sejam da seguinte natureza: cursos de pós-graduação em arquitetura e urbanismo; serviços da biblioteca abertos ao público; conferências, amostras e exposições. ${ }^{56}$

Em 1973, a Vila Penteado passou a abrigar o curso de pós-graduação da FAUUSP.

No ano de 1973 foi dado início a um novo período na história da edificação, que passou a acolher os seguintes grupos de estudo e pesquisa: planejamento urbano e regional; planejamento habitacional; racionalização da construção; planejamento de transportes; planejamento paisagístico e ambiental; semiótica do ambiente urbano; restauração e conservação de monumentos e conjuntos históricos e métodos; todos com ênfase na informação científica. Marcando este novo período no qual a edificação passou a brigar os cursos de especialização e pós-graduação da FAU, foi realizado com grande mérito o Curso de Restauração e Conservação de Monumentos e Conjuntos Históricos, em agosto de 1974, ministrado pelos

${ }^{56}$ Parecer emitido pela Comissão encarregada de estudar o destino a ser dado ao Prédio 'Vila Penteado', datado em 04/03/1969 e assinado pelos professores João Batista Vilanova Artigas, Lauro Bastos Birkholz e Juarez Rubens Brandão Lopes. Aprovado pela Congregação em sessão de 26/09/1969. 
professores Hugues de Varine-Bohan da França; Viana de Lima de Portugal e Vitor Pimentel ${ }^{57}$ do Peru (NASCIMENTO, 2002, p.145).

Para instalar o curso de pós-graduação, algumas reformas foram feitas, sendo que a necessidade de espaços amplos foi reduzida, em relação ao uso do período onde a Vila Penteado foi ocupada pelo curso de graduação da FAUUSP.

Alguns dos ambientes da Vila Penteado desse período são apresentados nas figuras 35 a 38 .
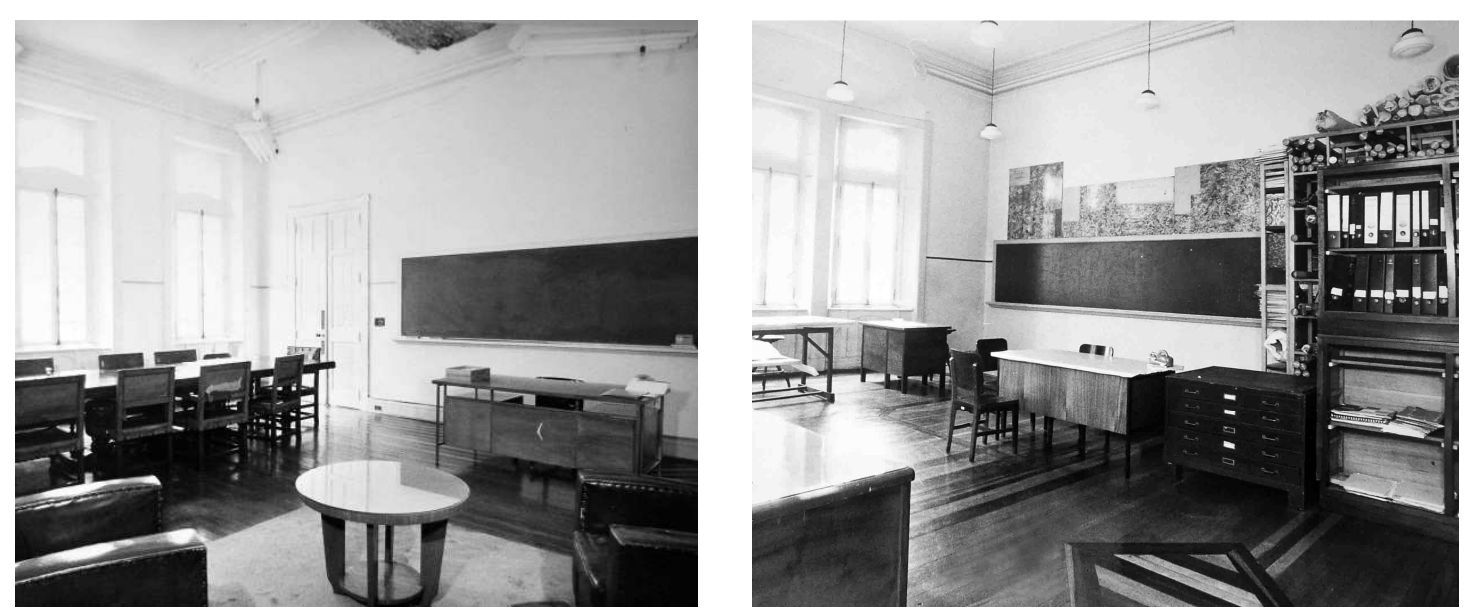

Figura 35 - Fotos dos ambientes internos da Vila Penteado no período da graduação Fonte: Fotos pertencentes ao Trabalho de Graduação Final "Vila Penteado: vida nova em velho prédio", de Alberto de Prado, 1979.
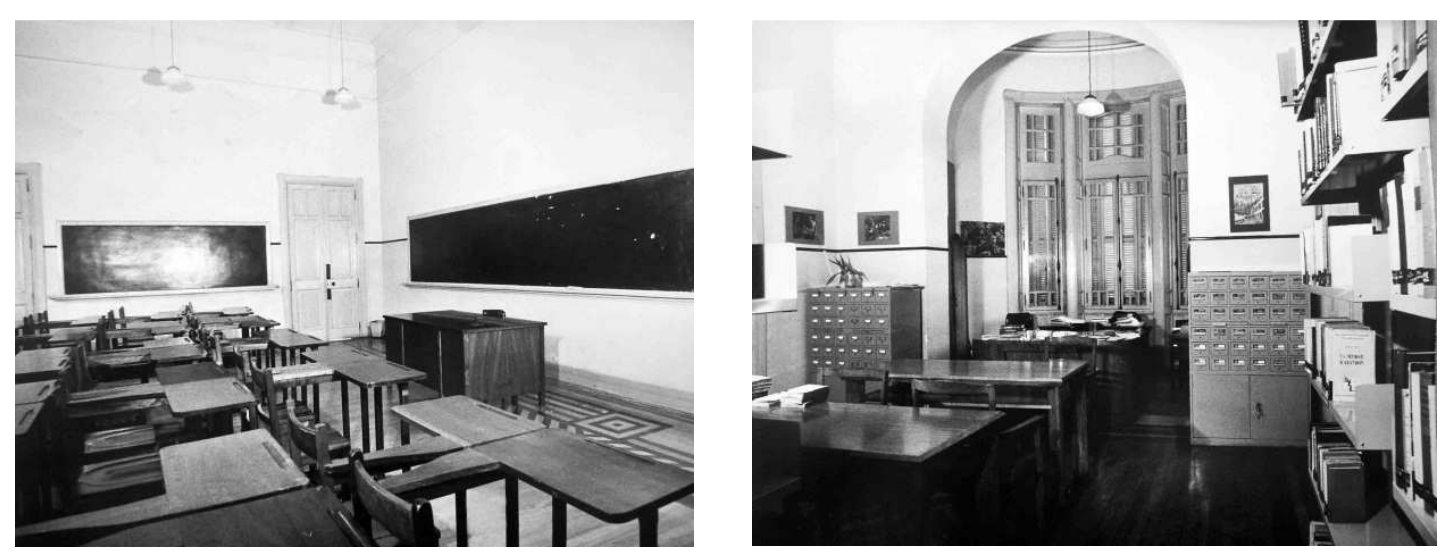

Figura 36 - Fotos dos ambientes internos da Vila Penteado no período da graduação Sala de aula na foto à esquerda e biblioteca à direta.

Fonte: Fotos pertencentes ao Trabalho de Graduação Final "Vila Penteado: vida nova em velho prédio", de Alberto de Prado, 1979.

${ }^{57}$ Vitor Pimentel participou da elaboração da Carta de Veneza de 1964. 


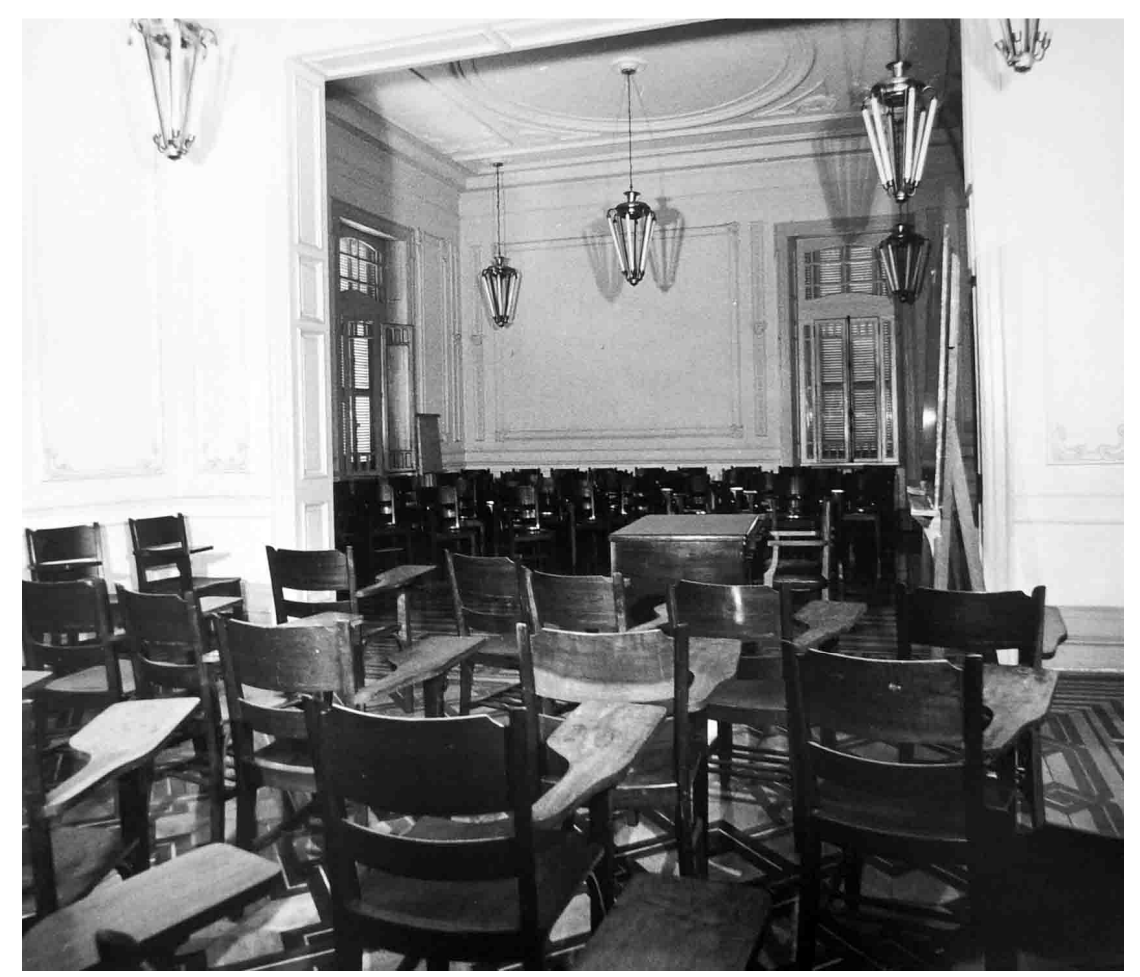

Figura 37 - Foto das antigas salas Luis XV e Maria Antonieta, no período da graduação foram usadas como salas de aula e, hoje, como auditório Destaque para o mobiliário e lustres.

Fonte: Fotos pertencentes ao Trabalho de Graduação Final "Vila Penteado: vida nova em velho prédio", de Alberto de Prado, 1979.
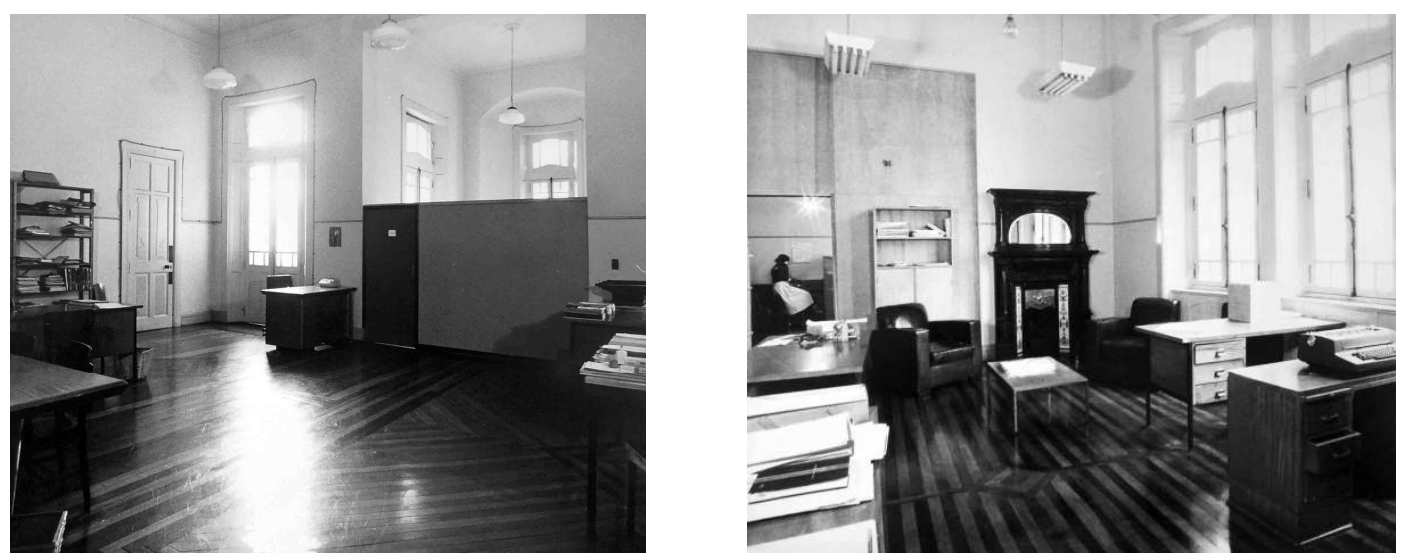

Figura 38 - Fotos dos antigos dormitórios, usados como sala de contabilidade e sala de aula no período da graduação e, hoje, como secretaria Destaque para as divisórias incorporadas.

Fonte: Fotos pertencentes ao Trabalho de Graduação Final "Vila Penteado: vida nova em velho prédio", de Alberto de Prado, 1979.

Com o início do uso da Vila Penteado pelo curso de pós-graduação, as ações de manutenção foram retomadas, mas as limitações financeiras tornaram-se obstáculos, como comenta o Prof. Roberto Simões, no Boletim Técnico número 12 (1993, p.10): 
[...] essa ação fica cerceada pelas limitações orçamentárias decrescentes na Universidade. A partir dos anos 70 , motivado por essa carência de recursos e pela insensibilidade dos órgãos públicos em geral, acentua-se a falta da realização de obras de manutenção e preservação do bem público.

Ainda na década de 1970, foram realizadas obras de adequação no terreno da Vila Penteado, onde os pavilhões anexos foram demolidos. O Processo RUSP, $N^{0} 18.034 / 75$, indica que foi autorizada, pelo Reitor Dr. Waldyr Muniz Oliva, a demolição do pavilhão, construído junto a divisa lateral e entrada principal do prédio da Vila Penteado, em sessão datada em 07 de outubro de 1975. E o Processo ${ }^{\circ}$ 99.1.319.16.3, solicita que seja autorizada licitação para venda da demolição de pavilhão do prédio, sito à Rua Maranhão, 88.

Em 1976, a documentação pedindo o tombamento da Vila Penteado foi organizada, através do trabalho realizado por membros da Comissão de Atividades Extra Curriculares da FAU (CAEC FAU). A importância da Vila Penteado pode então ser registrada e apresentada, através da "Exposição Vila Penteado", que resultou na pesquisa, análise e organização de documentação de extrema relevância. $O$ texto de Maria Cecília Naclério Homem Prado, intitulado "Relatório de Pesquisa" apresenta essa situação:

Os objetivos deste estudo seriam a utilização do material a ser levantado para a exposição sobre a residência, que, por sua vez, documentaria o processo de tombamento do prédio, e trazer documentação de interesse para a Escola. [...]

A exposição 'Vila Penteado' representa uma etapa fundamental no estudo da residência e da época em que foi construída, sendo resultante de uma somatória de longos esforços despendidos em várias fases de trabalho. Além da participação dos professores, os trabalhos estiveram sob a responsabilidade de funcionários especializados da Faculdade de Arquitetura e Urbanismo da Universidade de São Paulo, aos quais se juntou a colaboração dos alunos Antonio Carlos Carneiro e José Salles Costa Filho, autores do levantamento do prédio. (HOMEM, 1976, p.12).

Os estudos realizados originaram uma maquete do edifício, que permanece exposta na Vila Penteado.

O trabalho incluiu a recuperação de plantas e detalhes do levantamento métrico do edifício, que se fizeram acompanhar por um levantamento fotográfico circunstanciado em branco-e-preto e a cores, procurando registrar os vários ambientes e os detalhes construtivos característicos da obra. Procedeu-se depois a um trabalho de interpretação de elementos aerofotogramétricos, desde1930 e, por comparação, com apoio em fotografias antigas, foi elaborada maquete que possibilitou, por sua vez, uma análise da evolução do edifício no tempo. Com colaboração do 
arquiteto Gustavo Neves da Rocha Filho e do Sr. Hélio lagher, funcionário do Laboratório de Modelos e Ensaios, foi possível identificar diferentes etapas, com sucessivas ampliações e modificações na obra, registradas na maquete desmontável. (REIS FILHO, 2002).
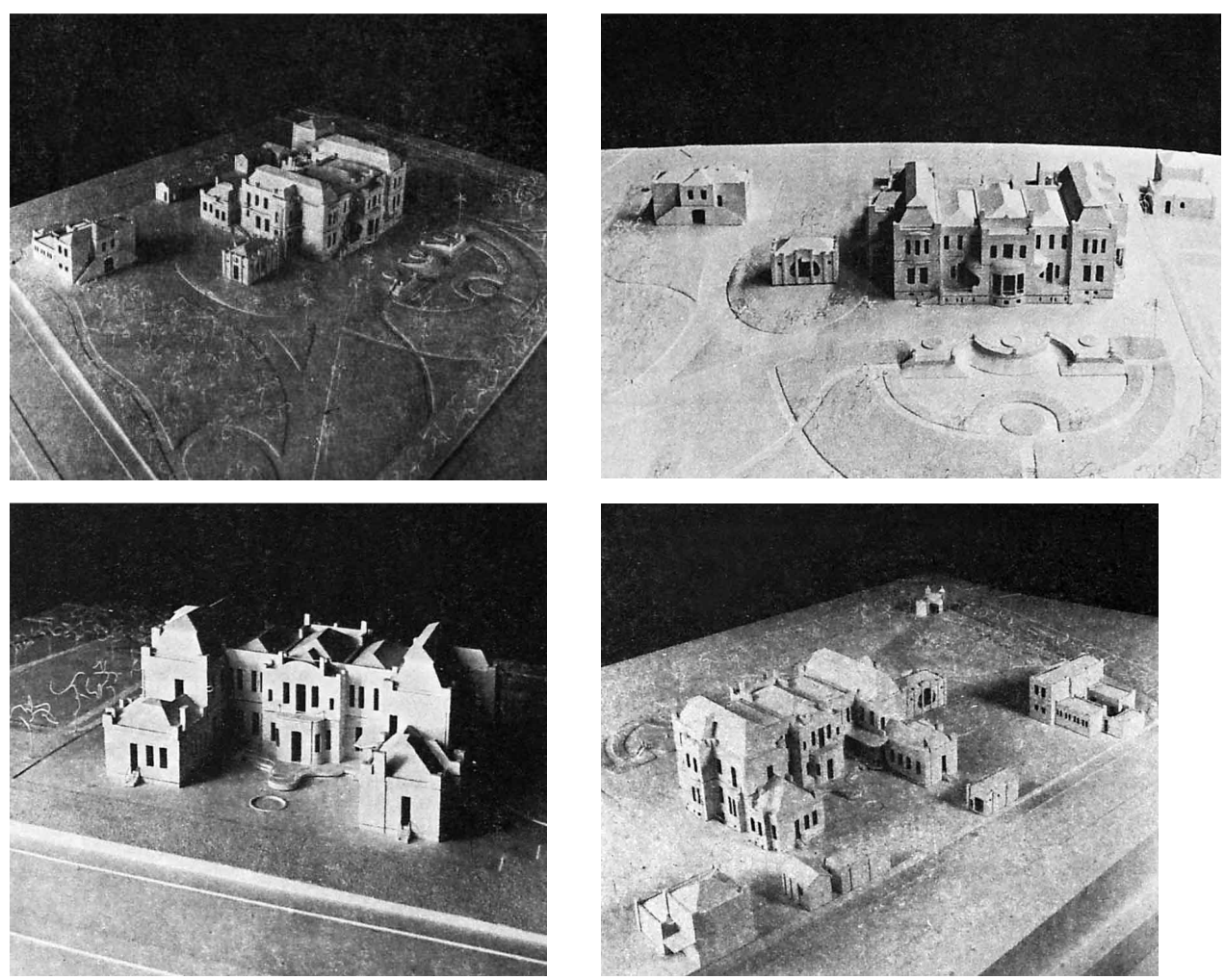

Figura 39 - Maquete da Vila Penteado

Fonte: HOMEM, Maria Cecília Naclério [Coord] e MACHADO, Lucio Gomes. Exposição Vila Penteado. Catálogo. São Paulo: FAUUSP, 1976.

A figura 39 apresenta fotos da maquete publicadas no catálogo "Exposição Vila Penteado" e as fotos, nas figuras 40 e 41, apresentam a mesma maquete, que permanece exposta no hall ao lado do Saguão do edifício.

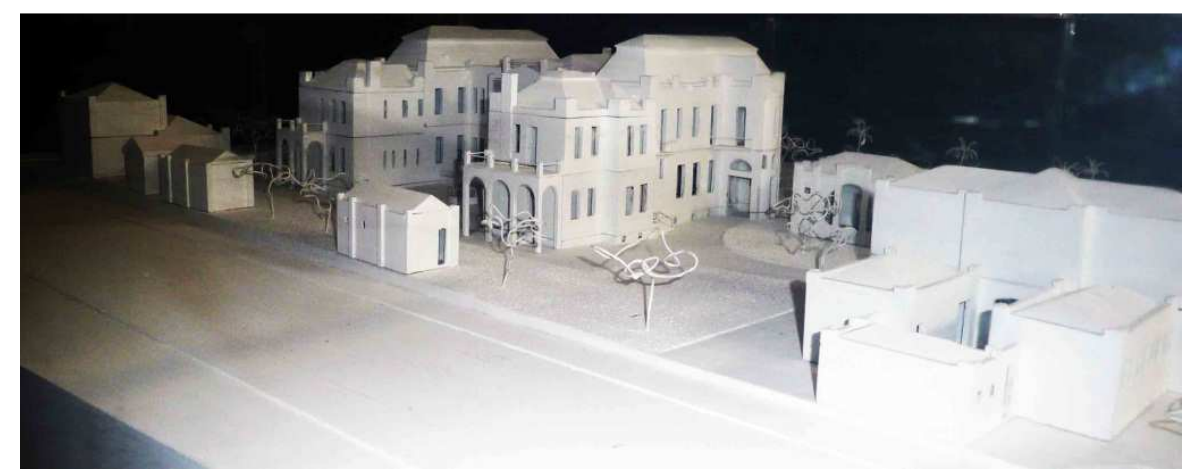

Figura 40 - Maquete da Vila Penteado Foto: Isis Roverso, dezembro de 2010. 

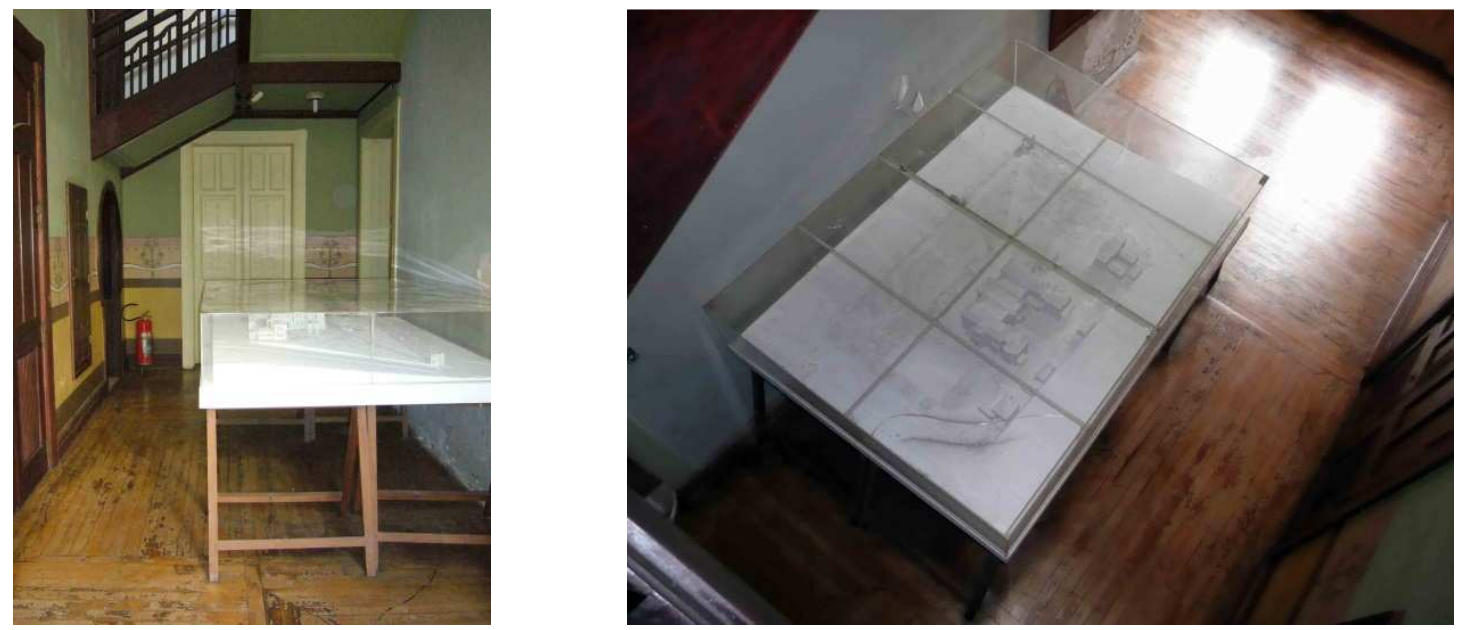

Figura 41 - Maquete da Vila Penteado

Fotos: Isis Roverso, foto da esquerda de abril de 2011 e foto da direita de dezembro de 2010.

O edifício Vila Penteado foi tombado pelo Conselho de Defesa do Patrimônio Histórico, Artístico, Arqueológico e Turístico do Estado de São Paulo CONDEPHAAT, em 27 de fevereiro de 1978 (Processo $N^{\circ}$ 08638/1969) e pelo Conselho Municipal de Preservação do Patrimônio Histórico, Cultural e Ambiental da Cidade de São Paulo - CONPRESP, com resolução de tombamento ex officio $n$. 5/91, em 05 de abril de 1991 (Processo N $16-001.857-91 * 00$ ).

As razões do tombamento podem ser observadas em um trecho retirado do livro "Bens Imóveis Tombados ou em Processos de Tombamento da USP" (LOURENÇO; et al, 1999, p.137), que cita o conteúdo do Processo 8638/69 do CONDEPHAAT ${ }^{58}$ :

O processo de tombamento foi aberto em 1/4/1969 a pedido do conselheiro Nestor Goulart Reis Filho, professor e representante da FAUUSP no Colegiado do Condephaat.

O serviço técnico do Conselho manifesta-se, em 17/3/1970: "trata-se de um dos raros exemplos qualificados do Art Nouveau aqui implantados no começo do século (...) apesar deste estilo representar para nós uma importação como outra qualquer que pouca influência exerceu no desenvolvimento posterior da arquitetura brasileira, (...) somos portanto favoráveis ao tombamento do presente imóvel dadas as qualidades intrínsecas do mesmo.

$O$ voto do relator do tombamento, o mesmo conselheiro, professor Nestor Goulart Reis Filho, considera que o conteúdo do trabalho desenvolvido na FAUUSP pela equipe que organizou a exposição e o catálogo Vila Penteado, em 1976, "justifica plenamente o tombamento proposto".

Num texto que consta no processo, sem assinatura e sem data, mas em papel timbrado da FAUUSP, no item Proposta de Tombamento, há a

${ }^{58}$ CONDEPHAAT, Processo 8638/69. São Paulo: 1969, apud LOURENÇO; et al, 1999. 
seguinte argumentação: "Dado que a obra representa um documento de uma etapa do desenvolvimento urbano de São Paulo e que possui características de projeto e execução que denotam elevada qualidade, e que salvo pequenas alterações resultantes da instalação da FAU a obra apresenta sua integridade original, propomos o tombamento do prédio. $O$ gradil ainda existente na face voltada à rua Maranhão bem como o chafariz aí existente não podem ser desvinculados do conjunto. O mobiliário faz parte integrante do conjunto e deve ser tombado juntamente com o edifício".

No dia seguinte ao tombamento realizado pelo CONDEPHAAT, o jornal Diário Popular, de 28 de fevereiro de 1978, publicou a reportagem "Mais um monumento histórico - A velha Vila Penteado foi tombada como patrimônio da vida cultural da cidade". Nessa reportagem são destacadas as características do edifício e sua história. A publicação encerra-se com a chamada para a exposição:

A partir de hoje, o Museu da Imagem e do Som, órgão da Secretaria da Cultura, Ciência e Tecnologia, instalará no local uma exposição sobre a 'Vila Penteado', organizada pela USP, mostrando os aspectos mais interessantes do prédio e seu uso, desde a construção até agora. Depois do dia 16 de março, o MIS apresentará uma exposição ainda mais completa sobre a 'Vila Penteado', sua sede. As duas exposições estarão abertas à visitação pública. ${ }^{59}$

Na mesma data, o jornal O Estado de São Paulo divulga a matéria "Governo tomba prédio da FAU - A Vila Penteado, na rua Maranhão, será preservada como monumento histórico" ${ }^{60}$ Além de comentar sobre a importância da Vila, as características da variação do art nouveau são ressaltadas na publicação.

Na década de 1980, conforme declara o Prof. Roberto Simões, no Boletim Técnico, número 12 (1993, p.10), houve o levantamento e diagnóstico das deficiências construtivas no edifício Vila Penteado. Essas deficiências estavam relacionadas a problemas encontrados nas esquadrias de madeira (especialmente das venezianas do pavimento superior) e nas argamassas de revestimento da fachada, onde diversas áreas encontravam-se comprometidas. Problemas existentes no telhado também foram relacionados nessa ocasião.

Segundo o Prof. Simões, a empresa COTTA Ltda. "executou a contento as 33 novas venezianas que haviam sido retiradas dos seus vãos, pelas administrações

\footnotetext{
59 Trecho da reportagem "Mais um monumento histórico - A velha Vila Penteado foi tombada como patrimônio da vida cultural da cidade", publicado pelo jornal Diário Popular em 28 de fevereiro de 1978.

${ }^{60}$ Reportagem "Governo tomba prédio da FAU - A Vila Penteado, na rua Maranhão, será preservada como monumento histórico" publicada no jornal O estado de São Paulo em 28 de fevereiro de 1978.
} 
anteriores da Faculdade, em tempos idos" (SIMÕES, 1993, p.40). Essa mesma empresa executou os trabalhos de recuperação geral das esquadrias e pintura externa do edifício, fazendo uso das recomendações dadas pelos técnicos do SPHAN $^{61}$ e IPT ${ }^{62}$. Ainda segundo o Prof. Simões, "a pintura, após 2 (dois) anos apresentou falhas na sua cor, pois iniciava-se um processo acelerado de desbotamento, acrescido de manchas escuras, pela existência e proliferação de fungos" (SIMÕES, 1993, p.40).

Os motivos que geraram as falhas construtivas, relatados na pintura externa executada, ocorreram em função de deficiências existentes nos materiais empregados e na mão-de-obra contratada.

\begin{abstract}
A cal utilizada não era de boa qualidade, bem como a mão-de-obra especializada, pois na atualidade, praticamente não se consegue o nível de qualidade desejado.

Não houve também a raspagem e o tratamento necessário das fachadas com material antifungo (banho com água sanitária e ou similar).(SIMÕES, 1993, p.41)
\end{abstract}

A partir de 1988, a Comissão de Patrimônio Cultural da USP - CPC, através do Programa Conservação e Restauração de Bens Arquitetônicos e Integrados, desenvolveu estudos sobre a Vila Penteado, evidenciando sua história. Na figura 42 é possível verificar, por exemplo, pontos divergentes entre o projeto de 1901 e a construção de 1903, apontados pelos estudos realizados pelo CPC.

Análise Retrospectiva dos Espaços

O Mapa de forros realizado pelo "Canteiro Escola" do CPC-USP em 1991 contribuiu para esclarecer a qualidade e categoria das modificações físicas na planta do edifício ocorridas entre a construção (1903), a reforma de 1949 realizada para abriga a FAU-USP, e a planta configurada na década de 1990, que não tinham sido documentadas convencionalmente, conforme explicitam os desenhos dessa prancha. ${ }^{63}$

\footnotetext{
${ }^{61}$ Serviço do Patrimônio Histórico e Artístico Nacional (SPHAN), atualmente denominado Instituto do Patrimônio Histórico e Artístico Nacional (IPHAN).

62 Instituto de Pesquisas Tecnológicas (IPT).

${ }^{63}$ Inventário Crítico 4/4, $1^{\text {a }}$. Etapa (1990 a 1992): estudo pormenorizado da arquitetura - mapeamento de forros, Painel 8, Vila Penteado. Arquivo CPC USP.
} 


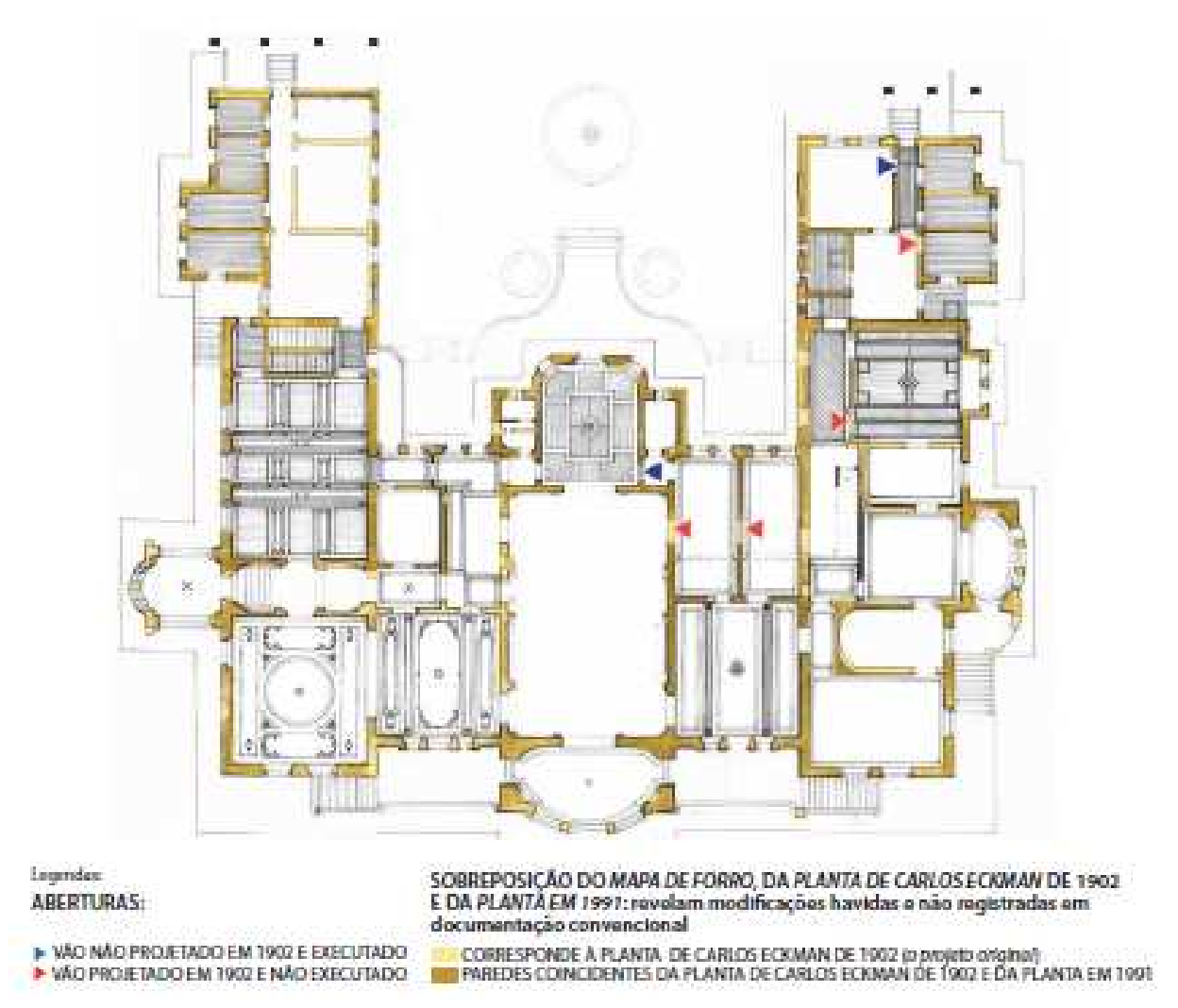

Figura 42 - Mapa de Forros x Planta Atual = Esclarecimentos sobre a planta construída em 1903

Fonte: CPC - Inventário Crítico 4/4, $1^{\mathrm{a}}$. Etapa (1990 a 1992): estudo pormenorizado da arquitetura - mapeamento de forros, Painel 8, Vila Penteado. Arquivo CPC USP.

Em setembro de 1990, as instalações elétricas do porão foram parcialmente reformadas, com o intuito de propiciar condições mínimas de segurança contra incêndios, sendo que as obras não foram concluídas, em função de limitações orçamentárias: "os serviços e obras vinculadas ao projeto elétrico do porão, desenhos 27.085/86 e 87, não foram totalmente concluídos" (SIMÕES, 1993, p. 46). Dessa forma "há necessidade de complementar a substituição de todos os condutores alimentadores dos quadros, a partir do quadro de distribuição geral, bem como substituir todos os condutores dos circuitos terminais do subsolo [...]" (SIMÕES, 1993, p. 46).

As obras realizadas no porão contemplaram a substituição da fiação elétrica antichamas, através de novos eletrodutos, substituição do quadro da chave-geral, instalação de luminárias e interruptores de acionamento. As obras foram realizadas pela empresa Comércio, Instalações e Montagens Elétricas S.A. - CIMEL, contratada pelo Fundo de Construções da USP (FUNDUSP).

$\mathrm{Na}$ figura 43 há fotos do quadro antigo de distribuição de luz e força, que se encontra, até os dias atuais, guardado no porão da Vila Penteado. 

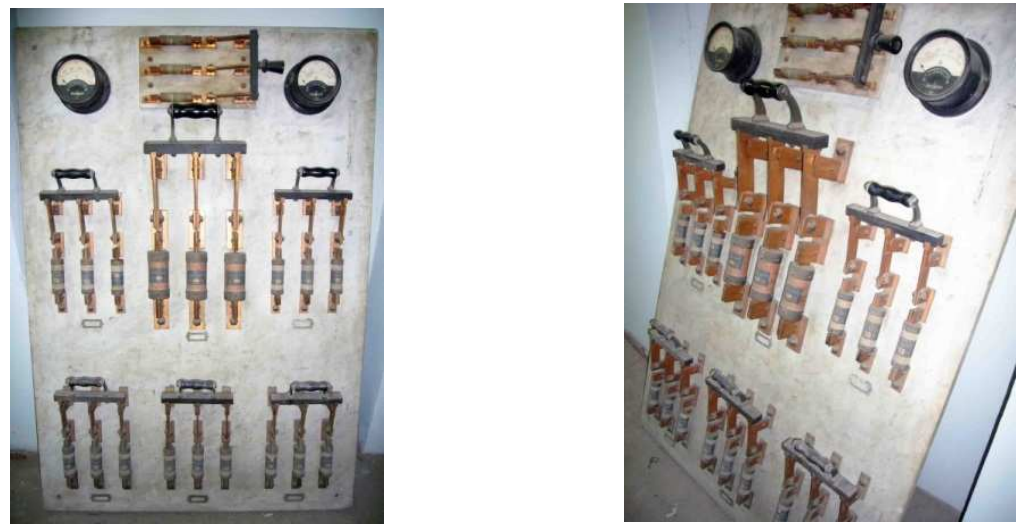

Figura 43 - Quadro original de luz e força guardado no porão da Vila Penteado Fotos: Isis Roverso, abril de 2011.

Em relação à cobertura, os trabalhos executados foram de revisão de alguns pontos, o que acabou por não resolver os problemas existentes, fazendo com que os vazamentos continuassem a comprometer as áreas internas da Vila Penteado.

No período de 15 a 30 de abril de 1993, foi realizada a exposição "SWEDEN BUILDS - Da Vila Penteado à Moderna Arquitetura Sueca", no Salão Caramelo da FAUUSP - Cidade Universitária. Com apoio da Associação Nacional dos Arquitetos Suecos (SAR), da Fundação para Pesquisa Ambiental (FUPAM), do Instituto dos Arquitetos do Brasil (IAB) e da Revista Arquitetura \& Construção (Editora Abril). Durante a exposição houve conferência com Ole Peter Reiter e debate com os arquitetos Frank Svensson, Joaquim Guedes, Roberto Loeb e Sergio Tepermann.

Na década de 1990, houve o desmoronamento parcial de algumas áreas de forro, o que acabou por provocar a interdição da Vila Penteado, por motivos de segurança. O Processo $\mathrm{N}^{0}$ 94.1.660.51.0, tratado em conjunto com o FUNDUSP/ PCO, através do Protocolo $N^{\circ}$ 94.5.1673.49.4, tem por assunto: "Informa que foi interditado por segurança o prédio da FAU Maranhão". Nesse processo contém o relatório de vistoria, de 5 de julho de 1994, assinado pelo engenheiro Fausto Tarran, do FUNDUSP, relatando sua visita à Vila Penteado, para análise do forro da sala contígua à Biblioteca, Mapoteca, que havia desmoronado no dia anterior. A partir do desmoronamento desse forro, iniciava-se um processo longo e detalhado para verificação da situação geral dos forros em estuque da Vila Penteado e das possíveis ações de preservação (verificar esse assunto no item 3.2.2 "Intervenções nos Forros"). 
No dia 08 de julho de 1994, em função da interdição do edifício Vila Penteado, foi publicada uma carta do professor Gustavo Neves da Rocha Filho, membro do Conselho Curador da FAU, no Jornal da Tarde, alertando sobre a situação em que se encontrava a Vila Penteado, patrimônio da sociedade paulistana.

Outros estudos foram realizados, como a vistoria e assessoria técnica para restauro da cobertura da Vila Penteado. Segundo Simões (1993, p.46 e 47), as obras de preservação e restauro, para a recomposição da cobertura da Vila Penteado, foram executadas pela empresa ARESTA Arquitetura e Restauro Ltda. (com sede em Curitiba), a partir das especificações técnicas "elaboradas pelo Prof. Antonio Luiz Dias de Andrade da FAUUSP e da Secretaria de Patrimônio Histórico e Artístico Nacional - SPHAN, juntamente com os arquitetos das instituições da USP [FUNDUSP e CPC-USP], que por sua vez viabilizaram a execução dos serviços especificados."

Sobre a qualidade dos trabalhos realizados pela ARESTA, o Prof. Simões declara (1993, p.47):

Realizou todos os serviços com presteza e conhecimento de causa, em que pesem os tropeços e açodamentos técnico-administrativos tão comuns em obras civis deste gênero.

A preservação e o restauro da cobertura foi concluída em tempo e hora, estando o edifício protegido das águas das chuvas e com possibilidade de prosseguir as obras de restauro programadas nas suas áreas internas.

Em 1998, foi desenvolvido o projeto de ocupação e restauro da biblioteca. Foi aprovado pela Fundação de Amparo à Pesquisa no Estado de São Paulo (FAPESP), em 1999, sendo que a obra foi concluída em 2002. As circunstâncias das obras realizadas na biblioteca são contempladas no item 3.2.6 "Intervenção na Área da Biblioteca".

$\mathrm{Na}$ década de 2000, diversas análises e estudos foram feitos visando à restauração do edifício Vila Penteado. O Relatório da Gestão do Edifício Vila Penteado, datado de 01 de março de 2002 a 01 de novembro de 2002, assinado pelos professores Antonio Carlos Barossi e Helena A. Ayoub Silva, traz informações sobre a requalificação e restauro integral do edifício:

O Edifício Vila Penteado, onde desde 1972 funciona a Pós-Graduação da FAU teve tratamento prioritário durante nossa gestão por constituir o único exemplar art nouveau, de arquitetura residencial em São Paulo, e principalmente devido ao estado de abandono em que se encontrava. 
A requalificação e restauro integral do edifício Vila Penteado $\left(2.500 \mathrm{~m}^{2}\right)$, foi orçado em 2001 em R\$3.700.000,00, conta com o apoio do Governo Federal (Ministério da Cultura) através da Lei Rouanet (8.313/91) e da Prefeitura o Município de São Paulo (Secretaria Municipal de Cultura) através da Lei Mendonça (10.923/90).

Com a proximidade do centenário do edifício, várias ações foram impulsionadas, visando à valorização e às comemorações da Vila Penteado. Essas ações tiveram caráter efetivo no edifício, com obras de recuperação e manutenção e também caráter documentário como a organização e a publicação do número especial da Revista Pós, intitulado "Vila Penteado 100 anos" (2002).

Em 2002 as fachadas da Vila Penteado foram trabalhadas pela empresa Logus Tecnologia em Obras, com acompanhamento da obra feito pelos gestores do edifício, professores e arquitetos Antônio Carlos Barossi e Helena Ayoub Silva, sendo que a arquiteta Regina Tirello, da CPC USP, realizou testes de cores nas fachadas (para informações detalhadas, ver item 3.2.3 "Pintura Mural e Fachadas").

Nesse mesmo período, foram abertos dois vãos de acesso entre a portaria atual (antigo escritório do conde Álvares Penteado) em direção à biblioteca. Essas aberturas permanecem até os dias atuais e apresentam-se marcadas com clara intervenção contemporânea, como pode ser observado nas fotos da figura 44 .
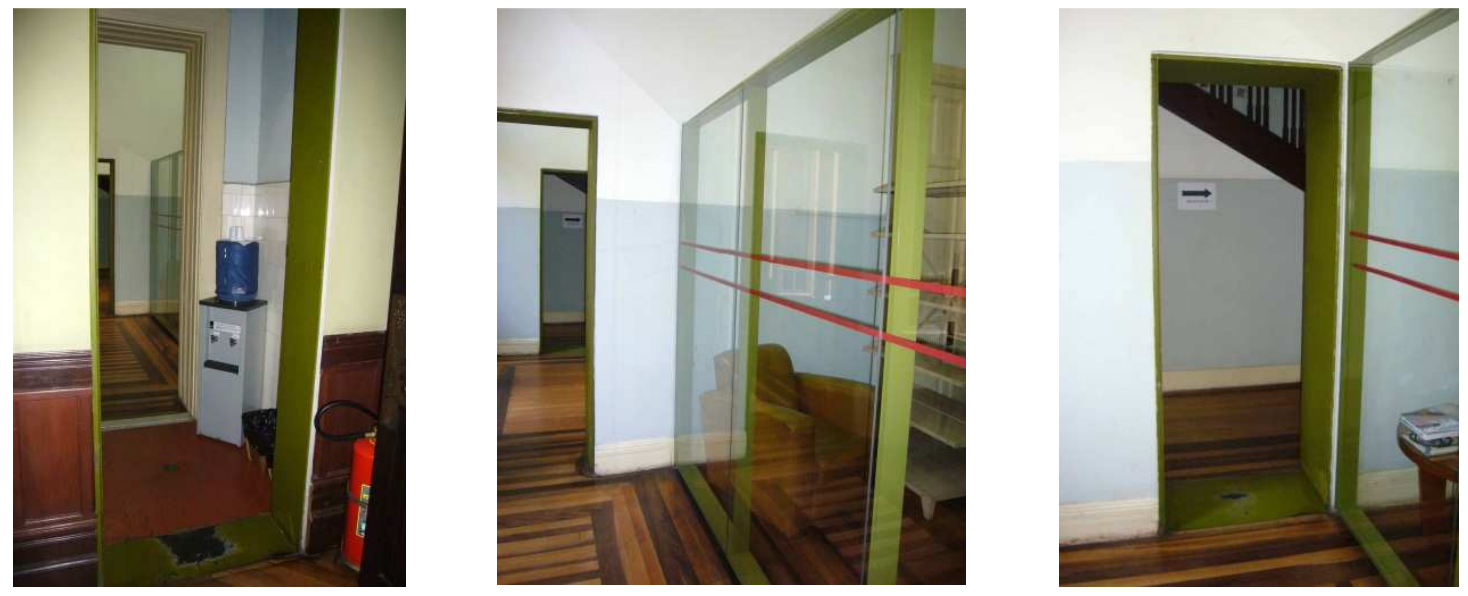

Figura 44 - Novas aberturas realizadas em 2002

Fotos: Isis Roverso, abril de 2011.

A decisão de abertura desses vãos foi analisada e discutida, sob pontos de vista distintos, inclusive dentro da perspectiva proposta pelo projeto de ocupação e restauro da biblioteca, projeto aprovado pelo CONDEPHAAT, cuja solução faz parte do projeto global de ocupação do edifício Vila Penteado, de autoria do Prof. Dr. 
Carlos Augusto Mattei Faggin, publicado parcialmente pela Fundação para a Pesquisa Ambiental - FUPAM, em 2002, no encarte "Projeto de Restauro e Recuperação do Edifício Vila Penteado".

O momento de decisão, sobre a abertura dos dois vãos, coincidiu com o andamento das obras na biblioteca, bem como os serviços de restauro em desenvolvimento pela CPC na portaria do edifício ${ }^{64}$, ou seja, a solução foi consolidada com as obras existentes e obteve a aprovação dos gestores da Vila Penteado, nos seguintes termos:

[...] somos favoráveis à execução do novo acesso proposto pelo projeto da biblioteca, complementado pela remoção do tabique existente e da parede sob a escada, bem como pela reintegração ao edifício através dessa circulação, a partir de projeto a ser desenvolvido, dos espaços onde hoje estão a copa dos funcionários e parte da biblioteca que será liberada. ${ }^{65}$

$\mathrm{Na}$ foto da figura 45 é possível notar o alinhamento entre o acesso original e as novas aberturas executadas.

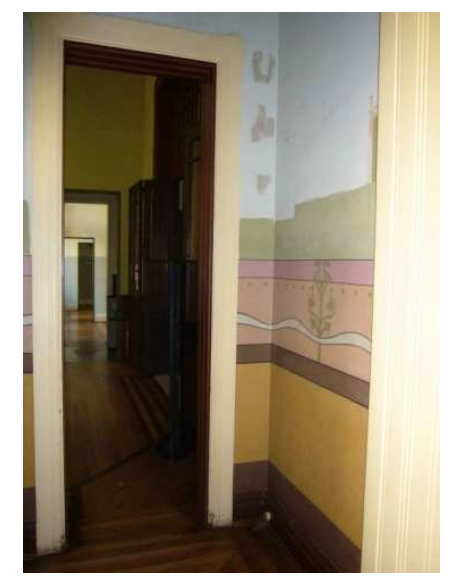

Figura 45 - Alinhamento das novas aberturas realizadas em 2002 Foto: Isis Roverso, abril de 2011.

Ainda no ano de 2002, os serviços de: recuperação, restauro e pintura das esquadrias externas de madeira e ferro do edifício Vila Penteado, foram iniciados

${ }^{64}$ Conforme registro no documento MANIFESTAÇÃO SOBRE A ABERTURA DE NOVO ACESSO À ALA DIREITA DA VILA PENTEADO (em relação à entrada principal / av Higienópolis, correspondente à residência de Antonio Prado Jr.), 12/08/2002, Prof. Antonio Carlos Barossi e Prof ${ }^{a}$ Helena Ayoub Silva, p.1.

${ }^{65}$ Ibidem, p.5. 
pela empresa Júlio Moraes Conservação e Restauro SCL. Detalhes desse trabalho estão registrados no item 3.2.4 "Levantamento e Recuperação das Esquadrias".

No início de 2003, através do contrato $87 / 2002^{66}$, a empresa Oxivida Engenharia Ltda. iniciou os trabalhos de pintura interna monocromática de paredes da Vila Penteado. Entretanto, cabe ressaltar que: a execução dos trabalhos em edifício patrimoniais deve ser realizada por empresas especializadas no campo do restauro, almejando obter a qualidade adequada. No caso das pinturas internas, o comentário do Prof. Dr. Júlio Roberto Katinsky, Presidente do Conselho Curador, registrado na Ata da 19a Reunião Ordinária do Conselho Curador da FAUUSP, evidencia a qualidade dos serviços de pintura:

\begin{abstract}
Sobre a obra de pintura interna do prédio, o Prof. Katinsky, observou e considerou de baixa qualidade os serviços de pintura nas áreas internas do prédio. A Prof ${ }^{a}$ Helena esclareceu que sendo a verba restrita (limitada) optou-se por serviços de pintura "comum" e não por serviços especializados de restauro, (cujo custo é maior) e, ponderou que a opção por pintura "comum" em função da verba, de certa forma, interfere na qualidade dos serviços. Sobre esse assunto o Prof. Barossi esclareceu, ainda, que a licitação, contrato e fiscalização estão sendo operacionalizado pelo COESF - antigo FUNDUSP. ${ }^{67}$
\end{abstract}

A questão da dificuldade em se obter recursos para o desenvolvimento dos trabalhos na Vila Penteado é uma constante. Na mesma ata, o Prof. Dr. Ricardo Toledo e Silva, Diretor da FAUUSP, "ponderou sobre a necessidade de se elaborar um programa/projeto de obras, o qual viabilizasse nova fonte de recursos", visando "dar continuidade as obras do prédio em questão [Vila Penteado] e em função da escassez de recursos". 68

Nos anos seguintes, a busca por recursos que possibilitem o planejamento global das ações de preservação da Vila Penteado tona-se uma constante. $\mathrm{O}$

${ }^{66}$ Conforme a Ata de Reunião da Coordenadoria do Espaço Físico da USP - COESF, datada em 14/01/2003, o contrato 87/2002 estabelece que a empresa Oxivida Engenharia Ltda. foi contratada para executar os serviços de pintura interna de paredes, forros e pintura das esquadrias de ferro e madeira, com início de obras agendado para o dia 03 de fevereiro de 2003. Nessa ata a $\operatorname{Prof}^{a} \operatorname{Dr}^{a}$. Helena Aparecida Ayoub Silva representa a Unidade da Pós-graduação, edifício Vila Penteado, os engenheiros Jetro Echterhoff Takatohi e Antonio Carlos Orsi representam a COESF e a empresa contratada, Oxivida Engenharia Ltda., é representada pelo Eng. Roberto Manin Frias e pela Eng ${ }^{a}$. Marta Sayuri Yamassaki.

${ }^{67}$ Ata da 19 ${ }^{\underline{a}}$ Reunião Ordinária do Conselho Curador da FAUUSP, 25 de abril de 2003, p.1 e 2.

68 Ibidem, p.2. 
documento $^{69}$ datado de outubro de 2003, para o Prof. Antonio Marcos de Aguirra Massola, Coordenador da COESF, do Prof. Ricardo Toledo e Silva, Diretor, contém uma solicitação orçamentária para Vila Penteado, baseada nas manifestações dos professores gestores do edifício, Prof ${ }^{a}$. Helena Ayoub Silva e Prof. Antonio Carlos Barossi, para projetos de arquitetura, prospecções e projeto de restauro de elementos artísticos, projeto de estrutura, de instalações elétricas, eletrônicas e de telefonia, instalações hidrossanitárias, prevenção e combate a incêndios, reformas dos sanitários, instalações para área de café e obras gerais para habitabilidade dos porões utilizáveis.

Aliado a busca por recursos, a identificação de área e situações de risco também foram registradas, como o $3^{\text {o }}$ Relatório da "Avaliação das condições de segurança contra incêndio e de uso dos edifícios da FAUUSP"70 que trata da situação existente no edifício Vila Penteado. Como justificativa para esse relatório, o texto, constante do mesmo, apresentado a seguir, é claro:

\begin{abstract}
Muitos dos edifícios pertencentes à Universidade de São Paulo, dentro ou fora de seus campi, não foram projetados e construídos à luz das regulamentações vigentes à sua época, sejam estas de âmbito municipal, estadual ou federal. Desta forma, normalmente, várias das exigências que constam do Código de Obras e Edificações do Município de São Paulo, do Código Sanitário do Estado de São Paulo, assim como a regulamentação do Corpo de Bombeiros do Estado de São Paulo, além das Normas regulamentadoras do Ministério do Trabalho, não foram observadas no momento de sua construção e nem realizadas adaptações, conforme exigências legais posteriores.

No caso do edifício Vila Penteado, em particular, pode-se afirmar que não havia exigência de segurança contra incêndio à época de sua construção como unidade residencial, como não existe até hoje.

Porém, o edifício Vila Penteado sofreu um aumento do risco de incêndio decorrente da alteração de uso, de residência para escola, e das inovações tecnológicas que sobrecarregaram as instalações elétricas, principalmente na última década. Existem, assim, um potencial grande de se estar colocando em risco a segurança das pessoas que trabalham, estudam ou simplesmente transitam por esse edifício, sem falar no risco ao patrimônio físico (o próprio edifício), assim como ao seu conteúdo (acervo). Portanto, verifica-se a necessidade de se conhecer as atuais condições de segurança do edifício, para que medidas adequadas sejam tomadas para a sua
\end{abstract}

69 Of. GD/163/FAU/02102003, de 02/10/2003, para Prof. Cr. Antonio Marcos de Aguirra Massola, Coordenador da COESF - Coordenadoria do Espaço Físico da Universidade de São Paulo, de Prof. Ricardo Toledo e Silva, Diretor.

${ }^{70}$ Avaliação das condições de segurança contra incêndio e de uso dos edifícios da FAUUSP - 3oㅜ Relatório - Edifício Vila Penteado. Núcleo de Pesquisa em Tecnologia da Arquitetura e Urbanismo da Universidade de São Paulo (NUTAU/USP), 22 de março de 2004. Equipe técnica: Prof ${ }^{\mathrm{a}}$ Dra. Rosaria Ono - FAUUSP e NUTAU/GSI - Coordenadora dos Trabalhos; Prof. Dr. Ualfrido Del Carlo - FAUUSP e NUTAU/GSI; Eng. Dr. Alexandre Itiu Seito - NUTAU/GSI; Cel. E Eng. Antonio Alfonso Gill NUTAU/GSI. 
proteção e de seus usuários tanto no dia-a-dia como numa situação de emergência.

Outros relatórios e laudos foram redigidos na década de 2000, como o Laudo Técnico $^{71}$, sobre as Instalações Elétricas, datado em 03 de agosto de 2007, feito pela Empresa Barreto Engenharia Ltda. (detalhes sobre esse laudo e as condições das instalações elétricas são apresentados nos itens 3.2.5 "Instalações Elétricas", 3.4.3 "Projeto de Instalações Elétricas" e 4.1.9 "Instalações Eletromecânicas").

A década de 2010 inicia-se com a continuidade das reflexões sobre o edifício, por parte dos gestores, Prof. Dr. Antonio Carlos Barossi e $\operatorname{Prof}^{\mathrm{a}} \mathrm{Dr}^{\mathrm{a}}$ Helena Ayoub Silva, da presidente da Comissão de Pós Graduação (CPG), $\operatorname{Prof}^{\mathrm{a}} \operatorname{Dr}^{\mathrm{a}}$ Maria Lucia Refinetti Martins, por parte do GEEF, Arq ${ }^{a}$ Eunice Bruno, e ainda sob o olhar de toda a comunidade FAUUSP, afinal, o estado atual da Vila Penteado inspira cuidados.

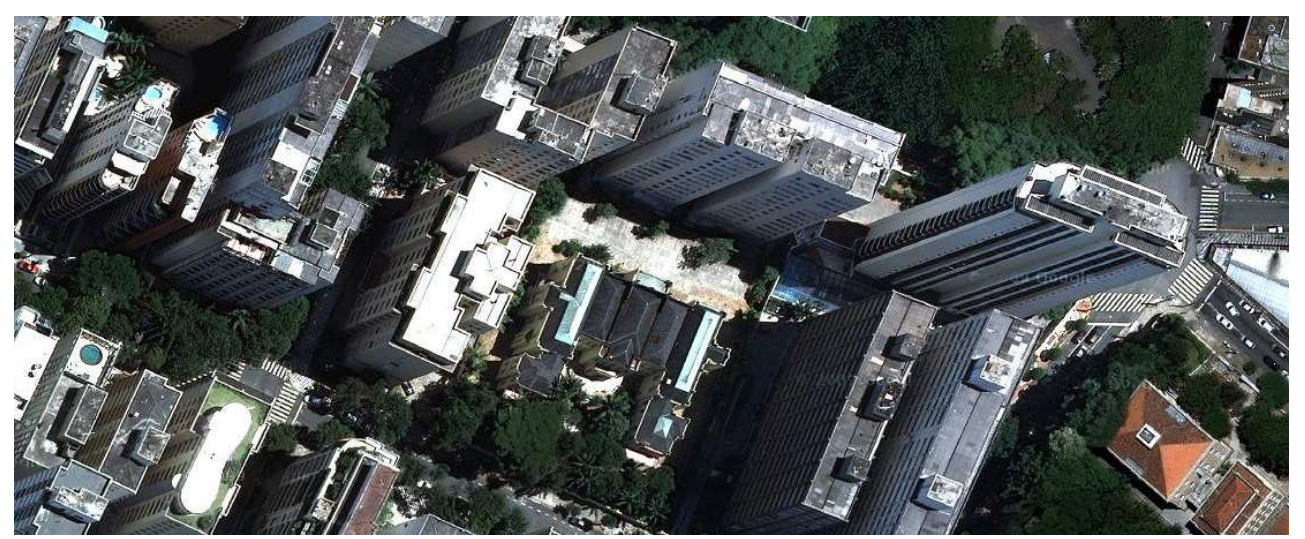

Figura 46 - Foto aérea do entorno do lote do edifício Vila Penteado Rua maranhão, 88, Higienópolis, São Paulo - SP.

Fonte: http://maps.google.com.br/, acessado em 20 de julho de 2011.

${ }^{71}$ Laudo Técnico, Instalações Elétricas, 03/09/2007, DOC N: RL-271-E-01, BARRETO Engenharia Ltda. 


\subsubsection{DESCRIÇÃO FORMAL DA VILA PENTEADO}

A Vila Penteado apresenta um corpo central e duas alas laterais estendidas, somando $2.206,42 \mathrm{~m}^{2}$, conforme o cadastro imobiliário. Possui pavimento térreo e superior, além de porão, exigência legal da época de construção, e sótão. O porão é parcialmente ocupado, visto ter altura de pé-direito suficiente para 0 desenvolvimento de atividades diversas, em alguns de seus ambientes. O sótão abriga instalações diversas e não tem ocupação humana, apesar de ter pé-direito generoso, em grande parte de sua área.

Dentre os ambientes do palacete, o saguão central, designado como livingroom, recebe destaque como centro de convivência e encontro, troca de ideias e informações, desde sua primeira ocupação até os dias de hoje.

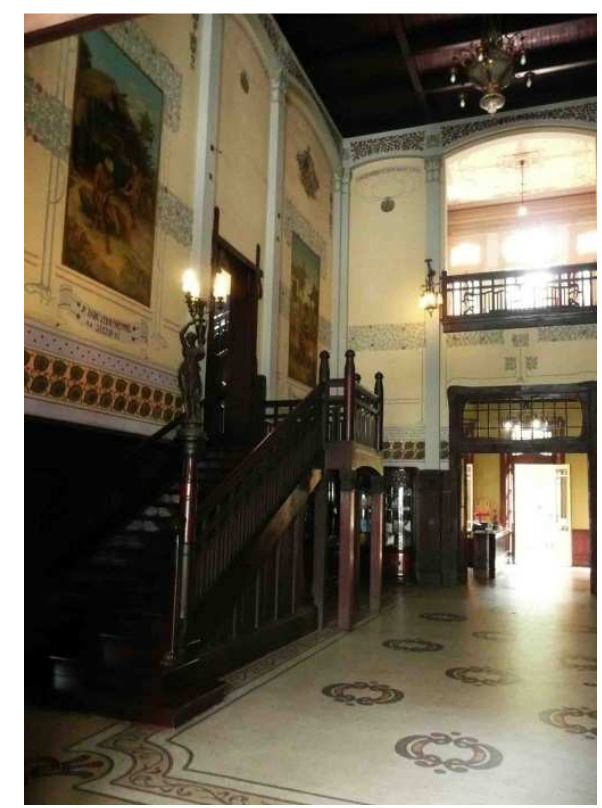

Figura 47 - Saguão da Vila Penteado: local de convivência Fonte: Foto de Isis Roverso, dezembro de 2010.

A Vila Penteado possui paredes estruturais em alvenaria de tijolos cerâmicos e estrutura de madeira. Apesar de não existir uma modulação fixa, as paredes portantes principais podem ser identificadas através da localização de seis eixos perpendiculares a Rua Maranhão. E, no sentido paralelo a mesma rua, encontramse os eixos secundários das paredes em alvenaria, garantindo, de forma geométrica, a estabilidade estrutural do edifício. A figura 48 apresenta a distribuição desses eixos na planta na Vila Penteado. 


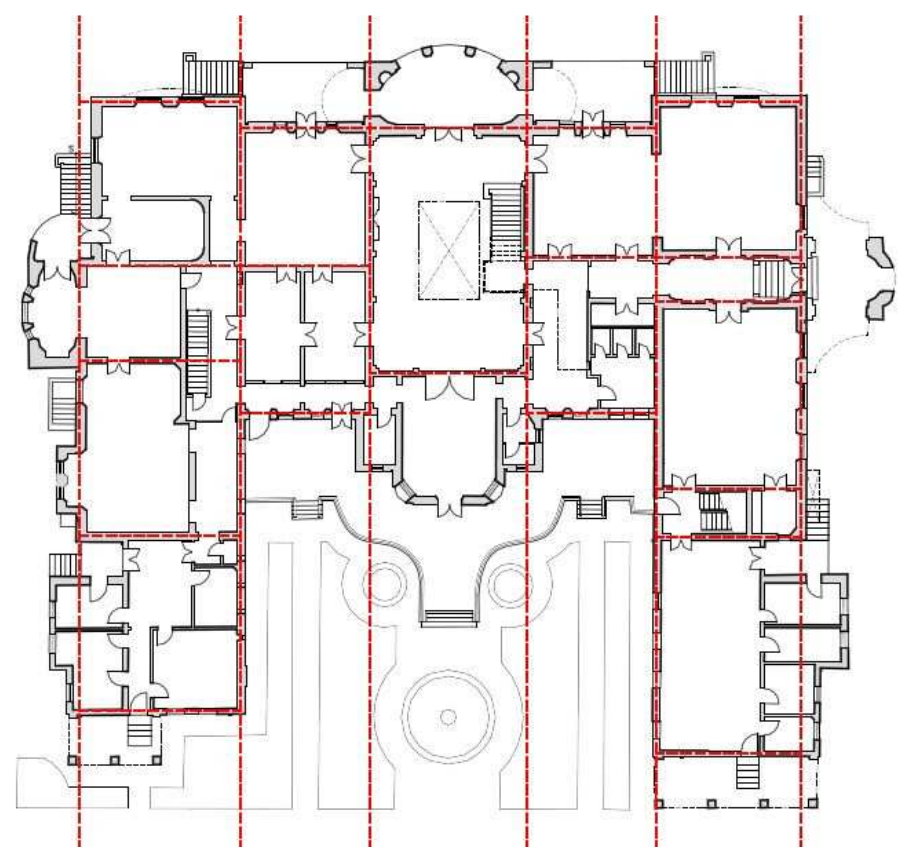

Figura 48 - Planta da Vila Penteado com indicação dos principais eixos estruturais Fonte: Identificação dos eixos realizada pela Arq $^{\mathrm{a}}$ Isis Roverso, em 2011, sobre a base de desenho: Planta do Pavimento Térreo do Edifício Vila Penteado, Prancha 03/12, FAUUSP, Arquivo GEEF.

As paredes estruturais apresentam espessura maior em sua base e vão gradativamente tendo sua seção reduzida até restringirem-se a espessuras menores na área da cobertura. A figura 49 apresenta uma foto da região do porão onde é possível perceber as dimensões das alvenarias e a figura 50 apresenta, em desenho, parte do corte transversal, onde é possível perceber a diferença de espessura das alvenarias entre os pavimentos do edifício.

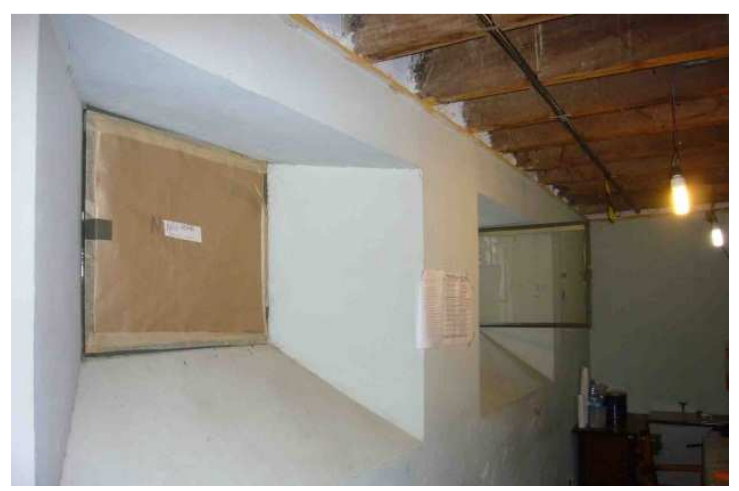

Figura 49 - Parede periférica do porão Fotos: Isis Roverso, abril de 2011. 


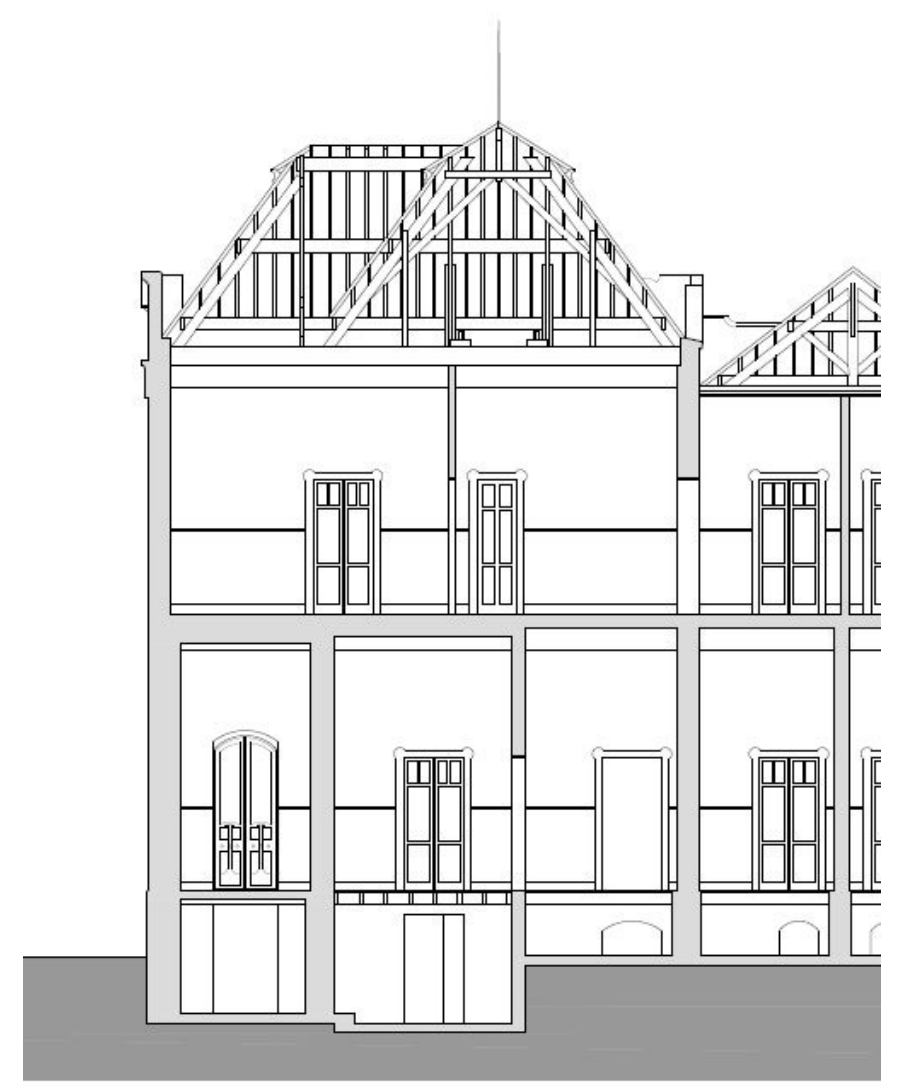

Figura 50 - Corte Transversal parcial da Vila Penteado, com destaque para e espessura das alvenarias

Fonte: Parte do desenho - Corte Transversal do Edifício Vila Penteado, Prancha 07/12, FAUUSP, Arquivo GEEF.

Além das paredes portantes, o uso de tijolos como elementos estruturais também pode ser visto nos arcos e abobadilhas. A área do porão conta com 0 sistema de abobadilhas simples e apoiadas em perfis metálicos.

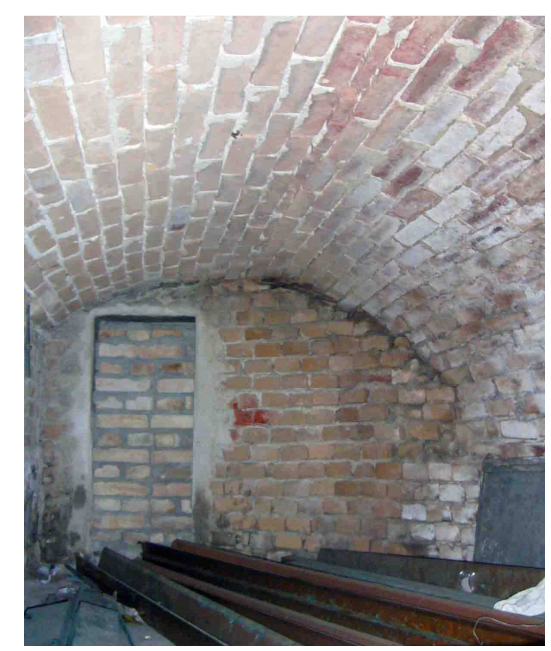

Figura 51 - Abobadilhas do teto do porão da Vila Penteado Fonte: Foto de Isis Roverso, abril de 2011. 
A área central do edifício, que revela o maior vão, é estruturada sobre abobadilhas de tijolos, apoiadas em perfis metálicos. A figura 52 apresenta uma foto do teto do porão dessa área central e na figura 53 é possível verificar a mesma área em desenho, identificada com o número 01.

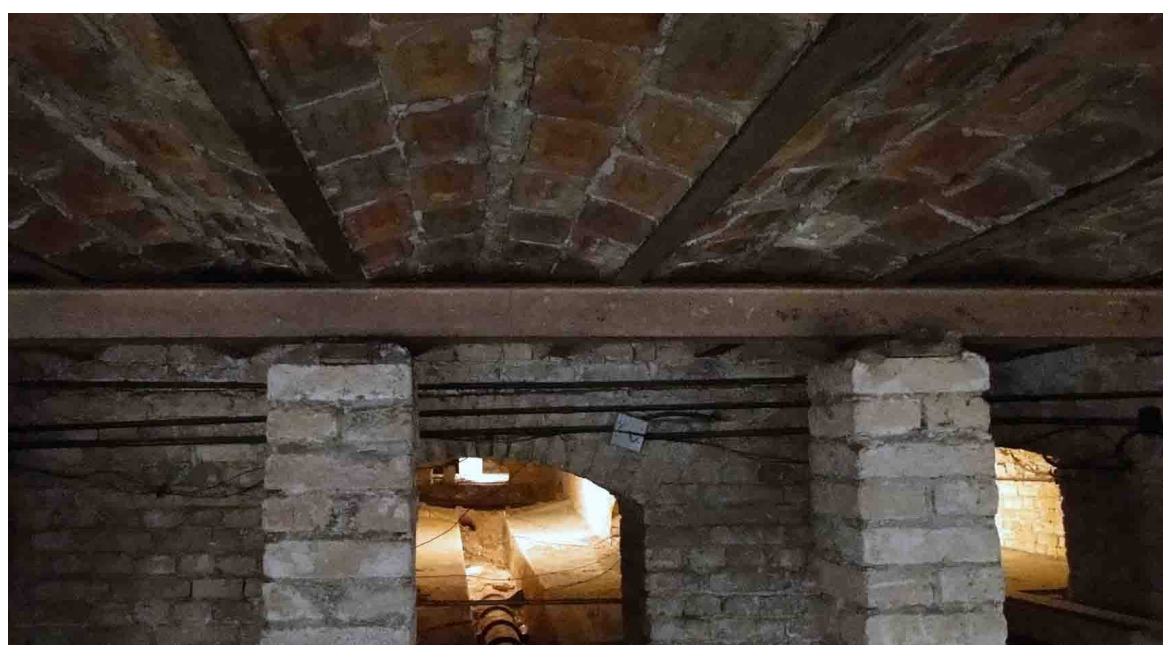

Figura 52 - Abobadilhas do teto do porão, estruturando o piso do saguão principal, localizado no pavimento térreo

Fonte: Foto de Isis Roverso, agosto de 2011.

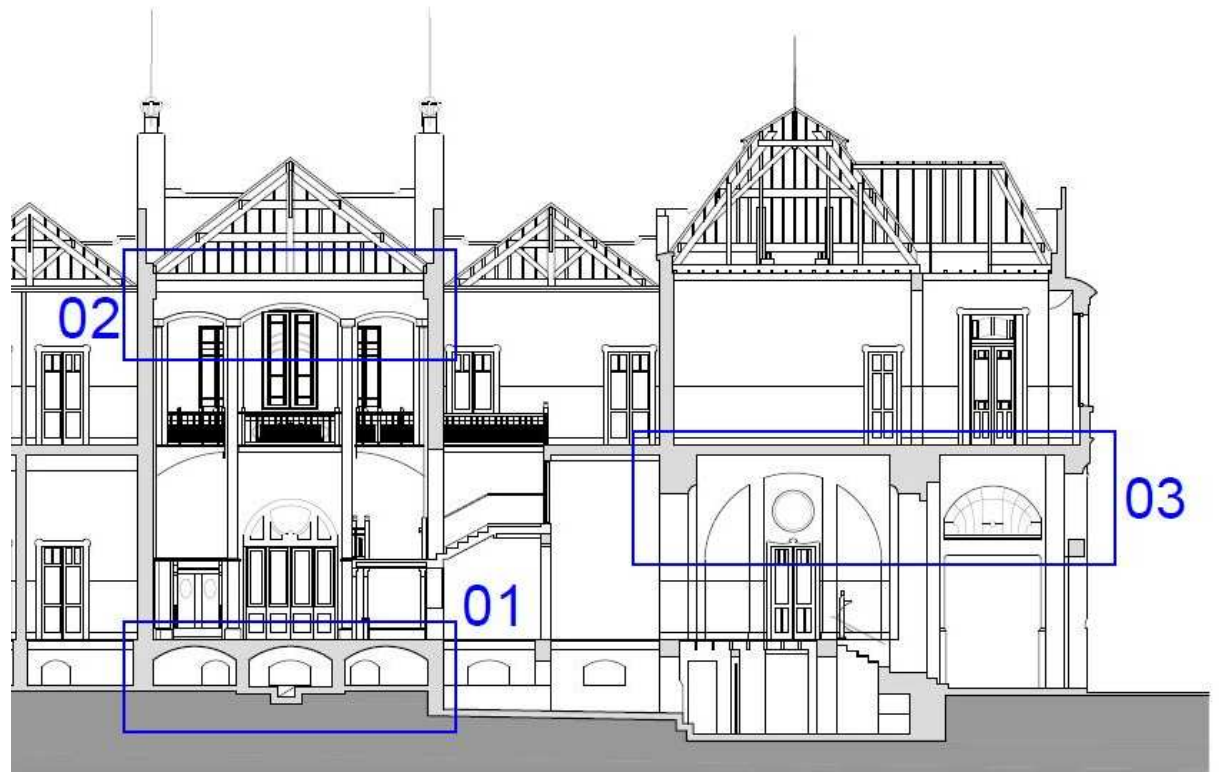

Figura 53 - Corte Transversal parcial da Vila Penteado, com destaque para o emprego de arcos e abobadilhas estruturais

Fonte: Identificação dos elementos estruturais realizado pela Arq $^{\text {a Isis }}$ Roverso em 2011, sobre a base de desenho: Corte Transversal do Edifício Vila Penteado, Prancha 07/12, FAUUSP, Arquivo GEEF.

O princípio do uso do arco como estrutura para as alvenarias também pode ser visto em outras áreas da Vila Penteado, como as áreas destacadas na figura 53, com os números 02 e 03 . A área 02 refere-se aos arcos existentes em todo o 
perímetro do Saguão e a área 03 refere-se ao corredor de acesso lateral, ao lado da Sala dos Espelhos. Essas duas áreas podem ser contempladas nas fotos das figuras 54 e 55 .

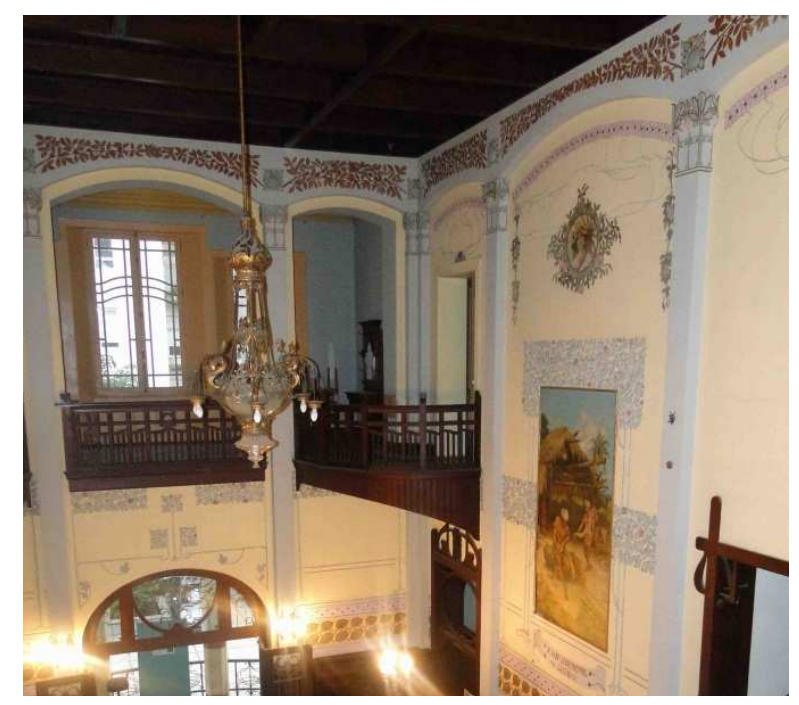

Figura 54 - Saguão da Vila Penteado: destaque para o conjunto de arcos que acompanham o perímetro da área

Fonte: Foto de Isis Roverso, novembro de 2011.
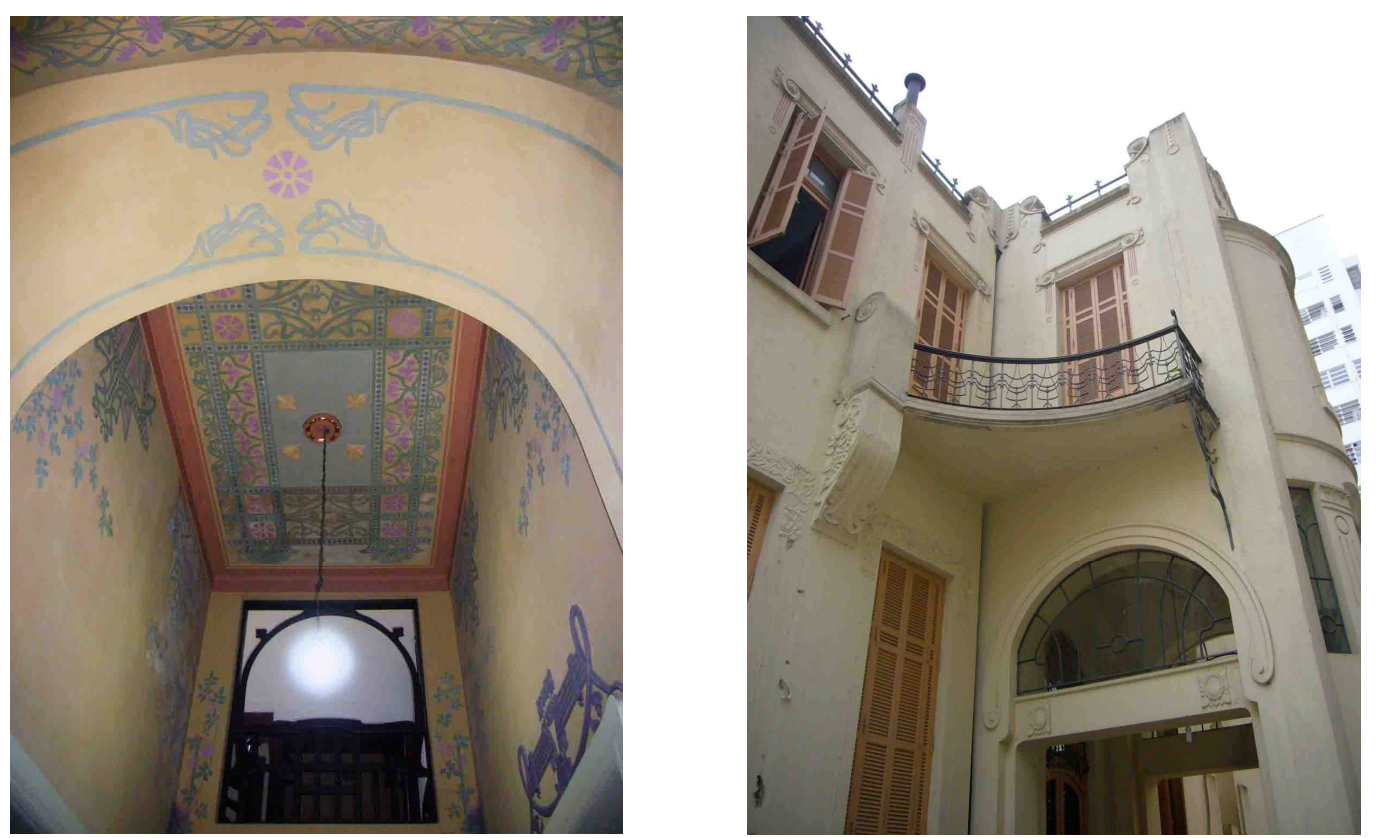

Figura 55 - Área interna e externa do corredor lateral: destaque para os arcos que auxiliam a estrutura e complementam a ornamentação art nouveau Fonte: Foto de Isis Roverso, abril de 2011.

As mísulas também são empregadas em diversos pontos do edifício, ainda na figura 55 é possível notar mísulas suportando o balcão (ver foto da direita). Vale 
destacar o fato de serem usados materiais diferentes para as mísulas, como visto nessa foto: de um lado a mísula é feita em alvenaria de tijolos revestida, e do outro em ferro ornamentado.

As paredes são revestidas externa e internamente com argamassa. As fachadas apresentam ornamentação em baixo e alto relevo.

Destaca-se a harmonia dessa obra, decorrente da excelência do projeto, do emprego de mão-de-obra qualificada e escolha de materiais de acabamento coerentes entre si, muitos deles importados ou esculpidos e modelados no local (SILVA, H. A. A.; et al, 2007).

Os gradis, guarda-corpos e demais detalhes também são trabalhados com a linguagem art nouveau. Alguns detalhes surpreendem, como os mosaicos (ver um exemplo na figura 56), o corrimão da escadaria lateral (ver foto da figura 57) e os ornamentos internos do Saguão (ver um dos ornamentos na figura 59).

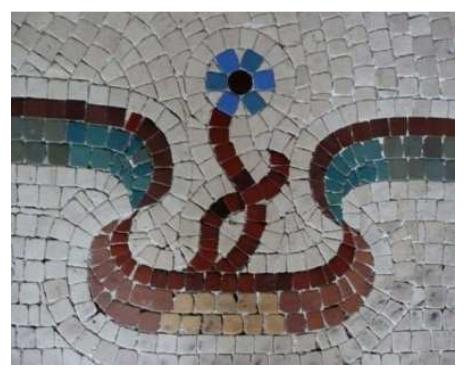

Figura 56 - Detalhe do mosaico: montagem artesanal de tesselas irregulares Fonte: Foto de Isis Roverso, dezembro de 2010.
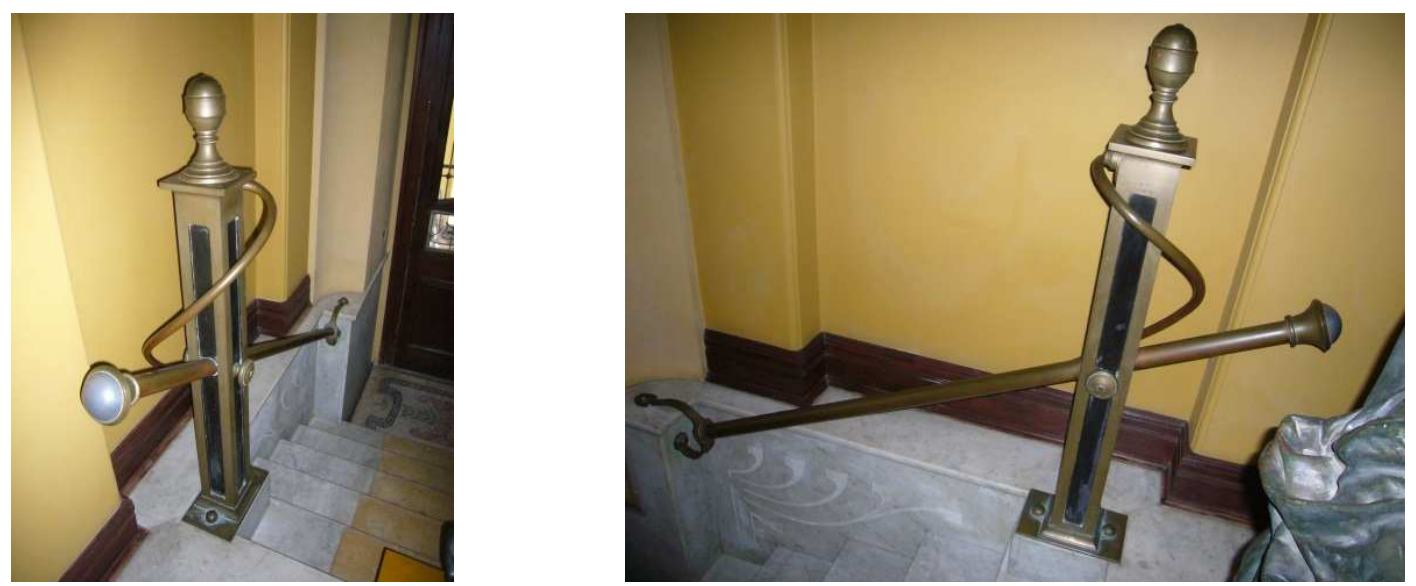

Figura 57 - Corrimão metálico da escadaria interna lateral da Vila Penteado Fotos: Isis Roverso, abril de 2011.

Não apenas esse exemplar de corrimão da Vila Penteado, como diversos outros detalhes existentes já foram objeto de estudos e análise. O Processo $\mathrm{N}^{\circ}$ 
83.1.22618.51.6 apresenta, dentre outros, desenho desse corrimão (ver figura 58), evidenciando a sua análise através da observação e detalhamento em 1983, momento no qual o Prof. Dr. Carlos Alberto Cerqueira Lemos foi encarregado de providenciar o projeto de restauração do edifício Vila Penteado. Com a orientação do Prof. Carlos Lemos, estagiários mantidos pelo FUNDUSP, alunos da FAUUSP, desenharam de forma detalhada as plantas, cortes e elevações da Vila Penteado.

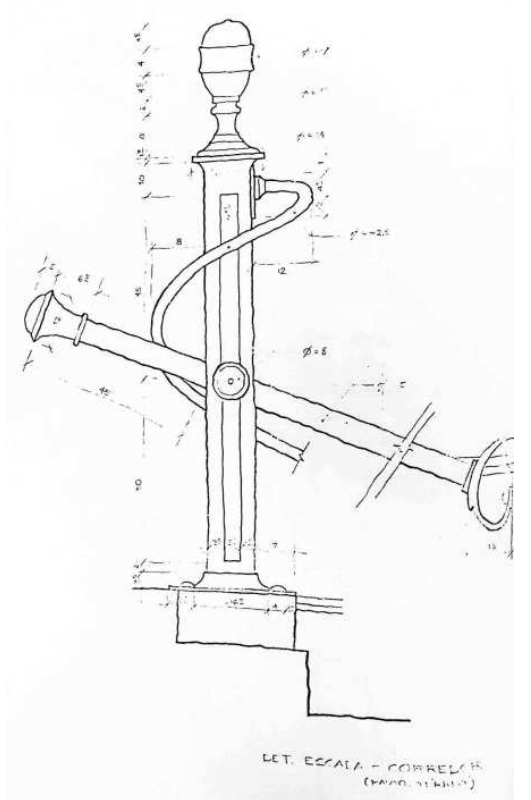

Figura 58 - Desenho do corrimão metálico da escadaria interna lateral da Vila Penteado Fonte: Processo N 83.1.22618.51.6, Doc Base: OF/ 1319/ 83/ FAU.

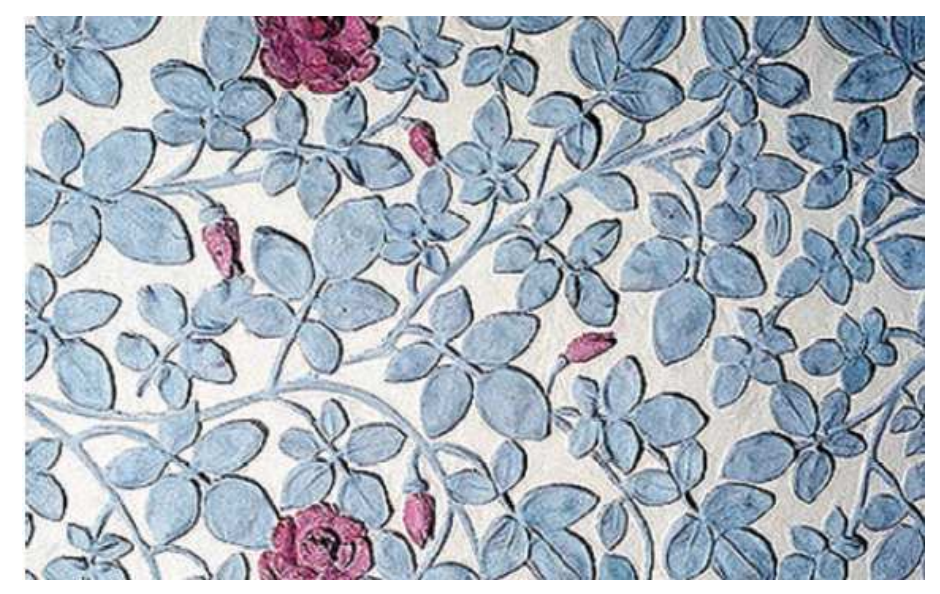

Figura 59 - Detalhe do ornamento interno do Saguão da Vila Penteado Estuques representando roseiras, semelhantes aos dos balcões da fachada principal. Fonte: Painel de Análise Formal: ornamentação 2/2, 1a Etapa (1990 a 1992): estudo pormenorizado da arquitetura. Interiores. Arquivo CPC USP, 1993.

Internamente, quase todos os ambientes receberam pinturas murais artísticas, que posteriormente foram recobertas por pinturas monocromáticas e, no 
final da década de 1980, foram inicialmente e parcialmente reveladas através dos estudos realizados pela Comissão de Patrimônio Cultural e posteriormente por seu órgão sucessor, o Centro de Preservação Cultural da Universidade de São Paulo, CPC USP, através do Canteiro-Escola de Restauração de Pinturas Murais, sob a coordenação da arquiteta restauradora Regina Tirello. Esses estudos mostraram que, por vezes, num mesmo ambiente, há camadas pictóricas de épocas distintas, revelando desenhos com características próprias.

As pinturas murais, além de compor a decoração dos cômodos, participam da formulação arquitetônica da casa, contribuindo com as definições programáticas e hierarquização dos ambientes. Características do proprietário também são reveladas, como no caso do suporte de madeira da escada do Saguão, esculpido em forma de ramo de café (notar detalhe na foto da figura 60 ).

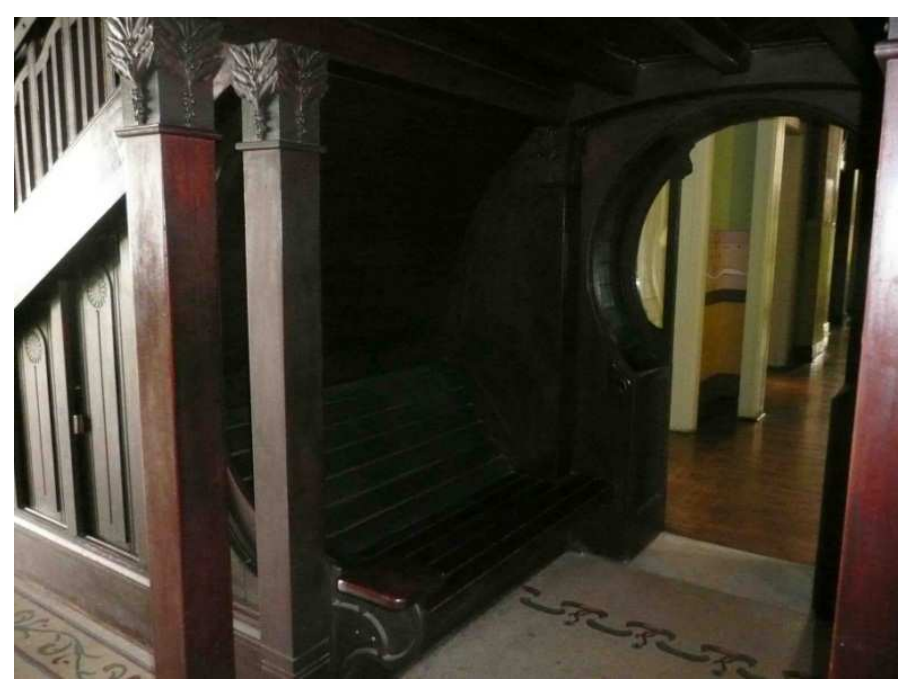

Figura 60 - Banco sob a escada do Saguão: destaque para o detalhe em forma de ramo de café esculpido no apoio da escada Foto: de Isis Roverso, dezembro de 2010.

Entretanto, a escolha pelo elemento relacionado a uma das ocupações do proprietário não é a única razão para a sua inclusão na residência, como Maria Cecília França Lourenço expõe no texto "Vila Penteado: memória e futuro", que aqui tem um de seus parágrafos transcrito:

O café comparece, por vezes, estilizado nos elementos curvilíneos, sendo simbólico na construção de um dos momentos significativos para a plasmação de conceitos sobre a paulistaneidade, segundo o ponto de vista das elites cafeicultoras. Reitere-se que tal temática não pode ser considerada simplesmente como uma decisão do patriarca, mas se fecunda dos eflúvios da época, em que o destino da cultura cafeeira preocupa, pois 
antes representara um caminho desejável para o estado, para o país e para os negócios familiares. (LOURENÇO, 2002).

Na Vila Penteado, a estrutura de madeira não é vista apenas nas escadas de acesso entre o pavimento térreo e o superior, como também na sustentação do telhado e dos pisos. A estrutura original do telhado foi executada em Peroba Rosa e Pinho de Riga. E para a estrutura original dos pisos foram utilizadas Peroba Rosa, Cabriúva Parda, Guatambú e Pinho do Paraná (segundo o Relatório da Empresa TECNOMAD-161/89). As esquadrias também foram executadas em madeira, sendo que nas venezianas foi empregado Pinho de Riga.

A madeira também foi empregada em diversos outros elementos não estruturais. Alguns desses elementos podem ser vistos nas fotos da figura 61 .
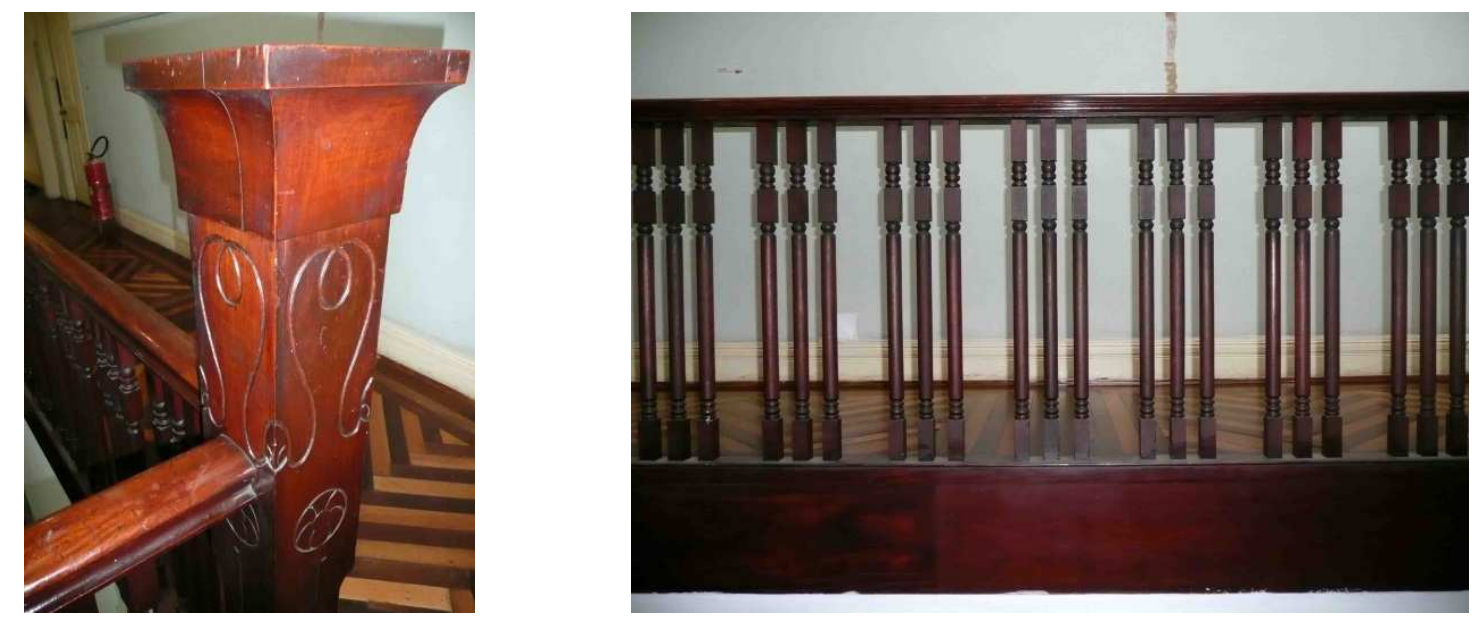

Figura 61 - Guarda-corpo em madeira da escada próxima a biblioteca Foto: de Isis Roverso, dezembro de 2010.

O Relatório da Empresa TECNOMAD ${ }^{72}$ apresenta a identificação dos tipos de madeira usados nos elementos estruturais e não estruturais, do edifício Vila Penteado. Essa tabela foi reproduzida nesse trabalho, na tabela 1, visando documentar os elementos em madeira existentes no casarão.

\footnotetext{
72 A TECNOMAD - Consultoria e Serviços Ltda. foi contratada em 1990/91 pela Cidade Universitária Armando de Salles Oliveira (CUASO) com apoio do FUNDUSP, dirigido na época pelo Prof. Dr. Geraldo Gomes Serra, para a realização de avaliações vinculadas aos Serviços de diagnóstico do "Estado de Conservação das Estruturas e Componentes de Madeira do Edifício", conforme consta no relato do Prof. Roberto Leme Simões, integrante do corpo técnico do FUNDUSP, registrado no Boletim Técnico número 12, 1993, p.11.
} 


\begin{tabular}{|c|c|c|}
\hline \multirow{2}{*}{ Elementos Construtivos } & \multicolumn{2}{|c|}{ Tipos de Madeira } \\
\hline & Nomenclatura Comercial & Nomenclatura Científica \\
\hline \multicolumn{3}{|l|}{ Estrutura do Telhado } \\
\hline \multirow{2}{*}{ Tesouras e terças } & Peroba Rosa & Aspidosperma polyneuron \\
\hline & Pinho de Riga $\left(^{*}\right)$ & $\left({ }^{* *}\right)$ \\
\hline Caibros e ripas & Peroba Rosa & Aspidosperma polyneuron \\
\hline \multirow[t]{2}{*}{ Barroteamento do forro } & Peroba Rosa & Aspidosperma polyneuron \\
\hline & Pinho do Paraná & Araucária angustifolia \\
\hline \multirow[t]{2}{*}{ Forro de madeira } & Pinho de Riga $\left(^{*}\right)$ & $\left({ }^{* *}\right)$ \\
\hline & Peroba Rosa & Aspidosperma polyneuron \\
\hline Ripas do estuque de forro & Palmeira & Família Palmae \\
\hline \multicolumn{3}{|l|}{ Estrutura de Piso } \\
\hline Barroteamento do piso & Peroba Rosa & Aspidosperma polyneuron \\
\hline \multirow{3}{*}{ Assoalho } & Cabriúva parda & Myrocarpus spp. \\
\hline & Guatambú & Aspidosperma spp. \\
\hline & Peroba Rosa & Aspidosperma polyneuron \\
\hline $\begin{array}{l}\text { Barroteamento do forro do } \\
\text { porão }\end{array}$ & Pinho do Paraná & Araucária angustifolia \\
\hline
\end{tabular}

\section{Elementos não estruturais}

Escada (estrutura portante, degraus, corrimãos, lambril, guarda-corpos) - saguão ala

direita e esquerda

Lambril

Pinho de Riga $\left(^{*}\right)$

Tabela 2 - Tipos de madeira empregados nos elementos construtivos do edifício Vila Penteado.

Fonte: Relatório TECNOMAD - 161/89. (*) Nome comercial associado ao porto de onde era exportada a madeira: porto de Riga, capital da Letônia (GONZAGA, 2006, p.37).

$\left({ }^{* *}\right)$ Autores sugerem que o pinho de Riga possa corresponder à espécie florestal Pinus sylvestris $L$. (MACHADO et al, 2003)

Alguns forros originais foram executados em madeira, enquanto que outros foram executados em estuque, com pinturas decorativas (para informações detalhadas, ver o item 3.2.2 "Intervenções nos Forros").

Os pisos da Vila Penteado, além dos executados em madeira, foram feitos utilizando-se ladrilho hidráulico e placas de cerâmica, sendo que esses pisos referem-se às áreas úmidas do palacete. 
A cobertura do casarão Vila Penteado foi executada em telhas de pedra ardósia, "seguindo a tendência europeia da época de construção da edificação, com complementos (rufos, espigões, rincões, calhas e grampos de fixação das telhas) em cobre" (NASCIMENTO, 2002, p.151).

Elementos executados em ferro e vidro também podem ser encontrados na Vila Penteado como, por exemplo, as claraboias, novidade para a época em que foi projetada.

O mobiliário também apresentada riqueza de detalhes. Alguns exemplares, dessa mobília, podem ser vistos em uso na Vila Penteado, como é o caso das cadeiras, hoje usadas na Sala de Reuniões da CPG (Comissão de Pós Graduação), que recentemente foram restauradas pela empresa Reformaflex. Essas cadeiras são apresentadas nas fotos das figuras 62,63 e 64 .

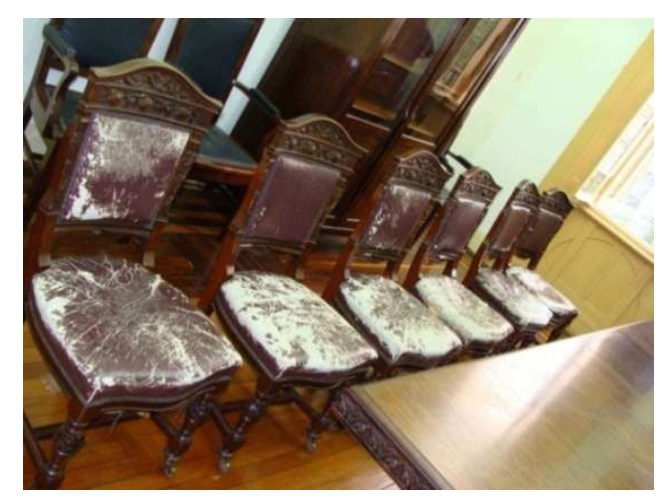

Figura 62 - Cadeiras antes do restauro Foto: de Isis Roverso, outubro de 2010.
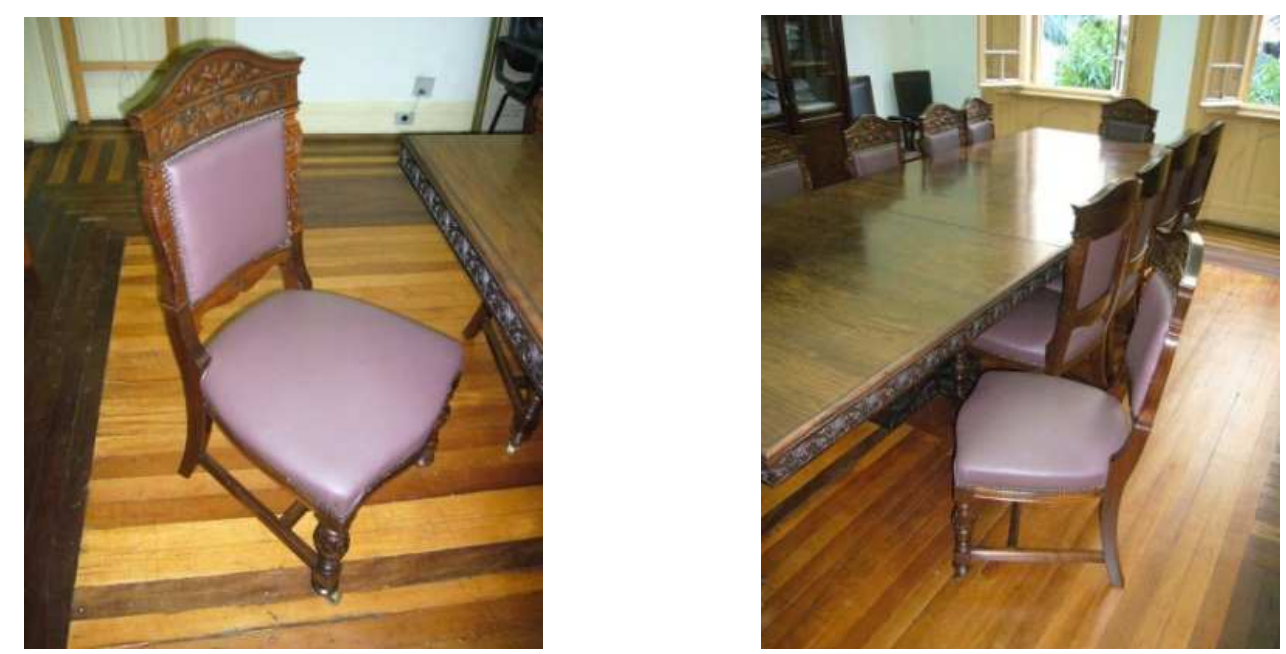

Figura 63 - Cadeiras após o restauro feito pela empresa Reformaflex Sob orientação da arquiteta Dinorah: lustração e troca das molas, taxinhas, espuma e acabamento em couro vaqueta natural cor vinho

Foto: de Isis Roverso, abril de 2011. 

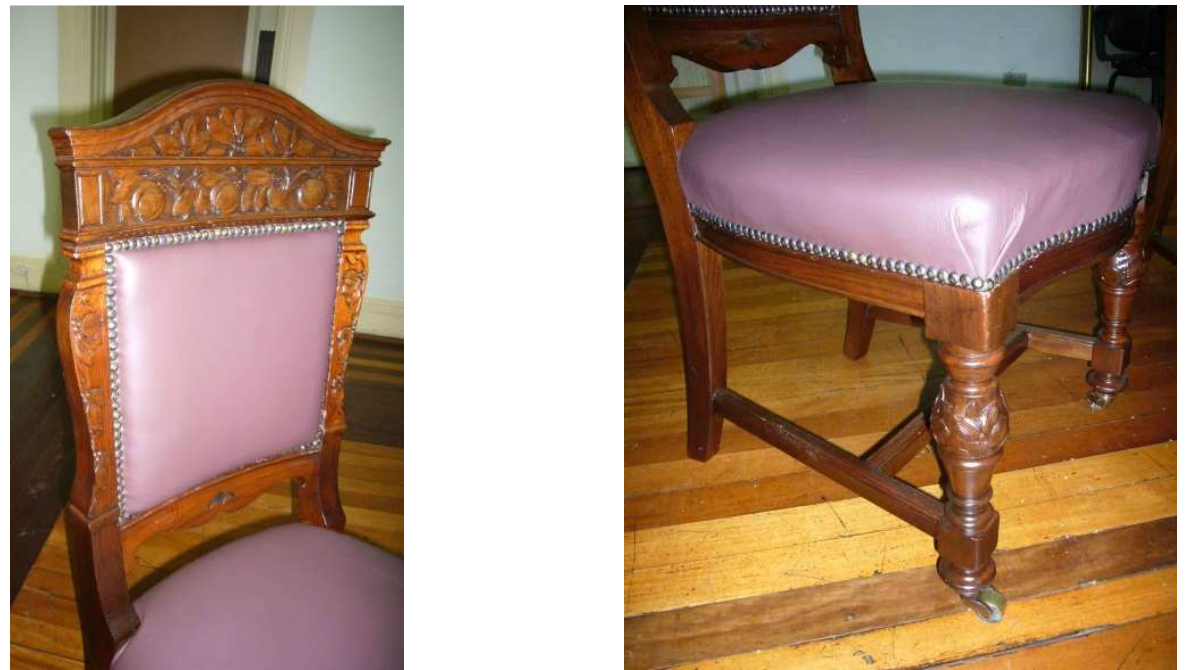

Figura 64 - Detalhes das cadeiras

Destaque, na foto à esquerda, para os entalhes decorativos na madeira e, na foto à direita, para o rodízio metálico que auxilia a movimentação deste móvel.

Foto: de Isis Roverso, abril de 2011.

Sobre o mobiliário e decoração original da Vila Penteado, o texto "A 'Vila Penteado' como residência" (HOMEM, 1976, p. 71), traz informações detalhadas:

\begin{abstract}
A decoração era aquela típica em São Paulo das residências da classe sócio-econômica à qual pertencia a família Penteado: Gobelins, Sèvres, bronzes de Moureau e Barbedienne, porcelanas da Saxônia, 'chinoiseries' e mármores italianos. Iluminadas por muitos lampadários, todas as salas eram cobertas de tapetes da Boêmia e passadeiras belgas. Muitos móveis provieram da Casa Mercier, de Paris. No grande saguão, a longa escada de madeira era coberta por uma passadeira com motivos geométricos e, nas paredes, três pinturas a óleo, de autoria de Oscar Pereira da Silva e De Servi, procuravam compor a história da indústria nacional, vendo-se numa delas, a primeira fábrica de Antonio Penteado, a Fábrica Santana. A decoração aí era ao gosto inglês, com lareira e móveis da Casa Maple, da Inglaterra. O escritório, contíguo ao saguão, dando para os jardins dos fundos, era decorado com móveis de acaju, vagamente "Empire". A mobília da sala de jantar, parte da qual decora ainda a Vila, graças à iniciativa de Honório Penteado, compunha-se de duas cristaleiras, três grandes buffets com espelhos, longa mesa e cadeiras de espaldar alto, de madeira entalhada com motivos vegetais brasileiros: goiabas e ramos de café. A mesa e as cadeiras encontram-se na sala da Congregação da Faculdade de Arquitetura e Urbanismo, na Cidade Universitária.
\end{abstract}

Mas, não apenas o casarão e seus interiores foram projetados detalhadamente, os jardins também receberam especial atenção: "os jardins também obedeciam ao estilo 'art nouveau': estavam sistematizados espécimes da vegetação tropical e árvores frutíferas de pequeno porte, formando um pomar." (HOMEM, 1976, p. 72). 
A Vila Penteado hoje se destaca como patrimônio histórico arquitetônico por, entre outras coisas, ser um dos últimos remanescentes do estilo art nouveau da cidade de São Paulo. Segundo informações da Secretaria da Cultura, o casarão Vila Penteado "é considerado o primeiro edifício art nouveau paulista e seu melhor exemplar [...]". ${ }^{73}$ E, segundo Nestor Goulart Reis Filho (2002, p.21),

A Vila Penteado constitui um patrimônio cultural do estado e da cidade de São Paulo, sendo um dos únicos exemplares remanescentes da artnouveau e de residência de grandes proprietários de fazendas de café ou ligadas ao início da industrialização em fins do século 19 e início do 20, mas é também um patrimônio histórico da vida cultural da cidade.

O edifício foi projetado com rigor de desenho nas esquadrias de madeira, maçanetas, assoalhos, baixos e altos-relevos dos ornamentos e arranjo singular dos mosaicos. Tanto a volumetria, quanto os detalhes remetem ao estilo escolhido na época do projeto. Hoje a leitura desses elementos é possível, aliada às marcas da passagem do tempo. Trata-se de um edifício que carrega história, não ficando destinado a algum lugar da história, e sim fazendo parte dela.

${ }^{73}$ Texto de Julita Scarano, constante no site da Secretaria da Cultura, Governo do Estado de São Paulo, sobre o bem tombado: Vila Penteado (Localização: Rua Maranhão, 88. Número do Processo: 08638/69. Resolução de Tombamento: Resolução de 27/02/1978. Publicação do Diário Oficial: Poder Executivo, Seção I, 28.02.1978, p. 37. Livro do Tombo Histórico: inscrição no 117, p. 18, 27/06/1979). http://www.cultura.sp.gov.br/portal/site/SEC/menuitem.bb3205c597b9e36c3664eb10e2308ca0/?vgne xtoid=91 b6ffbae7ac1210VgnVCM1000002e03c80aRCRD\&ld=92d0688c3e6bc010VgnVCM20000003 $01 \mathrm{a} 8 \mathrm{c} 0$ acessado em 21 de fevereiro de 2012. 


\title{
3.2DOCUMENTAÇÃO EXISTENTE
}

Ao longo das últimas décadas, diversos documentos foram elaborados, tratando de aspectos distintos do edifício Vila Penteado.

Parte do conteúdo, dos documentos e projetos existentes, foi publicada em duas ocasiões. Um deles, motivado pela organização e seleção de textos e projetos, que culminou no catálogo "Exposição Vila Penteado", foi publicado em 1976, justificando o pedido de tombamento da Vila Penteado. Esse trabalho foi coordenado pela pesquisadora Maria Cecília Naclério Homem Prado. E o número especial da Revista Pós: "Vila Penteado 100 anos", como parte das ações comemorativas do centenário da Vila Penteado, publicado em 2002.

\begin{abstract}
A exposição sobre a 'Vila Penteado' é uma apresentação organizada dos resultados do trabalho de documentação do processo de tombamento e de análise, estudo e proposição de diretrizes para a restauração, ocupação e uso do edifício.

Os trabalhos foram iniciados em $1974 \mathrm{com}$ ampla pesquisa histórica sobre o edifício, realizada por Maria Cecília Naclério Homem Prado, abrangendo a família inicialmente proprietária, o bairro e a época, bem como o arquiteto Carlos Ekman e o conjunto de sua obra. (REIS FILHO, 2002).
\end{abstract}

No ano de 1993, durante a gestão da professora Gilda Collet Bruna, uma série de Boletins Técnicos, impressos pelo Laboratório de Programação Gráfica da FAUUSP, foram organizados com o objetivo de divulgar a situação, intervenções e importância da Vila Penteado. Nesse contexto, o texto de apresentação de Gilda Collet Bruna, destaca:

A Vila Penteado, focalizada em detalhes em vários Boletins Técnicos, tem
um significado especial na formação de atitudes e valores culturais da
cidade de São Paulo, que se irradiaram, na primeira metade do século,
inicialmente a partir das elites da época, disseminando-se aos pouco, por
uma nova classe cultural nascente e em expansão, a dos arquitetos
urbanistas nela formados.
Atitudes e valores culturais podem aqui ser entendidos amplamente, como
querem antropólogos e historiadores 'para se referir a quase tudo que pode
ser aprendido, em uma dada sociedade,74, porém traduzidos por obras
arquitetônicas e urbanísticas que representem esse aprendizado.
Nesse sentido, a Vila Penteado deve ser lembrada pelo interesse artístico e
técnico que desperta, pois representa o ecletismo da arquitetura do mundo
desenvolvido. Ao abrigar, desde 1948, a Faculdade de Arquitetura e

74 BURKE, Peter. Cultura Popular na Idade Moderna, São Paulo, Cia. das Letras, 1989, 385p. (Traduzido do Original Inglês, c. 1978). 
Urbanismo da Universidade de São Paulo, torna-se a sede de uma liderança acadêmica e intelectual, que ainda hoje permanece, estendendo sua influência a todo o Brasil, com os cursos de pós-graduação nela instalados. Assim, produz e difunde o conhecimento, ao estimular o desenvolvimento de pesquisas na área humanística e tecnológica, tão necessárias à sociedade e a seu ambiente construído.

Alguns desses documentos trazem aspectos relevantes históricos, outros apontam falhas nos sistemas existentes e ainda outros apontam caminhos para ações de intervenção. Dos textos publicados nos boletins técnicos, cabe ressaltar 0 conteúdo de alguns desses trabalhos, como o de João Roberto Leme Simões "A Vila Penteado: especificações técnicas das obras de preservação e restauro do edifício à rua Maranhão - FAUUSP" (Boletim Técnico número 12), o texto de Regina Tirello "As Prospecções e Restaurações das Pinturas da Vila Penteado" (Boletim Técnico número 11) e o de Sheila Walbe Ornstein "A Tecnologia de Recuperação do Telhado do Edifício Vila Penteado da Faculdade de Arquitetura e Urbanismo" (Boletim Técnico número 3).

Os trabalhos comentados e ainda os conteúdos dos processos arquivados, ou em andamento da FAUUSP e COESF, revelam situações passadas e questões que requerem reflexão e ação, referentes à Vila Penteado. 


\subsubsection{DOCUMENTOS SOBRE A COBERTURA}

O significado da cobertura no contexto arquitetônico é destacado no texto de Ornstein (1993, p.9 e 22), evidenciando a importância desse sistema:

Constituída essencialmente por uma parte resistente (estrutura) e por um conjunto de componentes com função de vedação (telhado), incluindo eventualmente forro e isolação térmica, independentemente de seus padrões e atributos decorativos e de sua forma, trata-se de um elemento altamente vulnerável (área de exposição às intempéries muito extensa, comparativamente a outros elementos construtivos) sendo a sua deterioração inevitável caso não ocorram reparos adequados e manutenção periódica. (Ornstein; Roméro, 1992-b). Estes reparos são mais urgentes ainda quando se trata de edifício de reconhecido valor histórico, tal como a Vila Penteado, uma vez que a degradação da cobertura (umidade, poluição, infiltração de águas de chuva associada a deslocamento de telhas, ataque das madeiras por cupins, etc.) podem implicar na desintegração de outros materiais e elementos construtivos historicamente relevantes no edifício, tais como as alvenarias, as madeiras estruturais (pisos, por exemplo), pinturas e outros elementos decorativos de época, externos e internos).

[...]

Os especialistas no assunto indicam ser a cobertura de um edifício histórico, o elemento construtivo que exige o maior número de inspeções regulares durante a manutenção, recomendando o seguinte esquema (Azeredo Jr, 1990; Silva, 1991):

a. Inspeção constante: da cobertura em geral (por exemplo, quanto ao deslocamento de telhas e lançamento de objetos de edifícios vizinhos) e das calhas de escoamento de águas pluviais, sempre após fortes chuvas (por exemplo, quanto à obstrução por detritos);

b. Inspeção semestral: da cobertura e das calhas, substituindo partes danificadas (por exemplo, telhas quebradas);

c. Inspeção anual: idem anteriores; e,

d. Inspeção quinquenal: nesta inspeção, de longo prazo, a cobertura é verificada dentro da inspeção do edifício, incluindo o diagnóstico do estado de conservação e inspeção de todos os serviços de manutenção realizados anteriormente 'a', 'b' e 'c'.

Via de regra, a implementação de um programa regular de manutenção preventiva minimiza ou até evita as manutenções corretivas, ou seja, os reparos urgentes com custos elevados.

A cobertura do edifício Vila Penteado apresenta características particulares. As duas alas laterais da construção recebem telhados de mansarda: planos com grande inclinação e telhamento em pedra ardósia de cor cinza, que culminam em águas de menor inclinação, cobertas com telhas em cobre. O corpo central do edifício é dividido em três partes, cada qual com quatro águas cobertas por telhas em ardósia. Os planos de águas das alas laterais se destacam em relação ao corpo central, enfatizando as características da volumetria dessa obra.

Infelizmente, esse traçado de planos de águas delimita calhas em cobre para recebimento das águas pluviais, distribuídas transversalmente ao corpo do edifício e, 
no caso de extravasamento de água, o gotejamento ocorre para o interior do mesmo. Tanto as calhas, quanto os condutores verticais de águas pluviais são feitos em cobre e tem dimensões reduzidas.

$O$ desenho do telhado provoca também dificuldades para os serviços de manutenção de rotina. Para desobstruir calhas e condutores é necessário caminhar pelo telhado extremamente inclinado e não há locais apropriados para a fixação de cintos de segurança.

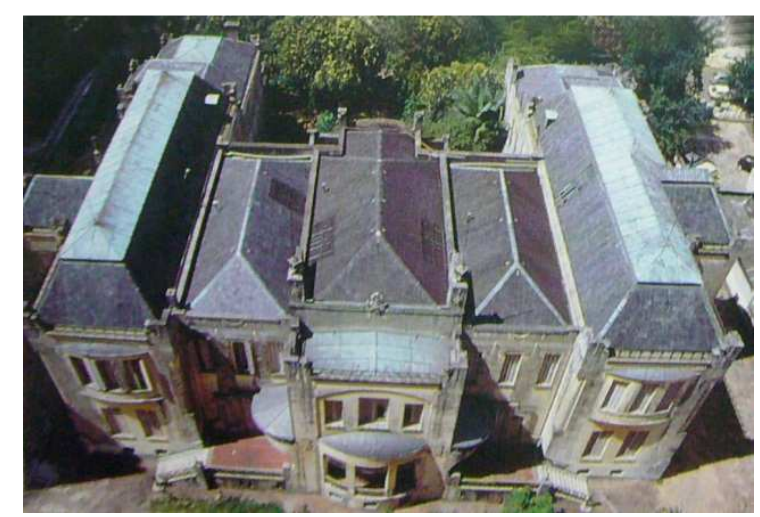

Figura 65 - Foto da Vila Penteado com destaque para os planos da cobertura Fonte: LOURENÇO; et al, 1999, p. 124. Foto de Ângela Garcia, 1996.

Nas alas laterais, os planos de águas com inclinação acentuada geram pédireito generoso no sótão (ver figura 66), facilitando o acesso às instalações elétricas ali existentes, manutenção das caixas d'água, etc.

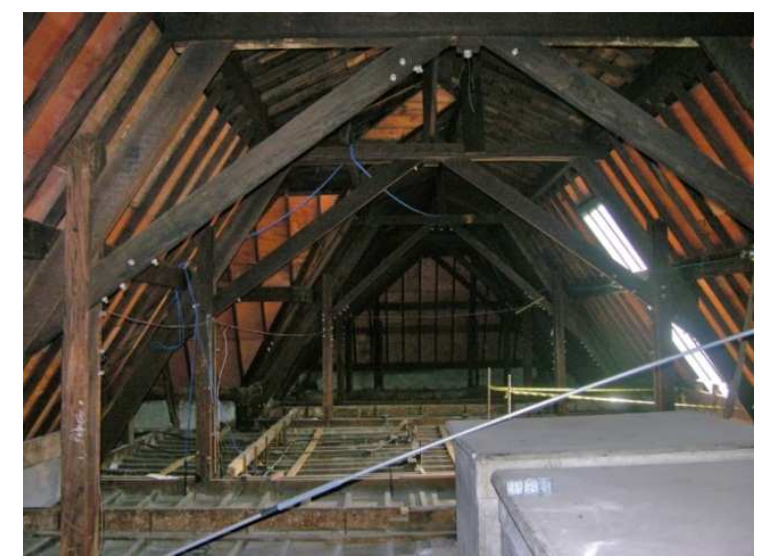

Figura 66 - Vista geral da estrutura da Cobertura da Vila Penteado, Ala Lateral Fonte: Relatório de Observações Gerais, FAU Maranhão, Arq ${ }^{a}$ Bárbara Ivo, fevereiro de 2009. 
Sobre o madeiramento da estrutura: "a cobertura original permanece em sua essência a mesma, sendo constituída de tesouras, vigas, terças, caibros e ripas de madeira (Peroba Rosa e Pinho de Riga) [...]" (ORNSTEIN, 1993, p.11).

Através do desenho da cobertura em corte, apresentado na figura 67, é possível notar que os diversos trechos da mesma não apresentam ligação interna. 0 acesso para as coberturas das alas laterais é feito através de alçapões existentes no forro. Acessando o sótão através desses alçapões é necessário sair da parte interna do telhado, através de lucarnas, para percorrer as áreas da cobertura sem acesso por alçapões, o que torna a manutenção em diversas áreas da cobertura difícil e insegura.

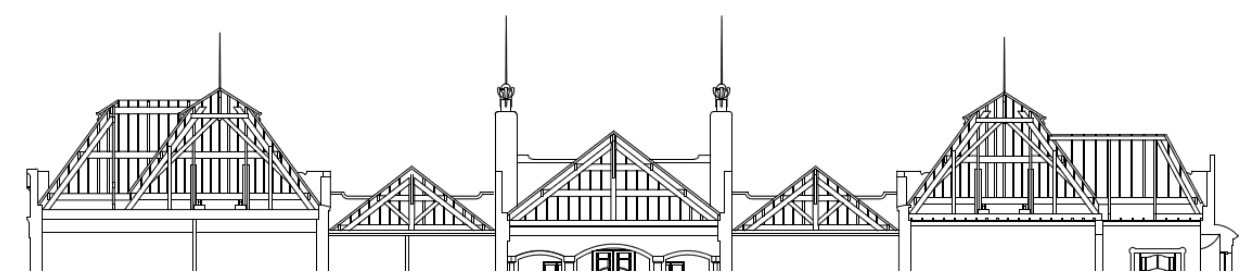

Figura 67 - Corte Longitudinal da Cobertura

Fonte: Desenho parcial da Folha 1/1, FAU Maranhão, Vila Penteado, Captação Águas Pluviais, Levantamentos, Planta Sótão, Diagrama de Cobertura e Cortes. Desenho Bárbara, Escala 1:150, Data 07/04/2009, Revisão 00. GEEF, FAUUSP 2009.

A cobertura da Vila Penteado foi reconstituída, conforme declara o texto da professora Ornstein (1993, p.12 e 13), no decorrer de 1991, especialmente em função das infiltrações generalizadas de águas pluviais. Essas infiltrações provocaram danos severos ao edifício, sendo que os problemas mais significativos foram os seguintes:

- Deslocamento e quebra de telhas de ardósia e peças complementares;

- Perda de impermeabilidade e resistência das telhas de ardósia;

- Oxidação por acúmulo de umidade nos colchetes de cobre originais, usados para fixar as telhas ao madeiramento, provocando o apodrecimento da madeira em pontos específicos;

- Estado precário de trechos de rufos, espigões, rincões e calhas originais em chapa de cobre;

- Obstrução de calhas e condutores;

Sobre a situação de perda de desempenho das telhas de ardósia, o texto de Ornstein (1993) esclarece: 
[...] as telhas de ardósia, largamente empregadas há séculos, sofreram perda de impermeabilidade e resistência, devido à degradação por agentes químicos agressivos existentes na atmosfera, gases e vapores d'água que se depositaram nas peças. De fato, a insuficiência de ventilação, possivelmente devido a limitações técnicas do período de construção, induziram a retenção de águas de chuvas agressivas nas junções das telhas inviabilizando evaporações e, assim, provocando esfarinhamentos e até mesmo escamamentos de algumas peças.

Em função dos problemas apresentados na cobertura, diversas infiltrações surgiram, provocando danos aos forros de estuque, onde a águas das chuvas, intensas e frequentes, atingiram a argamassa e provocaram o deslocamento das tramas de fasquias em diversos pontos.

Em contrapartida, a estrutura de madeira do telhado apresentava, em 1991, bom estado (situação que se mantém até os dias de hoje). Mas, como medida preventiva, foi realizado o pincelamento de um tratamento químico nas peças de madeira do forro e de sustentação do telhado.

As obras relatadas pela professora Ornstein (1993, p.14) iniciaram-se com o levantamento do estado de conservação do edifício, destacando-se os fatores que provocaram a deterioração dos elementos e, a partir desse levantamento, 0 planejamento das ações foi realizado.

Os serviços foram feitos por módulos, o que permitiu o uso contínuo do edifício, mesmo durante a execução dos serviços. O canteiro de obras foi locado na parte posterior do edifício e um pequeno monta-carga foi instalado junto à fachada posterior do mesmo. Ao iniciar os serviços de reconstituição do telhado, os forros de estuque foram protegidos internamente, "fixando-se com chapas de compensado interpoladas por placas de isopor" (ORNSTEIN, 1993, p.16). O escoramento por baixo dos forros, usando essas chapas, visava reduzir os riscos de desabamento e foram indicados pelo Arq. Antonio Luiz Dias de Andrade (Janjão), no Relatório de Vistoria Técnica, de 30 de maio de 1990. Cabe ainda destacar que esse relatório, juntamente com o Memorial de Especificações Técnicas, também elaborado pelo Arq. Luiz Dias de Andrade, foram dois dos documentos mais significativos que nortearam os serviços executados na cobertura da Vila Penteado em 1991. Os demais textos representativos, para orientação desses trabalhos, foram o Relatório de 9 de julho de 1990, autoria de Regina Tirello e Miguel Langella Neto, por parte da Comissão do Patrimônio Cultural - CPC, e o Diagnóstico sobre o estado de 
conservação das estruturas e componentes de madeira, produzido por firma especializada (ORNSTEIN, 1993, p.22 e 23).

O relatório ${ }^{75}$ da TECNOMAD traz em seu item "Conclusões e Recomendações":

Pode-se afirmar, com boa margem de segurança, que a estrutura de madeira está em bom estado e com desempenho satisfatório, sendo que os reparos a serem feitos são de pequena monta e que não implicam em nenhuma alteração significativa da forma atual.

Sobre os caibros, foram fixas chapas de compensado com impermeabilizante (manta de asfalto elastomérico e borracha intercalada de tela poliéster à base de três ou mais demãos aplicadas a frio), visando proteger a estrutura de madeira. Novas ripas de Peroba Rosa também foram instaladas.

As telhas em ardósia foram recuperadas ou substituídas, quando necessário: "no mínimo cerca de $20 \%$ das telhas originais não se encontravam em condições de reaproveitamento, mesmo que pré-tratadas, sendo substituídas por peças de ardósia, provenientes de jazidas selecionadas em Minas Gerais, próximas a Belo Horizonte" (ORNSTEIN, 1993, p.21). O requisito mais importante verificado para a escolha das telhas substituídas foi conter a mesma espessura das peças originais.

O tratamento dado às telhas originais, reaproveitáveis, consistiu no destelhamento, seleção das telhas em condições de uso, lavagem das mesmas, com água, sabão neutro e escova de aço macia, aplicação de hidrorrepelente metilfenilsilicônico, previamente testado em laboratório, "produto este que apresenta vantagens como: redução da absorção de água, produção de aumento de massa, consolidação da peça, e, inalterabilidade da cor desta quando exposta às intempéries e à radiação ultravioleta intensa” (ORNSTEIN, 1993, p.19).

O texto da professora Ornstein (1993, p.19) apresenta ainda alguns detalhes dos serviços executados: os ganchos ou colchetes originais de cobre, usados para fixar as telhas nas ripas, foram substituídos por peças em alumínio, visto os originais apresentarem oxidação. E calços circulares de neoprene fixados com pregos de aço galvanizados, foram posicionados entre as chapas de compensado e as ripas,

75 O relatório da TECNOMAD, assinado por Ennio Silva Lepage (diretor geral) e Waldivino de Carvalho Filho (consultor), com data de 4 de janeiro de 1990, faz parte do processo 94.1.660.51.0, folha 25 a 36 , mantido na COESF 
visando permitir a ventilação permanente e vaporação de águas pluviais acumuladas, objetivando o aumento da vida útil das telhas.

Finalizando o relato sobre as obras de reconstituição da cobertura da Vila Penteado, a professora Ornstein (1993, p.21 e 22) comenta sobre a importância da manutenção preventiva e ressalta a necessidade de se elaborar um projeto de conservação da cobertura, que conte com:

\begin{abstract}
- Inspeção cuidadosa e registro regular dos problemas identificados e das soluções adotadas, atualizando permanentemente os documentos gráficos e escritos relativos ao projeto e às intervenções realizadas, atualização esta sempre acompanhada de registro fotográfico;

- Elaboração de memorial de especificações técnicas, contemplando o roteiro e procedimentos a serem adotados nas inspeções, bem como no encaminhamento das soluções, sobretudo no que diz respeito aos critérios de seleção de mão-de-obra (que deverá ser compatível com o grau de complexidade da intervenção proposta) e dos materiais a serem adotados em particular quanto àqueles alternativos e substitutivos aonde o original não puder ser encontrado;

- Treinamento regular e cuidadoso da equipe técnica responsável pela manutenção e guarda do edifício, no sentido da compreensão 'do como zelar' pelo seu desempenho adequado, e, que medidas adotar face aos problemas específicos que possam ter origem durante a sua vida útil;

- Atenção, por parte da equipe de manutenção e guarda do edifício, para as observações e comentários dos usuários (leigos ou não), visando colher contribuições para a detecção sistemática do surgimento eventual de novas deficiências e patologias (Ornstein; Roméro, 1992-a). No caso, uma vez que os usuários são em sua maioria, profissionais na área de arquitetura, a colaboração pode ser particularmente bastante útil;

- Conscientização da população residente nos edifícios circunvizinhos, enfatizando por meio de folhetos explicativos a importância histórica do edifício em si e para o bairro em que moram (Higienópolis), procurando reduzir o lançamento de objetos e detritos na cobertura da Vila Penteado.
\end{abstract}

Nos anos de 2002 e 2003 foram realizadas obras de manutenção na cobertura da FAU Maranhão, com a recuperação e substituição de parte das calhas e condutores, conforme é apresentado no Relatório de Gestão da Vila Penteado de 2003 e no relatório do "Centenário da Vila Penteado: Restauração, da Vila Penteado à FAU Maranhão, Intervenções Recentes".

As obras de manutenção ocorreram nas seguintes áreas e sistemas:

- Rede externa de águas pluviais, com o mapeamento e desobstrução das mesmas e substituição de trechos de calhas e condutores em cobre;

- Caixas d'água, com a limpeza geral e dimensionamento, o que acarretou na exclusão de uma das oito caixas d'água; 
- Telhado, com a substituição de partes do telhamento em cobre e do assoalho em chapas de compensado, com impermeabilização em manta asfáltica na face superior.

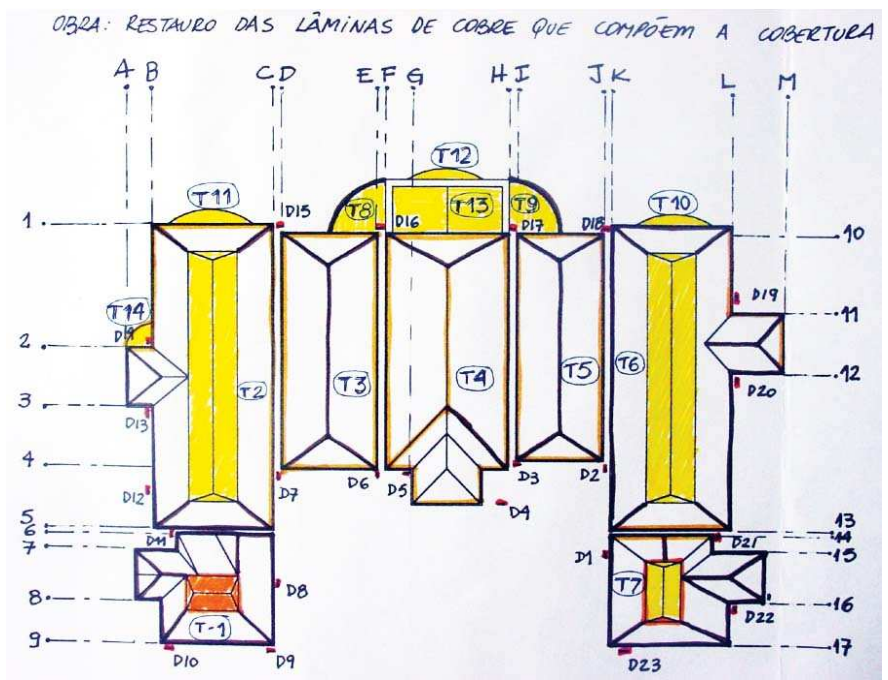

Figura 68 - Planta esquemática da Cobertura - Restauro das Lâminas de Cobre Fonte: Relatório Centenário da Vila Penteado: Restauração, Da Vila Penteado à FAU Maranhão, Intervenções Recentes, Antonio Carlos Barossi e Helena Ayoub Silva, 2002.

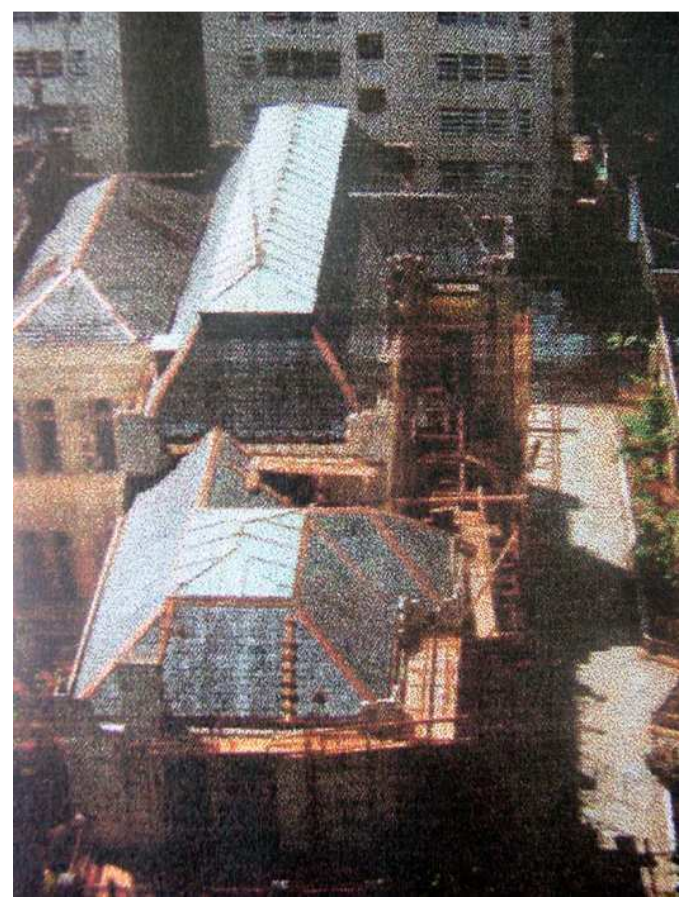

Figura 69 - Foto da Cobertura em Obras- Restauro das Lâminas de Cobre Fonte: Relatório Centenário da Vila Penteado: Restauração, Da Vila Penteado à FAU Maranhão, Intervenções Recentes, Antonio Carlos Barossi e Helena Ayoub Silva, 2002. 
Contudo, as calhas não foram redimensionadas nem substituídas em sua totalidade, o que provocou a continuidade dos problemas de vazamento no interior do edifício ao longo dos anos seguintes.

Em março de 2009, foi feita visita de inspeção e avaliação da cobertura pelo Eng. Waldivino de Carvalho Filho, da empresa TEMA Engenharia. A partir dessa vistoria, o Eng. Waldivino elaborou o "Parecer Técnico: Avaliação do estado de sanidade da estrutura de madeira do telhado e forro do edifício da Faculdade de Arquitetura e Urbanismo da USP".

Nesse parecer técnico consta a seguinte avaliação da estrutura:

O madeiramento de estrutura do telhado e forro está em bom estado de integridade física, não há nenhum indício de ruína, não foi constatada a presença de cupins em nenhum elemento da estrutura. ${ }^{76}$

Sobre o assoalho em chapa de compensado colocado em substituição à base original de tábuas de pinho de riga, o parecer é claro:

Embora a chapa de compensado não seja resistente a cupins e a fungos, o revestimento com manta asfáltica a torna impermeável evitando eventual umidade oriunda de vazamento através da cobertura de ardósia, como pôde ser observado durante a inspeção: em pontos onde há vazamentos na cobertura, devido a quebra ou deslocamento das telhas de ardósia, a umidade resultante deste vazamento aparece no encontro de parede e forro na linha de calha, confirmando a estanqueidade da manta asfáltica. ${ }^{77}$

O diagnóstico a respeito do dimensionamento das calhas é apresentado no parecer técnico:

Embora, o madeiramento esteja em bom estado e o risco de degradação biológica seja baixo, há problema de escoamento nas calhas que precisam ser redimensionadas. A umidade presente nas paredes é resultado de falha nas calhas, seja por ruptura na junta com os tubos de queda ou transbordamento da calha. ${ }^{78}$

O parecer técnico é finalizado com recomendações de intervenção:

\footnotetext{
${ }^{76}$ Parecer Técnico: Avaliação do estado de sanidade da estrutura de madeira do telhado e forro do edifício da Faculdade de Arquitetura e Urbanismo da USP, Cliente: Grupo Executivo de Gestão dos Espaços Físicos da FAUUSP. Elaborado pelo Eng. Waldivino de Carvalho Filho, CREA:06004404987, São Paulo, 26 de março de 2009, TEMA Engenharia, p.2.

${ }^{77}$ Ibidem.

${ }^{78}$ Ibidem.
} 
Para assegurar a estanqueidade da cobertura e escoamento das águas pluviais recomendo as seguintes intervenções:

- redimensionamento das calhas e dos vertedores;

- substituição ou reposicionamento de telhas de ardósia em alguns poucos pontos da cobertura, estimados em não mais que $1 \%$ da superfície total da cobertura;

- refazer as duas escolhas do sótão e o rufo junto às mesmas. ${ }^{79}$

Após dois meses da elaboração desse parecer técnico, em maio de 2009, foi realizado um levantamento das infiltrações existentes na cobertura da Vila Penteado. O resultado desse trabalho é observado nas pranchas contidas nas figuras 70 e 71.

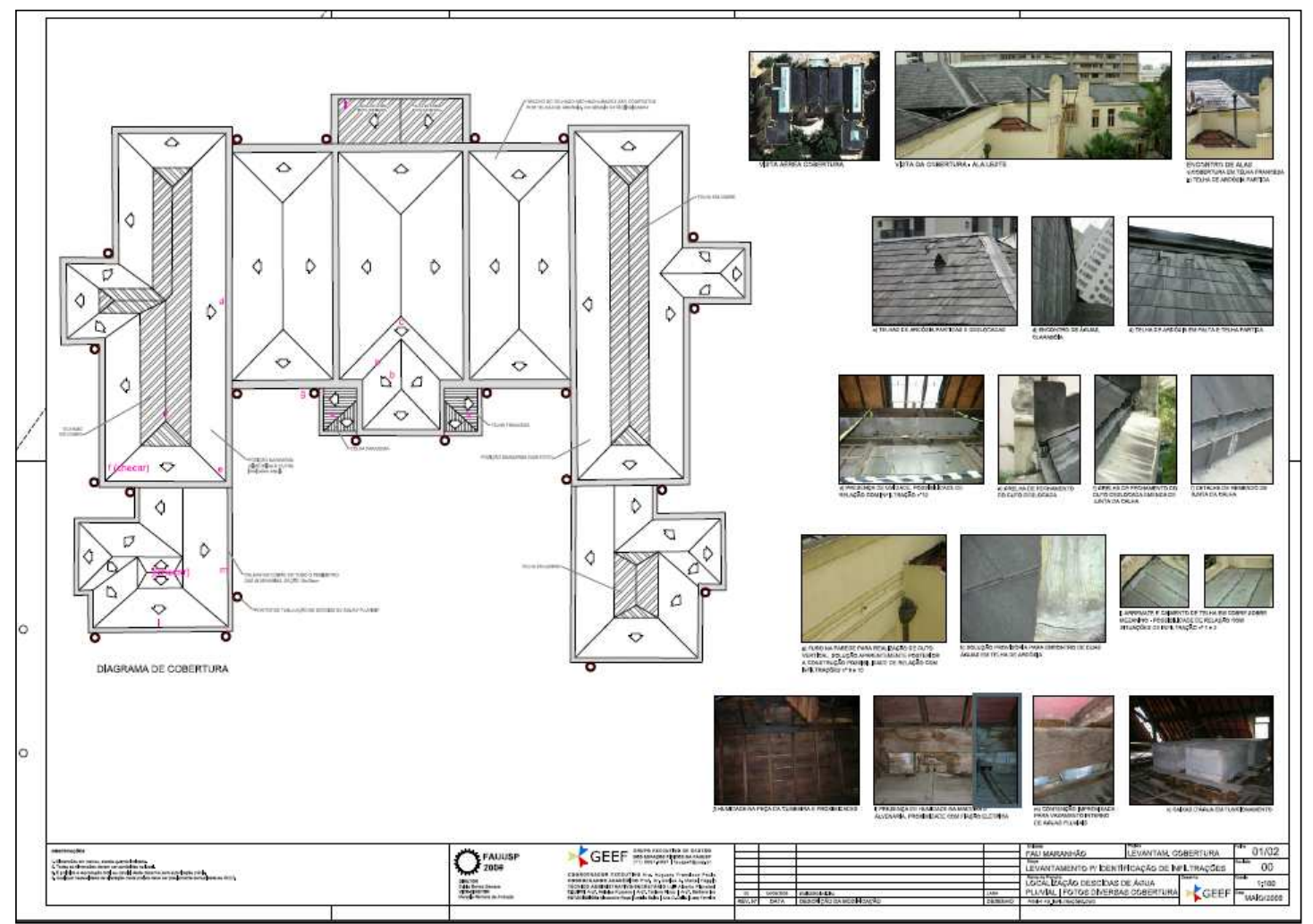

Figura 70 - Levantamento da Cobertura - FAU Maranhão

Fonte: Folha 1/2, FAU Maranhão, Levantamento para identificação de infiltrações. Localização das descidas de água pluvial/ Fotos diversas da cobertura. Desenho Lara, Escala 1:100, Data maio/ 2009, Revisão 00. GEEF, FAUUSP 2009.

${ }^{79}$ Parecer Técnico: Avaliação do estado de sanidade da estrutura de madeira do telhado e forro do edifício da Faculdade de Arquitetura e Urbanismo da USP, Cliente: Grupo Executivo de Gestão dos Espaços Físicos da FAUUSP. Elaborado pelo Eng. Waldivino de Carvalho Filho, CREA:06004404987, São Paulo, 26 de março de 2009, TEMA Engenharia, p.3. 


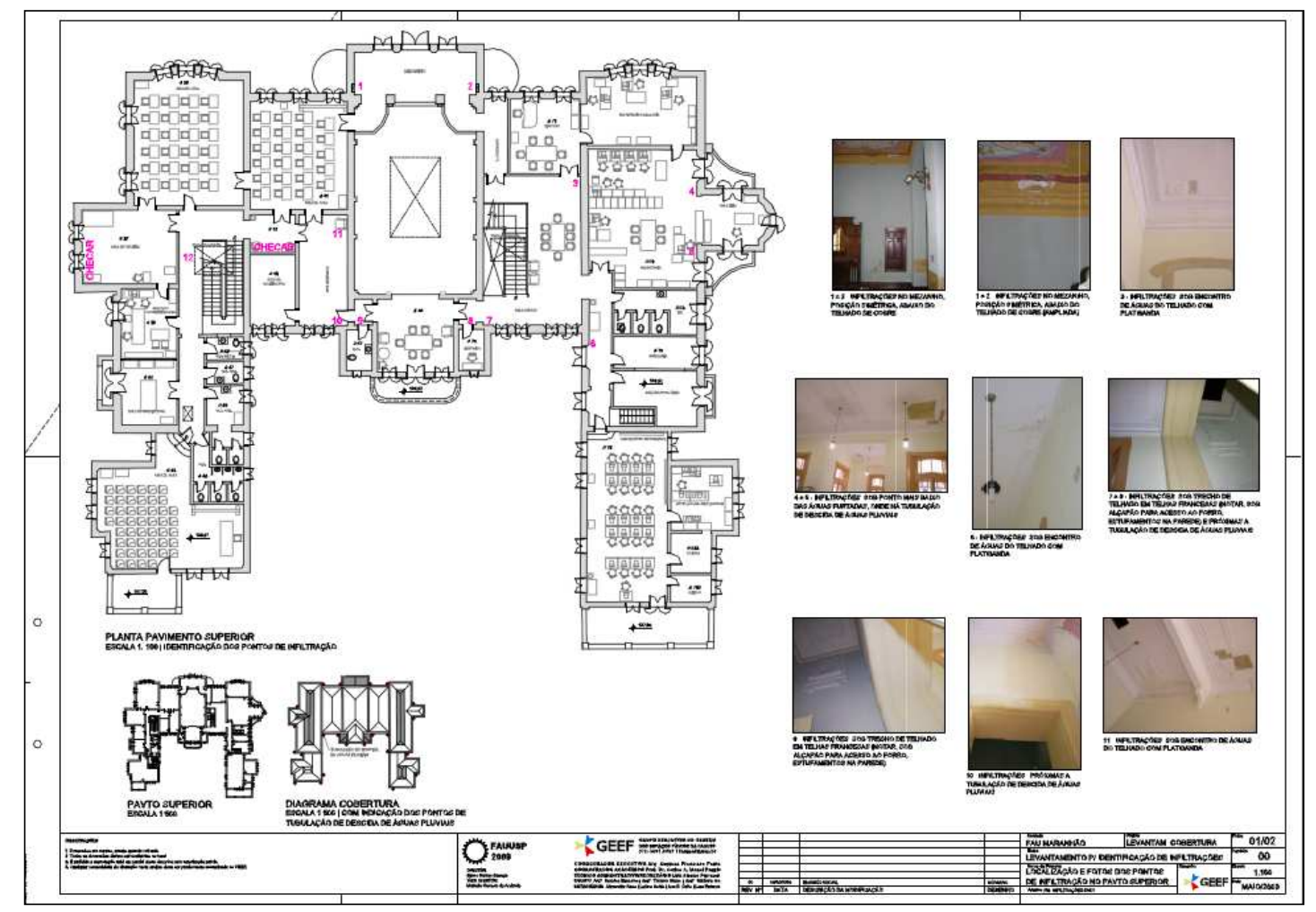

Figura 71 - Levantamento da Cobertura - FAU Maranhão

Fonte: Folha 2/2, FAU Maranhão, Levantamento para identificação de infiltrações. Localização e fotos dos pontos de infiltração no pavimento superior. Desenho Bárbara, Escala 1:100, Data maio/ 2009, Revisão 00. GEEF, FAUUSP 2009. 


\title{
3.2.2 INTERVENÇÕES NOS FORROS
}

Os forros da Vila Penteado apresentam características bem interessantes: estuque estruturado em fasquias da palmeira juçara (euterpe edulis), justapostas, envolvidas por camadas de argamassa de cal e areia. Entretanto, em alguns ambientes, não há estuque e sim réguas de madeira para compor os forros, sendo que "segundo a vistoria realizada por membros da CPC da USP em 1994, os forros de madeira da época da construção possuem tábuas de aproximadamente $14 \mathrm{~cm}$ de largura, enquanto as da reforma de 1909 apenas 9 cm" (NASCIMENTO, 2002, p.152).

Na década de 1980, já existia a preocupação com o estado de conservação das estruturas em madeira e dos estuques das diversas áreas do edifício.

\begin{abstract}
Em 1989, a empresa Tecnomad foi contratada para realizar uma vistoria do estado de conservação do edifício da Vila Penteado. Seu relatório de trabalho apontou a presença de cupins de madeira seca no sistema de cobertura e forros. Alguns trechos do forro também apresentavam sinais de deterioração (apodrecimento) devido a presença de umidade. Foi recomendado o tratamento químico da madeira contra os cupins e a eliminação das fontes de vazamento de água existentes.

Em 1992, parte do forro de uma das varandas externas desabou. Este quadro de deterioração viria a piorar ao longo dos anos, quando em 1994, o forro da área da mapoteca da biblioteca desabou parcialmente. Neste momento, o edifício passou por uma série de obras emergenciais e foi posteriormente interditado. Um relatório de vistoria apresentado por uma comissão de técnicos da Universidade de São Paulo apontou como causas do desabamento o ataque de cupins - danificando a trama da juçara de suporte do estuque - e a presença de umidade, proveniente de infiltração pluvial. Além disto, foram propostas como técnica para consolidação do estuque a instalação de uma tela metálica presa à estrutura da cobertura, utilizando pinos de latão, e a utilização de resina para consolidar a argamassa.

A biodeterioração foi considerada como o fator predominante para a falência parcial do forro [...].

Diante da situação, a Comissão resolveu por adotar algumas medidas emergenciais, entre elas o escoramento do forro de alguns cômodos. (SILVA, H. A. A.; et al , 2007).
\end{abstract}

Em 1992, foi executada descupinização geral do edifício, como é comentado em carta ${ }^{80}$, datada em 21 de julho de 1994, da diretora da FAUUSP, Gilda Collet Bruna, para o diretor da empresa Tecnomad, Sr. Ennio Silva Lepage. Nessa carta a diretora Gilda Bruna relembra que a Tecnomad realizou serviços de descupinização na Vila Penteado, mas que, em função do desmoronamento de parte do forro da

${ }^{80}$ A carta mencionada consta do processo 94.1.660.51.0, folha 22, mantido na COESF. 
Mapoteca (incidente ocorrido em 4 de julho de 1994), foi possível verificar que existem cupins nessa região. Nessa carta foi solicitada nova vistoria para avaliação da situação existente.

Com o desmoronamento de forros e da constatação da existência de cupins, vistorias e relatórios foram executados. Em 8 de julho de 1994, o Prof. Antonio Luiz Dias de Andrade, juntamente com o Prof. Carlos Lemos, realizaram inspeção técnica no edifício. Essa vistoria foi relatada à diretora Gilda Collet Bruna, em carta com data de 12 de julho de 1994, onde se lê a seguinte conclusão: "é urgente, portanto, executar os serviços de consolidação completa dos forros do edifício." ${ }^{11}$

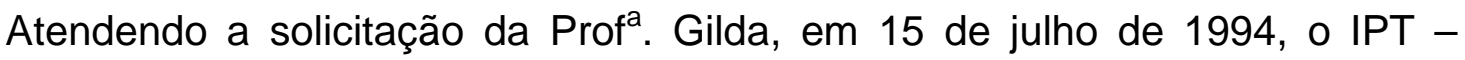
Instituto de Pesquisas Tecnológicas - enviou técnicos do Agrupamento de Propriedades Básicas e de Preservação de Madeiras da Divisão de Produtos Florestais e Têxteis, para a realização de vistoria preliminar na Vila Penteado. Essa vistoria foi acompanhada pelo Prof. Gustavo Neves da Rocha Filho e pela Arq $^{a}$ Regina Tirello e teve por objetivo avaliar as condições, para fornecimento de orçamento, visando à avaliação do estado atual do estuque e apresentação de sugestões, para controle do processo de desabamento.

Em 1999, a situação emergencial dos forros da Vila Penteado foi evidenciada em relatório ${ }^{82}$ redigido pelo engenheiro Fausto Chocair Tarran, do FUNDUSP.

\footnotetext{
2. Estado Atual do Forro

2.1 Atualmente, vários trechos do forro em estuque encontram-se escorados. Essas escoras são constituídas de chapas de madeira compensada, enrijecidas com caibros ou sarrafos, fixadas às vigas de sustentação do forro por meio de 4 parafusos.

Em um trecho do forro do pavimento superior, os parafusos foram substituídos por pontaletes de madeira apoiados no piso do pavimento superior.

2.2 Dois trechos do forro da Sala 25 (térreo) desabaram: o primeiro em 1994 e o outro em outubro p.p.

[...]

3. Verificações da Escola Politécnica

Disse, ainda, a Prof ${ }^{a}$ Maria Alba ${ }^{83}$ que o critério para a instalação de escoras foi a observação de 'som cavo', sob percussão do forro.
}

\footnotetext{
${ }^{81}$ A carta mencionada consta do processo 94.1.660.51.0, folhas 11 e 12, mantido na COESF.

${ }^{82}$ Relatório: FAU Maranhão, Forro de Estuque, 11/11/1999, FUNDUSP, Eng. Fausto Chocair Tarran. Esse documento conta com os seguintes itens: 1.Descrição Geral, 2.Estado Atual do Forro, 3. Verificações da Escola Politécnica, 4.Verificações do FUNDUSP, 5.Causas dos desabamentos, 6.Segurança, 7.Segustão para o reforço, 8.Conclusões.

${ }^{83}$ Prof $^{\text {a }}$ Maria Alba Cincotto
} 
Nesse mesmo relatório (TARRAN, 1999), o engenheiro Fausto aponta as possíveis causas dos desabamentos ocorridos em 1994 e 1999, de trechos dos forros da Vila Penteado:

5. Causas dos desabamentos

5.1 Os desabamentos da parte inferior do estuque ocorrem pela perda de aderência entre argamassa e varas de palmeira e ruptura dos septos de argamassa que ligam a lamina de argamassa situada $\underline{\text { sob }}$ as varas com a lamina situada sobre a argamassa.

5.2 A perda de aderência, entre argamassa e palmeira, ocorre por dois motivos: secagem das varas com consequente redução de sua seção transversal e por esforços repetidos (e alterados), entre argamassa e palmeira, devidos às variações de temperatura e umidade (ruptura por fadiga).

5.3 A ruptura dos septos em argamassa deveu-se às tensões de tração (perpendicular ao plano do estuque) e de cisalhamento devidas aos esforços repetidos de flexão. Estes esforços são devidos às variações higrotérmicas e à circulação de pessoas.

Há, ainda, o agravante da redução da resistência da argamassa, sob a ação prolongada da água (item 3.5). Neste caso há, também, a deterioração das palmeiras sob a ação de fungos.

A partir da verificação da situação dos forros por parte do FUNDUSP, a situação de segurança em uso dos espaços é analisada e sugestões paliativas de reforço das áreas de forro em estuque são propostas:

\section{Segurança}

Pode-se supor, e algumas verificações feitas no forro do pavimento superior o indicam, que a aderência entre argamassa e varas já não mais existe. Pode-se supor, também, que os septos de ligação estejam se rompendo.

São, portanto, necessárias medidas urgentes de reforço do estuque, ou sua remoção, para garantir a segurança dos usuários.

\section{Sugestão para reforço}

7.1 A maneira mais simples de fixar a lamina inferior da argamassa, às vigas suporte, seria por meio de parafusos regularmente espaçados. Para verificar a eficiência dessa fixação, e o espaçamento máximo, forma feitos alguns ensaios com pedaços de lamina inferior do estuque que desabou do forro da Sala 25.

$[\ldots]$

8. Conclusões

8.1 O estuque de toda a edificação (exceto Sala 25) deverá ser reforçado.

8.20 forro da Sala 25 que esteve, por longo período de tempo, sob a ação da umidade, não aceita recuperação. Deverá ser inteiramente removido e, posteriormente, substituído por forro de gesso ou estuque com argamassa de cimento e areia aderente a tela metálica.

8.3 O forro que não sofreu ação da umidade deverá ser reforçado. Se adotada a solução com parafusos recomenda-se coloca-los nos cruzamentos de malha de $50 \times 50 \mathrm{~cm}^{2}$, no forro do pavimento térreo, e $45 \times 50$ $\mathrm{cm}^{2}$ no forro do pavimento superior. 
Esses parafusos teriam cabeça com diâmetro mínimo de $8 \mathrm{~mm}$. Seriam utilizadas arruelas de neoprene, ou durepoxi, com diâmetro igual ou maior que $8 \mathrm{~mm}$ e as cabeças dos parafusos ficariam aparentes (externas).

8.4 Recomenda-se restringir o acesso de público ao piso superior da edificação. $^{84}$

Em novembro de 1999, o engenheiro Fausto redigiu o Memorial Descritivo para fixação do forro de estuque da Vila Penteado, por meio de parafusos, condições de obra que foram executadas e acompanhadas pelo FUNDUSP. Silva (2011) afirma que o procedimento do aparafusamento do forro nos barrotes foi definido pelo FUNDUSP, porém sem a concordância da FAUUSP. Futuramente esse tipo de fixação deve ser substituído (informação verbal) ${ }^{85}$.

Em função dos problemas de infiltração da cobertura que provocaram 0 desmoronamento de trechos do forro, os mesmos receberam soluções paliativas até que em 2000, quando foram iniciadas as obras de intervenção na área da biblioteca da Pós-Graduação da FAUUSP, os forros receberam tratamento adequado, visando a sua consolidação e restauro das pinturas murais.

\begin{abstract}
Segundo relatório apresentado pela arquiteta Regina Tirello a partir de prospecções cromáticas no edifício, todos os forros em estuque da antiga residência são decorados com pintura mural. Nas salas correspondentes aos cômodos íntimos, a decoração limita-se às faixas de 40 a $70 \mathrm{~cm}$ no contorno dos ambientes, enquanto nos ambientes sociais as pinturas estendem-se por toda superfície (NASCIMENTO, 2002: p.92).
\end{abstract}

A técnica encontrada para consolidar os forros partiu da escolha entre duas alternativas detalhadas no artigo "A Consolidação dos Forros da Vila Penteado - em estuque estruturado por fasquias de juçara", publicado na Revista Brasileira de Arqueometria, Restauração e Conservação.

Duas alternativas foram pesquisadas: a primeira proposta pela engenheira Cláudia Bastos do Nascimento que previa a retirada da camada superior da argamassa e aplicação de leite de cal, a segunda sugerida por Antonio Sarasá previa também a retirada da camada superior da argamassa e a aplicação de resina acrílica bicomponente e autonivelante constituída por: componente cimentício especial com aditivos, agregados minerais e componente líquido composto por polímeros acrílicos aditivados.

Após testes para determinação da resistência à tração, a segunda alternativa se mostrou mais adequada (SILVA, H. A. A.; et al, 2007).

\footnotetext{
${ }^{84}$ Relatório: FAU Maranhão, Forro de Estuque, 11/11/1999, FUNDUSP, Eng. Fausto Chocair Tarran

85 Informação fornecida pela Profa. Helena Ayoub Silva, durante o exame de qualificação desta autora, no dia 29 de agosto de 2011
} 


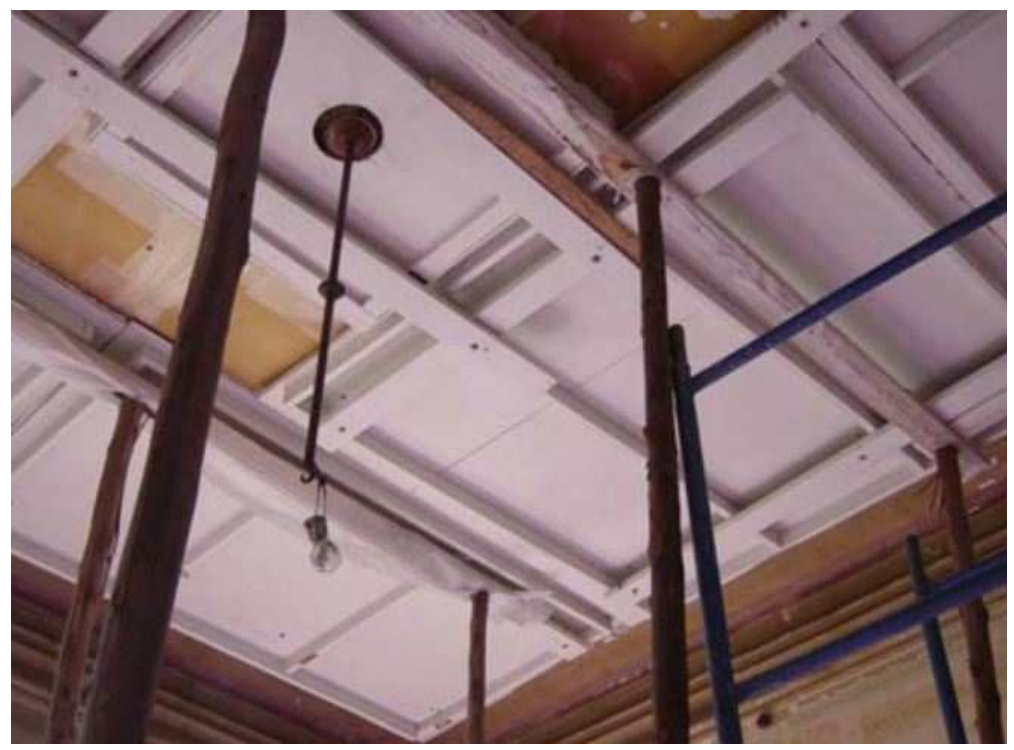

Figura 72 - Escoramento do forro do mezanino da Vila Penteado Fonte: SILVA, H. A. A.; et al, 2007, p. 306. Foto Antônio Sarasá.

Os testes para verificação da melhor solução para recuperação dos forros em estuque foram realizados pelo laboratório Falcão Bauer - Centro Tecnológico de Controle de Qualidade. E o relatório de ensaio E/68.056/01, Argamassa de Revestimento - Determinação da Resistência de Aderência à Tração, de 14 de novembro e 2001, apresentou a seguinte conclusão:

5. Conclusão: Com base nos resultados obtidos nos ensaios de verificação da aderência, observou-se que a situação argamassa acrílica/argamassa mista resultaram melhor desempenho em relação à situação argamassa mista/argamassa mista. ${ }^{86}$

A recuperação do forro e das pinturas ficou a cargo do conservador e restaurador Antônio Luís Ramos Sarasá Martin, do Ateliê Sarasá. A consolidação da argamassa do forro com resina acrílica teve que ser feita por cima, com a retirada do assoalho do piso superior, evitando qualquer dano à fibra ou à pintura do forro. Foi retirada toda a cimalha existente e, em seguida, feita a colocação da resina acrílica, agregando a fibra e a argamassa antiga. Dessa forma, a pintura sobre a argamassa pôde ser recuperada pelo lado de baixo do forro.

${ }^{86}$ I.a.falcão bauer - centro tecnológico de controle de qualidade, Relatório de Ensaio E/68.056/01, 14/11/2001, ARGAMASSA DE REVESTIMENTO, DETERMINAÇÃO DA RESISTÊNCIA DE ADERÊNCIA À TRAÇÃO, Interessado: Atelier Artístico Sarasá/ FAU - Faculdade de Arquitetura e Urbanismo da Universidade de São Paulo, Obra: Prédio de Pós Graduação, Rua Maranhão, 85 Higienópolis - SP, (37.113). 
A sequência desse trabalho pode ser observada nas fotos das figuras 73 a 78, que apresentam desde a numeração e retirada das réguas do assoalho para acesso a área do forro, até a execução das camadas de resinas, aplicadas sob e sobre a instalação das telas de arame galvanizado.

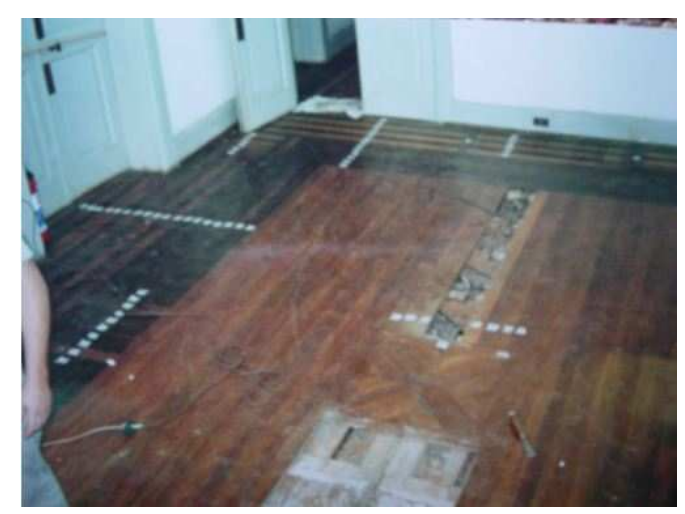

Figura 73 - Abertura do piso para intervenção no forro do Pavimento Térreo Fonte: SILVA, H. A. A.; et al, 2007, p. 306. Foto Antônio Sarasá.

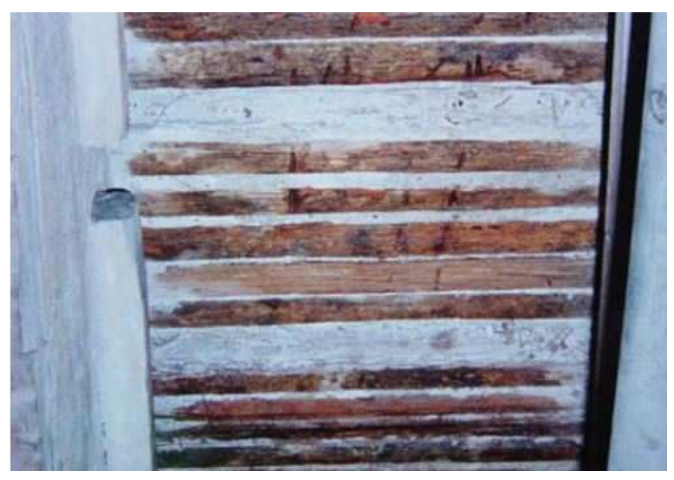

Figura 74 - Fasquias de juçara com a primeira camada de resina acrílica Fonte: SILVA, H. A. A.; et al, 2007, p. 306. Foto Antônio Sarasá.

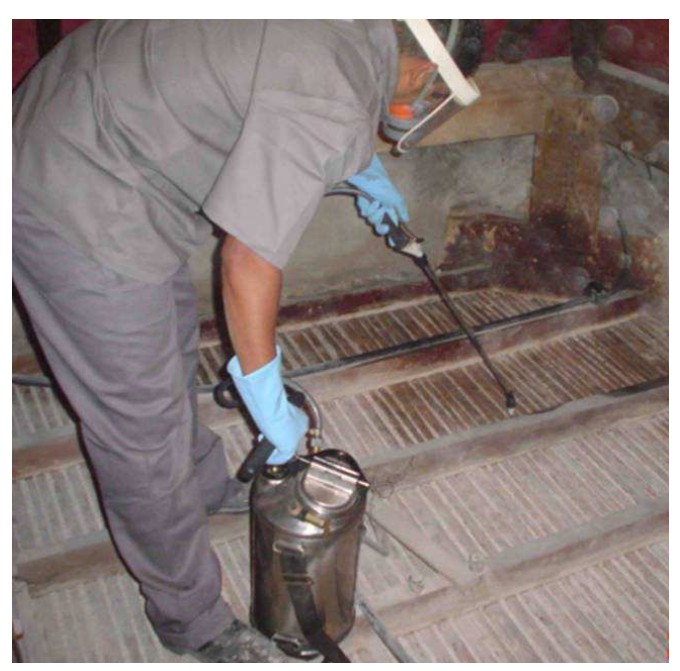

Figura 75 - Descupinização das estruturas em madeira Fonte: Foto apresentada no Relatório de Gestão de 2006 da Vila Penteado. 


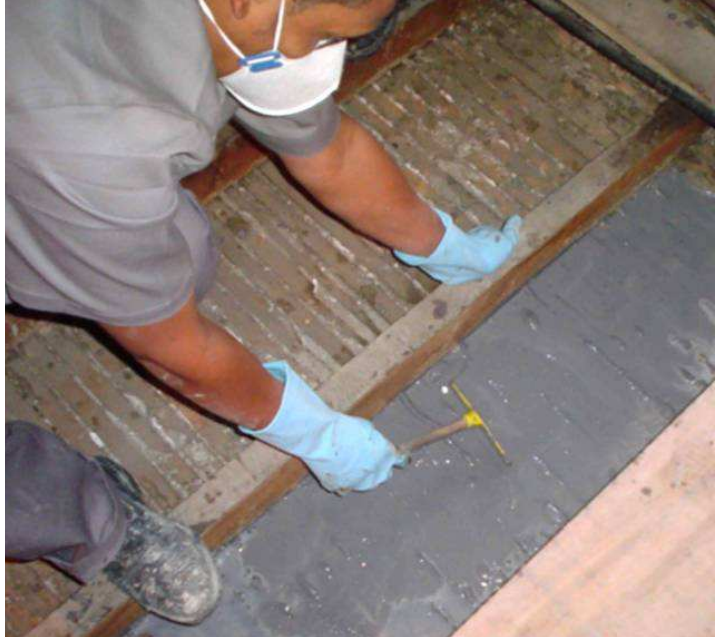

Figura 76 - Execução da primeira camada de resina

Fonte: Foto apresentada no Relatório de Gestão de 2006 da Vila Penteado.

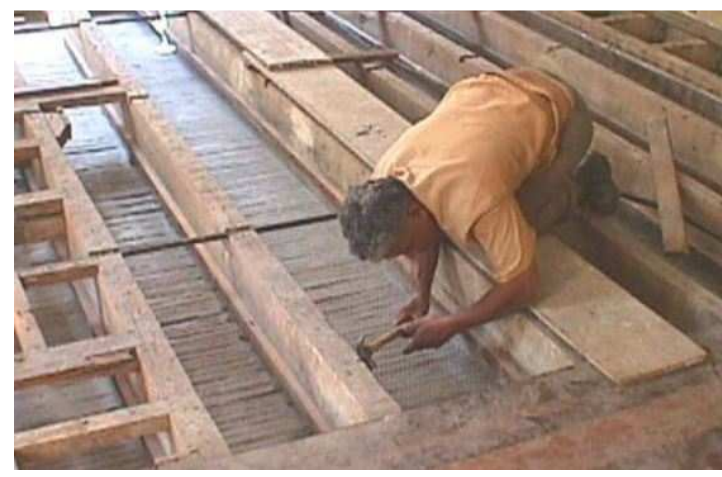

Figura 77 - Instalação das telas de arame galvanizado Fonte: SILVA, H. A. A.; et al, 2007, p. 306. Foto Antônio Sarasá.

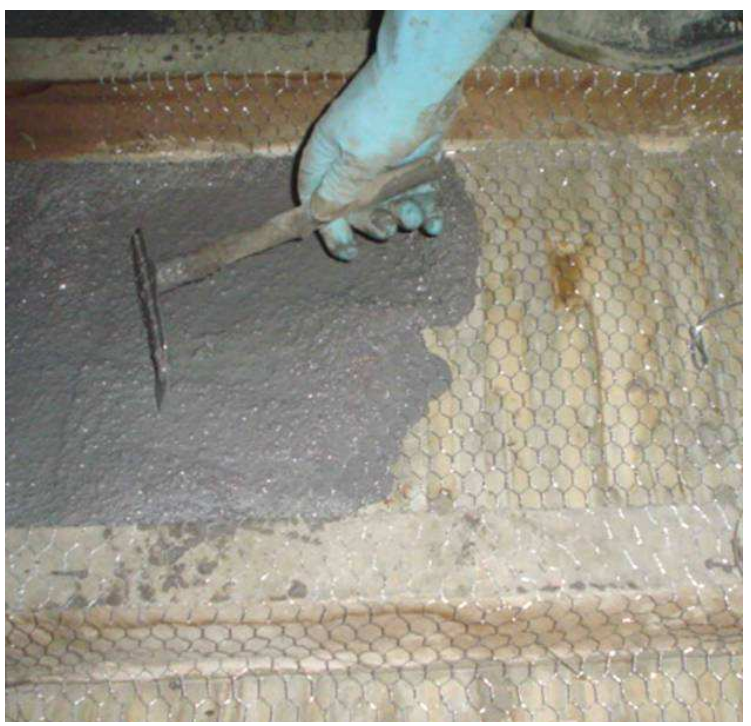

Figura 78 - Execução da segunda camada de resina Fonte: Foto apresentada no Relatório de Gestão de 2006 da Vila Penteado. 


\subsubsection{PINTURA MURAL E FACHADAS}

A Vila Penteado originalmente recebeu pinturas murais em boa parte de suas paredes internas e de seus forros, e o Centro de Preservação Cultural da Universidade de São Paulo, CPC USP, elaborou estudos e executou intervenções em algumas áreas desse edifício. Criado em outubro de 2002, o CPC é o órgão que veio substituir a Comissão de Patrimônio Cultural, criado em 1986, e é subordinado à Pró-Reitoria de Cultura e Extensão Universitária da Universidade de São Paulo.

Os estudos para a restauração da pintura mural formulados pelo CPC foram registrados com a intenção de aprimorar e divulgar o conhecimento científico a respeito do restauro, como é possível notar na apresentação do CPC:

O Programa Conservação e Restauração de Bens Arquitetônicos e Integrados tem como objetivos:

- Contribuir com a preservação, conservação e restauração de edifícios de valor histórico-cultural pertencentes à Universidade de São Paulo;

- Propor, realizar pesquisas, produção, desenvolver sistemas de diagnóstico, registro e procedimentos preservacionistas

Busca-se divulgar conhecimentos específicos a respeito de restauro, conservação de murais e elementos componentes da arquitetura baseados nos conceitos diretores da preservação cientifica, numa prática interdisciplinar na área de conservação e restauração de bens arquitetônicos e integrados e, fornecer, através da estruturação de canteiros de restauração, formação especializada e prática de graduandos, provenientes de diversas áreas do conhecimento, compatíveis com o campo da preservação de bens culturais, em áreas não existentes nos cursos regulares da USP. ${ }^{87}$

O treinamento de profissionais que possam lidar diretamente com a prática da restauração também é objetivado pelo CPC:

O Canteiro de Restauração de Pinturas Murais configura-se em experiência bem sucedida de treinamento para formação de auxiliares de restauração em pinturas murais artísticas. As etapas deste programa desenvolvido para o treinamento dos estudantes - estagiários compreendem desenvolvimento de trabalhos diferenciados, que adequam-se à problemática técnica e estética imposta pelo edifício/mural sobre o qual se trabalhará. ${ }^{88}$

O trabalho do CPC inicia-se com a identificação das áreas de interesse, desenvolvendo os trabalhos da chamada primeira etapa:

${ }^{87}$ http://www.usp.br/cpc/v1/php/wf03_conservacao.php, último acesso em 05 de maio de 2011.

${ }^{88}$ Ibidem. 
a) Estudos históricos e materiais para reconhecimento da estratigrafia arquitetônica, não documentada convencionalmente, por meio de identificação e datação indicativa de argamassas/ adornos/ componentes e pinturas murais antigas;

b) Identificação das pinturas com sondagens de superfície (estratigrafia cromática);

c) Pré-consolidação preventiva de rebocos/ áreas de pintura em desprendimento;

d) Sondagens;

e) Decapagem das sobrepinturas que encobrem por onamentos/ pinturas de interesse. ${ }^{89}$

A segunda etapa dos trabalhos corresponde às intervenções de conservação e restauração:

f) Tratamento/consolidamento do substrato;

g) Limpeza;

h) Consolidamento da película pictórica;

i) Tratamento de lacunas/nivelamento;

j) Preparação da superfície para reintegração estética/imprimação;

k) Reintegração cromática final, adequada a casuística formal proposta pela obra. ${ }^{90}$

Na Vila Penteado, os trabalhos dos "Canteiros de Restauração do CPC-USP" iniciaram-se em 1989 e se estenderam até 2002. Foram analisados oito ambientes sob a supervisão da restauradora e arquiteta Regina A. Tirello, com a participação de mais de cinquenta estagiários bolsistas que participaram de trabalhos de pesquisas históricas, levantamentos métricos, inventários de elementos componentes da arquitetura, sondagens prospectivas, estudos cromáticos e restauração das pinturas murais. Esses trabalhos foram organizados em três etapas:

1ํㅡㄹ Etapa = Análises da arquitetura e arqueologia de superfície (de 1990 a 1992): análise prospectiva e documental com o intuito de ser estabelecida a cronologia arquitetônica e as características construtivas da casa.

$2^{\text {a }}$ Etapa = Sondagens estratigráficas e diagnósticas (de 1992 a 1993): trabalhos de identificação e decapagem das pinturas murais artísticas originais, dos ambientes dos dois pavimentos da casa; e caracterização das cores antigas da fachada. Através desse trabalho realizado nos ambientes foi possível constatar sobreposição de pinturas murais, sendo as mesmas classificadas por três ciclos ornamentais (todos executados originalmente até meados da década de 1920,

\footnotetext{
${ }^{89} \mathrm{http}: / /$ www.usp.br/cpc/v1/php/wf03_conservacao.php, último acesso em 05 de maio de 2011.

${ }^{90}$ Ibidem.
} 
quando a casa ainda abrigava o uso residencial) onde o primeiro ciclo corresponde ao das pinturas de estilo art nouveau.

$3^{\text {a }}$ Etapa = Restauração das pinturas murais e ornamentos (de 1993 a 2002): a restauração completa da pintura foi efetivada em oito ambientes, considerados nobres da casa, pertencentes ao primeiro ciclo ornamental do edifício. Os ambientes são os seguintes: saguão central, sala de jantar, saleta superior 1, escritório do conde, corredor $1,2,3$ e 4 . A conduta de restauração teve como base a linha conservativa, opondo-se à recuperação antiquaria. As técnicas usadas foram a da pintura a óleo e a tempera.

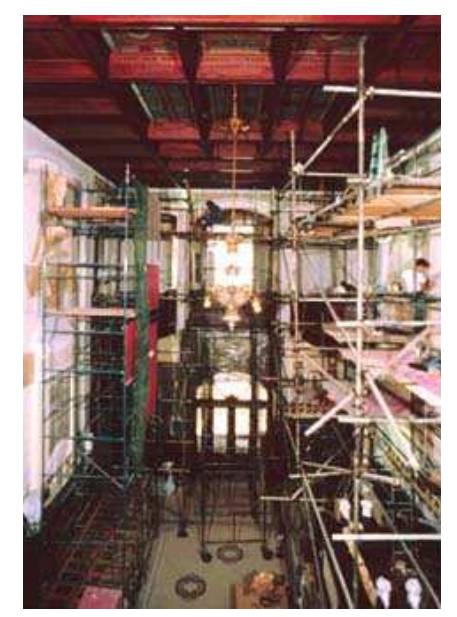

Figura 79 - Equipe de estagiários do Canteiro de Restauro do CPC-USP durante a restauração das pinturas murais do saguão principal em 1993

Fonte: CPC USP. Foto Roberto Bogo, 1993.

O conteúdo detalhado dos trabalhos executados pela CPC na Vila Penteado pode ser observado no artigo "O restauro dos murais art-nouveau da Vila Penteado e o Canteiro-Escola da CPC-USP: uma experiência de formação qualificada" de autoria de Regina A. Tirello, publicado na revista intitulada Vila Penteado: 100 anos, número especial da Revista Pós, do Programa de Pós Graduação da Faculdade de Arquitetura e Urbanismo da USP, publicada em 2002, por ocasião das comemorações do centenário do edifício. ${ }^{91}$

Entretanto, visando exemplificar esse trabalho, as figuras 80 a 92 apresentam uma amostra do mesmo.

91 Esse artigo encontra-se disponível no site do CPC, no seguinte endereço: http://www.usp.br/cpc/v1/php/wf09_downloads.php. 

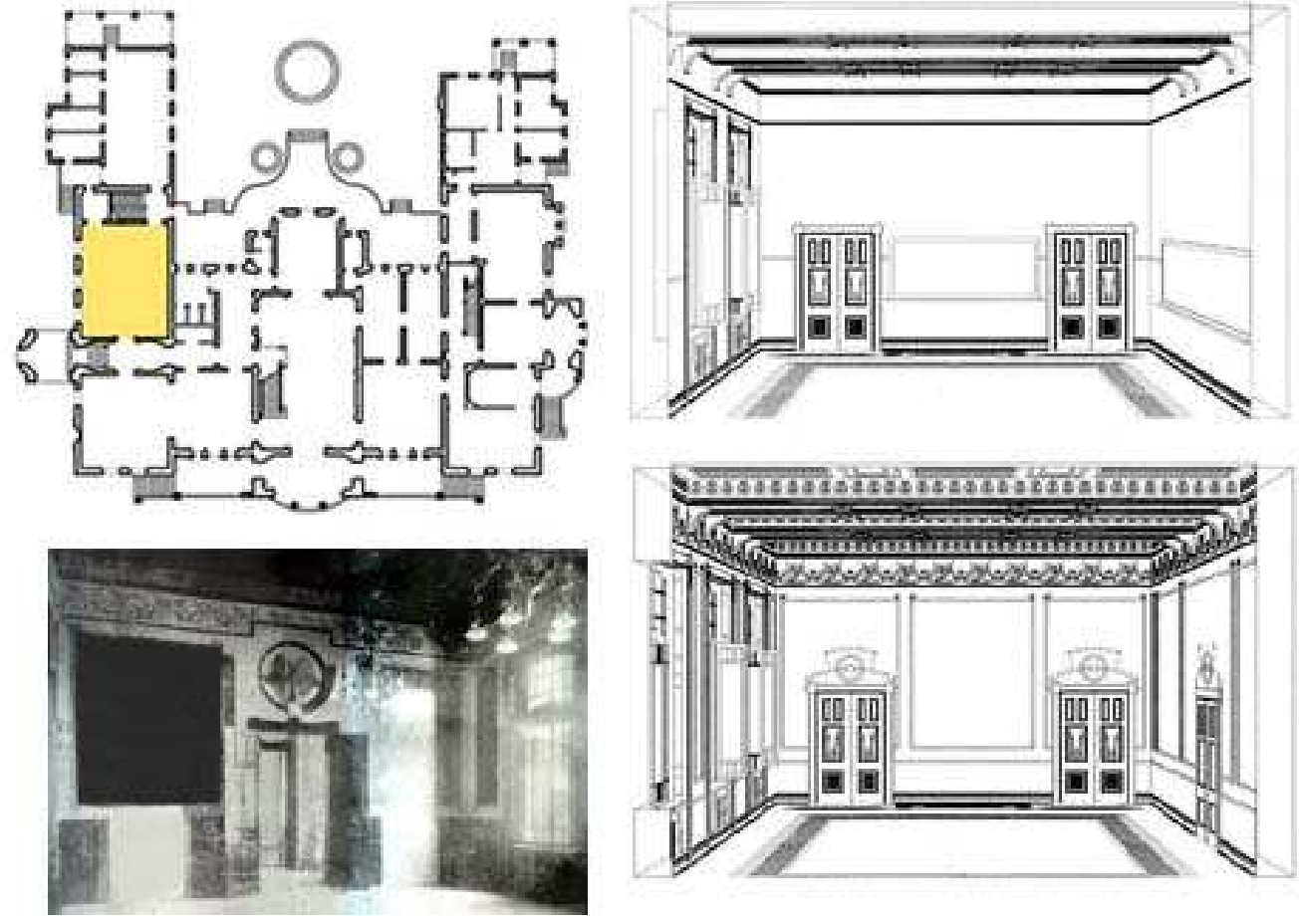

Figura 80 - Simulação computadorizada com base em dados de prospecção de superfície arquitetônica

$\mathrm{Na}$ vista superior a sala de jantar tal qual a encontrada no início dos trabalhos da CPC, no desenho inferior a simulação gráfica de como era a sala originalmente, com aberturas primitivas e ornatos.

Fonte: CPC USP.
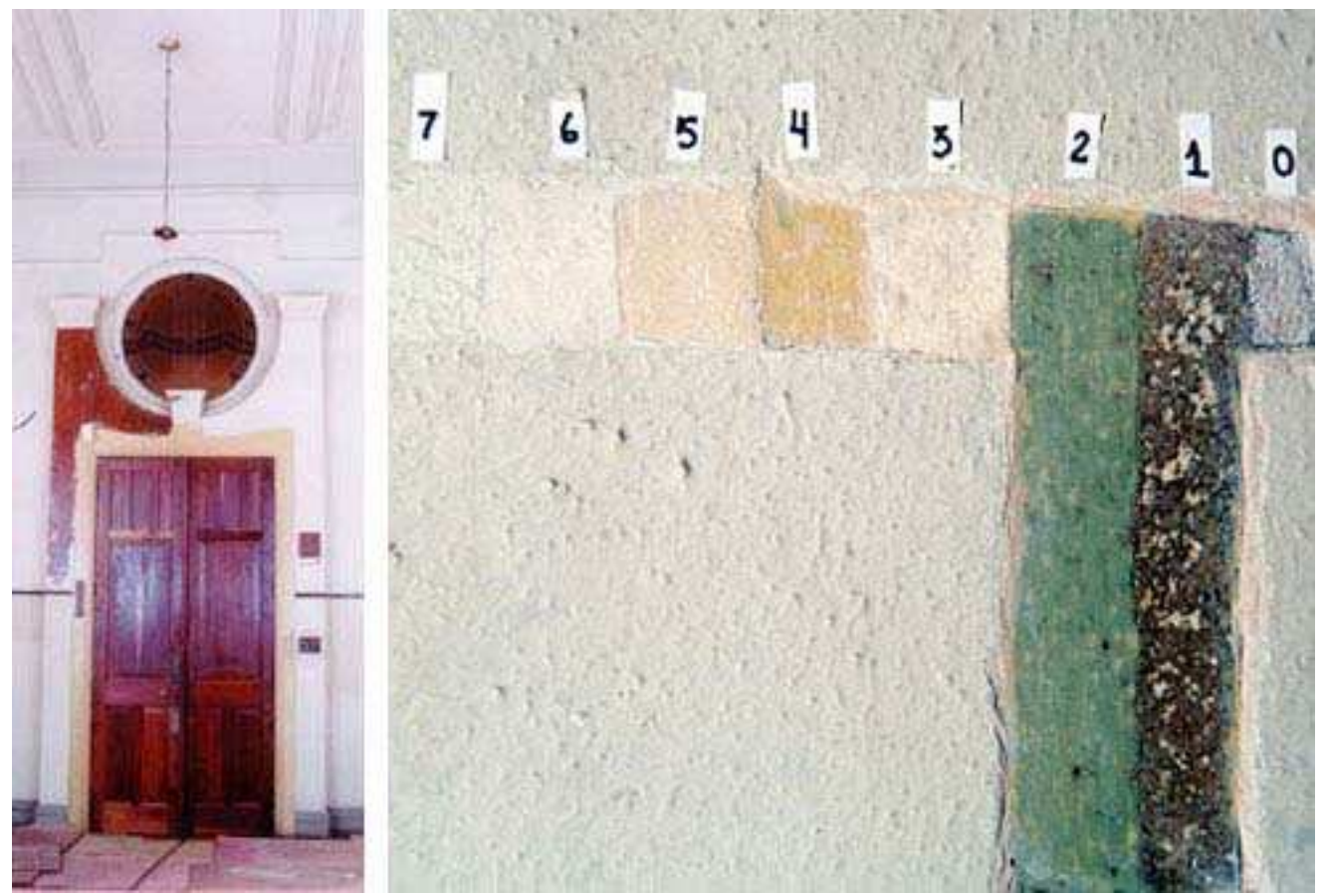

Figura 81 - Cômodos antes do restauro

Até 1996, as pinturas e cores originais da sala de jantar do conde Álvares Penteado estiveram encobertas por seis camadas de tinta, conforme se observa nessa faixa estratigráfica.

Fonte: CPC USP. 


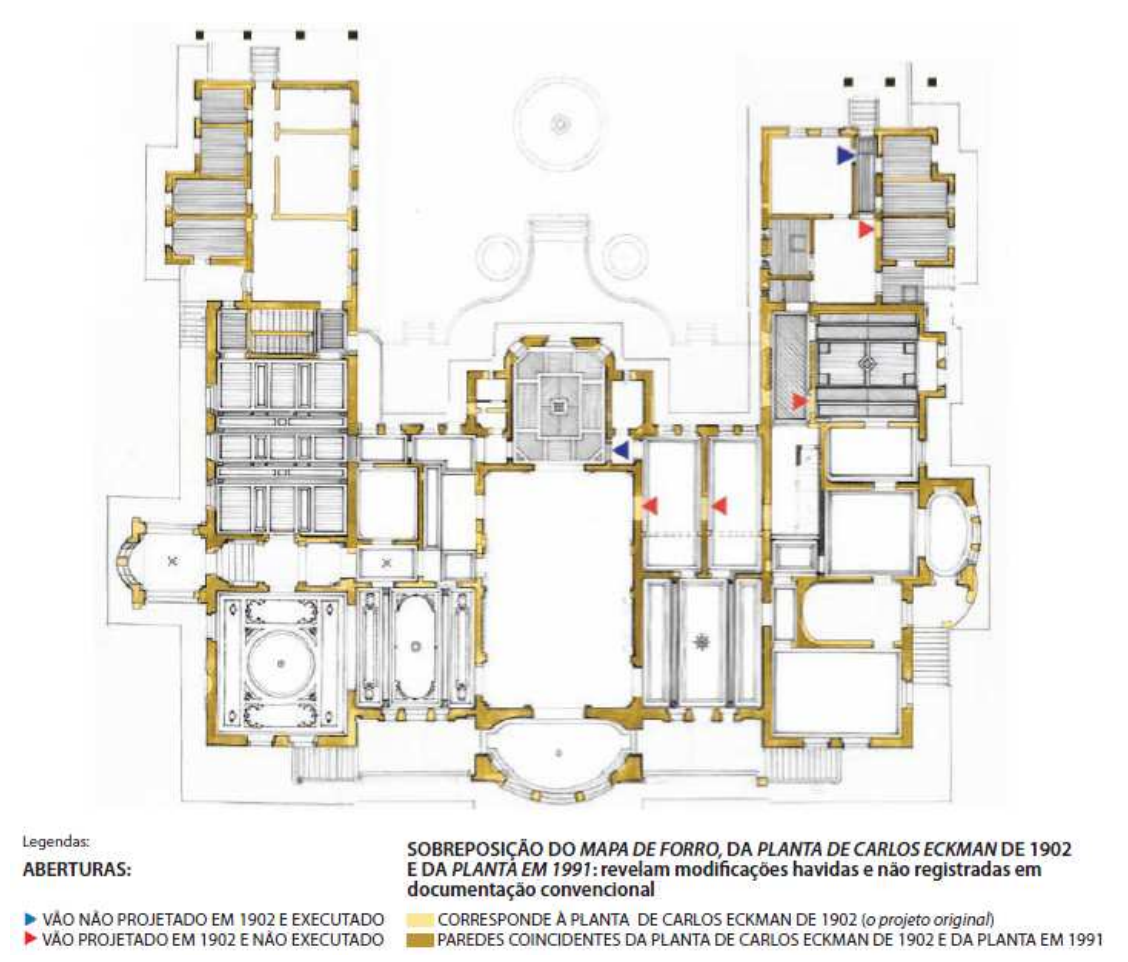

Figura 82 - Mapa de Forros x Planta atual = esclarecimentos sobre a planta construída em 1903

Fonte: Painel de Inventário Crítico 4/4, 1a Etapa (1990 a 1992): estudo pormenorizado da arquitetura. Mapeamento de Forros. Arquivo CPC USP.

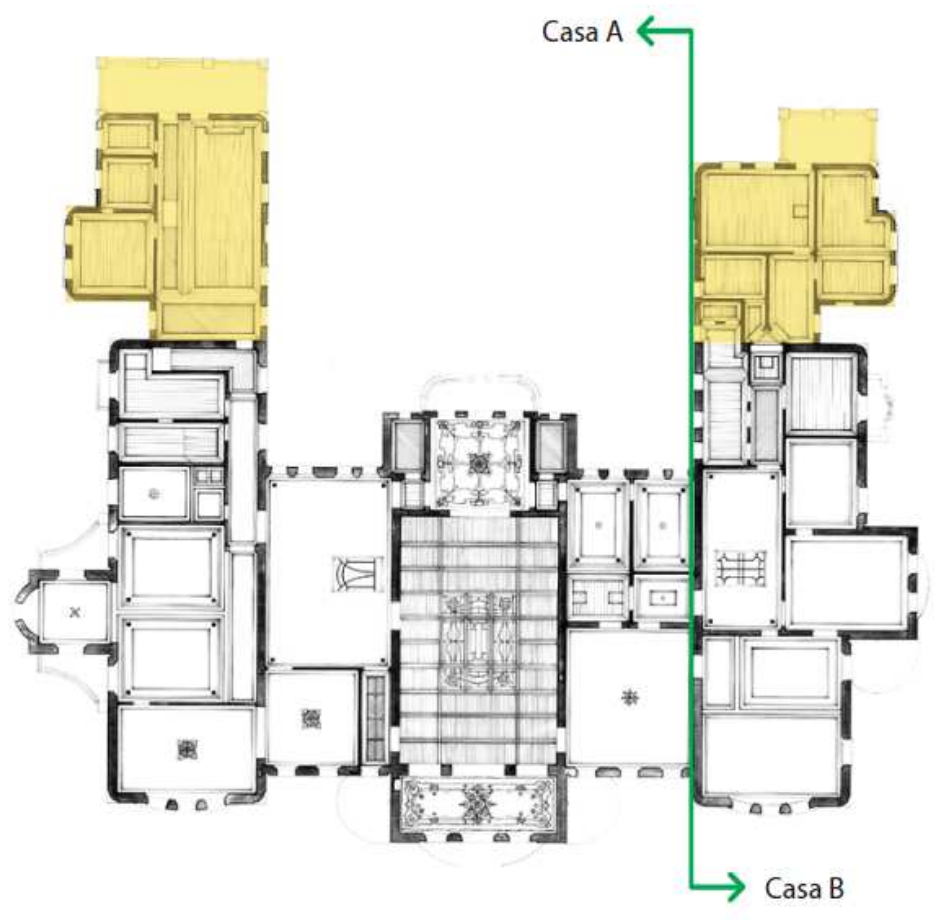

Legenda:

AREA CORRESPONDENTE A AMPLIAÇÃO DAS DEPENDENCIAS DE SERVIÇO DAS DUAS RESIDENCIAS: a Casa de Alvares Penteado Casa A) e Casa de António Prado (Casa B)

Figura 83 - Modificação espacial documentada: ampliação do 2 o pavimento em 1906 Fonte: Painel de Inventário Crítico 4/4, 1르 Etapa (1990 a 1992): estudo pormenorizado da arquitetura. Mapeamento de Forros. Arquivo CPC USP. 


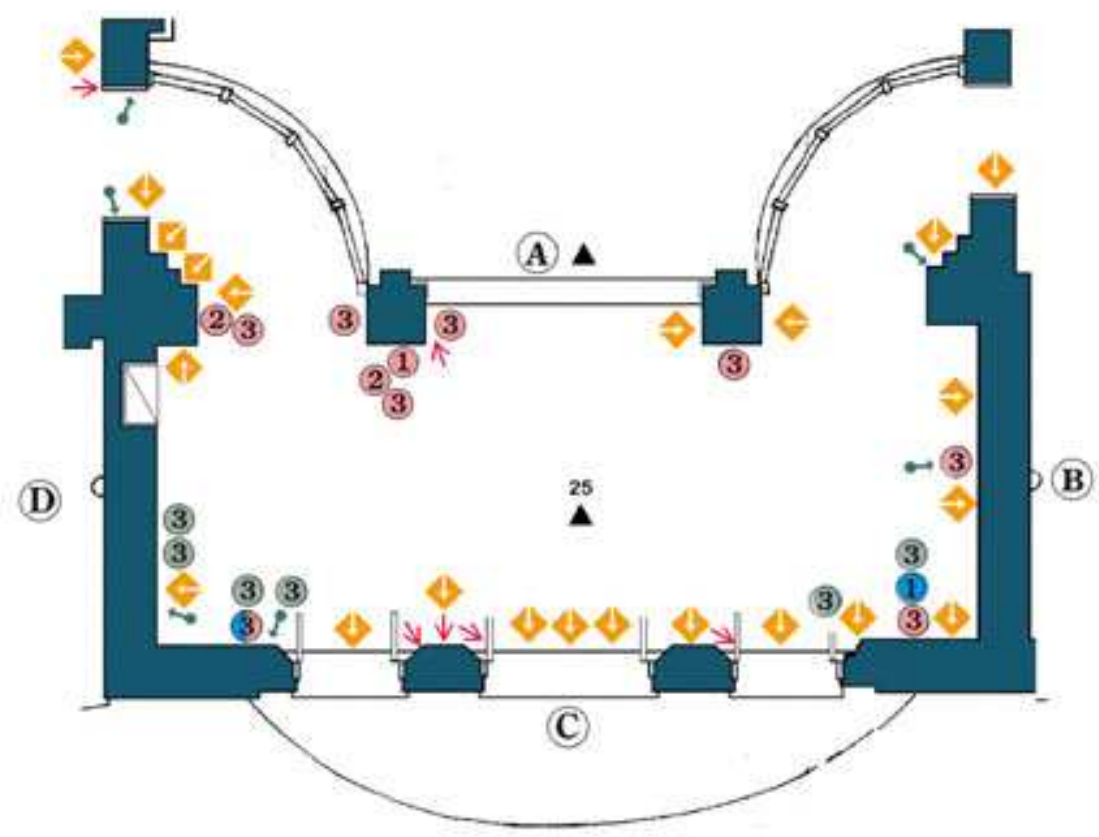

Figura 84 - Mapeamento dos pontos de sondagem e decapagem realizadas para identificação de pinturas artísticas nas paredes para planejamento de futuros restauros Fonte: CPC USP. Imagem Regina Tirello, 1997.

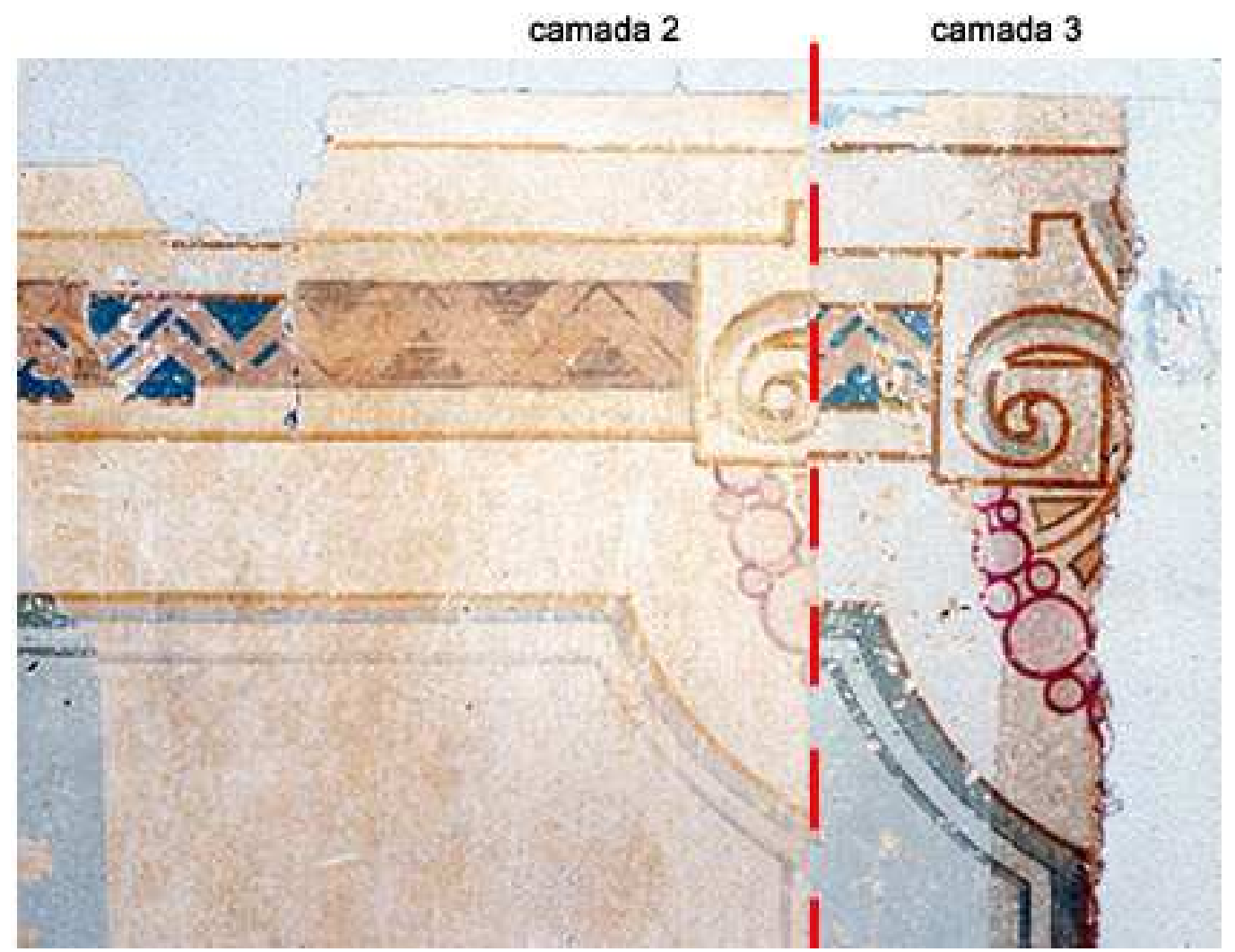

Figura 85 - Exemplo de camadas ornamentadas nas paredes da Saleta Superior I, correspondentes ao segundo e terceiro ciclo ornamental da casa Fonte: CPC USP. Foto Regina Tirello, 1997. 


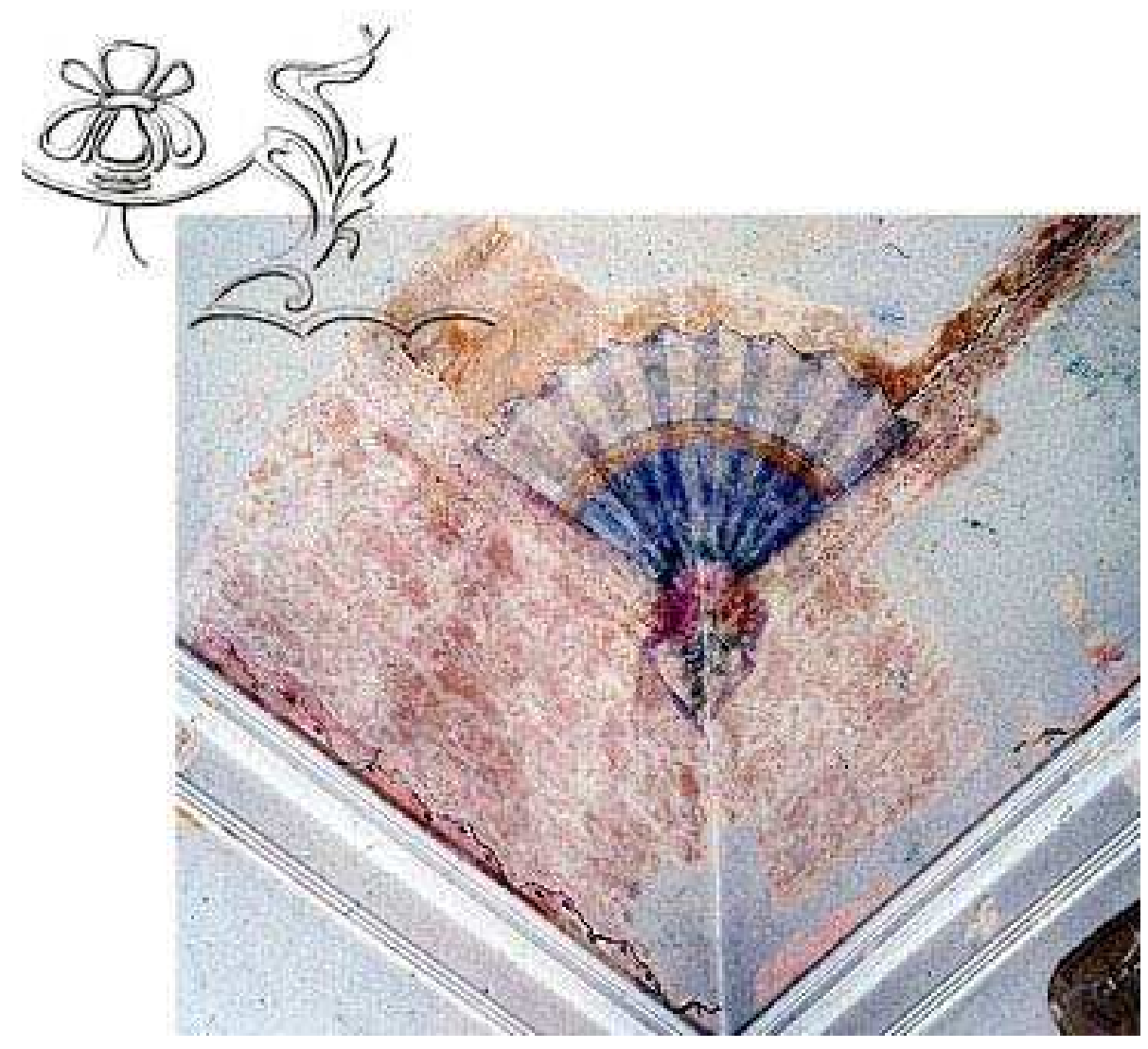

Figura 86 - Modelo de pintura mural identificada com decapagem Esta pintura, de motivo rendilhado, existe no antigo toucador contíguo à sala de jantar do Conde e no vestíbulo da casa de Antônio Prado, o seu genro. Fonte: CPC USP. Foto Roberto Bogo, 1992.
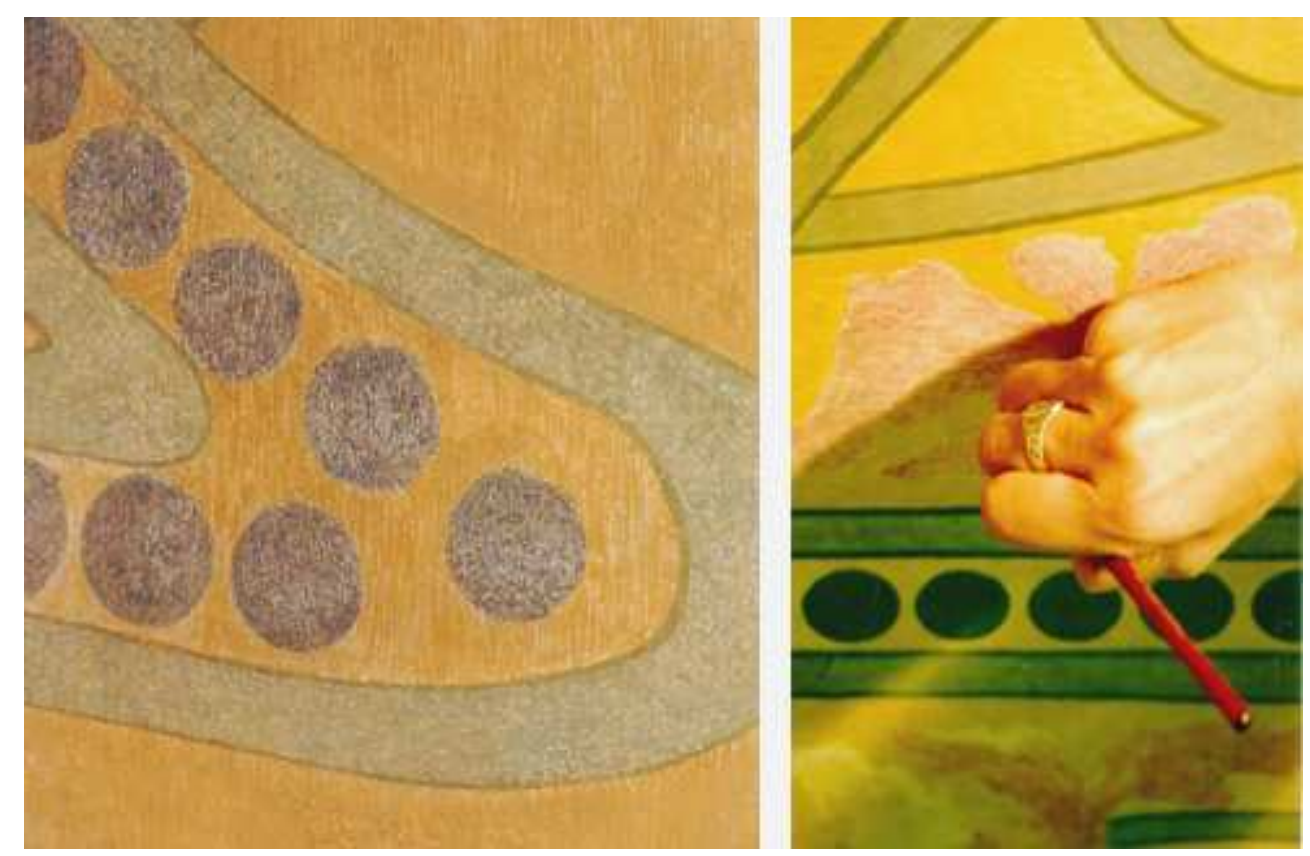

Figura 87 - As lacunas de cor dos murais foram reintegradas por meio do método da seleção cromática (trattegio)

Diferenciando as áreas de pintura original daquelas restauradas, sem prejuízo para a leitura global do ornato.

Fonte: CPC USP. Foto Roberto Bogo, 1994. 


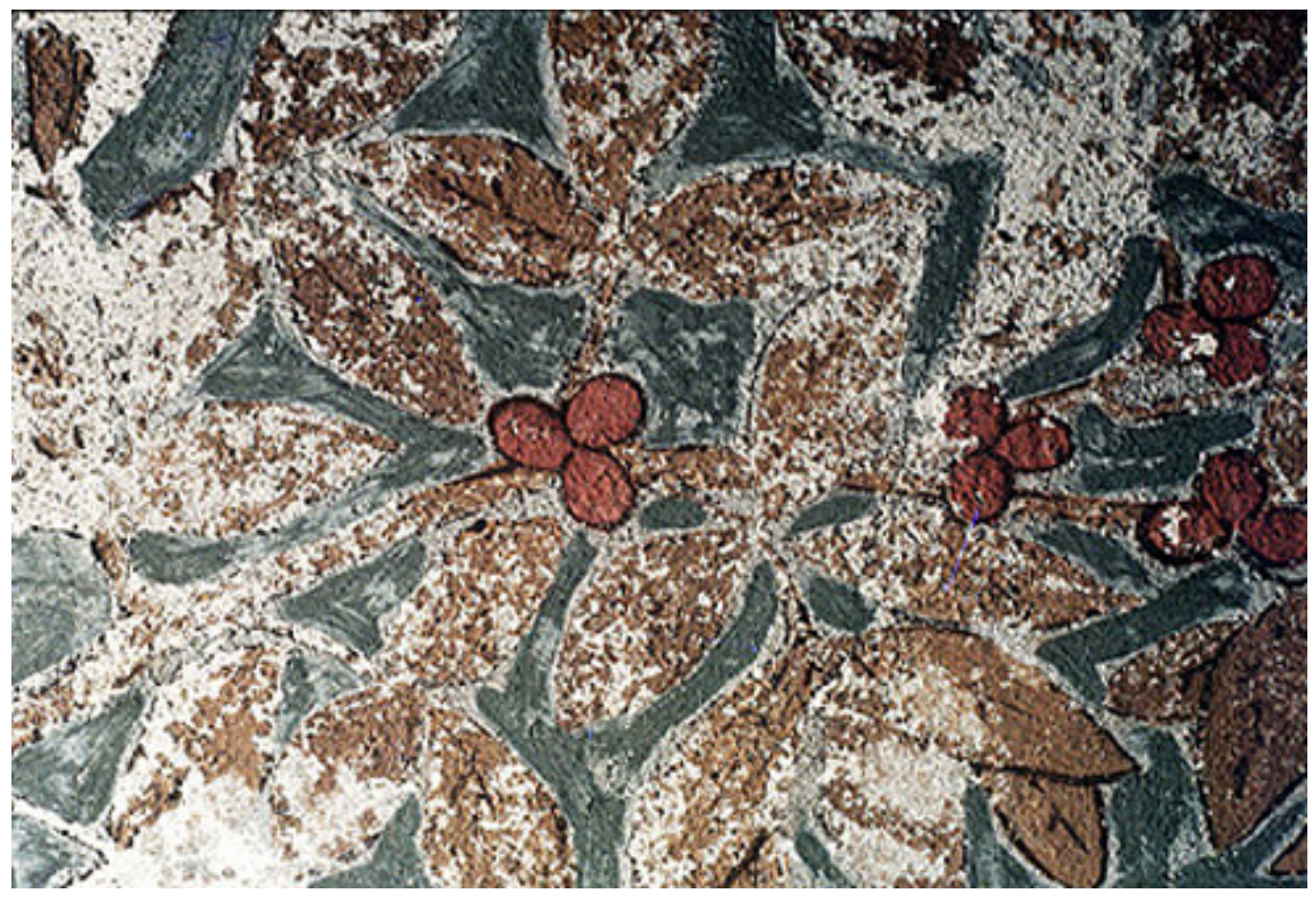

Figura 88 - Estado de conservação do barramento representando plantas de café A pulverulência da pintura produziu grandes lacunas. Optou-se por fixar as partes em que o desenho e cores ainda eram legíveis. Fonte: CPC USP. Foto Roberto Bogo, 1993.

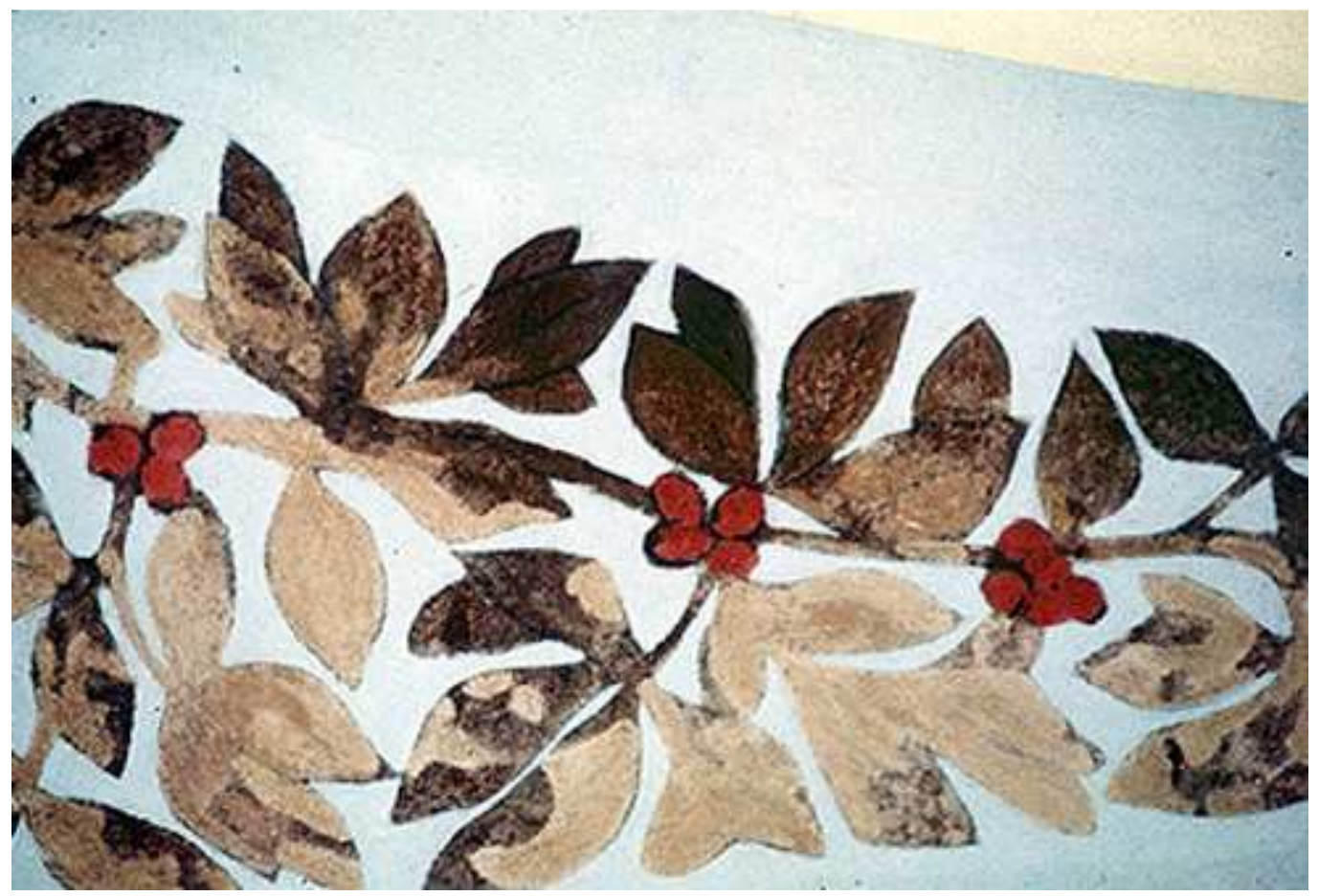

Figura 89 - Após consolidação das partes integras, as áreas de lacuna foram niveladas e preparadas para a reintegração cromática Fonte: CPC USP. Foto Roberto Bogo, 1993. 


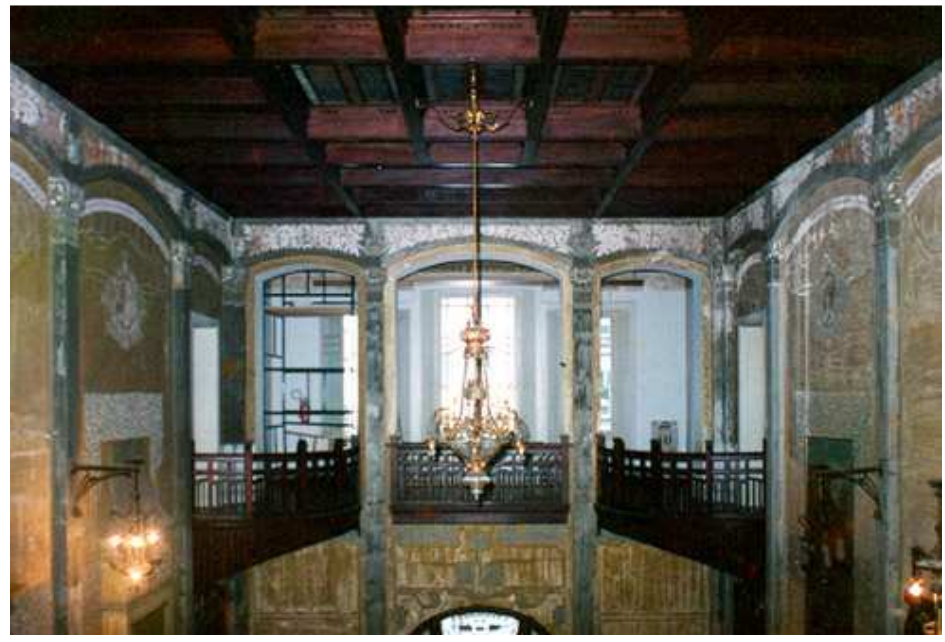

Figura 90 - Vista geral do Saguão antes das intervenções de restauro Fonte: CPC USP. Foto Roberto Bogo, 1993.
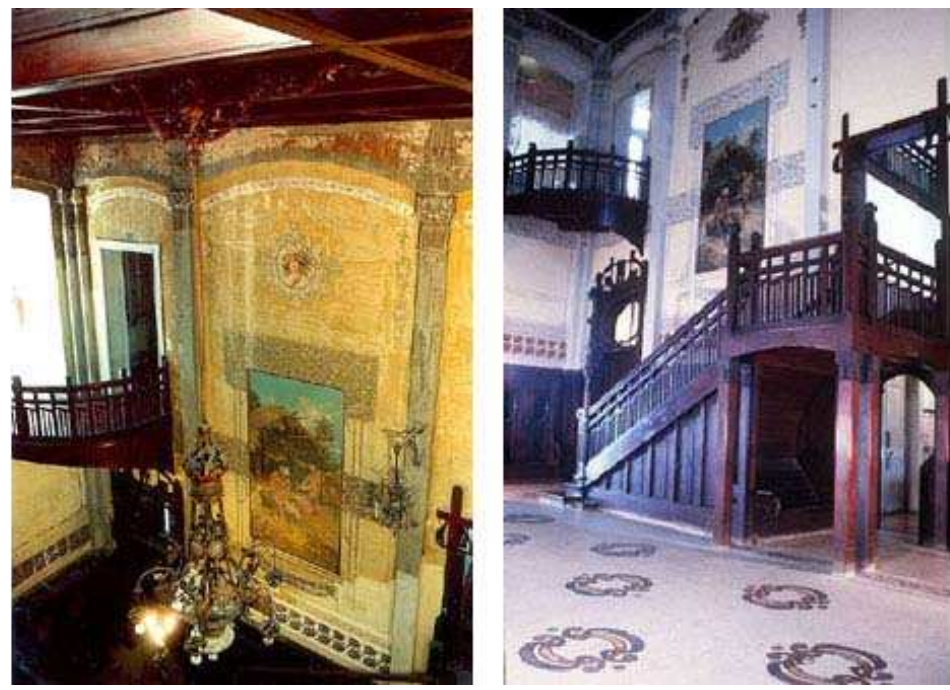

Figura 91 - Saguão da Vila Penteado antes e depois do restauro Fonte: CPC USP. Fotos Roberto Bogo, 1993; Ângela Garcia, 1996, respectivamente.

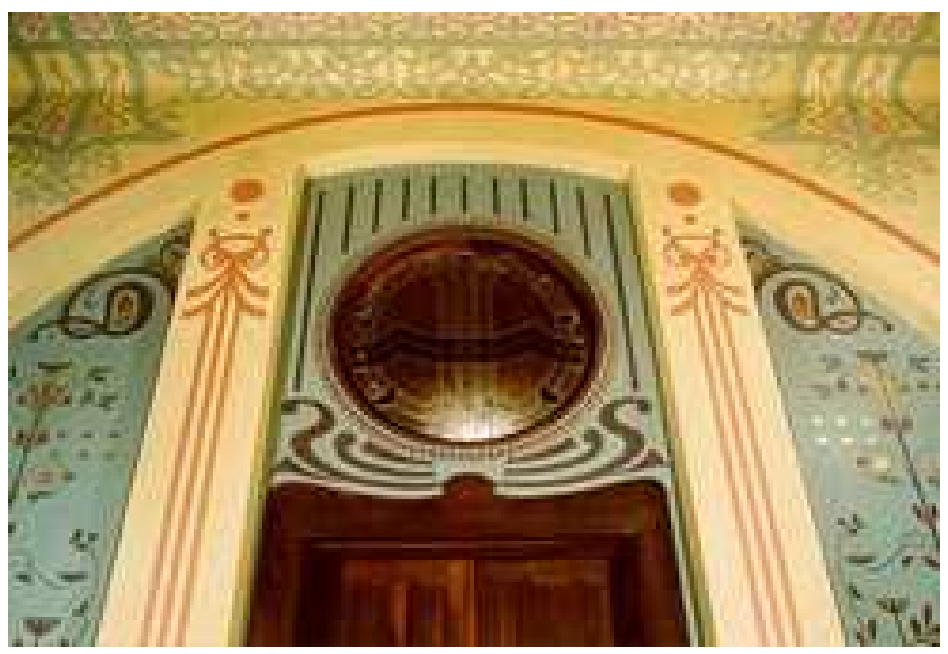

Figura 92 - A parede da porta de acesso à sala de vistas após a conclusão do restauro Fonte: CPC USP. Foto Angela Garcia, 1998. 
As pinturas murais da Vila Penteado tem elevada importância, como relata Regina A. Tirello (1993, p.9):

\begin{abstract}
$\mathrm{Na}$ Vila Penteado são tantos os exemplos de pinturas murais técnica e estilisticamente significativos, que resultaria impossível a escolha de qual painel restaurar se considerássemos apenas seus valores formais. $O$ edifício constitui-se por si só em um importante 'laboratório' de estudos, tanto para as questões relativas às ambiências das casas burguesas no início do século em São Paulo, como para o aprofundamento de questões de ordem mais técnica e específica sobre o restauro e conservação de pinturas murais. E foi, justamente por esse motivo, escolhido entre os tantos edifícios de valor histórico, pertencentes à USP, para o desenvolvimento do Programa de Formação de Restauradores em Pinturas Murais. Programa criado pela Comissão de Patrimônio Cultural e mantido pela Pró Reitoria de Cultura e Extensão da USP com um duplo objetivo: formar técnicos especializados, de que o mercado é tão carente, e principalmente, zelar pelo patrimônio da própria Universidade.
\end{abstract}

O trabalho de recomposição das argamassas e pinturas externas teve especificação da CPC e foi registrado no Relatório "Centenário da Vila Penteado: Restauração, da Vila Penteado à FAU Maranhão, Intervenções Recentes”. Antes da execução desse trabalho, as fachadas apresentavam-se deterioradas, como pode ser visto nas fotos da figura 93.
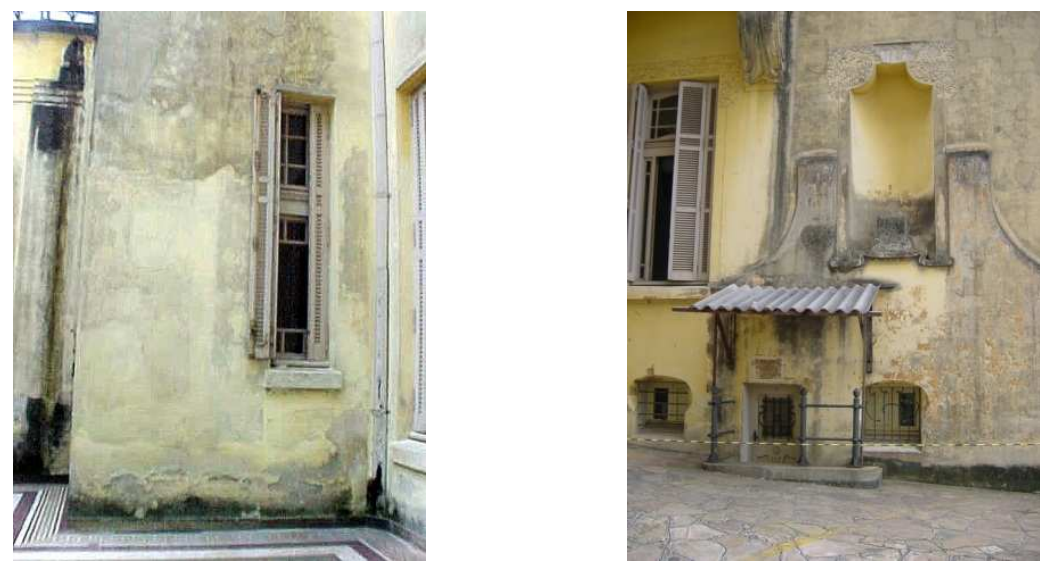

Figura 93 - Fachadas da Vila Penteado em 2002

Fonte: Relatório Centenário da Vila Penteado: Restauração, Da Vila Penteado à FAU Maranhão, Intervenções Recentes, Antonio Carlos Barossi e Helena Ayoub Silva, 2002.

Segundo Carlos Lemos (2002, p. 36), na Vila Penteado originalmente "muita coisa foi esculpida e modelada no local, a partir dos desenhos do arquiteto, principalmente as típicas ramagens do estilo floreal em relevo na massa do sobrerevestimento das fachadas". 
Com o trabalho de recuperação das fachadas, foi observado que algumas áreas apresentavam falhas no acabamento de superfície e foram preenchidas com argamassa de cal, cimento e areia numa proporção definida pela arquiteta Regina Tirello, da CPC. Entretanto, diversas áreas das fachadas possuem intervenções antigas que foram empregadas sem o necessário critério e, principalmente a textura, difere muito da argamassa original. $O$ estudo dessas áreas ainda não foi realizado.

O material usado do trabalho de pintura das fachadas foi doado pela empresa Tintas Ypiranga. Foram empregadas tintas acrílicas com acabamento fosco. Testes foram realizados pela Tintas Ypiranga para avaliar as cores previamente definidas a partir de estudos de prospecções orientados pela CPC. Os trabalhos de lavagem, recuperação das argamassas, lixamento e pintura das fachadas da Vila Penteado, realizados entre agosto e novembro 2002, foram executados pela empresa Logus Tecnologia, contratada através de licitação pública, por carta convite número 05/2002, Processo N² 2002.1.388.16.9.

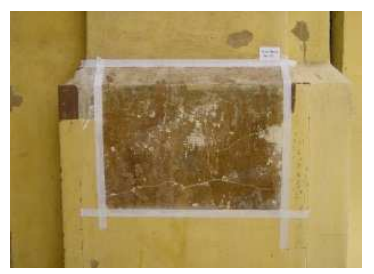

Figura 94 - Estudos de prospecção orientados pela CPC

Fonte: Relatório Centenário da Vila Penteado: Restauração, Da Vila Penteado à FAU Maranhão, Intervenções Recentes, Antonio Carlos Barossi e Helena Ayoub Silva, 2002.
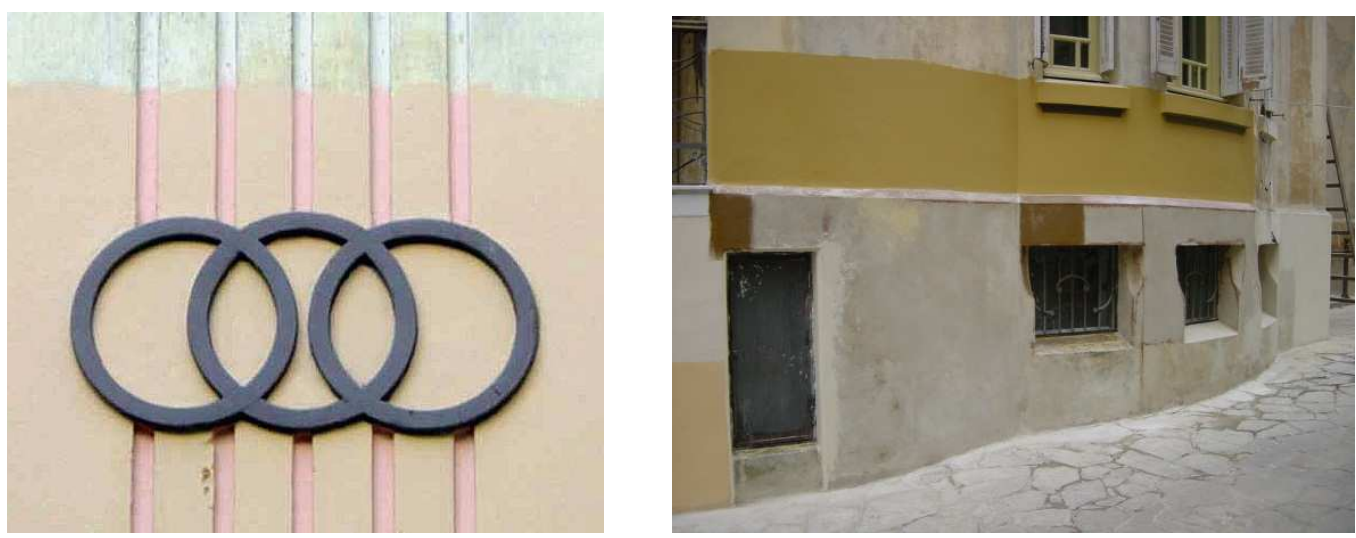

Figura 95 - Teste de cor nas Fachadas da Vila Penteado

Fonte: Relatório Centenário da Vila Penteado: Restauração, Da Vila Penteado à FAU Maranhão, Intervenções Recentes, Antonio Carlos Barossi e Helena Ayoub Silva, 2002.

embasamento original escurecido do edifício foi debatido onde a questão da escala foi destacada: originalmente, o edifício era situado em terreno de grandes 
dimensões e a situação atual hoje se mostra bem diferente, o que impede o uso da cor de base escura.

Desenhos em aquarela do Arq. Carlos Ekman também foram analisados, visando avaliar as intenções projetuais iniciais.

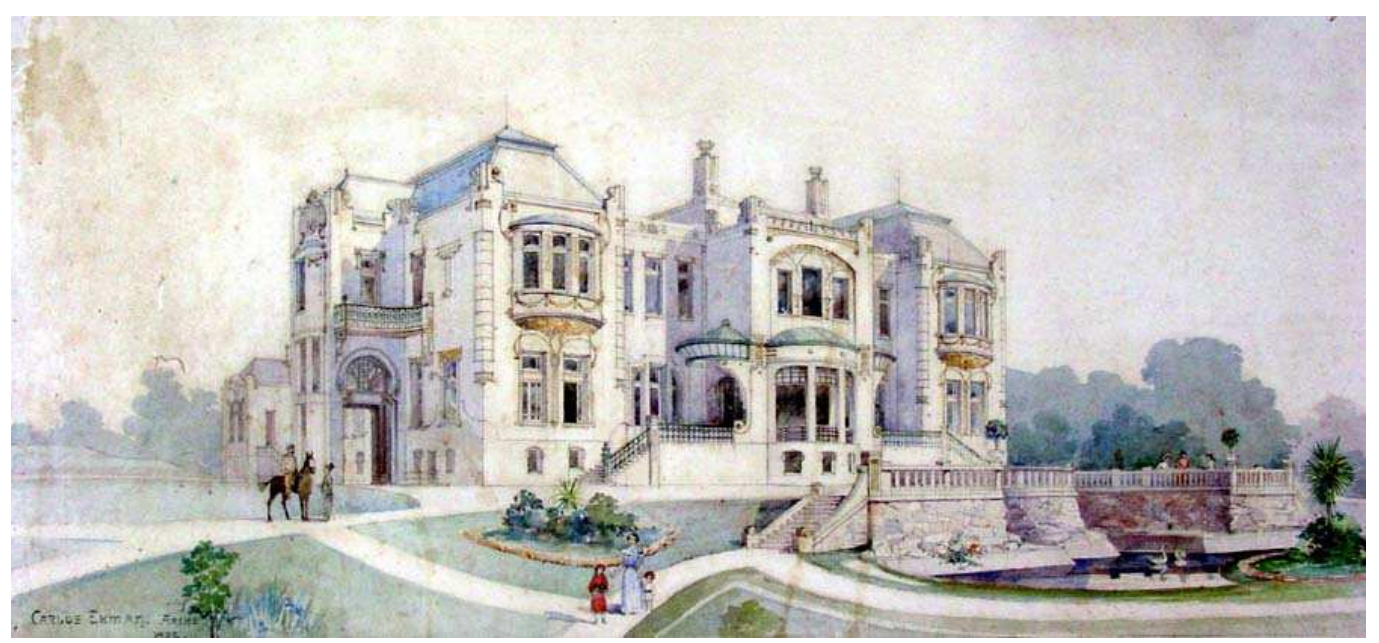

Figura 96 - Aquarela do Arq. Carlos Ekman

Fonte: Relatório Centenário da Vila Penteado: Restauração, Da Vila Penteado à FAU Maranhão, Intervenções Recentes, Antonio Carlos Barossi e Helena Ayoub Silva, 2002.

Em reunião datada de 10 de outubro de 2002, com os responsáveis pela obra por parte da empresa Logus e Comissão de Gestão, foi decidida a cor da 1ำ demão de tinta: fundo amarelo Pantone $19-8 C^{92}$.

Aliado ao estudo cromático das fachadas foi feito o levantamento cadastral dos ornatos na mesma, sendo que alguns desses desenhos podem ser observados nas figuras 97 a 99.

92 Segundo Relatório de Acompanhamento de Obra, Vila Penteado - pintura das fachadas, AgostoNovembro 2002. Acompanhamento da obra: Arq. Antônio Carlos Barossi, Arq ${ }^{a}$ Helena Ayoub Silva. Estagiária da Pós-graduação: Arqa Sabrina Fontenele. 

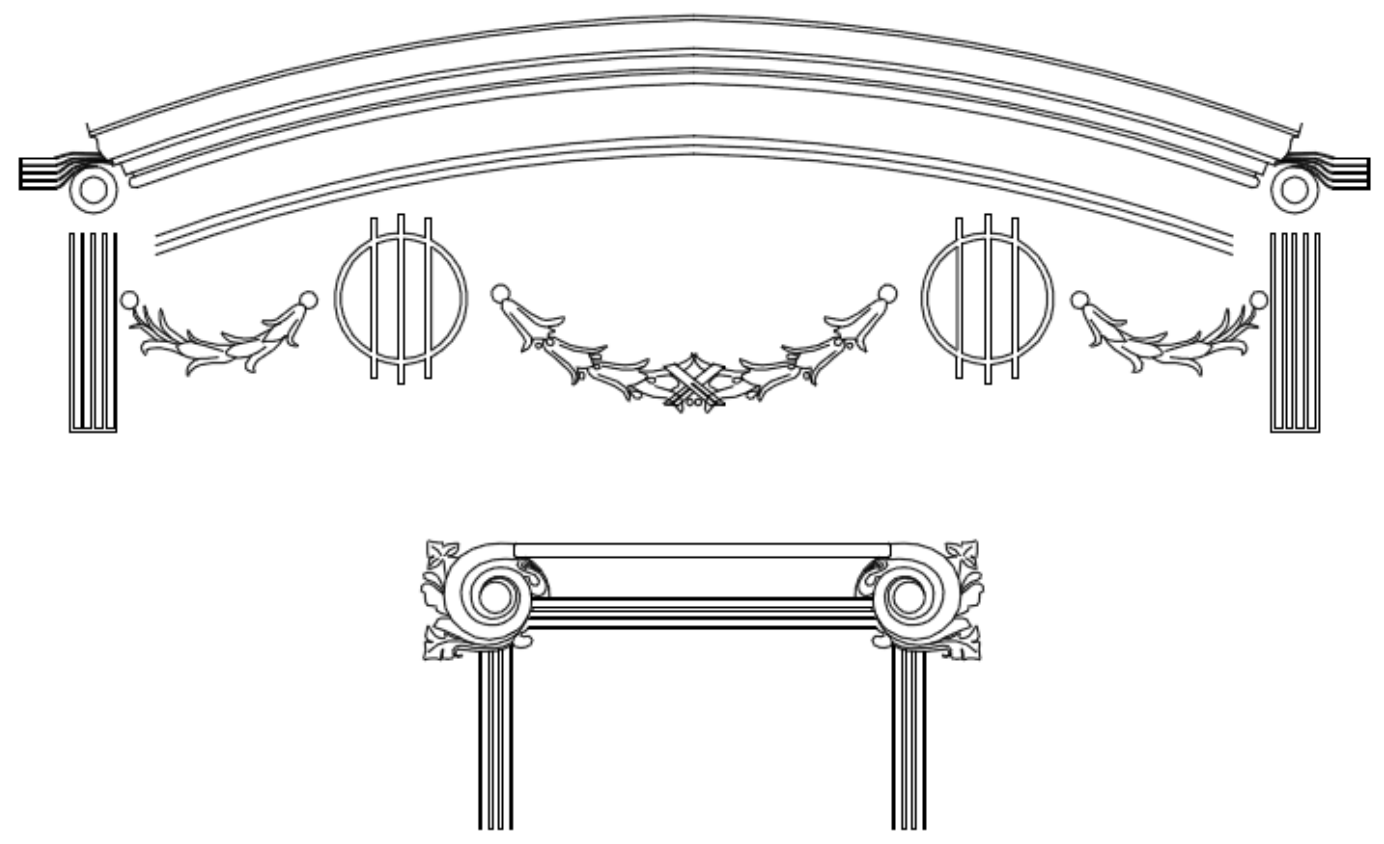

○

$\bigcirc$
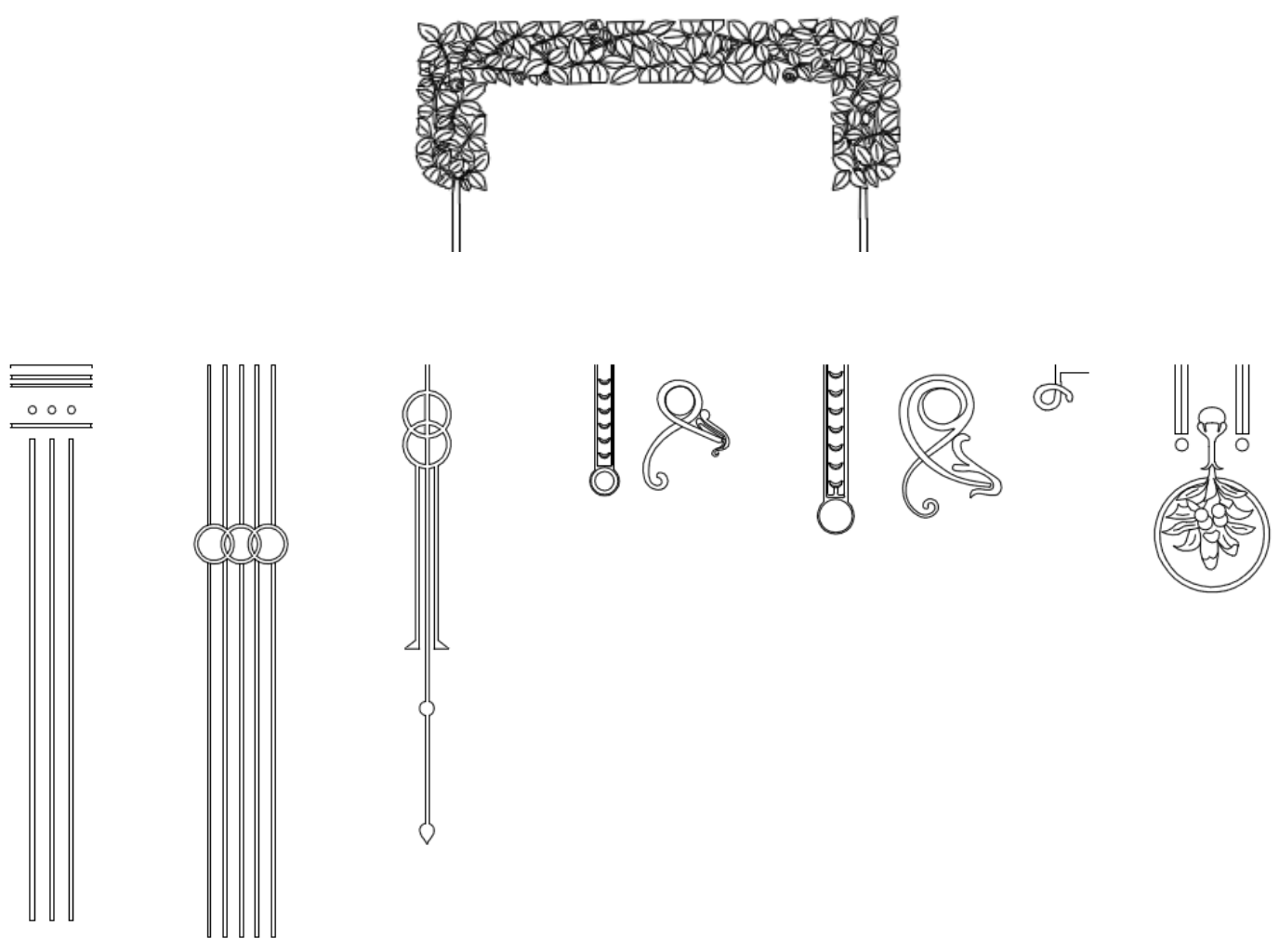

Figura 97 - Desenhos dos ornatos das fachadas da Vila Penteado Fonte: Levantamento cadastral GEEF, apresentado parcialmente no Relatório Centenário da Vila Penteado: Restauração, Da Vila Penteado à FAU Maranhão, Intervenções Recentes, Antonio Carlos Barossi e Helena Ayoub Silva, 2002. 

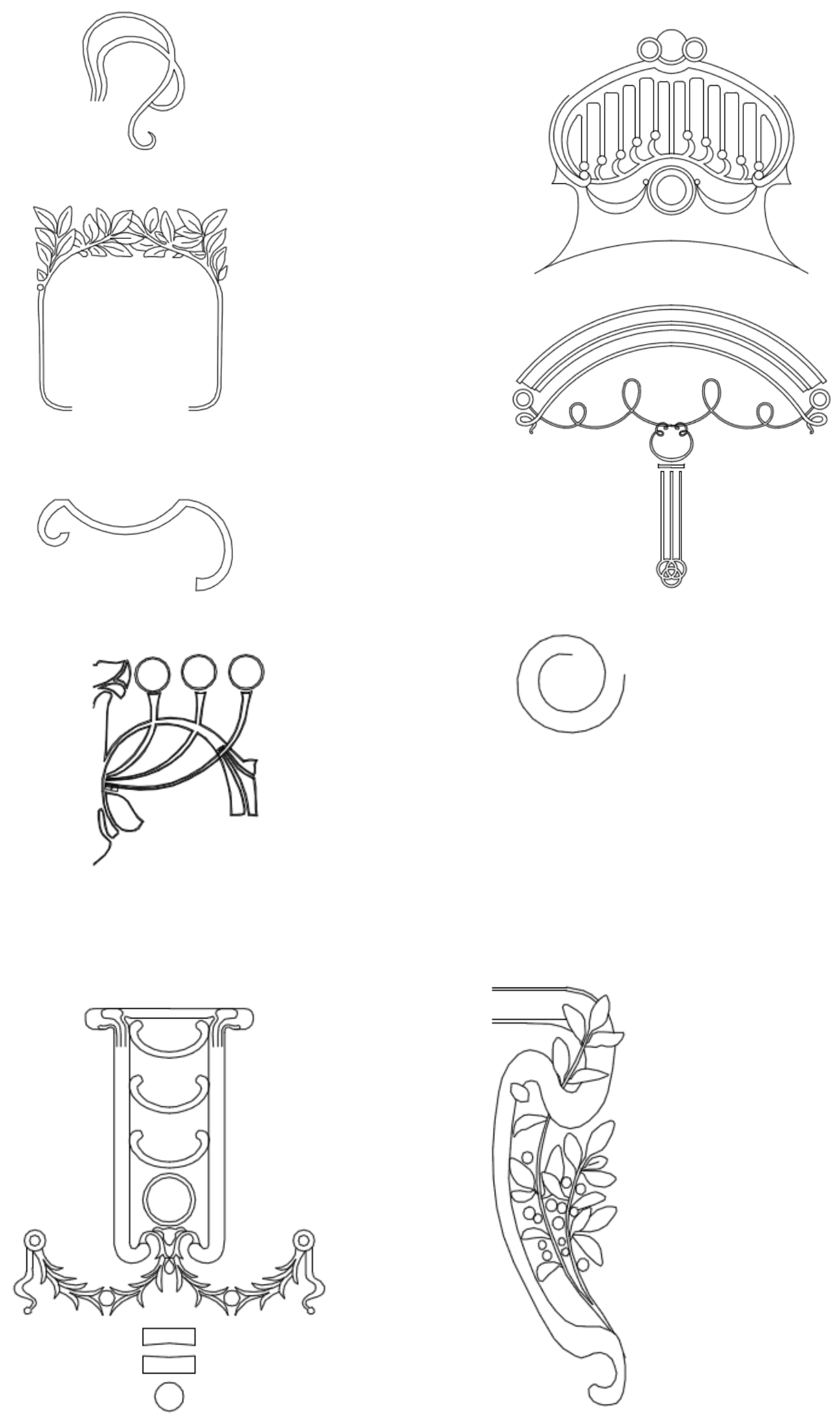

Figura 98 - Desenhos dos ornatos das fachadas da Vila Penteado Fonte: Levantamento cadastral GEEF, apresentado parcialmente no Relatório Centenário da Vila Penteado: Restauração, Da Vila Penteado à FAU Maranhão, Intervenções Recentes, Antonio Carlos Barossi e Helena Ayoub Silva, 2002. 

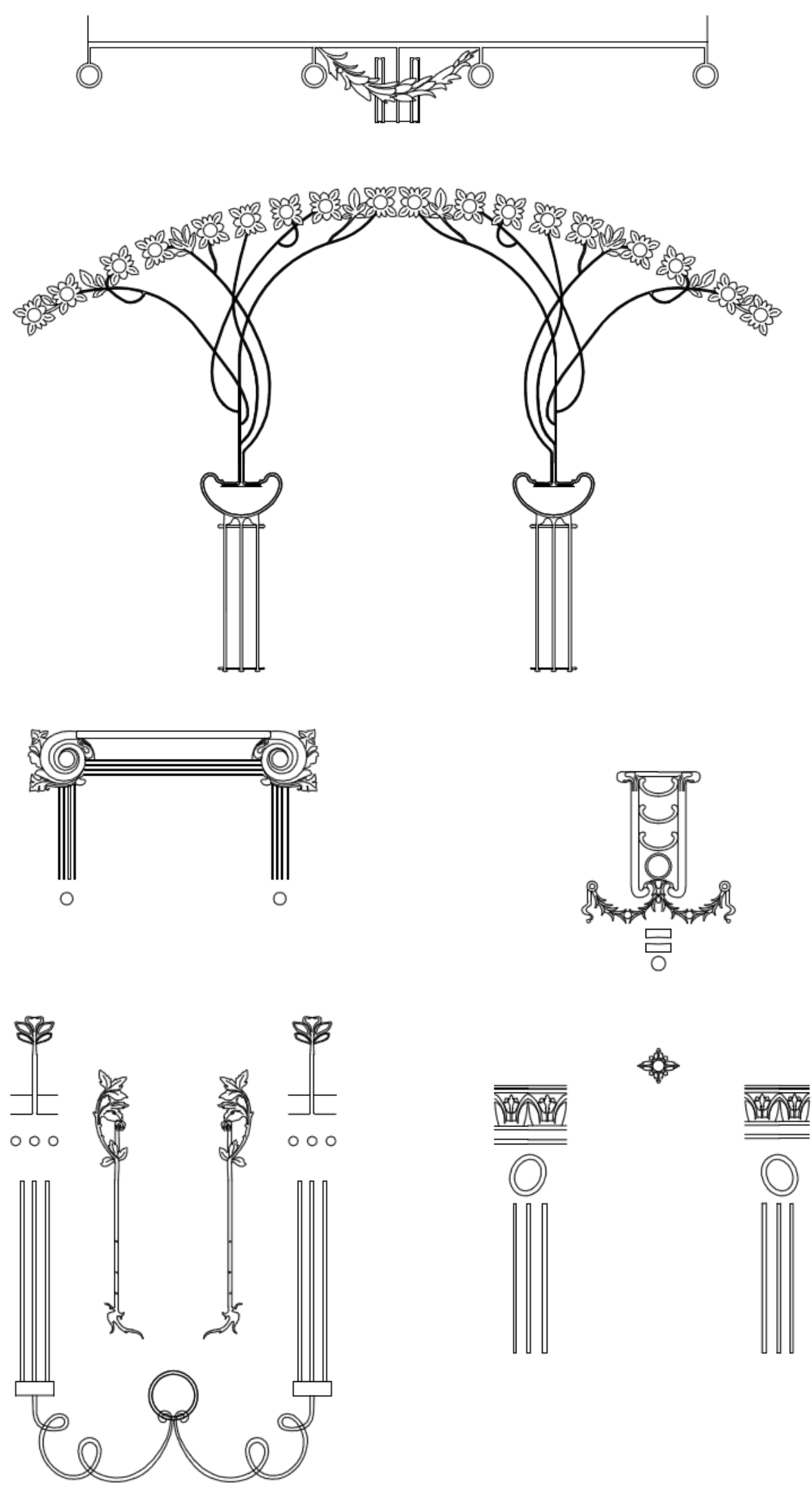

Figura 99 - Desenhos dos ornatos das fachadas da Vila Penteado

Fonte: Levantamento cadastral GEEF, apresentado parcialmente no Relatório Centenário da Vila Penteado: Restauração, Da Vila Penteado à FAU Maranhão, Intervenções Recentes, Antonio Carlos Barossi e Helena Ayoub Silva, 2002. 
Juntamente com o trabalho nas fachadas, foi realizada a recuperação dos muros da Vila Penteado. E, segundo Relatório de Acompanhamento de Obra ${ }^{93}$, do período de 30 de setembro a 06 de outubro de 2002, quando foi iniciada a lavagem das superfícies dos muros, grande parte ruiu, entretanto, a empresa Logus foi solicitada a refazer essas áreas com argamassa comum (aprovada pelo Arq. Carlos Barossi).

${ }^{93}$ Relatório de Acompanhamento de Obra, Vila Penteado - pintura das fachadas, Agosto-Novembro 2002. Acompanhamento da obra: Arq. Antônio Carlos Barossi, Arq ${ }^{a}$ Helena Ayoub Silva. Estagiária da Pós-graduação: Arq $^{\text {a }}$ Sabrina Fontenele. 


\subsubsection{LEVANTAMENTO E RECUPERAÇÃO DAS ESQUADRIAS}

O Centro de Preservação Cultural da Universidade de São Paulo, CPC USP, fez o levantamento não apenas das pinturas murais e ornamentos das fachadas como também dos demais elementos da Vila Penteado compostos madeira e metal. Esse levantamento foi catalogado em fichas padronizadas como mostra a figura 100.

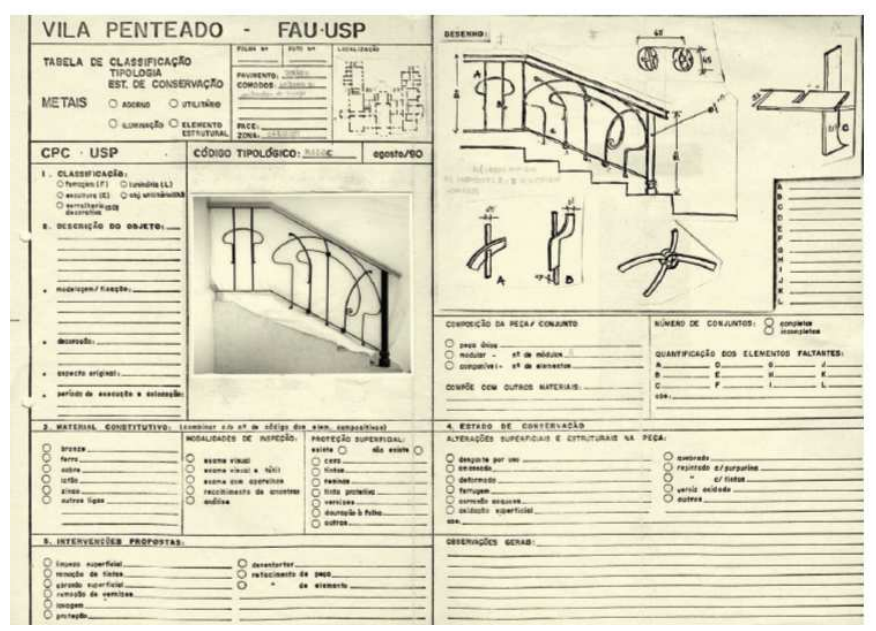

Figura 100 - Exemplo de Ficha de Inventário: Metais (ficha de registro dos elementos componentes de metal)

Fonte: Painel de Inventário Crítico 1/4, 1르 Etapa (1990 a 1992): estudo pormenorizado da arquitetura. Metais, Madeiras e Estuques. Arquivo CPC USP.

O trabalho de levantamento e identificação dos componentes abrangeu as esquadrias e ferragens das mesmas, onde registros fotográficos e desenhos técnicos e de observação foram elaborados (ver figuras 101 a 103).

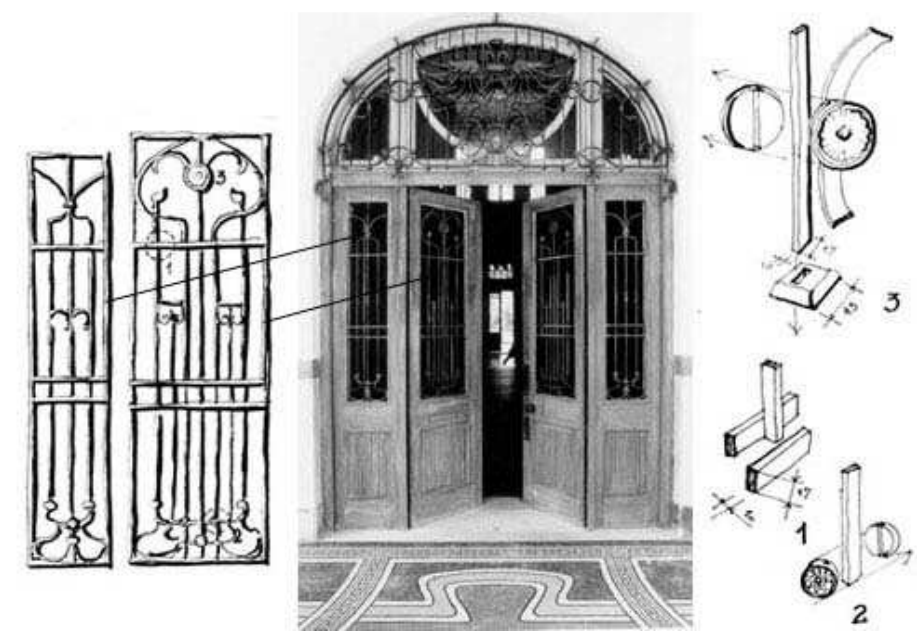

Figura 101 - Serralheria (metal) e madeira. Detalhe do sistema de encaixe do gradil que compõe uma das portas de entrada do palacete Fonte: Desenho CPC USP, 1990. 


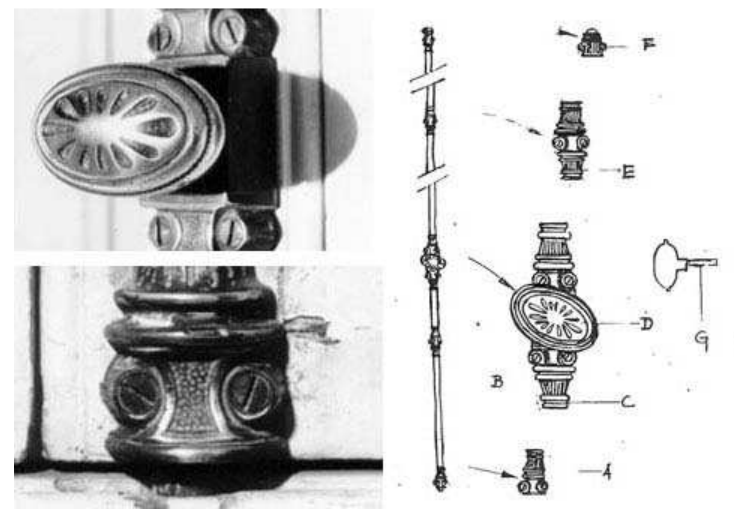

Figura 102 - Metal. Foto e desenho do sistema de montagem de ferragem de janela da ala nobre da casa

Cada peça tem liga metálica diversa.

Fonte: Desenho CPC USP, 1990.
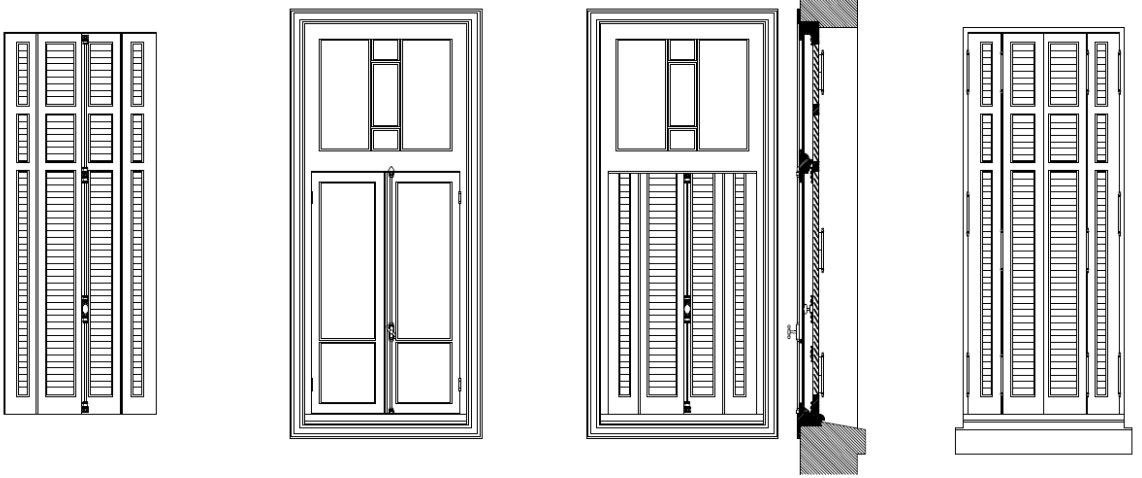

Figura 103 - Desenho técnico detalhado de uma das janelas da Vila Penteado Fonte: Arquivo GEEF.

As esquadrias também receberam estudos de prospecção de suas pinturas, como mostra o "Relatório Centenário da Vila Penteado: Restauração, Da Vila Penteado à FAU Maranhão, Intervenções Recentes".

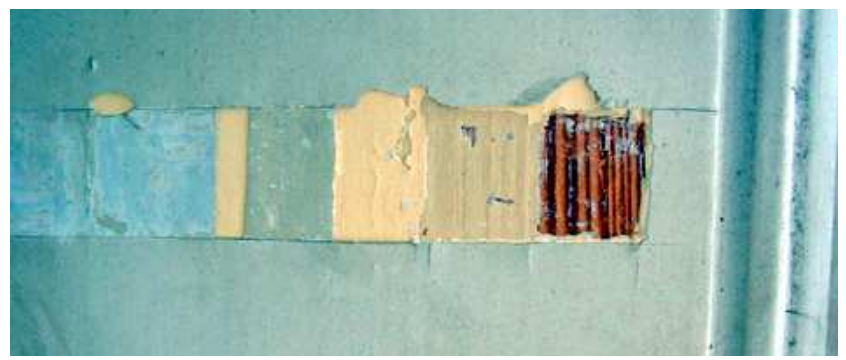

Figura 104 - Foto de prospecção de pintura de folhas internas Fonte: Foto apresentada no Relatório Centenário da Vila Penteado: Restauração, Da Vila Penteado à FAU Maranhão, Intervenções Recentes, Antonio Carlos Barossi e Helena Ayoub Silva, 2002. 


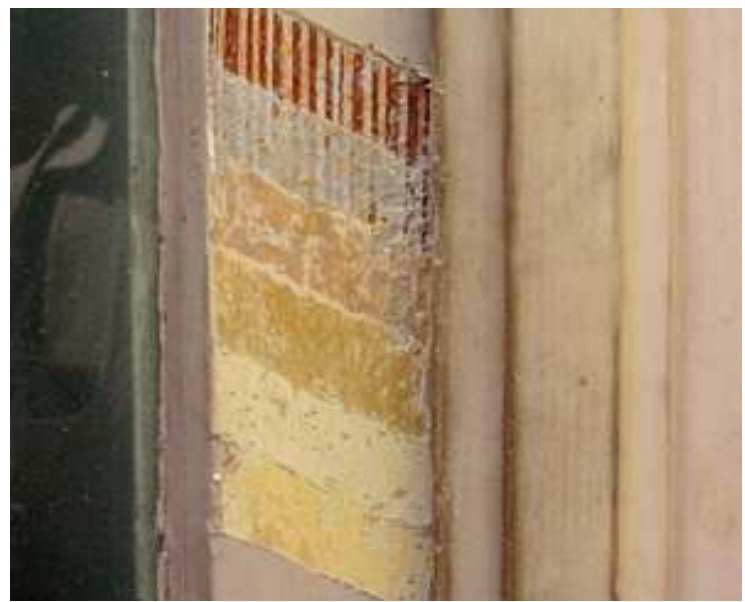

Figura 105 - Foto de prospecção de pintura de folhas externas Fonte: Foto apresentada no Relatório Centenário da Vila Penteado: Restauração, Da Vila Penteado à FAU Maranhão, Intervenções Recentes, Antonio Carlos Barossi e Helena Ayoub Silva, 2002.

O Relatório de Gestão de 2003 apresenta, entre outros itens, o trabalho de recuperação das esquadrias externas, contemplando a reposição de ferragens e reforços especiais. Todas as esquadrias metálicas e de madeira foram restauradas pela empresa Júlio Moraes Conservação e Restauro SCL e o material utilizado foi doado pelas Tintas Ypiranga.

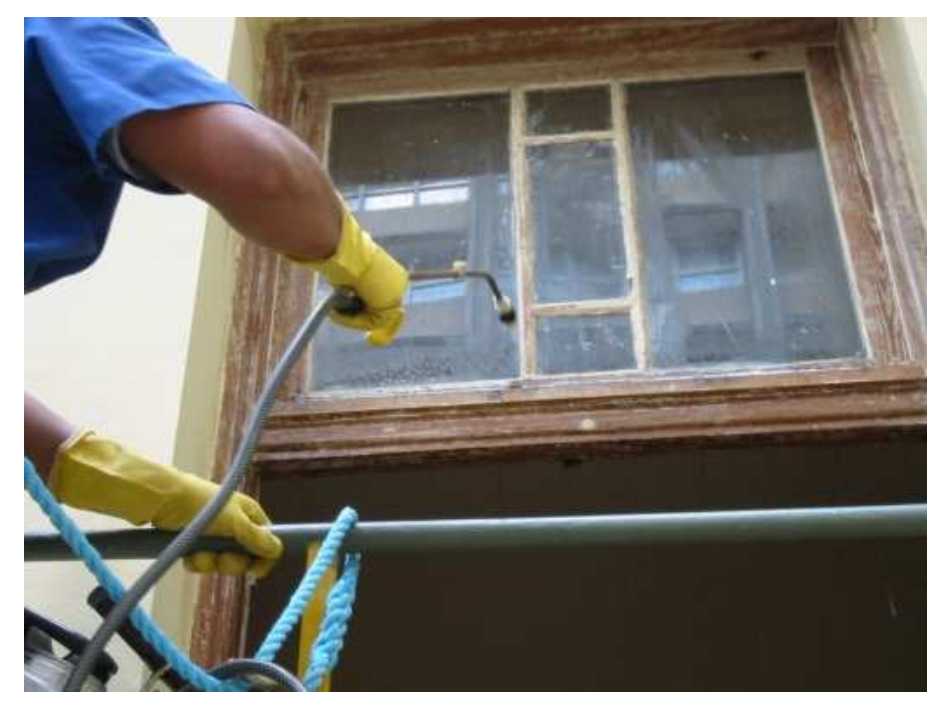

Figura 106 - Foto do trabalho de recuperação das esquadrias externas Fonte: Foto apresentada no Relatório de Gestão de 2003, gestores Antonio Carlos Barossi e Helena Ayoub Silva, 2002. 

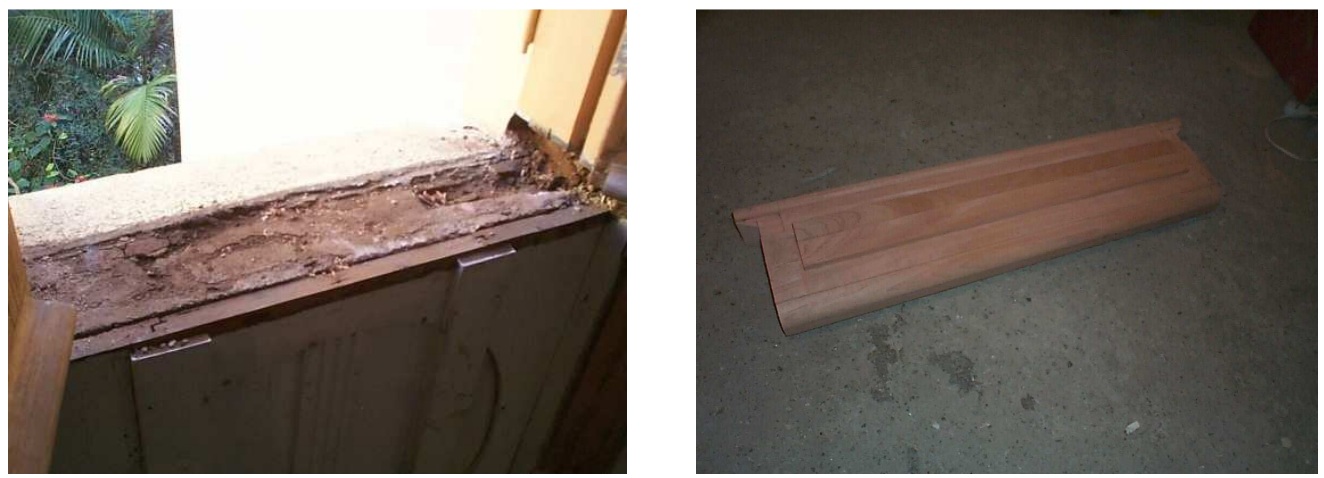

Figura 107 - Foto do trabalho de recuperação dos peitoris das esquadrias externas

Fonte: Foto apresentada no Relatório de Gestão de 2003, gestores Antonio Carlos Barossi e Helena Ayoub Silva, 2002.

Nas atas ${ }^{94}$ de reunião do período de obras, entre os gestores da Vila Penteado, professores Antonio Carlos Barossi e Helena Ayoub Silva, e os responsáveis pela empresa contratada, Júlio Moraes e Cláudio Ekeda, é possível verificar algumas condições dos trabalhos de recuperação, restauro e pintura das esquadrias externas de madeira e ferro do edifício Vila Penteado:

- Prospecções complementares nas esquadrias foram executadas pela empresa Júlio Moraes Conservação e Restauro SCL, para confirmação das cores a serem empregadas na pintura, sendo que os resultados confirmaram as cores previamente estabelecidas;

- As cremonas e demais elementos metálicos de ferro foram pintados da mesma cor dos elementos da madeira;

- Foi aprovada a sugestão de Tintas Ypiranga, para o uso de Sparlack Knotting 99150, como fundo nivelador para madeiras;

- As peças de ferro dos gradis receberam acabamento em tinta na cor grafite;

- Os corrimãos de madeira foram pintados na cor marrom acetinado Duralack, código 730.1150;

- Os vidros das vidraças não foram retirados, assim como a massa de fixação, sendo que a pintura foi executada considerando-se que a massa, feita na cor apropriada, será reposta posteriormente. A exceção encontra-se no caso dos vidros quebrados que foram substituídos nesse momento

${ }^{94}$ Atas de reunião referentes aos Serviços de Recuperação, Restauro e Pintura das Esquadrias Externas de Madeira e Ferro do Edifício Vila Penteado, do período de 14/11/2002 a 20/12/2003, empresa contratada: JÚLIO MORAES Conservação e Restauro SCL. 


\title{
3.2.5 INSTALAÇÕES ELÉTRICAS
}

As instalações elétricas da Vila Penteado apresentam falhas diversas e insegurança ao uso. Conforme relatado no "Relatório de Observações Gerais, FAU Maranhão, Arq ${ }^{a}$ Bárbara Ivo, fevereiro de 2009", o sistema elétrico e a estanqueidade do edifício é uma "questão prioritária e urgente".

\begin{abstract}
Segundo o Sr. Wilson (também chamado de "Didi" por quem o conhece), que trabalha no setor de manutenção do edifício da FAU Maranhão há cerca de 17 anos, já houve mais de uma situação em que, ao acender algumas luminárias, ele observou curtos-circuitos com presença de chamas, quando ele próprio então cuidou de cortar os fios com alicate e refazer as emendas. Em suas palavras, o edifício é "um barril de pólvora", devido à quantidade de madeira e demais materiais inflamáveis e à precariedade da fiação.

Além da má qualidade das instalações elétricas, infiltrações, umidade e goteiras do telhado agravam a questão, principalmente no mezanino, onde a infiltração acarreta goteiras exatamente sobre os quadros de distribuição. De acordo com o Arnaldo, eletricista responsável pela manutenção do prédio, há pontos do telhado onde não há segurança para visita de inspeção, e 0 andaime do edifício não tem peças suficientes para possibilitar esta inspeção. ${ }^{95}$
\end{abstract}

Entretanto, o conhecimento da precariedade das instalações, especialmente das elétricas, já é antigo. Em 1998 foi elaborado pela empresa Ramoska \& Castellani um Projeto de Instalações Elétricas buscando adequar a situação dessas instalações na FAU Maranhão.

Em 2006 a empresa Bim \& Alves Engenharia de Projetos Ltda. desenvolveu um projeto de reforma geral para as instalações elétricas. Entretanto, em 2007, motivado por um curto-circuito ocorrido em uma caixa de derivação das instalações elétricas situada no porão, a empresa Barreto Engenharia Ltda foi contratada para elaborar um laudo técnico das instalações onde é possível destacar alguns trechos:
4. DA VISTORIA
4.1. Proteção contra sobrecorrentes (sobrecarga e curto-circuito)
- Foi identificado dano irreversível à isolação dos cabos de alimentação geral, conectados ao medidor de energia elétrica (derretimento e torção da isolação), na caixa de entrada e medição (compartimento lacrado pela Concessionária).
- Inexistência de coordenação de proteção entre os disjuntores e correspondentes condutores em todos os quadros de distribuição elétrica que foram vistoriados. Ou seja, a corrente nominal dos disjuntores é

\footnotetext{
${ }^{95}$ Texto extraído do Relatório de Observações Gerais, FAU Maranhão, Arqa ${ }^{a}$ Bárbara Ivo, fevereiro de 2009.
} 
incompatível com a capacidade de condução de corrente dos condutores, em nada assegurando a devida proteção. ${ }^{6}$

A foto da figura 108, extraída do laudo técnico, exemplifica a situação apontada:

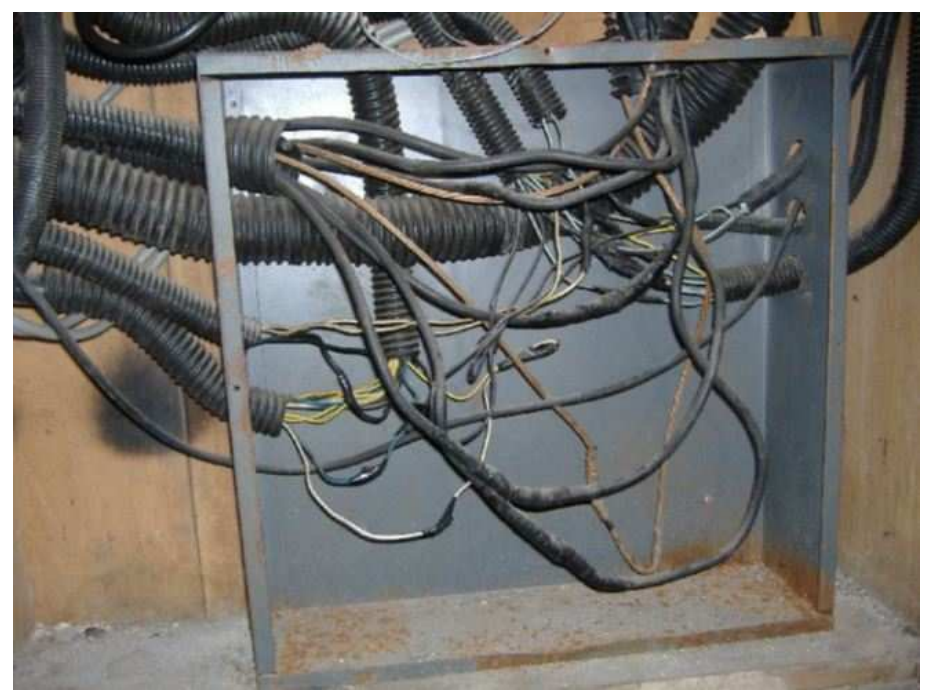

Figura 108 - Instalação, emendas e conexões em situação de risco

Fonte: Laudo Técnico RL-271-E-01 de 03/09/07 elaborado pela empresa Barreto Engenharia Ltda, Assinado pelo Engenheiro Eletricista Paulo E. Q. M. Barreto.

O parecer do laudo é claro e aponta para o risco grave e iminente de incêndio de origem elétrica, de perda desse patrimônio histórico e do acervo técnico nele contido, além do elevado risco à segurança dos usuários.

Em virtude da análise feita, as recomendações apresentadas pelo laudo técnico são as seguintes:

Por todas estas razões recomendamos:

a) imediata suspensão das atividades desenvolvidas no local e sua desocupação;

b) retirada de todo o acervo histórico;

c) desenergização total das instalações elétricas (desde a chave geral);

d) realização de uma inspeção de diagnóstico das instalações elétricas, com o objetivo de identificar as necessidades de segurança e de utilização das instalações, para elaboração do correspondente projeto de reforma.

e) elaboração de plano de gestão em segurança do trabalho, para o atendimento à Norma Regulamentadora ํo 10 do Ministério do Trabalho e Emprego. ${ }^{97}$

96 Texto extraído do Laudo Técnico RL-271-E-01 de 03/09/07, elaborado pela empresa Barreto Engenharia Ltda, Assinado pelo Engenheiro Eletricista Paulo E. Q. M. Barreto em setembro de 2007, p. 3. 
Em virtude do apresentado neste laudo técnico, a mesma empresa, Barreto Engenharia Ltda., foi contratada para elaborar um projeto para reforma parcial das instalações elétricas, visando suprir as necessidades urgentes de reparos, sendo que a reforma geral das instalações elétricas deveria ser feita assim que possível.

A empresa Barreto Engenharia apresentou em 2008 o projeto básico e memorial descritivo, contendo os seguintes princípios para reforma:

Como regra geral, e de forma sintética, os princípios adotados nesta reforma foram:

- Manter a infra-estrutura existente de eletrodutos e caixas;

- Manter os circuitos alimentadores de quadros que estivessem em boas condições de conservação e de capacidade de atendimento às cargas;

- Reformar totalmente os quadros de distribuição;

- Remover totalmente os condutores de todos os circuitos terminais (exceto da Biblioteca);

- Eliminar as irregularidades existentes e apontadas no citado Laudo;

- Lançar novos circuitos alimentadores de quadros e novos quadros de distribuição onde necessários;

- Executar novos circuitos terminais. ${ }^{98}$

Em março de 2009, foi decidido em reunião no GEEF que o projeto de reforma parcial seria arquivado e o projeto reforma geral das instalações elétricas seria orçado:

Em relação à questão da situação das instalações elétricas do edifício, decidiu-se por realizar orçamentos para o projeto completo da BIM Engenharia, desenvolvido a partir de diretrizes que se alinham ao projeto de adequação de layout do edifício, já aprovado em Congregação, e, caso necessário, adaptações ou complementações podem ser acordadas quando em contato com as empresas que se propuserem a realizar o orçamento. (...) Sendo assim, o projeto básico realizado pela empresa Barreto Engenharia será arquivado e não será orçado. ${ }^{99}$

Após essa reunião as empresas TEC-INSTAL Instalações Técnicas e a empresa Lumina Comércio e Instalações Elétricas Ltda. apresentaram propostas

97 Texto extraído do Laudo Técnico RL-271-E-01 de 03/09/07, elaborado pela empresa Barreto Engenharia Ltda, Assinado pelo Engenheiro Eletricista Paulo E. Q. M. Barreto em setembro de 2007, p. 6.

98 Texto extraído do Memorial Descritivo de Reforma das Instalações Elétricas EP-277-E-01 de 02/04/08 para o edifício Vila Penteado, elaborado pela empresa Barreto Engenharia Ltda.

${ }^{99}$ Texto extraído da Ata de Reunião no GEEF FAUUSP sobre o Edifício FAU Maranhão, realizada em 02 de março de 2009 com a presença da Arq $^{a}$ Bárbara Ivo, relatora da ata, Prof ${ }^{a}$ Helena Ayoub e Prof $\stackrel{a}{a}$ Maria Angela Faggin P. Leite. 
comerciais de fornecimento de mão-de-obra e material para a execução da reforma das instalações elétricas da FAU Maranhão. 


\subsubsection{INTERVENÇÃO NA ÁREA DA BIBLIOTECA}

A Biblioteca da Pós-Graduação foi formada em 1973, a partir dos acervos da Assessoria em Planejamento - ASPLAN S.A. e da Sociedade de Análises Gráficas e Mecanográficas Aplicadas aos Complexos Sociais - SAGMACS, adquiridos pela Diretoria da FAUUSP.

Em 1973 a Diretoria da FAUUSP adquiriu os acervos da ASPLAN S.A. Assessoria em Planejamento e da SAGMACS - Sociedade de Análises Gráficas e Mecanográficas Aplicadas aos Complexos Sociais, com a finalidade de iniciar um centro de documentação em planejamento urbano, como subsídio aos grupos de pesquisa e aos cursos de especialização e de pós-graduação, alguns que já estavam instalados e outros que estavam em fase de implantação no prédio da Rua Maranhão, 88.

$[\ldots]$

Além da aquisição das Bibliotecas da ASPLAN e da SAGMACS, recebeu doações de vários outros acervos, ressaltando-se os das famílias dos professores Anhaia Mello, Eustáquio de Toledo e Enoch da Rocha Lima.

O acervo inicial da Biblioteca era constituído principalmente de: planos diretores, estudos de viabilidade técnico-econômica feitos por solicitação de firmas e entidades governamentais, obras de interesse regional, urbano e rural, acústica, conforto térmico, iluminação.

A essa formação inicial somaram-se as teses defendidas na FAUUSP, os livros adquiridos com verba CAPES para as disciplinas oferecidas no Curso de Pós-Graduação, além da hemeroteca, composta por artigos publicados pelos professores da FAUUSP em jornais. ${ }^{100}$

O projeto de adequação e requalificação da Biblioteca da Pós Graduação, de autoria do Arq. José Armênio de Brito Cruz, do escritório Piratininga Arquitetos Associados, foi executado com recursos ${ }^{101}$ da Fundação de Amparo à Pesquisa no Estado de São Paulo - FAPESP, e teve a coordenação do arquiteto e professor da FAUUSP, Júlio Roberto Katinsky, Diretor da FAUUSP no período, e apoio do Prof. Carlos Faggin, do Conselho Curador da FAUUSP.

O projeto foi desenvolvido em 1998 e foi aprovado pela FAPESP em $1999^{102}$, sendo que a obra foi concluída em 2002. A área de projeto contempla $250 \mathrm{~m}^{2}$ e foi

100 Informação obtida em http://www.fau.usp.br/fau/secoes/biblio/index.html, acesso em 07 de fevereiro de 2012.

${ }_{101}$ Segundo o Relatório da Gestão do Edifício Vila Penteado - 01/03/202 à 01/11/2002, Prof. Antonio Carlos Barossi e Prof ${ }^{a}$ Helena A. Ayoub Silva, "A Biblioteca da Vila Penteado, Pós-Graduação, ocupando área de $200 \mathrm{~m} 2$, foi objeto de restauro e modernização com verbas da FAPESP, obtidas no final da gestão do Prof. Dr. Julio Roberto Katinsky. Essas verbas alcançaram a quantia de $\mathrm{R} \$ 377.774,00$. A Comissão de Orçamento de Patrimônio da USP concedeu para finalização dos trabalhos a quantia de $\mathrm{R} \$ 28.000,00$ (inaugurada no dia 08.11.2002)".

102 Ibidem. 
realizada pelo Ateliê Sarasá, com instalações prediais elétricas reformadas pela TEC-INSTAL.

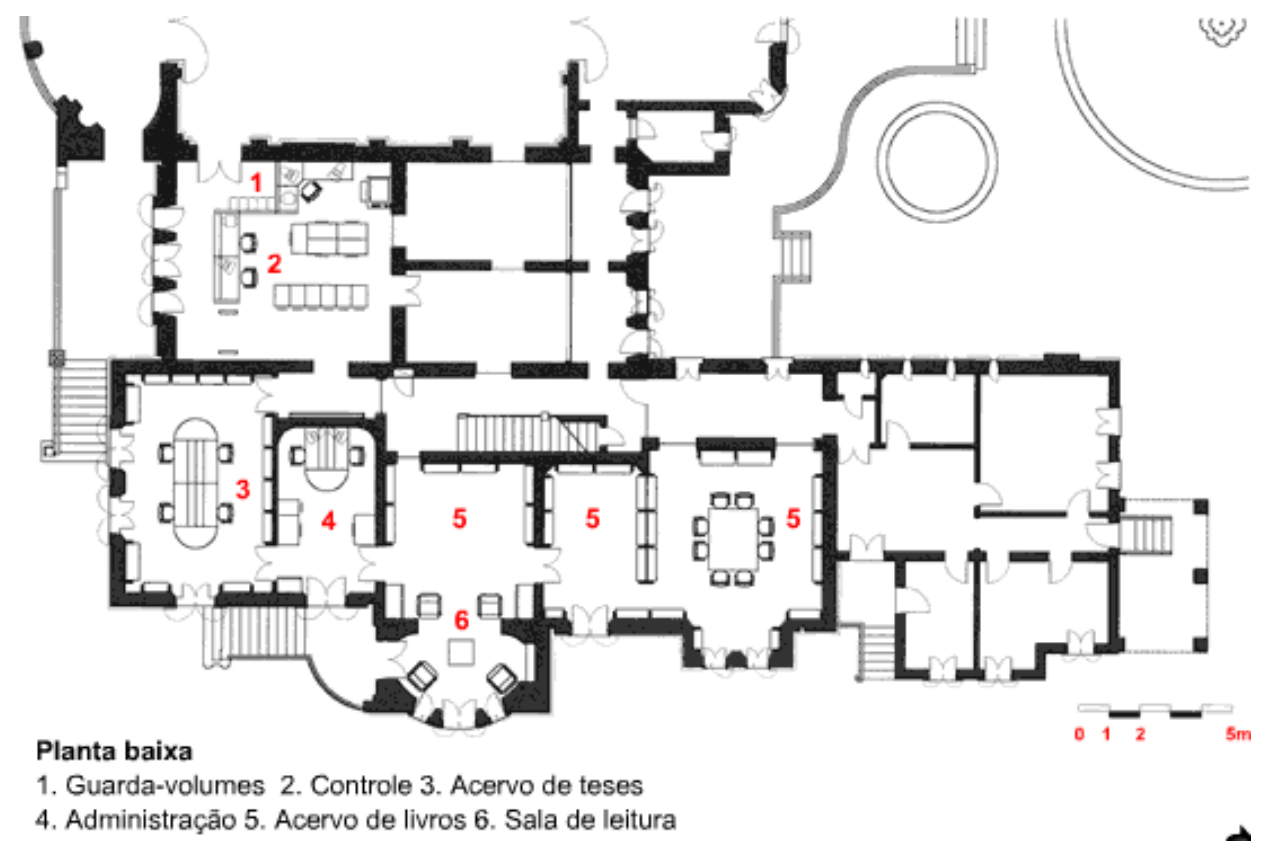

Figura 109 - Planta da Biblioteca

Fonte: Desenho publicado na Revista Projeto Design, Edição 275, janeiro de 2003, disponível em http://www.arcoweb.com.br/arquitetura/jose-armenio-de-brito-cruzbiblioteca-da-22-01-2003.html.

A área destinada a Biblioteca torna-se diferenciada do restante do edifício em função do uso e das intervenções sofridas. Inicialmente destinada à casa adjunta, hoje o espaço é reservado ao estudo, leitura e contemplação. A construção é poética, seu trajeto propicia a construção lenta de um cenário sensível.

A necessidade de entendimento do significado dos espaços fez com que o projeto de requalificação da biblioteca assumisse uma postura interpretativa do espaço, onde alguns ambientes originais tiveram sua intenção recuperada, por exemplo, na sala de jantar, a grande mesa de refeições voltou a ocupar o seu lugar inicial, como mostra a figura 110, sendo que agora seu uso destina-se à leitura; já no escritório do genro do conde Penteado, as estantes foram dispostas de modo a marcar o lugar das antigas paredes. 


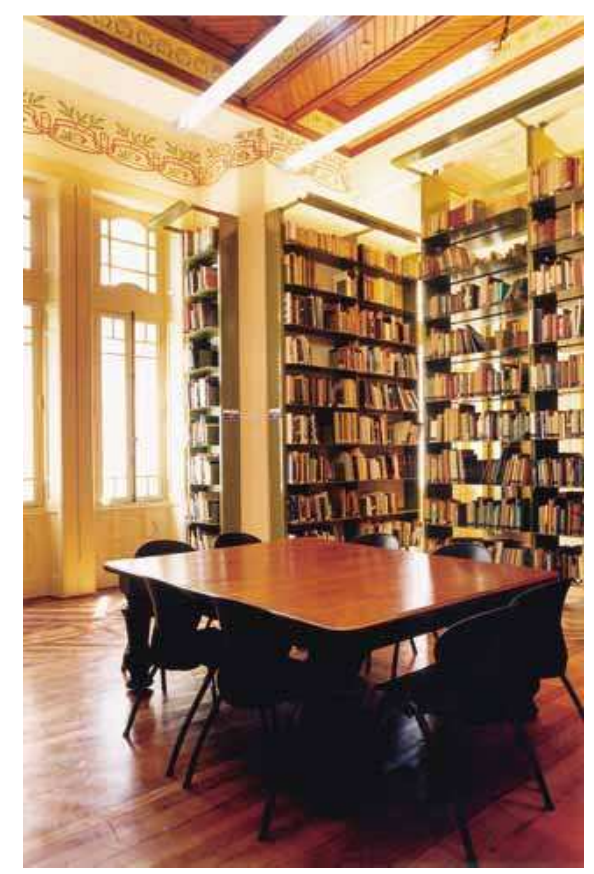

Figura 110 - Mesa de jantar retomou seu lugar na sala

Fonte: Foto publicada na Revista Projeto Design, Edição 275, janeiro de 2003, disponível em http://www.arcoweb.com.br/arquitetura/jose-armenio-de-brito-cruzbiblioteca-da-22-01-2003.html. Foto Cristiano Mascaro.

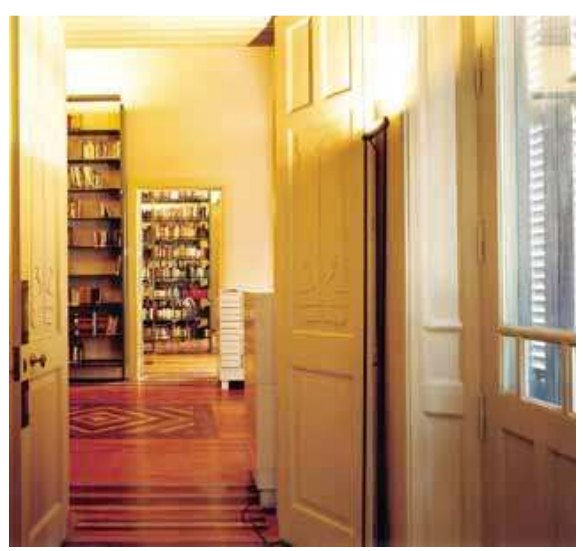

Figura 111 - As distâncias entre as prateleiras foram projetadas para livros de diversas dimensões

Fonte: Foto publicada na Revista Projeto Design, Edição 275, janeiro de 2003, disponível em http://www.arcoweb.com.br/arquitetura/jose-armenio-de-brito-cruzbiblioteca-da-22-01-2003.html. Foto Cristiano Mascaro.

Chapas de aço foram usadas na confecção das prateleiras das novas estantes, fixadas nas paredes de alvenaria. A visualização do forro e do assoalho foi favorecida pela fixação das prateleiras nas paredes. Outro detalhe a ressaltar é a iluminação principal das salas da biblioteca projetada de forma associadas às estantes, o que facilitou a nova distribuição das instalações e ainda ressaltou os forros com pintura mural restaurada. A nova iluminação é direcionada para o forro que, além de destacá-lo, propicia um ambiente agradável envolto nessa iluminação 
indireta, como pode ser observado na foto da figura 112. Nos locais de leitura, a iluminação foi trabalhada com luminárias de piso.

As instalações de eletricidade, lógica e telefonia foram reformadas e seu trajeto passa pelo porão e adentra em cada ambiente por pontos específicos.

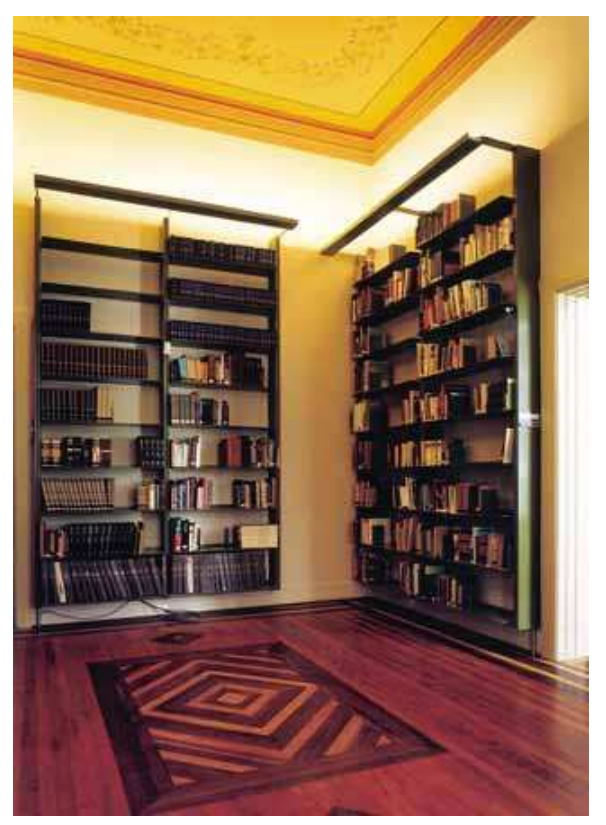

Figura 112 - Fixação das prateleiras nas paredes liberou o piso da carga dos livros Fonte: Foto publicada na Revista Projeto Design, Edição 275, janeiro de 2003, disponível em http://www.arcoweb.com.br/arquitetura/jose-armenio-de-brito-cruzbiblioteca-da-22-01-2003.html. Foto Cristiano Mascaro.

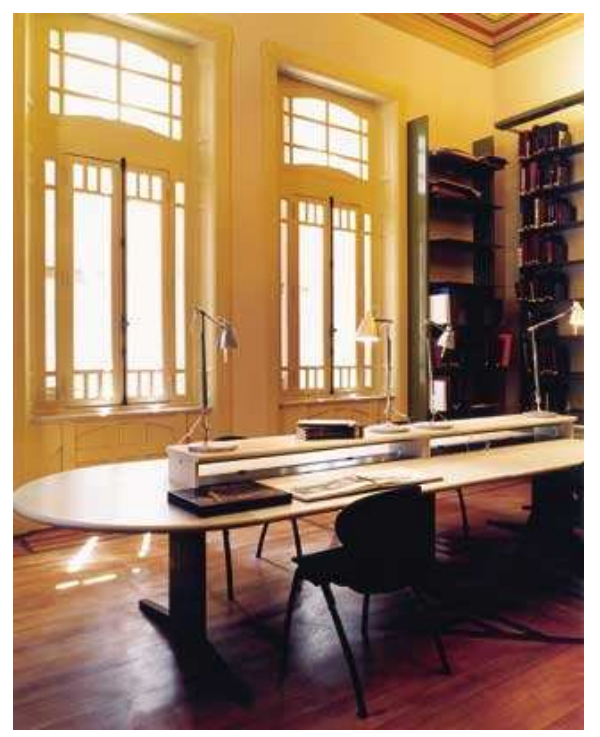

Figura 113 - Sala do acervo de teses, com mesa para consulta

Fonte: Foto publicada na Revista Projeto Design, Edição 275, janeiro de 2003, disponível em http://www.arcoweb.com.br/arquitetura/jose-armenio-de-brito-cruzbiblioteca-da-22-01-2003.html. Foto Cristiano Mascaro. 


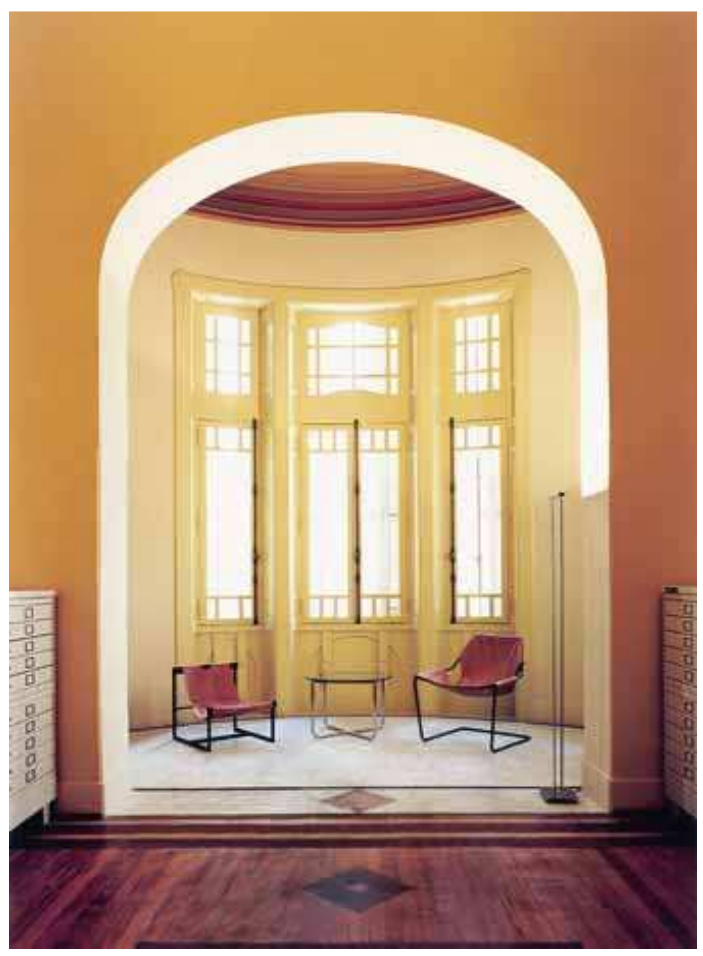

Figura 114 - Local contemplativo e de reflexão: o espaço fechado do alpendre recebeu duas cadeiras

A da direta é desenhada por Arq. Paulo Mendes da Rocha e a da esquerda é de autoria do Arq. Júlio Katinsky.

Fonte: Foto publicada na Revista Projeto Design, Edição 275, janeiro de 2003, disponível em http://www.arcoweb.com.br/arquitetura/jose-armenio-de-brito-cruzbiblioteca-da-22-01-2003.html. Foto Cristiano Mascaro. 


\title{
3.2.7 PLANO DIRETOR PARTICIPATIVO
}

Os estudos para a elaboração do Plano Diretor Participativo iniciaram-se em 2010 e o mesmo tem por objetivo:

\begin{abstract}
Promover um processo participativo de formulação de diretrizes para o uso dos espaços físicos da FAU, capaz de orientar a elaboração de projetos de reforma, restauro, construção e adequação de curto, médio e longo prazos para os distintos espaços atualmente ocupados pela comunidade FAU. ${ }^{103}$
\end{abstract}

O processo teve início em 2009 com a greve de estudantes na FAUUSP, motivada pela não concordância com as obras em andamento no edifício FAUUSP da graduação, edifício Vilanova Artigas. Em congregação aberta, foi feita a proposta de se instituir um Conselho Curador para elaboração do Plano Diretor e em 2010 as equipes de trabalho foram constituídas.

O trabalho foi organizado em etapas e culminou no fórum realizado no primeiro semestre de 2011, para discussão da pré-proposta do Plano Diretor. As etapas trabalhadas organizaram-se em três eixos: leitura participativa, leitura técnica e leitura patrimonial.

As leituras sobre os edifícios da FAU, pelas várias equipes, foram feitas paralelamente: a leitura participativa contou com a mobilização de alunos, professores, funcionários e demais pessoas interessadas nesse processo; a equipe técnica trabalhou com as questões de desempenho, através do levantamento das condições físicas, baseado na análise visual e panorâmica; a equipe de patrimônio voltou-se à análise das características formais, documentais e materiais dos edifícios, para que sejam efetivamente respeitadas. Os trabalhos de leitura técnica foram coordenados pela Profá Érica Yoshioka e, os relacionados às questões de patrimônio e preservação, foram coordenados pela Prof를 Beatriz Kühl.

A leitura participativa envolveu os usuários de cada território, que foram convidados para participar de oficinas. As oficinas eram dedicadas a locais específicos da FAUUSP, sendo que um desses locais é o Edifício Vila Penteado. As oficinas iniciavam-se com a visita ao local e posteriormente os principais problemas e qualidades eram levantados.

\footnotetext{
${ }^{103} \mathrm{http}: / /$ www.fau.usp.br/fau/administracao/congregacao/planodiretor/participativo/index.html, acessado em 24 de abril de 2011
} 
A leitura técnica trabalhou o preenchimento de fichas em campo, em cada um dos ambientes e para cada um dos subsistemas. A partir das anotações das fichas e do levantamento fotográfico, foram produzidas planilhas. No levantamento das condições físicas, as diretrizes da ISO 6241:1984 - International Organization for Standardization Performance standards in building - Principles for their preparation and factors to be considered e o trabalho de sistematização feito, pelo Prof. Dr. João Roberto Leme Simões, na tese de livre docência intitulada Patologias - Origens e Reflexos no Desempenho Técnico-construtivo dos Edifícios (2004), foram observadas e adaptadas às peculiaridades da FAUUSP. Entretanto, não houve a preocupação de cruzar os requisitos de desempenho do usuário com diretrizes de tombamento, em função das questões metodológicas envolvidas e a falta de clareza nos critérios de análise para essa fusão de campos disciplinares. No entanto, as características patrimoniais foram estudadas paralelamente aos trabalhos da equipe de leitura técnica.

A equipe de leitura patrimonial debruçou-se inicialmente nos trabalhos relacionados à cronologia programática dos edifícios e posteriormente sobre questões mais amplas, de forma a produzir bases para uma discussão que ocorreu entre janeiro e fevereiro de 2011 e que levou à definição dos princípios, diretrizes e ações previstas no texto do Plano, que foi discutido no Fórum.

O resultado do trabalho é um primeiro diagnóstico da situação atual para embasar princípios e diretrizes gerais, para os edifícios da Faculdade, a serem seguidos em futuros projetos de intervenção, ou seja, não se trata de propostas projetuais concretas, visto não ser esse o intuito do Plano Diretor.

Os resultados das equipes técnicas foram somados, ou seja, foi feita a soma de diretrizes para a apresentação do plano geral. Um dos trabalhos apresentados, derivado dos estudos para o Plano Diretor, é a análise cronológica dos edifícios da FAUUSP.

Nas figuras 115 a 118, destacam-se alguns desenhos que tratam da alteração de uso da Vila Penteado. 


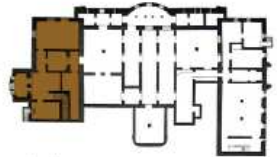

subsolo

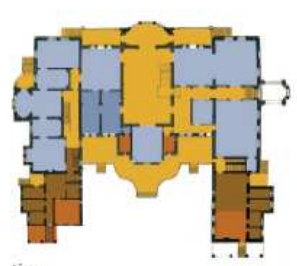

térreo

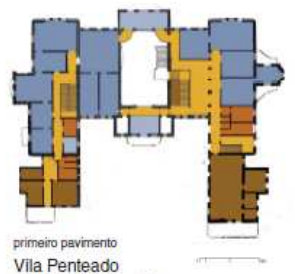

periodo residencia

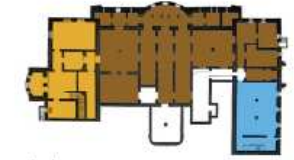

subsolo

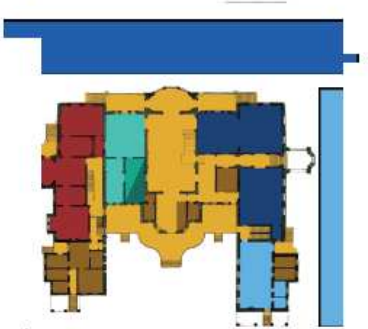

téneo

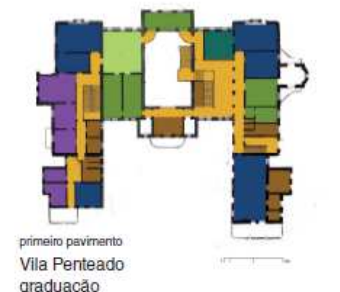

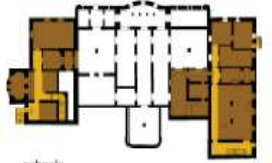

subsolo
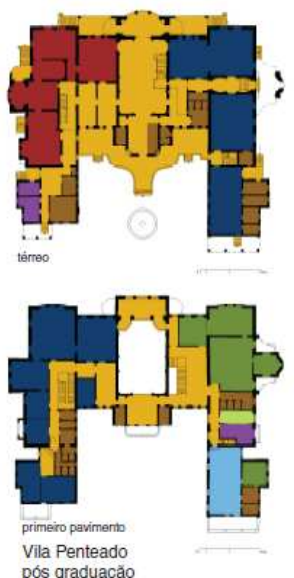

pós graduaçăo

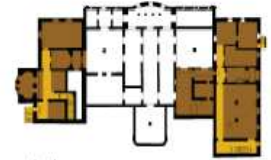

subsolo
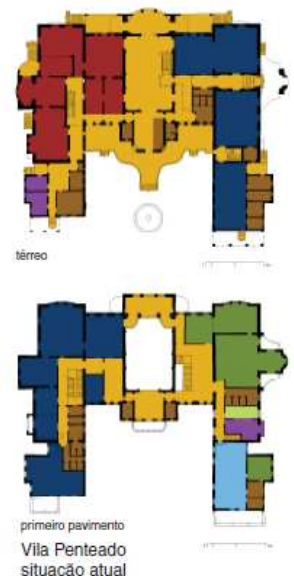

plano
diretor
participativo

cronologia

cronologia da ocupação da vila penteado

Figura 115 - Cronologia de ocupação da Vila Penteado

Fonte: cronologia.pdf, disponível em

http://www.fau.usp.br/fau/administracao/congregacao/planodiretor/material/leitura_patri monial/index.html.
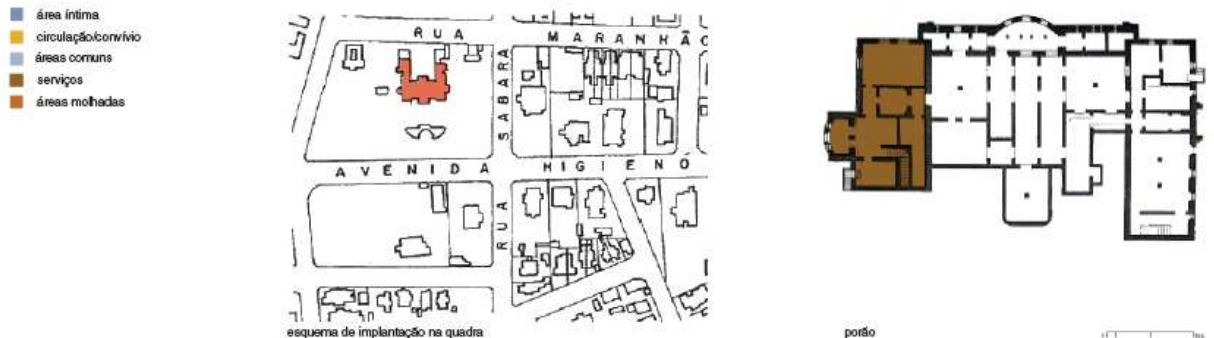

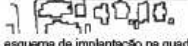

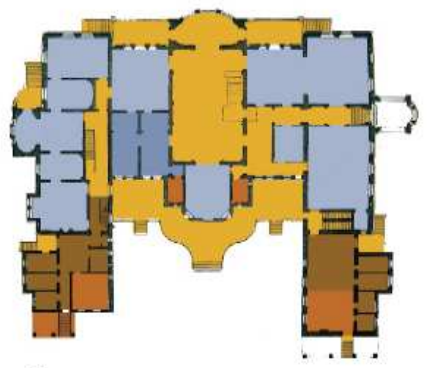

poras

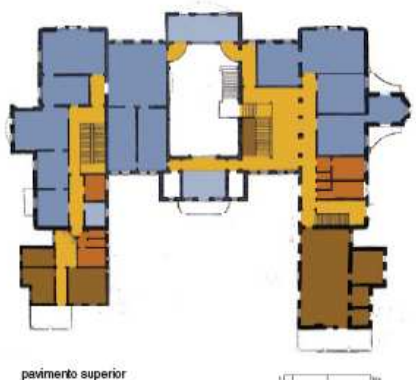

plano
dirator
participativo

Figura 116 - Cronologia de ocupação do prédio FAU Maranhão RESIDENCIAL

Fonte: cronologia.pdf, disponível em

http://www.fau.usp.br/fau/administracao/congregacao/planodiretor/material/leitura_patri monial/index.html. 

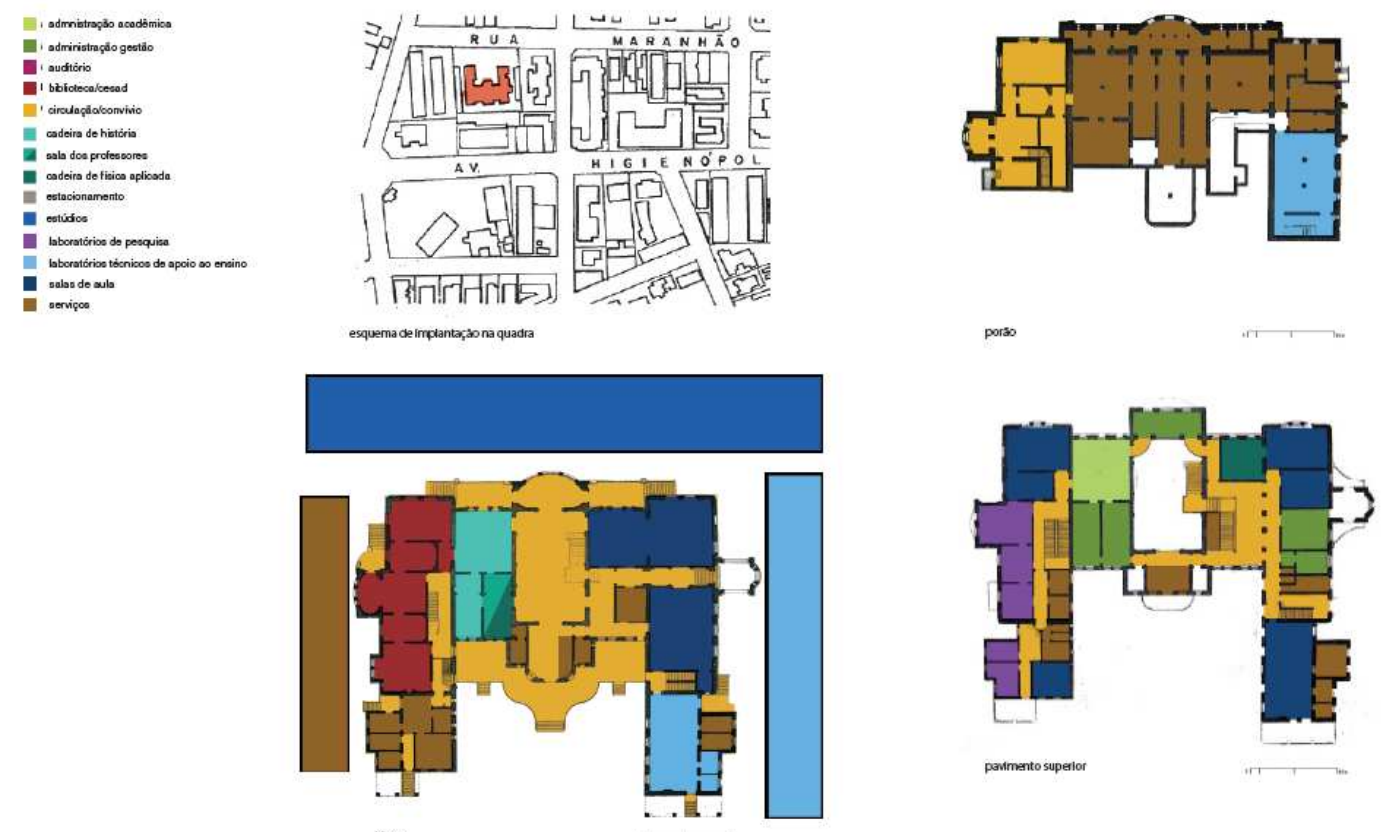

\section{$\mathcal{Z}_{\substack{\text { pamo } \\ \text { particicativo }}}$ cronologia}

cronología da ocupação do prédio FAU Maranhão GRADUAÇÃO

Figura 117 - Cronologia de ocupação do prédio FAU Maranhão GRADUAÇÃO Fonte: cronologia.pdf, disponível em http://www.fau.usp.br/fau/administracao/congregacao/planodiretor/material/leitura_patri monial/index.html.
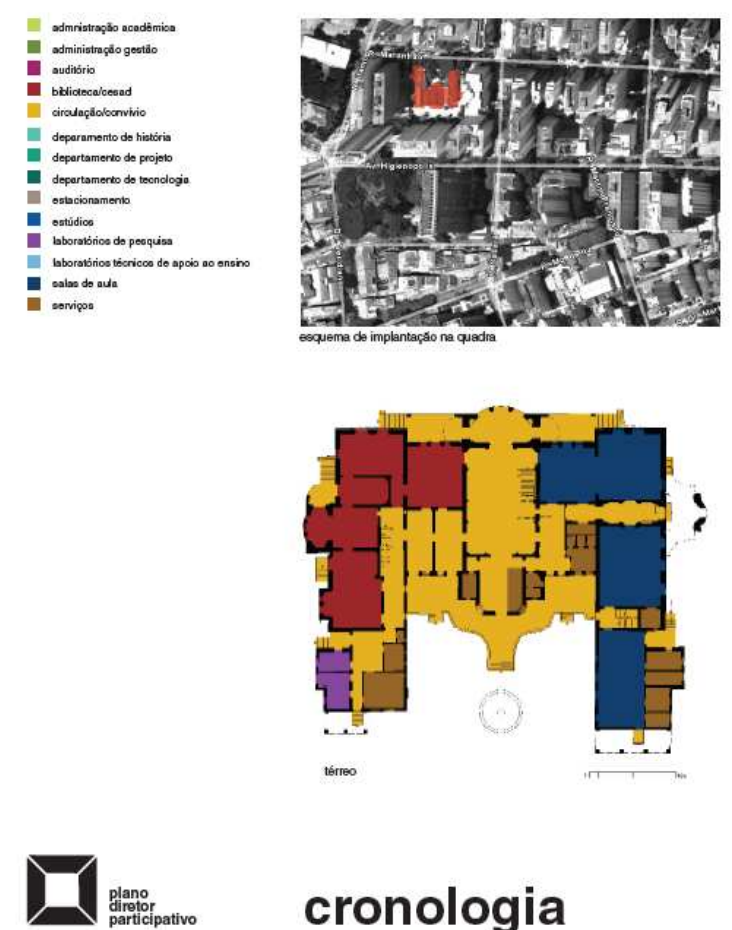
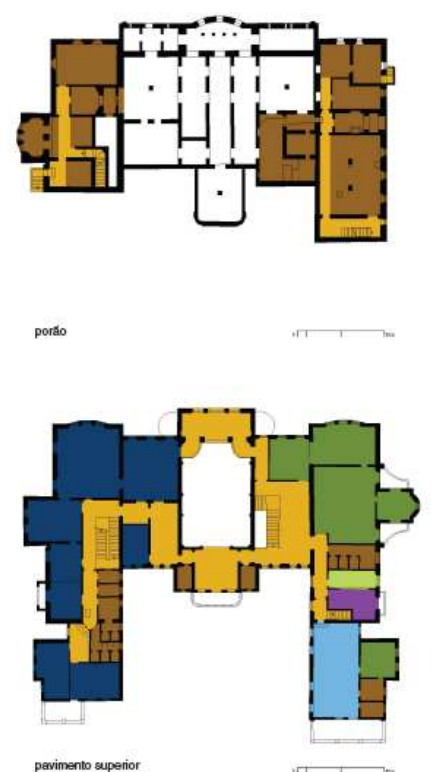

Figura 118 - Cronologia de ocupação do prédio FAU Maranhão PÓS GRADUAÇÃO Fonte: cronologia.pdf, disponível em http://www.fau.usp.br/fau/administracao/congregacao/planodiretor/material/leitura_patri monial/index.html. 


\subsection{LEVANTAMENTO CADASTRAL}

Desde as plantas originais para aprovação nos órgãos públicos e construção da Vila Penteado, diversos desenhos foram produzidos. Alguns de forma detalhada e precisa, outros artísticos e perceptivos. Alguns desses trabalhos, especialmente os recentes de cunho técnico, são resgatados nas páginas seguintes.

\subsubsection{ELEMENTOS GRÁFICOS: BASES DIGITAIS}

Ao longo dos últimos anos, bases digitais com o levantamento cadastral da Vila Penteado foram elaboradas. Os primeiros desenhos digitais foram formalizados a partir da confirmação dos levantamentos cadastrais e foram apresentados no Relatório de Gestão da Vila Penteado de 2003.

A partir desses primeiros desenhos, plantas, cortes e principalmente vistas das diversas paredes foram detalhadas, com a finalidade de registrar esse patrimônio e ainda permitir o desenvolvimento dos diversos projetos necessários ao entendimento e desenvolvimento das ações relacionadas à manutenção e preservação do edifício.

As figuras 119 a 130 apresentam uma amostra dos desenhos resultantes desse minucioso levantamento cadastral. A figura 119 corresponde à implantação. A via situada abaixo do desenho refere-se à Rua Maranhão, atual entrada para a Vila Penteado (originalmente a entrada dos fundos). É importante notar a posição do norte, visando facilitar a localização dos demais desenhos, especialmente os registros das fachadas.

A figura 120 apresenta a planta do porão que, apesar de aparentar ter área generosa, a sua porção central é desprovida de uso, em função da altura reduzida de pé-direito. A área do porão confere qualidade à construção, em virtude de propiciar ventilação constante e manter a umidade afastada dos pisos em madeira. Com o passar os anos, algumas aberturas do porão foram fechadas. Essa ação fezse necessária visando reduzir a ventilação nessa área, algo que se fazia sentir no pavimento térreo, especialmente nos períodos de inverno. 

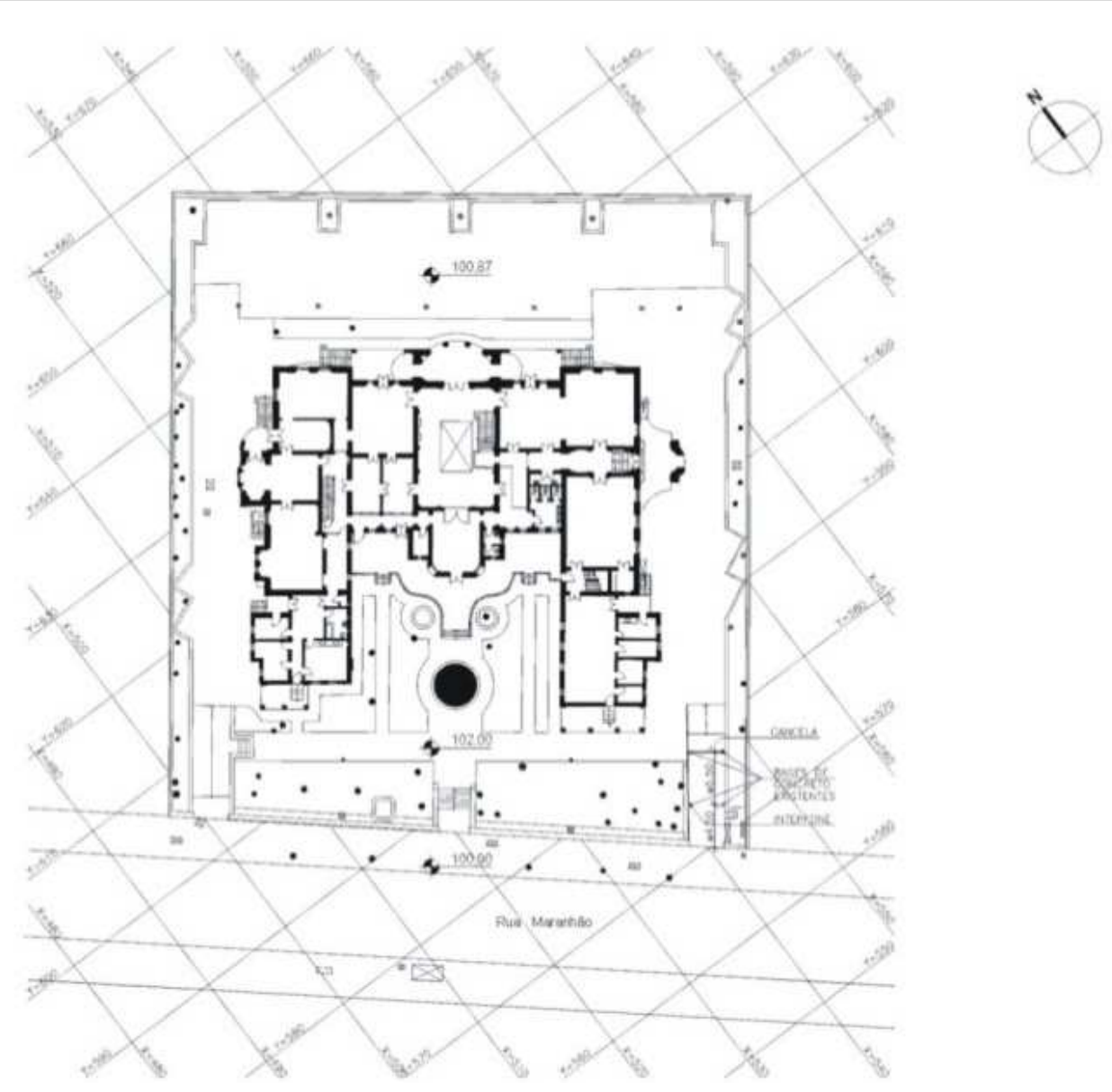

Figura 119 - Implantação do Edifício Vila Penteado

Fonte: Prancha 01/12, Universidade de São Paulo, Faculdade de Arquitetura e Urbanismo, Edifício Vila Penteado, Implantação, Escala 1:500.

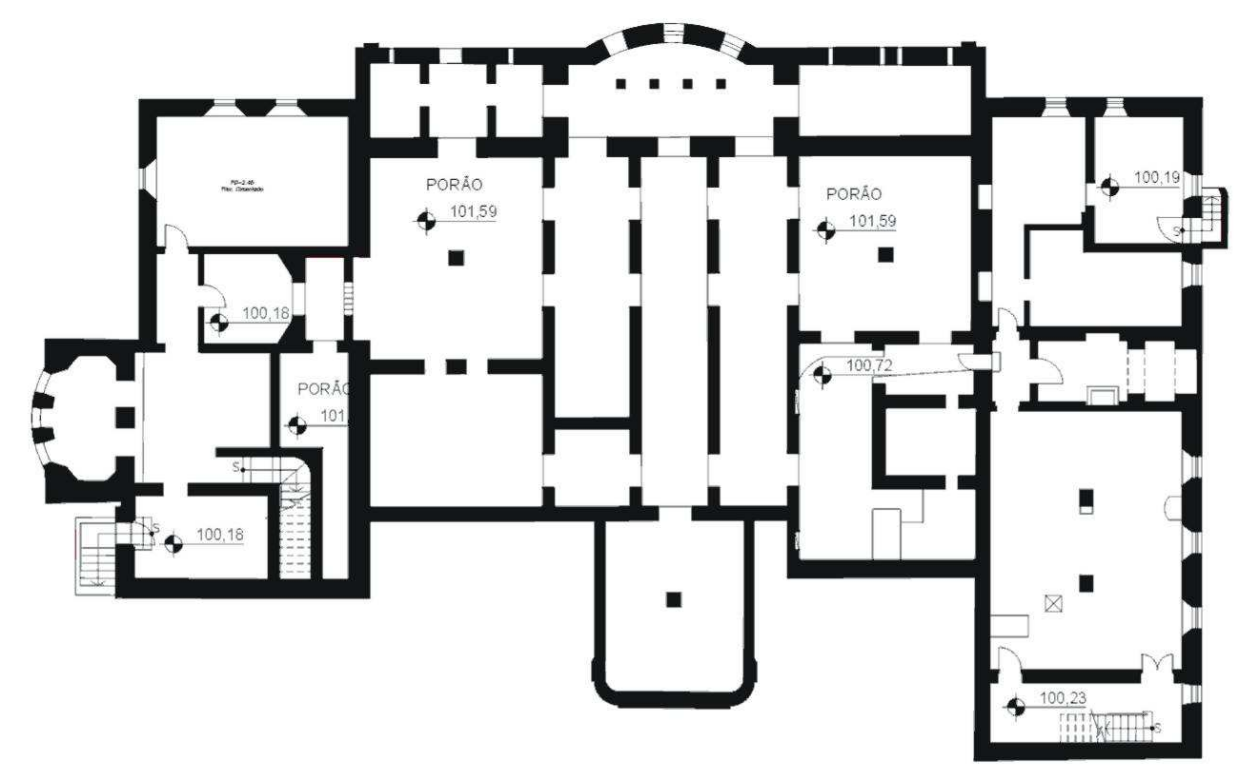

Figura 120 - Planta do Subsolo do Edifício Vila Penteado

Fonte: Prancha 02/12, Universidade de São Paulo, Faculdade de Arquitetura e Urbanismo, Edifício Vila Penteado, Planta do Subsolo e Ventilação Inferior, Escala $1: 200$. 


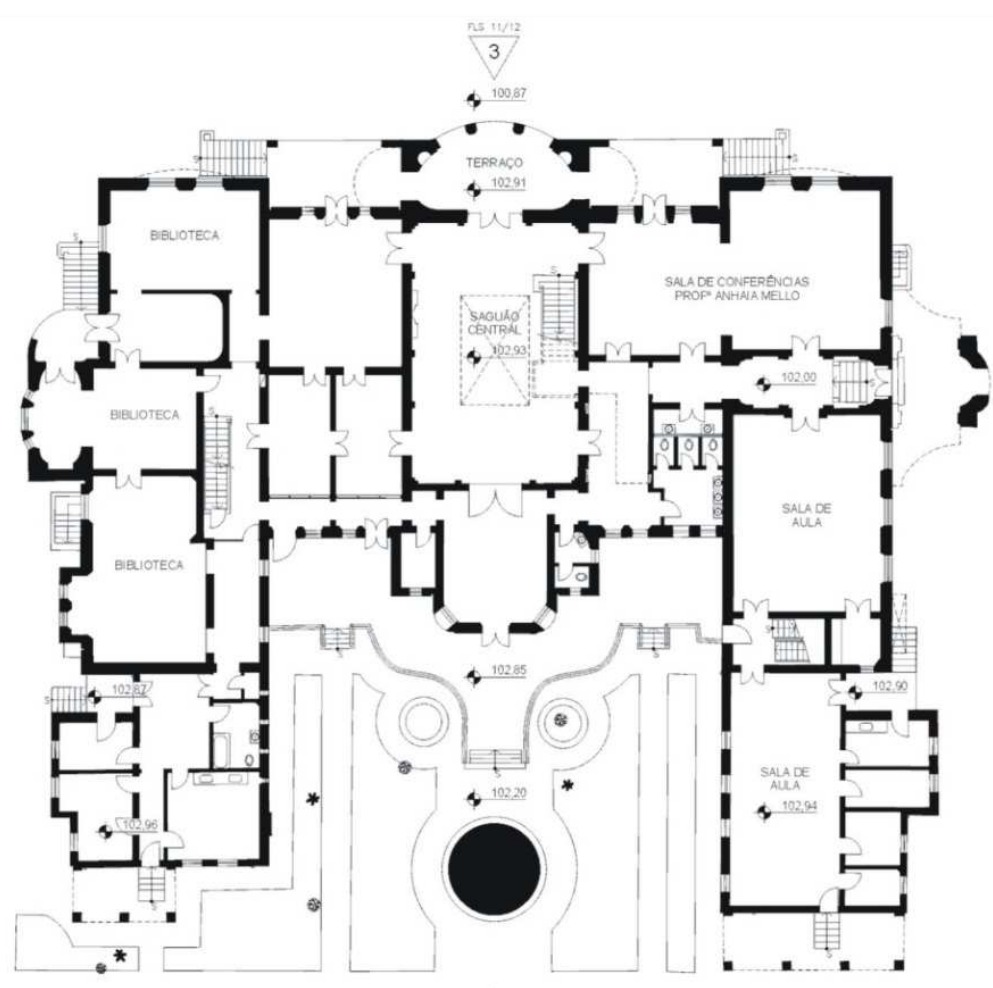

Figura 121 - Planta do Pavimento Térreo do Edifício Vila Penteado

Fonte: Prancha 03/12, Universidade de São Paulo, Faculdade de Arquitetura e Urbanismo, Edifício Vila Penteado, Planta do Pavimento Térreo, Escala 1:200.

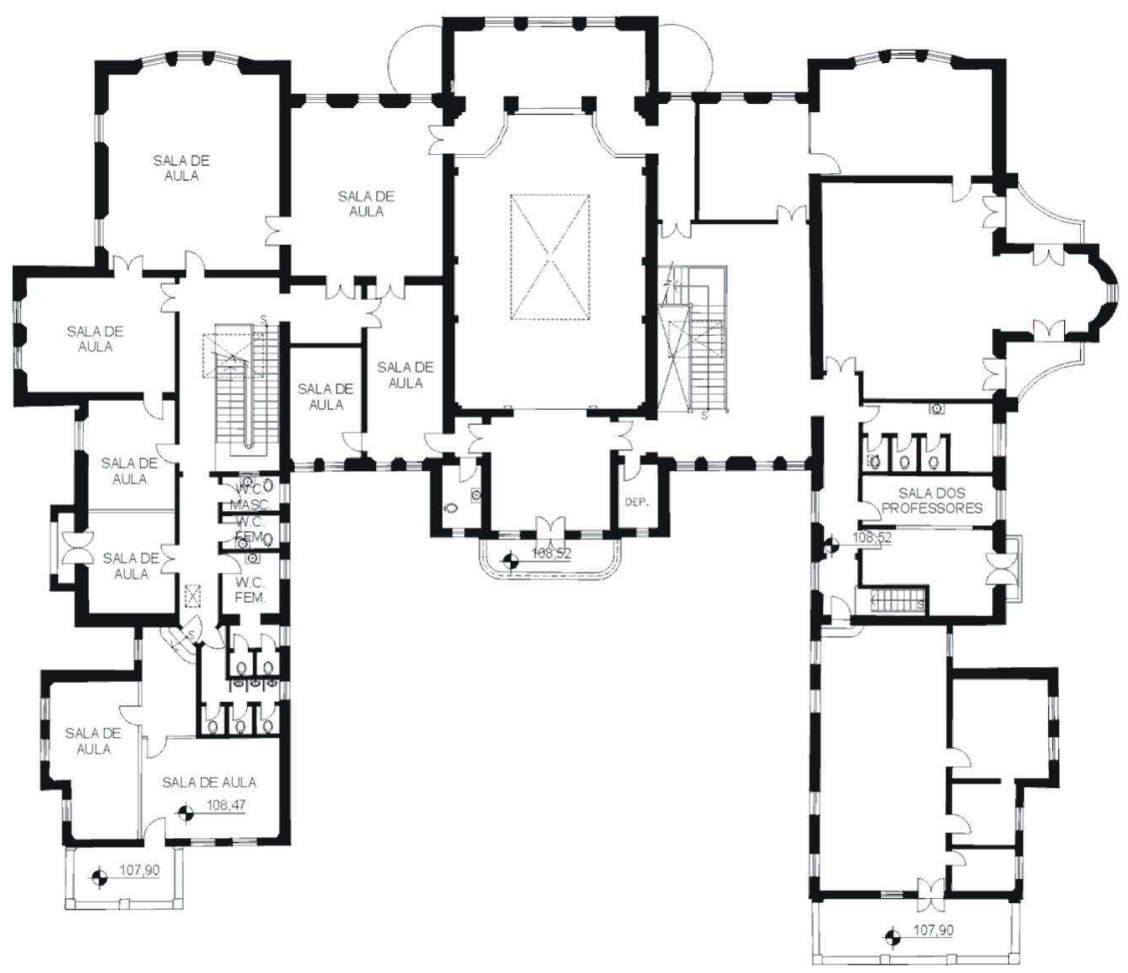

Figura 122 - Planta do Pavimento Superior do Edifício Vila Penteado

Fonte: Prancha 04/12, Universidade de São Paulo, Faculdade de Arquitetura e Urbanismo, Edifício Vila Penteado, Planta do Pavimento Superior, Escala 1:200. 


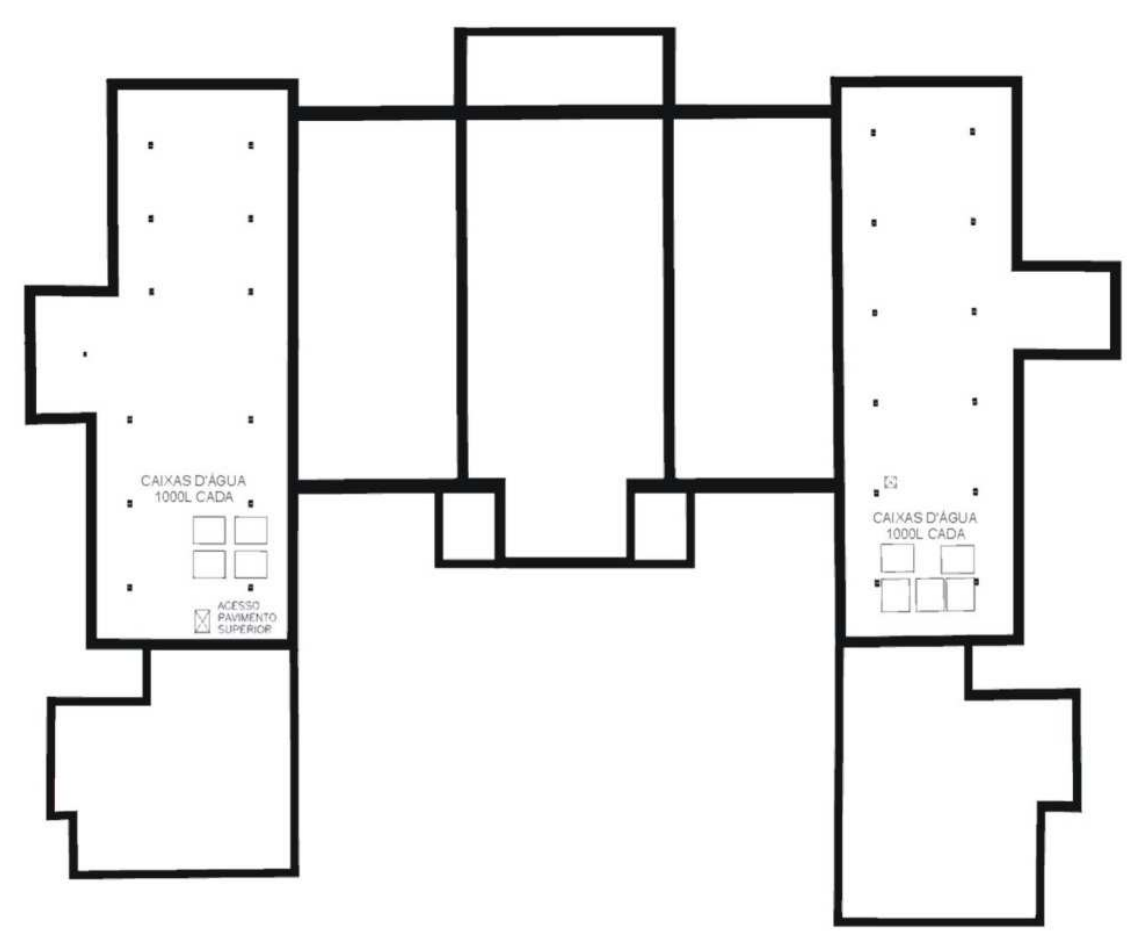

Figura 123 - Planta do Sótão do Edifício Vila Penteado Fonte: Prancha 05/12, Universidade de São Paulo, Faculdade de Arquitetura e Urbanismo, Edifício Vila Penteado, Planta do Sótão, Escala 1:200.

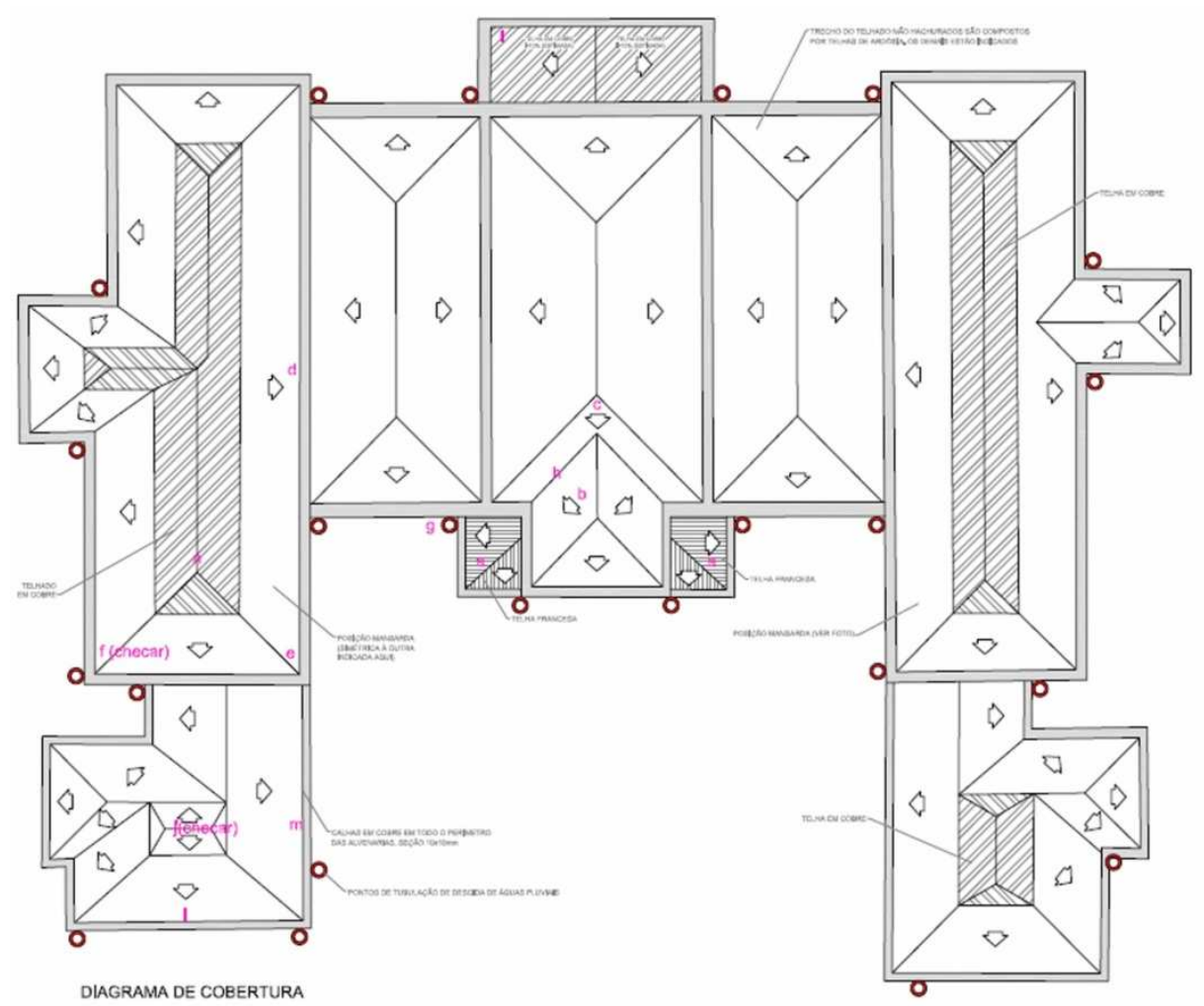

Figura 124 - Planta da Cobertura do Edifício Vila Penteado Fonte: Prancha 01/02, Universidade de São Paulo, Faculdade de Arquitetura e Urbanismo, FAU Maranhão, Levantamento p/ Identificação de Infiltrações, Localização descidas de água pluvial/ Fotos diversas cobertura. GEEF, Escala 1:100, Revisão 00, maio de 2009, Desenho Lara. 
A figura 125 apresenta o corte transversal da Vila Penteado. Nesse corte é possível notar a estrutura em madeira da cobertura e a falta de continuidade entre os trechos do sótão. As paredes portantes são evidenciadas, assim como são verificáveis as diversas alturas de pé-direito do porão, o que torna inutilizável a área da porção central do edifício, mas facilitam os trajetos de instalações, verificações rotineiras de manutenção e ainda auxilia a ventilação do imóvel. Ainda no corte transversal é possível notar, no lado direito, a escada de acesso lateral. Essa escada era usada pela família em dias de chuva e hoje é mantida fechada. $\mathrm{Na}$ área abaixo dessa escada encontra-se o quadro de entrada de luz e força da Vila Penteado.

O corte longitudinal, apresentado na figura 126, contempla a área do Saguão, revelando o pé-direito duplo e a relação de permeabilidade formal entre os ambientes, algo característico do art nouveau.

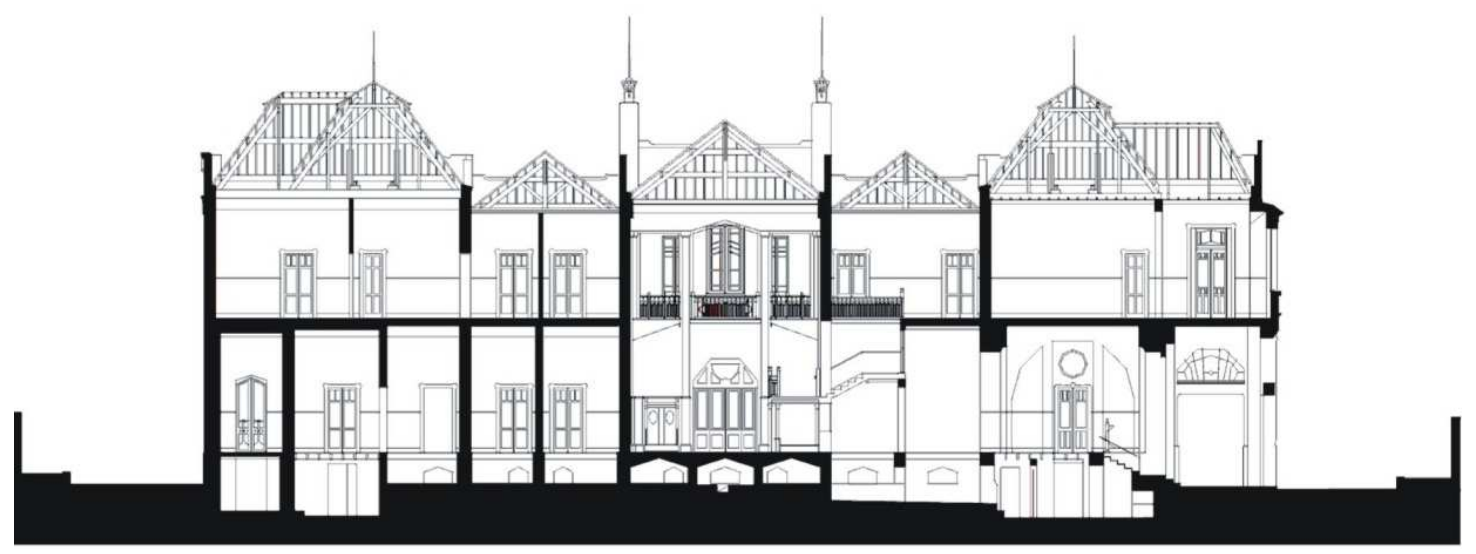

Figura 125 - Corte Transversal do Edifício Vila Penteado

Fonte: Prancha 07/12, Universidade de São Paulo, Faculdade de Arquitetura e Urbanismo, Edifício Vila Penteado, Corte Transversal, Escala 1:200.

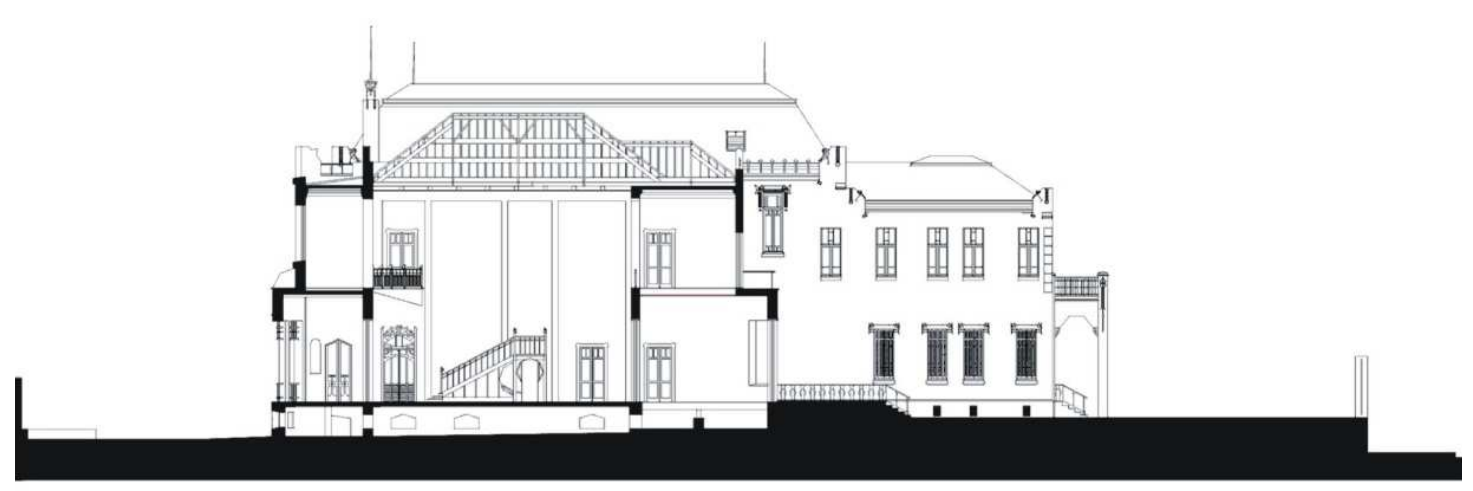

Figura 126 - Corte Longitudinal do Edifício Vila Penteado

Fonte: Prancha 08/12, Universidade de São Paulo, Faculdade de Arquitetura e Urbanismo, Edifício Vila Penteado, Corte Longitudinal, Escala 1:200. 


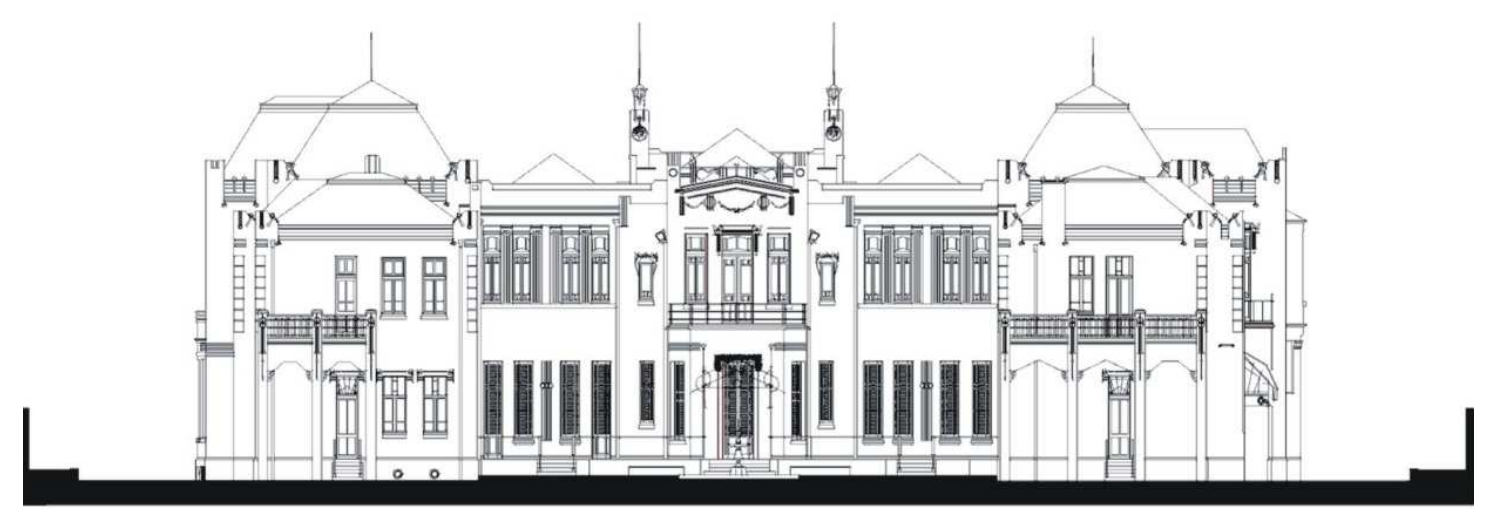

Figura 127 - Fachada Sudoeste do Edifício Vila Penteado

Fonte: Prancha 09/12, Universidade de São Paulo, Faculdade de Arquitetura e Urbanismo, Edifício Vila Penteado, Elevação 1, Escala 1:200.

A fachada sudoeste, figura 127, que tem acesso pela Rua Maranhão, originalmente contemplava os acessos às áreas de serviços da residência do conde Álvares Penteado e da residência de seu genro, Antonio Prado Junior, além de permitir o acesso direto ao escritório do conde, atual portaria da pós-graduação da FAUUSP.

A figura 128 apresenta a fachada sudeste, que contempla o acesso a Sala dos Espelhos (ver lado direito do desenho). No desenho da fachada sudeste é possível notar com clareza a indicação das janelas do porão, que permitem a ventilação constante do edifício.

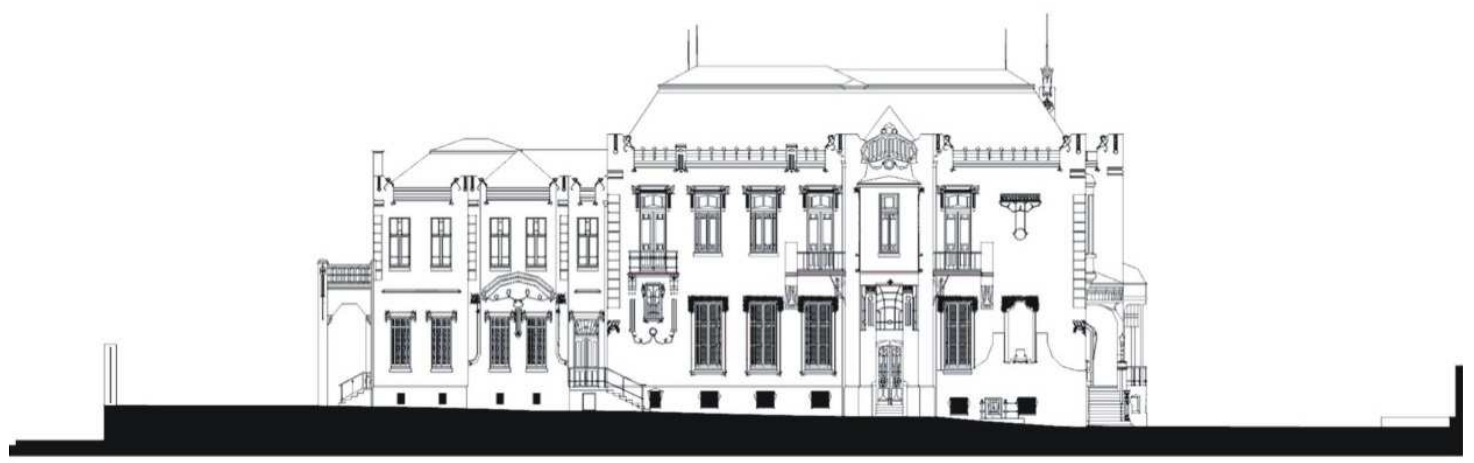

Figura 128 - Fachada Sudeste do Edifício Vila Penteado

Fonte: Prancha 10/12, Universidade de São Paulo, Faculdade de Arquitetura e Urbanismo, Edifício Vila Penteado, Elevação 2, Escala 1:200.

A fachada nordeste corresponde aos fundos da Vila Penteado, entrada principal original do projeto. O acesso central feito por duas escadas leva ao Saguão principal e o acesso lateral (ver porção direita do desenho) corresponde à entrada externa da Biblioteca, que é mantida fechada, permitindo o controle de acesso à 
mesma. $\mathrm{O}$ acesso lateral corresponde à entrada principal original da residência de Antonio Prado Junior. Essa entrada é melhor visualizada do desenho da figura 130 fachada noroeste.

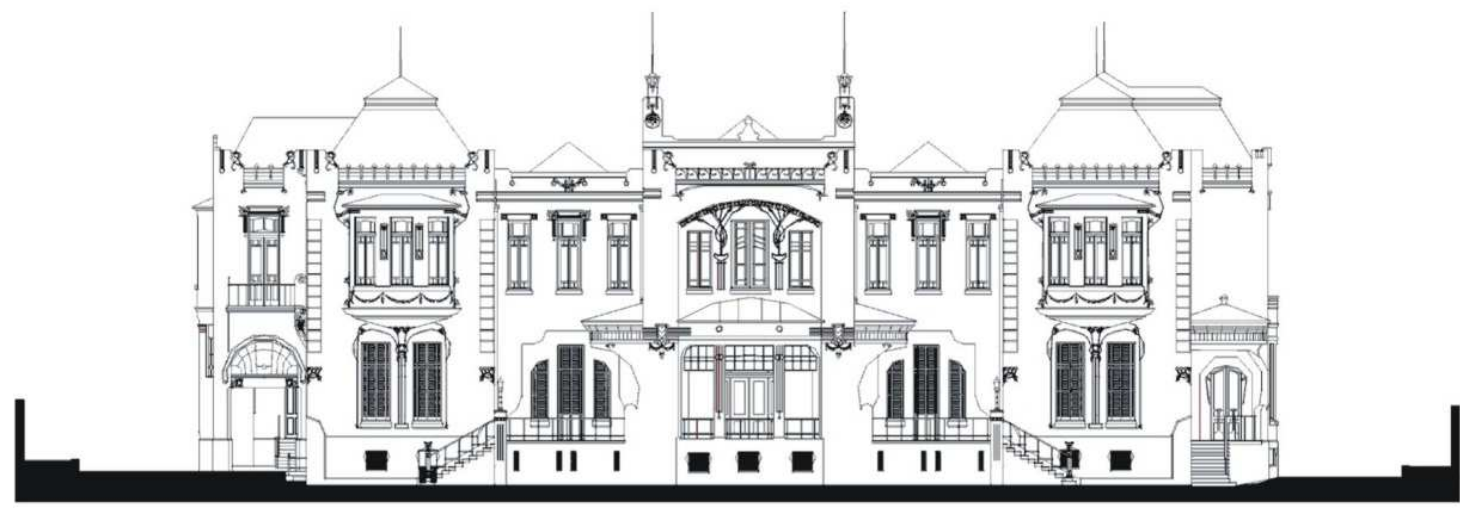

Figura 129 - Fachada Nordeste do Edifício Vila Penteado

Fonte: Prancha 11/12, Universidade de São Paulo, Faculdade de Arquitetura e Urbanismo, Edifício Vila Penteado, Elevação 3, Escala 1:200.

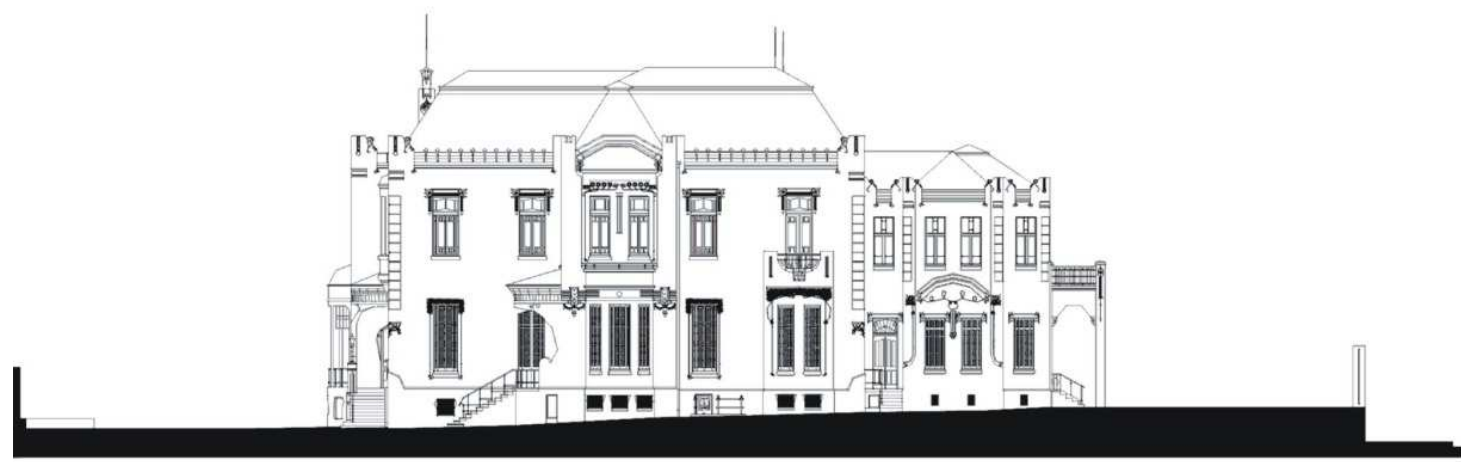

Figura 130 - Fachada Noroeste do Edifício Vila Penteado

Fonte: Prancha 12/12, Universidade de São Paulo, Faculdade de Arquitetura e Urbanismo, Edifício Vila Penteado, Elevação 4, Escala 1:200.

Além das plantas, cortes e elevações das fachadas, diversas salas foram detalhadas através do desenho técnico apresentado através de plantas e vistas. Esses desenhos encontram-se arquivados no GEEF, no formato de arquivo digital de desenho. Nas figuras 131 a 135 é possível ver o detalhamento de uma dessas salas: a Sala dos Espelhos.

A Sala dos Espelhos tem fundamental importância hoje para as atividades da pós-graduação, visto ser usada como auditório. Nessa sala, composta por duas áreas conjugadas, ocorre diversas atividades, tais como: apresentação de bancas de avaliação, palestras, seminários, conferências e outras tantas atividades relacionadas à arquitetura e cultura. 


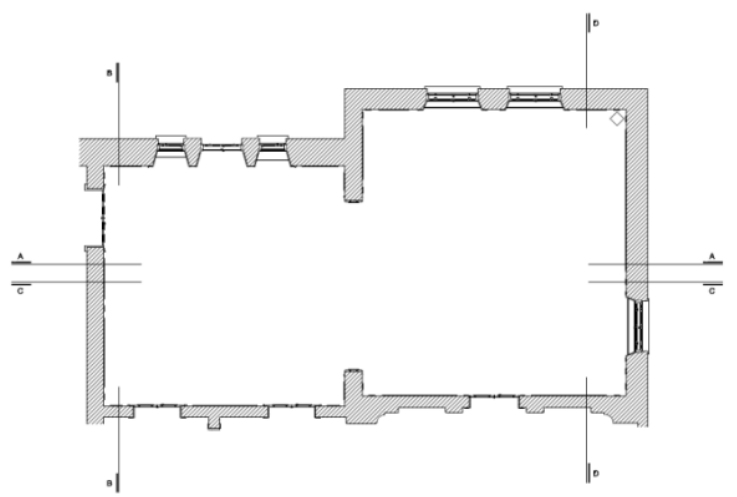

Figura 131 - Planta da Sala dos Espelhos - Sala de Conferências Prof. Anhaia Mello, Edifício Vila Penteado

Fonte: Desenho do Arq. João Osinski, GEEF.

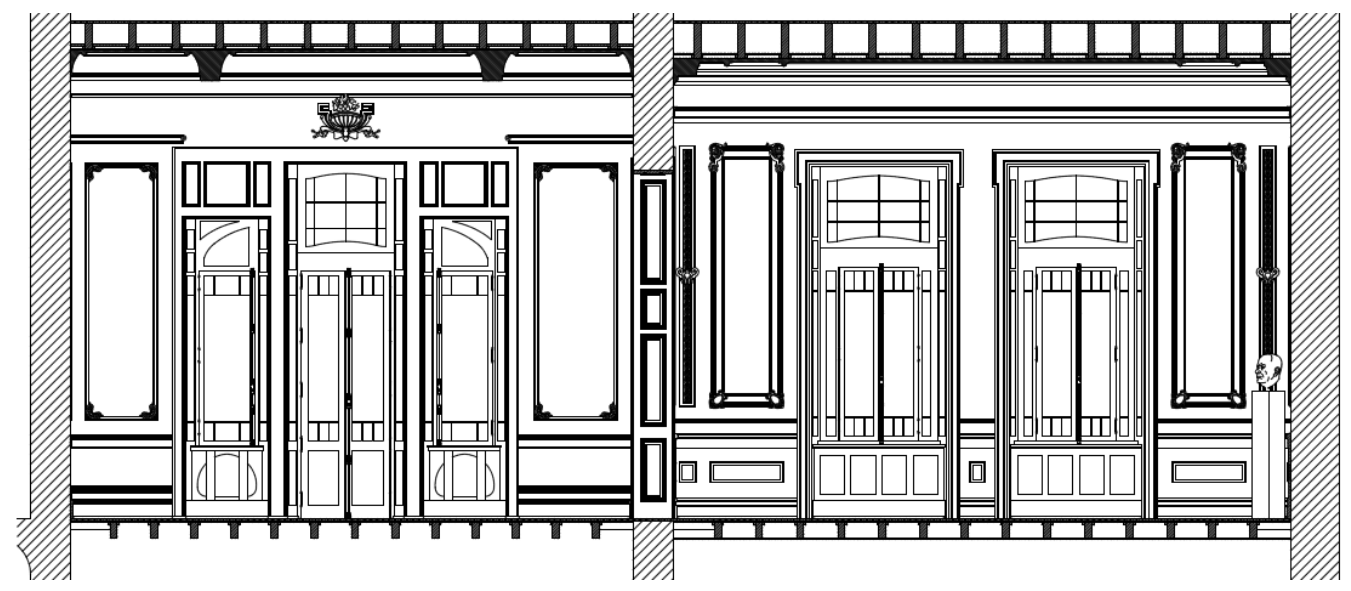

Figura 132 - Corte AA da Sala dos Espelhos - Sala de Conferências Prof. Anhaia Mello, Edifício Vila Penteado

Fonte: Desenho do Arq. João Osinski, GEEF.

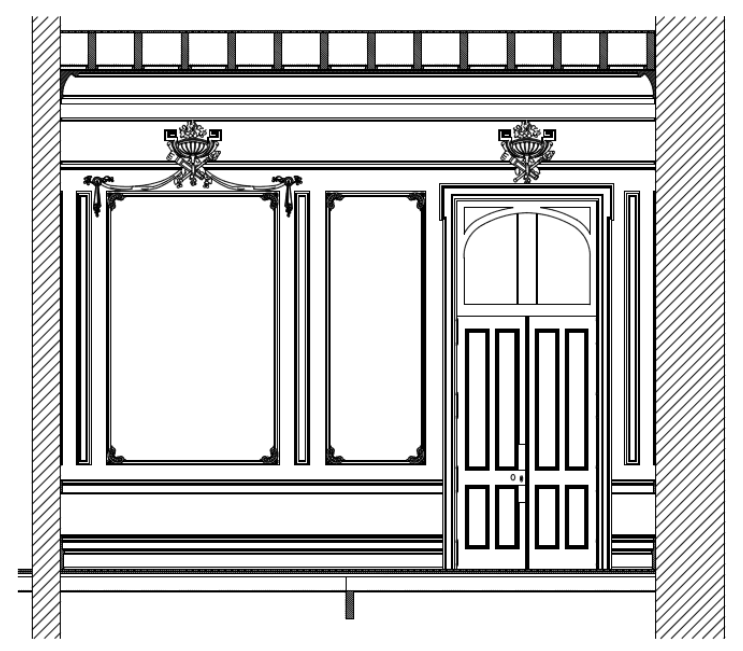

Figura 133 - Corte BB da Sala dos Espelhos - Sala de Conferências Prof. Anhaia Mello, Edifício Vila Penteado

Fonte: Desenho do Arq. João Osinski, GEEF. 


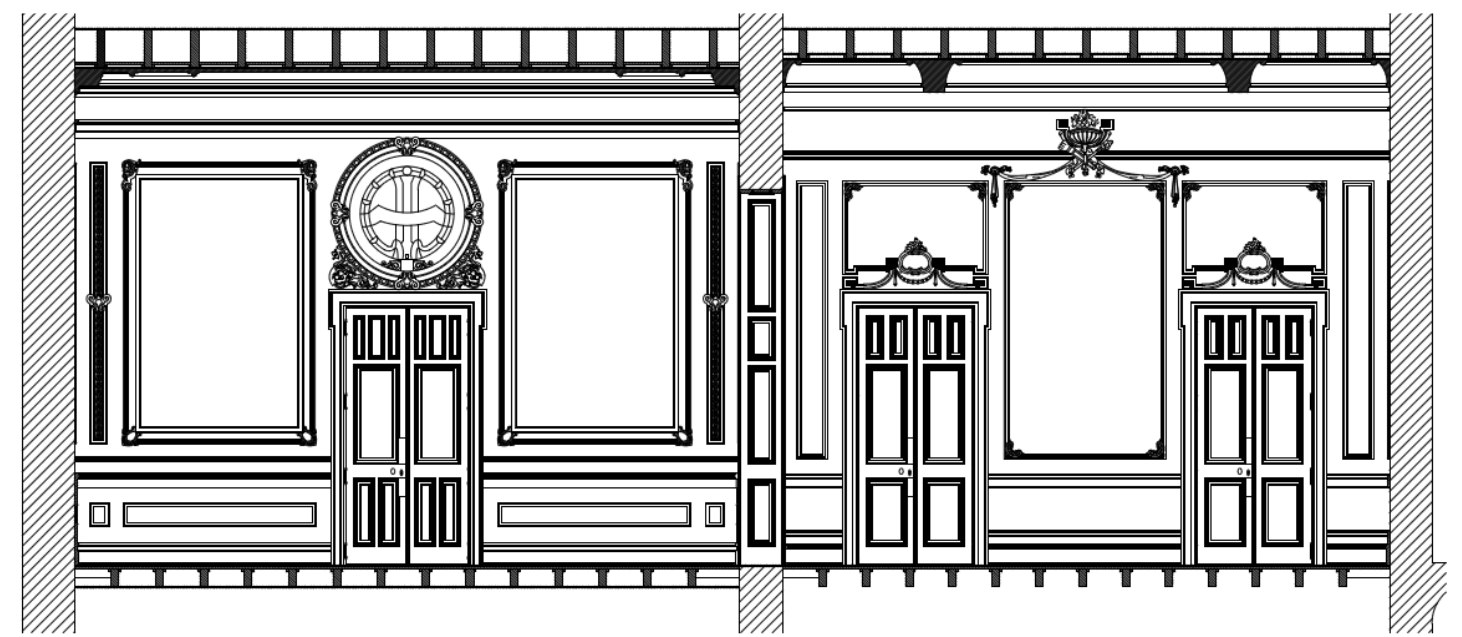

Figura 134 - Corte CC da Sala dos Espelhos - Sala de Conferências Prof. Anhaia Mello, Edifício Vila Penteado

Fonte: Desenho do Arq. João Osinski, GEEF.
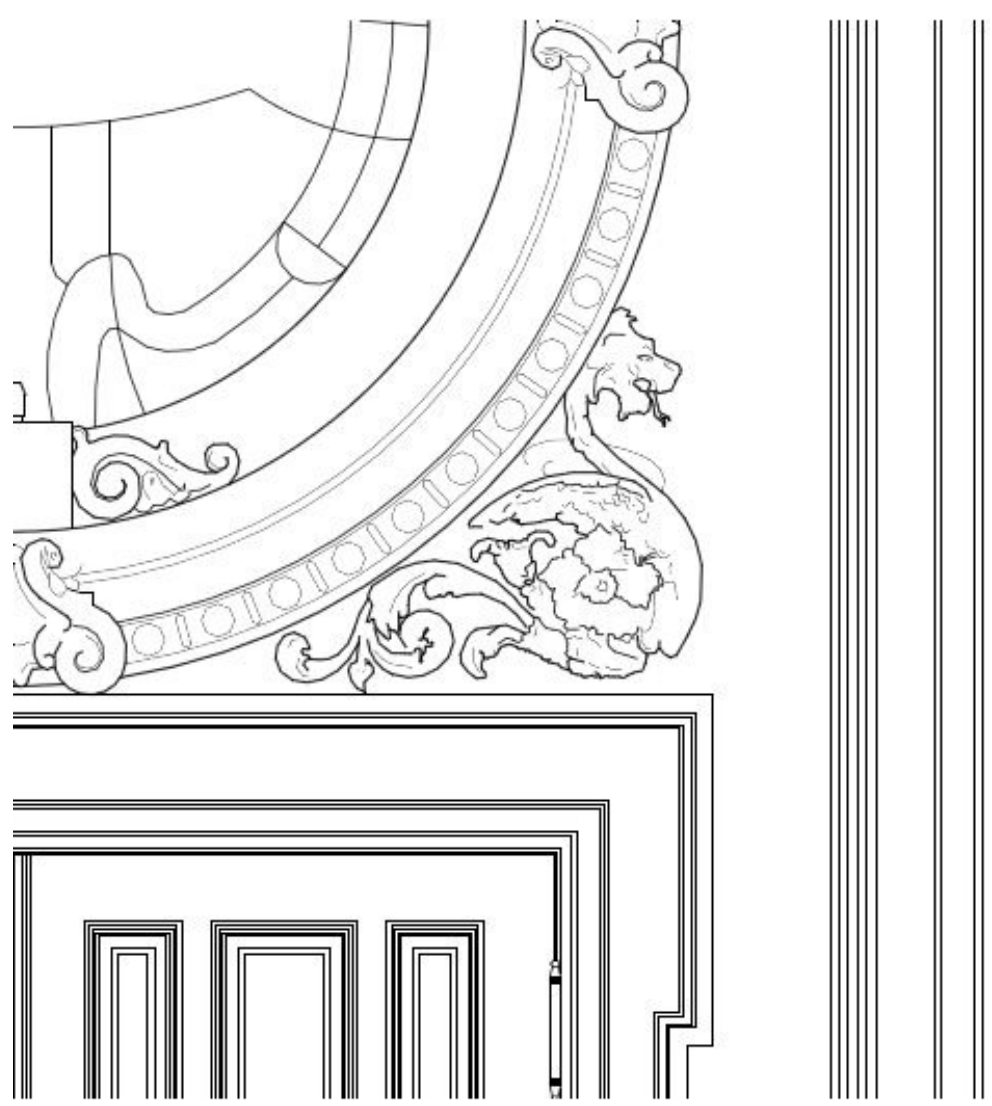

Figura 135 - Detalhe do Corte CC da Sala dos Espelhos - Sala de Conferências Prof. Anhaia Mello, Edifício Vila Penteado

Fonte: Desenho do Arq. João Osinski, GEEF.

Os desenhos das salas foram feitos de forma detalhada como pode ser observado na figura 135: detalhe da área sobre a porta que compõe o corte CC da Sala dos Espelhos. 


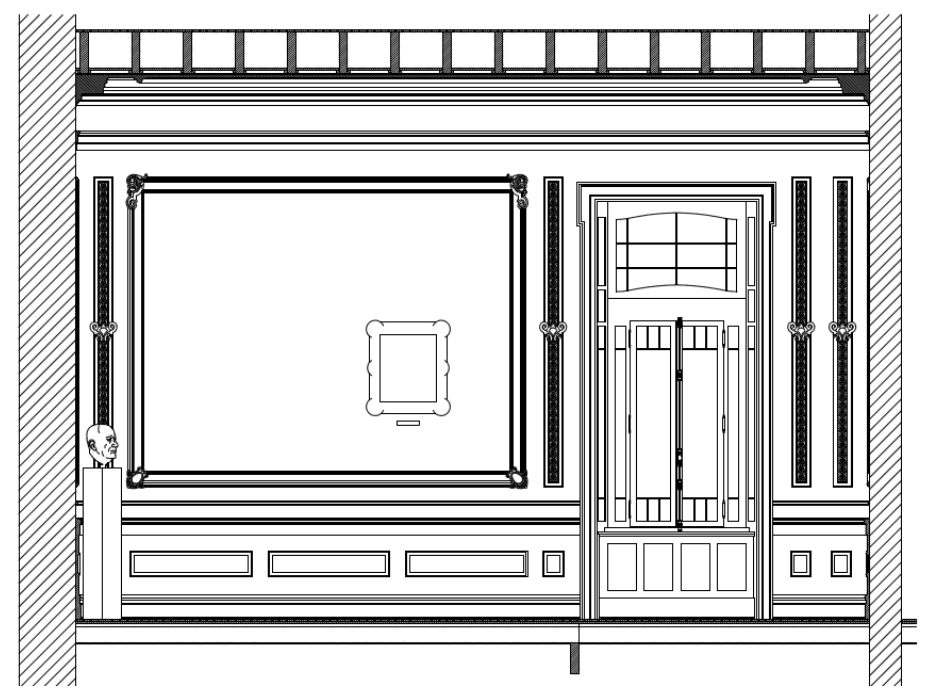

Figura 136 - Corte DD da Sala dos Espelhos - Sala de Conferências Prof. Anhaia Mello, Edifício Vila Penteado

Fonte: Desenho do Arq. João Osinski, GEEF.

O levantamento dos materiais de acabamento usados nas áreas de piso, parede e forro do Edifício Vila Penteado também foi realizado e organizado (ver figura 137). Além do levantamento do edifício, foi elaborado o levantamento cadastral simplificado do mobiliário existente. Esse levantamento consta do Relatório de Gestão da Vila Penteado de 2003.

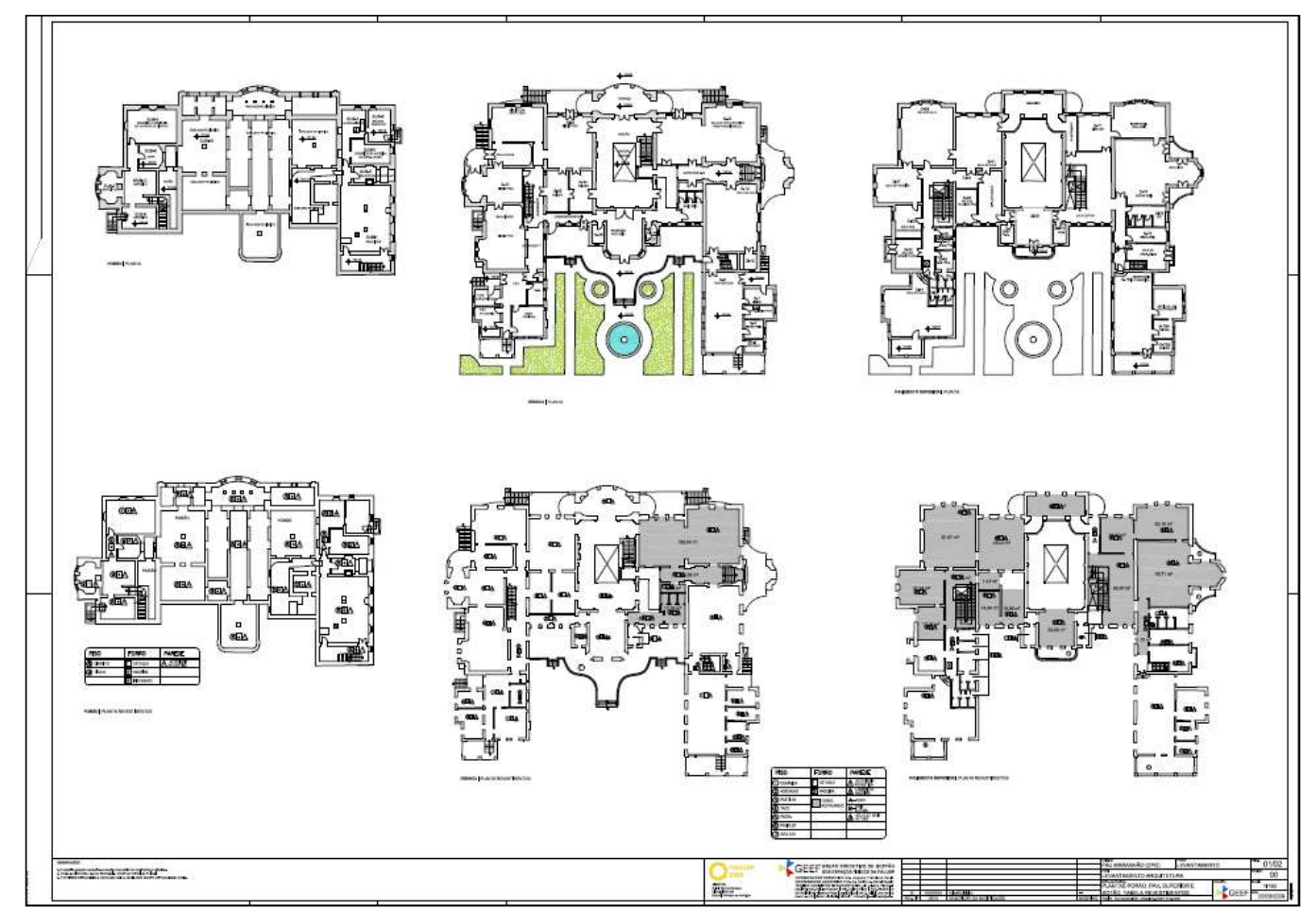

Figura 137 - Levantamento Arquitetura - FAU Maranhão (CPG)

Fonte: Folha 01/02, Plantas Porão, Pav. Térreo, Pav. Superior e Sótão, Tabela Revestimentos, GEEF, Escala 1:150, 25/03/2009. 


\subsection{PROJETOS RECENTES OU EM DESENVOLVIMENTO}

Desde sua concepção inicial como residência, a Vila Penteado passou por algumas fases. As mais significativas foram caracterizadas pelas alterações de uso, ou pela falta no mesmo, visto os dois momentos onde foi mantida fechada terem contribuído para a alteração de suas condições físicas, causando deterioração.

Entretanto, outros momentos contribuíram de forma positiva para a preservação da Vila. E a última década tem sido produtiva no sentido de promover estudos sobre as necessidades do edifício Vila Penteado. Alguns desses estudos ganharam dimensão de projeto e, embora não estejam compatibilizados entre si, esses projetos visam trazer informações importantes para o encaminhamento das decisões com relação às ações de preservação. 


\subsubsection{PROJETO DE REFORMA DOS SANITÁRIOS}

O Projeto de Reforma dos Sanitários foi apresentado no Relatório de Gestão da Vila Penteado de 2006, tendo como gestores os professores Antonio Carlos Barossi e Helena Ayoub Silva.

As instalações hidráulicas do edifício são precárias, insuficientes, apresentam falhas em sua localização e não são acessíveis. O Projeto de Reforma dos Sanitários prevê uma distribuição racional pelo edifício dos sanitários e contam a reforma geral das tubulações de água fria e de esgotamento sanitário. Nas figuras 138 a 147 são apresentados desenhos e tabelas que compõem o detalhamento do projeto de reforma dos sanitários. Os desenhos das figuras 138, 140, 142, 144 e 146 apresentam a localização dos ambientes sanitários no edifício e as figuras 139, 141, 143, 145 e 147, apresentam o desenho ampliado desses ambientes. Inicialmente os desenhos referem-se ao Sanitário Masculino do Pavimento Térreo.

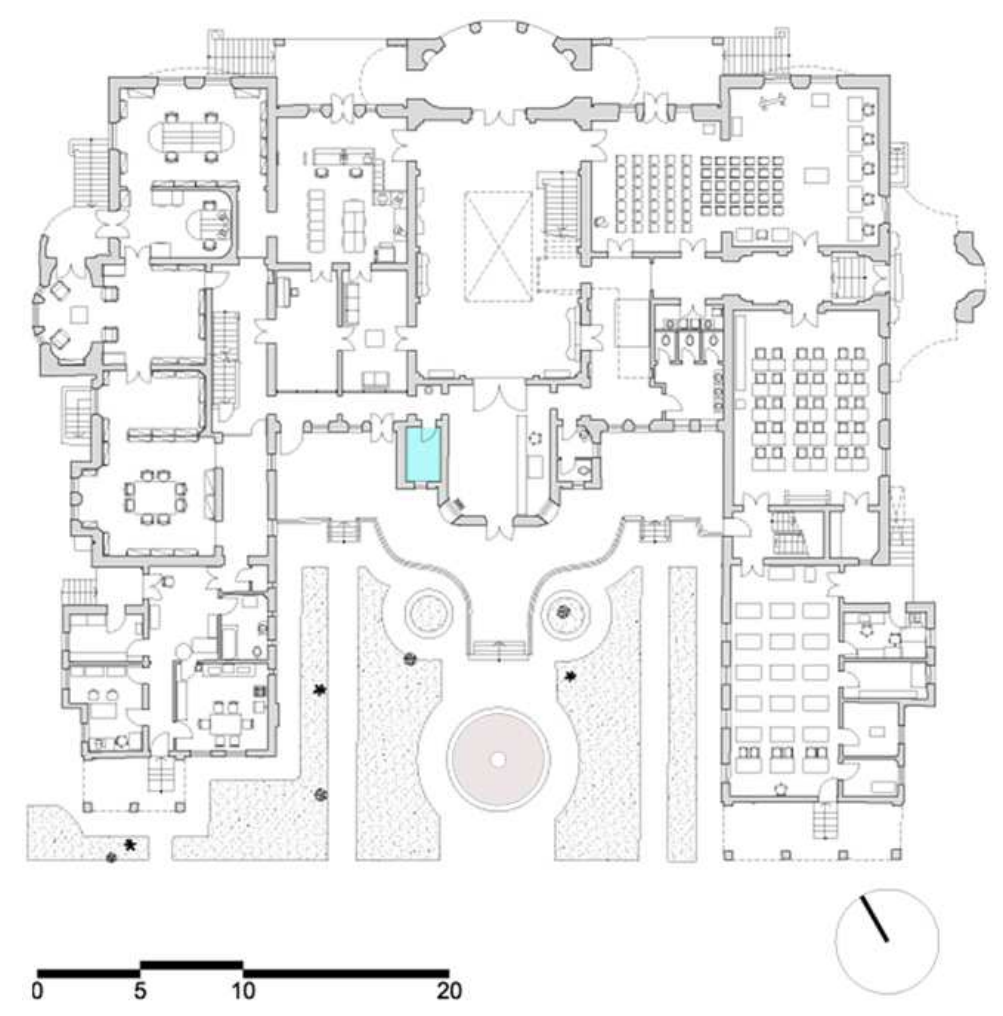

Figura 138 - Planta do Pav. Térreo (localização do sanitário masculino a reformar) Fonte: Desenho apresentado no Relatório de Gestão de 2006 da Vila Penteado. 

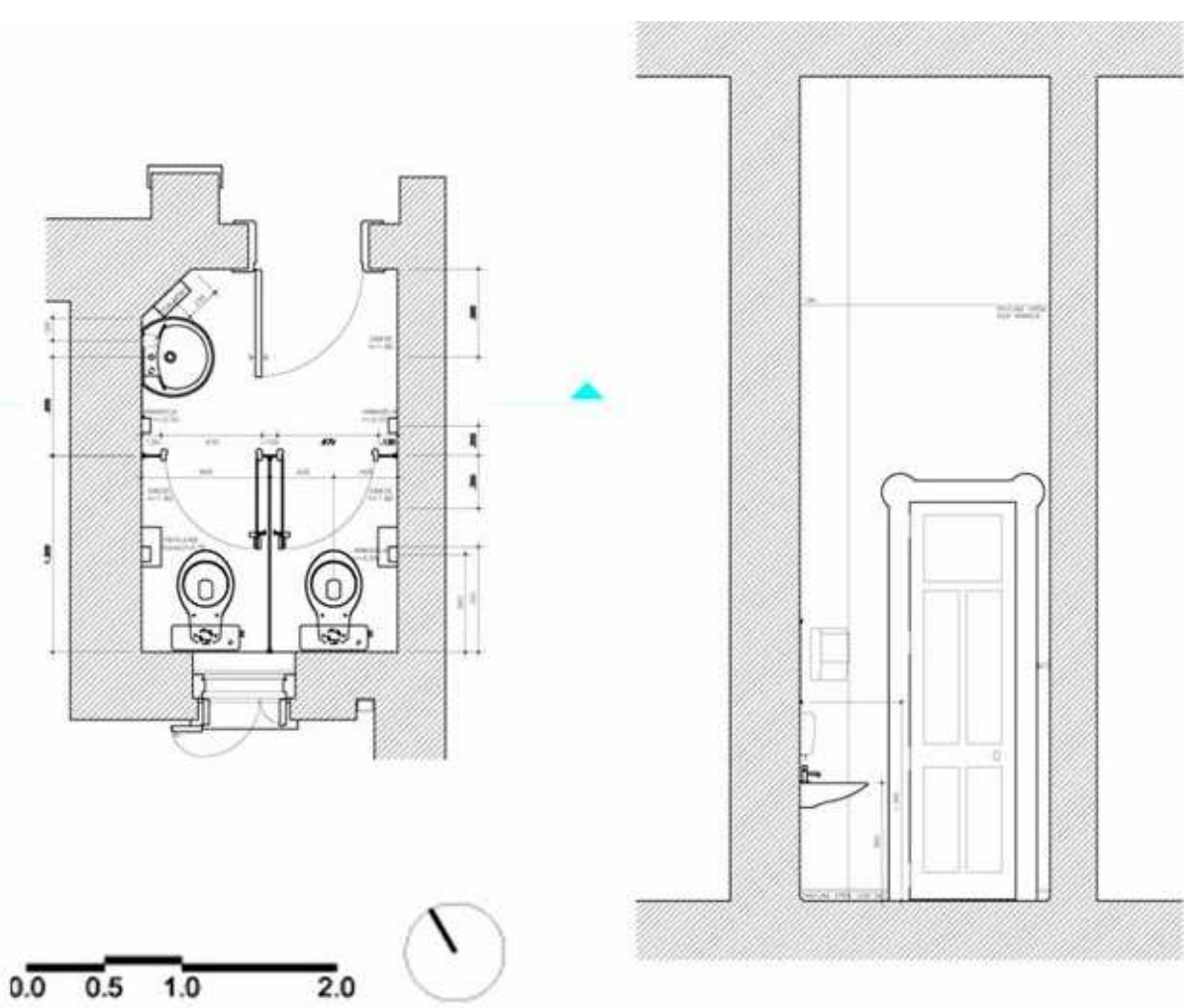

Figura 139 - Planta do Sanitário Masculino a reformar

Fonte: Prancha 01/04, FAU Maranhão, Sanitários, Planta - à construir, Projeto Helena Ayoub Silva e Antonio Carlos Barossi, Desenho João Osinski, Escala 1:20, data 2005. GEEF, FAU/ CUASO.

Desenho apresentado no Relatório de Gestão de 2006 da Vila Penteado.

Nas pranchas de detalhamento da reforma dos sanitários constam as seguintes observações:

1. Todas as medidas serão verificadas na obra;

2. Todos os azulejos existentes serão removidos;

3. As paredes serão lixadas ou apicoadas, e tratadas para receber acabamento em resina epóxi autonivelante Âncora cor branca Artcolor;

4. O piso será quebrado onde necessário para completa substituição das instalações hidráulicas existentes;

5. A recomposição dos trechos de piso quebrado será feita com massa fina sem cal e deverá observar os cuidados para receber acabamento em resina epóxi;

6. Todo o piso existente (remanescente e recomposto) será lixado e preparado para receber acabamento em resina epóxi autonivelante Âncora cor mel (padrão FAU) Artcolor;

7. O piso novo do banheiro se estende até a soleira. ${ }^{104}$

Nas pranchas há ainda informações tabeladas (ver tabelas 2, 3 e 4) quantificando os revestimentos, divisórias, louças, metais e acessórios.

${ }^{104}$ Prancha 01/04, FAU Maranhão, Sanitários, Planta - à construir, Projeto Helena Ayoub Silva e Antonio Carlos Barossi, Desenho João Osinski, Escala 1:20, data 2005. GEEF, FAU/ CUASO. 


\begin{tabular}{|c|c|c|}
\hline PISO & $\begin{array}{l}\text { PINTURA EPÓXI AUTONIVELANTE } \\
\text { tipo ÂNCORA cor mel (padrăo FAU) }\end{array}$ & $4,8 \mathrm{~m} 2$ \\
\hline \multirow[t]{2}{*}{ REVESTIMENTOS } & $\begin{array}{l}\text { PINTURA EPÓXI AUTONIVELANTE } \\
\text { tlpo ÂNCORA cor branca }\end{array}$ & $29,5 \mathrm{~m} 2$ \\
\hline & CAL & $13,1 \mathrm{~m} 2$ \\
\hline \multirow[t]{11}{*}{$\begin{array}{l}\text { DIVISÓRIAS } \\
\text { NEOCON OU FALCO }\end{array}$} & $\begin{array}{l}\text { LAMINADO MELAMINIICO ESTRUTURAL tlpo FÓRMICA TS espessura } 10 \mathrm{~mm} \\
\text { ACABAMENTO NAS DUAS FACES, COR BRANCO POLAR L190 - TX }\end{array}$ & \\
\hline & FRENTE (tlpo 1) $10 \times 180$ & 1 PEÇA \\
\hline & FRENTE (t|po 2) $13 \times 180$ & 2 PEÇAS \\
\hline & $\begin{array}{l}\text { LATERAIS } 130 \times 165 \\
\text { VERIFICAR RECORTE PRÓXIMO À JANELA }\end{array}$ & 1 PEÇA \\
\hline & PORTA $60 \times 165$ & 2 PEÇAS \\
\hline & $\begin{array}{l}\text { MONTANTES } \\
\mathrm{h}=180 \mathrm{CM}\end{array}$ & 4 PEÇAS \\
\hline & & 18 PEÇAS \\
\hline & $\begin{array}{l}\text { BOTÃO COM ENCAIXE EM FENDA - ACABAMENTO CROMADO } \\
\text { com chumbador para parede }\end{array}$ & 3 PEÇAS \\
\hline & $\begin{array}{l}\text { BOTÃO COM ENCAIXE EM FENDA - ACABAMENTO CROMADO } \\
\text { com chumbador para dlvisórla }\end{array}$ & 8 PEÇAS \\
\hline & $\begin{array}{l}\text { DOBRADIÇA COM PARADA } 15^{\circ} \text { - ACABAMENTO CROMADO } \\
\text { padrä́o fornecedor }\end{array}$ & XPEÇAS \\
\hline & $\begin{array}{l}\text { FECHO com TARJETA LIVRE-OCUPADO - ACABAMENTO CROMADO } \\
\text { com chumbador para dlvisórla }\end{array}$ & 2 PEÇAS \\
\hline
\end{tabular}

Tabela 3 - Tabela de Pisos/ Revestimentos/ Divisórias (Sanitário Masculino a reformar no Pavimento Térreo)

Fonte: Prancha 01/04, FAU Maranhão, Sanitários, Planta - à construir, Projeto Helena Ayoub Silva e Antonio Carlos Barossi, Desenho João Osinski, Escala 1:20, data 2005. GEEF, FAU/ CUASO.

\begin{tabular}{|c|c|c|}
\hline \multirow[t]{2}{*}{ LOUÇAS } & $\begin{array}{l}\text { BACIA SUSPENSA Ilnha NUOVA P132 } \\
\text { t|po DECA ou sIm|lar - COR BRANCA }\end{array}$ & 9 PEÇAS \\
\hline & $\begin{array}{l}\text { LAVATÓRIO E COLUNA SUSPENSA Ilnha NUOVA L13 e CS1 } \\
\text { tlpo DECA ou sImllar - COR BRANCA }\end{array}$ & 8 PEÇAS \\
\hline \multirow[t]{2}{*}{ METAIS } & $\begin{array}{l}\text { TORNEIRA PARA LAVATÓRIO tlpo DOCOL PRESSMATIC } 110 \text { ref } 17160806 \text { CROMADA } \\
\text { as tornelras exIstentes (com essa espec|flcaçăo) em bom estado serăo mant|las }\end{array}$ & 8 PEÇAS \\
\hline & $\begin{array}{l}\text { ACABAMENTO PARA REGISTROS } \\
\text { tlpo DECA LINHA PRATA C50 ou slmllar - CROMADA }\end{array}$ & 9 PEÇAS \\
\hline
\end{tabular}

Tabela 4 - Tabela de Louças/ Metais (Sanitário Masculino a reformar no Pavimento Térreo)

Fonte: Prancha 01/04, FAU Maranhão, Sanitários, Planta - à construir, Projeto Helena Ayoub Silva e Antonio Carlos Barossi, Desenho João Osinski, Escala 1:20, data 2005. GEEF, FAU/ CUASO.

\begin{tabular}{|l|l|r|}
\hline & & \\
\hline ACESSÓRIOS & $\begin{array}{l}\text { ESPELHO - VIDRO TEMPERADO } 6 \mathrm{~mm} \\
500 \times 998 \mathrm{~mm}\end{array}$ & 10 PEÇAS \\
\hline & $\begin{array}{l}\text { BARRA PARA PORTA DEFICIENTE FISICO - flxação no palnel TS } \\
\text { ComprImento 65 cm - dlametro 40 mm - CROMADA }\end{array}$ & 40 PEÇAS \\
\hline & $\begin{array}{l}\text { CABIDE } \\
\text { tipo DOCOL linha VALENCIA 1206 ou similar CROMADA }\end{array}$ & 1 PEÇAS \\
\hline & $\begin{array}{l}\text { SABONETEIRA DE PAREDE - MICRO SPRAY } \\
\text { tlpo LALEKLA 44340 Ou SIMILAR - cor BRANCA }\end{array}$ & 1 PEÇAS \\
\hline & $\begin{array}{l}\text { TOALHEIRO DE PAREDE } \\
\text { tlpo LALEKLA 44110 Ou SIMILAR - cor BRANCA }\end{array}$ & 17 PEÇAS \\
\hline & $\begin{array}{l}\text { PAPELEIRA DE PAREDE } \\
\text { tlpo LALEKLA 44265 Ou SIMILAR - cor BRANCA }\end{array}$ & \\
\hline
\end{tabular}

Tabela 5 - Tabela de Acessórios (Sanitário Masculino a reformar no Pavimento Térreo) Fonte: Prancha 01/04, FAU Maranhão, Sanitários, Planta - à construir, Projeto Helena Ayoub Silva e Antonio Carlos Barossi, Desenho João Osinski, Escala 1:20, data 2005. GEEF, FAU/ CUASO. 
Os desenhos das figuras 140 e 141 referem-se ao projeto de reforma do Sanitário do Pavimento Térreo, ver a localização desse ambiente na planta a seguir.

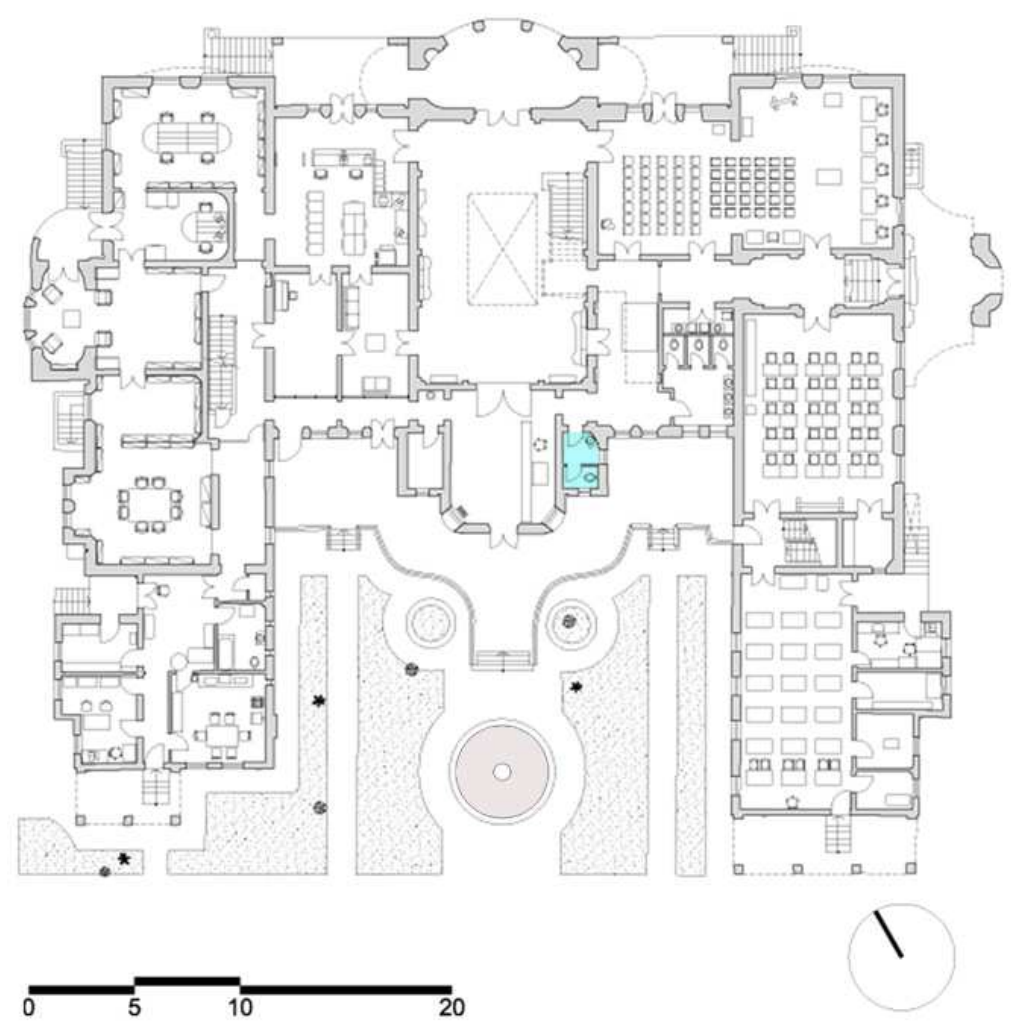

Figura 140 - Planta do Pav. Térreo (localização do sanitário a reformar) Fonte: Desenho apresentado no Relatório de Gestão de 2006 da Vila Penteado.
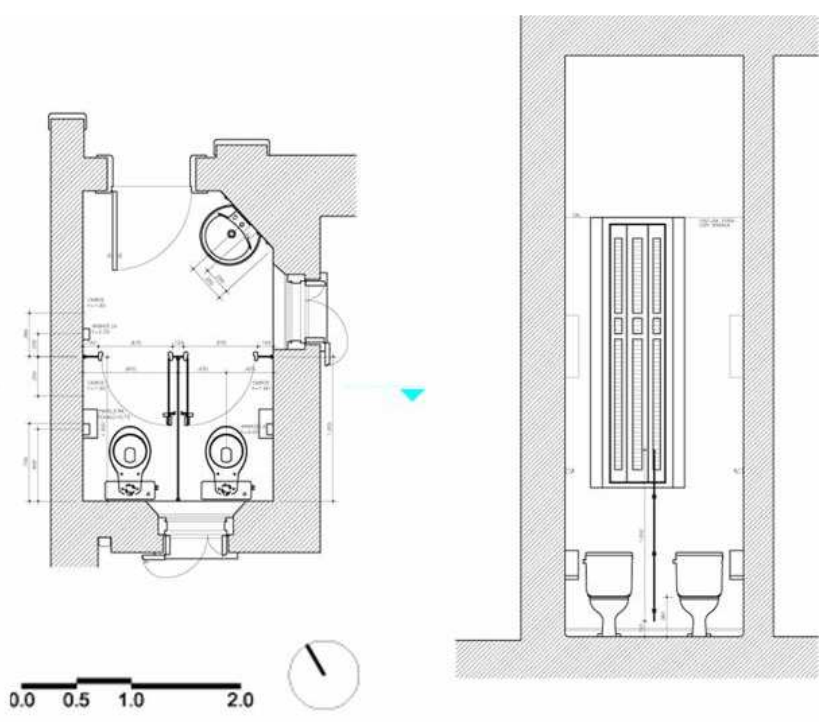

Figura 141 - Planta do Sanitário a reformar

Fonte: Prancha 02/04, FAU Maranhão, Sanitários, Planta - à construir, Projeto Helena Ayoub Silva e Antonio Carlos Barossi, Desenho João Osinski, Escala 1:20, data 2005. GEEF, FAU/ CUASO.

Desenho apresentado no Relatório de Gestão de 2006 da Vila Penteado. 
O Pavimento Térreo contará ainda com um sanitário unissex acessível, conforme é possível verificar nos dois desenhos das figuras 142 e 143.

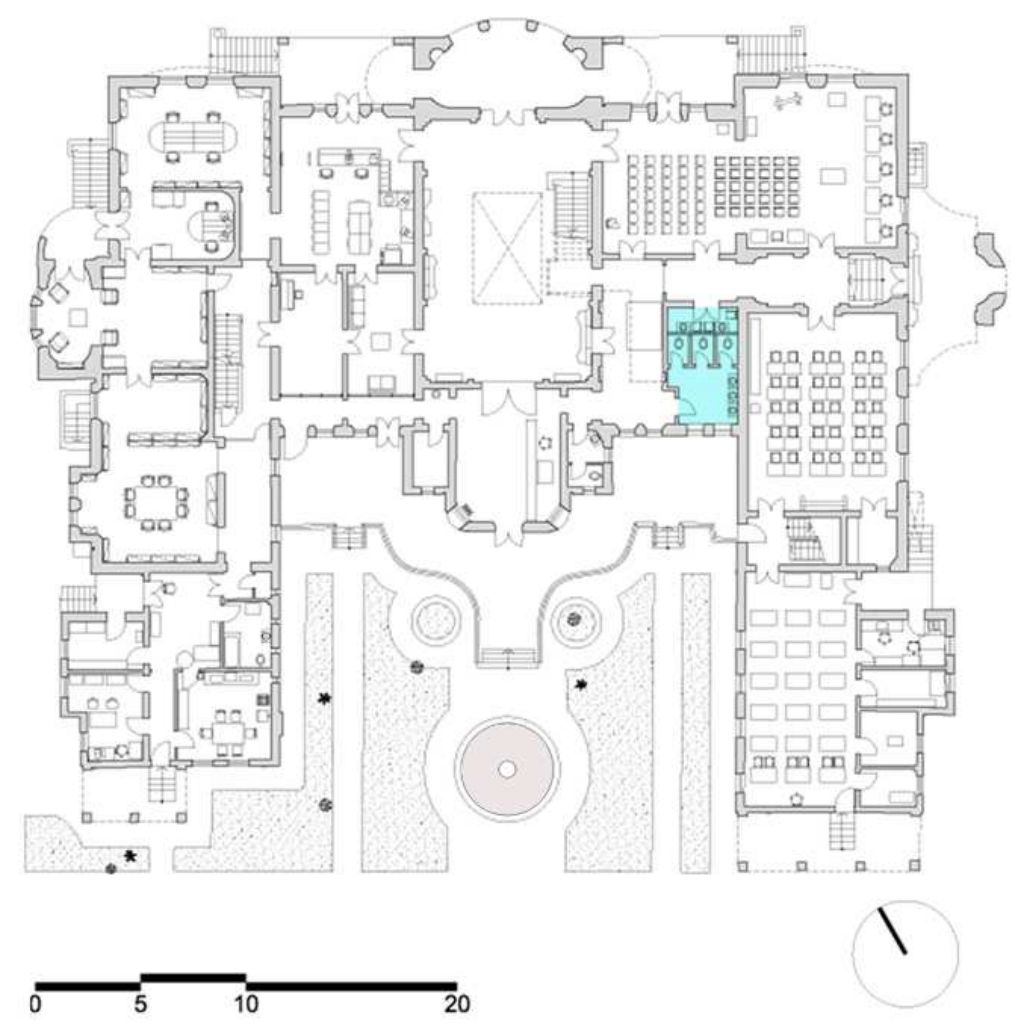

Figura 142 - Planta do Pav. Térreo (localização do sanitário acessível a reformar) Fonte: Desenho apresentado no Relatório de Gestão de 2006 da Vila Penteado.

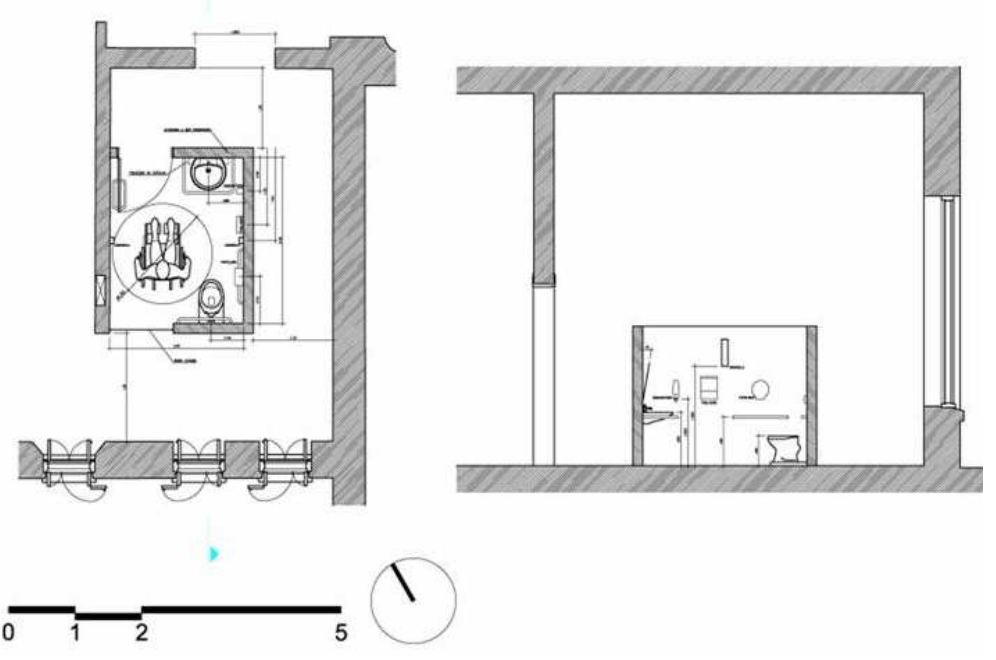

Figura 143 - Planta do Sanitário Feminino a reformar

Fonte: Sem Prancha, FAU Maranhão, Sanitários, Planta - à construir, Projeto Helena Ayoub Silva e Antonio Carlos Barossi, Desenho João Osinski, Escala 1:20, data 2005. GEEF, FAU/ CUASO.

Desenho apresentado no Relatório de Gestão de 2006 da Vila Penteado. 
Os desenhos das figuras 144 a 147 correspondem aos sanitários a reformar no Pavimento Superior.

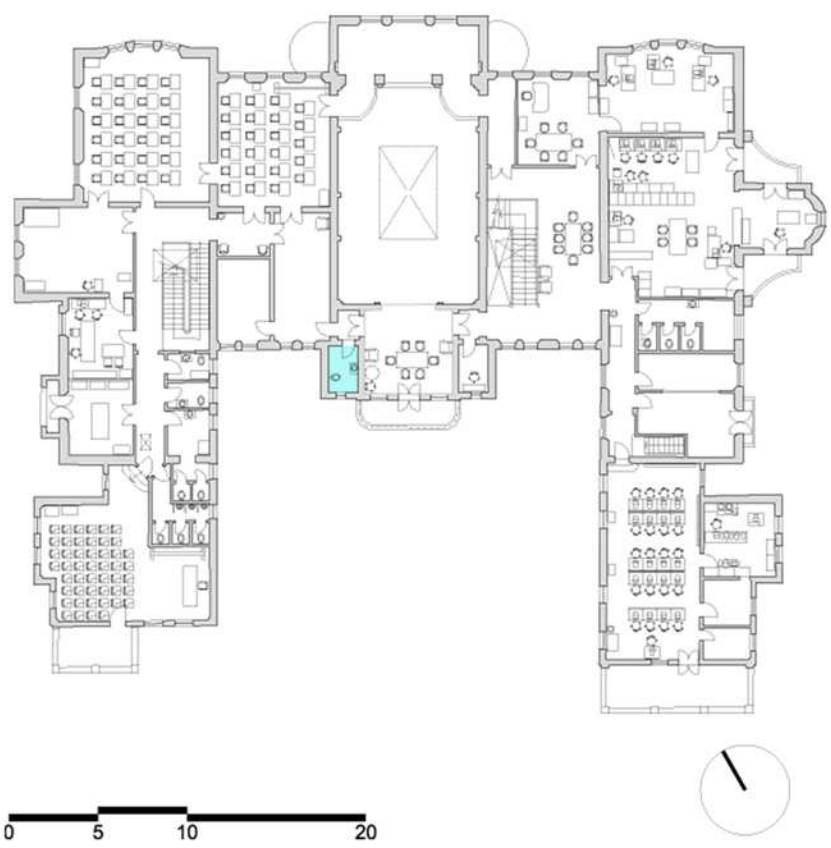

Figura 144 - Planta do Pav. Superior (localização do sanitário masculino a reformar) Fonte: Desenho apresentado no Relatório de Gestão de 2006 da Vila Penteado.

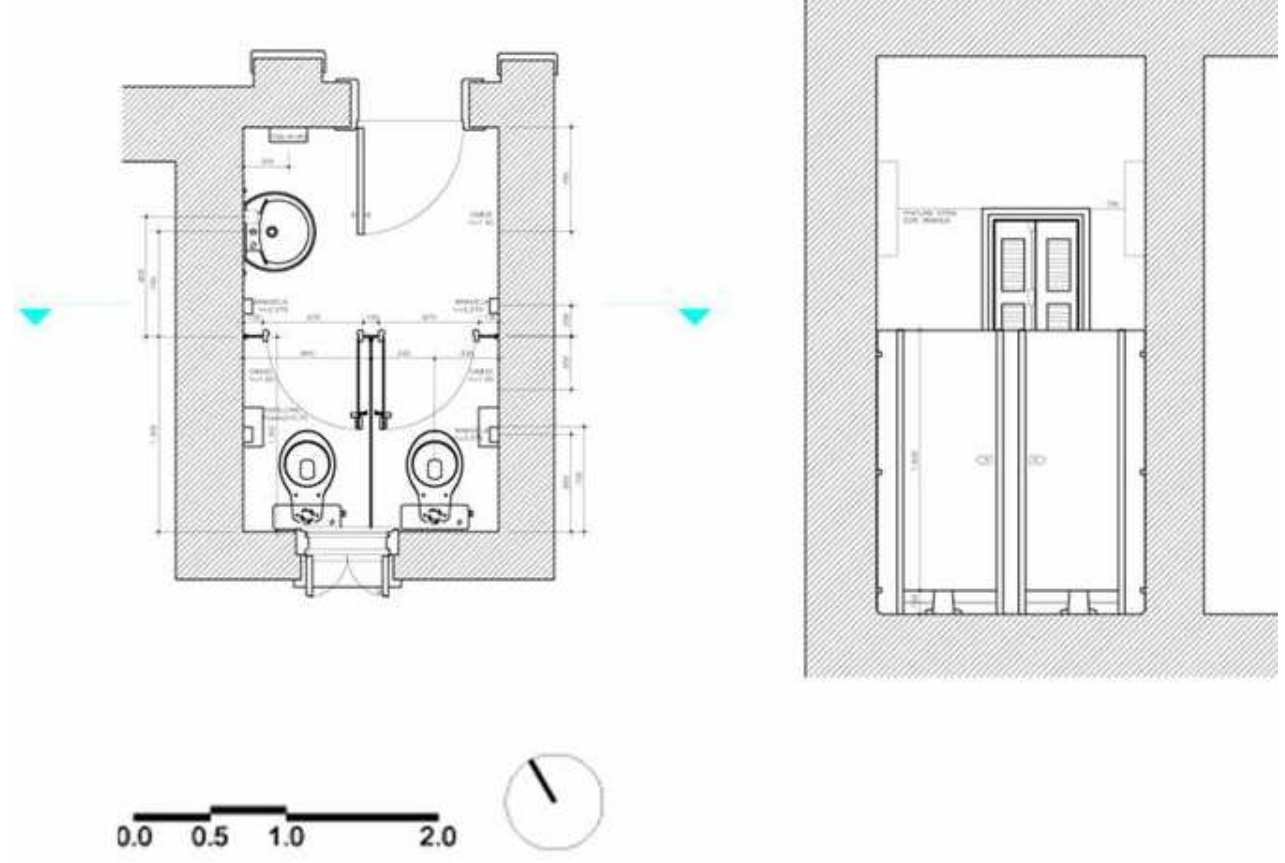

Figura 145 - Planta do Sanitário Masculino a reformar

Fonte: Prancha 3/4, FAU Maranhão, Sanitários, Planta - à construir, Projeto Helena Ayoub Silva e Antonio Carlos Barossi, Desenho João Osinski, Escala 1:20, data 2005. GEEF, FAU/ CUASO.

Desenho apresentado no Relatório de Gestão de 2006 da Vila Penteado. 


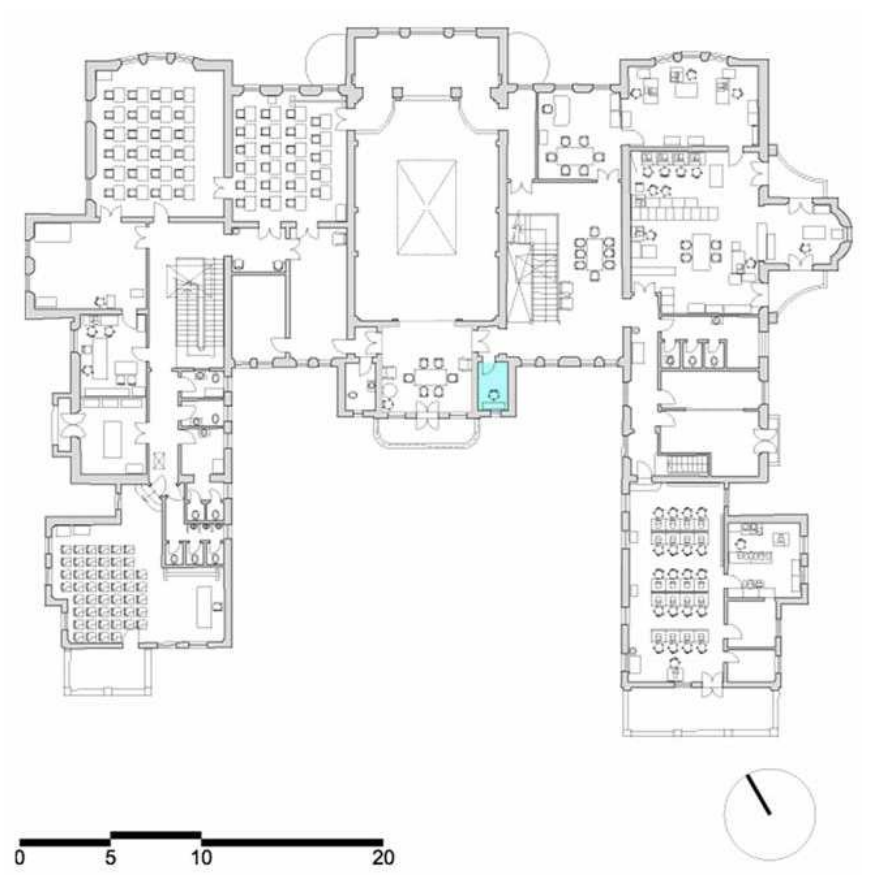

Figura 146 - Planta do Pav. Superior (localização do sanitário feminino a reformar) Fonte: Desenho apresentado no Relatório de Gestão de 2006 da Vila Penteado.
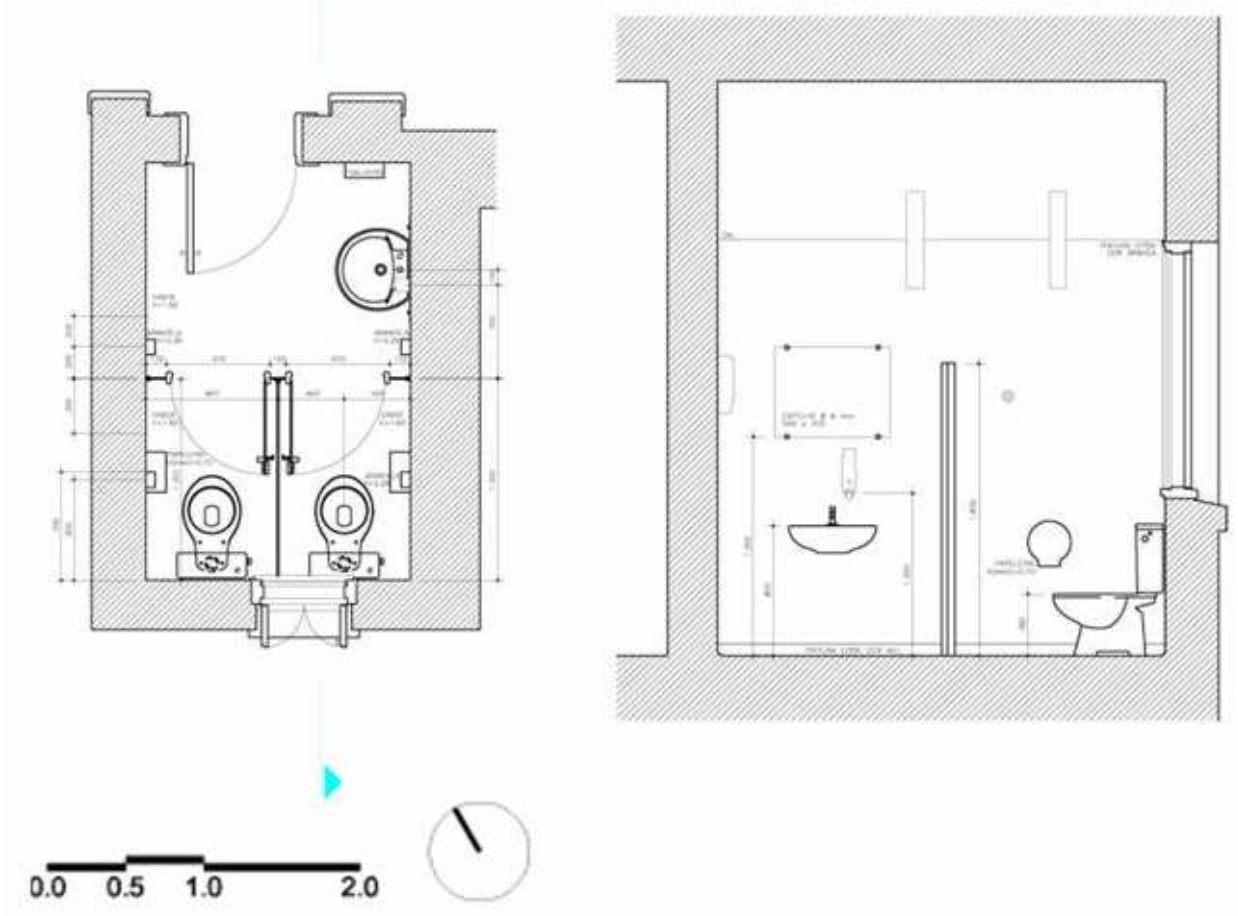

Figura 147 - Planta do Sanitário Feminino a reformar Fonte: Prancha 4/4, FAU Maranhão, Sanitários, Planta - à construir, Projeto Helena Ayoub Silva e Antonio Carlos Barossi, Desenho João Osinski, Escala 1:20, data 2005. GEEF, FAU/ CUASO.

Desenho apresentado no Relatório de Gestão de 2006 da Vila Penteado. 


\subsubsection{PROJETO DE PAISAGISMO}

O Projeto de Paisagismo foi desenvolvido preliminarmente e passou por consultas e discussão com a comunidade, conforme relata o Relatório de Gestão de 2003 da Vila Penteado.

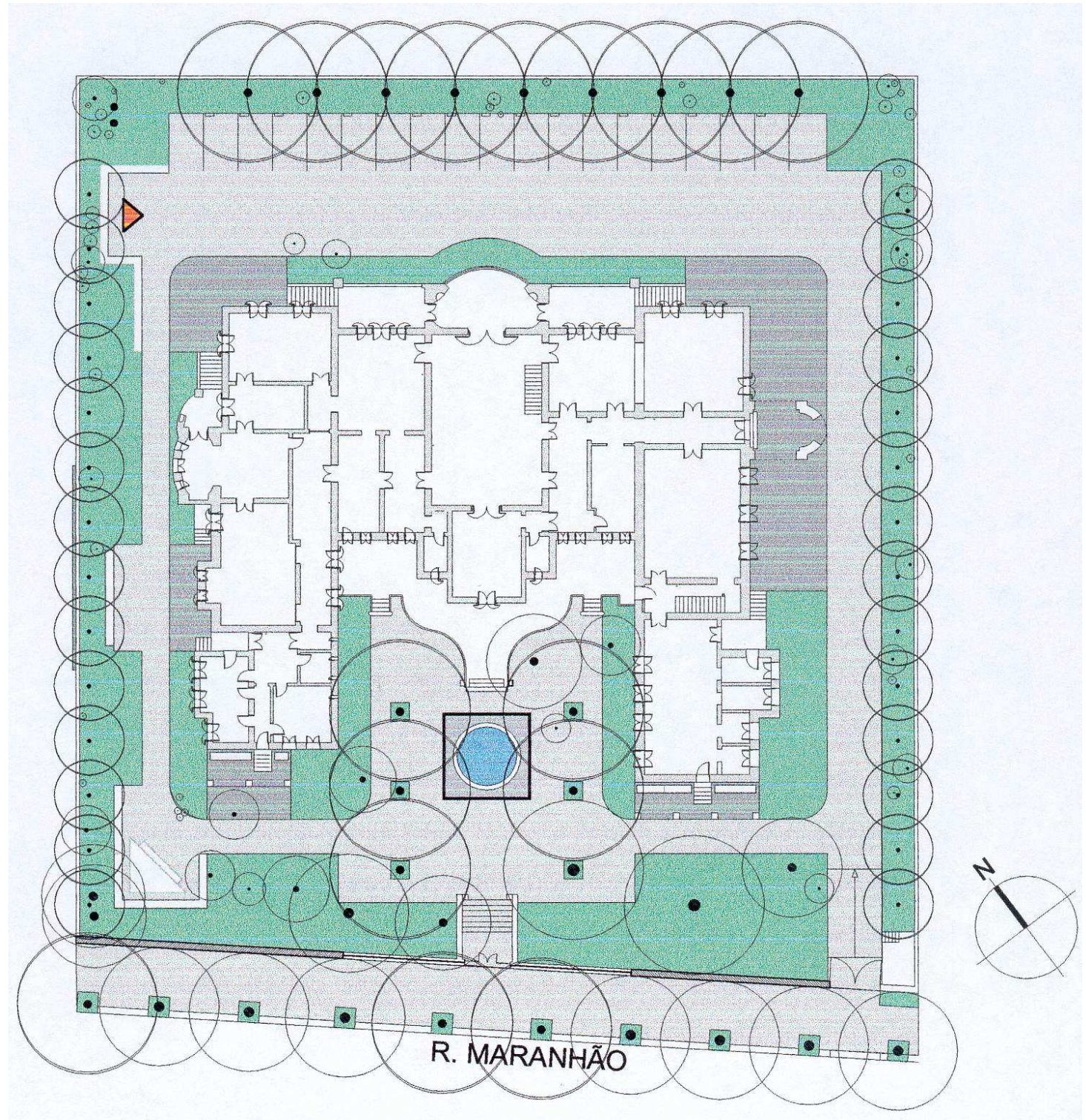

Figura 148 - Implantação com Estudo Preliminar do Projeto de Paisagismo Fonte: Prancha 1/1, USP - Faculdade de Arquitetura e Urbanismo, FAU - Maranhão, Rua Maranhão, 88 - Higienópolis - S.P. Paisagismo - Estudo Preliminar, Desenho Marcelo Kussunoki, Escala 1:200, Data: junho/2003. Projeto Paisagístico: Raul Pereira Arquitetos Associados.

Desenho apresentado no Relatório de Gestão de 2003 da Vila Penteado.

O Relatório de Gestão de 2003 apresenta ainda duas perspectivas (ver figuras 149 e 150) para melhor entendimento deste projeto. 


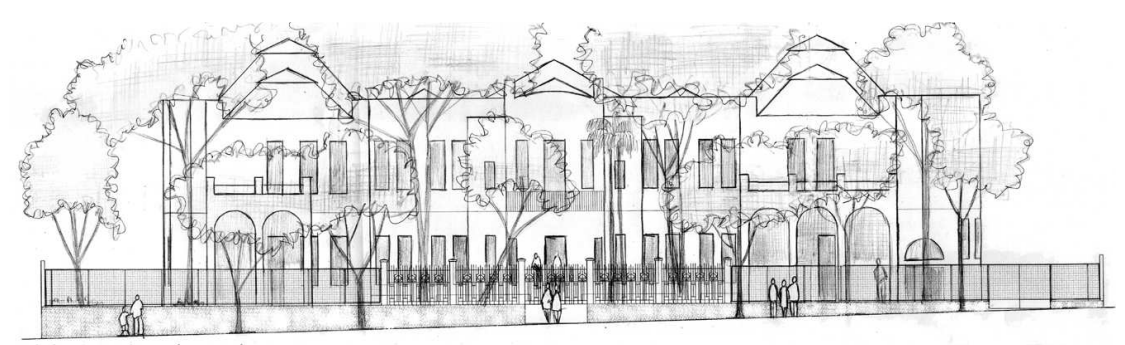

Figura 149 - Elevação Frontal da Vila Penteado, Estudo Preliminar do Projeto de Paisagismo

Fonte: Desenho apresentado no Relatório de Gestão de 2003 da Vila Penteado.

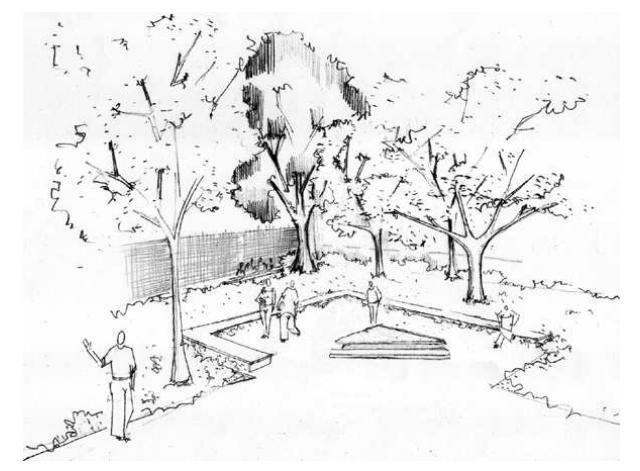

Figura 150 - Perspectiva, Estudo Preliminar do Projeto de Paisagismo Fonte: Desenho apresentado no Relatório de Gestão de 2003 da Vila Penteado.

A partir das consultas, o projeto foi revisado. Em 11 de outubro de 2006, o mesmo recebeu aprovação em reunião do Conselho Curador. O projeto foi aprovado por unanimidade pelos membros presente, sendo eles: Prof. Dr. Ricardo Toledo, Prof. Dr. Benedito Lima, $\operatorname{Prof}^{\mathrm{a}} \operatorname{Dr}^{\mathrm{a}}$ Maria Ângela Faggin, $\operatorname{Prof}^{\mathrm{a}} \operatorname{Dr}^{\mathrm{a}}$ Helena, $\operatorname{Prof}^{\mathrm{a}} \operatorname{Dr}^{\mathrm{a}}$ Cristina Leme, Prof. Dr. Antônio Carlos Barossi, Prof. Dr. Margarido e Prof. Dr. Wilson Jorge. No relatório da reunião as seguintes considerações foram relacionadas:

Foi aprovado:

- O projeto deve manter a grade original na fachada principal.

- O atual muro da fachada principal deve ser substituído por vidro temperado, a partir do nível do jardim.

- O muro das laterais e do fundo deve receber um complemento de uma chapa metálica perfurada.

- O estacionamento deve ter no mínimo 20 vagas.

- O piso a ser implantado é o intertravado, cor cinza e a disposição tipo "espinha de peixe".

- A calçada da rua maranhão deve também receber o piso intertravado. - A fonte deve ser restaurada, impermeabilizada e também deve ser instalada uma bomba de água com fluxo de retorno. ${ }^{105}$

${ }^{105}$ Trecho extraído do Relatório da Reunião do Conselho Curador datada em 11 de outubro de 2006, página única. 
Esse relatório ainda ressalta a necessidade do detalhamento do projeto e a sua aprovação junto ao CONDEPHAT, sendo que até o momento o projeto não foi encaminhado para esse órgão. "Obs: De acordo com o combinado este ante-projeto deve ser mais detalhado e encaminhado ao GEEF para analise geral. Posteriormente deve ser encaminhado ao CONDEPHAT." ${ }^{106}$

As figuras 151 e 152 apresentam duas das quatro pranchas que compõe 0 Projeto de Paisagismo aprovado. A primeira prancha do projeto, constante nesse trabalho, contempla a implantação com novo traçado do jardim. Inclui também pontos de iluminação sem definições de luminária e lâmpadas, considerados no projeto como "luminárias existentes". A segunda prancha traz a localização e identificação das espécies que deverão ser plantadas, conforme esse projeto. A terceira prancha, também inclusa nesse trabalho, apresenta a nova configuração dos gradis da fachada frontal, com a inclusão de área em chapa metálica perfurada pintada. A quarta e última prancha do Projeto de Paisagismo apresenta uma alternativa ao muro, com execução em taipa. Apresenta também o mobiliário, com algumas opções para os bancos das áreas externas ajardinadas.

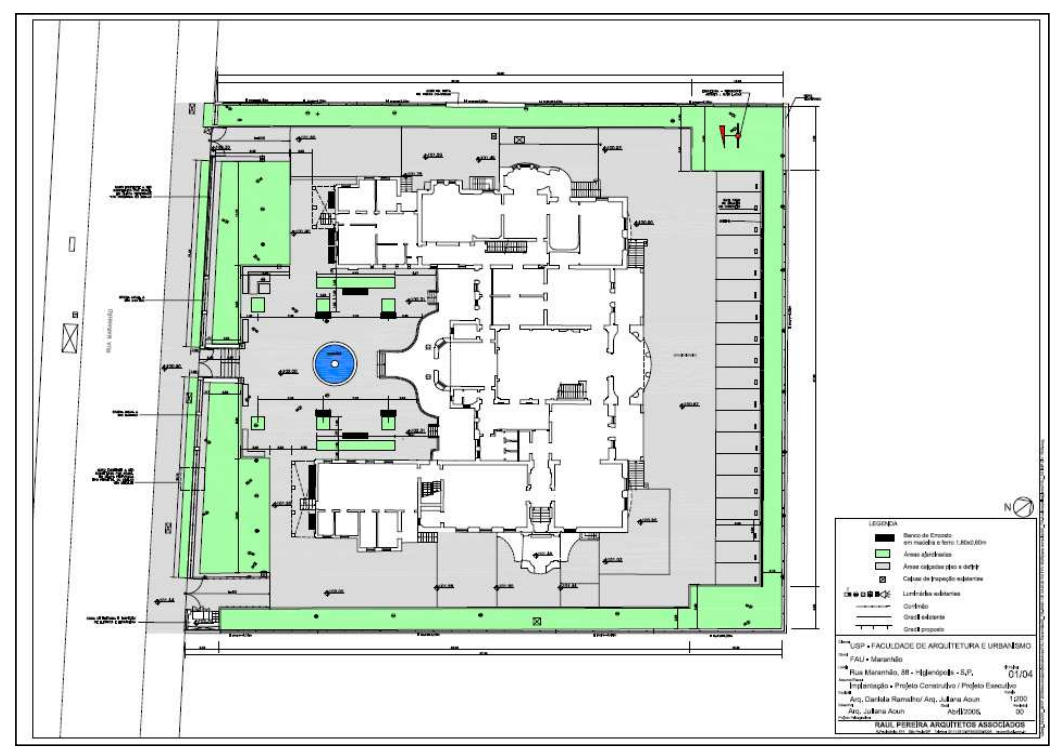

Figura 151 - Implantação do Projeto de Paisagismo

Fonte: Prancha 01/04, USP - Faculdade de Arquitetura e Urbanismo, FAU - Maranhão, Rua Maranhão, 88 - Higienópolis - S.P. Implantação - Projeto Construtivo/ Projeto Executivo, Equipe Arq $^{a}$ Daniela Ramalho/ Arq $^{a}$ Juliana Aoun. Desenho Arq ${ }^{a}$ Juliana Aoun, Escala 1:200, Data: abril/2006, Revisão 00. Projeto Paisagístico: Raul Pereira Arquitetos Associados.

${ }^{106}$ Trecho extraído do Relatório da Reunião do Conselho Curador datada em 11 de outubro de 2006, página única. 


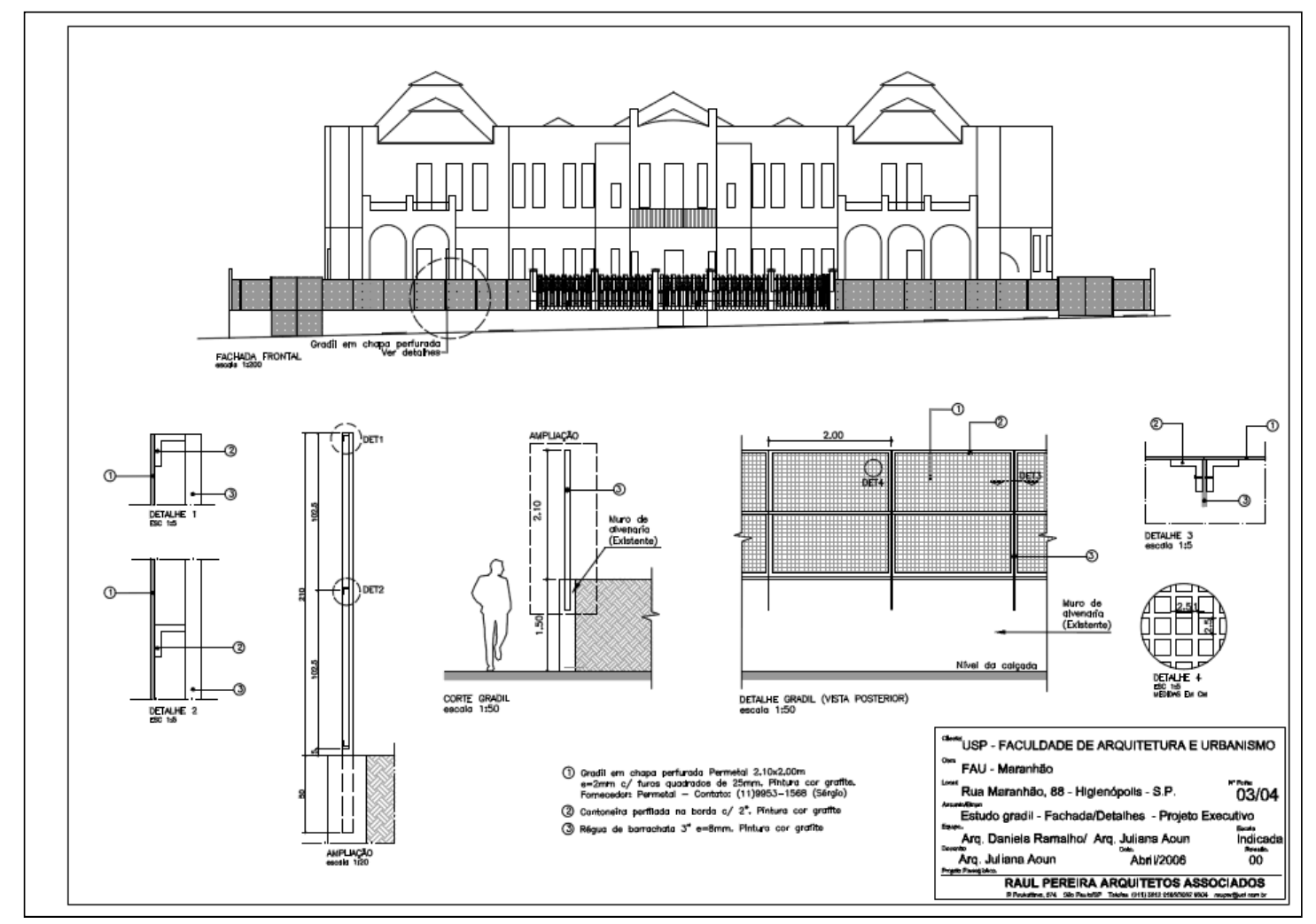

Figura 152 - Estudo Gradil, Projeto de Paisagismo

Fonte: Prancha 03/04, USP - Faculdade de Arquitetura e Urbanismo, FAU - Maranhão, Rua Maranhão, 88 - Higienópolis - S.P. Estudo gradil - Fachada/ Detalhes - Projeto Executivo, Equipe Arq $^{a}$ Daniela Ramalho/ Arq $^{a}$ Juliana Aoun. Desenho Arq ${ }^{a}$ Juliana Aoun, Escala Indicada, Data: abril/2006, Revisão 00. Projeto Paisagístico: Raul Pereira Arquitetos Associados. 


\subsubsection{PROJETO DE INSTALAÇÕES ELÉTRICAS}

O Projeto de Instalações Elétricas partiu do seguinte conceito: as novas instalações devem ser aparentes e destacadas das superfícies existentes (tanto paredes quanto forros). Conforme apresentado no desenho da figura 153.

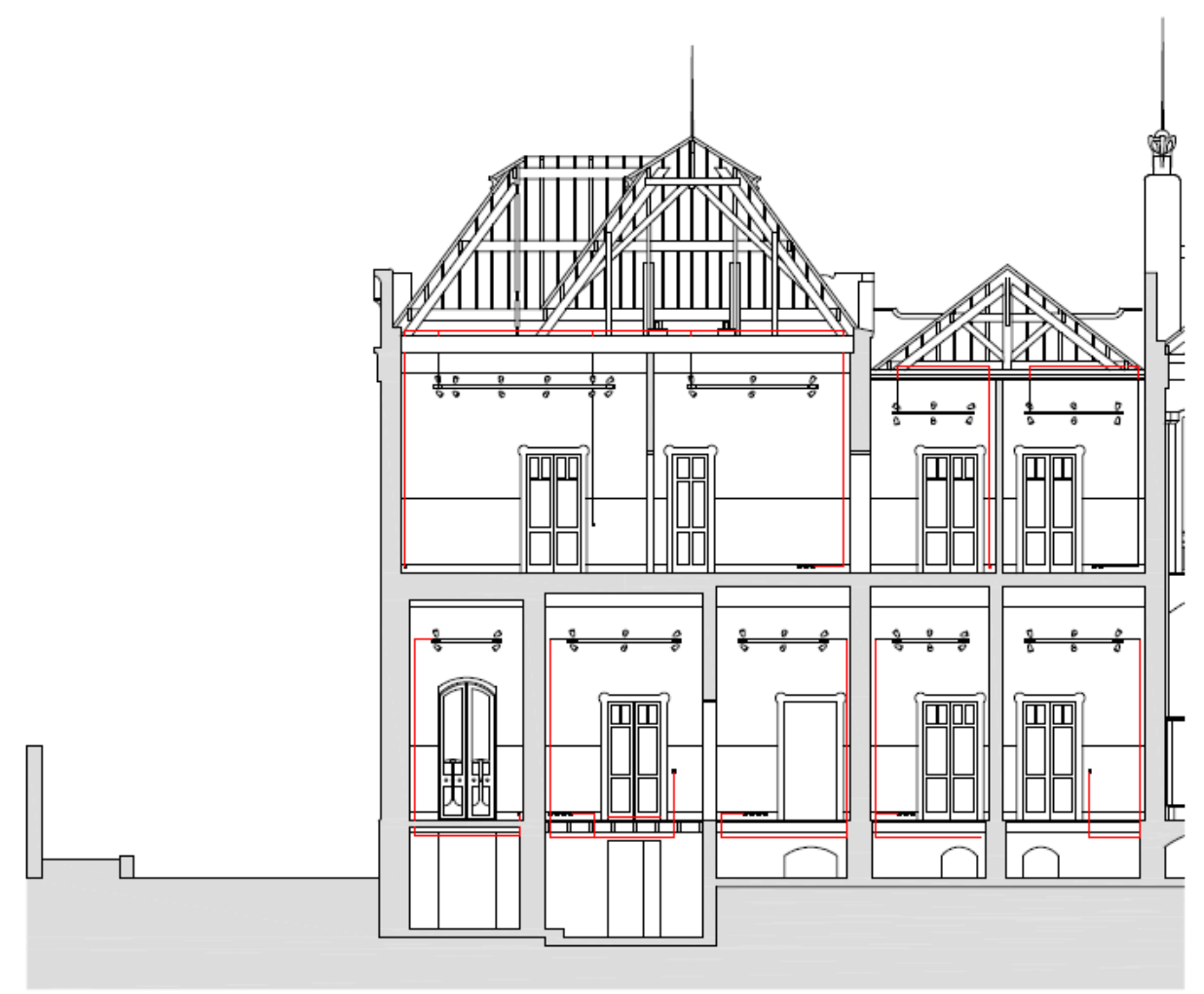

Figura 153 - Esquema do Novo Conceito de lluminação

Fonte: Prancha A-12/12, Universidade de São Paulo, Faculdade de Arquitetura e Urbanismo, Edifício Vila Penteado, Corte 2, junho de 2004, Escala 1:250, Estagiários Pedro Saito, Rafael Ramos e Vanezza Grossman.

Desenho apresentado no Relatório de Gestão de 2006 da Vila Penteado.

A iluminação deve ser independente do forro, sendo suspensa por perfilados e esta fixa a estrutura acima do forro por tirantes ou perfis metálicos. Haverá nova entrada de energia que alimenta o quadro geral localizado no porão. A partir desse quadro, todos os demais quadros de força e luz serão alimentados. O pavimento térreo deve ser alimentado pelo porão e o pavimento superior será alimentado através de trajeto encaminhado pelo sótão.

O conceito para a reforma das instalações elétricas foi apresentado no Relatório de Gestão da Vila Penteado de 2006. Nesse mesmo ano, o Projeto de Instalações Elétricas foi concluído pela Empresa Bim \& Alves Engenharia de 
Projetos Ltda, e foi aprovado junto ao CONPRESP e ao CONDEPHAAT mediante a apresentação de carta de diretrizes ${ }^{107}$ e desenhos esquemáticos indicativos.

A aprovação no CONPRESP foi publicada no Diário Oficial em 17 de junho de 2010 com o seguinte despacho:

Em sua reunião ordinária de 08 de junho de 2010, o colegiado do Conselho Municipal de preservação do Patrimônio Histórico, Cultural e Ambiental da Cidade de São Paulo - CONPRESP, com fundamento nos elementos constantes neste processo e considerando o parecer técnico do Departamento do Patrimônio Histórico e do Conselheiro Relator, manifestou-se favorável a reforma das instalações elétricas do imóvel conhecido como Vila Penteado, situado a Rua Maranhão, 88 - Higienópolis. Salientamos que deverá ser atendida toda a legislação edilícia incidente no local, bem como deverão ser consultados, se necessário, os órgãos de Preservação Estadual e Federal. ${ }^{108}$

A carta de diretrizes apresentada contém requisitos que devem ser atendidos pelo projeto, tais como a distribuição das instalações ser feita por eletrodutos $\mathrm{e}$ perfilados aparentes e destacadas das superfícies existentes, permitindo a leitura da arquitetura original distinta do novo sistema de instalações.

Traz ainda contribuições visando à organização dos projetos antes do início das contratações para as obras, tais como as constantes no item 4:

Item 4

A sugestão será incorporada em revisão do projeto a ser feita antes da licitação.

Observação:

Qualquer solução constante do projeto encaminhado e que não esteja de acordo com as descrições acima serão objeto de revisão antes da licitação. ${ }^{109}$

Em função das diretrizes que não estavam totalmente incorporadas no Projeto de Instalações Elétricas, já aprovado, foi necessário iniciar um levantamento dos pontos conflitantes, realizado pela $\mathrm{Arq}^{\mathrm{a}}$ Isis Roverso. Para tanto, a análise visual e fotográfica no local auxiliou esse trabalho e ainda as consultas aos desenhos

${ }^{107}$ Carta de diretrizes redigida em 21 de março de 2010, ao Conselho Municipal de Preservação do Patrimônio Histórico Cultural e Ambiental da Cidade de São Paulo - CONPRESP, Att. Sr. Walter Pires, Ref. Proc. 20090.336.619-0, Ofício oㅡ 0001/CONPRESP/2010.

${ }^{108}$ Situação do Processo 2009.0336619-0 Disponível em: <http://www3.prodam.sp.gov.br/simproc/navega.asp>. Acesso em: 26 jul. 2010.

${ }^{109}$ Carta de diretrizes redigida em 21 de março de 2010, ao Conselho Municipal de Preservação do Patrimônio Histórico Cultural e Ambiental da Cidade de São Paulo - CONPRESP, Att. Sr. Walter Pires, Ref. Proc. 20090.336.619-0, Ofício no 0001/CONPRESP/2010, p. 2. 
existentes da decoração das paredes internas e das fachadas. A conclusão dessa análise pode ser observada nos desenhos de levantamento de interferências apresentados nas figuras 154 a 158.

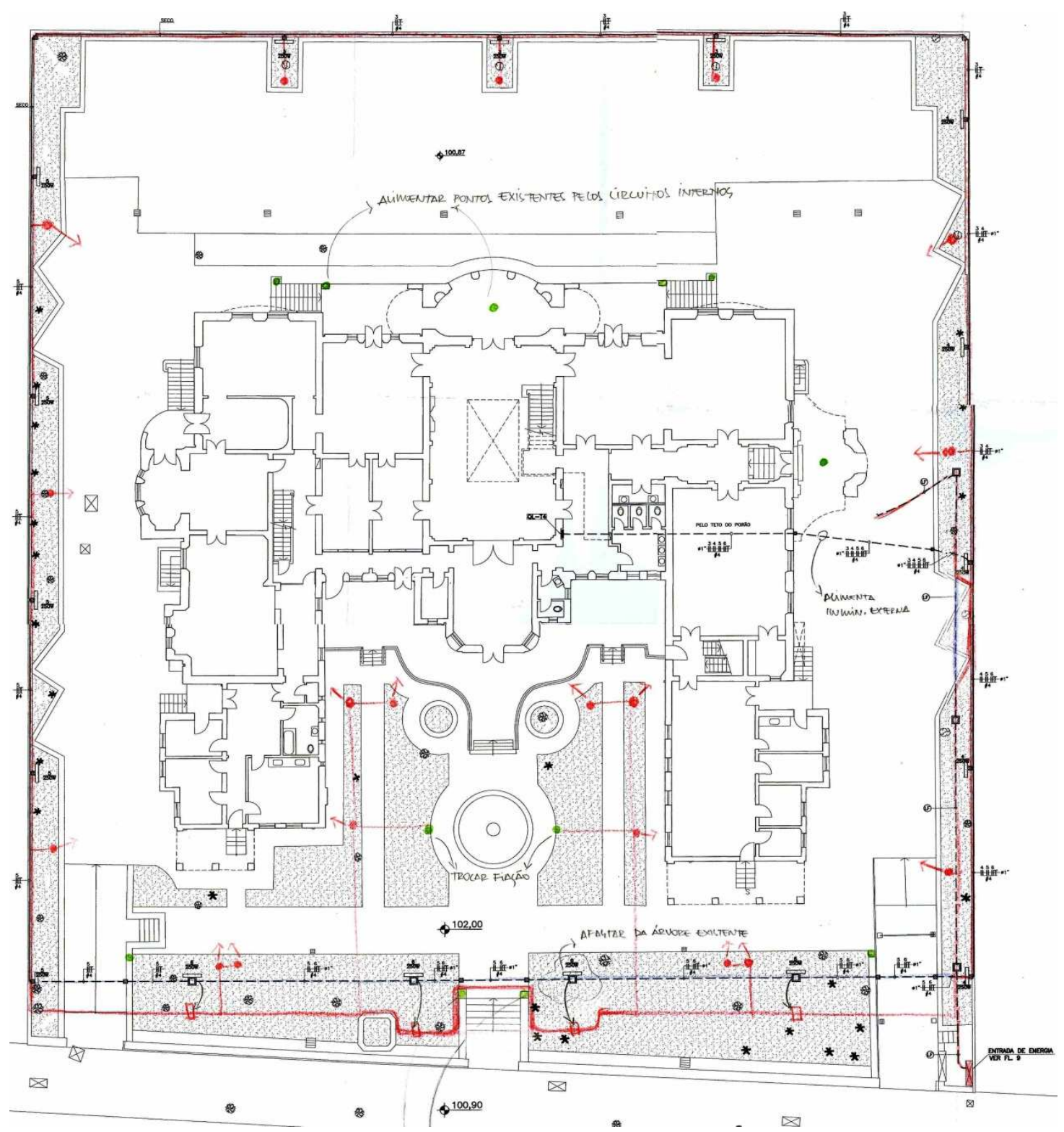

Figura 154 - Implantação do Edifício Vila Penteado

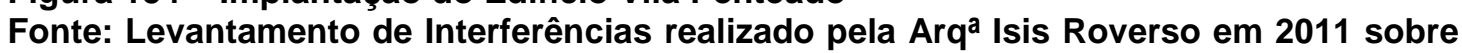
a base de desenho do Projeto de Instalações Elétricas da Empresa Bim \& Alves Engenharia de Projetos Ltda. 


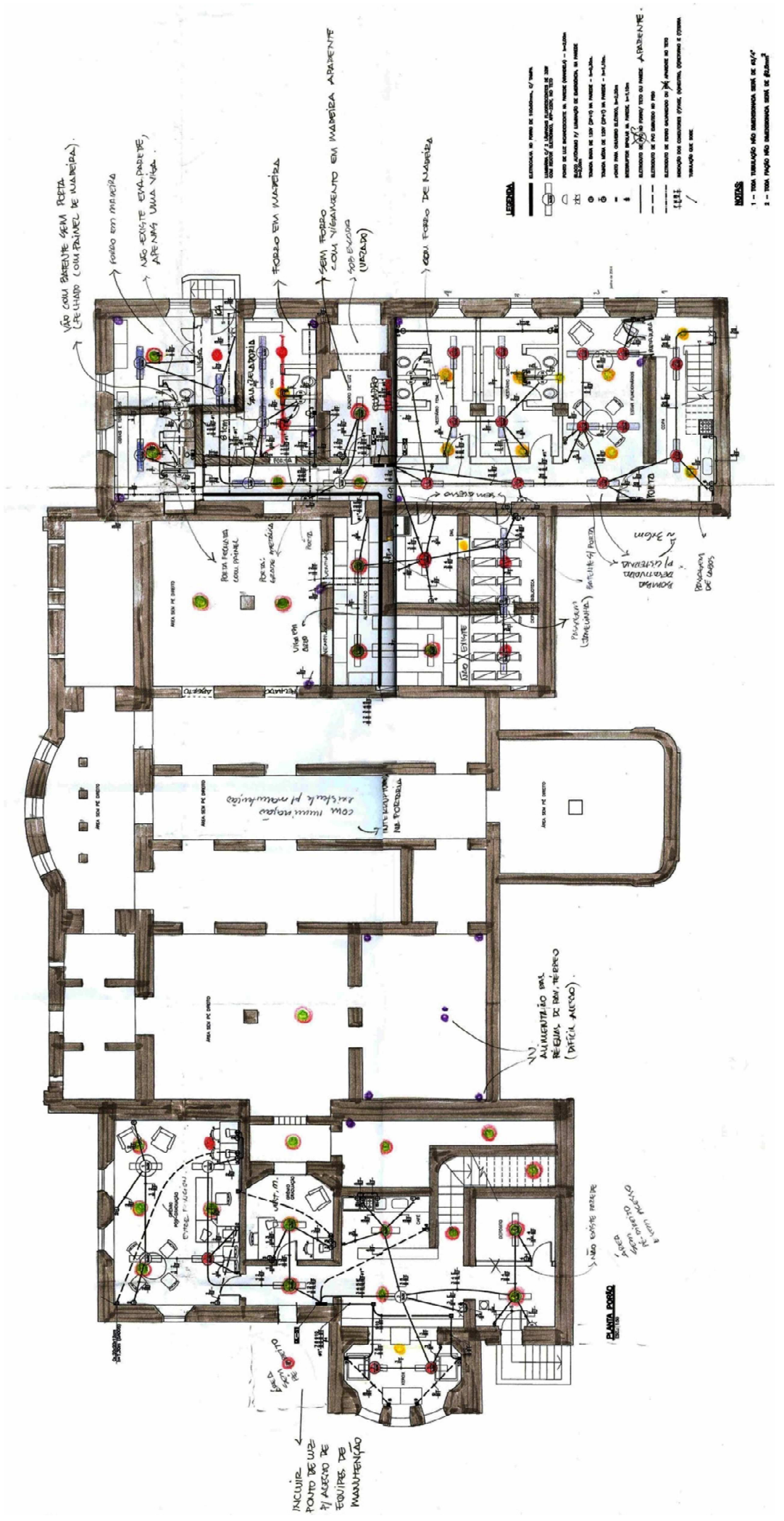

Figura 155 - Planta do Subsolo (Porão) do Edifício Vila Penteado Fonte: Levantamento de Interferências realizado pela Arq ${ }^{\mathrm{a}}$ Isis Roverso em 2011 sobre a base de desenho do Projeto de Instalações Elétricas da Empresa Bim \& Alves Engenharia de Projetos Ltda. 


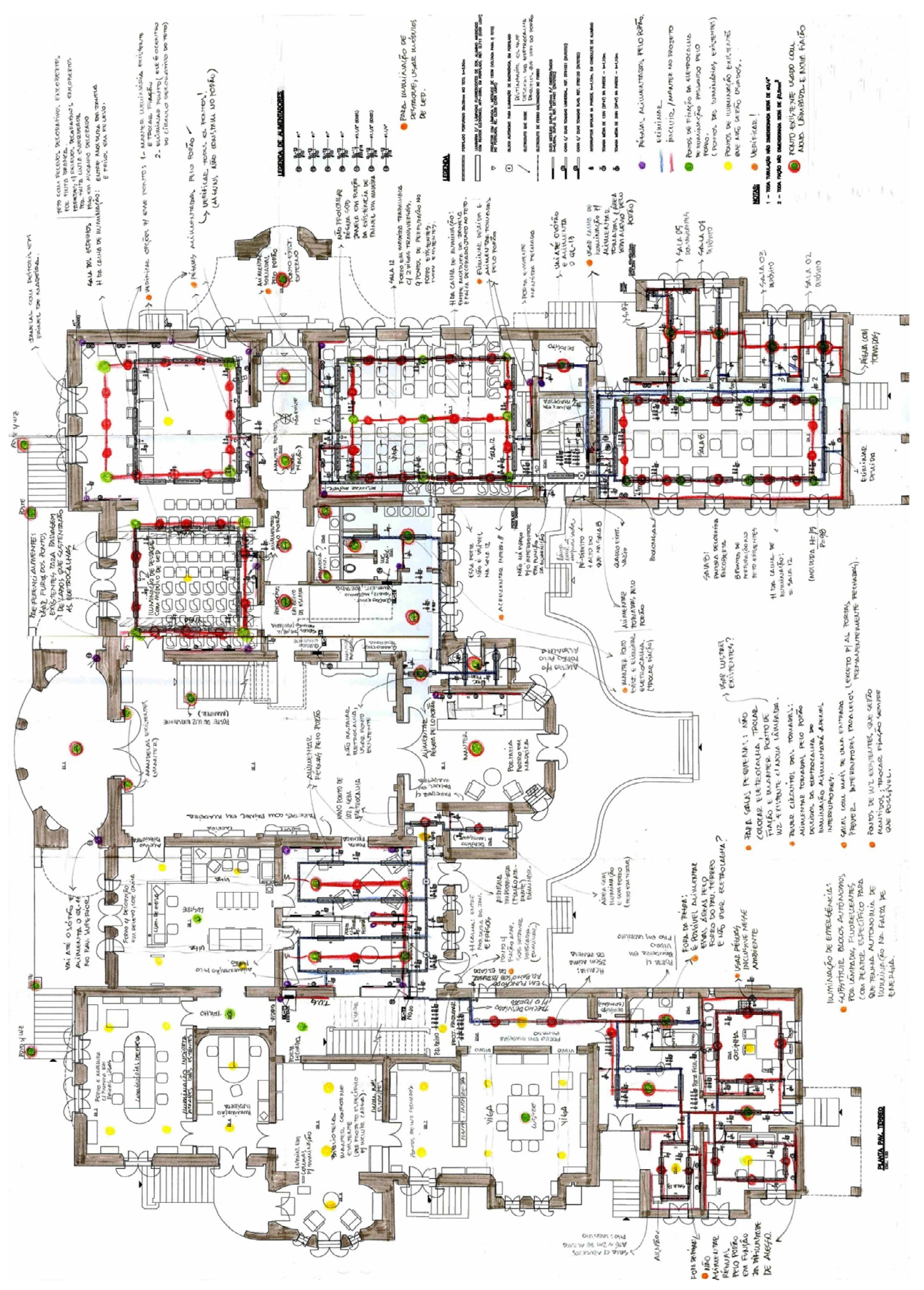

Figura 156 - Planta do Pavimento Térreo do Edifício Vila Penteado

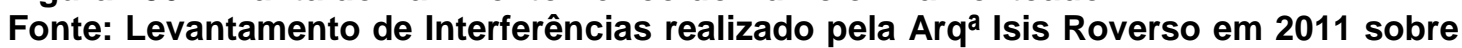
a base de desenho do Projeto de Instalações Elétricas da Empresa Bim \& Alves Engenharia de Projetos Ltda. 


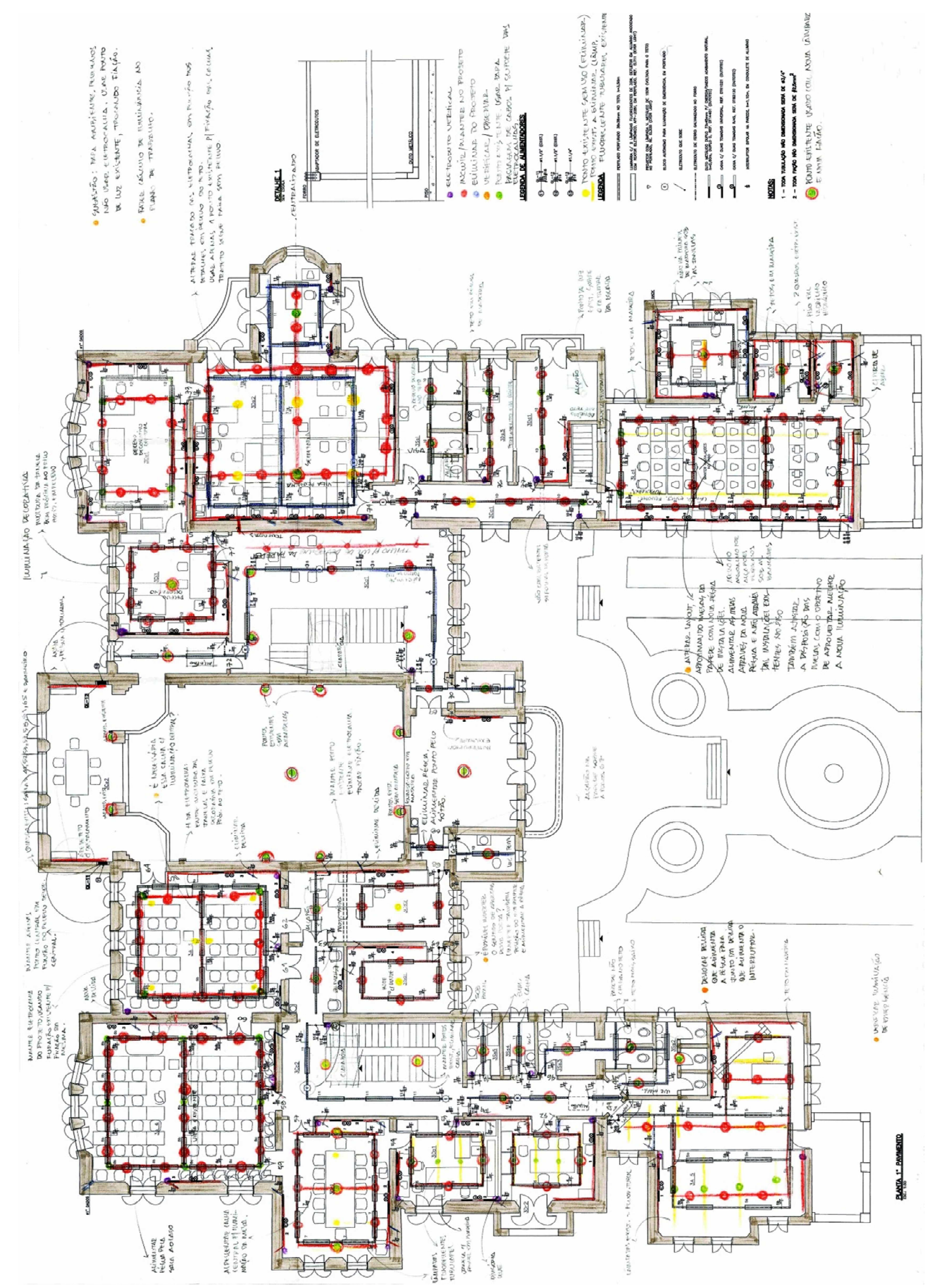

Figura 157 - Planta do Pavimento Superior do Edifício Vila Penteado

Fonte: Levantamento de Interferências realizado pela Arqa Isis Roverso em 2011 sobre a base de desenho do Projeto de Instalações Elétricas da Empresa Bim \& Alves Engenharia de Projetos Ltda. 


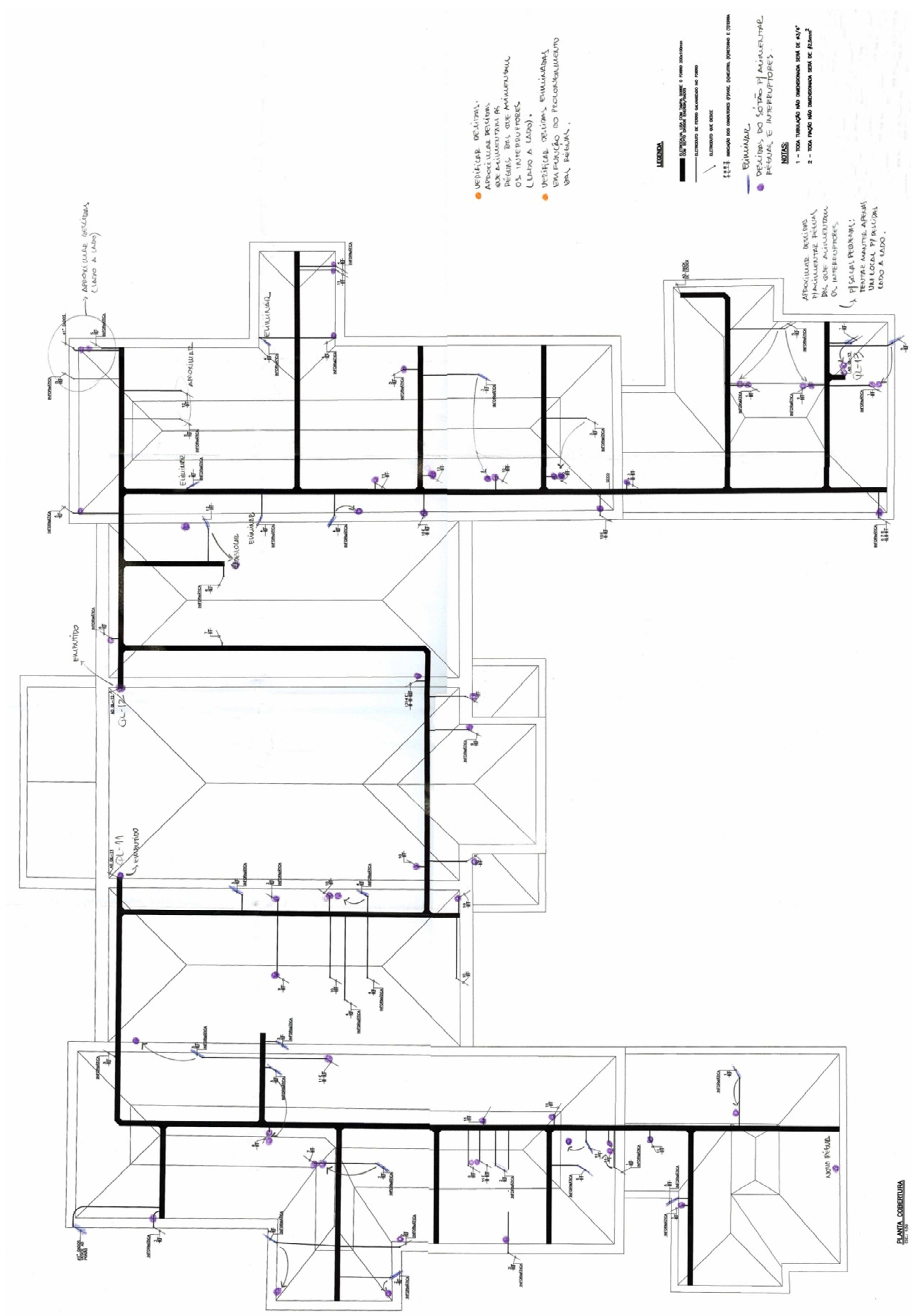

Figura 158 - Planta da Cobertura do Edifício Vila Penteado

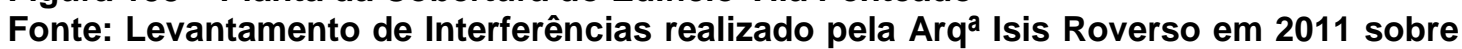
a base de desenho do Projeto de Instalações Elétricas da Empresa Bim \& Alves Engenharia de Projetos Ltda. 
Nas figuras de 154 a 158 os trajetos indicados em vermelho representam os pontos de luz, réguas de instalações e/ou perfilados para iluminação, que devem ser mantidos ou acrescentados ao projeto. Os trajetos na cor azul representam os elementos do projeto que deverão ser eliminados.

Os pontos de luz existentes que serão mantidos estão indicados na cor verde, circulados com a cor vermelha, sendo que esses pontos deverão receber novas lâmpadas e novos cabos alimentadores.

Os pontos de luz existentes que não serão usados estão indicados na cor amarela. Há ainda pontos de luz que não serão usados, mas a sua localização auxilia a instalação de cabos de suporte para os perfilados, ou seja, a fixação dos perfilados deverá privilegiar o uso desses pontos, onde já existe furação nos forros existentes.

Os pontos roxos indicam eletrodutos verticais e devem ser revisados, permitindo a continuidade das instalações entre andares. Há também indicações ressaltadas com a cor laranja. Essas indicações destacam itens que deverão ser verificados ou observados.

Como conclusão desse levantamento, é possível destacar que o Projeto de Instalações Elétricas atual não prevê o melhor trajeto dos perfilados para iluminação, nem para os eletrodutos, prejudicando a leitura adequada da arquitetura da Vila Penteado, então, os trajetos devem ser ajustados.

A verificação pontual dos ambientes originou um novo traçado, que busca a funcionalidade dos espaços, aliada à qualidade estética dos tetos e paredes, permitindo uma boa leitura do patrimônio arquitetônico. A sequência de fotos da Sala de Conferências Prof. Anhaia Mello, conhecida como Sala dos Espelhos, exemplifica essa situação.

Tanto nas fotos da figura 160, como no trecho da Planta de Forros da Vila Penteado, que é apresentada na figura 159, é possível notar que os dois ambientes, que compõem a Sala dos Espelhos, não são simétricos. Cada ambiente contém um desenho específico de forro, o que faz com que o traçado dos perfilados, de suporte da nova iluminação, também acompanhe esse desenho. Entretanto, o projeto de instalações elétricas de 2006 prevê um traçado simétrico para os perfilados que sustentarão as novas luminárias. Esse traçado corresponde ao desenho do forro do ambiente menor, mas atrapalha a leitura da gramática da arquitetura do ambiente maior da Sala dos Espelhos (ver figura 161). 


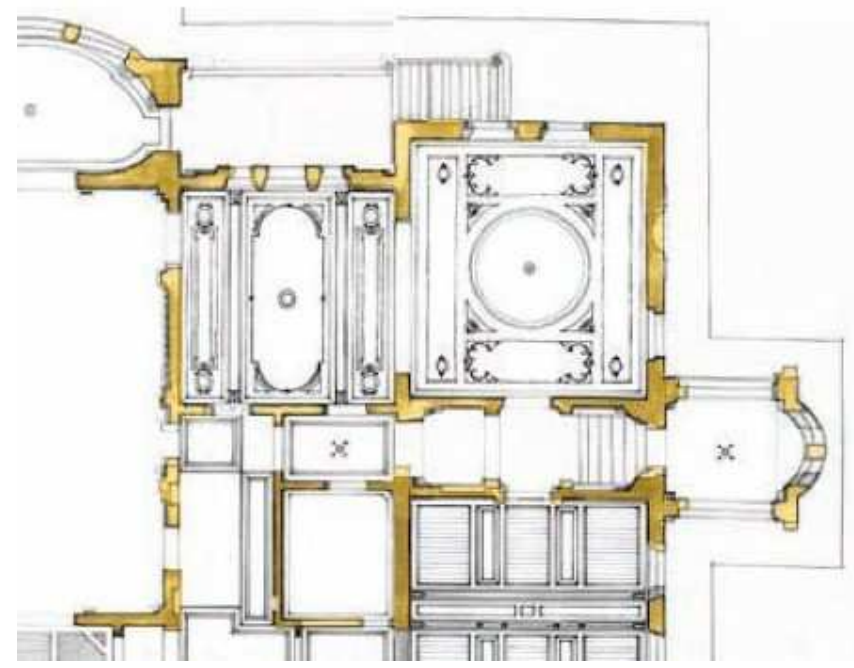

Figura 159 - Trecho da Planta de Forro do Pavimento Térreo da Vila Penteado Fonte: Painel de Inventário Crítico 4/4, 1를 Etapa (1990 a 1992): estudo pormenorizado da arquitetura. Mapeamento de Forros. Arquivo CPC USP

Área delimitada pelo retângulo magenta corresponde a Sala dos Espelhos
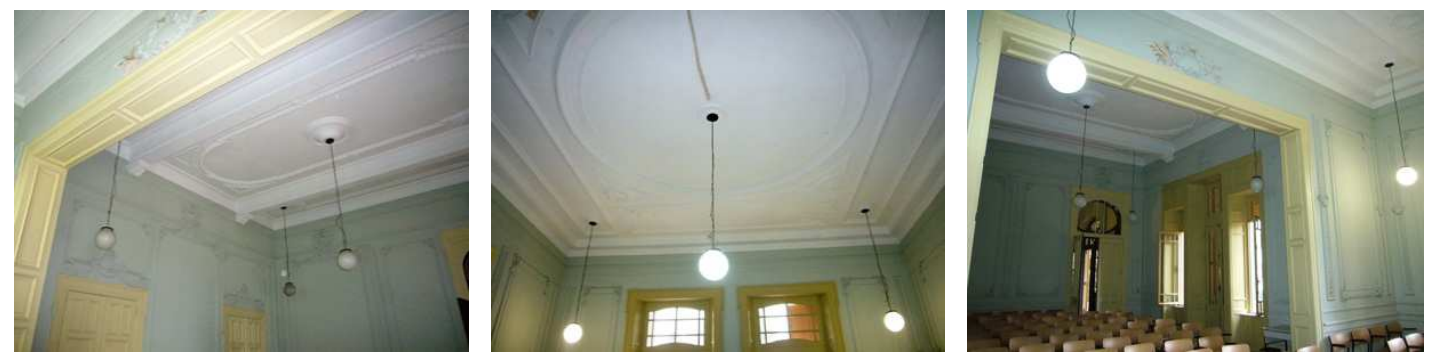

Figura 160 - Fotos da decoração dos forros da Sala dos Espelhos da Vila Penteado Foto: Isis Roverso, abril de 2011.

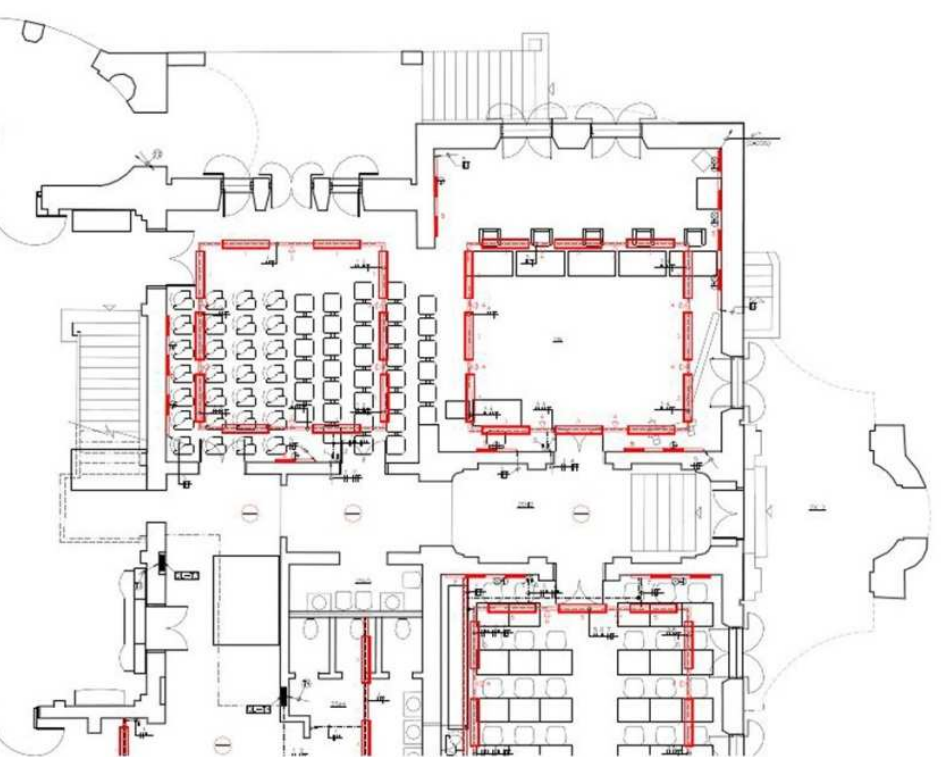

Figura 161 - Trecho da Planta do Pavimento Térreo do Edifício Vila Penteado Fonte: Projeto de Instalações Elétricas da Empresa Bim \& Alves Engenharia de Projetos Ltda, Folha E-3/9, desenho Eduardo, escala 1:50, nov. 2006. 
A figura 162 apresenta o levantamento das interferências com a sugestão do novo traçado. O novo traçado para os perfilados aparece na cor vermelha e os pontos indicados pela cor verde representam os locais onde hoje já existem luminárias. Esses pontos marcados na cor verde devem receber, preferencialmente, os cabos de sustentação dos perfilados, evitando-se a furação excessiva do forro para passagem desses cabos.

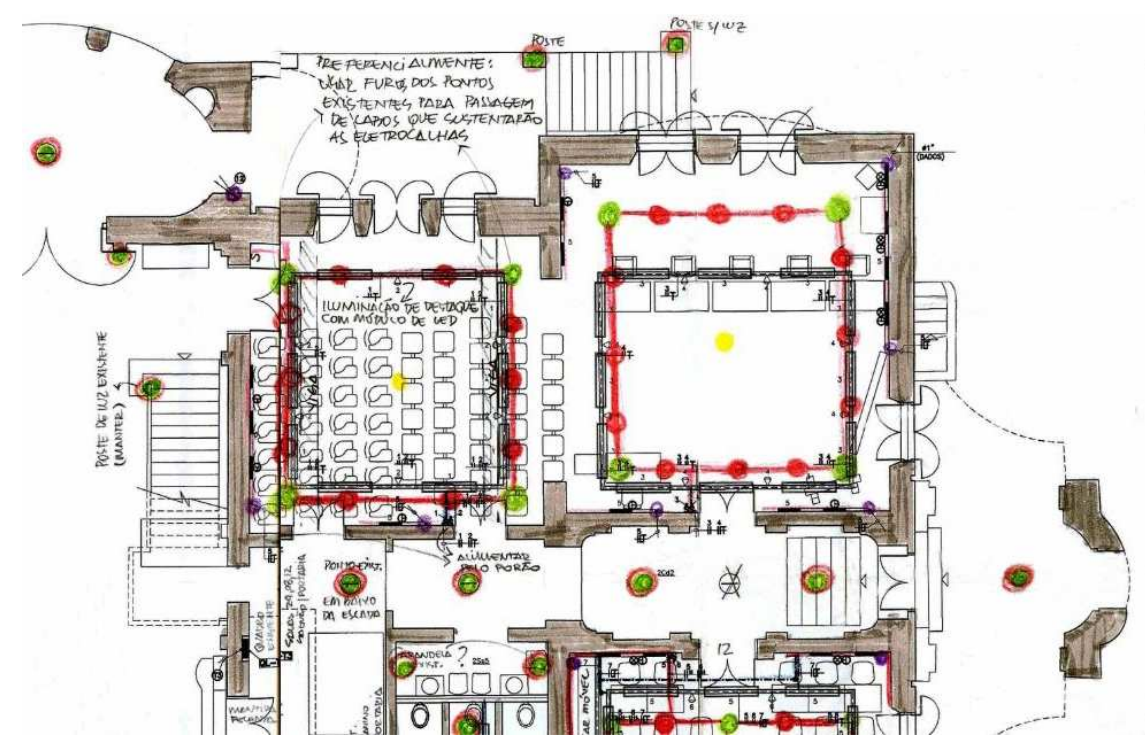

Figura 162 - Trecho da Planta do Pavimento Térreo do Edifício Vila Penteado

Fonte: Levantamento de Interferências realizado pela Arq ${ }^{\mathrm{a}}$ Isis Roverso em 2011 sobre a base de desenho do Projeto de Instalações Elétricas da Empresa Bim \& Alves Engenharia de Projetos Ltda, 2006.

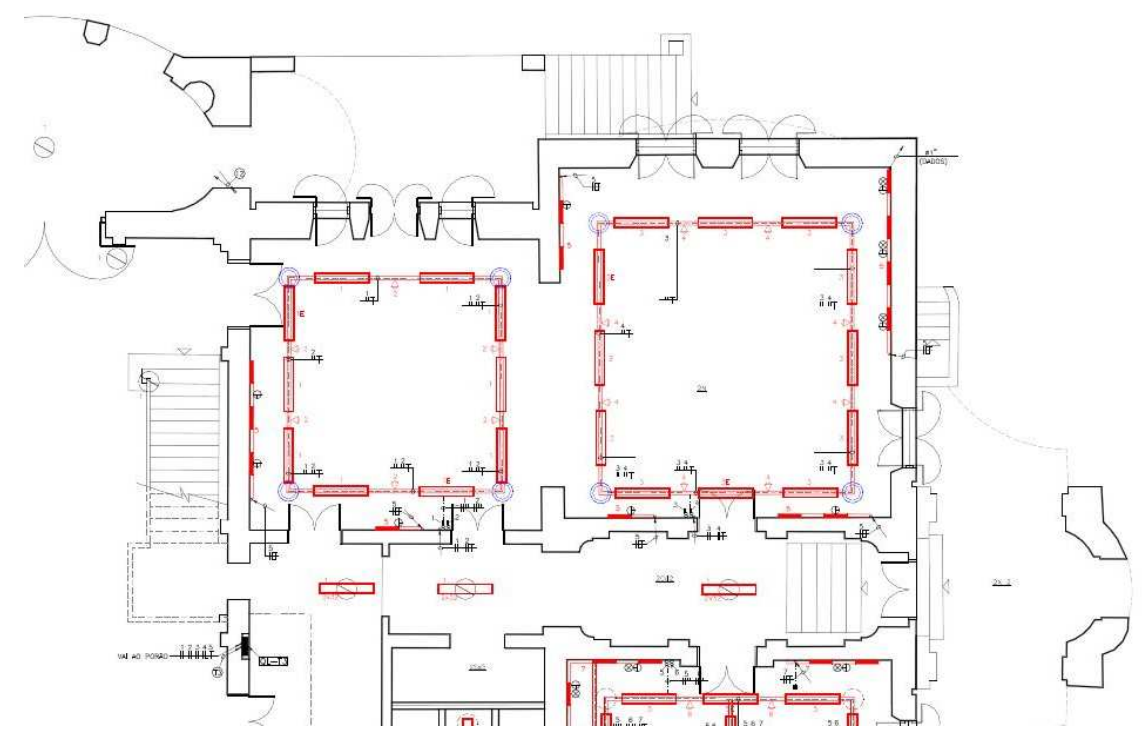

Figura 163 - Trecho da Planta do Pavimento Térreo do Edifício Vila Penteado Fonte: Projeto de Instalações Elétricas da Empresa Bim \& Alves Engenharia de Projetos Ltda, Folha E-3/9, revisado pelo eng. Marcio Urbani em jun. 2006. 
O trecho que representa a Sala dos Espelhos do projeto revisado de instalações elétricas pode ser visualizado na figura 163, onde os trajetos dos perfilados foram ajustados, facilitando a visualização da ornamentação dos forros.

Em função da análise dos trajetos dos perfilados e da verificação de outras interferências existentes, algumas diretrizes foram traçadas visando a revisão do projeto de instalações elétricas. Em relação aos perfilados, seu traçado deverá ser alterado em boa parte das salas, respeitando a decoração dos forros, ou seja, a distribuição das luminárias e trajeto dos perfilados devem colocar-se de tal forma que possibilitem visualizar os forros decorados, tanto os coloridos e desenhados, quanto os que apresentam atualmente apenas variações de relevo. Os perfilados terão ainda altura variável entre as salas, devendo ficar entre a guarnição superior das janelas e os frisos que emolduram os forros, dessa forma, não irão gerar excesso de ruído na leitura da arquitetura dos interiores.

Já em relação às réguas, para pontos de força, dados e telefonia, a revisão do projeto trata da sua atual falta de continuidade. A extensão dessas réguas é desejável, porque permite eliminar o excesso de descidas de eletrodutos pelas paredes. Essas réguas serão fixadas nas paredes acima da altura dos rodapés e terão afastamento propiciado por perfil " $U$ " horizontal de dimensão menor que a régua, ou seja, a régua será sobreposta a um perfil não visível que a manterá afastada da parede. Inicialmente essas réguas seriam instaladas sobre sapatas fixas nos assoalhos, mas essa alternativa foi descartada porque, além de ser preciso perfurar o piso em madeira, as sapatas metálicas não trariam estabilidade adequada às réguas e as limpezas de rotina dos pisos seriam prejudicadas.

Por vezes, o mesmo ambiente recebe mais de um eletroduto vertical, quando for esse o caso, o projeto deve apresentar os eletrodutos, preferencialmente, na mesma parede, instalados lado a lado, interferindo dessa forma uma única vez na parede em questão. Quando possível, as réguas das faces opostas de uma mesma parede serão alimentadas com um único eletroduto, ou seja, será feito pequeno furo na parede para passagem da fiação, eliminando assim mais uma interferência com novo eletroduto na face oposta da mesma parede (essa solução só poderá ser usada em casos específicos, onde não cause dano às paredes decoradas).

A iluminação das salas pequenas será revista, especialmente as salas do pavimento superior, onde a alimentação dos pontos de luz é facilitada pelo sótão. Os 
perfilados serão eliminados, incluindo nova iluminação no ponto de luz existente no forro. A troca da fiação existente é recomendada e o ponto de luz mantido deverá receber nova lâmpada a ser especificada.

Salas com mais de uma entrada deverão ter interruptores paralelos, sendo que as portas mantidas permanentemente trancadas não serão consideradas. Os quadros elétricos serão de sobrepor e deverão contar com um Dispositivo de Proteção Contra Surtos Atmosféricos (DPS).

As áreas de circulação, especialmente a área do Saguão, terão a sua iluminação original mantida, entretanto, é necessário realizar a troca da fiação existente. Os pontos de luz mantidos correspondem às áreas de circulação (especialmente do pavimento superior) e pequenas salas.

A iluminação de destaque prevista no projeto sofrerá alterações. Os pontos direcionados para os forros deverão receber módulos de leds. A escolha deu-se em função da disponibilidade atual desse tipo de iluminação, que não projeta calor juntamente com o foco de luz. As demais lâmpadas e luminárias de uso geral e de tarefa ainda deverão ser especificadas.

O Projeto de Instalações Elétricas deverá prever ainda carga para a futura implantação do sistema de segurança (iluminação de emergência, bomba para hidrantes, sistema de alarme, etc.) e das instalações destinadas à acessibilidade do edifício, como a plataforma acessível que auxiliará no trajeto entre o térreo e o pavimento superior da Vila Penteado.

O ideal seria já compatibilizar o Projeto de Instalações Elétricas com o Projeto de Prevenção e Combate a Incêndios e com os demais Projetos de Instalações, Paisagismo e Arquitetura de Interiores (alteração no uso e ocupação das áreas existentes). Entretanto, tanto Projeto de Prevenção e Combate a Incêndios como o Projeto de Instalações Hidráulicas e o Projeto de Acessibilidade ainda não foram desenvolvidos. Mas, em relação à iluminação de emergência, é possível substituir os blocos autônomos por circuitos de emergência, que deverão ser atendidos por uma central com baterias, ou ainda usar lâmpadas fluorescentes com reator específico, que permitem a autonomia da luminária na falta de energia.

O Projeto de Paisagismo feito pelo Arq. Raul Pereira, para a Vila Penteado, contempla alguns pontos para iluminação sem especificação de lâmpadas e luminárias (esses pontos correspondem aos projetados em 1998, no Projeto de Instalações Elétricas elaborado pela empresa Ramoska \& Castellani). Esses pontos 
estão locados em novas áreas de jardim, ou seja, não correspondem com as áreas de jardim existentes. Em virtude do exposto, o Projeto Elétrico trará novos pontos de iluminação, que não correspondem aos constantes no Projeto de Paisagismo, mas que garantem a iluminação externa conferindo ainda alguma flexibilidade para futuras alterações.

É preciso destacar ainda algumas alterações pontuais no Projeto de Instalações Elétricas. A primeira delas diz respeito à iluminação externa. Os pontos de luz existentes (postes nas entradas e na área do chafariz) deverão ter seus cabos alimentadores trocados. Novos pontos de luz, além dos poucos existentes, deverão ser previstos para iluminamento dos trajetos e fachadas. O trajeto da iluminação externa frontal deve prever o desvio em relação à região das raízes das árvores existentes.

Os circuitos das tomadas do pavimento térreo deverão ser revistos, fazendo com que todas as tomadas sejam alimentadas pelo porão, sendo que as descidas dos perfilados devem atender apenas aos interruptores. A exceção a essa regra encontra-se nas áreas sem acesso pelo porão, indicadas na planta do pavimento térreo, onde as tomadas serão alimentadas pelos perfilados.

As tomadas projetadas na cozinha atual serão substituídas por réguas com pontos de força, conforme padrão do restante do projeto. A iluminação existente na área aberta ao lado da atual secretaria será mantida e os perfilados projetados serão eliminados. Um trilho para iluminação de destaque da parede divisória com a secretaria será incorporado ao projeto, visando ressaltar os arcos a serem revelados nessa parede.

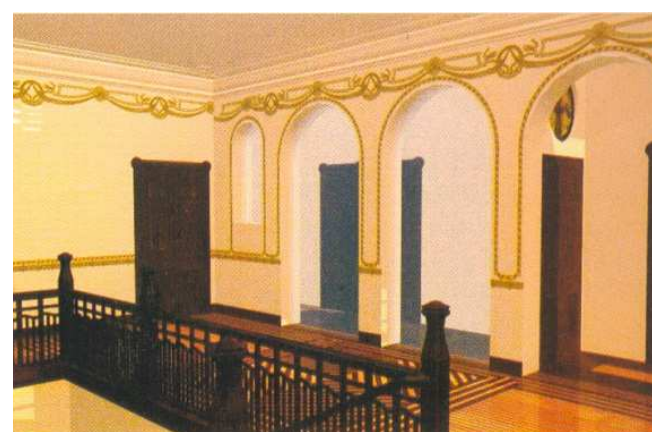

Figura 164 - Saguão de Acesso, Pavimento Superior (junto à escada principal): simulação dos arcos recuperados e decorados com guirlandas do século passado Fonte: Vila Penteado 100 anos. Revista Pós - número especial. São Paulo, FAU-USP, 2002,v.1, p. 160. 
O layout do laboratório de informática deverá ser modificado. As mesas deverão ficar junto à nova régua de instalações, para serem alimentadas pela mesma. Dessa forma, a instalação existente sob o assoalho dessa sala será eliminada. É necessário ainda eliminar o excesso de descidas de eletrodutos do sótão para o pavimento superior. Quando for necessário descer eletrodutos próximos, estes deverão ser instalados lado a lado.

O Projeto de Instalações Elétricas prevê o uso atual das áreas com exceção ao Porão, que já consta a nova ocupação. Quando a proposta de alteração de layout for implantada no edifício, algumas réguas deverão ser realocadas, sendo que a iluminação sofrerá alterações mínimas, visto que a revisão atual contempla o trajeto dos perfilados, favorecendo a leitura dos forros decorados existentes e dessa forma serão mantidos mesmo depois da alteração do uso das salas.

Em função do volume de itens a serem revisados, no Projeto de Instalações Elétricas, o Eng. Marcio Urbani, da Empresa Lumina Comércio e instalações Elétricas Ltda., foi contratado para realizar a revisão desse projeto, incorporando os itens analisados e ainda desenvolvendo o Sistema de Proteção Contra Descargas Atmosféricas (SPDA).

A partir dos pontos destacados, a revisão do Projeto Elétrico foi elaborada e entregue em junho de 2011, pelo eng. Marcio.

Na figura 165 é possível visualizar o Sistema de Proteção Contra Descargas Atmosféricas. Esse sistema utiliza os elementos metálicos existentes na cobertura: calhas, condutores verticais de águas pluviais, rufos e telhas em cobre.

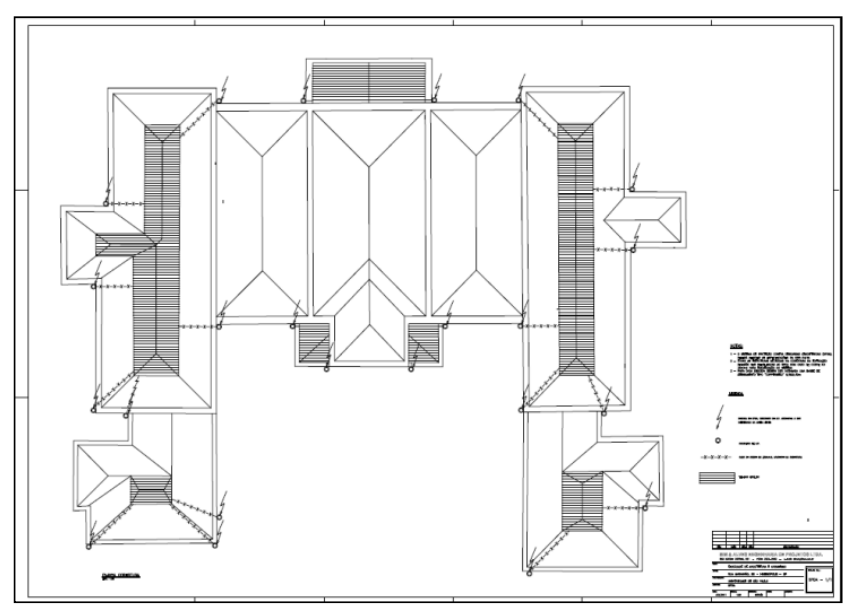

Figura 165 - Planta da Cobertura do Edifício Vila Penteado Fonte: Prancha SPDA - 1/1, Projeto de Instalações Elétricas da Empresa Bim \& Alves Engenharia de Projetos Ltda, revisão feita por Márcio, jun/2011, escala 1:50. 
A respeito da área da Biblioteca, o Projeto de Instalações Elétricas considera essa área como existente a ser mantida. Sua carga está alocada nos diagramas correspondentes, mas não há informações detalhadas sobre a reforma feita nas instalações em 2000. Entretanto, o relatório de uma reunião, feito com o Sr. Luís Alexandre Mozzilli, da empresa TEC-INSTAL, em 26 de fevereiro de 2009, no GEEF FAU, esclarece melhor a situação em que as obras foram executadas:

O Senhor Luís Alexandre foi o responsável pelas instalações quando da reforma da biblioteca do edifício da FAU Maranhão em 2000. Localizado através do contato com o arquiteto José Armênio, procuramo-lo a fim de levantar informações acerca deste projeto, quando ele então se prontificou a fornecer ao GEEF toda a informação de que dispusesse.

Segundo ele, a priori, a instrução relativa às instalações elétricas foi a de se revitalizarem e utilizarem somente os pontos elétricos existentes. A posteriori, com a necessidade de instalações de iluminação decorativa, foi elaborado um descritivo do que deveria ser feito (e não um projeto), aprovado pelo Prof. Katinsky. Segundo ele, e como se pode observar no edifício, estas instalações foram feitas a partir de nova tubulação no porão e, dentro da biblioteca, a instalação foi totalmente articulada independente das paredes. Também se aproveitou a oportunidade da descupinização realizada nos forros, desmontados para tal, para substituir a fiação em toda a região da biblioteca. Não foi feito um "as built" destas instalações. Para a viabilização da execução destas instalações, o trabalho foi feito em etapas, em função de valores financeiros, para que se dividisse o montante.

À época da reforma da biblioteca, ficaram com ele cópias de um projeto de instalações elétricas completo para o edifício, executado pela empresa Ramoska \& Castellani em 1998, para efeito de eventuais consultas. No entanto, ele não foi utilizado, e também não se averiguou se foi executado ou não. Na ocasião desta reunião, o Sr. Luís forneceu ao GEEF este projeto, em cópia impressa. Pela numeração das folhas, esta cópia está aparentemente incompleta, mas era o de que dispunha a empresa contatada. $^{110}$

É importante registrar que o levantamento das instalações da biblioteca deveriam fazer parte, se não do projeto, do as built, visando facilitar futuras ações de manutenção do edifício.

110 Texto extraído do Relatório da reunião com o Sr. Luís Alexandre, da empresa TEC-INSTAL, em 26 de fevereiro de 2009, no GEEF FAU, Cidade Universitária. EDIFÍCIO FAU MARANHÃO: LEVANTAMENTO DE DOCUMENTAÇÃO, Rua Maranhão, 88, Higienópolis, São Paulo, GEEF FAUUSP. Relatório feito por Bárbara Ivo, arquiteta GEEF FAUUSP. 



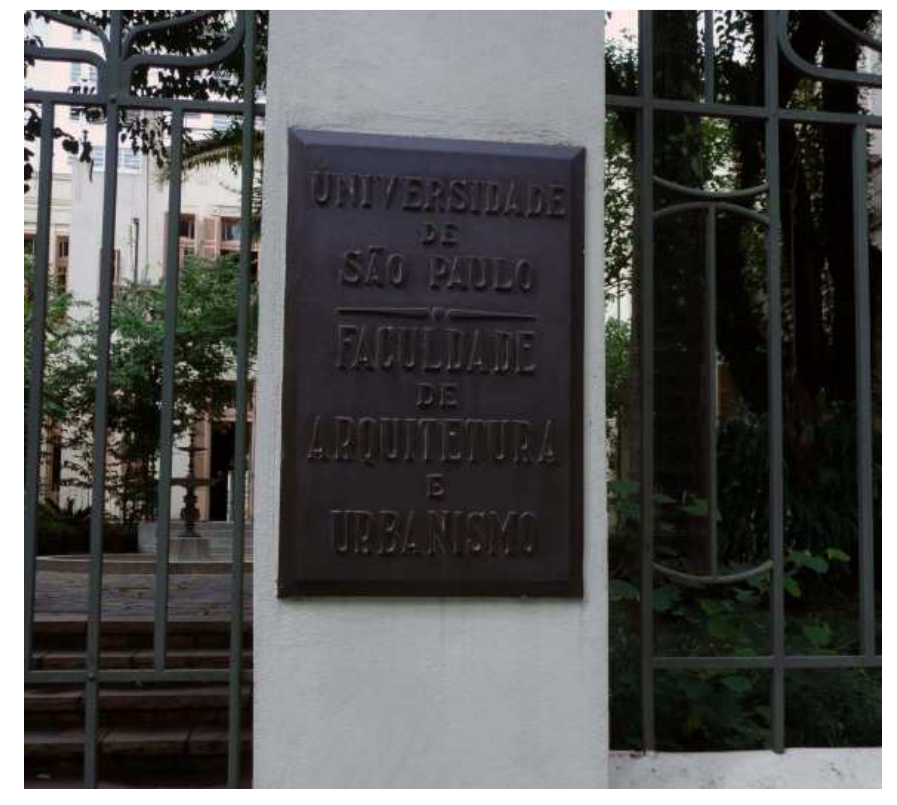

Figura 166 - Placa de identificação da Vila Penteado Foto: Isis Roverso, dezembro de 2010. 



\section{ANÁLISE DE DESEMPENHO DOS SISTEMAS DO EDIFÍCIO VILA PENTEADO}

Visando o entendimento da situação atual do edifício Vila Penteado, o quarto capítulo aborda a análise dos seus sistemas. Essa análise é feita a partir de inspeções locais, conforme procedimentos metodológicos, apresentados no Capítulo 1.

Os conteúdos apresentados no Capítulo 3 - histórico, documentação das intervenções realizadas, levantamento cadastral, estudos e projetos recentes - são usados na análise de desempenho e auxiliam a compor o quadro de estado atual em que se encontra o edifício.

\subsection{DOCUMENTAÇÃO FOTOGRÁFICA E ANÁLISE DOS SISTEMAS}

Visando facilitar o entendimento da situação atual desse edifício, a análise de desempenho dos sistemas é apresentada e exemplificada através do levantamento fotográfico. Outros documentos e ainda outras ferramentas, como o desenho, são utilizados para completar a análise.

Os sistemas do edifício são analisados conforme conceituação do Capítulo 1.

As falhas construtivas são apresentadas no sistema, onde as mesmas foram detectadas, embora a origem da falha possa estar em outro sistema da edificação, conforme esclarecimentos das análises circunstanciadas. Os reflexos dessas falhas são analisados quanto ao impacto que produzem nos requisitos de desempenho e, por conseguinte, nas exigências e necessidades dos usuários.

Algumas das falhas detectadas no levantamento foram corrigidas recentemente (segundo semestre de 2011). No entanto, foram descritas para 0 registro das ações corretivas.

Nas figuras 167 a 169 é possível visualizar a planta do pavimento do porão, do pavimento térreo e a planta do pavimento superior da Vila Penteado. Nesses desenhos há a numeração das salas, identificando cada ambiente.

A sigla SUB, na planta do porão, representa a designação "subsolo", e referese aos ambientes desse nível que têm pé direto adequado ao desenovlvimento de atividades humanas. 
A letra S representa o termo "sala" para as demais plantas.

A identificação dos ambientes se faz necessária para o entendimento das questões apontadas no levantamento fotográfico.

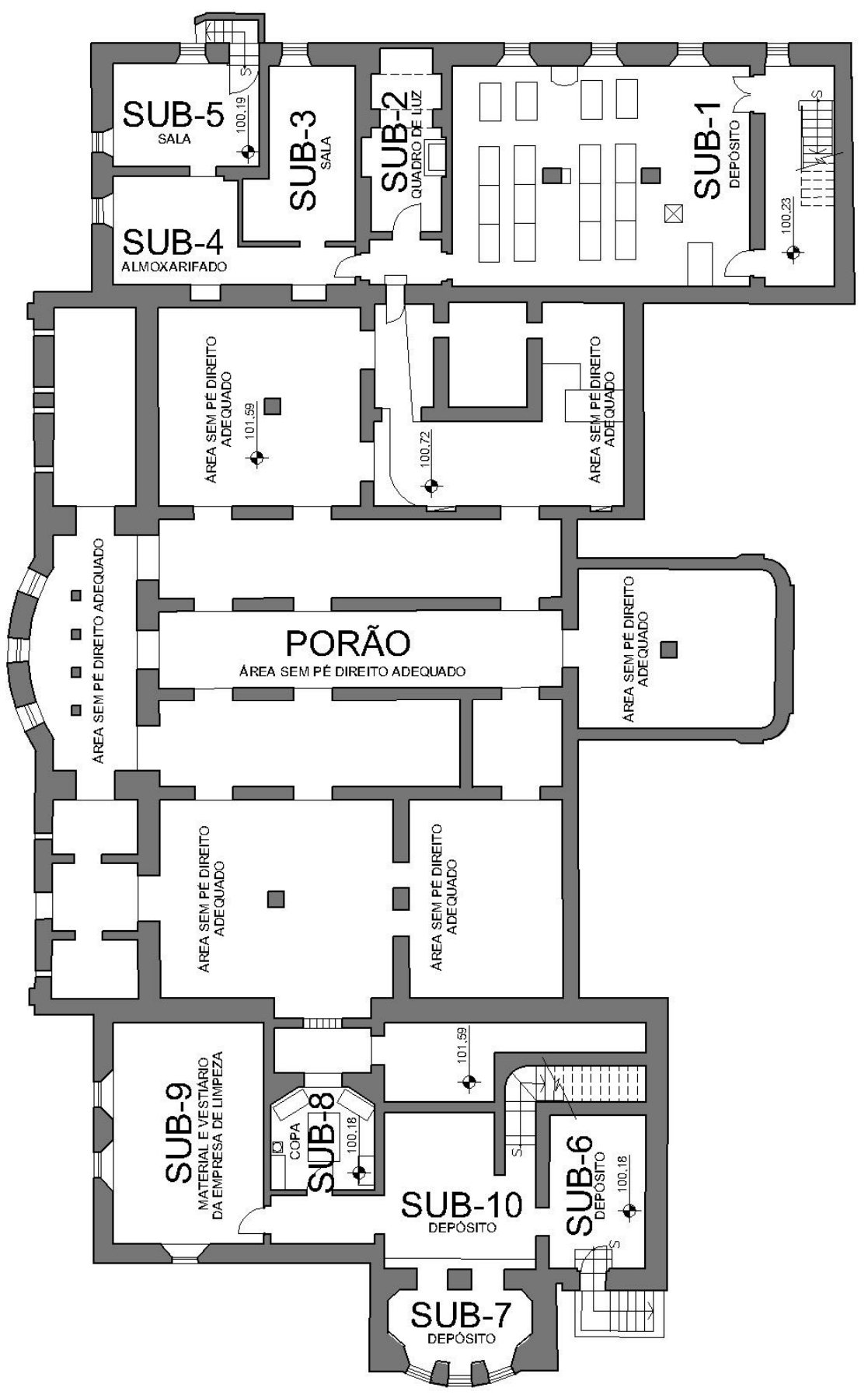

Figura 167 - Planta do Porão do Edifício Vila Penteado Fonte: Planta modificada a partir da Planta do Porão do Edifício Vila Penteado de junho de 2004, FAUUSP, Escala 1:250, Folha 1/3, Estagiários Pedro Saito, Rafael Ramos e Vanessa Grossman. 


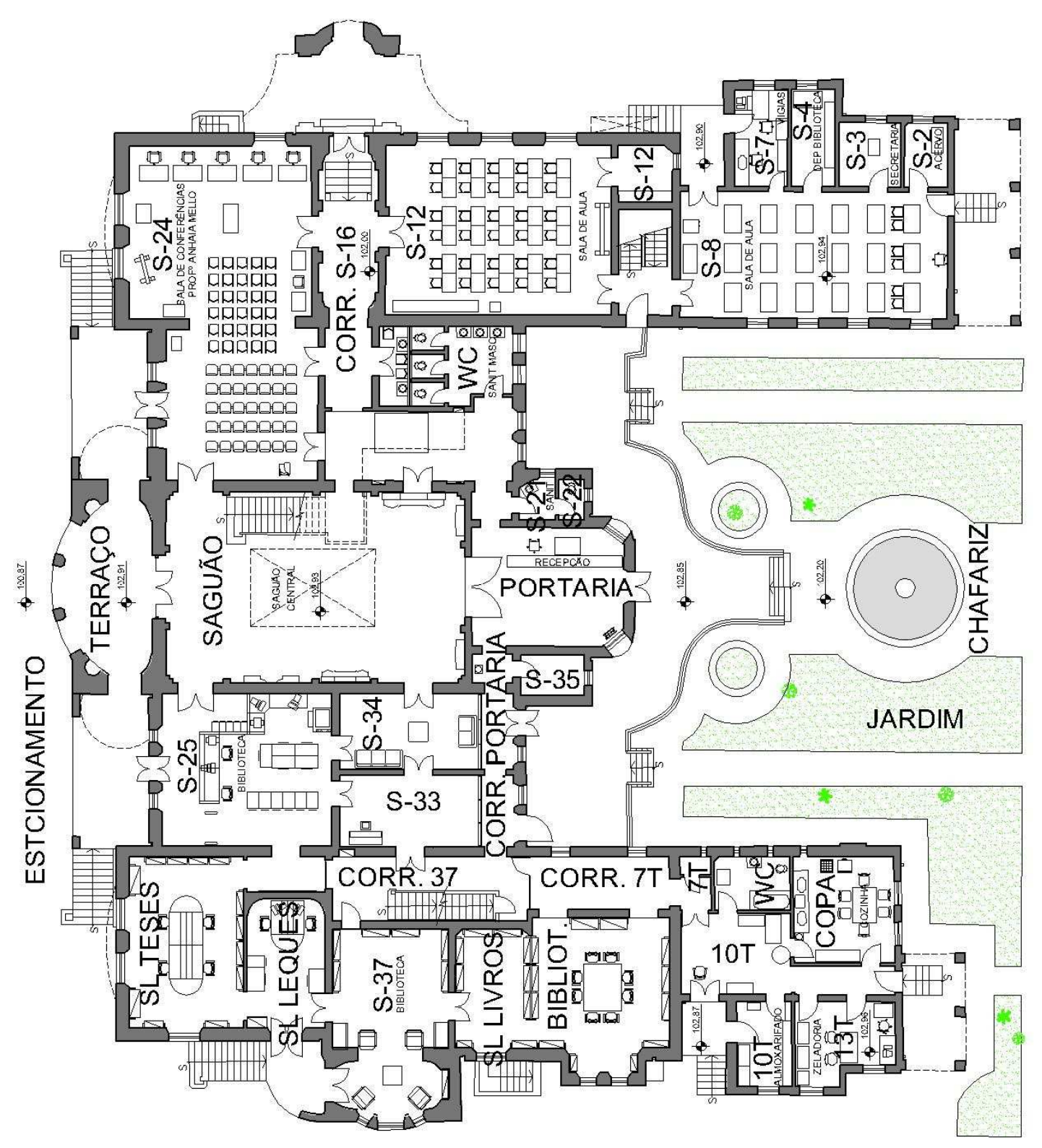

Figura 168 - Planta do Pavimento Térreo do Edifício Vila Penteado

Fonte: Planta modificada a partir da Planta do Pavimento Térreo do Edifício Vila Penteado de junho de 2004, FAUUSP, Escala 1:250, Folha 2/3, Estagiários Pedro Saito, Rafael Ramos e Vanessa Grossman. 


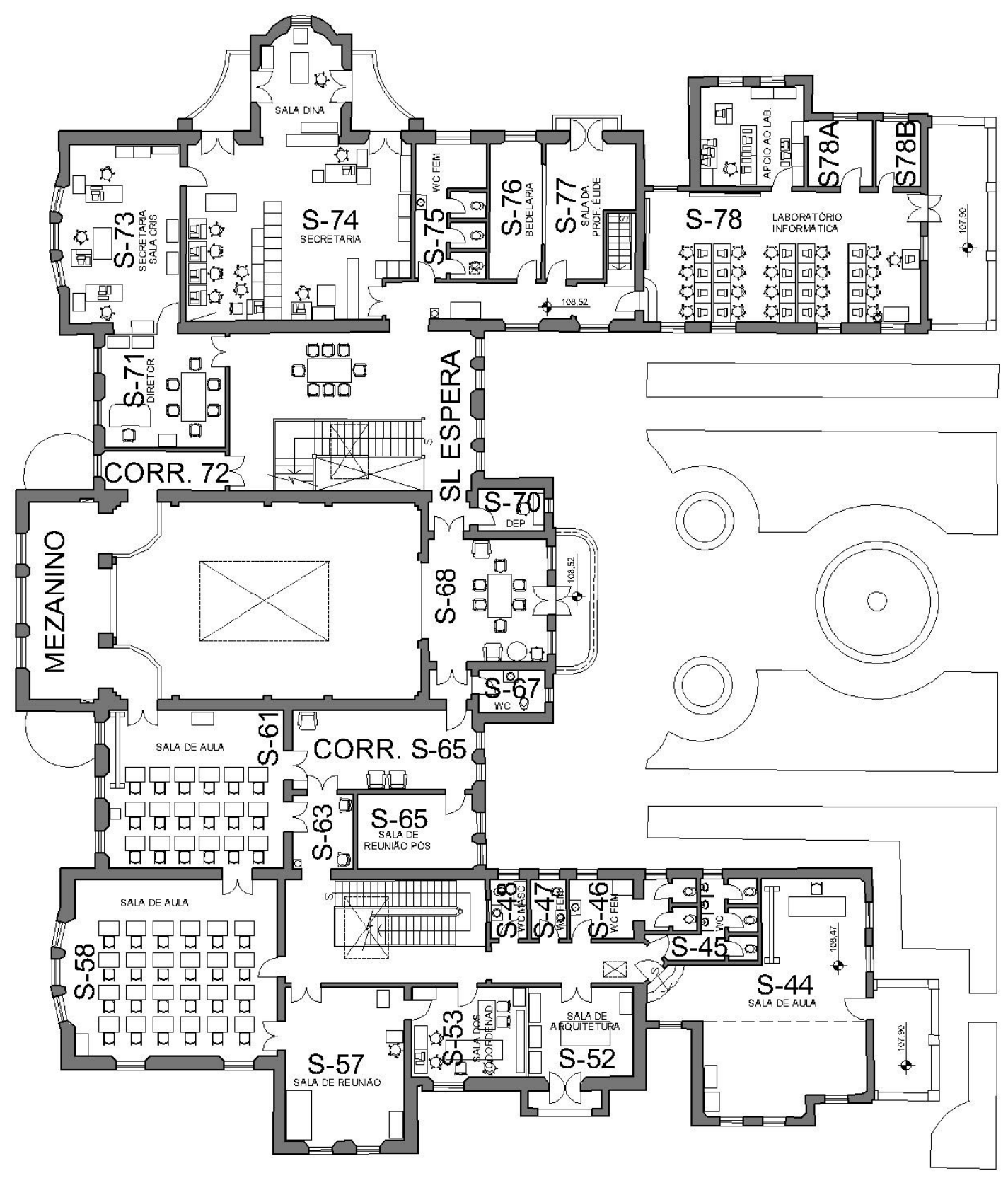

Figura 169 - Planta do Pavimento Superior do Edifício Vila Penteado

Fonte: Planta modificada a partir da Planta do Pavimento Superior do Edifício Vila Penteado de junho de 2004, FAUUSP, Escala 1:250, Folha 1/3, Estagiários Pedro Saito, Rafael Ramos e Vanessa Grossman. 


\subsubsection{TERRAPLENO}

No sistema do terrapleno é importante notar as condições do terreno e de implantação do edifício, evidenciando pontos positivos e negativos relacionados aos acessos, circulações, drenagem, orientação solar, etc.

O edifício da Vila Penteado teve sua implantação privilegiada em relação à insolação, ventilação e visuais de abertura, como é possível notar no desenho do Prof. Silvio Macedo (ver figura 170).

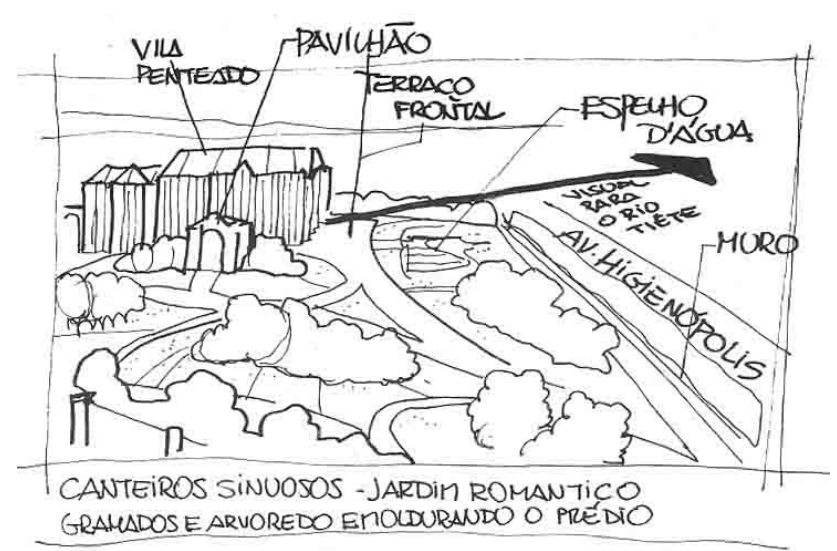

Figura 170 - Implantação da Vila Penteado

Fonte: MACEDO, 2002, p. 111. Desenho: Silvio Soares Macedo.

A implantação original apresentava o edifício posicionado no local mais alto do terreno, permitindo boa visualização e ventilação. Além da posição elevada em relação ao terreno, o edifício recebeu um pavimento de base, porão, elevando o pavimento térreo. Esse distanciamento, entre o piso térreo e o solo, confere qualidade ao imóvel, visto apresentar distanciamento da umidade presente no substrato. Por outro lado, essa posição elevada desfavorece a acessibilidade universal.

Como já comentado, a Vila foi projetada em terreno de maiores dimensões e, após o desmembramento do lote, passou a ocupar área reduzida, tendo, inclusive, sua entrada principal alterada da Avenida Higienópolis para a Rua Maranhão.

Com a ocupação dos lotes ao redor do edifício, a Vila Penteado perdeu parte da qualidade relacionada à ventilação e insolação. Os desenhos das figuras $171 \mathrm{e}$ 172 apresentam claramente a conformação inicial e a atual, envolta a edifícios. 


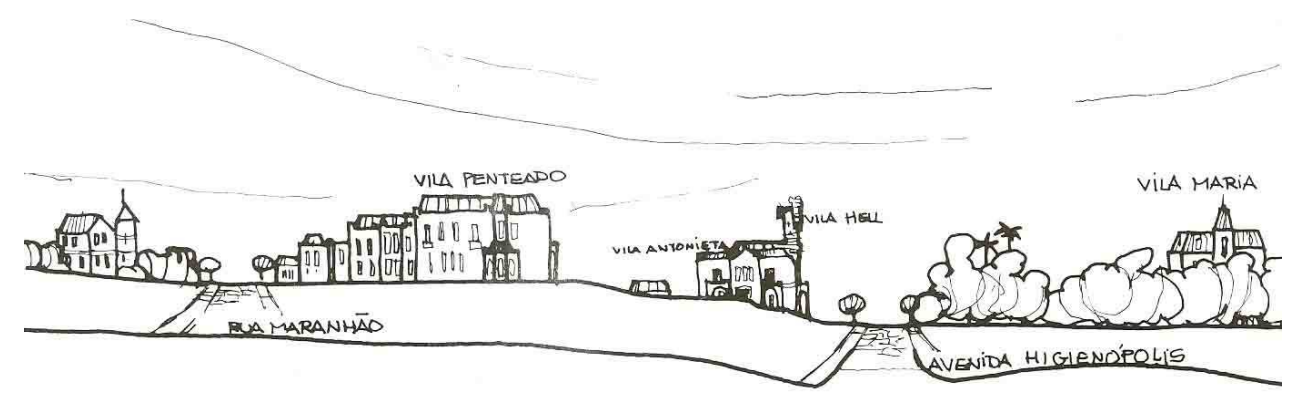

Figura 171 - Loteamento com inserção da Vila Penteado Fonte: MACEDO, 2002, p. 114. Desenho: Silvio Soares Macedo.

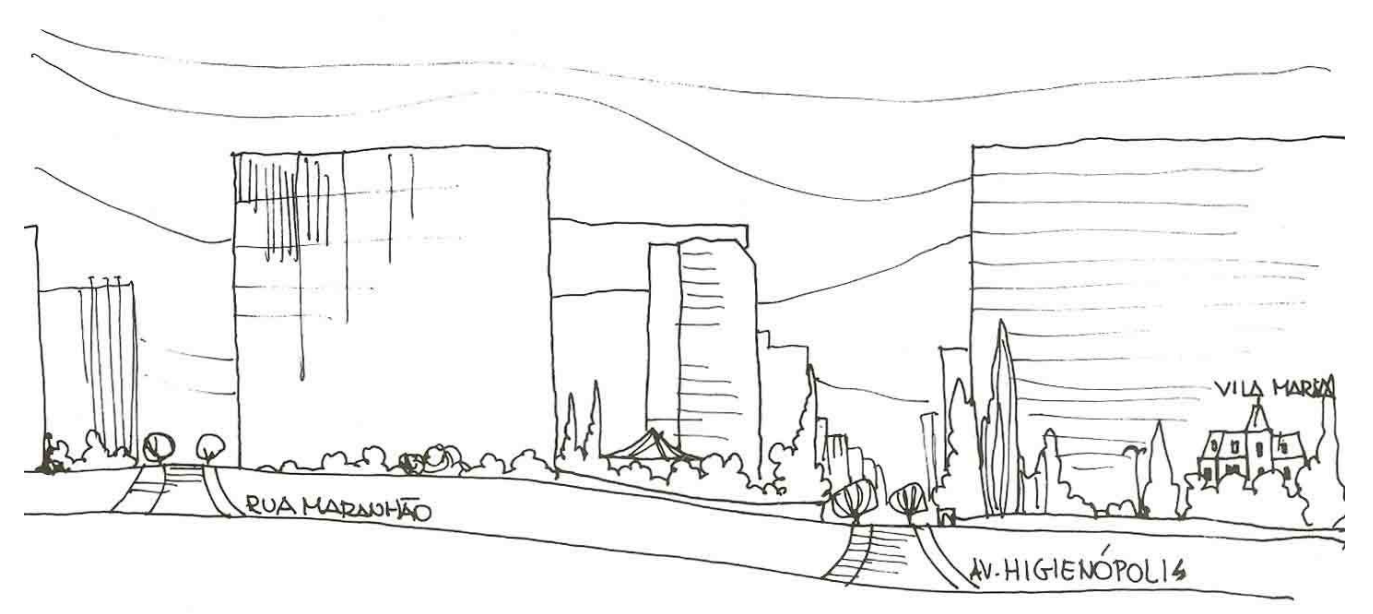

Figura 172 - Vila Penteado cercada por prédios altos em 1992 Fonte: MACEDO, 2002, p. 115. Desenho: Silvio Soares Macedo.

Como resultante da alteração da entrada, o acesso principal passou a se dar pelo antigo escritório, área que sofre desgaste em seu piso de madeira, principalmente em dias de chuva (ver item 4.1.8 "Pavimentos"). A área elevada de acesso à portaria, revestida em mosaico, também não é adequada para o tráfego atual de pessoas que, aliado a falta de cobertura para proteção de chuvas, apresenta fissuras (essa situação também é detalhada no item 4.1.8 "Pavimentos").

Os jardins também sofreram alterações e hoje apresentam alguns problemas como o enraizamento aflorado de árvores (ver fotos da figura 173).

A Vila Penteado permanece em local elevado, mesmo com as alterações ocorridas no terreno. As fotos da figura 176 apresentam uma das duas rampas de acesso à Vila. Entretanto, as duas rampas existentes são destinadas ao acesso de veículos, restando apenas a escadaria central para o uso dos pedestres. $O$ acesso 
ao edifício também é promovido por escadas, dessa forma, a acessibilidade ${ }^{111}$ da Vila Penteado não é adequada.
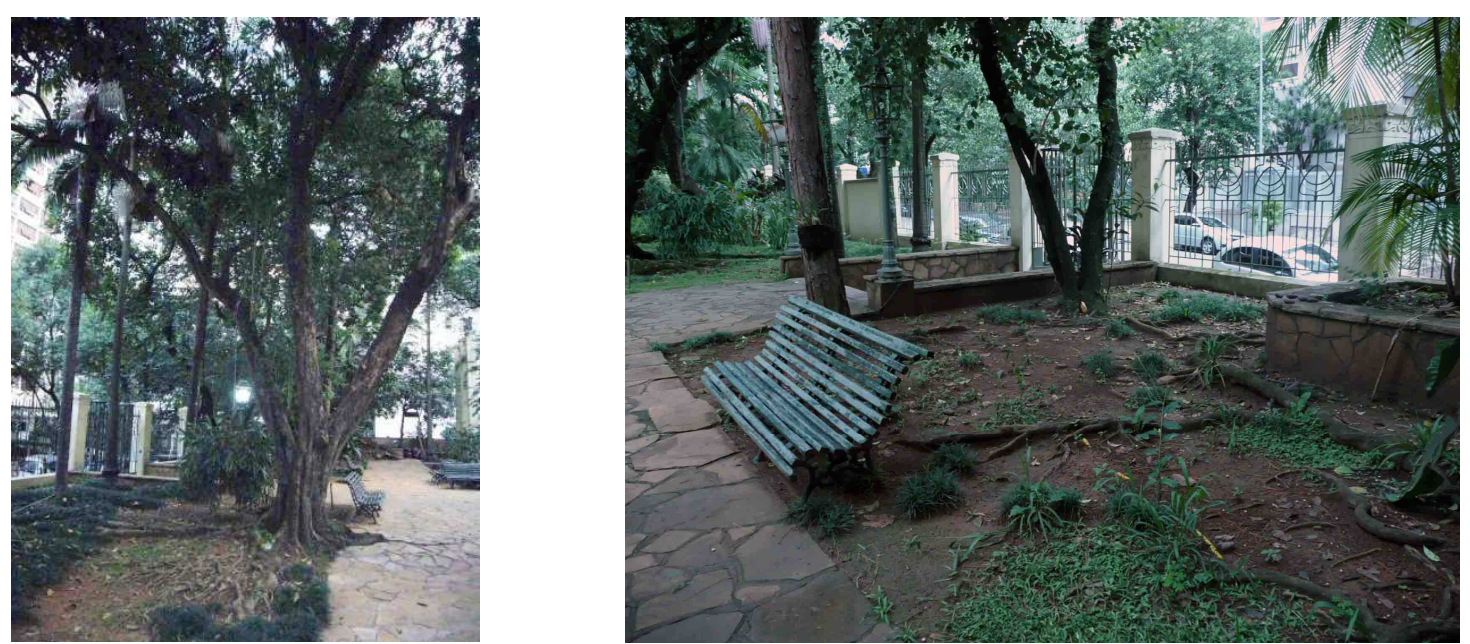

Figura 173 - Jardins da Vila Penteado Fotos: Isis Roverso, abril de 2011 e dezembro de 2010.
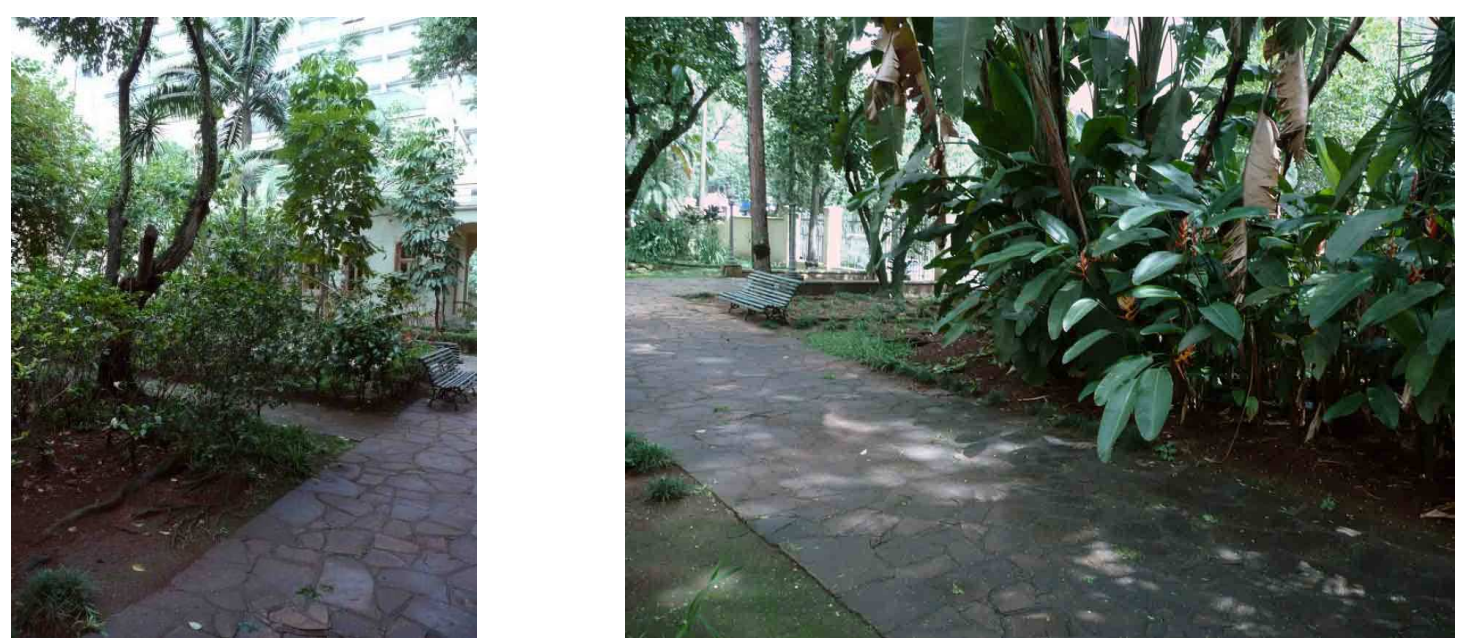

Figura 174 - Jardins da Vila Penteado Fotos: Isis Roverso, dezembro de 2010.

${ }^{111}$ Além da dificuldade de acesso de pessoas portadoras de necessidades especiais, a Vila Penteado também não conta com as adaptações necessárias para atender as demais questões relacionadas com a acessibilidade universal. A dissertação de mestrado de Silvana Serafino Cambiaghi, de 2004, que versa sobre a acessibilidade, tem como estudo de caso a situação existente na Vila Penteado. CAMBIAGHI, Silvana Serafino. Desenho universal: métodos e técnicas de ensino na graduação de arquitetos e urbanistas. Dissertação de mestrado. São Paulo: Faculdade de Arquitetura e Urbanismo da Universidade de São Paulo, 2004. 

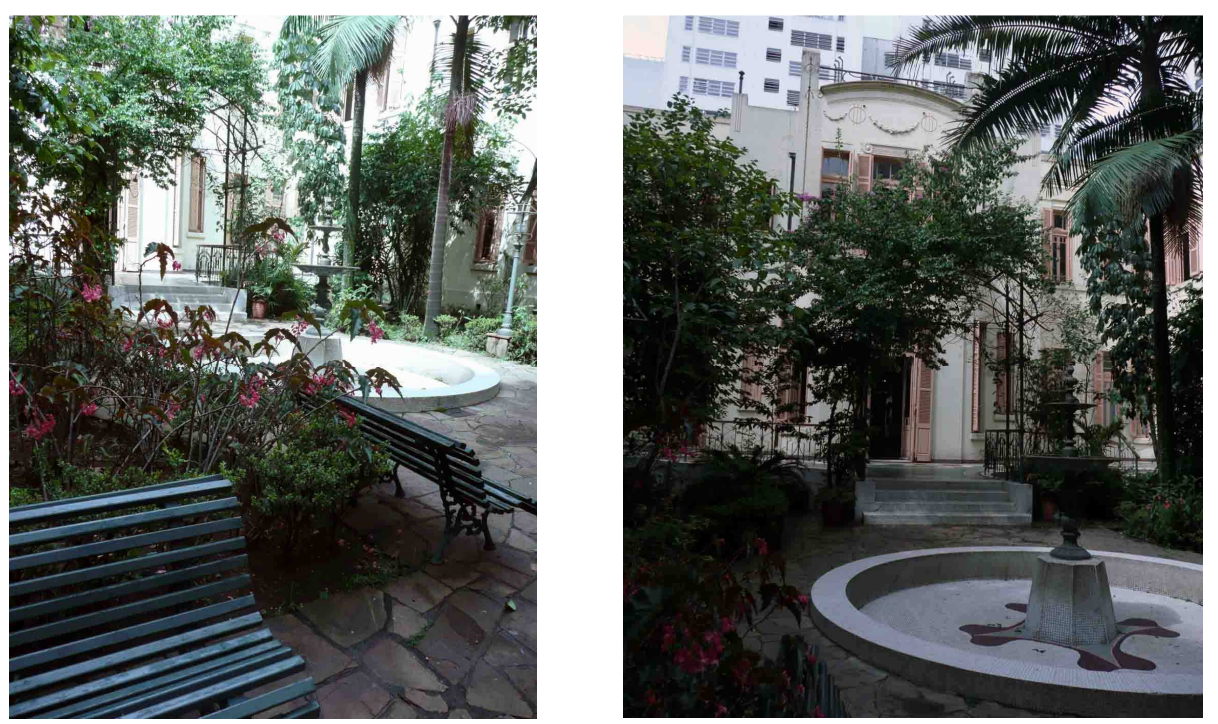

Figura 175 - Chafariz da Vila Penteado Fotos: Isis Roverso, dezembro de 2010.
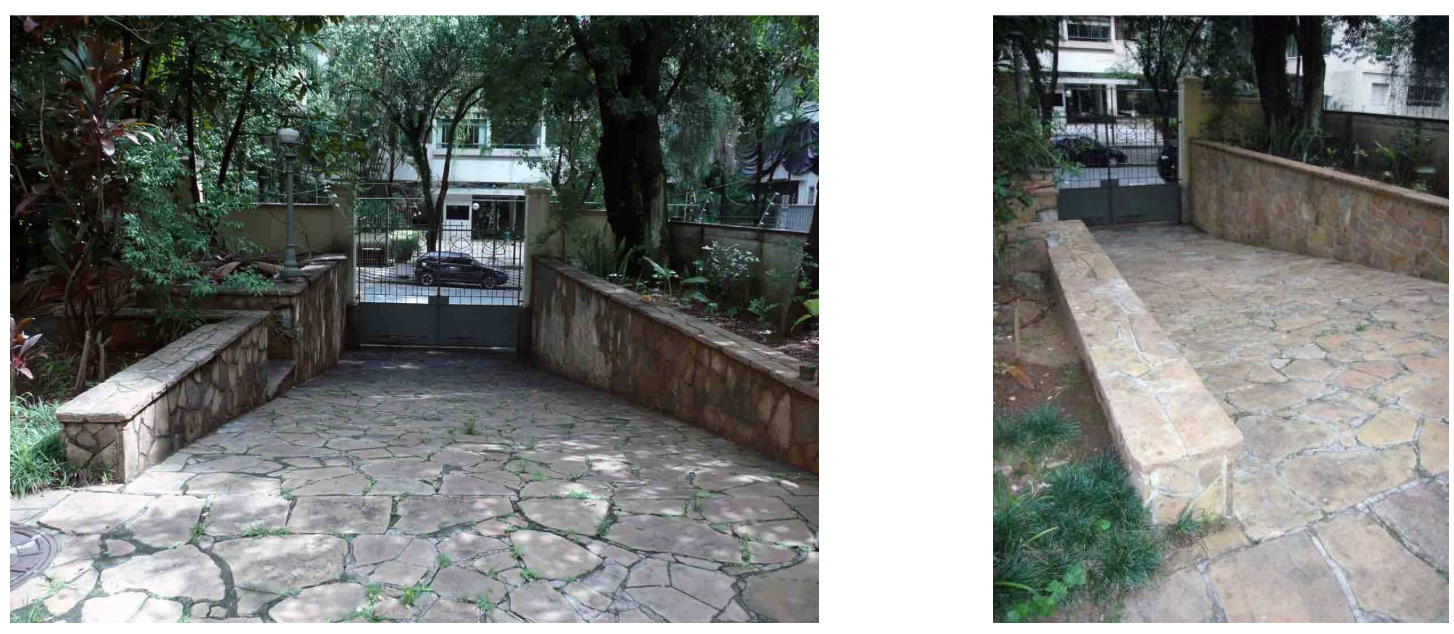

Figura 176 - Rampa de acesso

Fotos: Isis Roverso, dezembro de 2010 e abril de 2011. 


\subsubsection{FUNDAÇÃO}

Não há documentação específica sobre a fundação da Vila Penteado, nem tão pouco relatos de inspeções feitas nesse sistema. Entretanto, é possível afirmar que as condições das fundações são estáveis e adequadas, visto que não apresentam fissuras, recalques, ou qualquer outra deformação visível.

Comparando fotos antigas do porão com a situação atual, é possível verificar que não existem alterações estruturais. As fotos das figuras 177 e 178 apresentam áreas registradas na década de 1970 e nos dias de hoje.
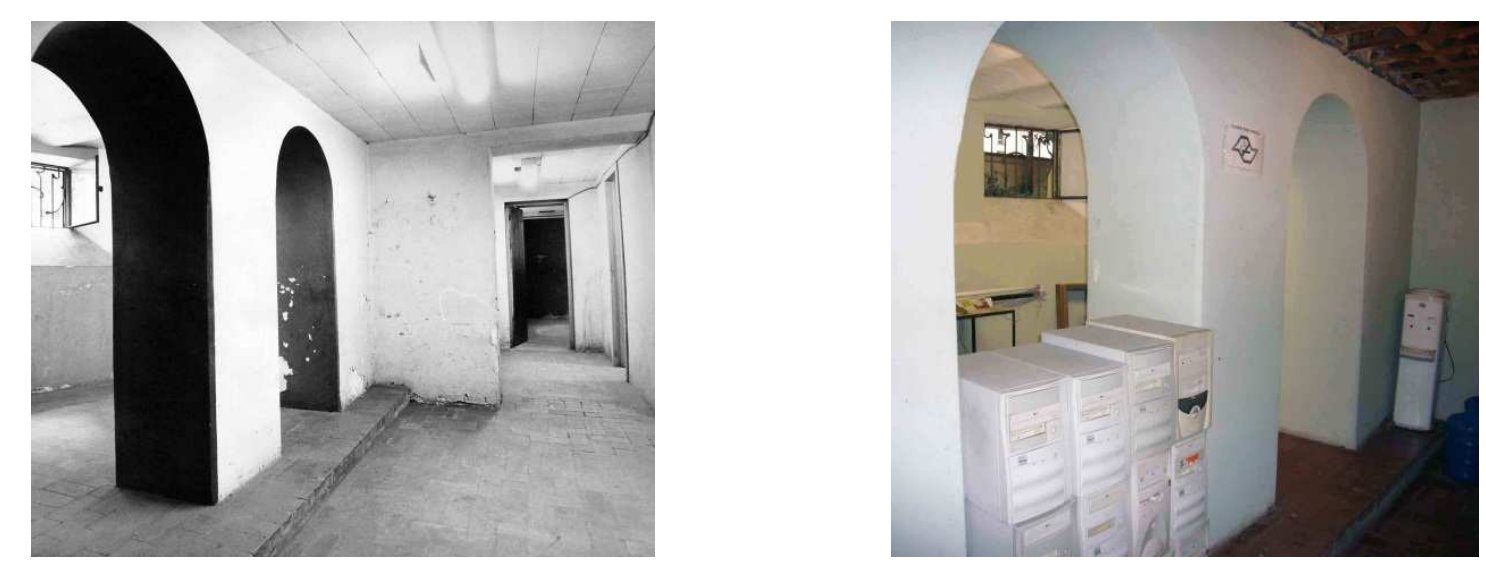

Figura 177 - À esquerda, foto do porão da década de 1970 e, à direita, foto atual da mesma área

Fonte: Foto, à esquerda, pertencente ao Trabalho de Graduação Final "Vila Penteado: vida nova em velho prédio", de Alberto de Prado, 1979. Foto, à direita, de Isis Roverso, abril de 2011.
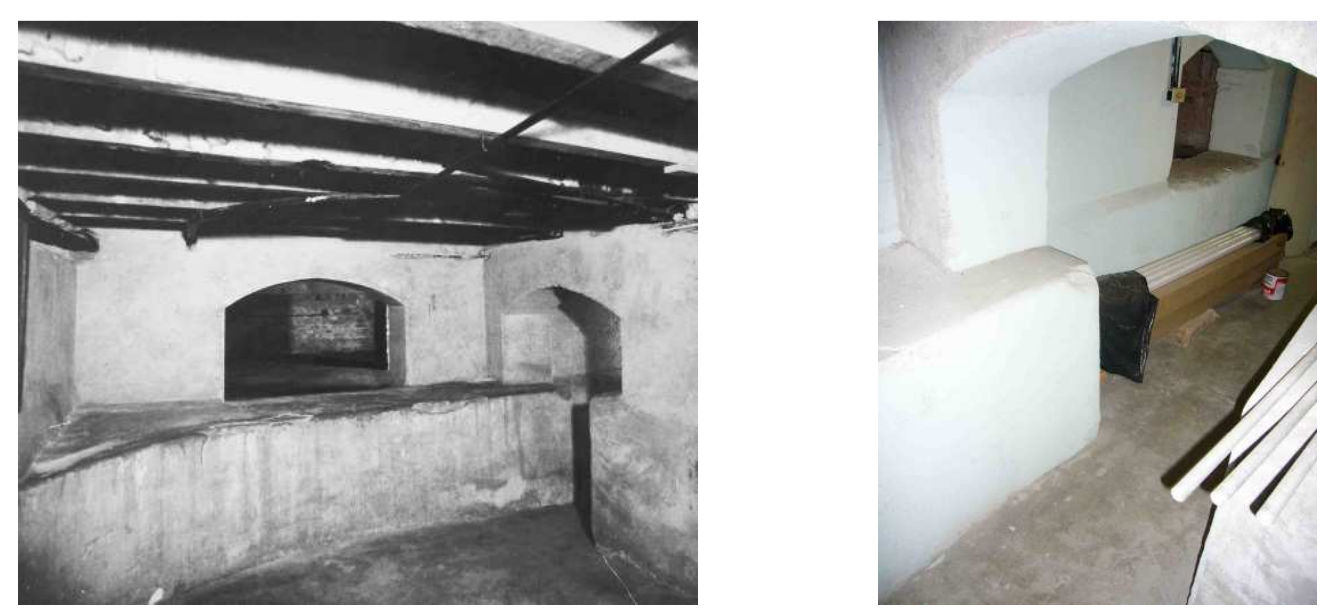

Figura 178 - Comparação da foto da década de 1970 com a situação atual: estrutura estável

Fonte: Foto, à esquerda, PRADO, 1979 e foto, à direita, de Isis Roverso, abril de 2011. 


\subsubsection{ESTRUTURA}

A supraestrutura da Vila Penteado também não apresenta sinais de alteração, mantendo sua integridade.

Parte da estrutura é composta por peças em madeira e o relatório ${ }^{112}$ da empresa TECNOMAD - Consultoria e Serviços Ltda, de 1990/91, "Estado de Conservação das Estruturas e Componentes de Madeira do Edifício", assegura a estabilidade estrutural dessas peças.

Entretanto é necessário manter esse sistema em constante observação, especialmente em relação a possíveis ações de degradação biológica, visto já ter sido verificada a presença de cupins de solo, em 1989, algo comum na região do bairro Higienópolis. Em 1992, foi executada descupinização geral do edifício e, em 2009 , foi feita visita de inspeção e avaliação ${ }^{113}$ do sistema estrutural da cobertura e forro da Vila Penteado. Nessa inspeção de 2009 foi constatado que o madeiramento está em bom estado de integridade física e que não há cupins em nenhum elemento da estrutura. As fotos das figuras 179 e 180 apresentam peças da estrutura em madeira visíveis na área do porão.
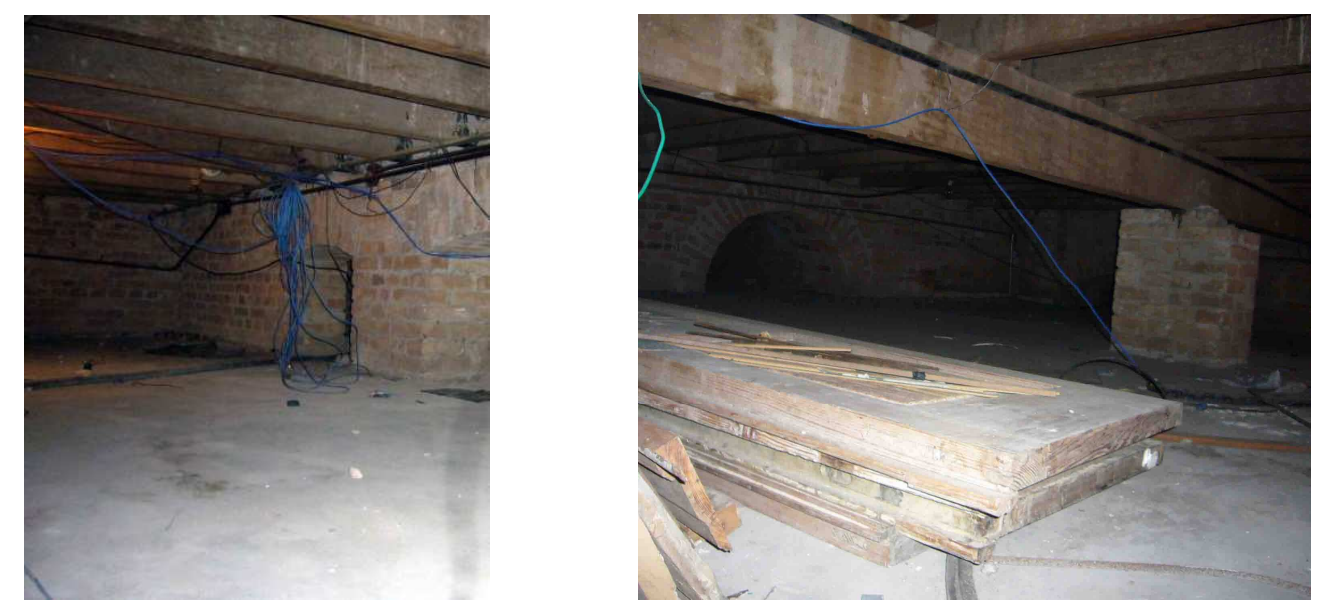

Figura 179 - Estrutura de madeira visível no porão Fotos: Isis Roverso, abril de 2011

\footnotetext{
112 Para mais detalhes sobre o relatório da empresa TECNOMAD, ver o item 3.1.4.1 "Descrição Formal da Vila Penteado" desse trabalho e o relato do Prof. Roberto Leme Simões, registrado no Boletim Técnico número 12, 1993, p.11.

113 Parecer Técnico: Avaliação do estado de sanidade da estrutura de madeira do telhado e forro do edifício da Faculdade de Arquitetura e Urbanismo da USP, Cliente: Grupo Executivo de Gestão dos Espaços Físicos da FAUUSP. Elaborado pelo Eng. Waldivino de Carvalho Filho, CREA:06004404987, São Paulo, 26 de março de 2009, TEMA Engenharia, p.2.
} 

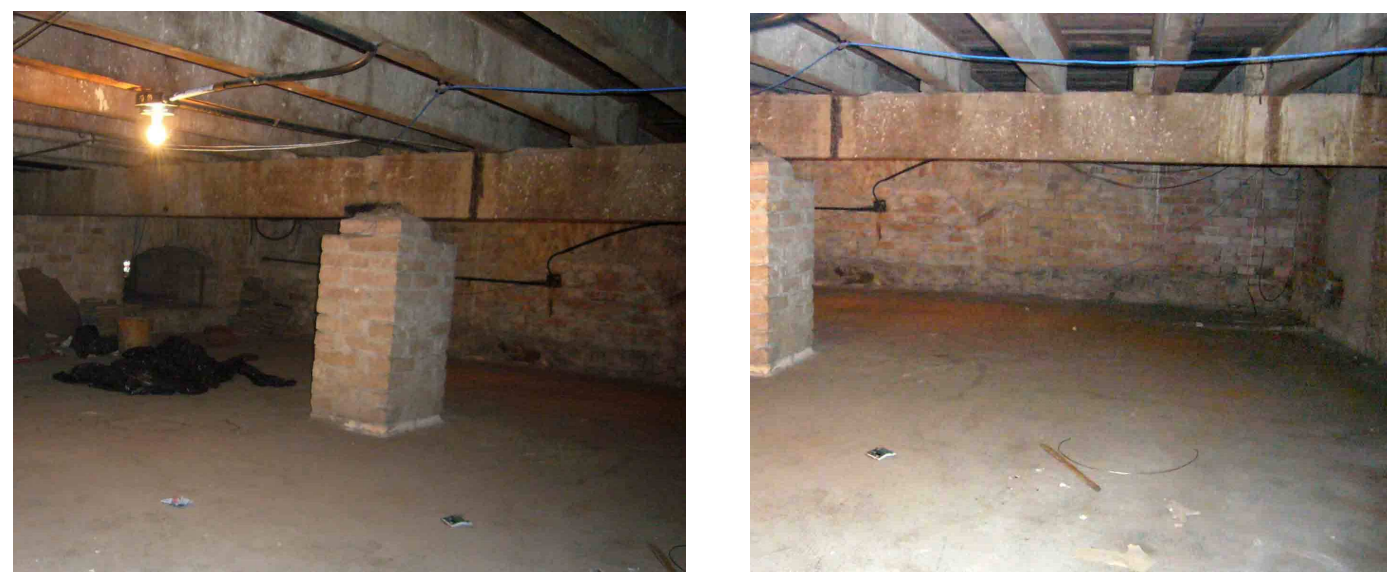

Figura 180 - Estrutura de madeira visível no porão

Fotos: Isis Roverso, abril de 2011.

Como já comentado no item 3.3.1 "Elementos Gráficos: Bases Digitais", algumas aberturas do porão foram fechadas, visando reduzir a ventilação nessa área, equilibrando, assim, a temperatura do edifício, especialmente nos períodos de inverno. Uma dessas aberturas, que foi vedada, pode ser vista na foto da figura 181, que apresenta também uma das vigas de madeira existente na área do porão.

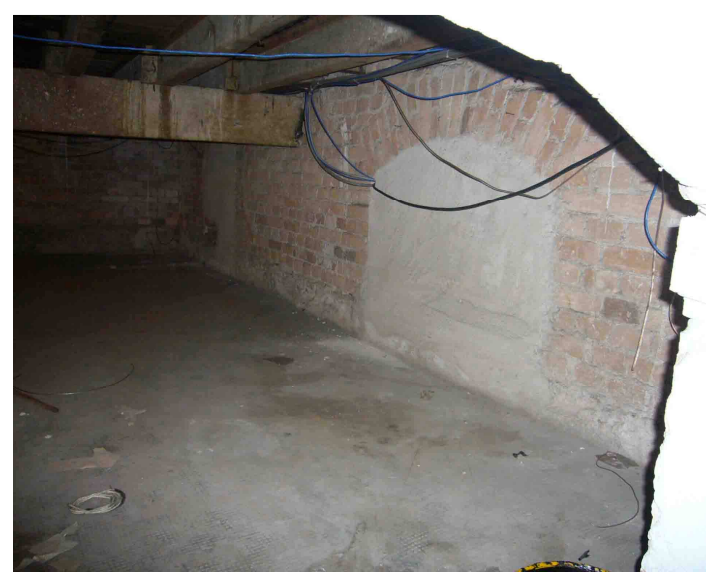

Figura 181 - Estrutura de madeira visível e abertura vedada no porão Foto: Isis Roverso, abril de 2011.

Apesar do desempenho adequado da estrutura de madeira encontrado na Vila Penteado, alguns problemas pontuais podem ser observados. Um deles encontra-se no preenchimento, visando o reforço, de um trecho danificado de uma das vigas visíveis no porão (área SUB-9 do porão). A foto da figura 182 apresenta a viga comentada. 


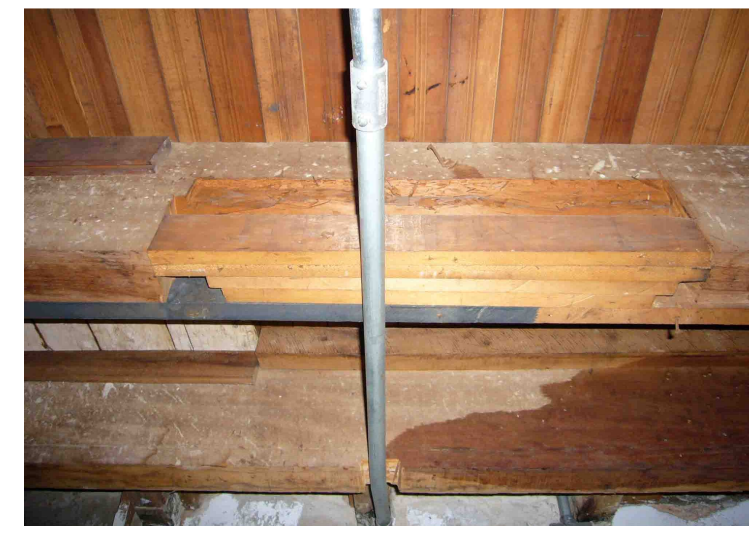

Figura 182 - Viga em madeira com preenchimento Foto: Isis Roverso, abril de 2011.

É possível verificar ainda que, na área do porão sob a Biblioteca, várias vigas em madeira foram recortadas para a passagem de eletrodutos, ação desnecessária, visto que os eletrodutos poderiam passar por baixo das vigas.
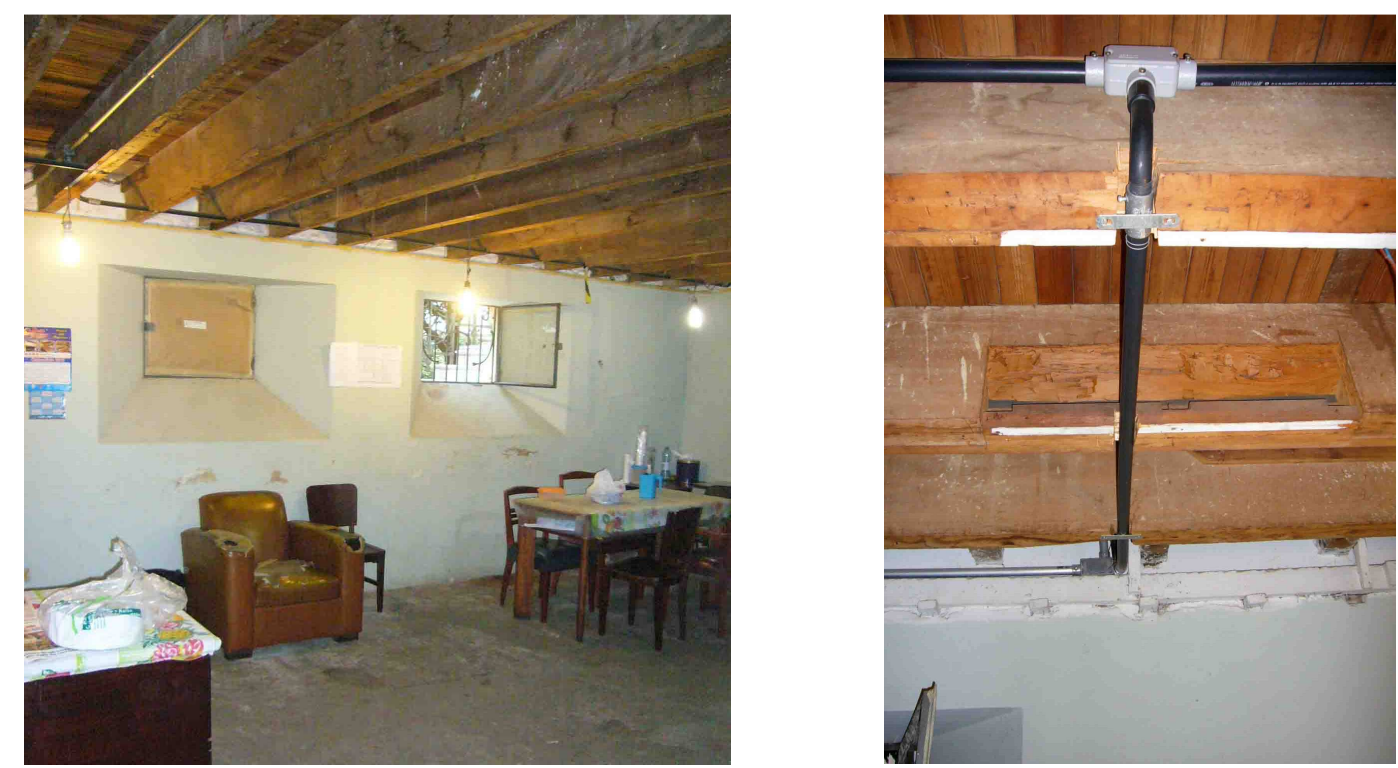

Figura 183 - Vigas de madeira cortadas para passagem dos eletrodutos da biblioteca Fotos: Isis Roverso, abril de 2011.

Os demais elementos estruturais, como os arcos, apresentam-se em condições adequadas, sem deformações visíveis. A figura 184 apresenta a foto das abobadilhas em tijolos apoiadas sobre perfis metálicos. Sistema plenamente estável. 


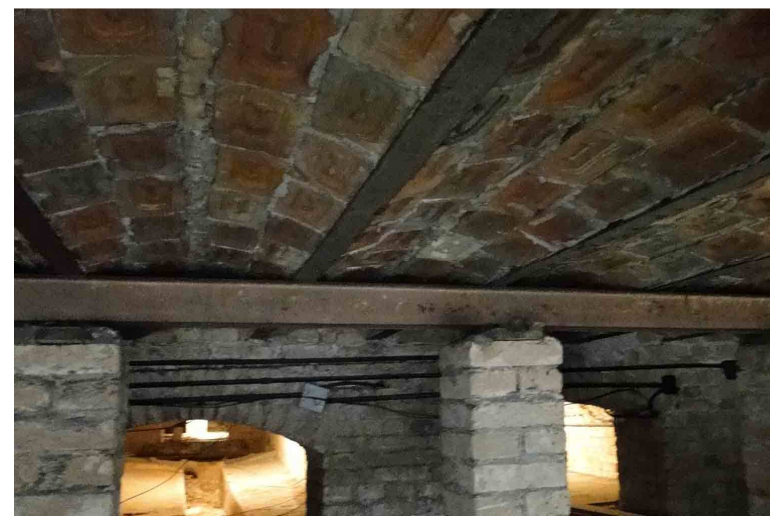

Figura 184 - Abobadilhas em tijolos sobre perfis metálicos Foto: Isis Roverso, agosto de 2011. 


\subsubsection{COBERTURA}

O sistema da cobertura contempla a estrutura de suporte em madeira e revestimento (telhamento). Os materiais e intervenções ocorridas na cobertura estão detalhados no item 3.2.1 "Documentos sobre a Cobertura".

A cobertura necessita de cuidados emergenciais e, em função da dificuldade de acesso, a abrangência das ações imediatas não pôde ser avaliada. Dessa forma faz-se necessário estabelecer condições adequadas para a vistoria de toda a cobertura, através da locação de plataforma elevatória. Entretanto, é possível afirmar que a cobertura necessita de formulação de projeto de restauro global, contendo, ao menos:

- Detalhamento do sistema de cobertura existente, com indicação das áreas danificadas e soluções para: estrutura, telhamento e drenagem das águas de chuva;

- Restauro, recolocação e redimensionamento dos condutores em cobre, ampliando a capacidade do sistema de captação de águas pluviais;

- Especificação de subcobertura que permita a ventilação, auxilie na estanqueidade e melhore o conforto térmico do edifício;

- Detalhamento de sistema auxiliar que ajude as vistorias da manutenção periódica.

As figuras 185 a 190 apresentam fotos com a situação atual da cobertura da Vila Penteado.

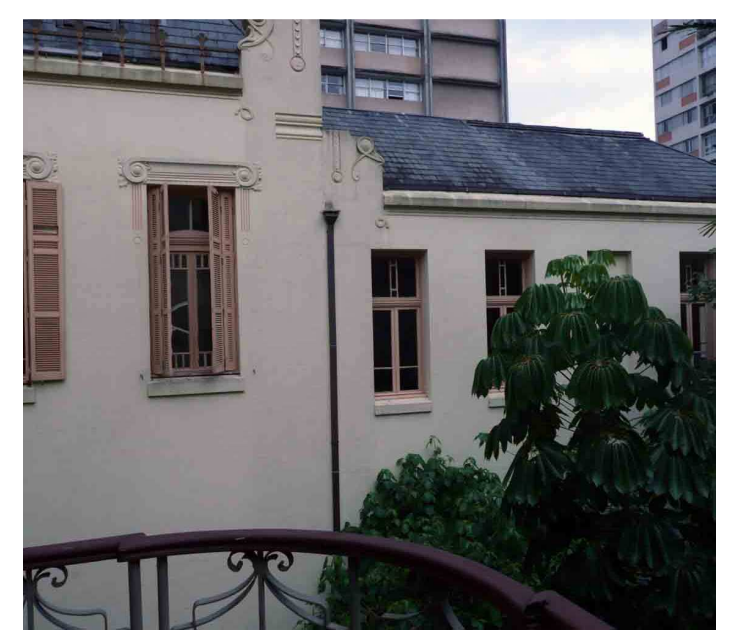

Figura 185 - Cobertura da Vila Penteado: telhamento em cobre e ardósia Foto: Isis Roverso, dezembro de 2010. 

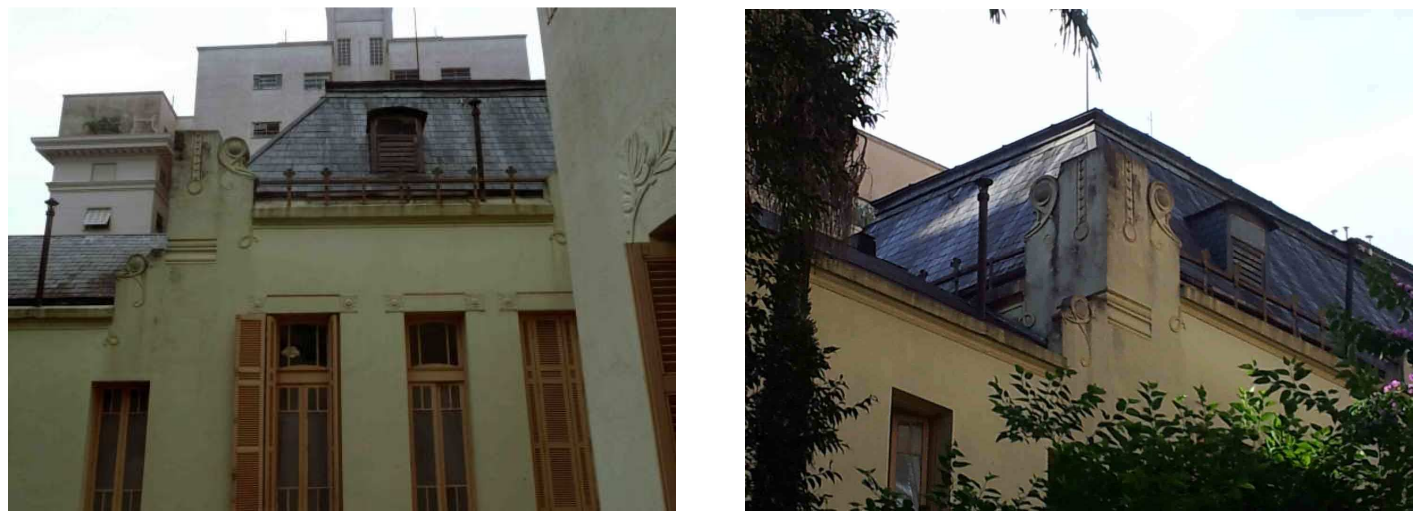

Figura 186 - Cobertura da Vila Penteado: sem beirais e com ornamentos metálicos Fotos: Isis Roverso, dezembro de 2010 e outubro de 2011.

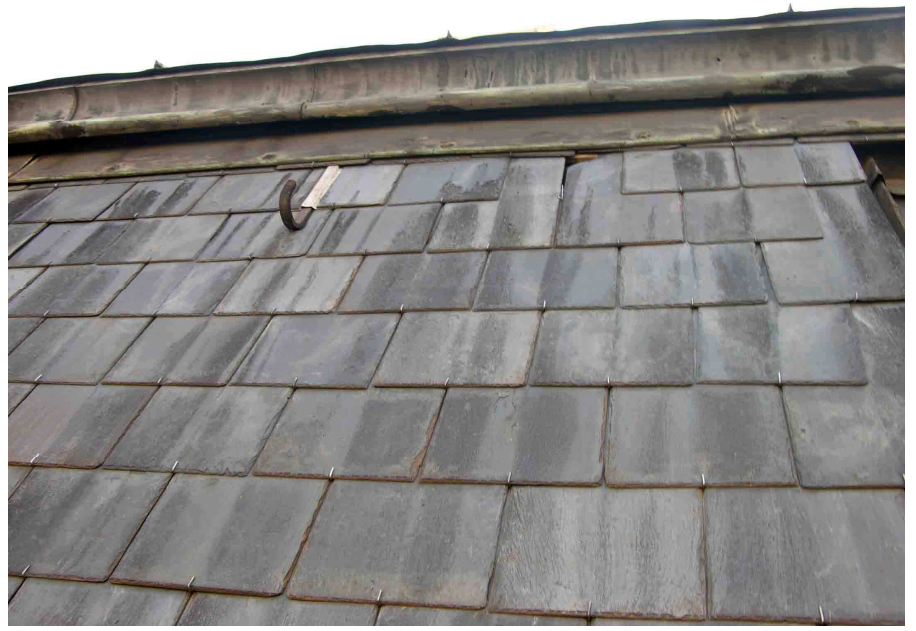

Figura 187 - Cobertura da Vila Penteado: águas em telhas de pedra ardósia Foto: Isis Roverso, junho de 2011.

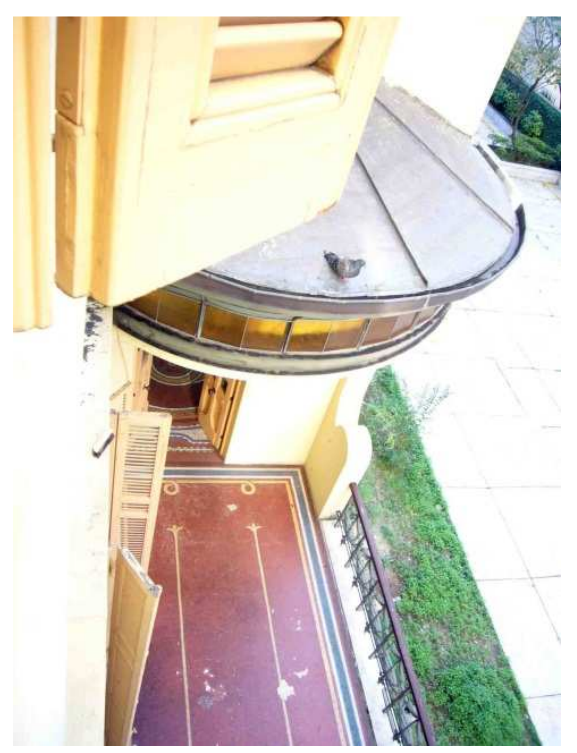

Figura 188 - Cobertura da Vila Penteado: água em chapas de cobre Foto: Isis Roverso, abril de 2011. 

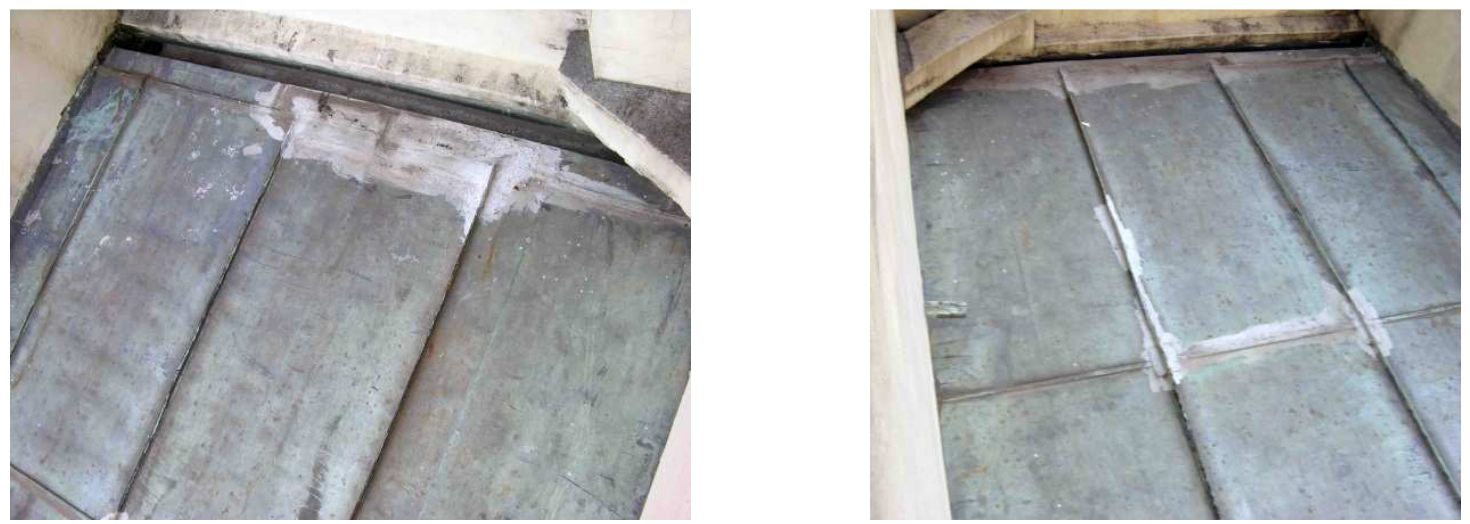

Figura 189 - Cobertura da Vila Penteado: água sobre mezanino em chapas de cobre (local com vazamento que provou o desmoronamento de parte do forro em estuque) Fotos: Arnaldo Gomes de Almeida, junho de 2011.
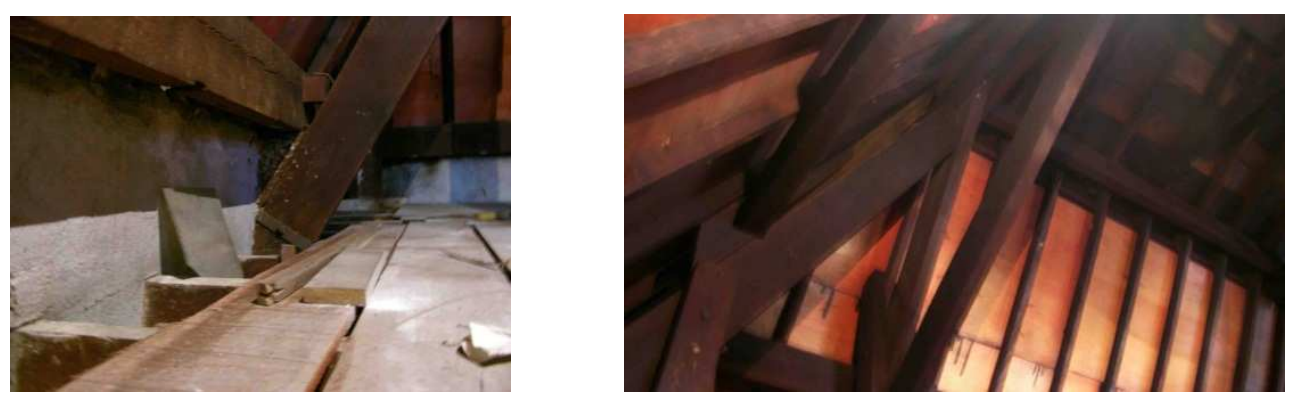

Figura 190 - Cobertura da Vila Penteado: chapas de compensado, impermeabilizadas, fixas sobre caibros de madeira.

Fotos: Isis Roverso, junho de 2011. 


\subsubsection{VEDOS}

Os vedos contemplam as vedações verticais internas e externas (paredes) e horizontais (forros), internas ou externas. Visando facilitar a organização desse trabalho, as vedações horizontais (forros), são apresentadas com seus revestimentos, no item 4.1.7.2 "Tetos e Forros".

Tanto as vedações externas quanto as divisões internas da Vila Penteado apresentam condições de desempenho satisfatórias. As falhas construtivas relacionadas aos vedos encontram-se nos revestimentos (para informações detalhadas, verificar o item 4.1.7.1 "Revestimento das Paredes").

As fotos, constantes nas figuras 191 a 194, apresentam, por amostragem, a situação atual dos vedos externos da Vila Penteado.
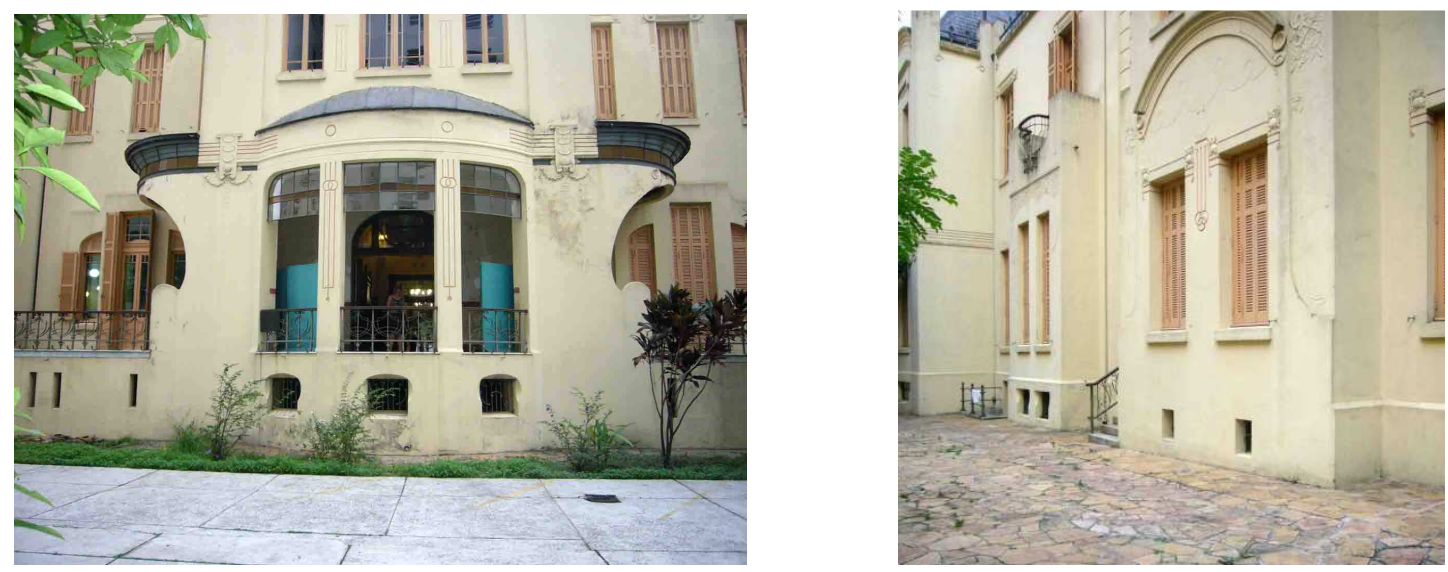

Figura 191 - Fachada posterior e lateral direita da Vila Penteado Fotos: Isis Roverso, abril de 2011.
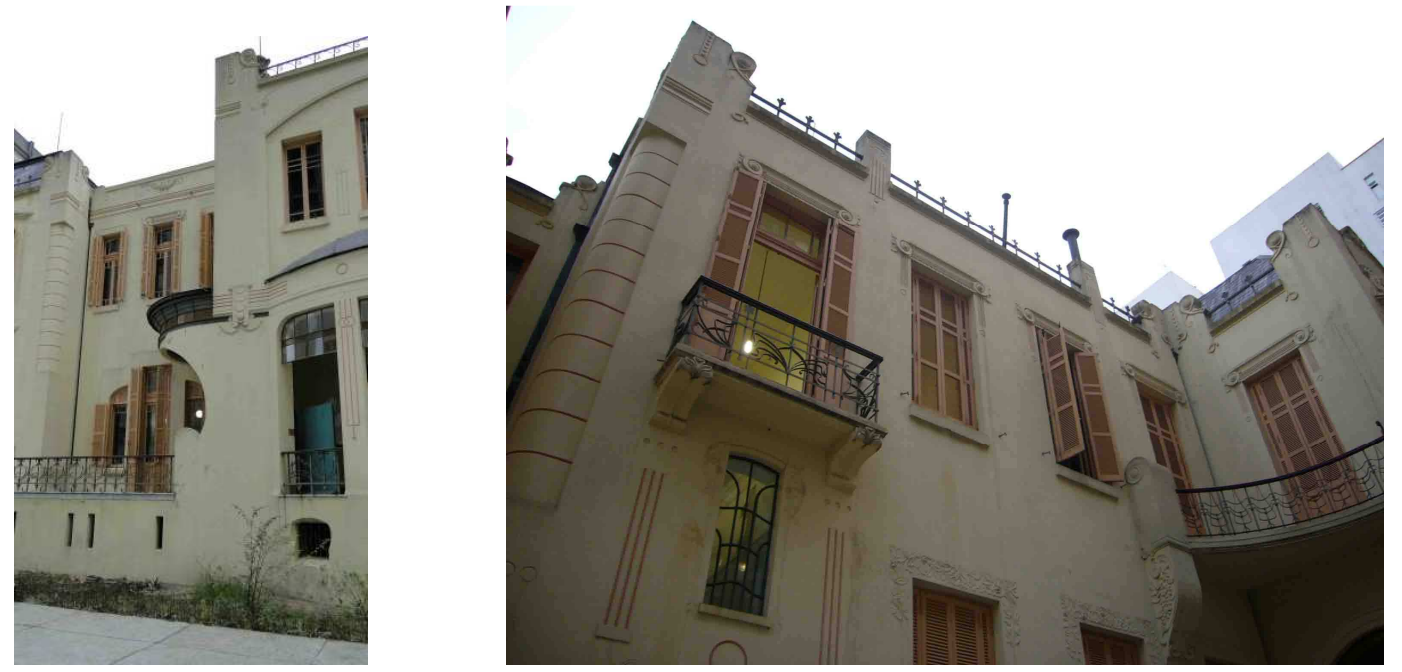

Figura 192 - Fachada posterior e lateral esquerda da Vila Penteado Fotos: Isis Roverso, agosto e abril de 2011. 

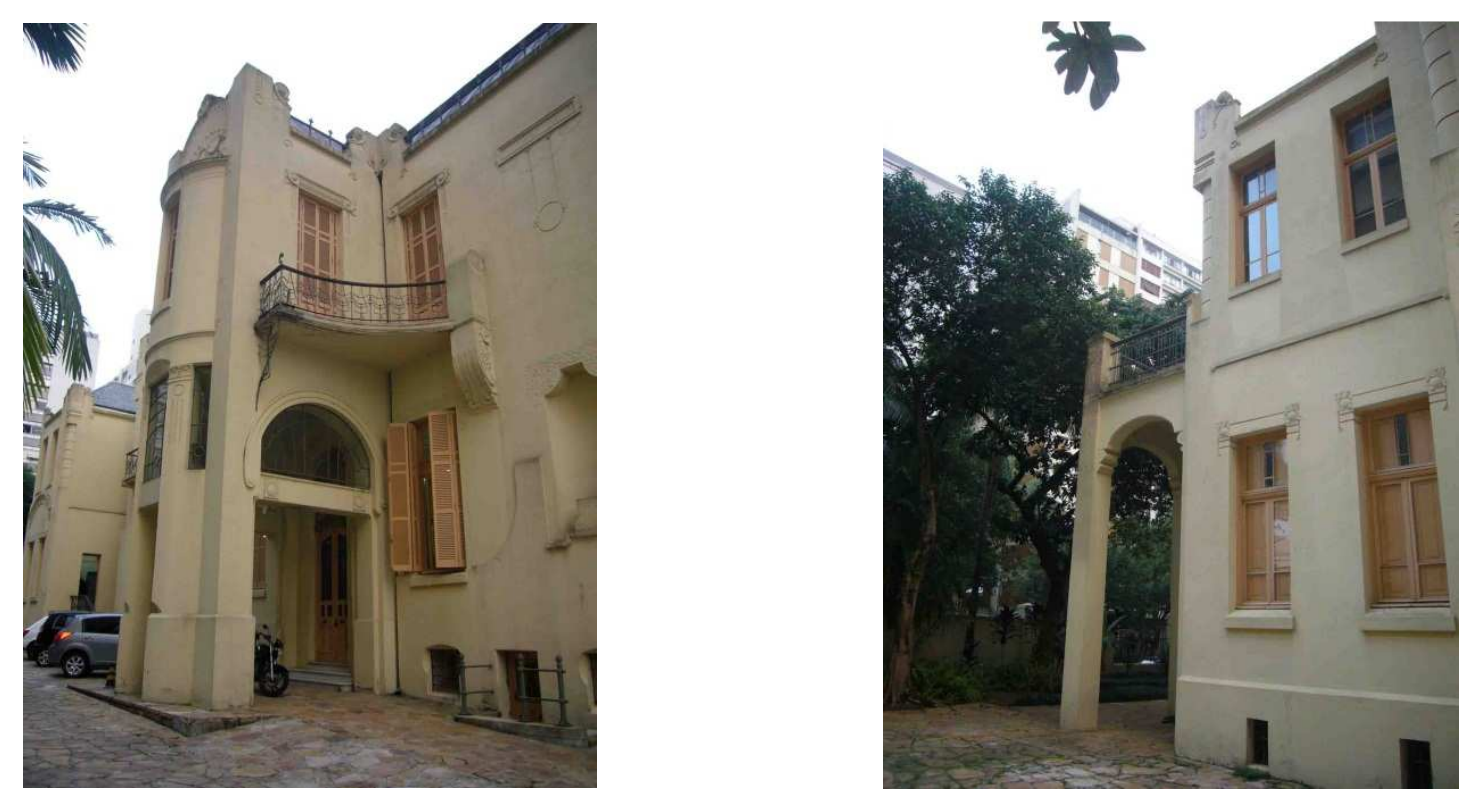

Figura 193 - Fachada lateral esquerda da Vila Penteado Fotos: Isis Roverso, abril de 2011.

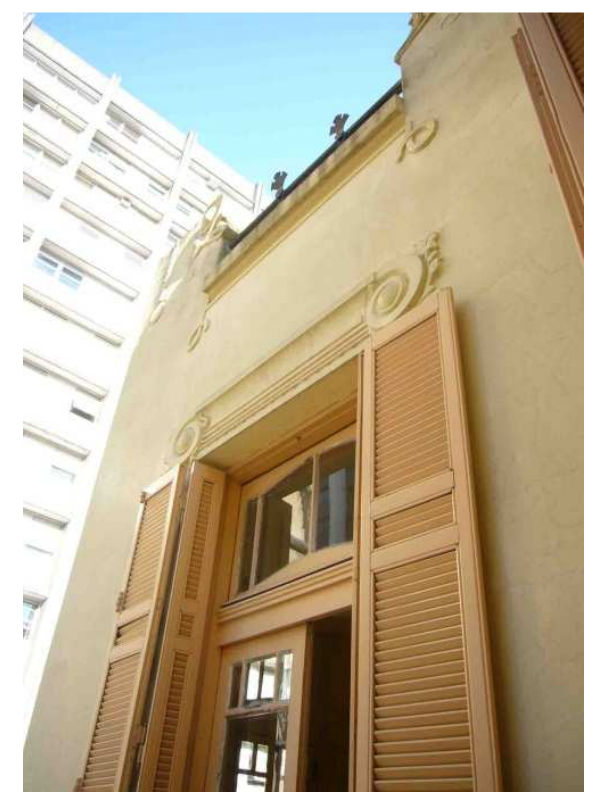

Figura 194 - Detalhe da fachada da Vila Penteado Foto: Isis Roverso, abril de 2011.

As divisões internas aprensentam a qualidade compatível com o sistema. Entretanto, visando organizar algumas áreas, como a secretaria e a Sala 44, divisórias leves foram instaladas. $E$ ainda outras foram executadas em alvenaria a meia altura, como é o caso das divisórias dos banheiros, sendo que essas últimas também poderiam ser executadas em materiais leves, o que iria conferir menor espessura ao vedo e permitiria melhor ocupação dos pequenos espaços. 

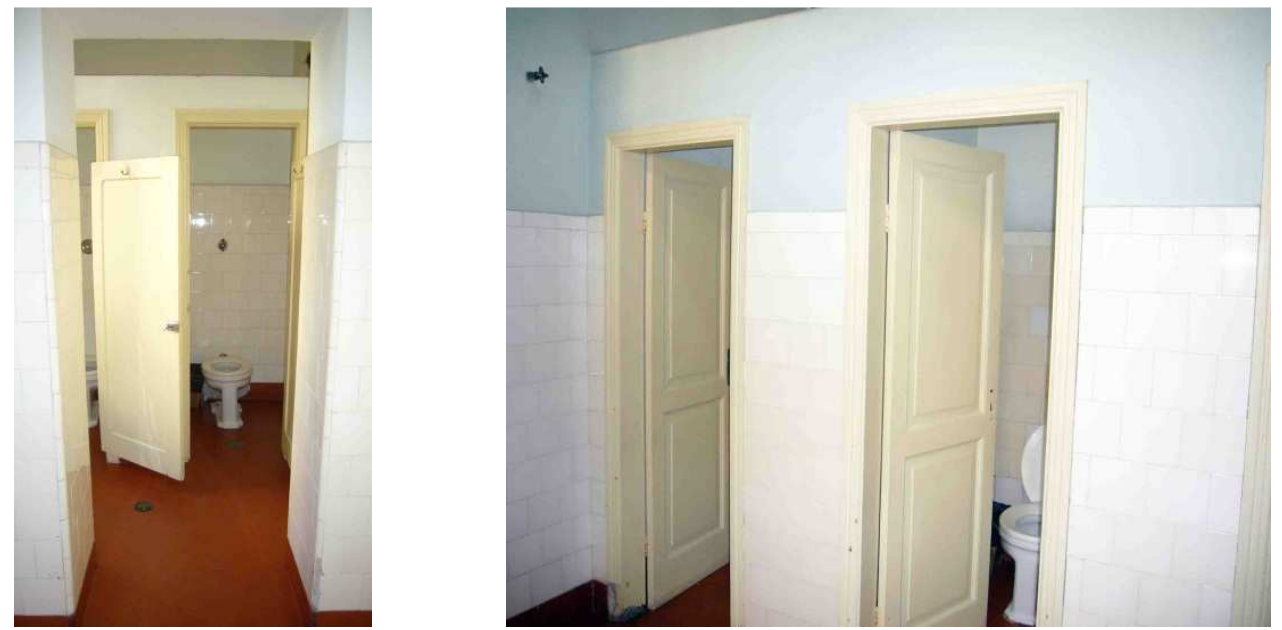

Figura 195 - Divisórias em alvenaria dividindo das áreas internas dos banheiros (S46 e Sanitário Masculino)

Fotos: Isis Roverso, abril de 2011.
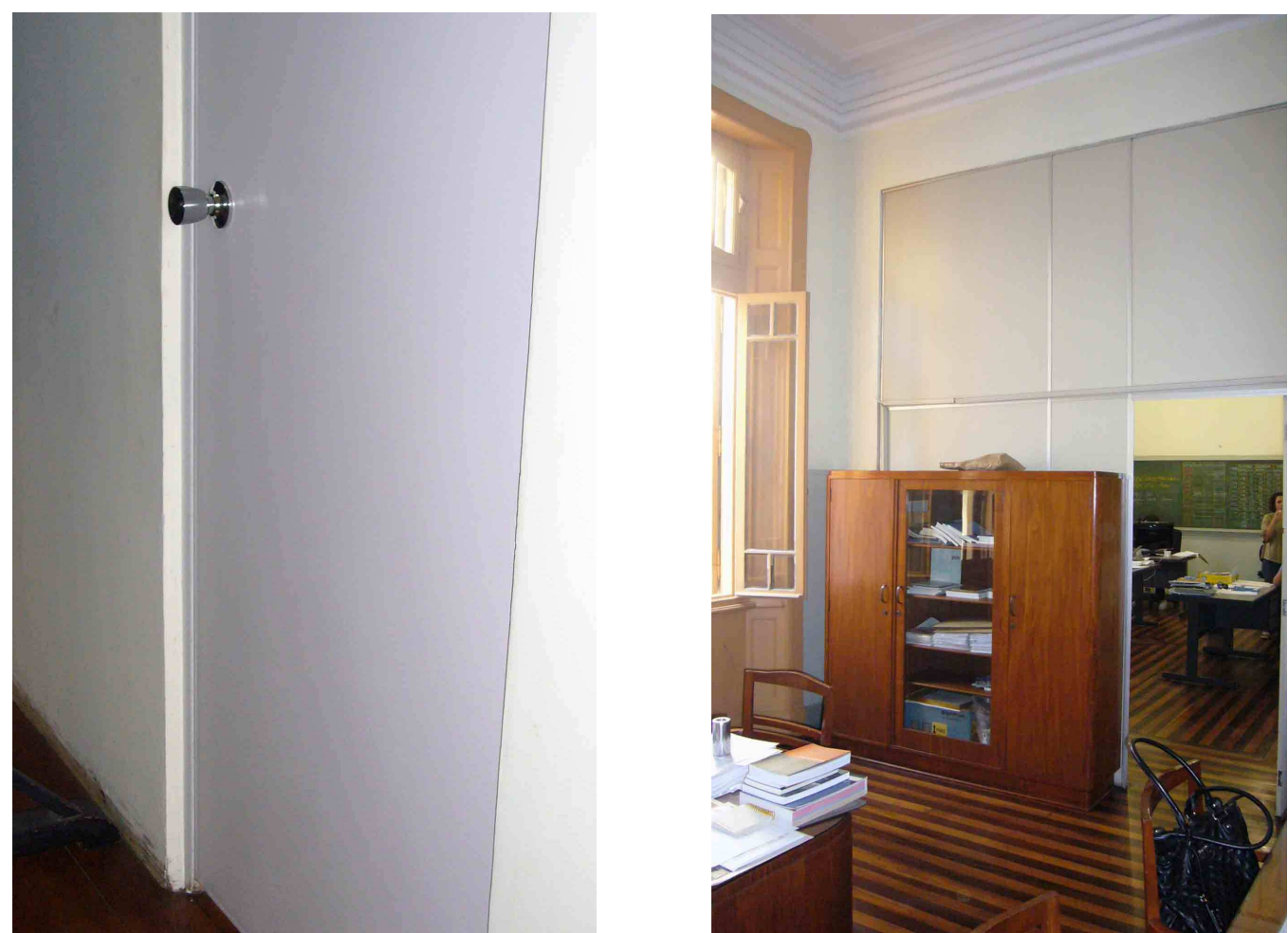

Figura 196 - Divisória leve da Sala 44 e da Secretaria (entre S71 e S73) Foto: Isis Roverso, abril de 2011. 


\subsubsection{VÃOS}

No item "Vãos", além da análise das esquadrias (portas e janelas), os corrimãos e guarda-corpos também foram verificados. Esses elementos foram incluídos nesse item por apresentarem materiais semelhantes aos das esquadrias e também pelo fato de terem recebido manutenção no mesmo período que as portas e janelas externas.

De maneira geral, as falhas detectadas nas esquadrias (portas e janelas) e nos corrimãos, geram reflexos negativos na segurança ao uso da edificação. Os usuários encontram dificuldades no manuseio das portas e janelas; notadamente nas externas, devido ao estado de deterioração. As falhas nesse sistema deixam a edificação mais vulnerável a possíveis invasões. Além disso, a falta de estanqueidade das folhas das esquadrias facilita a entrada de água de chuva no edifício, potencializando os riscos de queda e a deterioração precoce dos revestimentos internos de pisos e paredes.

Os corrimãos fragmentados não se prestam mais à função essencial de garantir a segurança do usuário no trânsito pelas escadas e sacadas, especialmente, em dias chuvosos, quando os pisos externos tornam-se mais escorregadios.

\subsubsection{ESQUADRIAS EXTERNAS}

As esquadrias externas apresentam, de forma geral, desgaste motivado pelo uso e, principalmente, pelo intemperismo.

A última ação de manutenção efetiva e global ocorreu, segundo o Relatório de Gestão de 2003 da Vila Penteado, com o desenvolvimento do trabalho de recuperação das esquadrias externas, contemplando a reposição de ferragens e reforços especiais. Todas as esquadrias metálicas e de madeira foram restauradas pela empresa Júlio Moraes Conservação e Restauro.

Segundo as atas de reuniões, realizadas entre os gestores do edifício Vila Penteado, Prof ${ }^{a}$ Helena Ayoub Silva e Prof. Antonio Carlos Barossi, e a empresa Júlio Moraes Conservação e Restauro, representada por Júlio Moraes e Cláudio Ekeda, os seguintes materiais foram usados nos serviços de recuperação, restauro e pintura das esquadrias externas:

- Sparlack Knotting 99150, como fundo nivelador para madeiras; 
- Produto DRAGNET 384 CE e solvente EXXOL D-80, usados na imunização preventiva das peças de madeira.

E em carta assinada pela Prof ${ }^{a}$ Helena Ayoub Silva para Tintas Ypiranga, At. Sr. Ewerton, de 11 de abril de 2003, solicitando materiais para pintura das esquadrias externas e internas, constam os seguintes materiais:

- Esmalte sintético acetinado cor E4.25.65;

- Esmalte sintético acetinado cor F6.15.80 para pintura das portas internas e rodapés.

Desde esses trabalhos de recuperação das esquadrias, já se passaram quase dez anos, período em que não houve manutenção preventiva e a situação atual constatada reflete essa falta de manutenção, visto que boa parte dos problemas encontrados é resultante das ações do intemperismo e limite da vida útil dos materiais de acabamento e proteção.

Os problemas gerais, encontrados em diversas esquadrias de madeira, são exemplificados nas fotos das figuras 197 a 204, sendo eles:

1. Perda de material de fixação dos vidros provocado pelo ressecamento da massa;

2. Descascamento da pintura, motivado pela perda da capacidade de alongamento da película;

3. Desprendimento das ferragens da base de fixação provocado pelo apodrecimento da madeira;

4. Oxidação e corrosão das ferragens;

5. Desprendimento de partes das folhas das portas e janelas devido ao apodrecimento da madeira.
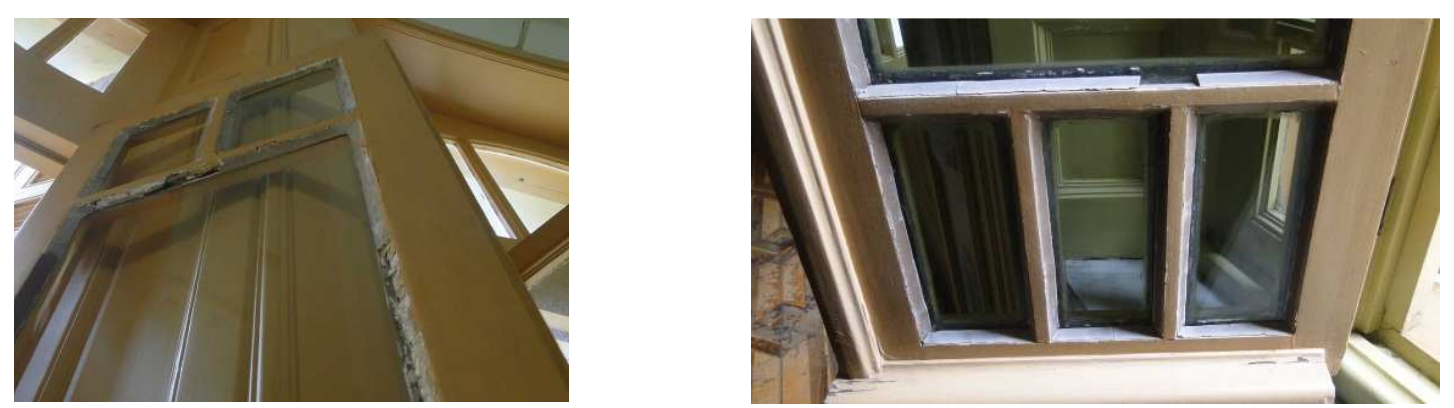

Figura 197 - Janela da Sala 73 (Secretaria) e janela da Sala dos Espelhos: perda de material de fixação dos vidros provocado pelo ressecamento da massa

Fotos: Isis Roverso, janeiro de 2012. 


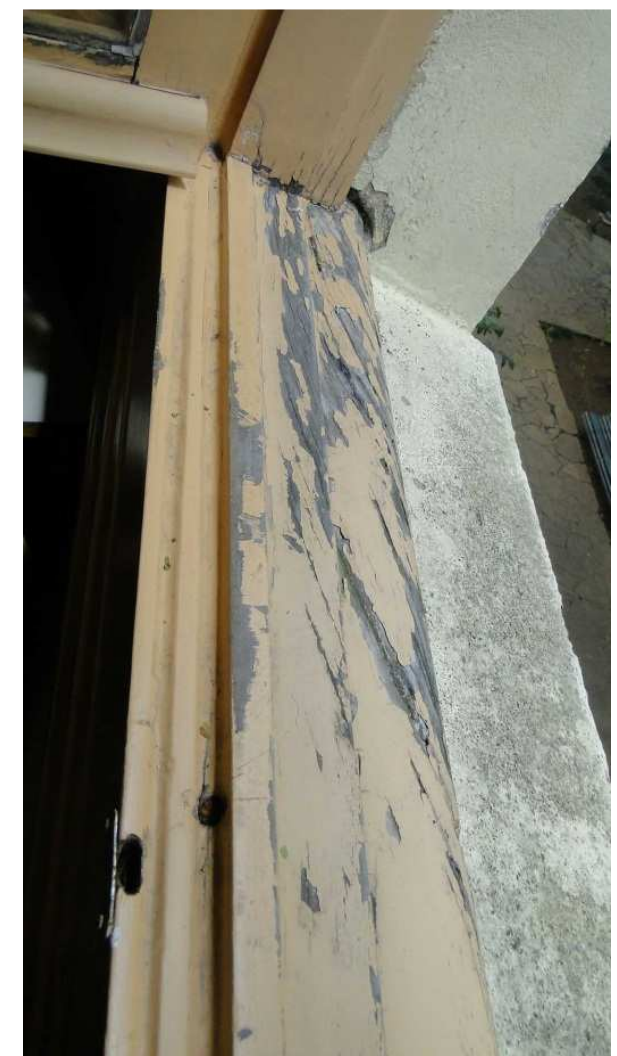

Figura 198 - Peitoril da Janela da Sala 44: falha da pintura e consequente degradação da madeira provocada por incidência solar contínua sem proteção Foto: Isis Roverso, janeiro de 2012.
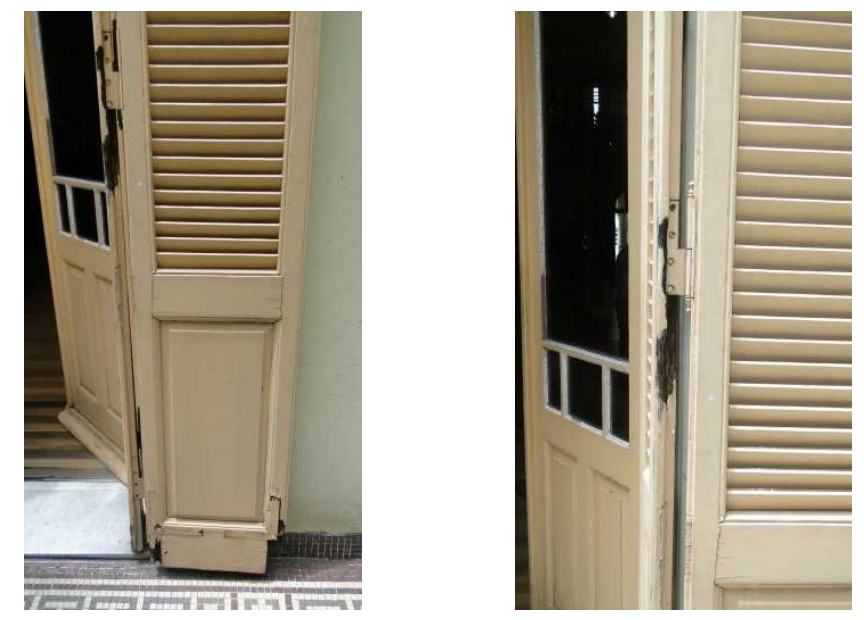

Figura 199 - Porta de Entrada (acesso à portaria): a área de suporte da dobradiça está comprometida, o que causa, inclusive, insegurança no caso de uma tentativa de arrombamento

A base da folha veneziana também está danificada.

Fotos: Isis Roverso, janeiro de 2012. 

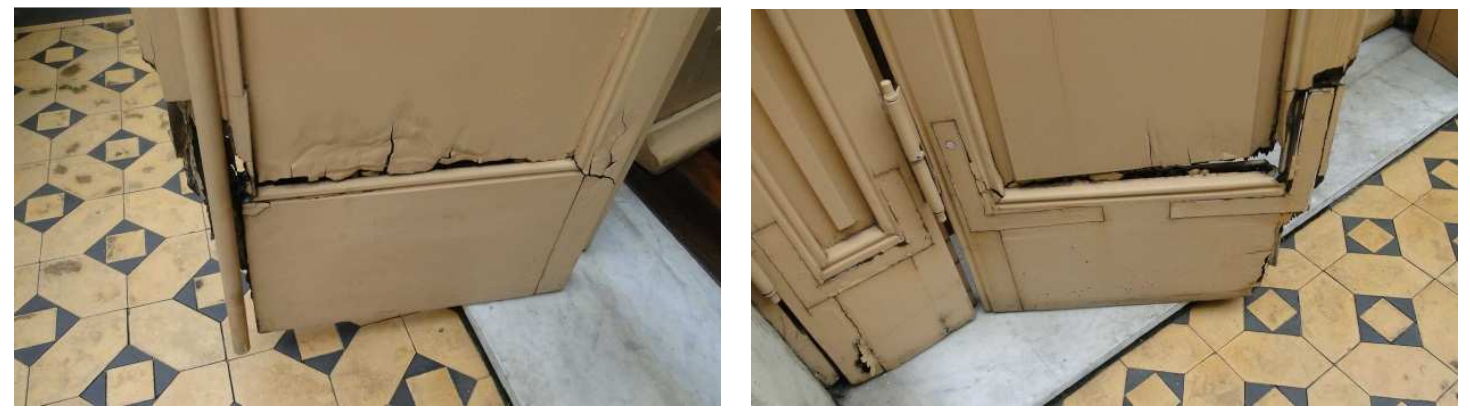

Figura 200 - Porta de acesso ao terraço da Sala 52: base da folha veneziana está se desprendendo

Fotos: Isis Roverso, janeiro de 2012.

Outra situação frequente é a perda de aletas das folhas venezianas. Algumas dessas aletas que se soltaram foram guardadas, como comentou o funcionário Arnaldo Gomes de Almeida, e outras se perderam devido ao apodrecimento ou desfragmentação total, motivado pelo ressecamento da peça.
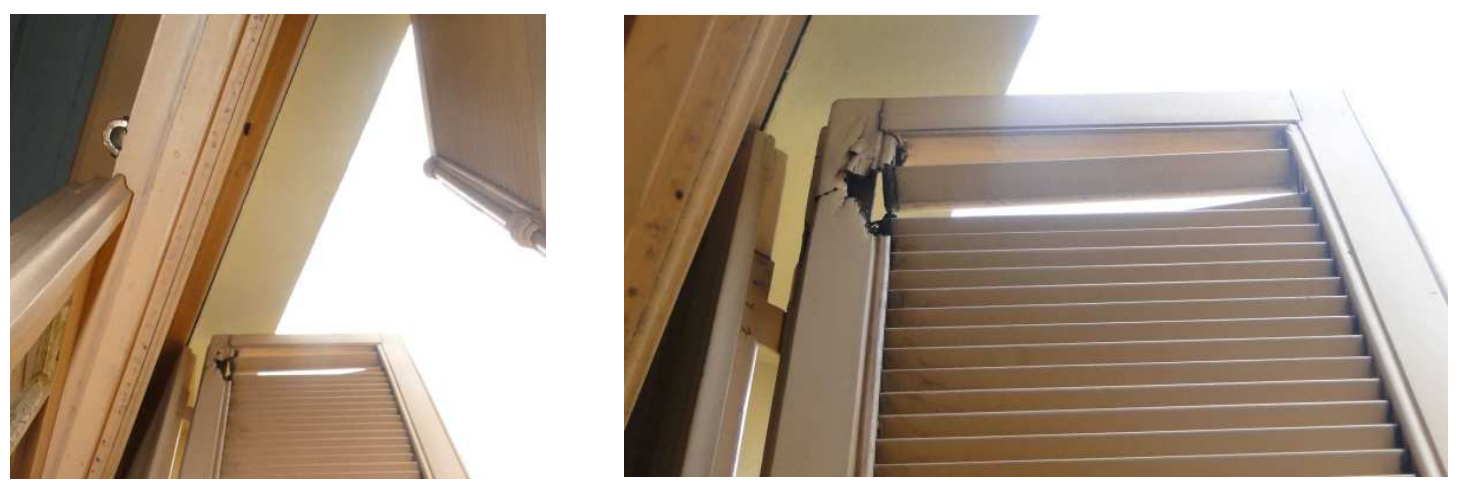

Figura 201 - Janela da Sala 77: moldura da folha veneziana danificada com aleta solta Fotos: Isis Roverso, janeiro de 2012.
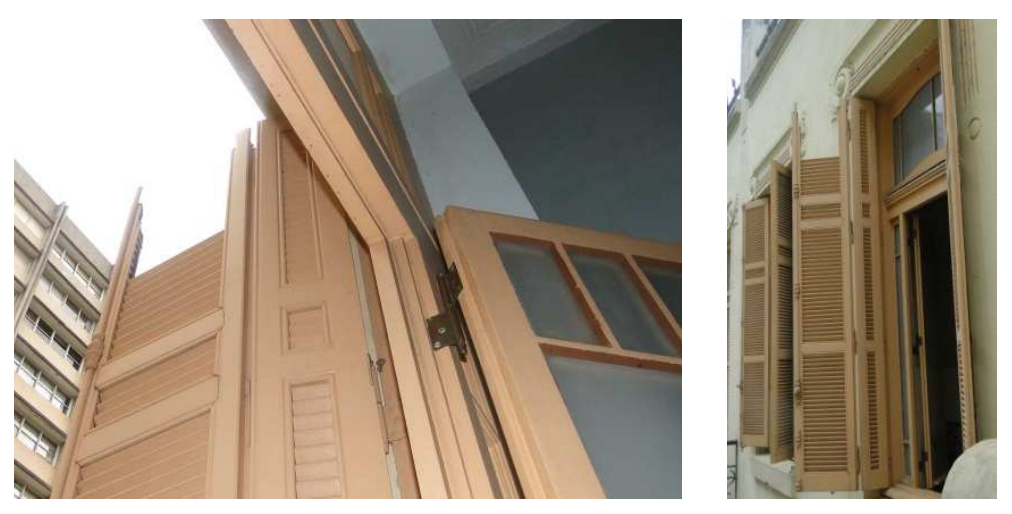

Figura 202 - Janela da Sala 75 (Banheiro Feminino): faltam aletas e a parte superior da moldura da folha veneziana

Fotos: Isis Roverso, janeiro de 2012. 

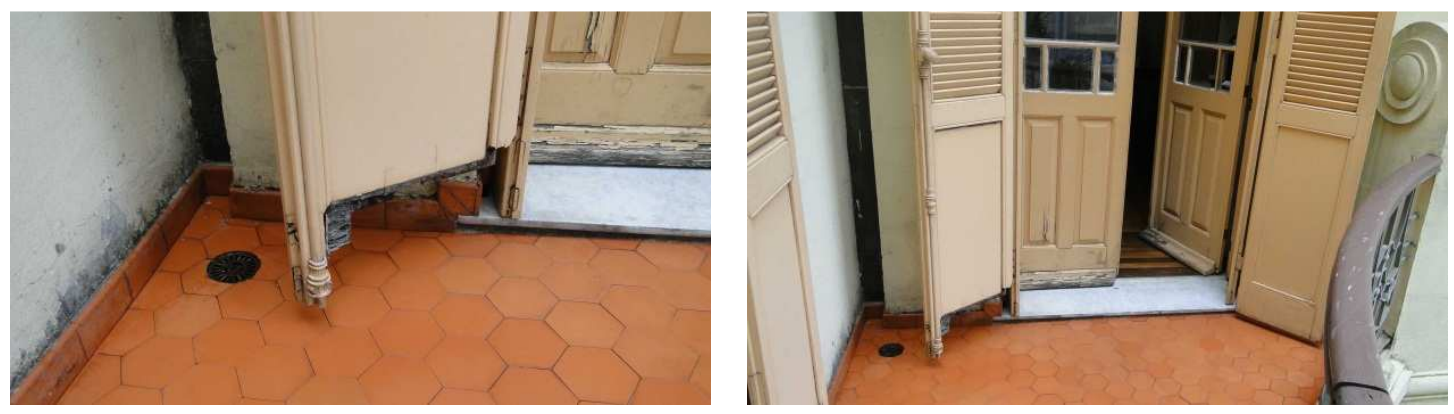

Figura 203 - Porta do terraço esquerdo da Secretaria, Sala 74: as peças de madeira da parte inferior da porta se soltaram

Fotos: Isis Roverso, janeiro de 2012.
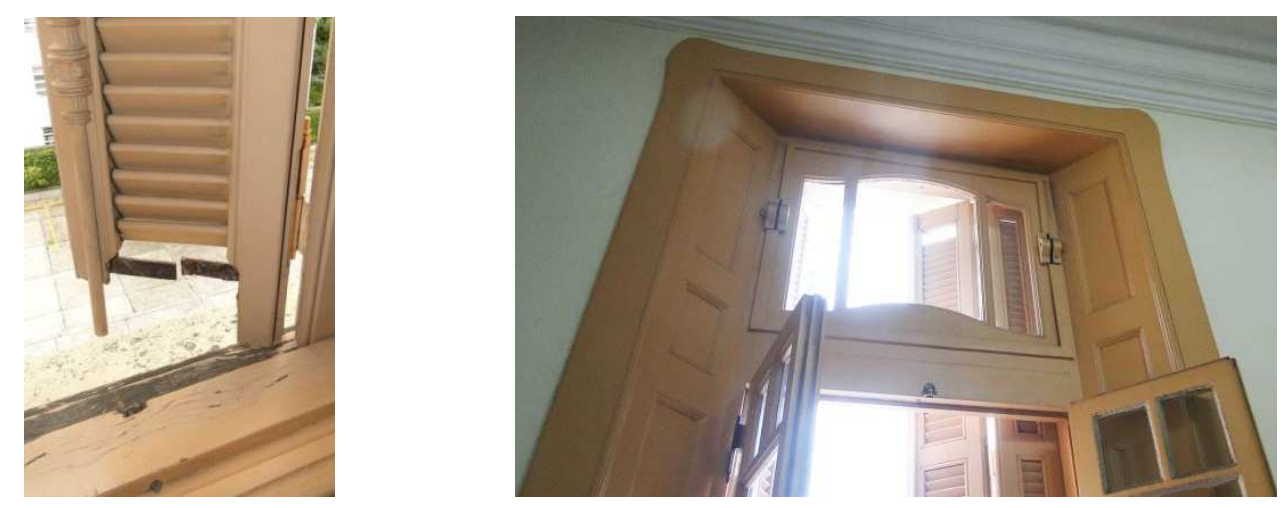

Figura 204 - Janela da Sala 71 (Diretoria): tanto a parte superior quanto a parte inferior da folha veneziana apresenta aletas faltando e ainda danos na moldura da folha Fotos: Isis Roverso, janeiro de 2012.

\subsubsection{ESQUADRIAS INTERNAS}

Comparando com a situação das esquadrias externas, as internas apresentam bom estado de conservação, sendo necessário apenas formular e realizar um plano de manutenção periódica, evitando que pequenas falhas ou inadequações sejam perpetuadas.

\section{Exemplos disso são:}

1. Ajustes feitos nas dobradiças da porta do sanitário feminino do piso superior: por falta de ajustes, a porta permaneceu parcialmente aberta por anos, dificultando o acesso e limitando a privacidade dos usuários (figura 205);

2. A substituição da porta do sanitário masculino no piso térreo, que contava há anos com uma porta improvisada, não adequada ao uso. Sua dimensão reduzida causava constrangimento aos usuários do sanitário (figura 206 e 207);

3. Reinstalação de uma porta na área dos lavatórios que se encontrava exposta há ano. A porta dupla original estava guardada no porão e em novembro de 
2011 foi instalada, como pode ser visto na figura 208. No momento do levantamento faltava executar o acabamento dessa porta dupla.
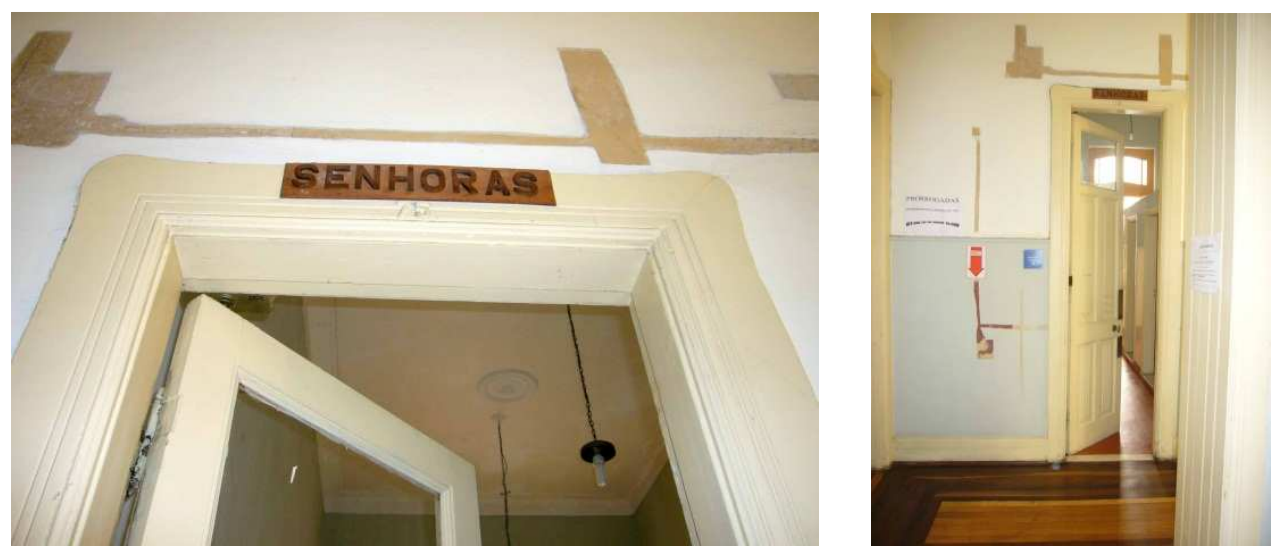

Figura 205 - Porta do banheiro feminino que, por falta de ajustes, permanecia constantemente semi aberta

Foto: Isis Roverso, abril de 2011

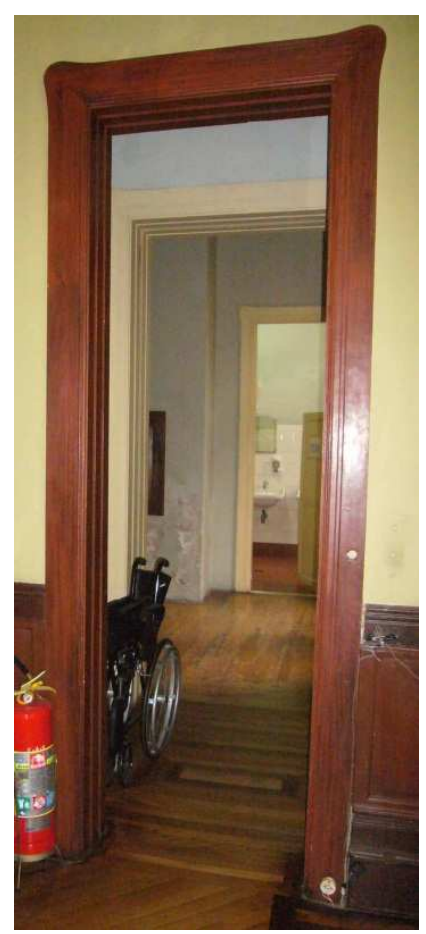

Figura 206 - Porta improvisada do sanitário masculino, em segundo plano, com dimensões reduzidas que permitiam a visualização interna do sanitário a partir da portaria

Foto: Isis Roverso, abril de 2011. 

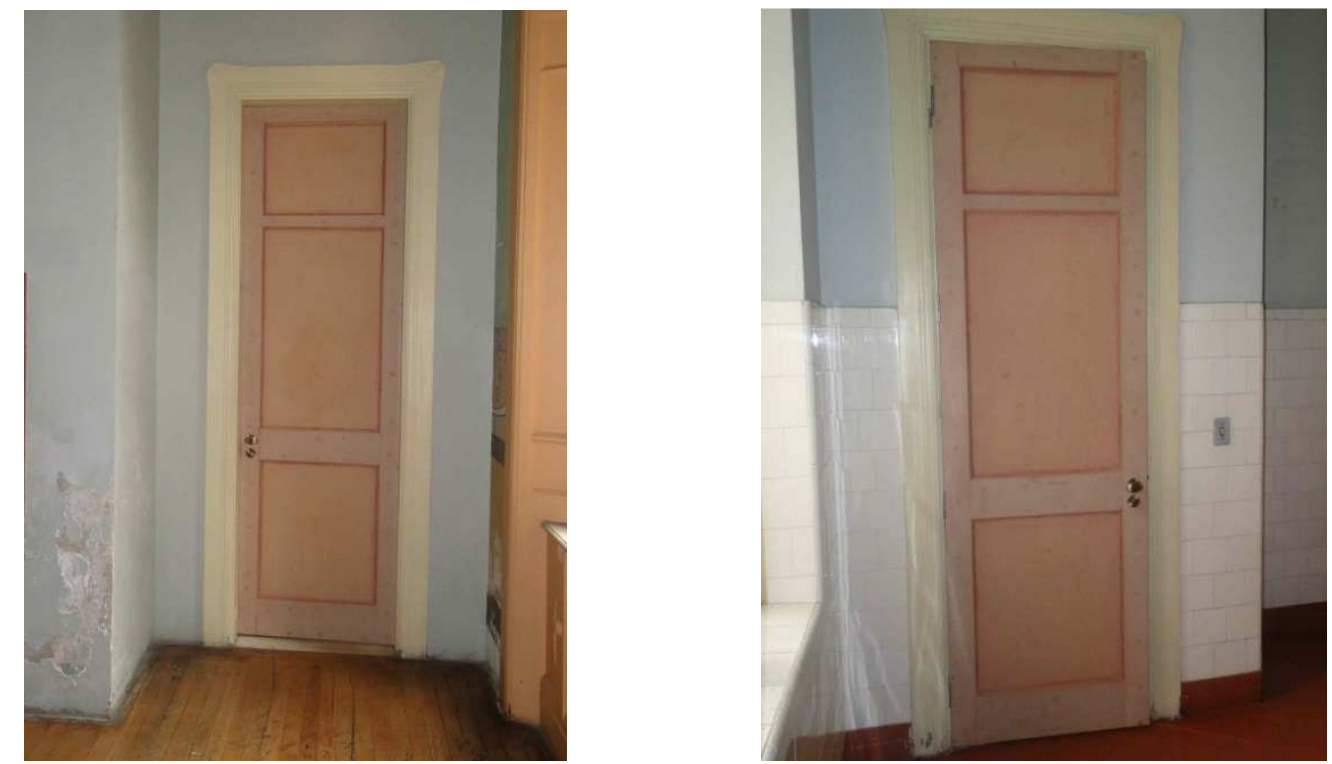

Figura 207 - Nova porta do banheiro masculino, vista externa e interna Foto: Isis Roverso, novembro de 2011.

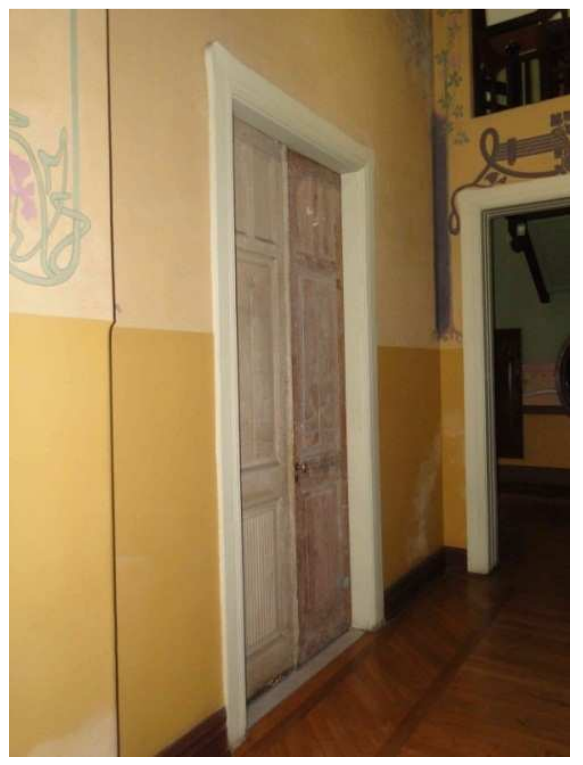

Figura 208 - Porta dupla instalada na área dos lavatórios Foto: Isis Roverso, novembro de 2011.

\subsubsection{ESQUADRIAS METÁLICAS E COMPLEMENTOS}

A Vila Penteado conta também com esquadrias metálicas, como é o caso da porta de acesso à sala do quadro de entrada de luz e força (sala localizada no porão), e também o caso dos três portões de entrada para a Vila. Na figura 209 há fotos do portão de entrada de pedestres, onde é notável a existência de pontos de oxidação, que já causaram, inclusive, perda do material (como é o caso da base do portão, que sofre mais como a ação das águas de chuva). 
O ferro também é usado em gradis, como os que compõem o fechamento da Vila com o muro frontal, e ainda é empregado como grades de segurança, em diversas esquadrias de madeira.

O desenho dessas peças é bem variado, mas todas seguem um padrão que remete às características art nouveau, sendo que esse tipo de trabalho com o ferro também pode ser visto nas bases dos guarda-corpos externos.
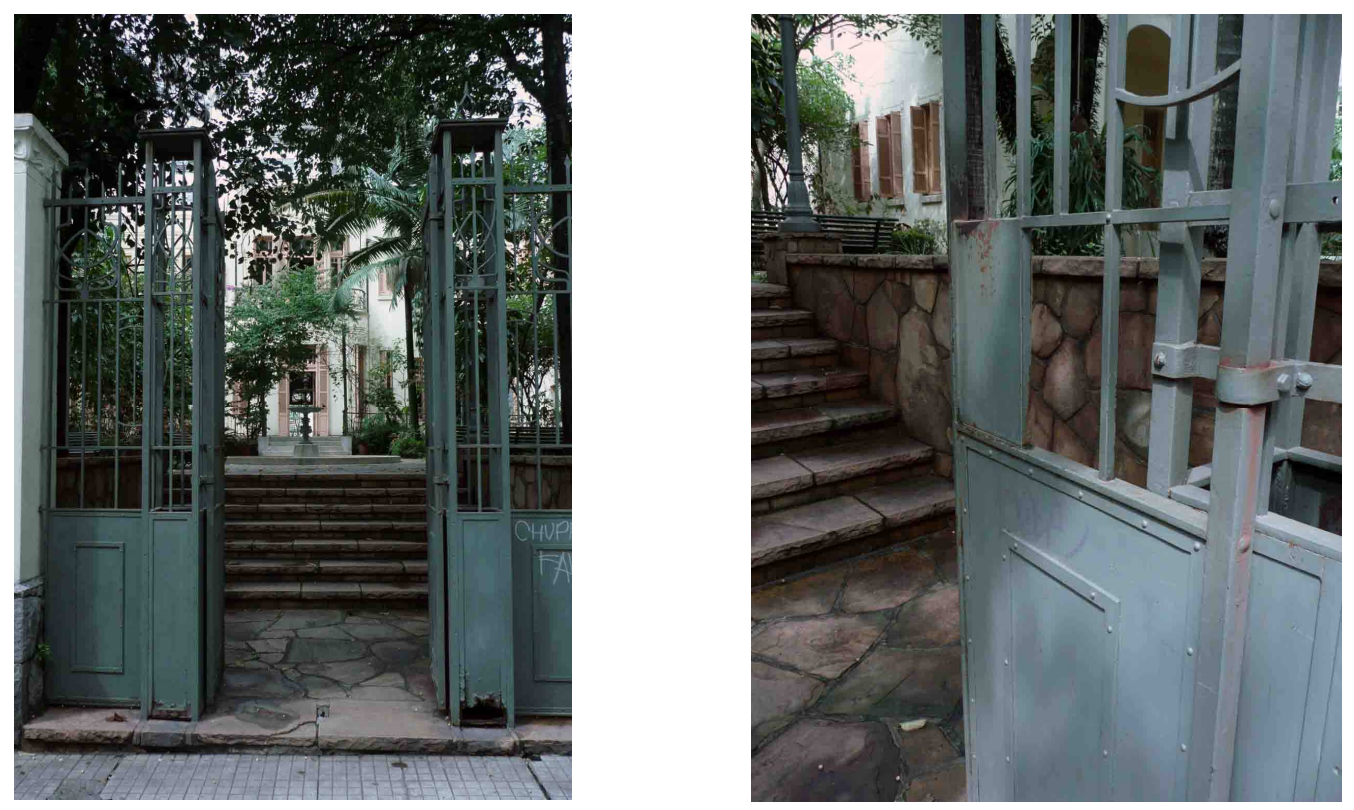

Figura 209 - Portão de entrada

Foto: Isis Roverso, dezembro de 2010.

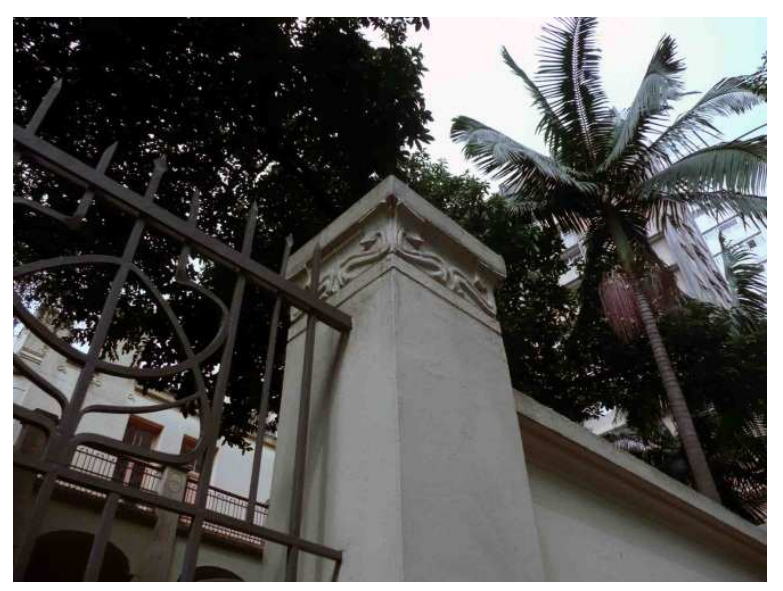

Figura 210 - Muro de divisa com a calçada: gradil metálico ornamentado Foto: Isis Roverso, dezembro de 2010. 

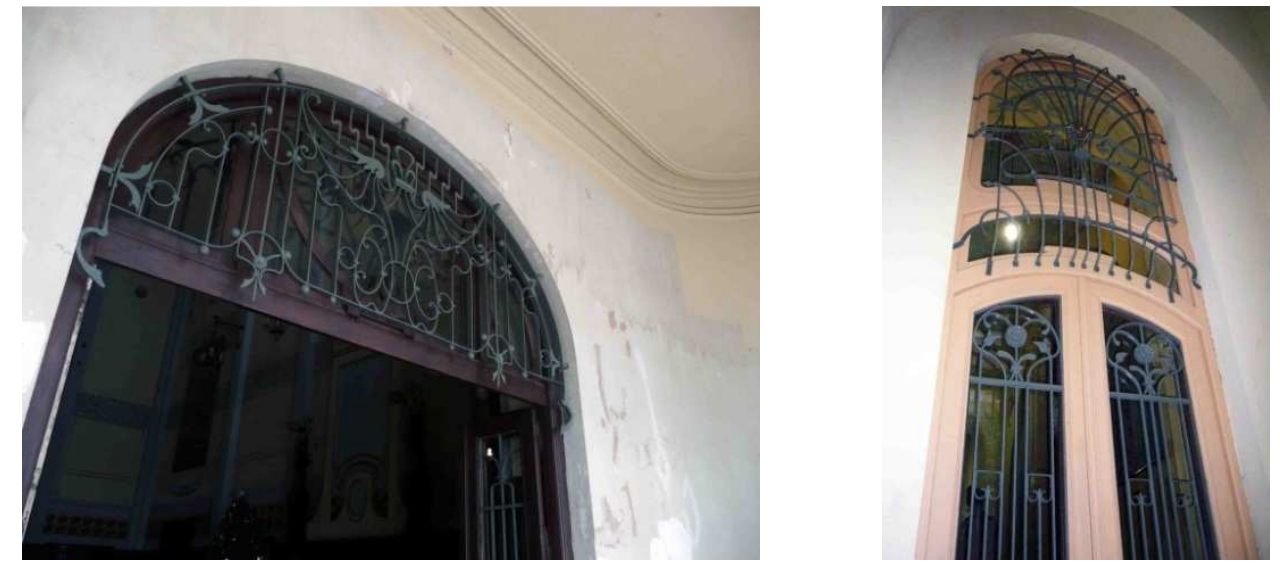

Figura 211 - Grade da porta de acesso da fachada posterior e vista externa da porta de acesso lateral (corredor S16)

Fotos: Isis Roverso, dezembro de 2010 e abril de 2011.

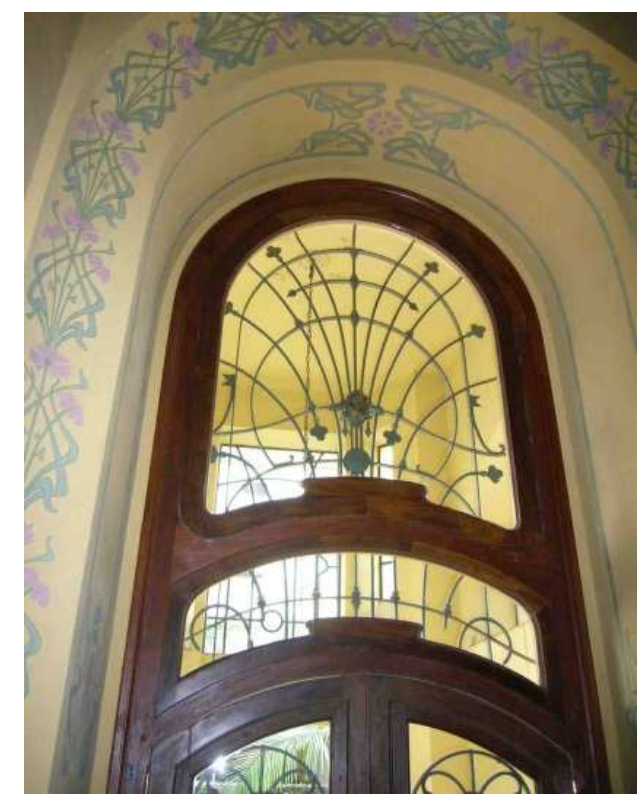

Figura 212 - Grade da porta de acesso lateral (corredor S16) e da janela do porão Foto: Isis Roverso, abril de 2011.
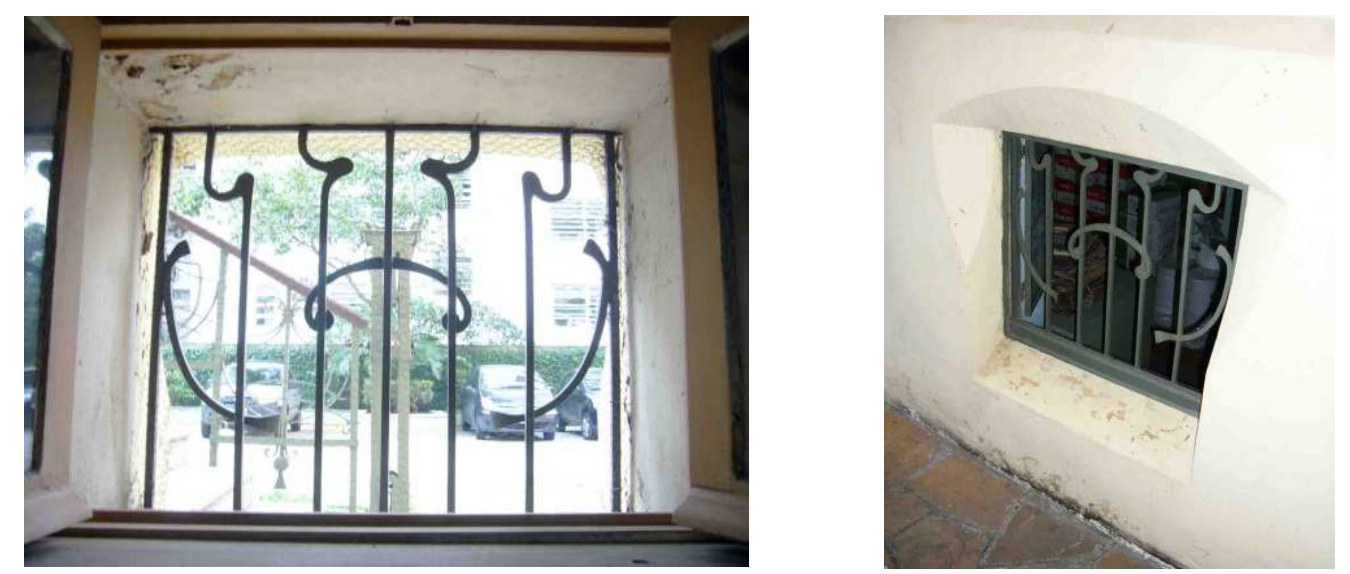

Figura 213 - Vista interna e externa da grade da janela do porão Foto: Isis Roverso, abril de 2011. 
As ferragens das esquadrias da Vila Penteado apresentam ornamentação art nouveau, e tem recebido destaque ao longo anos, através do olhar atento dos usuários. A figura 214 apresenta uma das maçanetas da Vila Penteado fotografa na década de 1970.

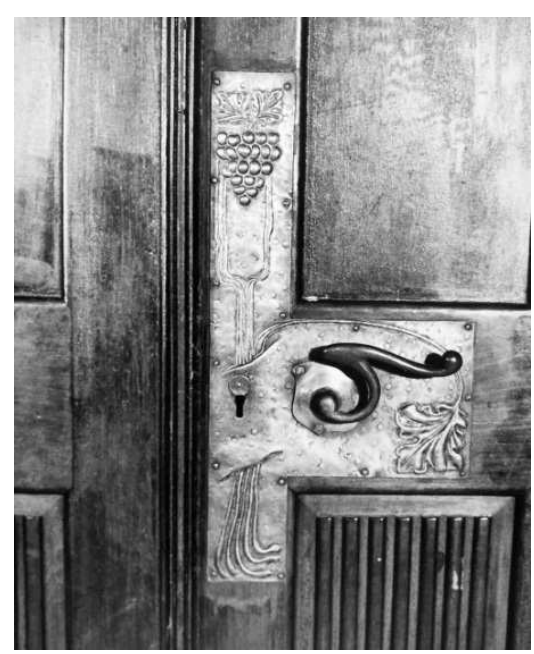

Figura 214 - Maçaneta da Vila Penteado Fonte: PRADO, 1979.

Alguns exemplos de ferragens são apresentados nas figuras 215 e 216 . Vale destacar a qualidade das peças, tanto em relação ao material quanto em relação à forma.
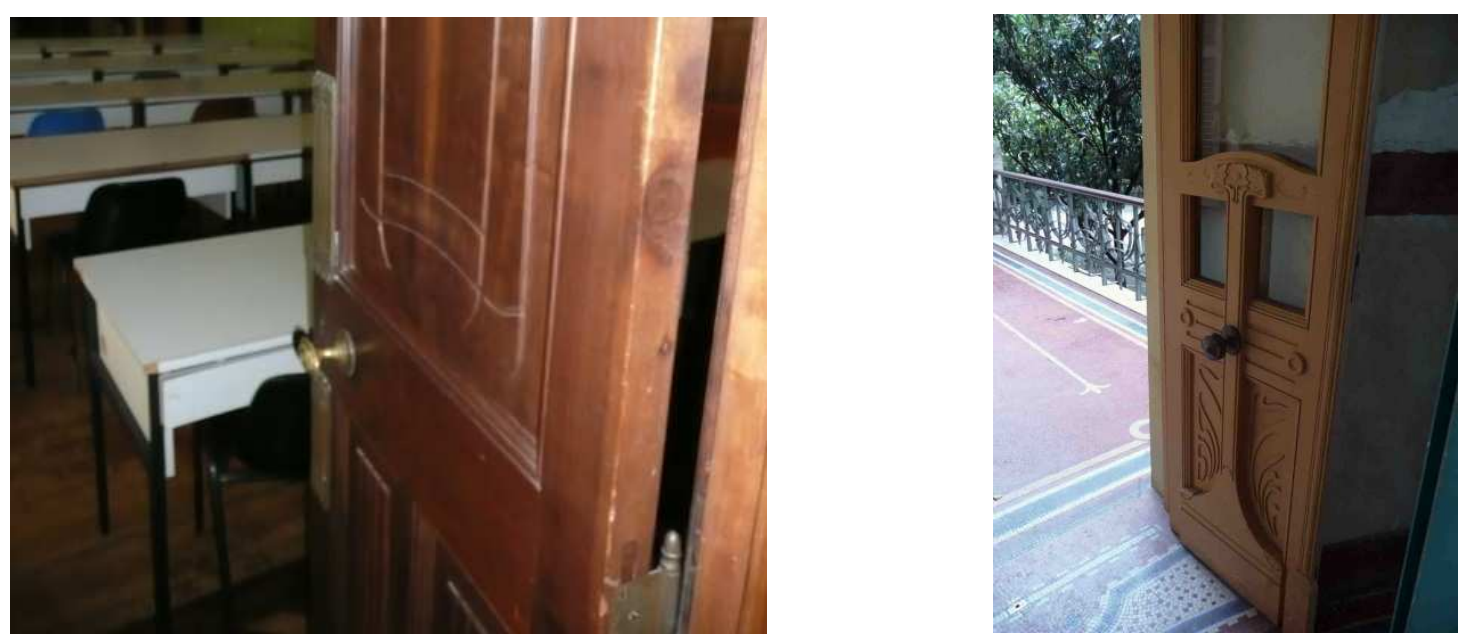

Figura 215 - Maçaneta e dobradiça da porta da Sala 12 e puxador da porta externa Foto: Isis Roverso, dezembro de 2010. 

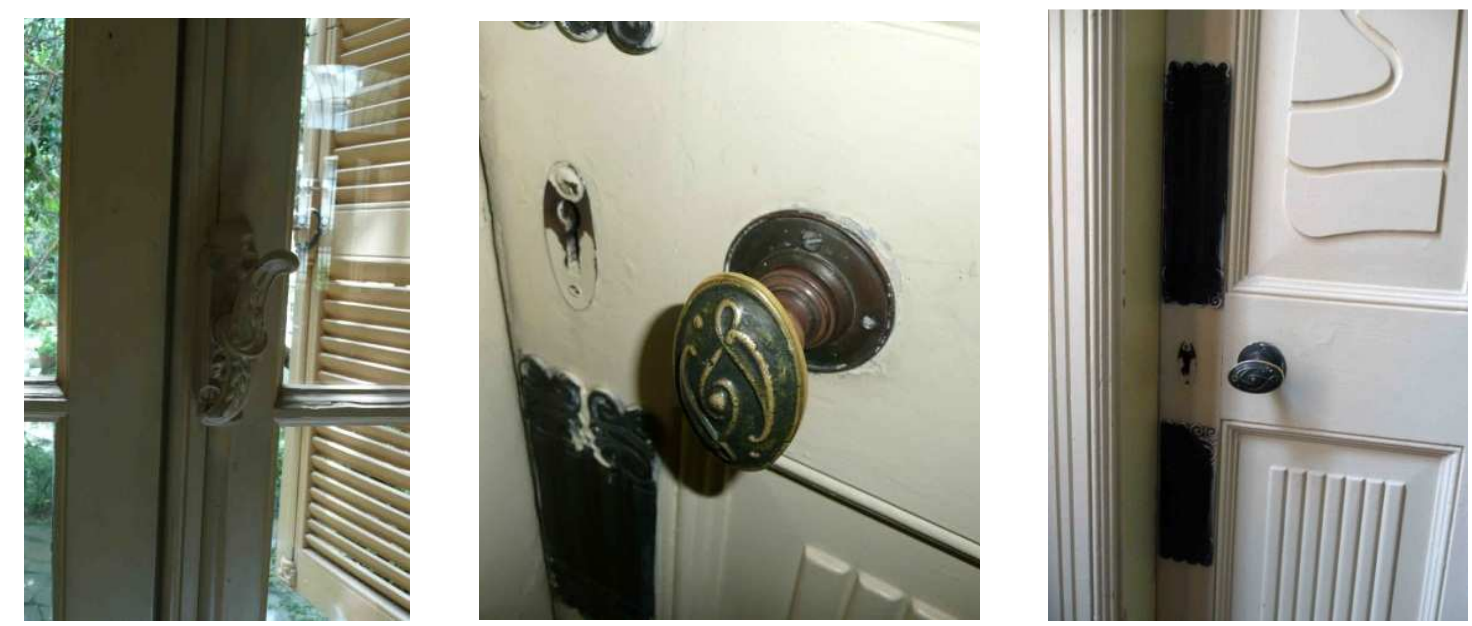

Figura 216 - Tranqueta e maçanetas Foto: Isis Roverso, dezembro de 2010.

Entretanto, a falta de rigor teórico dificulta as operações de manutenção. Por exemplo: quando há a falta de uma das peças, seja maçaneta, dobradiça ou outro complemento, qual é o critério para a inserção de um novo elemento? O resultado não deveria ser o apresentado na figura 217.

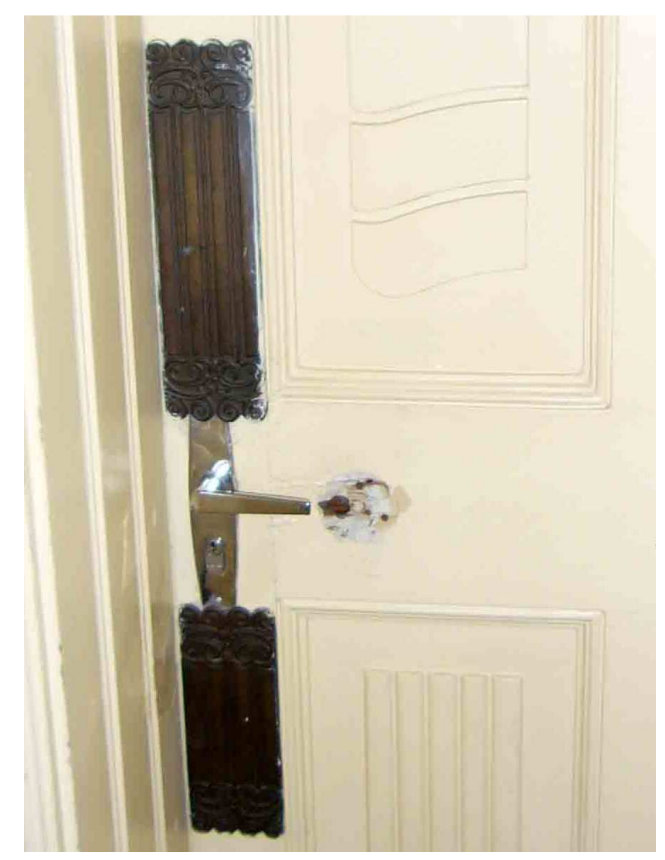

Figura 217 - Maçaneta substituída da Saleta S70 Foto: Isis Roverso, abril de 2011. 


\subsubsection{CORRIMÃOS E GUARDA-CORPOS}

Os guarda-corpos externos possuem: base metálica, em ferro ornamentado, e área de pega em madeira maciça. As peças metálicas precisam passar por repintura, mas as áreas mais prejudicadas são as em madeira.

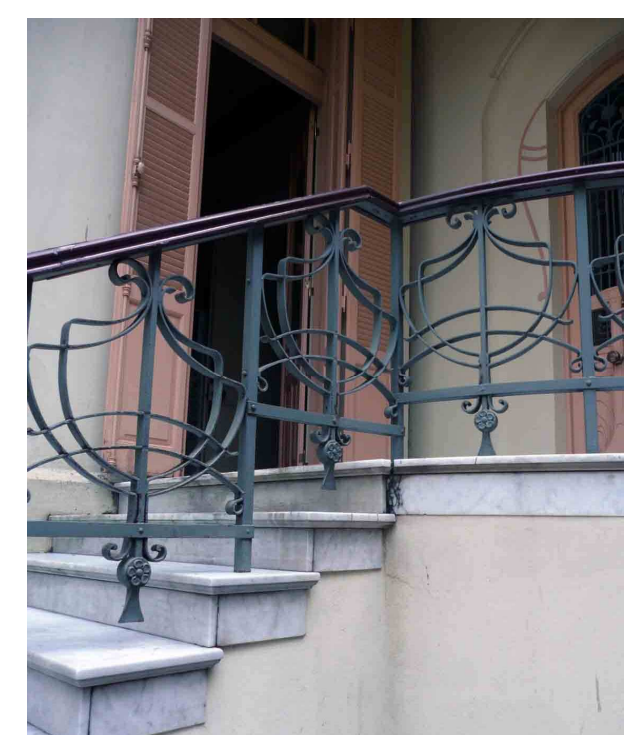

Figura 218 - Guarda-corpo: base metálica ornamentada e pega em madeira com acabamento em pintura

Fotos: Isis Roverso, dezembro de 2010.

A madeira de acabamento dos guarda-corpos não é original do edifício e, portanto, pode ser substituída, caso seja necessário. Dessa forma, os trechos danificados deverão ser substituídos e o restante deverá ser recuperado através da retirada da tinta existente, lixamento, calafetação das emendas entre peças de madeira, aplicação de produto impermeabilizante, hidropelente, com filtro solar e ação fungicida e inseticida, e pintura final em esmalte sintético. Caso a especificação da tinta seja semelhante à usada na manutenção dos corrimãos e guarda-corpos ocorrida no ano de 2003, a cor será marrom com acabamento acetinado, da Tintas Ypiranga, Duralack (código 730.1150). O acabamento com o impermeabilizante e com a tinta esmalte deverá receber manutenção a cada cinco anos.

No pavimento térreo há $67,25 \mathrm{~m}$ de guarda-corpos e no pavimento superior há $40,45 \mathrm{~m}$ de guarda-corpos.

Nas fotos das figuras 219 a 221 são apresentados alguns dos trechos danificados dos guarda-corpos da Vila Penteado. 

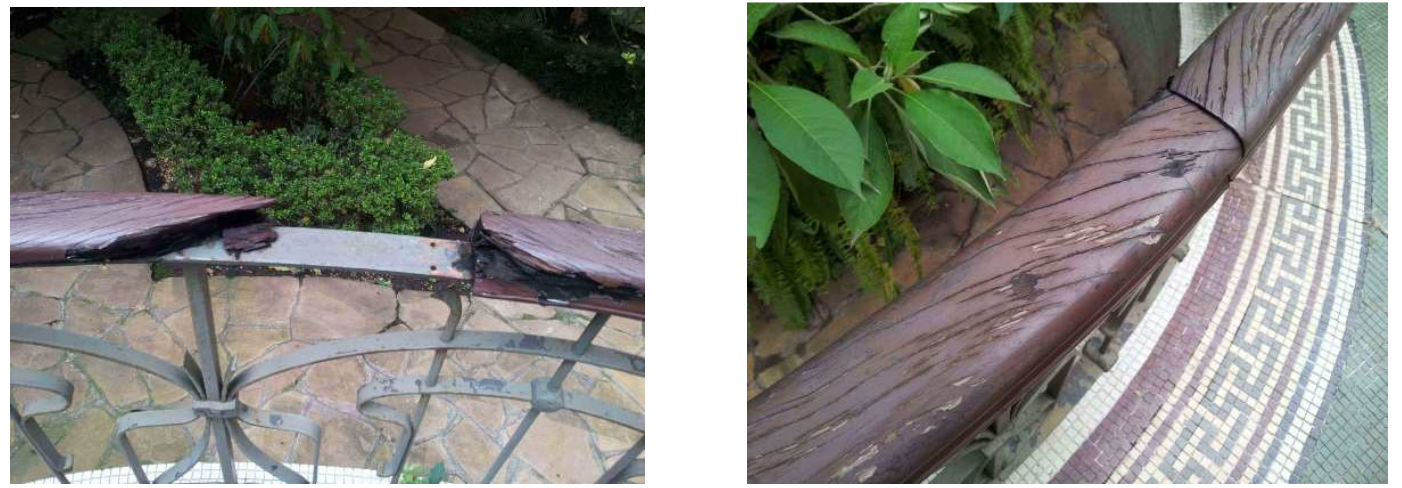

Figura 219 - Trechos do guarda-corpo próximo à fachada frontal Fotos: Isis Roverso, outubro de 2011.
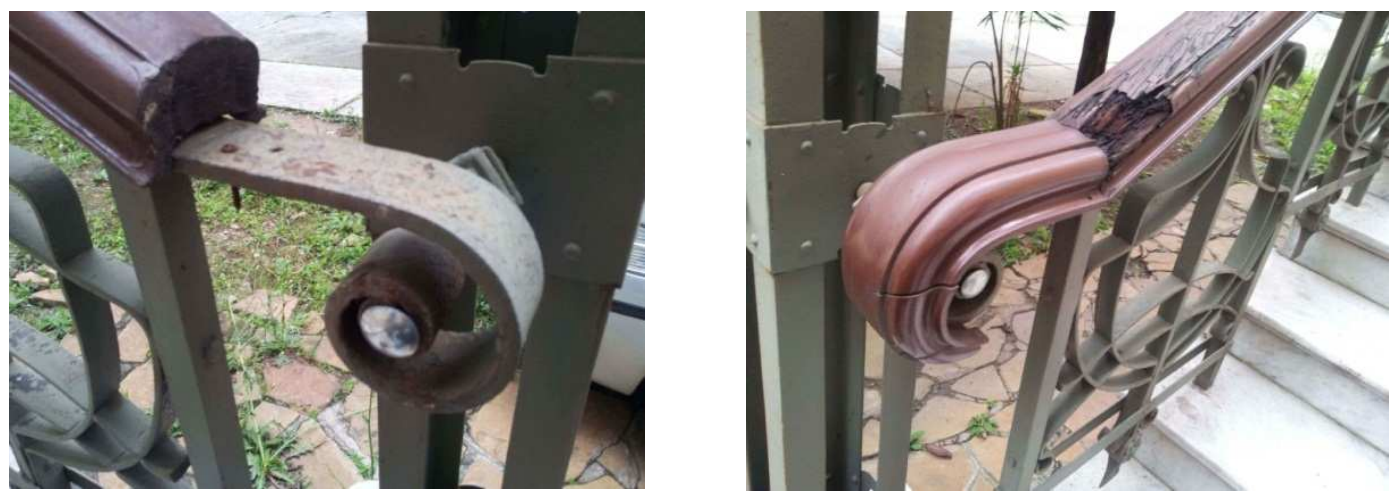

Figura 220 - Finalização do corrimão das escadas próximas à fachada posterior Foto: Isis Roverso, outubro de 2011.

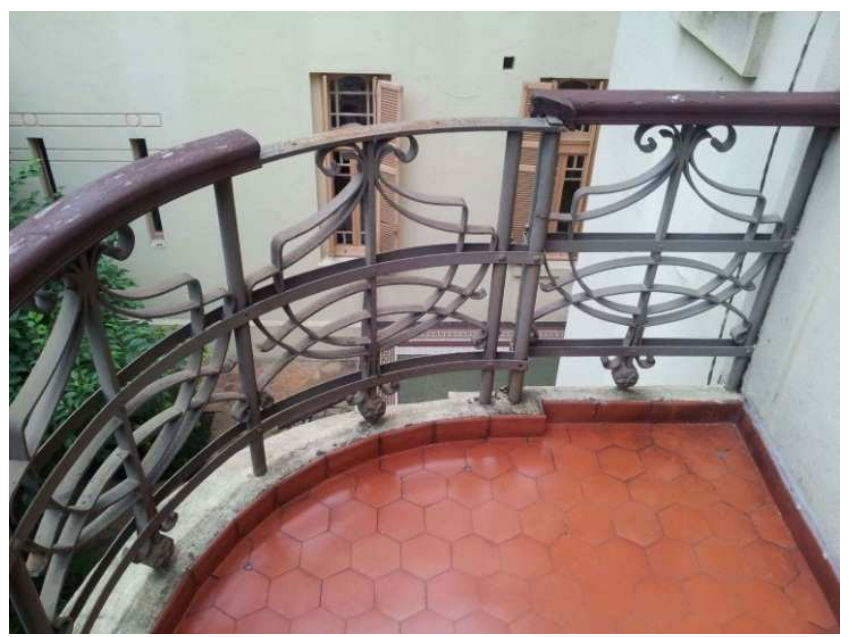

Figura 221 - Trecho do guarda-corpo do mezanino Foto: Isis Roverso, outubro de 2011.

\subsubsection{PARAMENTOS}

Os paramentos referem-se ao condicionamento das superfícies, ou seja, definem os revestimentos de vedos verticais e horizontais, pinturas de vedos e de caixilhos, visando conferir os atribudos necessários aos substratos. 
Visando facilitar a organização das informações, o item "Paramentos" engloba os revestimentos das paredes (internas e externas), os tetos e forros. Os acabamentos das esquadrias estão contemplados no item 4.1.6 "Vãos".

\subsubsection{REVESTIMENTOS DAS PAREDES}

As paredes da Vila Penteado, como já mencionado no item 3.2.3 "Pintura Mural e Fachadas", são revestidas com pinturas murais, sendo que parte delas foi revelada, através dos trabalhos realizados pelo "Canteiros de Restauração do CPCUSP", no período de 1989 até 2002. Como resultado, hoje é possível contemplar ambientes com pinturas murais, outros com pequenos trechos do trabalho de estratigrafia e ainda outros que mantém as camadas de pintura monocromática cobrindo as pinturas murais originais. Nas figuras 222 a 224 é possível observar alguns dos ambientes com as características comentadas.
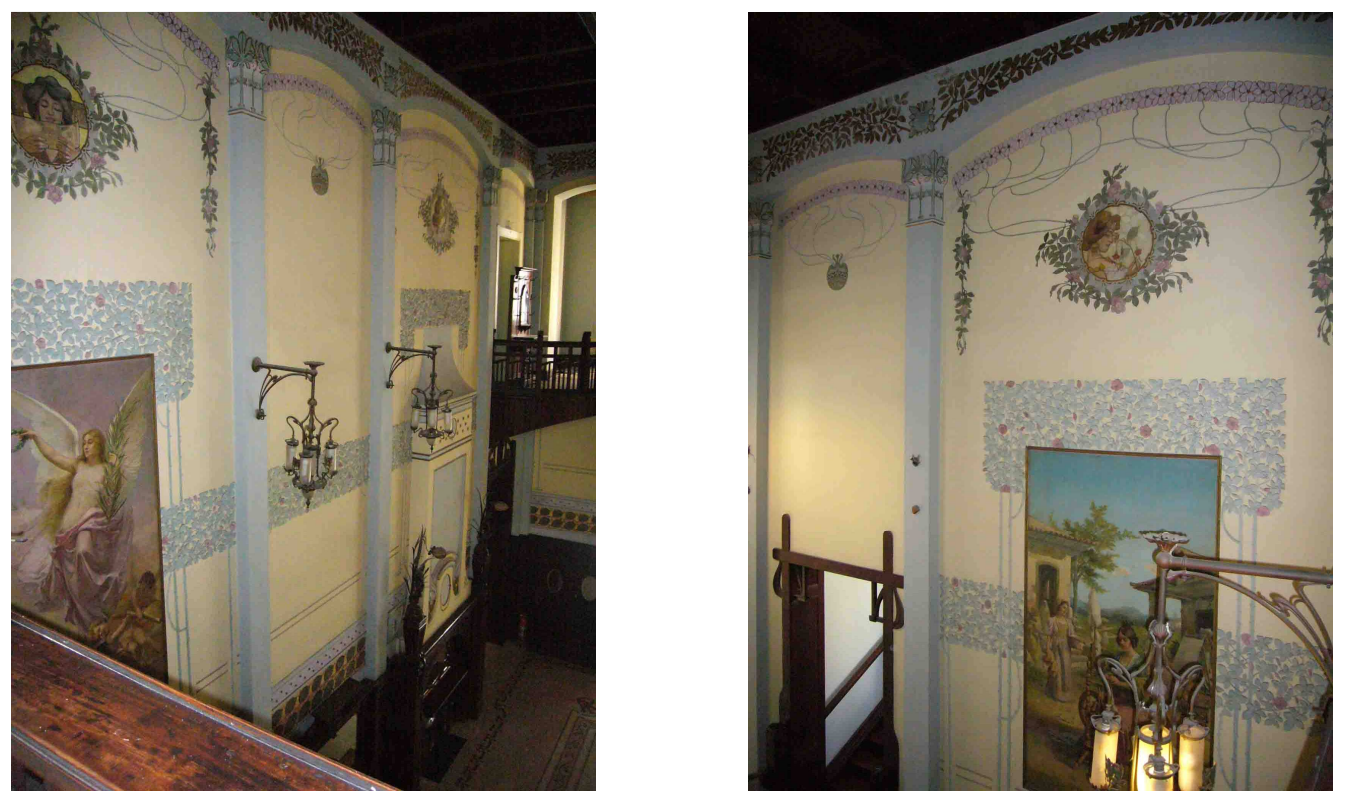

Figura 222 - Pinturas murais do Saguão: à esquerda, "Glorificação da Indústria", pintura de Carlo De Servi e, à direita, "A indústria do século XVI ao XVIII, pintura de Oscar Pereira da Silva

Fotos: Isis Roverso, abril de 2011. 

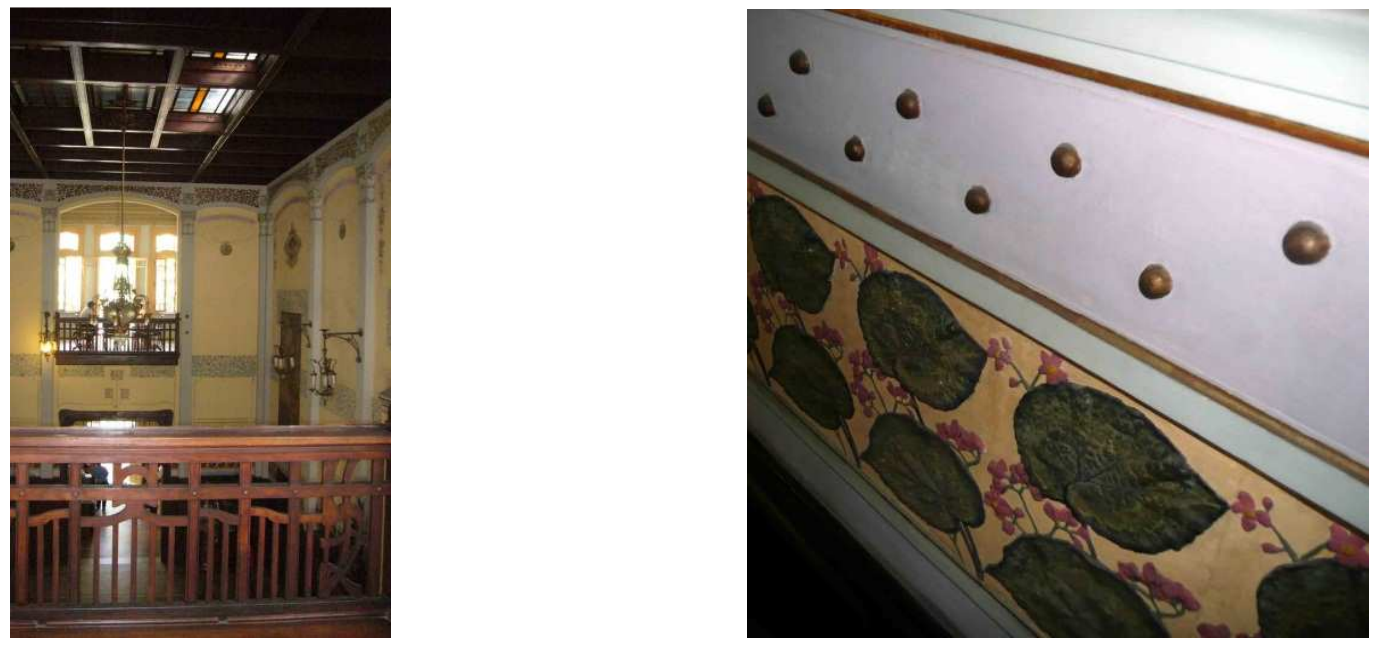

Figura 223 - Pinturas murais do Saguão e detalhe em relevo Foto: Isis Roverso, abril de 2011 e dezembro de 2010.
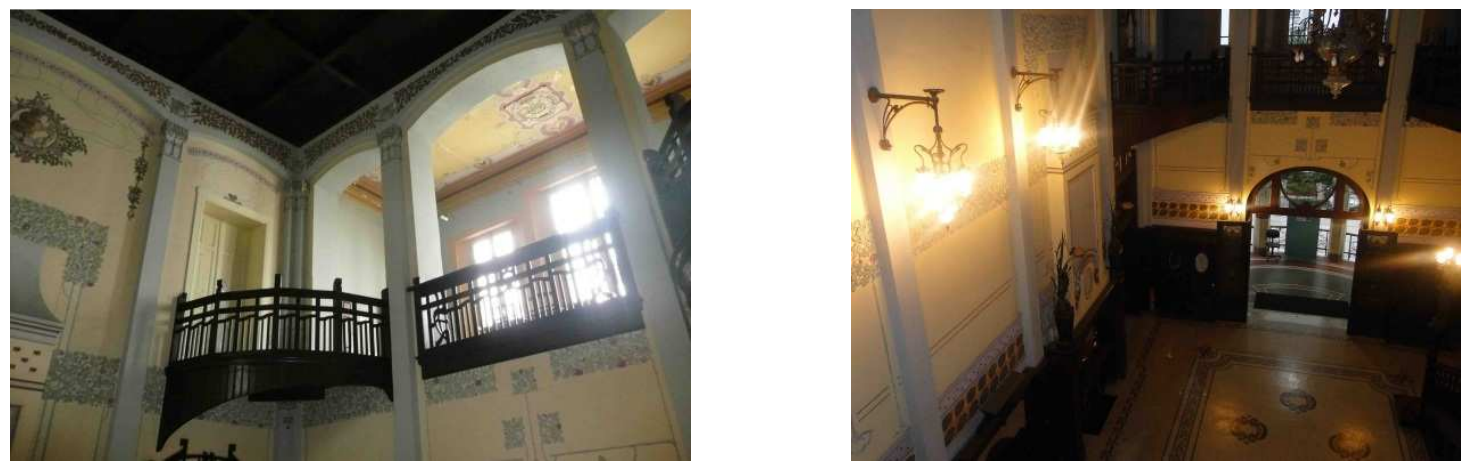

Figura 224 - Pinturas murais do Saguão

Fotos: Isis Roverso, dezembro de 2010 e novembro de 2011.

As pinturas murais no Saguão encontram-se bem conservadas. Os corredores próximos a Sala 12 também tiveram suas pinturas murais reveladas, entretanto, nessas áreas já há sinais de deterioração, especialmente ao lado do banheiro masculino.
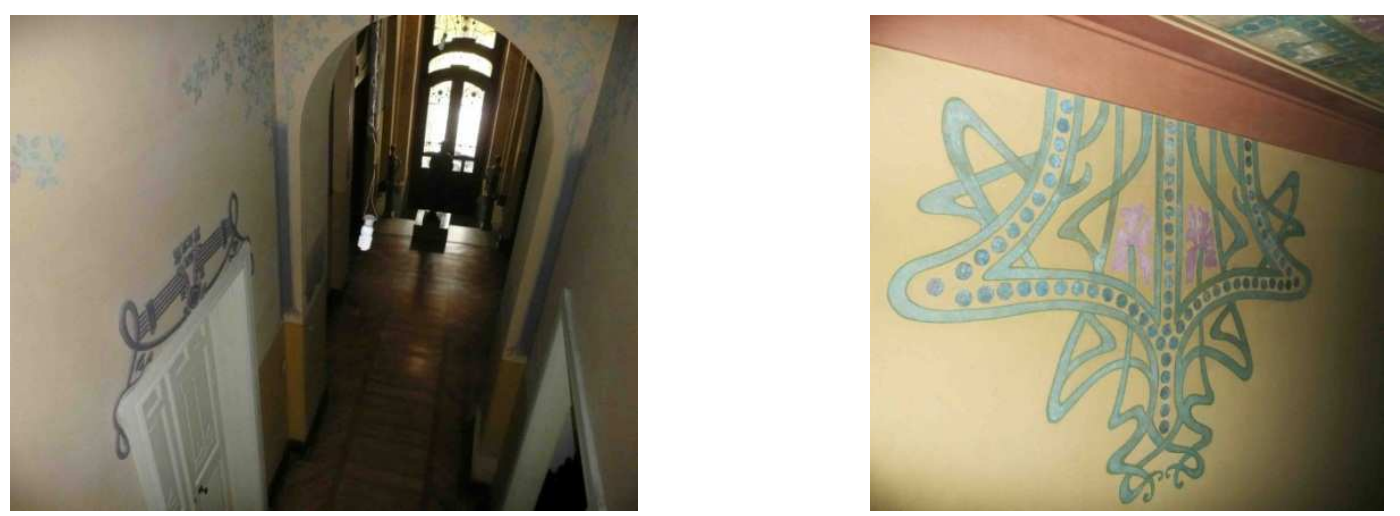

Figura 225 - Paramento e detalhe do corredor S16 Fotos: Isis Roverso, dezembro de 2010. 

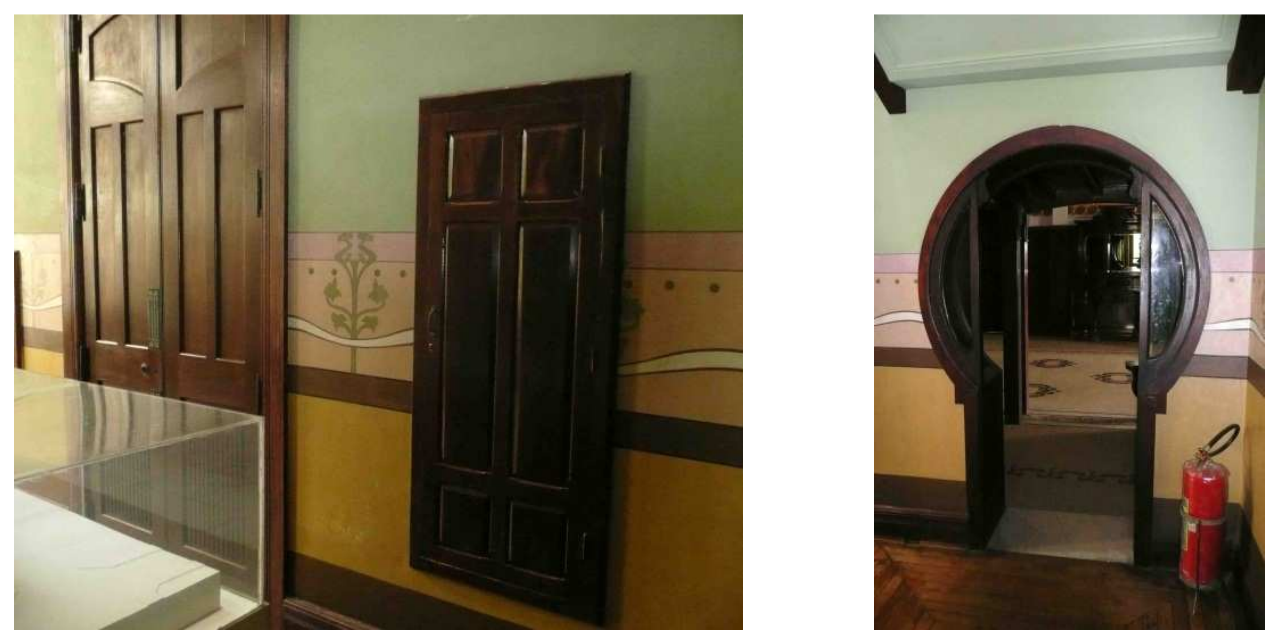

Figura 226 - Hall da maquete, próximo ao corredor S16 Fotos: Isis Roverso, dezembro de 2010.

A área do hall da maquete, ao lado do banheiro masculino, é a região que apresenta deterioração acelerada, com descascamento e desagregação de material.
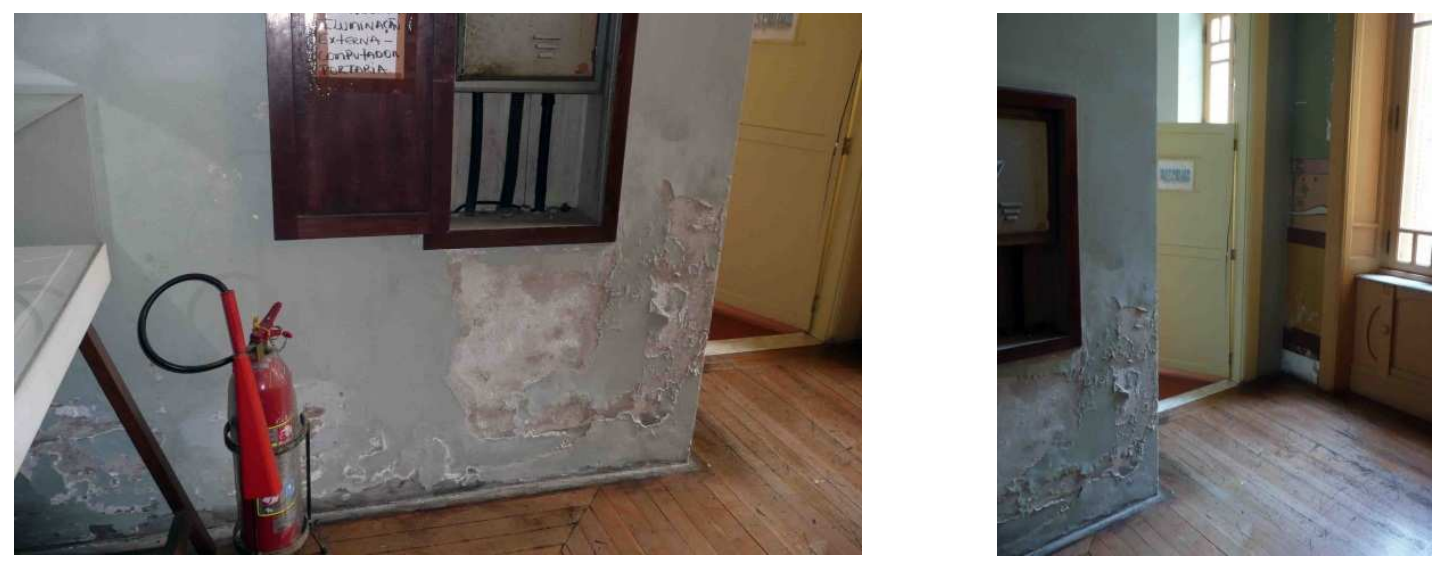

Figura 227 - Área deteriorada do hall da maquete Fotos: Isis Roverso, dezembro de 2010.

O trabalho ocorrido no início da década de 2000 também englobou a Sala 12, mas, em relação às paredes, o critério usado difere do usado no Saguão e corredores próximos: a Sala 12 recebeu pintura monocromática em duas tonalidades e o trabalho de ornamentação ficou restrito ao roda-teto, como pode ser visto nas fotos das figuras 228 e 229. A cor escolhida refere-se à cor de fundo identificada como original desse ambiente (antiga sala de jantar da residência). ${ }^{114}$

114 Detalhes sobre os trabalhos realizados na Sala 12 foram publicados em: TIRELLO, Regina A. O restauro dos murais art-nouveau da Vila Penteado e o canteiro-escola da CPC-USP: uma experiência de formação qualificada. Vila Penteado: 100 anos. Revista do programa de pós-graduação em arquitetura e urbanismo da FAUUSP - número especial. São Paulo: FAUUSP, 2002, p. 159. 


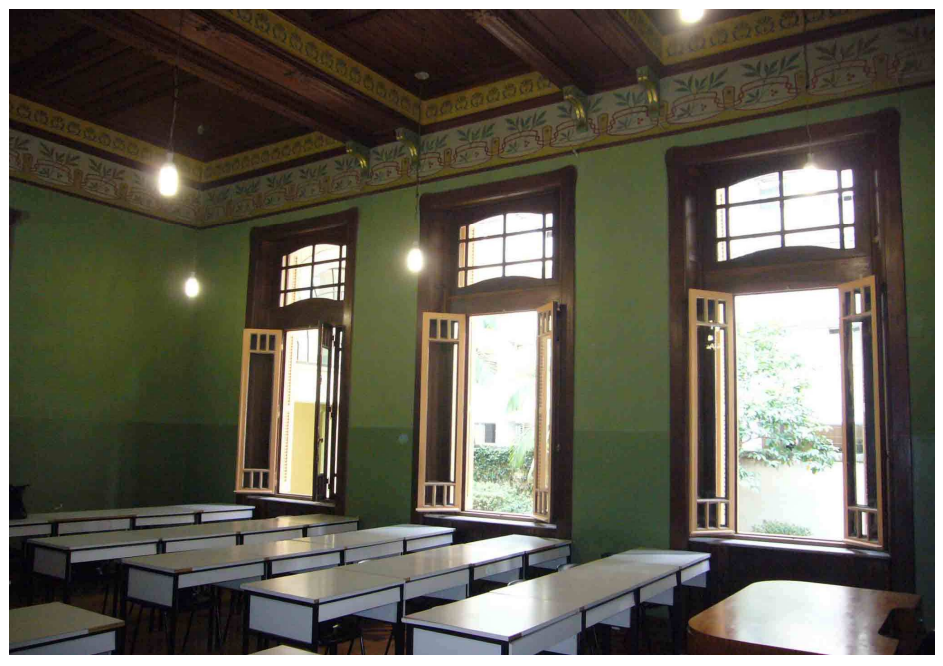

Figura 228 - Sala 12: com pintura monocromática e roda-teto ornamentado Foto: Isis Roverso, abril de 2011.
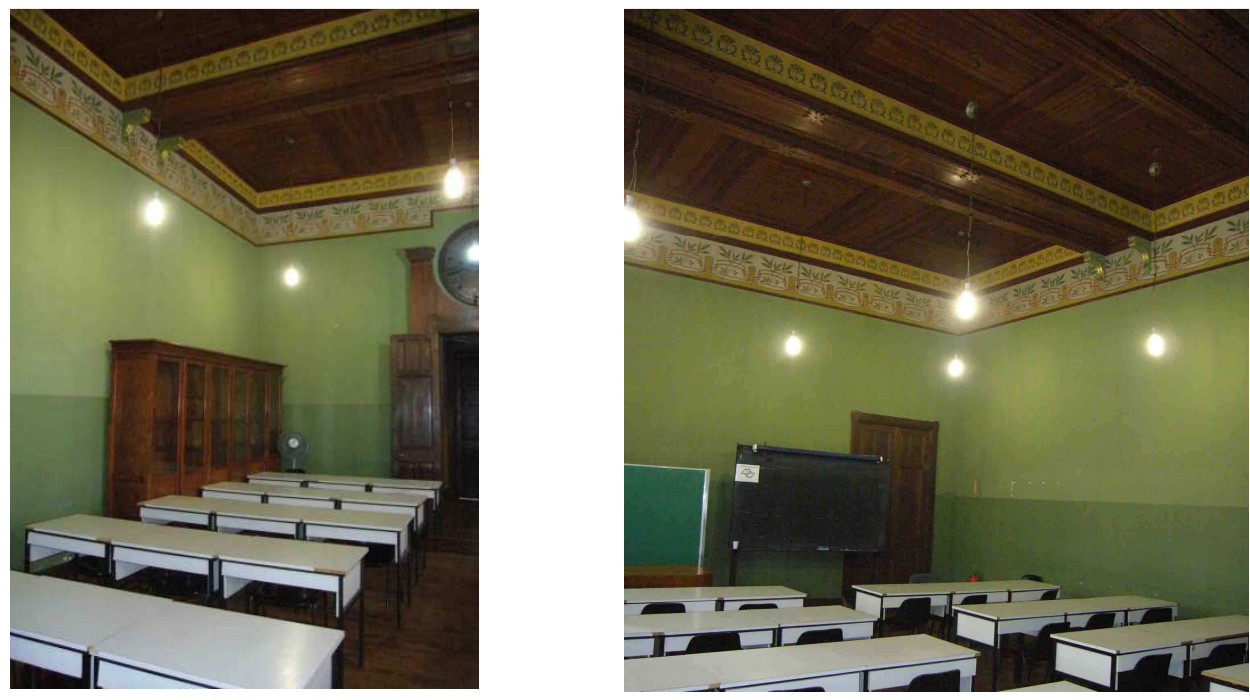

Figura 229 - Sala 12: com pintura monocromática em duas tonalidades Fotos: Isis Roverso, abril de 2011.

A portaria também recebeu pintura monocromática (ver figura 230), no ano de 2002 e a biblioteca também teve suas paredes adequadas no mesmo período (informações detalhadas, dos trabalhos realizados na biblioteca, estão registradas no item 3.2.6 “Intervenção na Área da Biblioteca”). 


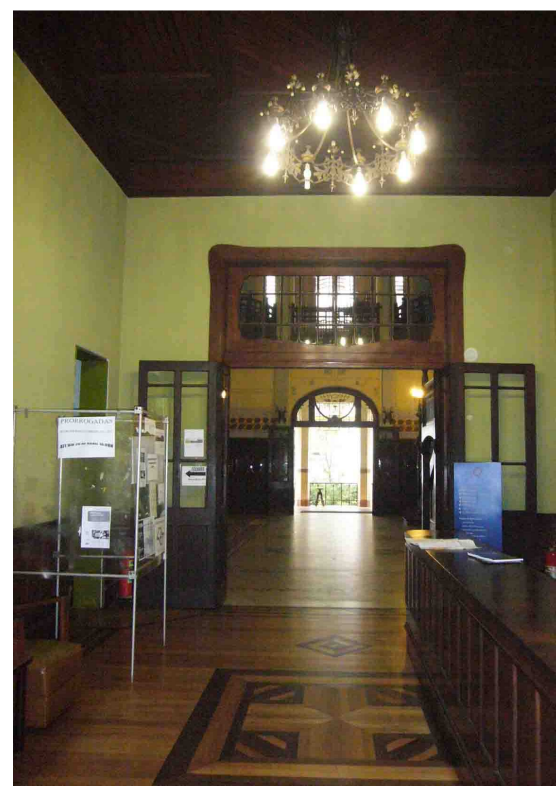

Figura 230 - Pintura monocromática na Portaria Foto: Isis Roverso, abril de 2011.
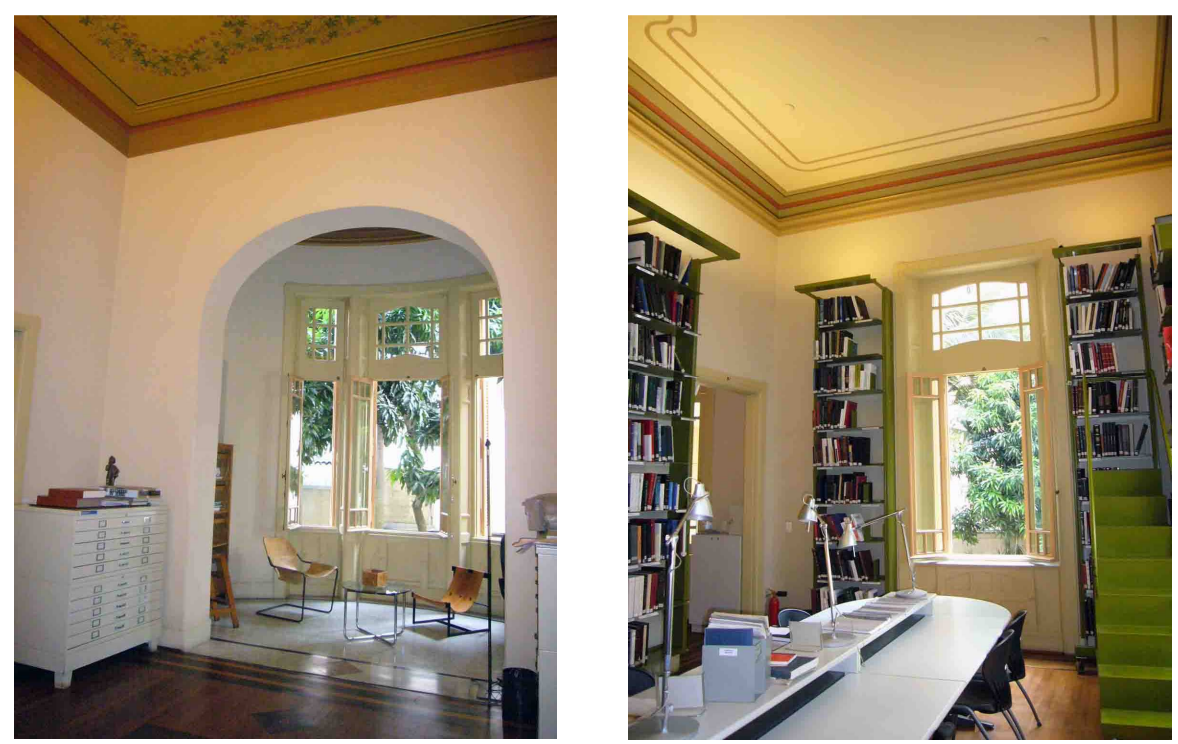

Figura 231 - Acabamentos da Biblioteca após intervenção de 2002 Fotos: Isis Roverso, abril de 2011. 

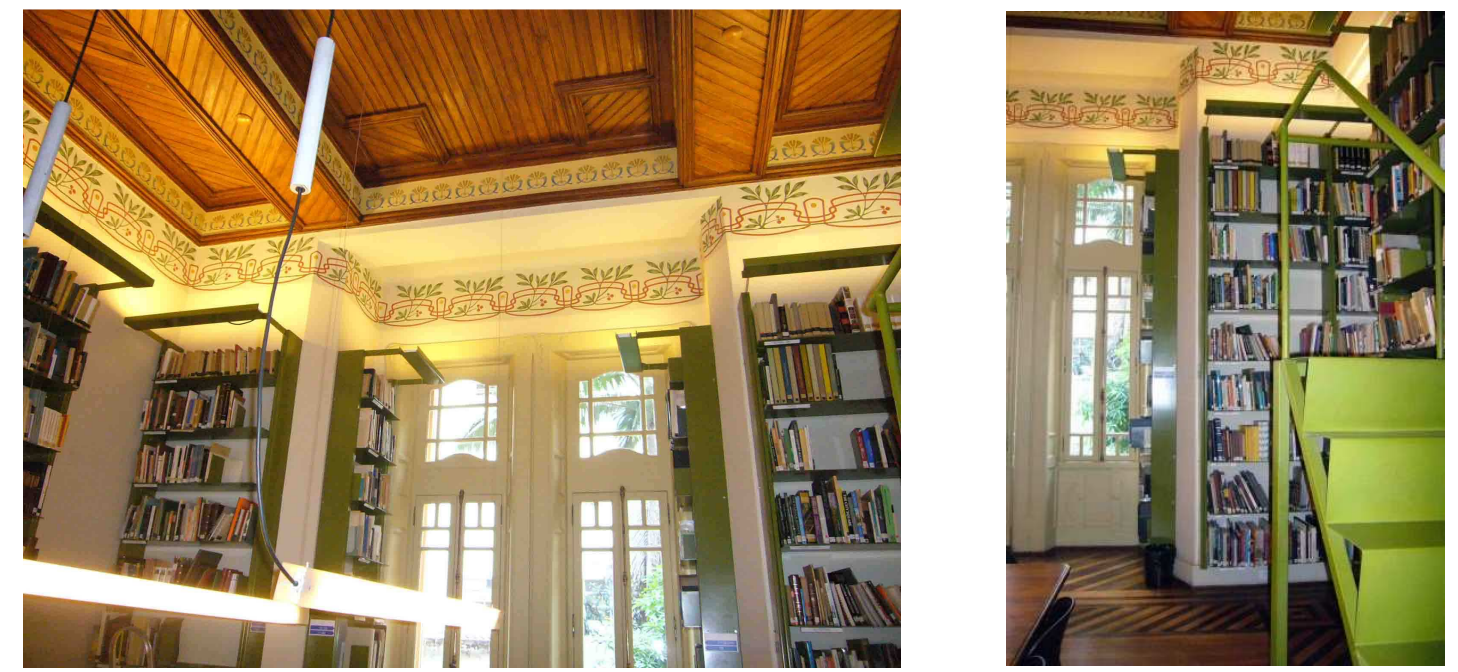

Figura 232 - Acabamentos da Biblioteca após intervenção de 2002 Fotos: Isis Roverso, abril de 2011.

Outros ambientes mantêm o acabamento em pintura uniforme, executada em períodos anteriores.

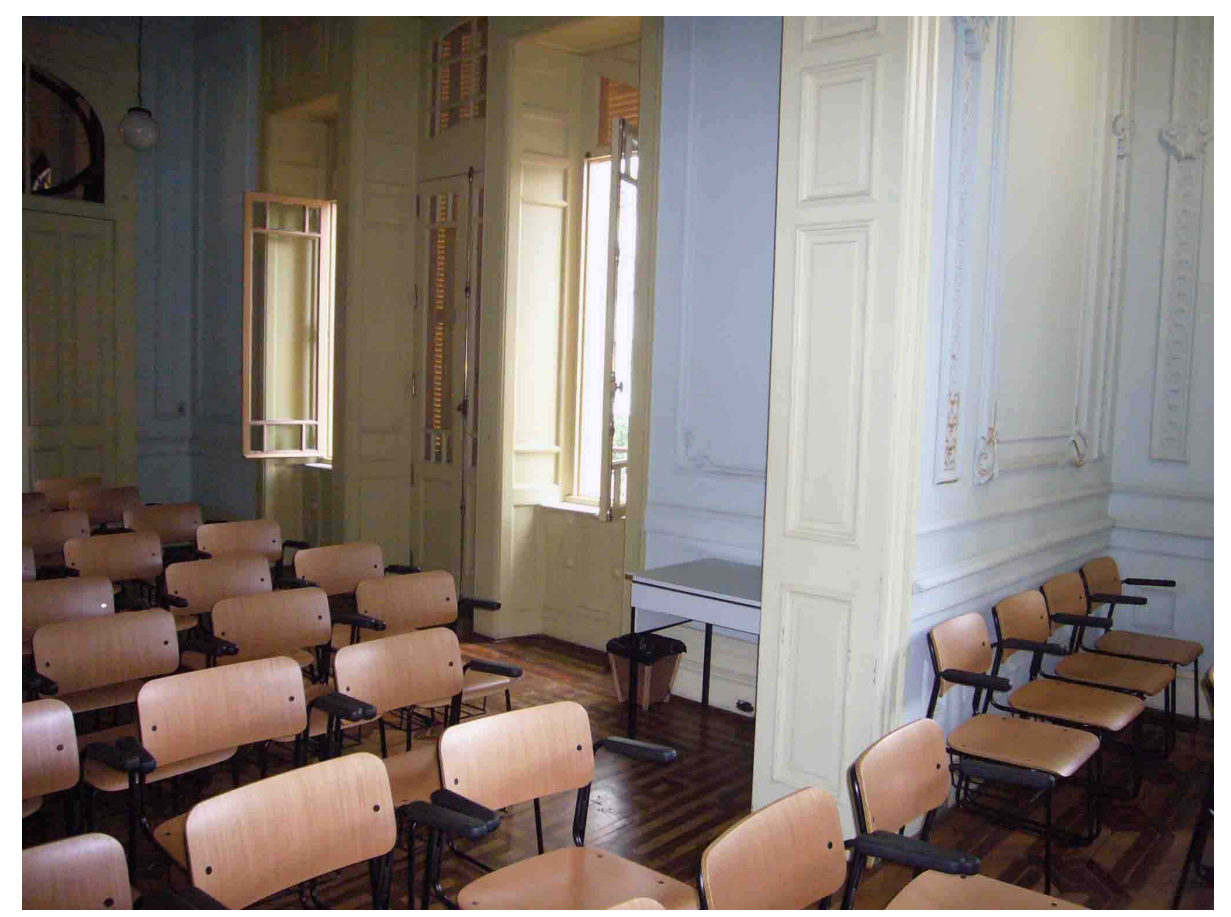

Figura 233 - Sala dos Espelhos: pintura monocromática e trechos destacados para análise estratigráfica

Foto: Isis Roverso, abril de 2011. 

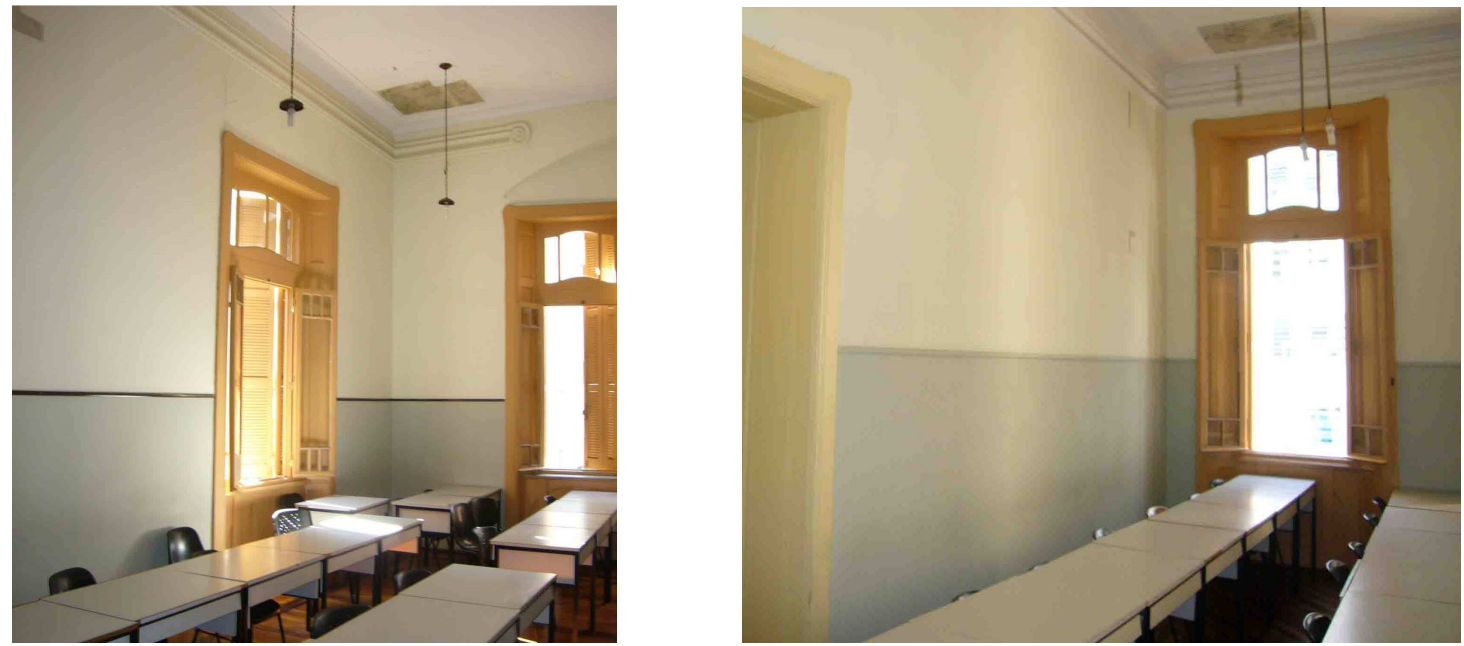

Figura 234 - Salas de aula (Sala 58 e 61) com pintura monocromática em duas tonalidades

Fotos: Isis Roverso, abril de 2011.

Análises estratigráficas, presentes ainda hoje da Vila, são apresentadas nas fotos das figuras 235 e 236.
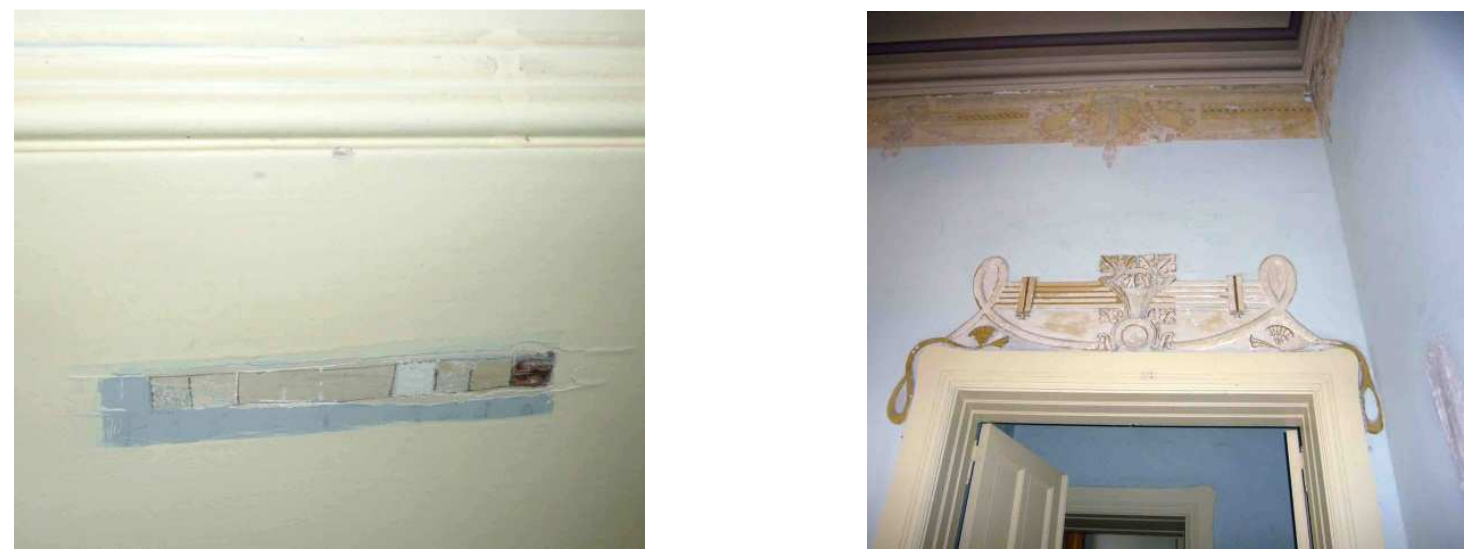

Figura 235 - Análise estratigráfica realizada no corredor S57 e na Sala 68 Fotos: Isis Roverso, dezembro de 2010 e abril de 2011.
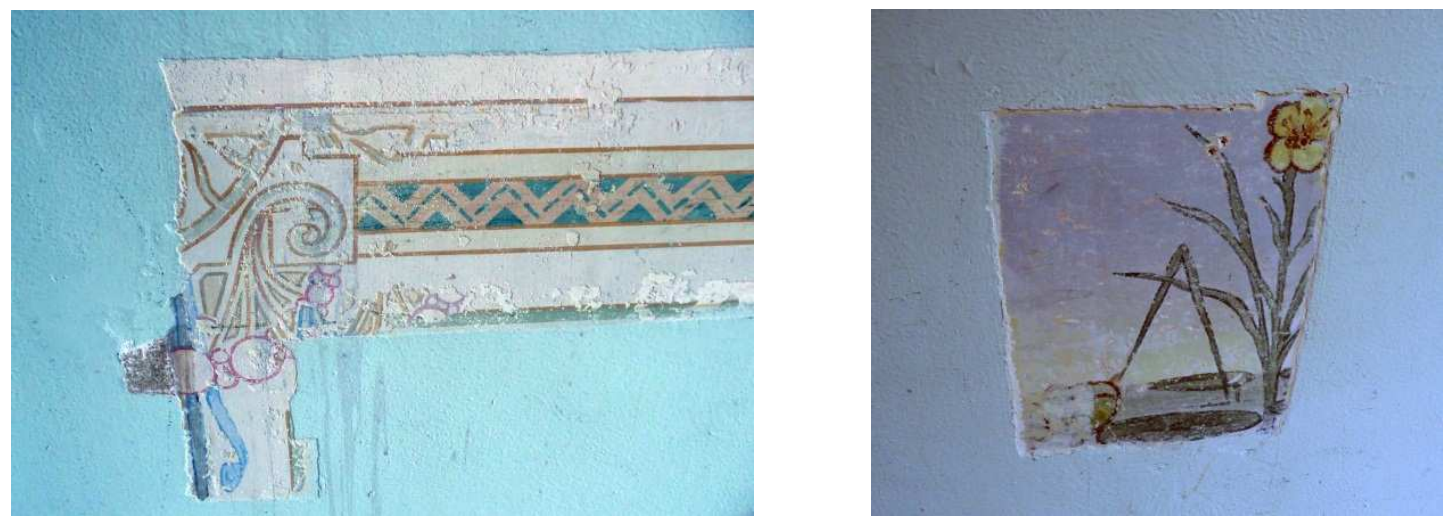

Figura 236 - Análise estratigráfica realizada na Sala 68 Fotos: Isis Roverso, dezembro de 2010. 
Nem todos os ambientes receberam originalmente pinturas murais. Há ainda ambientes com revestimentos realizados no período onde a Vila Penteado foi adaptada para receber as instalações do curso de graduação da FAUUSP, é o caso dos azulejos instalados nos banheiros (ver figuras 237 e 238).
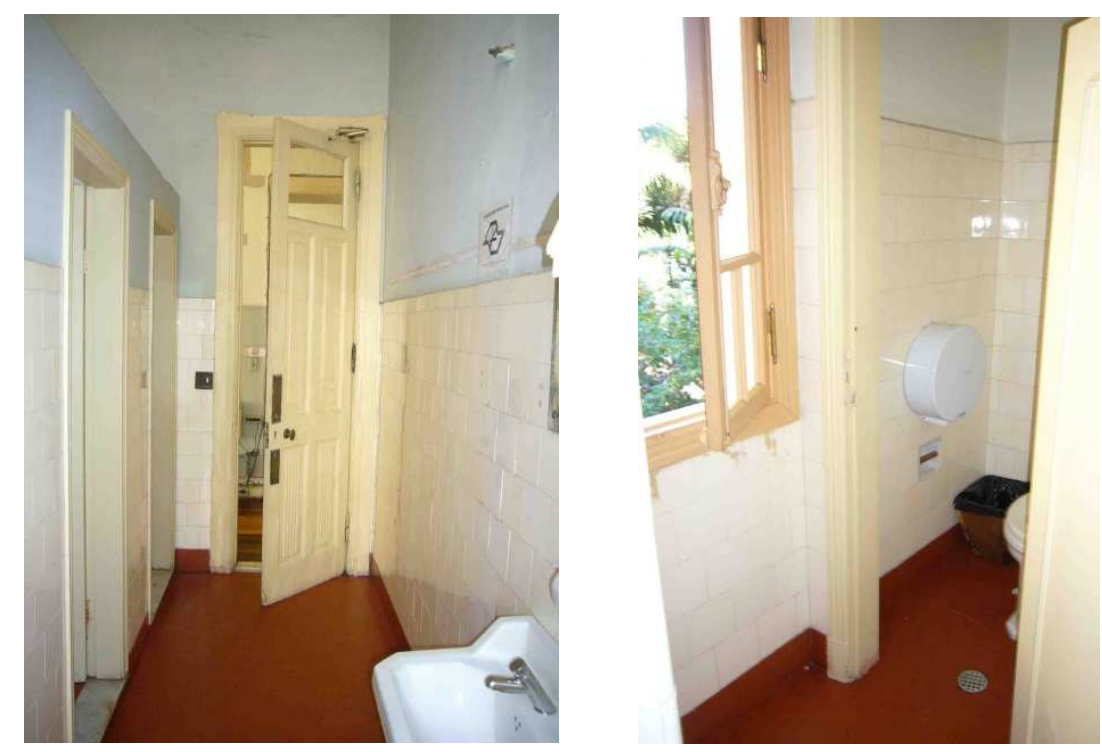

Figura 237 - Paredes azulejadas dos banheiros: WC Feminino S75 e S46 Fotos: Isis Roverso, abril de 2011.

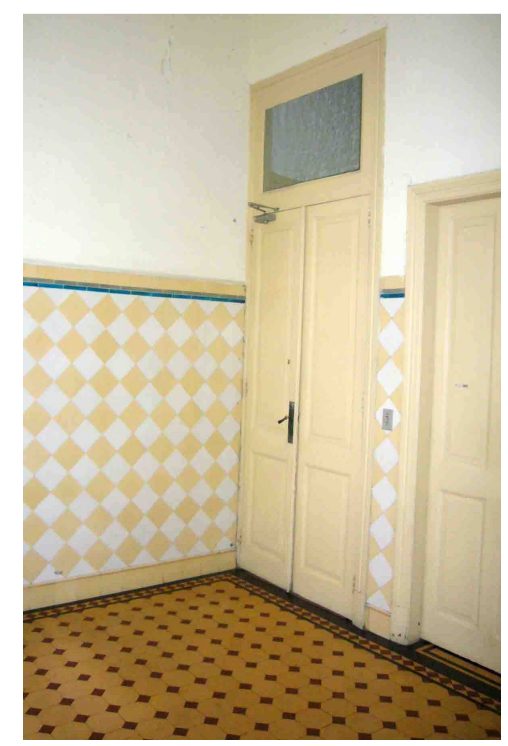

Figura 238 - Paredes azulejadas da Sala 10T Foto: Isis Roverso, abril de 2011.

Internamente, as paredes que tem seus revestimentos mais deteriorados são:

- Paredes da área do hall da maquete (figura 227);

- Paredes da copa, do hall de serviços (10T) e da Sala 44, que apresentam descascamento (figura 239); 
- Paredes do porão, que apresentam desagregamento de material (figura 240).

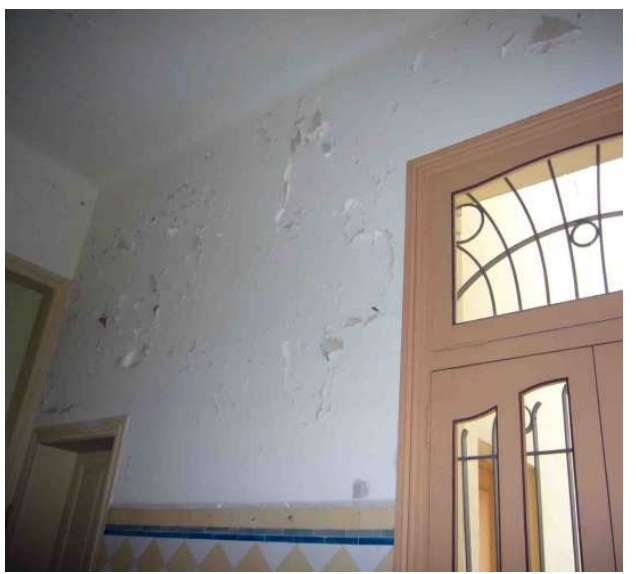

Figura 239 - Sala 10T: paredes com acabamento deteriorado - descascamento Foto: Isis Roverso, abril de 2011.
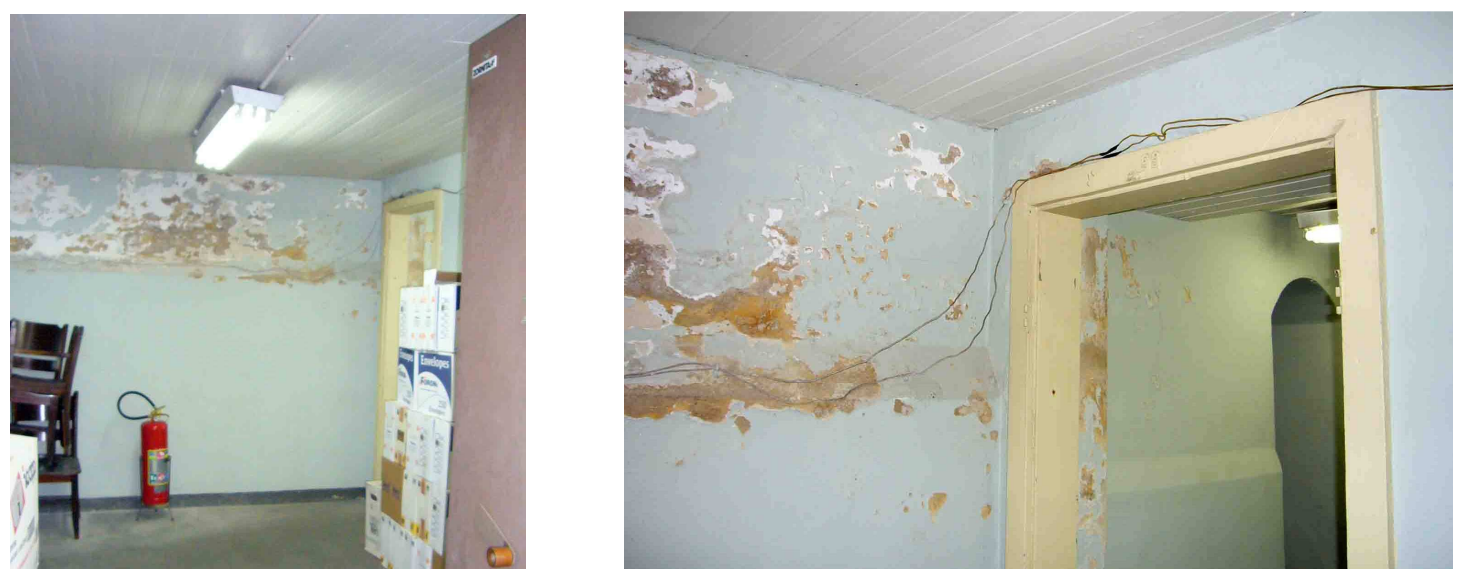

Figura 240 - Porão: paredes com acabamento deteriorado - desagregamento de material

Foto: Isis Roverso, abril de 2011.

Os revestimentos externos das paredes apresentam deterioração, especialmente nas áreas próximas ao piso e no topo (áreas junto à cobertura), que recebem maior incidência da variação das ações climáticas.

As áreas dos peitoris das janelas, especialmente da fachada frontal, também apresentam desagregação e descascamento da pintura de acabamento. Essa situação está vinculada ao decréscimo de qualidade relacionada à estanqueidade, proporcionada pela base da janela (peitoril com acabamento em madeira). 

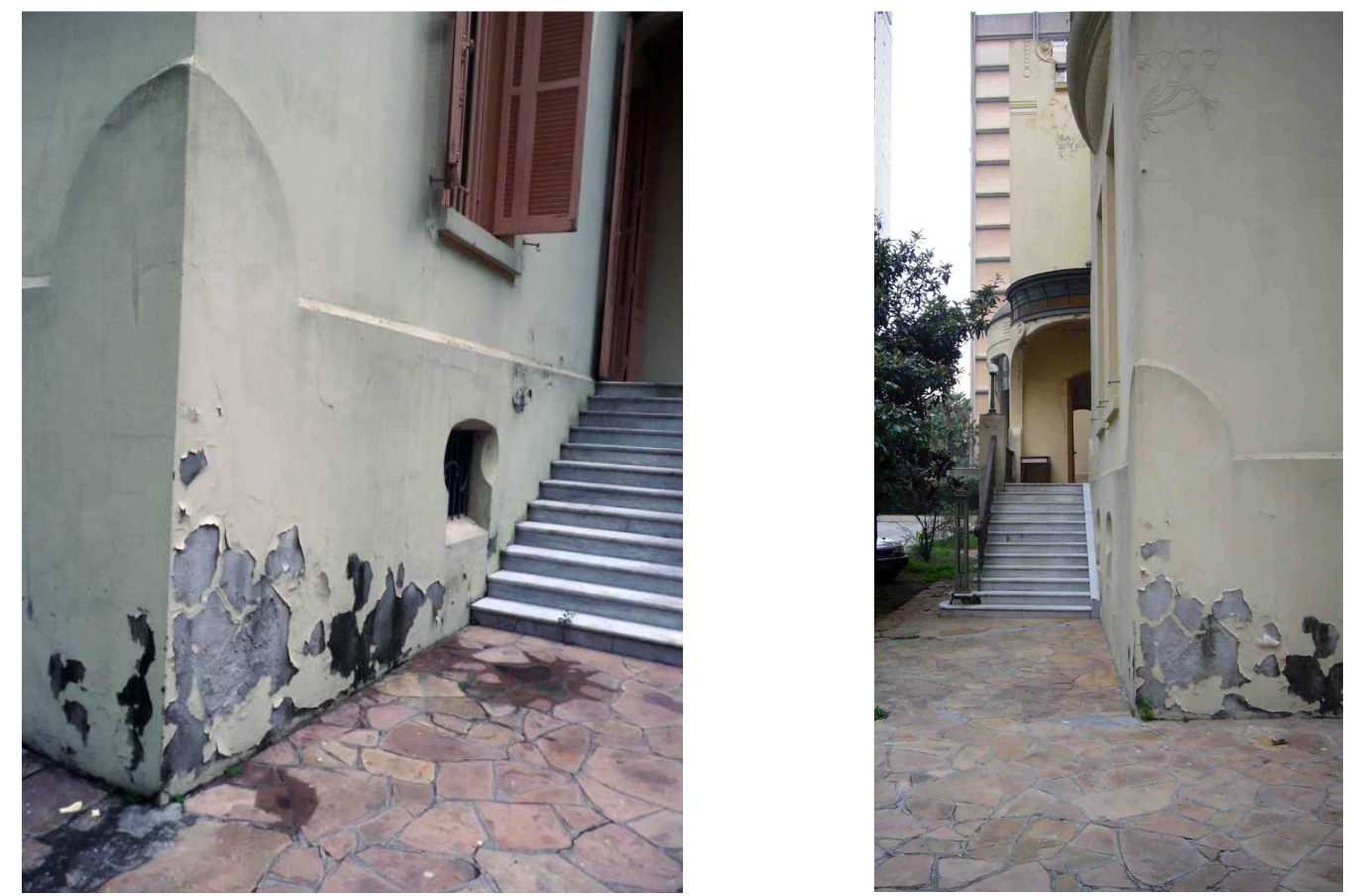

Figura 241 - Paramentos deteriorados junto ao piso Fotos: Isis Roverso, dezembro de 2010 e abril de 2011.

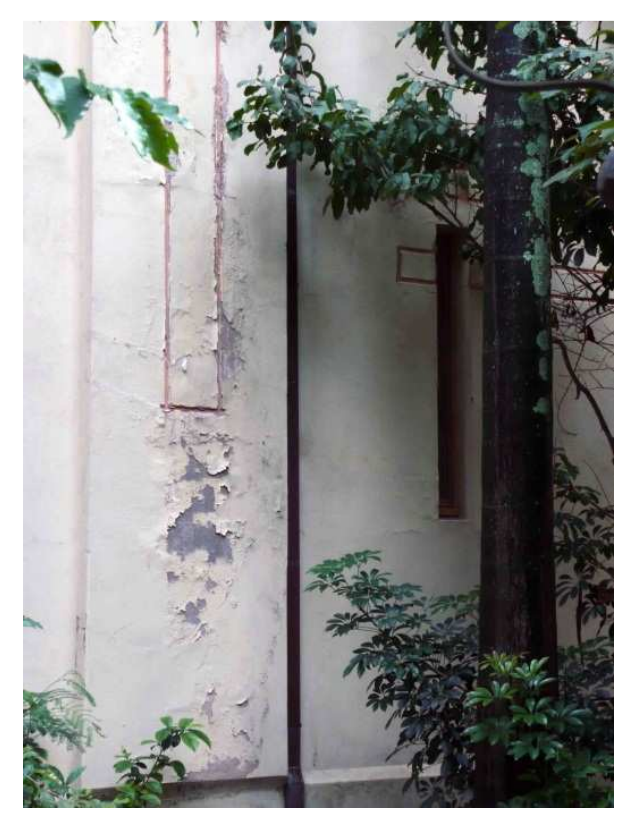

Figura 242 - Paramentos deteriorados na região do banheiro e copa Fotos: Isis Roverso, abril de 2011. 

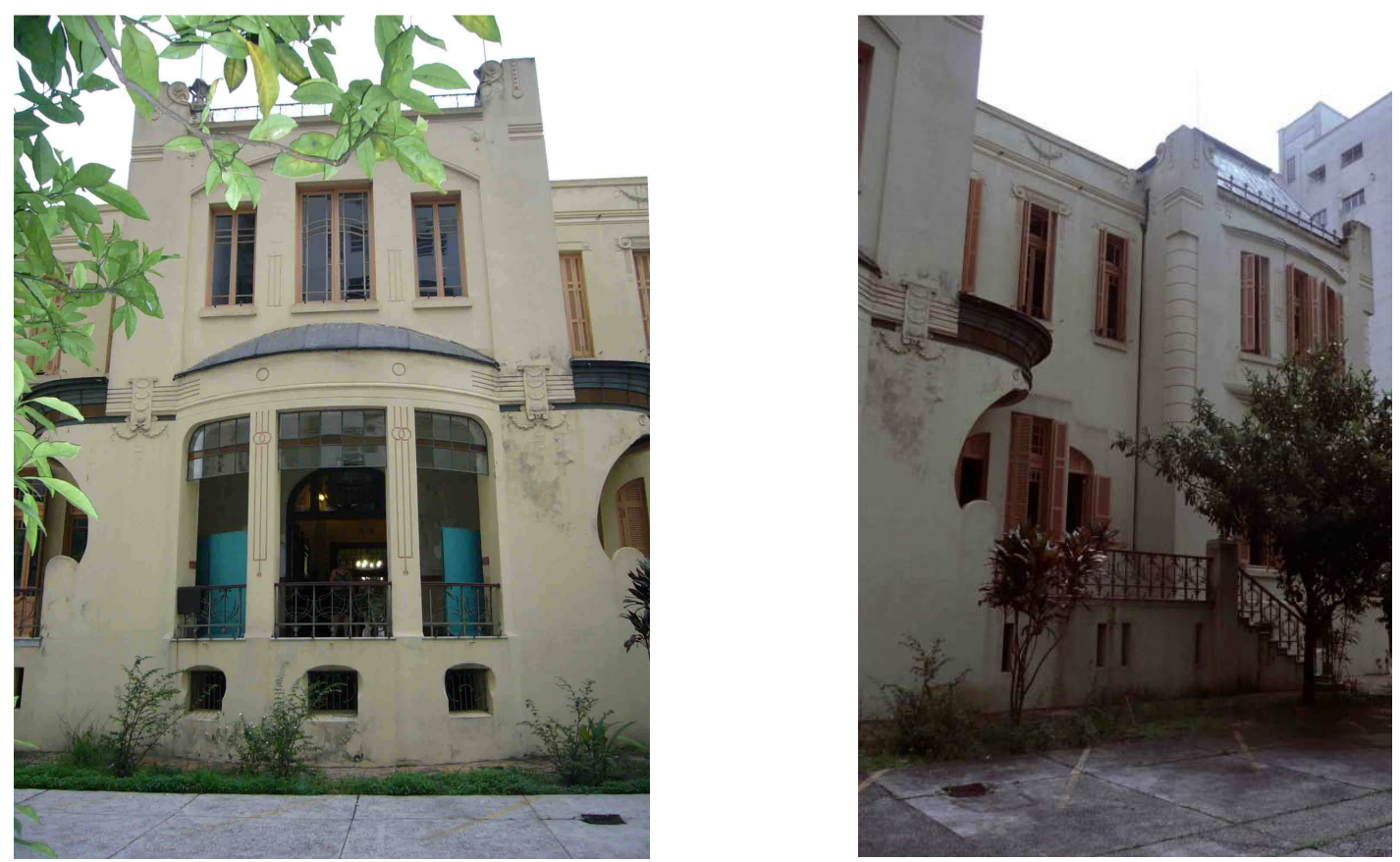

Figura 243 - Área deteriorada próxima à cobertura em cobre que protege o terraço da entrada posterior da Vila Penteado

Fotos: Isis Roverso, abril de 2011 e dezembro de 2010.
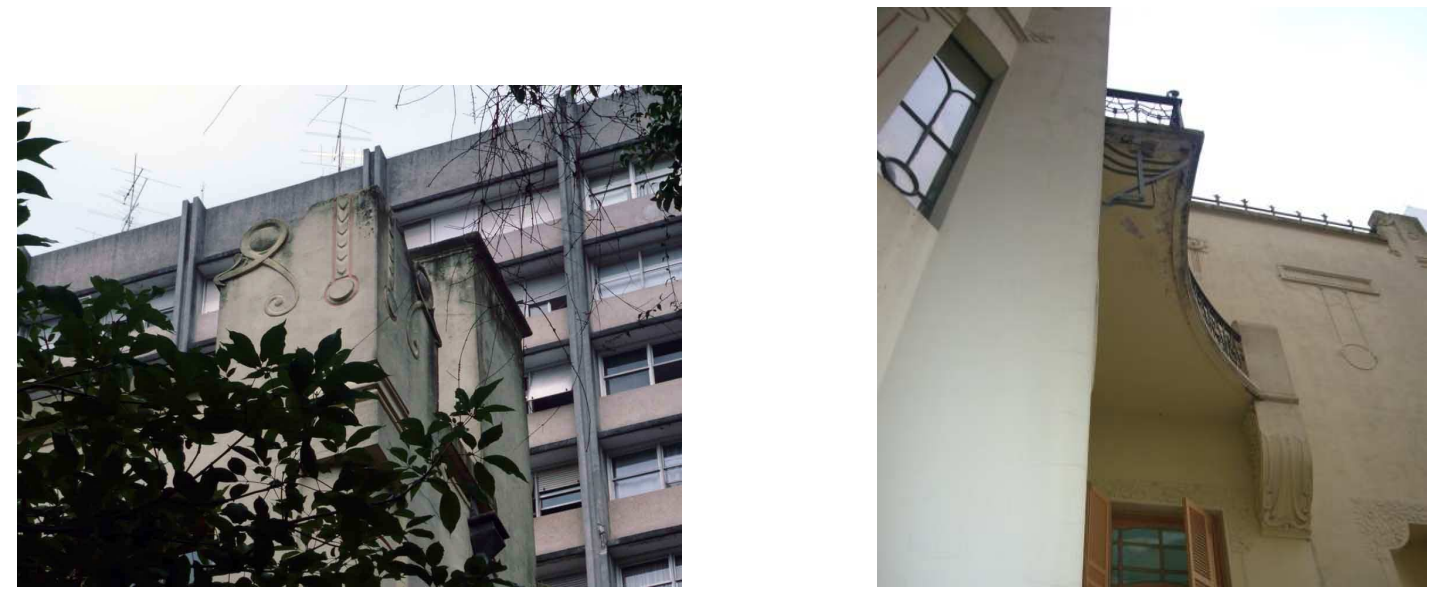

Figura 244 - À esquerda, área deteriorada no topo do edifício e, à direta, sob o balcão Fotos: Isis Roverso, dezembro de 2010 e abril de 2011.

Quanto à situação dos revestimentos externos da Vila Penteado, o parecer das professoras Beatriz Mugayar Kühl, Claudia Oliveira e Helena Ayoub Silva, entitulado "FAU-Maranhão: Considerações sobre o uso e Transformação"115, esclarece a situação no item "O que é necessário para a FAU-Maranhão":

115 Parecer elaborado em julho de 2007, encaminhado para o diretor da FAUUSP. Texto integrante dos arquivos pessoais das professoras, disponibilizado para consulta, através de arquivo digital, pela $\operatorname{Prof}^{a} \operatorname{Dr}^{\mathrm{a}}$ Claudia Oliveira e, em cópia física, pela $\operatorname{Prf}^{\mathrm{a}} \operatorname{Dr}^{\mathrm{a}}$ Helena Ayoub. 
- $\quad$ superfícies arquitetônicas (exterior e interior)

- verificar o estado de conservação das argamassas e identificar as transformações feitas ao longo do tempo para o tratamento de eventuais intervenções problemáticas;

- diagnosticar a origem de desplacamentos pontuais do revestimentos das faces externas das paredes do porão;

determinar os procedimentos necessários para a remoção da última pintura feita com tintas à base de polímeros sobre a argamassa à base de cal, que fatalmente levará à desagregação da argamassa e de todos os seus sutis relevos, comprometendo um documento histórico e estético da mais alta importância, podendo ainda comprometer a própria argamassa de assentamento dos tijolos;

- especificar materiais e técnicas compatíveis para se fazer as eventuais consolidações de partes desagregadas, integrações e repintes; - determinar periodicidade de verificação, métodos e periodicidade de limpezas e repintes.

As áreas externas, protegidas por cobertura, também apresentam decréscimo da qualidade, como é visível na área do terraço, de acesso posterior, da Vila Penteado.
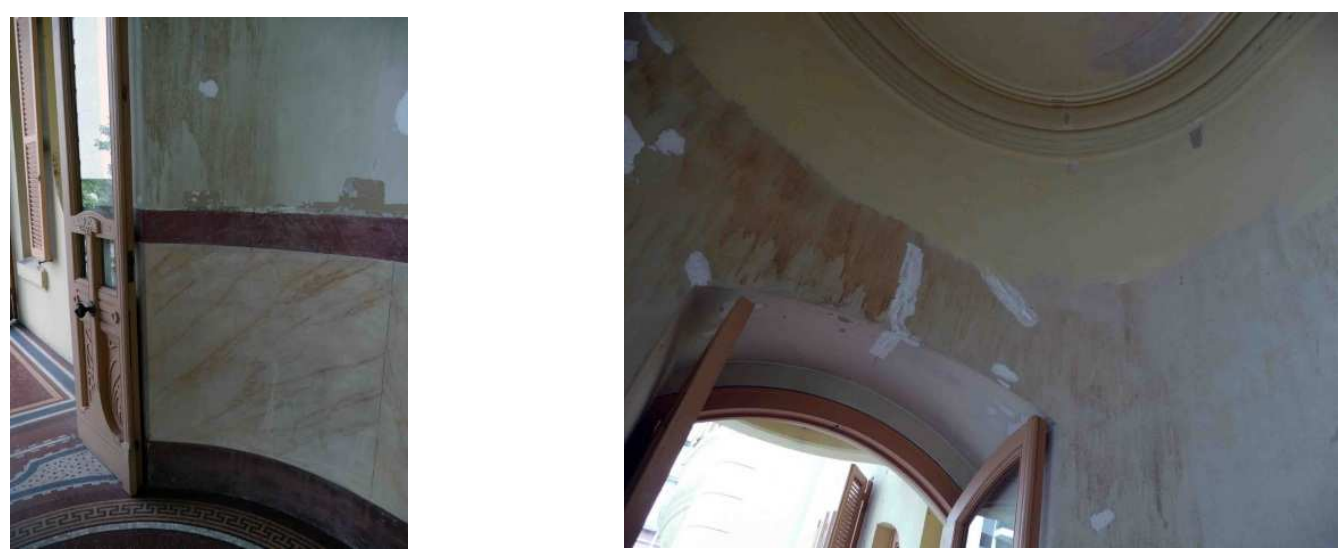

Figura 245 - Área do terraço posterior da Vila Penteado, pavimento térreo Fotos: Isis Roverso, dezembro de 2010.

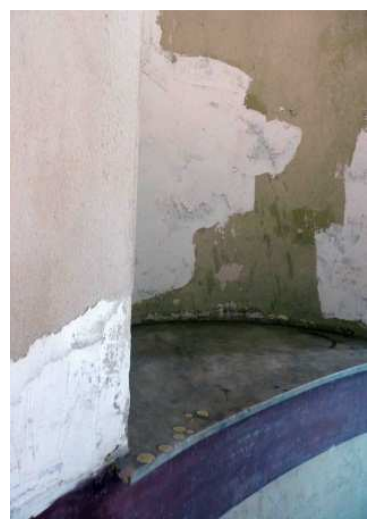

Figura 246 - Detalhe de uma das paredes da área do terraço posterior da Vila Penteado, pavimento térreo

Fotos: Isis Roverso, dezembro de 2010. 


\subsubsection{TETOS E FORROS}

Como já detalhado no item 3.2.2 "Intervenções nos Forros", há áreas na Vila Penteado com forro em madeira e outras áreas com forro em estuque estruturado em fasquias da palmeira juçara, justapostas, envolvidas por camadas de argamassa de cal e areia.

Os forros do pavimento térreo apresentam menor incidência de falhas construtivas do que os do pavimento superior. Isso se dá em função do problema recorrente aos forros, que está relacionado à falta de estanqueidade do edifício: tanto a cobertura, quanto os terraços apresentam deficiências construtivas, sendo que na cobertura os problemas tem origem antiga e resultam em deterioração severa nos forros, chegando a provocar desabamentos, como os ocorridos e já comentados nos itens 3.1.4 "O Edifício: Vila Penteado" e 3.2.2 "Intervenções nos Forros".

Tanto os forros em madeira, quanto os em estuque, apresentam deterioração devido às infiltrações, sendo que as áreas de forro em estuque acabam sendo mais prejudicadas. Uma dessas áreas é o forro do Mezanino, onde parte ruiu. $\mathrm{O}$ destacamento do revestimento do forro do mezanino, registrado na figura 247 , deixou à vista a estrutura de fasquias de palmeira juçara.
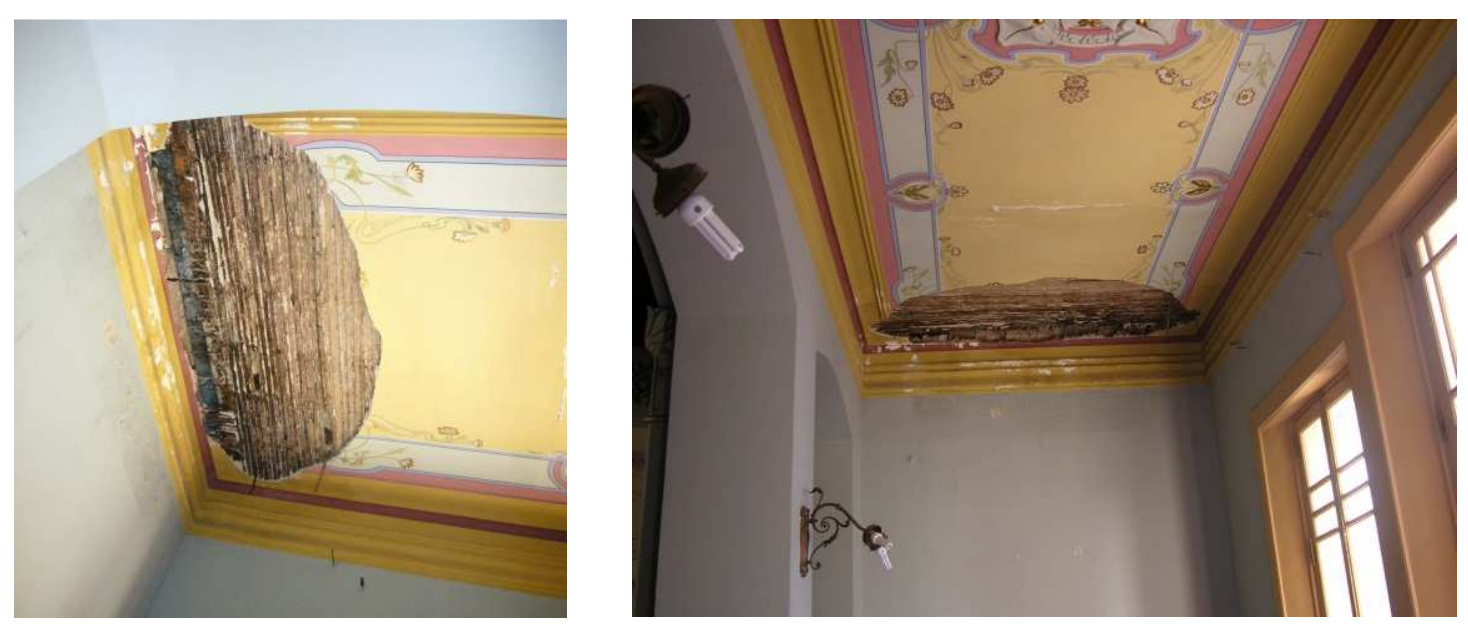

Figura 247 - Forro do Mezanino

Fotos: À esquerda, de Isis Roverso (abril de 2011) e à direita, de Eunice Bruno (junho de 2011).

Os pontos "1" e "2" indicados na planta da figura 248, já apresentavam sinais de deterioração em vistoria realizada em 2009 (figura 249). Os sinais de umedecimento do forro eram resultantes da falta de estanqueidade na cobertura. 


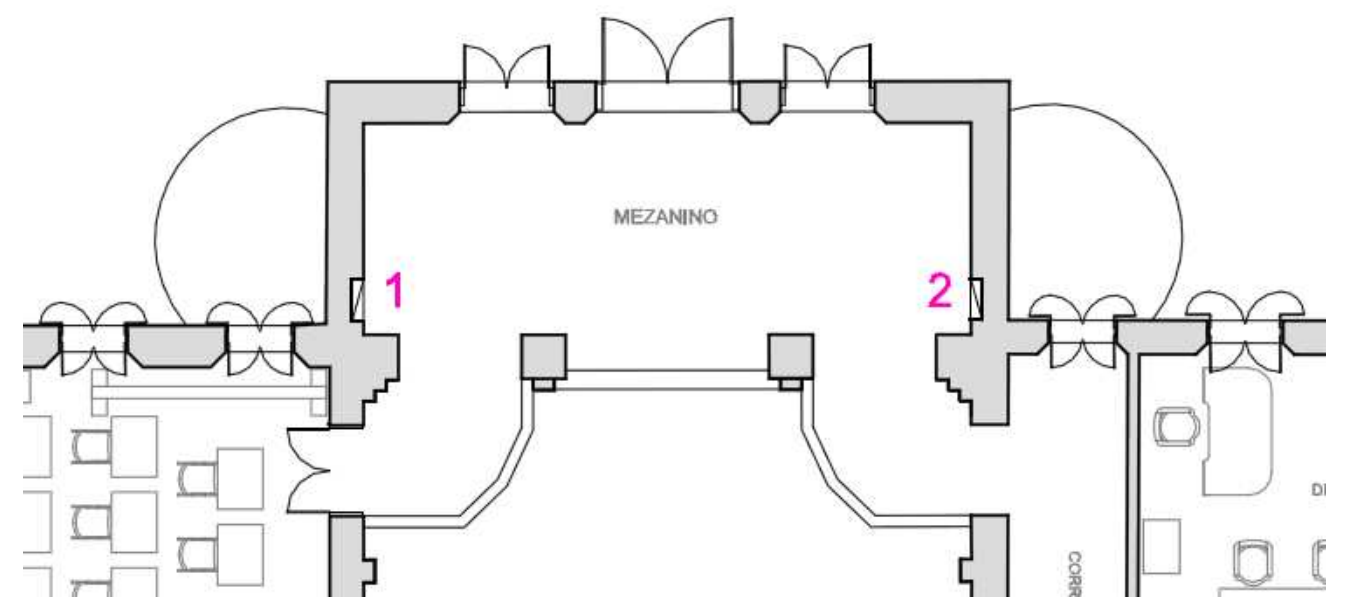

Figura 248 - Parte do Levantamento da Cobertura - FAU Maranhão

Fonte: Folha 2/2, FAU Maranhão, Levantamento para identificação de infiltrações. Localização e fotos dos pontos de infiltração no pavimento superior. Desenho Bárbara, Escala 1:100, Data maio/ 2009, Revisão 00. GEEF, FAUUSP 2009.

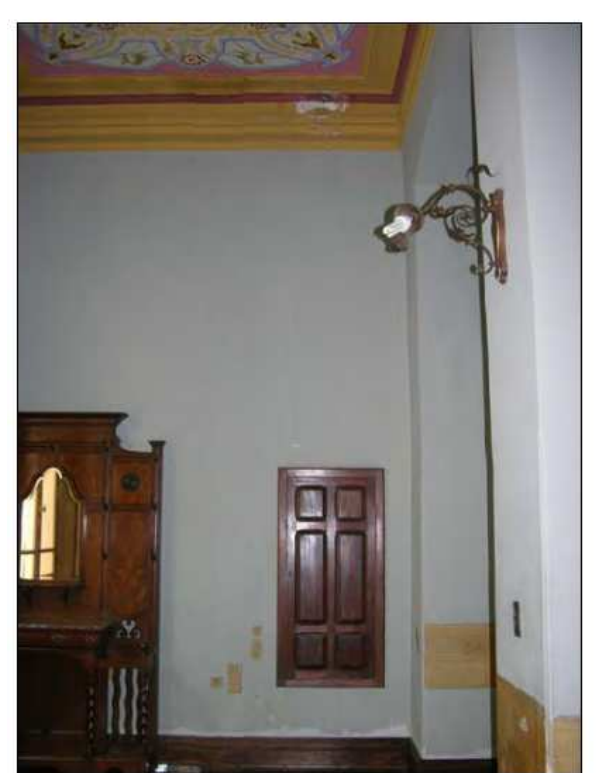

1 e 2 - INFILTRAÇÕES NO MEZANINO, POSIÇÃO SIMÉTRICA, ABAIXO DO TELHADO DE COBRE

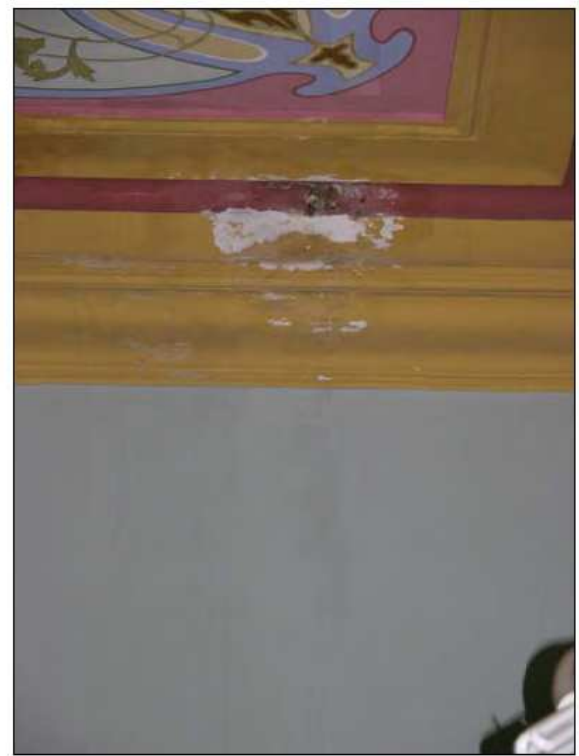

1 e 2 - INFILTRAÇÕES NO MEZANINO, POSIÇÃO SIMÉTRICA, ABAIXO DO TELHADO DE COBRE (AMPLIADA)

Figura 249 - Fotografias do Levantamento da Cobertura - FAU Maranhão

Fonte: Folha 2/2, FAU Maranhão, Levantamento para identificação de infiltrações. Localização e fotos dos pontos de infiltração no pavimento superior. Desenho Bárbara, Escala 1:100, Data maio/ 2009, Revisão 00. GEEF, FAUUSP 2009.

Motivadas pelo ocorrido, novas vistorias foram realizadas em 2011. Foi identificado o local de infiltração de água na cobertura de cobre, além da insuficiência do sistema de captação de águas pluviais que provoca 0 transbordamento da água nas calhas, potencializando o problema da infiltração. A vista superior da cobertura sobre a área de forro danificada pode ser observada na foto da figura 250 . 


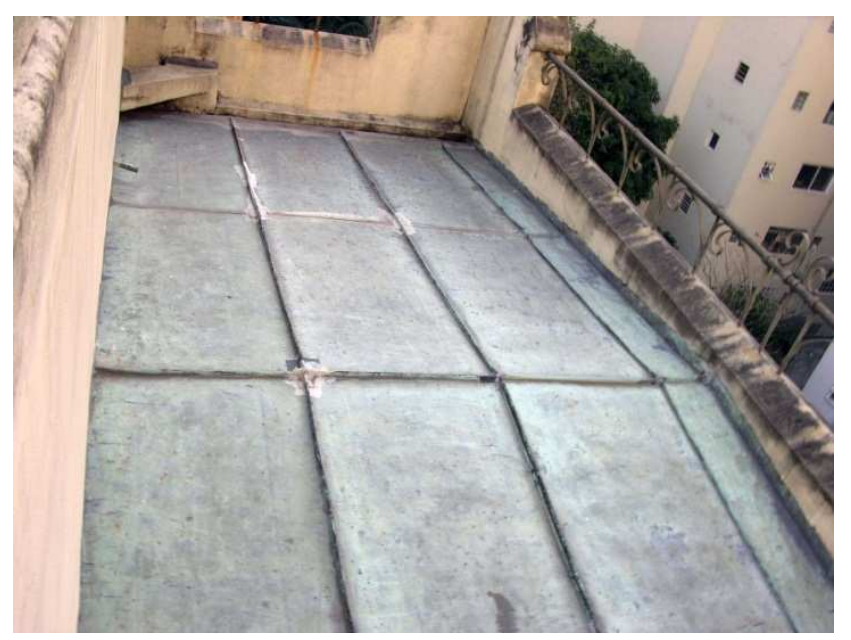

Figura 250 - Fotografia da cobertura em cobre sobre o Mezanino Fonte: Foto Arnaldo Gomes de Almeida, funcionário da manutenção da FAU Maranhão, 29 de junho de 2011.

Outra constatação foi a dificuldade no acesso a diversas áreas da cobertura, o que dificulta sobremaneira as vistorias frequentes, que deverão ser realizadas para evitar novas falhas como esta.

É clara a necessidade de elaboração de um projeto de restauro para o sistema da cobertura. Os itens relevantes para esse projeto foram relacionados no relatório da reunião de junho de 2011.

O Projeto de Restauro da Cobertura deverá considerar:

- Levantamento detalhado da cobertura existente;

- Redimensionamento da captação de águas pluviais. Restauro ou recolocação dos condutores em cobre;

- Colocação de subcobertura que permita a ventilação, além de melhorar a estanqueidade da cobertura e o conforto térmico do edifício (subcobertura com desempenho semelhante às membranas de alto desempenho DuPont Tyvek);

- Colocação de passarelas e cabos que permitam a manutenção periódica (o projeto deverá propor solução que facilite 0 acesso às diversas áreas dessa cobertura);

- Reforma do telhamento, com substituição das áreas danificadas em telhas de ardósia e de cobre;

- Aprovação nos órgãos de preservação do patrimônio (CONPRESP e CONDEPHAAT);

- Manual de manutenção. ${ }^{116}$

116 Texto extraído do Relatório referente à Reunião de 28 de junho de 2011 . FAUUSP - Edifício Vila

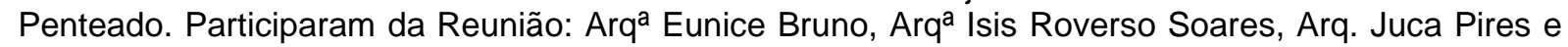
Arq. Lourenço de Fiore da empresa Pires, Giovanetti, Guardia Restauro de Patrimônio Histórico e Arq. Ivan Xavier da empresa Lamé Housing Arquitetura. A redação desse documento foi feita por Isis Roverso Soares. 
Em função da gravidade dos reflexos desta falha na segurança ao uso da edificação, as obras emergenciais de reparo da cobertura do Mezanino não puderam aguardar a elaboração do Projeto de Restauro da Cobertura.

No mês de dezembro de 2011, a empresa RS Hidráulica Desentupidora, representada pelo Sr. Rosvaldo Silveira, executou soldas na cobertura em cobre sobre o Mezanino do Pavimento Superior da Vila Penteado. No primeiro fim de semana do ano de 2012 houve forte chuva e não foram constatados vazamentos na área do forro do Mezanino, o que sugere que o problema de infiltração nessa área, por enquanto, está resolvido.

As fotos das figuras 251 e 252 apresentam a área do forro do Mezanino, após os trabalhos de manutenção da cobertura dessa área.

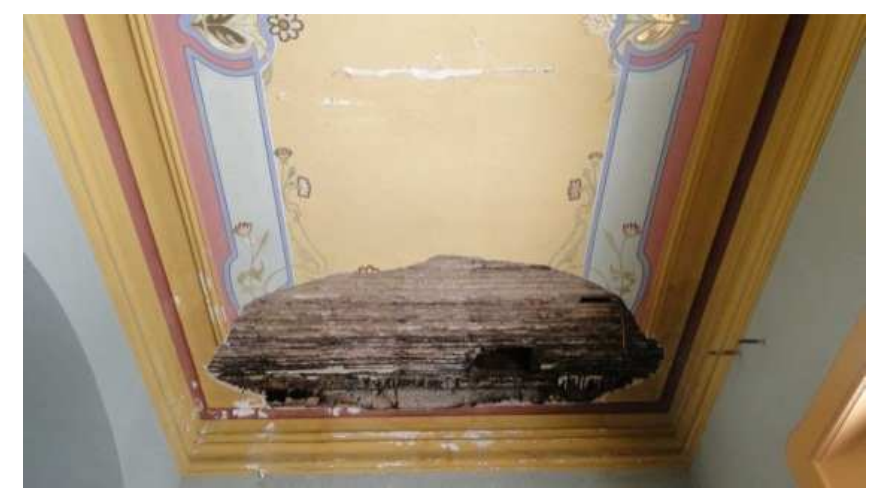

Figura 251 - Forro do Mezanino: área que apresentava vazamento devido à falha na solda da cobertura em cobre

Foto: Isis Roverso, janeiro de 2012.
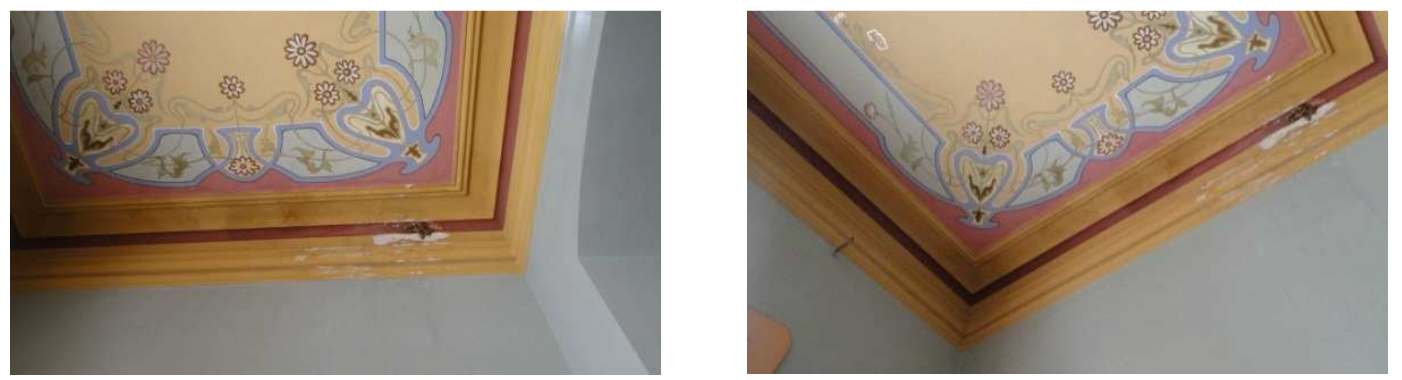

Figura 252 - Forro do Mezanino: área que apresentava vazamento devido à falha na solda da cobertura em cobre

Fotos: Isis Roverso, janeiro de 2012.

Outras áreas do pavimento superior também apresentam vazamentos antigos. Como comentado pelo funcionário Arnaldo Gomes de Almeida, alguns trechos do telhado vazam sempre, especialmente nos período de chuvas, então, há baldes posicionados no forro do pavimento superior exatamente nesses pontos 
específicos, evitando maiores danos ao forro. A figura 253 mostra um desses pontos, localizado no corredor em frente à Sala 65, e a figura 254 apresenta outro local de forro com sinais de infiltração de águas pluviais.

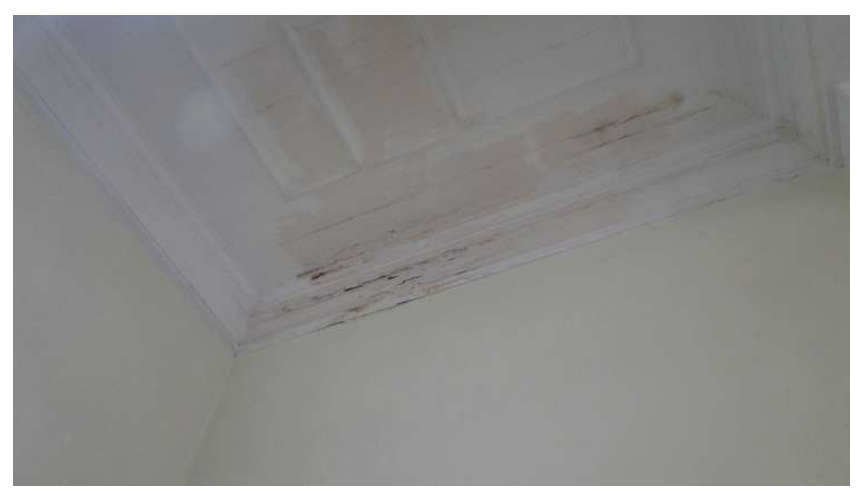

Figura 253 - Forro do corredor em frente à Sala 65: vazamento constante no período de chuvas, sendo que acima do forro há um balde que contém parte desse vazamento Foto: Isis Roverso, outubro de 2011.

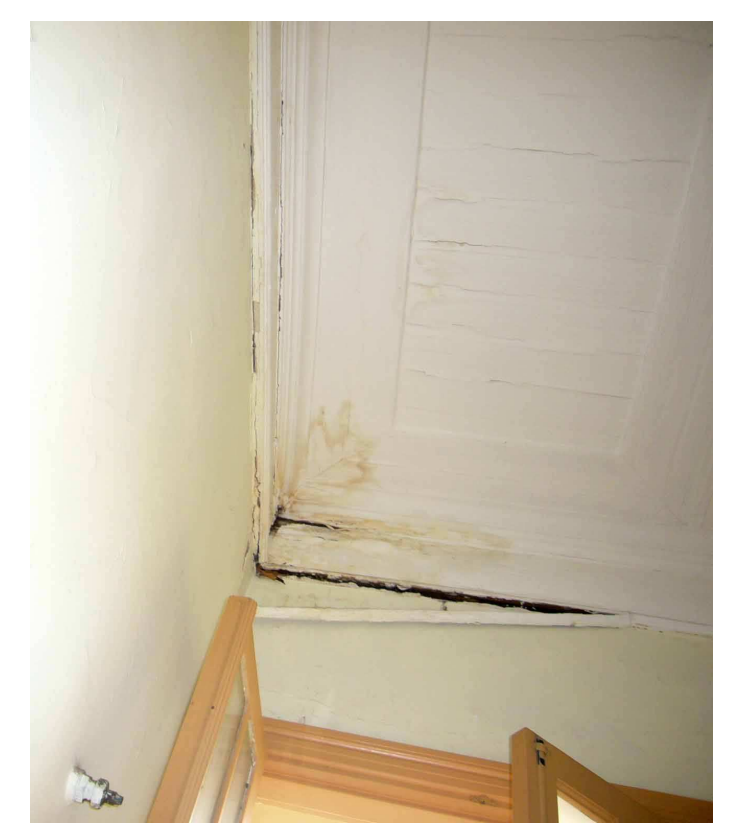

Figura 254 - Forro do WC Feminino S46, Pavimento Superior Foto: Isis Roverso, abril de 2011.

Há também vazamentos recentes, como é possível notar no forro da Sala dos Espelhos (figura 255). Provavelmente a infiltração de águas de chuva está ocorrendo através da soleira existente no terraço da secretaria. Uma sugestão viável seria impermeabilizar a área visível sob a soleira (ver foto da figura 256) e acompanhar se a infiltração existente da Sala dos Espelhos regride. 


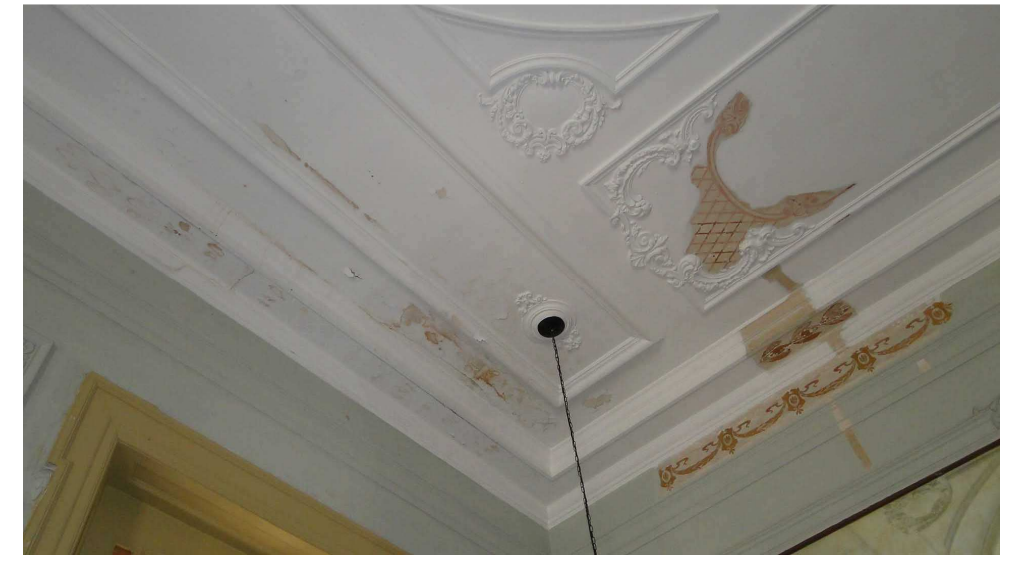

Figura 255 - Forro da Sala dos Espelhos: vazamento recente Foto: Isis Roverso, outubro de 2011.

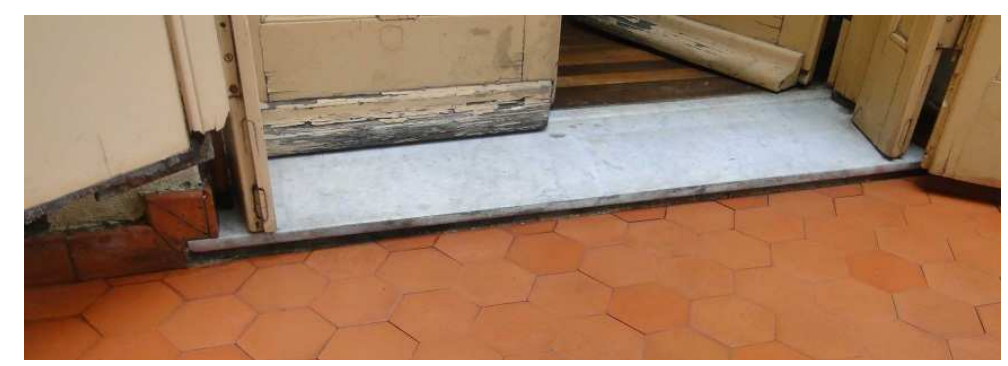

Figura 256 - Terraço esquerdo da Secretaria (Sala 74) Foto: Isis Roverso, outubro de 2011.

Outras áreas apresentam problemas relacionados ao descascamento, como é possível notar nas fotos da Sala 44 e da Copa (ver figura 257 e 258).

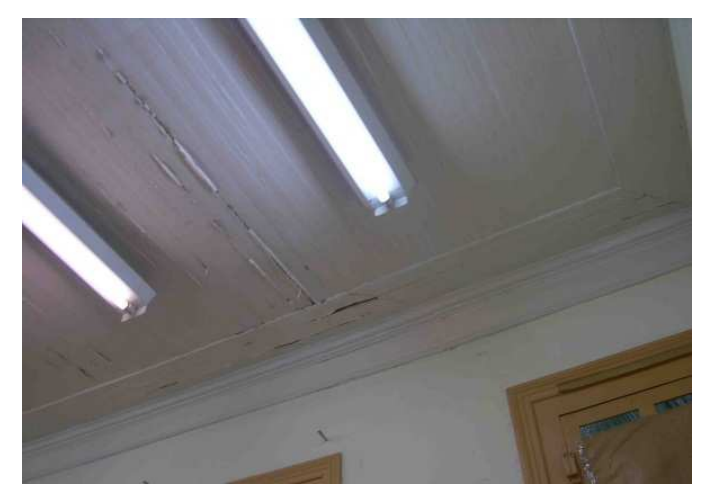

Figura 257 - Forro em madeira da Sala 44: descascamento Foto: Isis Roverso, junho de 2011. 

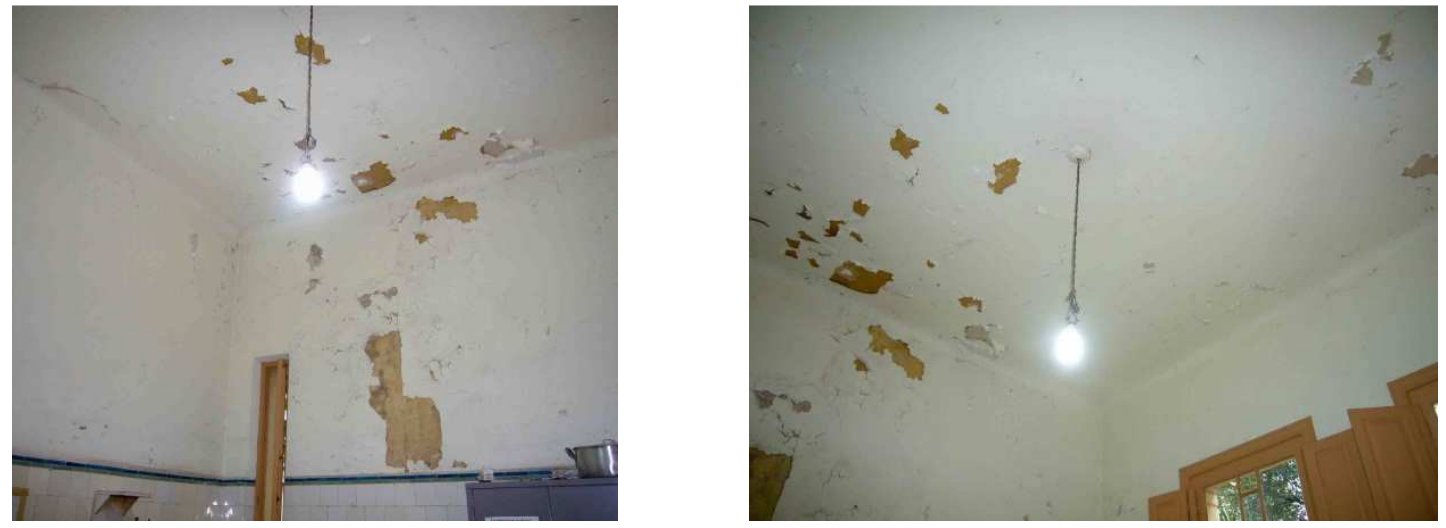

Figura 258 - Descascamento dos paramentos da Copa: situação que provoca falta de higiene no ambiente

Fotos: Isis Roverso, abril de 2011.

Mas é preciso ressaltar que diversas áreas, especialmente os ambientes da Biblioteca e da Sala 12, apresentam bom desempenho dos paramentos horizontais. Cabe relembrar que essas áreas receberam intervenção a cerca de dez anos (ver condições relatadas no item 3.2.6 "Intervenções na Área da Biblioteca"). As fotos das figuras 259 a 266 destacam as áreas mencionadas.

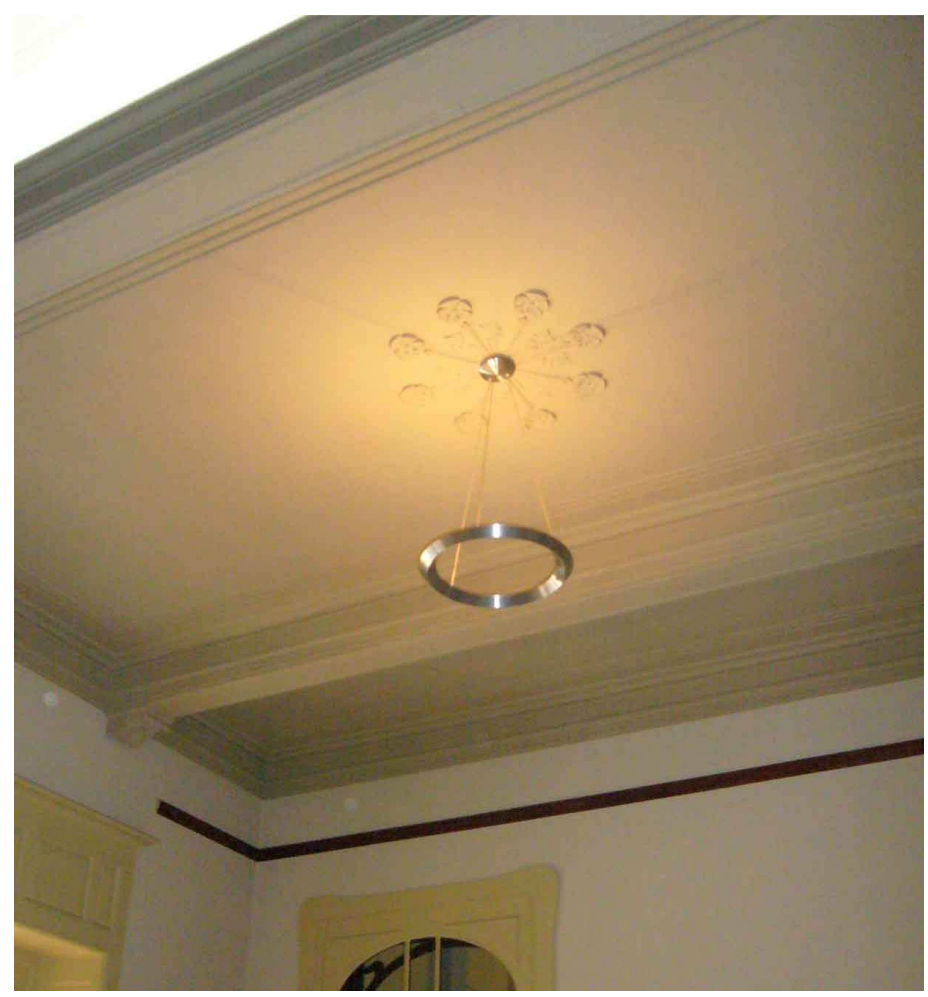

Figura 259 - Forro em estuque com pintura mural da Sala 25 - Biblioteca Foto: Isis Roverso, abril de 2011. 

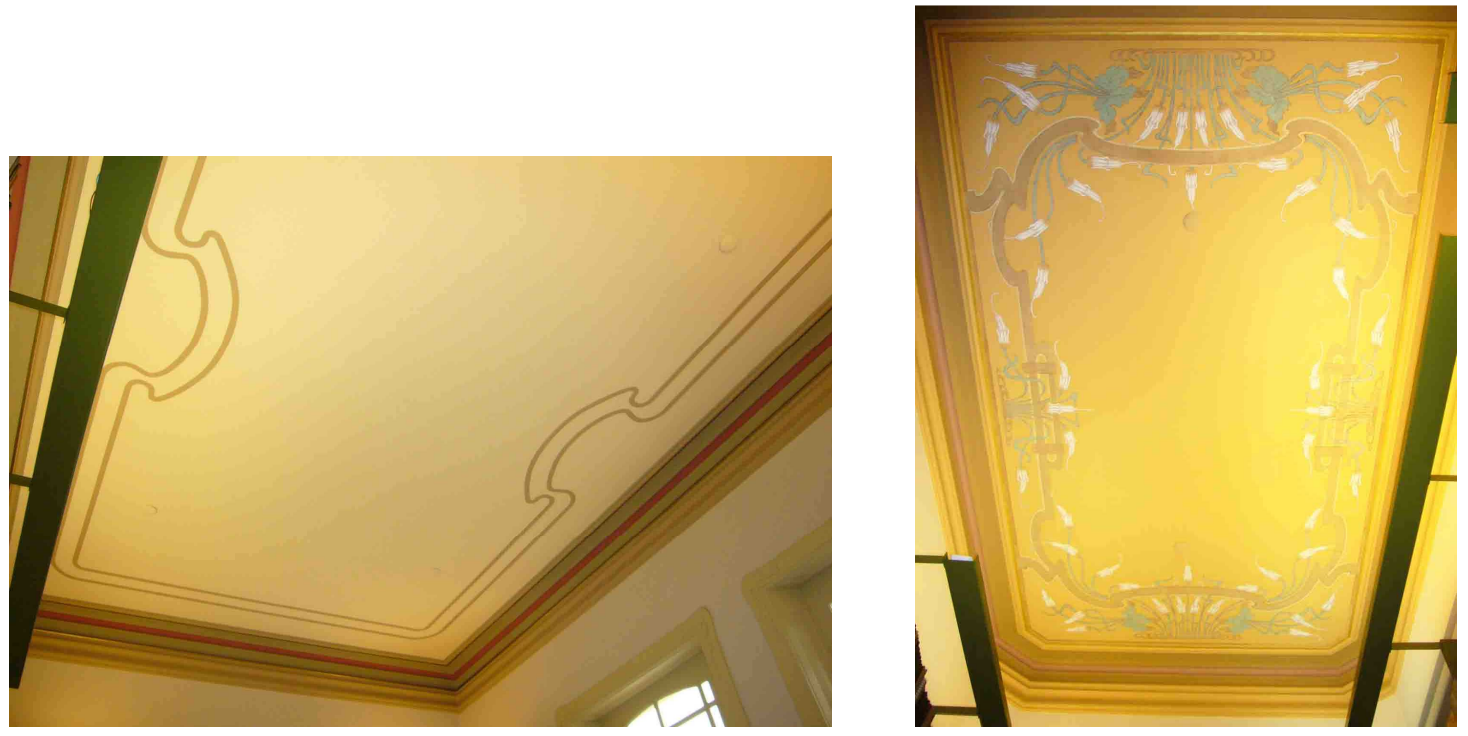

Figura 260 - Forro em estuque com pintura mural da Sala dos Livros e das Teses Biblioteca

Fotos: Isis Roverso, abril de 2011.
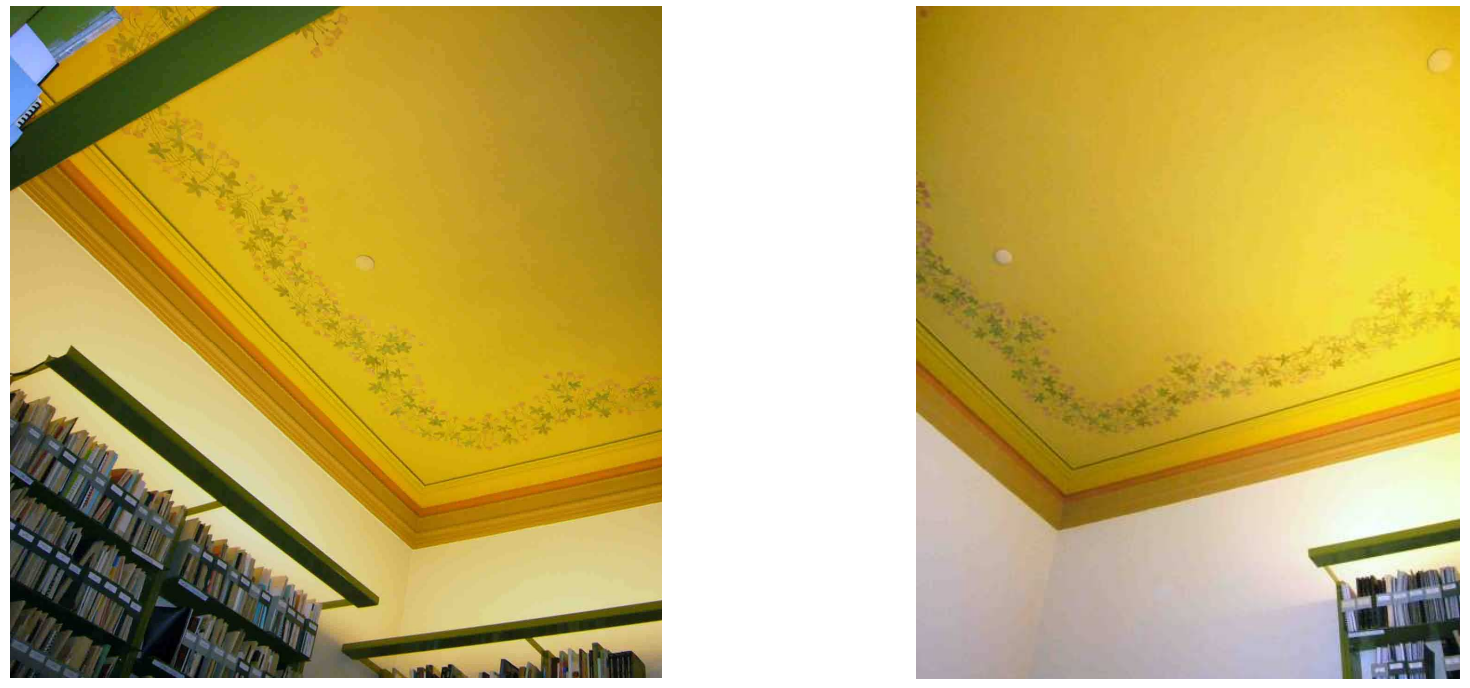

Figura 261 - Forro em estuque com pintura mural da Sala 37 da Biblioteca Fotos: Isis Roverso, dezembro de 2010.

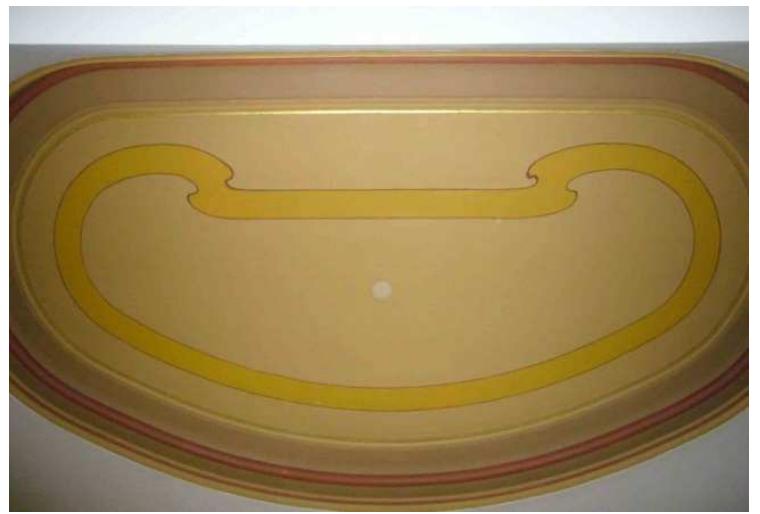

Figura 262 - Forro em estuque da Sacada da Biblioteca Foto: Isis Roverso, dezembro de 2010. 

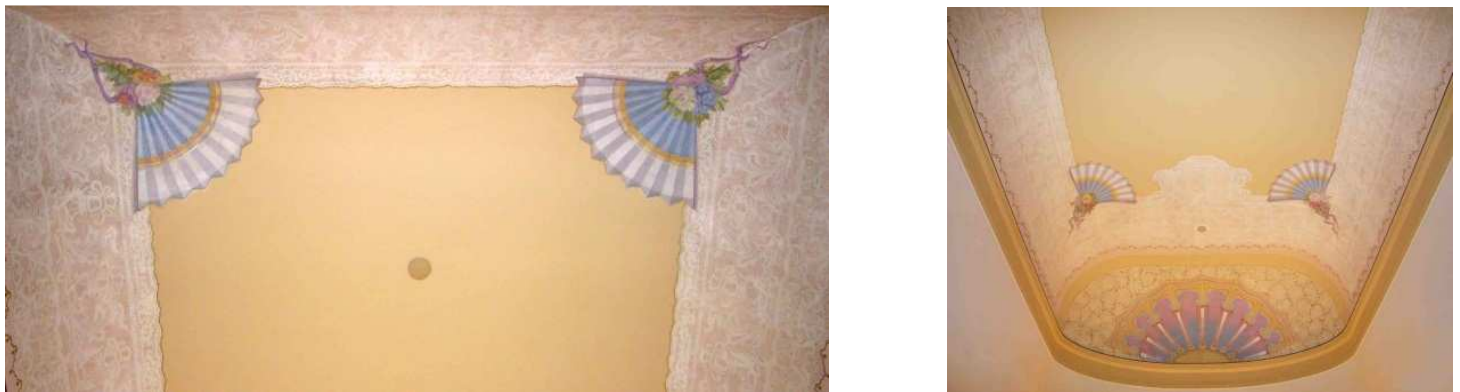

Figura 263 - Forro em estuque com pintura mural da Sala dos Leques da Biblioteca Fotos: Isis Roverso, abril de 2011.
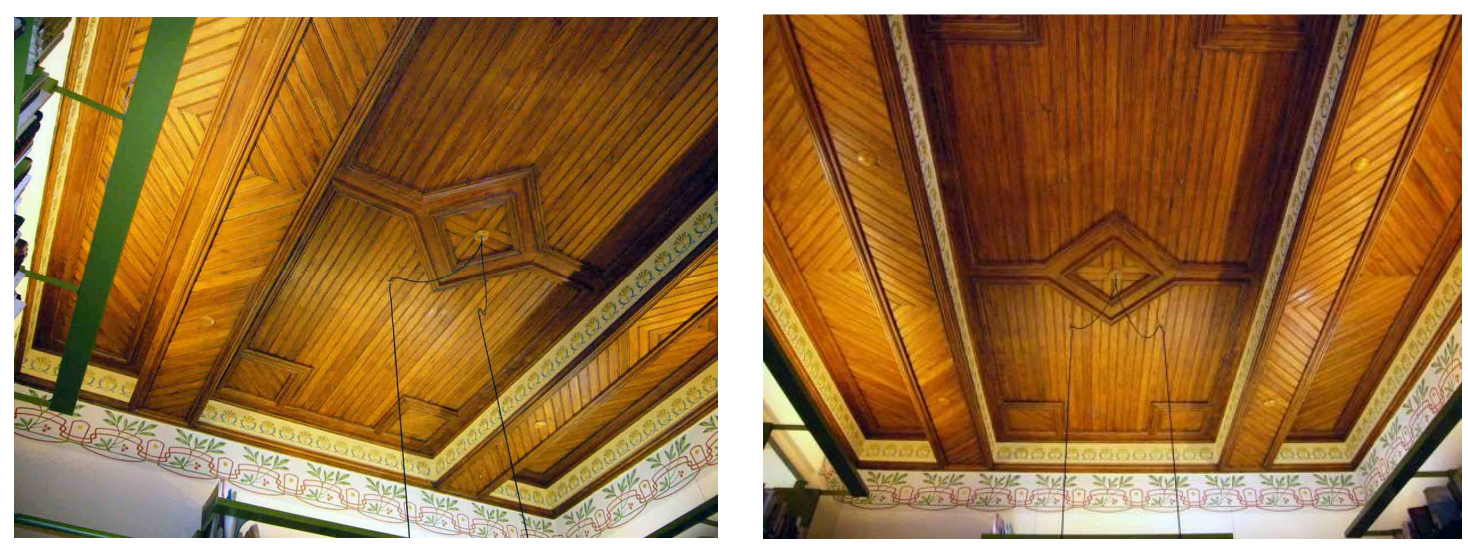

Figura 264 - Forro em réguas de madeira da Biblioteca Fotos: Isis Roverso, abril de 2011.
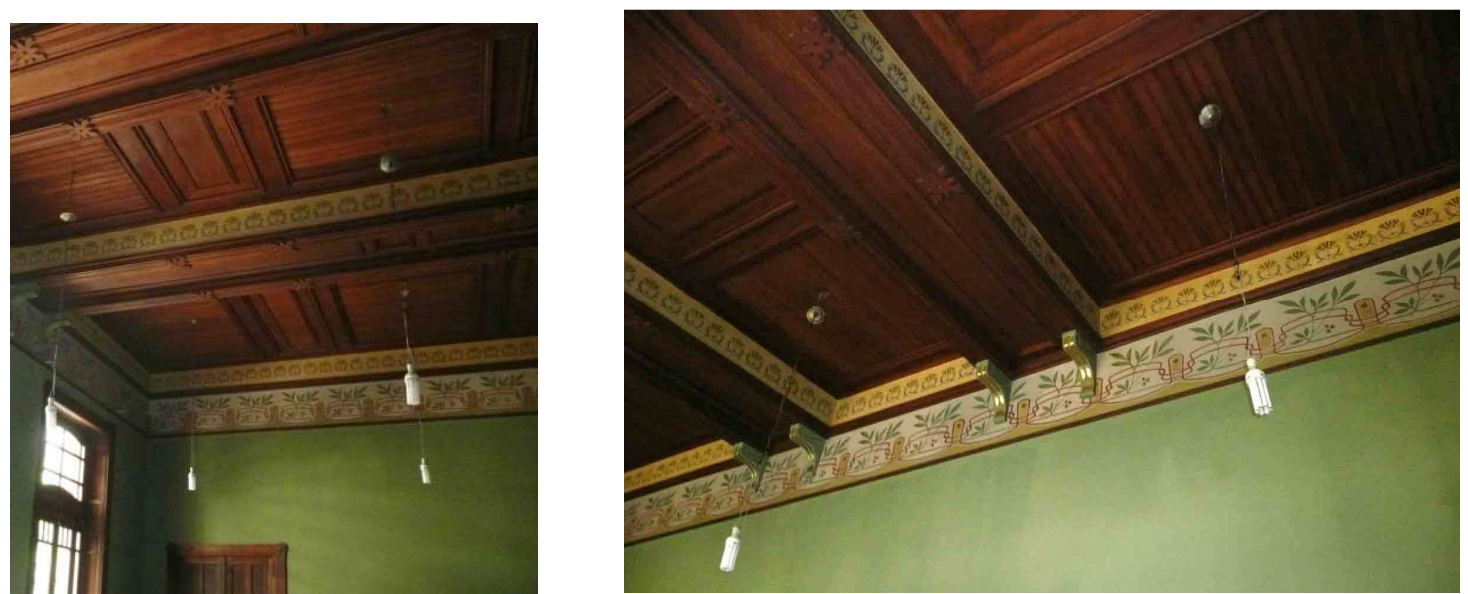

Figura 265 - Forro em réguas de madeira da Sala 12 Fotos: Isis Roverso, dezembro de 2010.

Os forros em madeira da Vila Penteado, assim como os assoalhos, são compostos por desenhos e formatos diversos. Trabalhos em alto e baixo relevo, no caso dos forros, e tonalidades variadas de madeira, no caso dos assoalhos. 

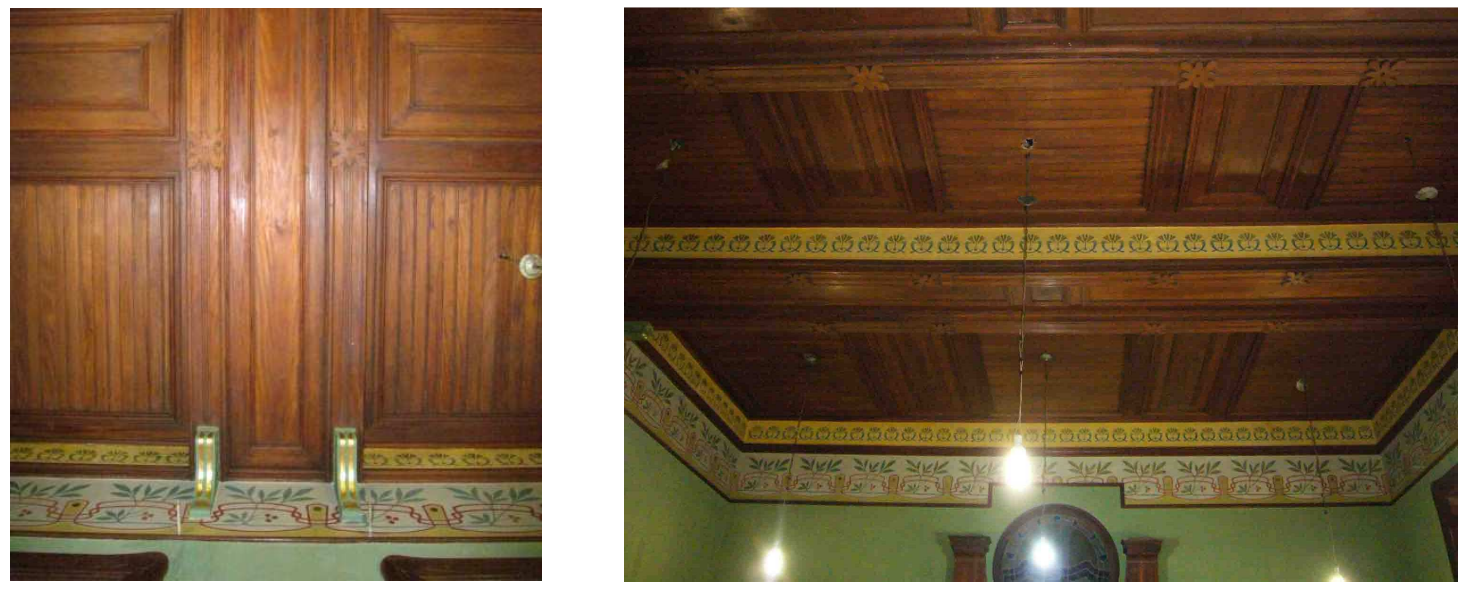

Figura 266 - Forro em réguas de madeira da Sala 12 Fotos: Isis Roverso, abril de 2011.

Outras áreas também foram restauradas há uma década e hoje apresentam os forros bem conservados. Aqui é possível destacar a área da Portaria, do Saguão e corredor em frente à Sala 12.
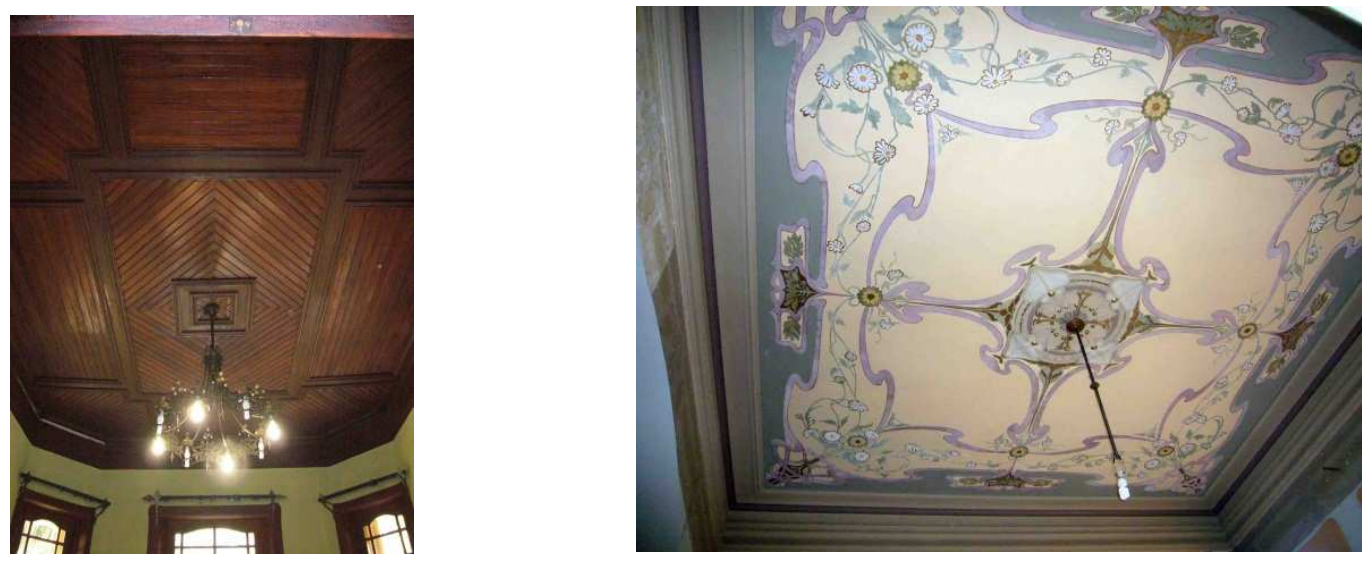

Figura 267 - Forro em réguas de madeira da Portaria e forro em estuque com pintura mural da Sala 68 (conjugada com o Saguão)

Fotos: Isis Roverso, abril de 2011.
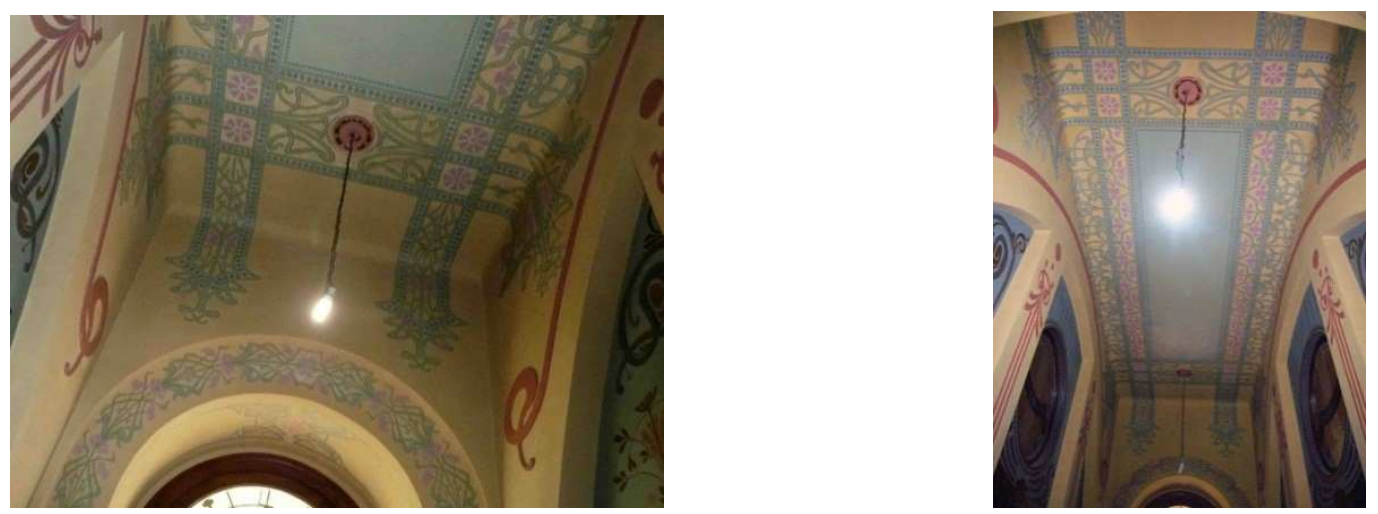

Figura 268 - Forro restaurado do Corredor S16 (em frente à Sala 12) Fotos: Isis Roverso, dezembro de 2010 e abril de 2011. 
Outros técnicas e materiais também são vistos nos paramentos horizontais da Vila Penteado, tais como forro em madeira ripada e acabamento argamassado.
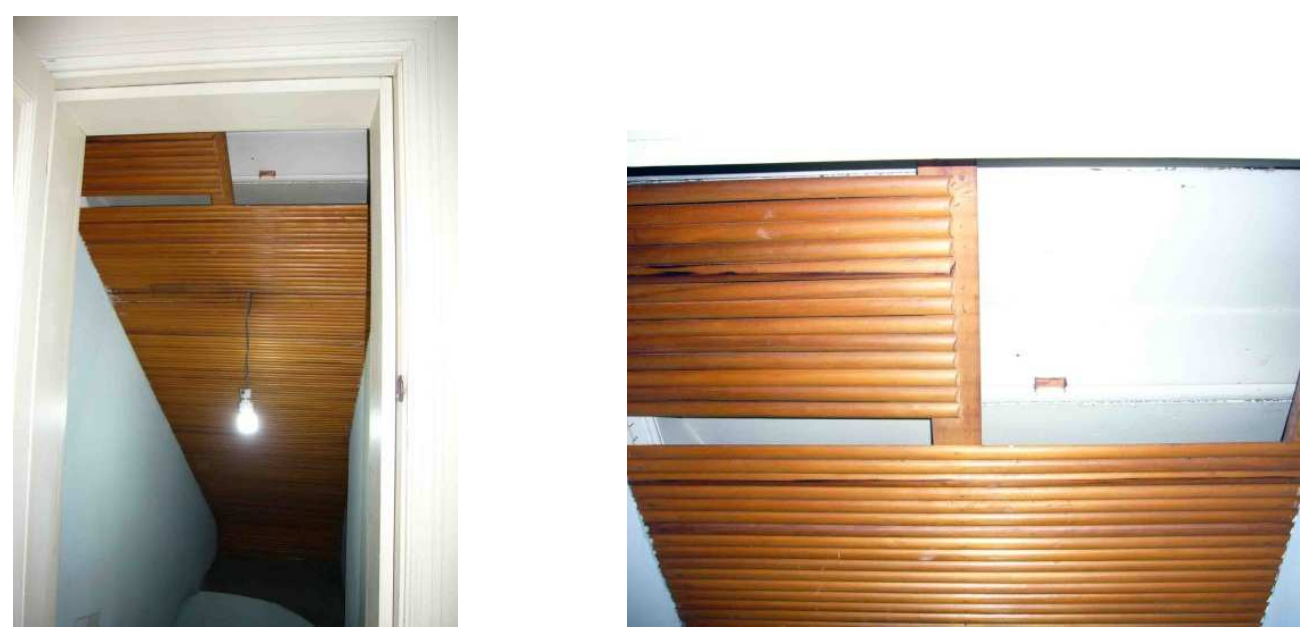

Figura 269 - Forro em madeira ripada da escada de acesso ao porão Fotos: Isis Roverso, abril de 2011

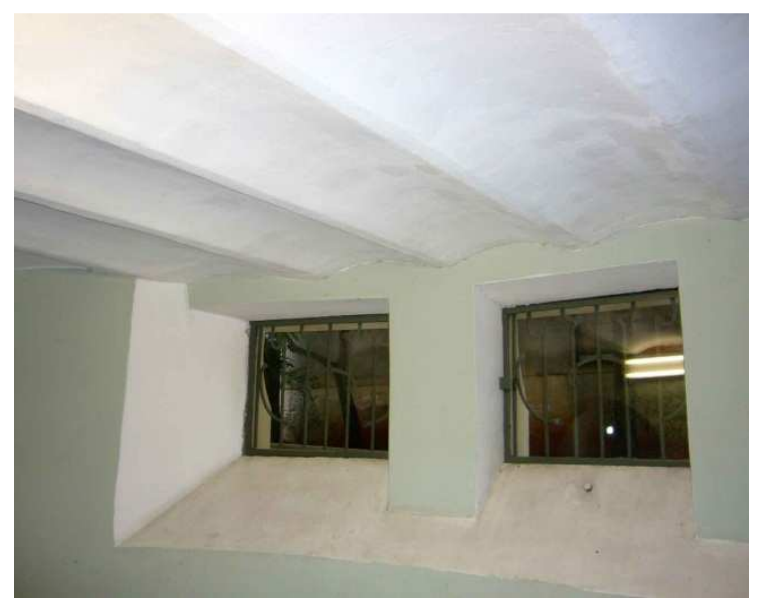

Figura 270 - Abóbodas do teto com revestimento argamassado Foto: Isis Roverso, abril de 2011.

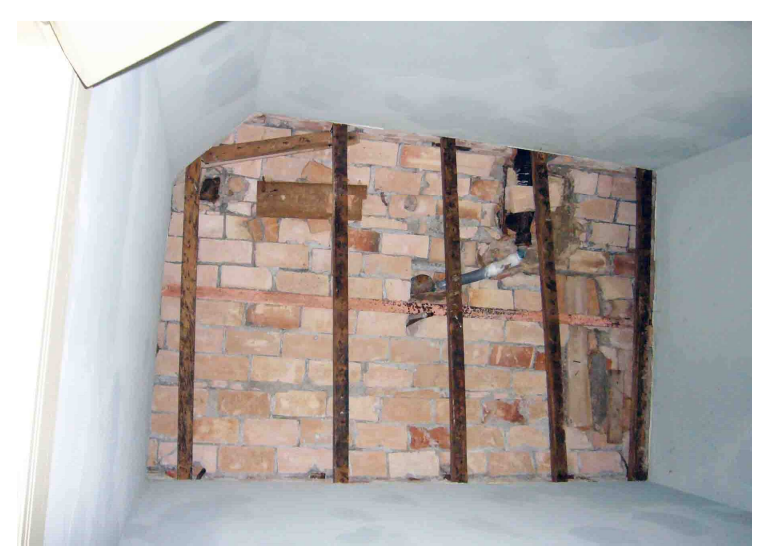

Figura 271 - Teto em tijolos da Saleta S35 Foto: Isis Roverso, abril 2011 
Há ainda forros com vitral e claraboias, sendo que o vitral do Saguão deve ser destacado em função das suas dimensões e detalhes ornamentais (as figuras 272 , 273 e 274 apresentam os vitrais e claraboias da Vila Penteado).
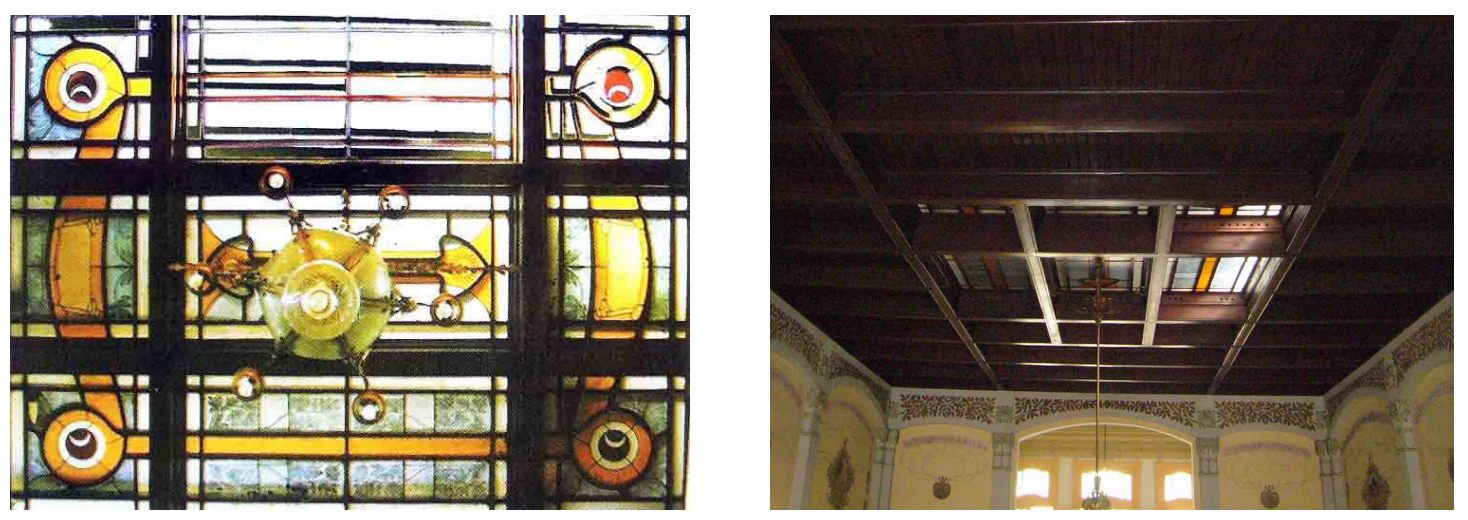

Figura 272 - Vitral do Saguão

Fotos: À esquerda, Candida Maria Vuolo, publicada em "Vila Penteado: 100 anos". Revista do programa de pós-graduação em arquitetura e urbanismo da FAUUSP número especial. São Paulo: FAUUSP, 2002, p. 104. Foto à direita: Isis Roverso, abril de 2011.

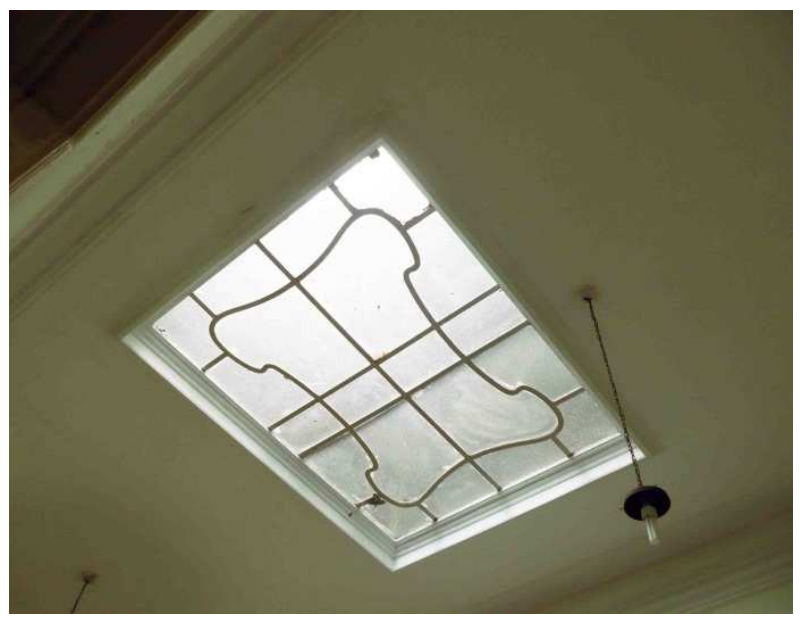

Figura 273 - Claraboia sobre corredor em frente à Sala 57 Foto: Isis Roverso, dezembro de 2010.

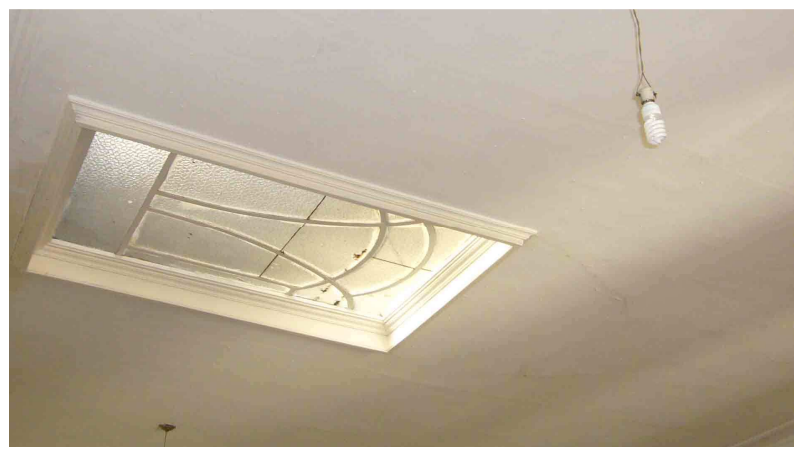

Figura 274 - Claraboia sobre Sala de Espera do Pavimento Superior Foto: Isis Roverso, abril de 2011. 
O vitral e as claraboias estão posicionados sobre as áreas de circulação (centro do saguão e escadas de acesso ao pavimento superior), o que auxilia a iluminação natural dessas áreas, entretanto, as ações de limpeza e manutenção não são facilitadas pela altura excessiva do pé-direito dessas regiões, dificultando o acesso.

Visando propiciar algum acesso ao sótão, há alguns alçapões instalados nos forros de madeira, do pavimento superior, da Vila Penteado.
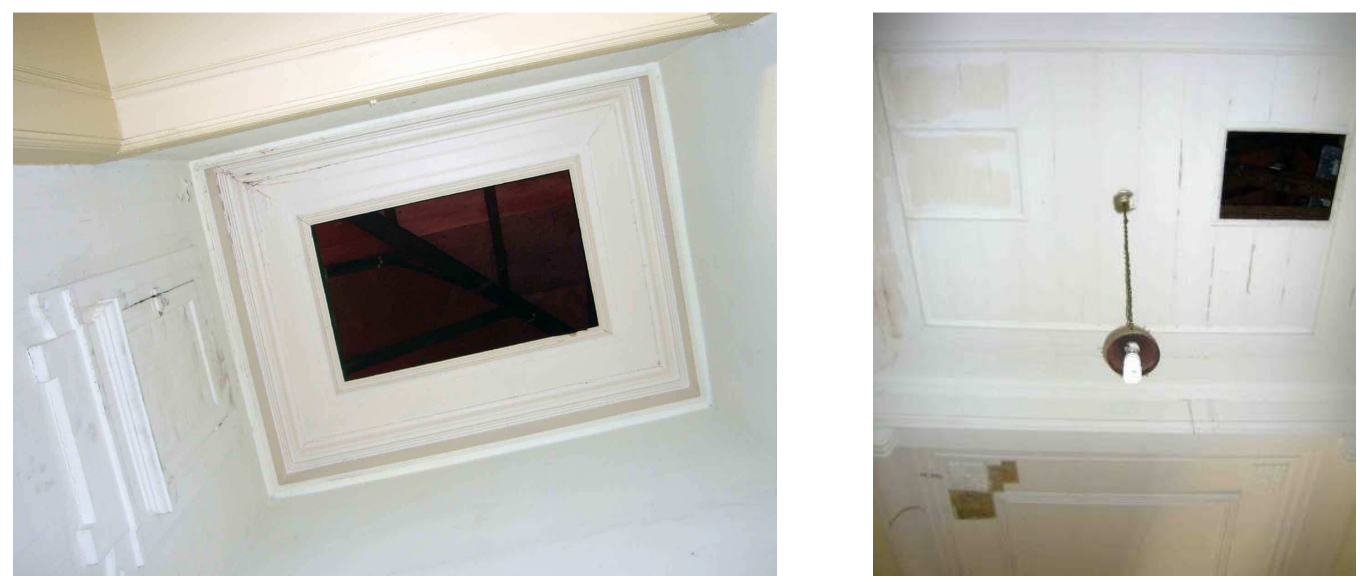

Figura 275 - Alçapões de acesso ao sótão - Hall S70 e Corredor S65 Foto: Isis Roverso, abril de 2011.
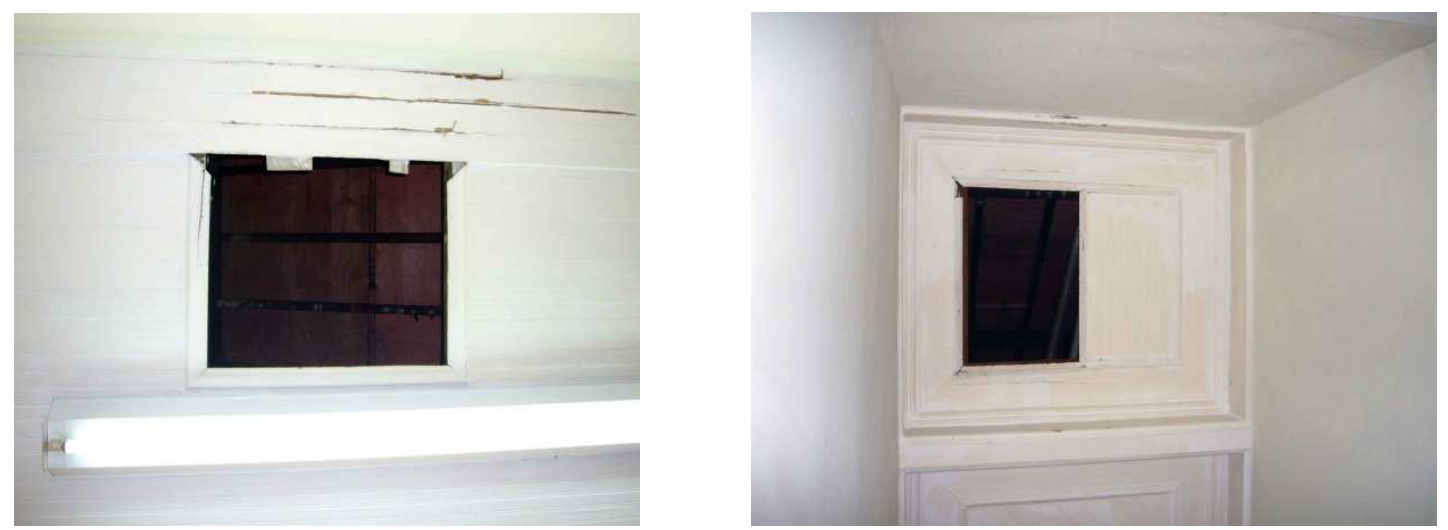

Figura 276 - Alçapões de acesso ao sótão - Sala 44 e WC Feminino S46 Foto: Isis Roverso, abril de 2011. 


\subsubsection{PAVIMENTOS}

No sistema de pavimentos, não apenas os revestimentos, como também as bases (substratos) são importantes elementos de análise.

A Vila Penteado conta com diversos materiais compondo sua pavimentação, sendo eles: pisos em madeira, mosaicos, pedras, granilite, ladrilho hidráulico, cerâmica, cimentado e tijolo.

\subsubsection{PISOS EM MADEIRA}

Diversos ambientes da Vila Penteado tem como acabamento de piso a madeira. A forma como estão dispostas as réguas variam de ambiente para ambiente.

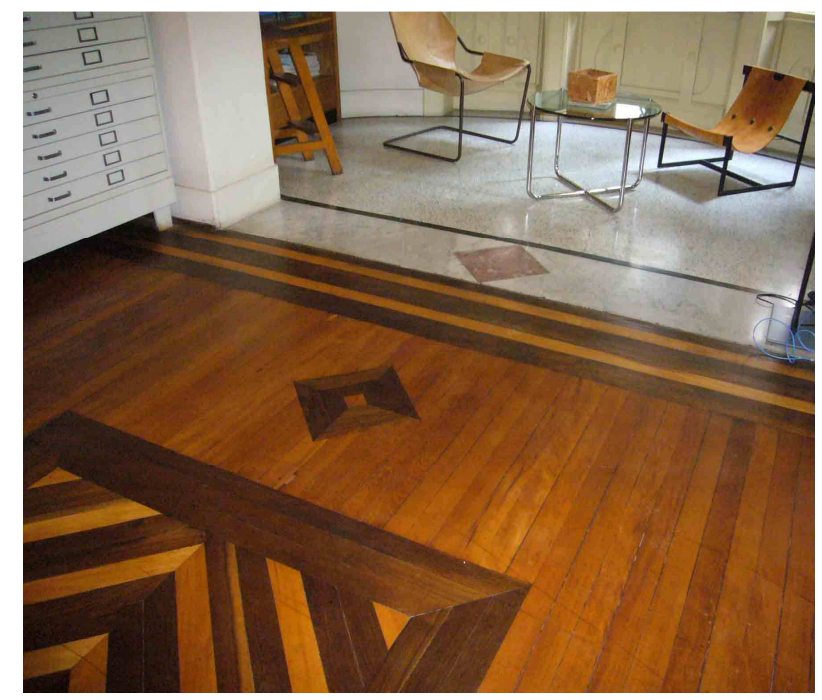

Figura 277 - Assoalho de madeira da Biblioteca Foto: Isis Roverso, abril de 2011.
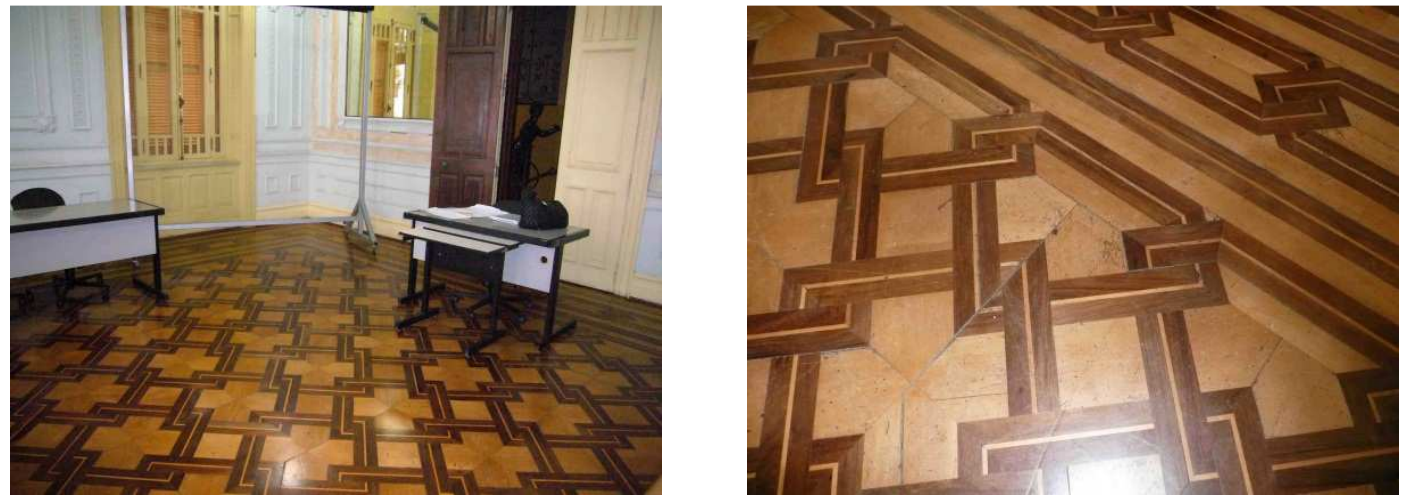

Figura 278 - Assoalho de madeira da Sala dos Espelhos Foto: Isis Roverso, abril de 2011. 

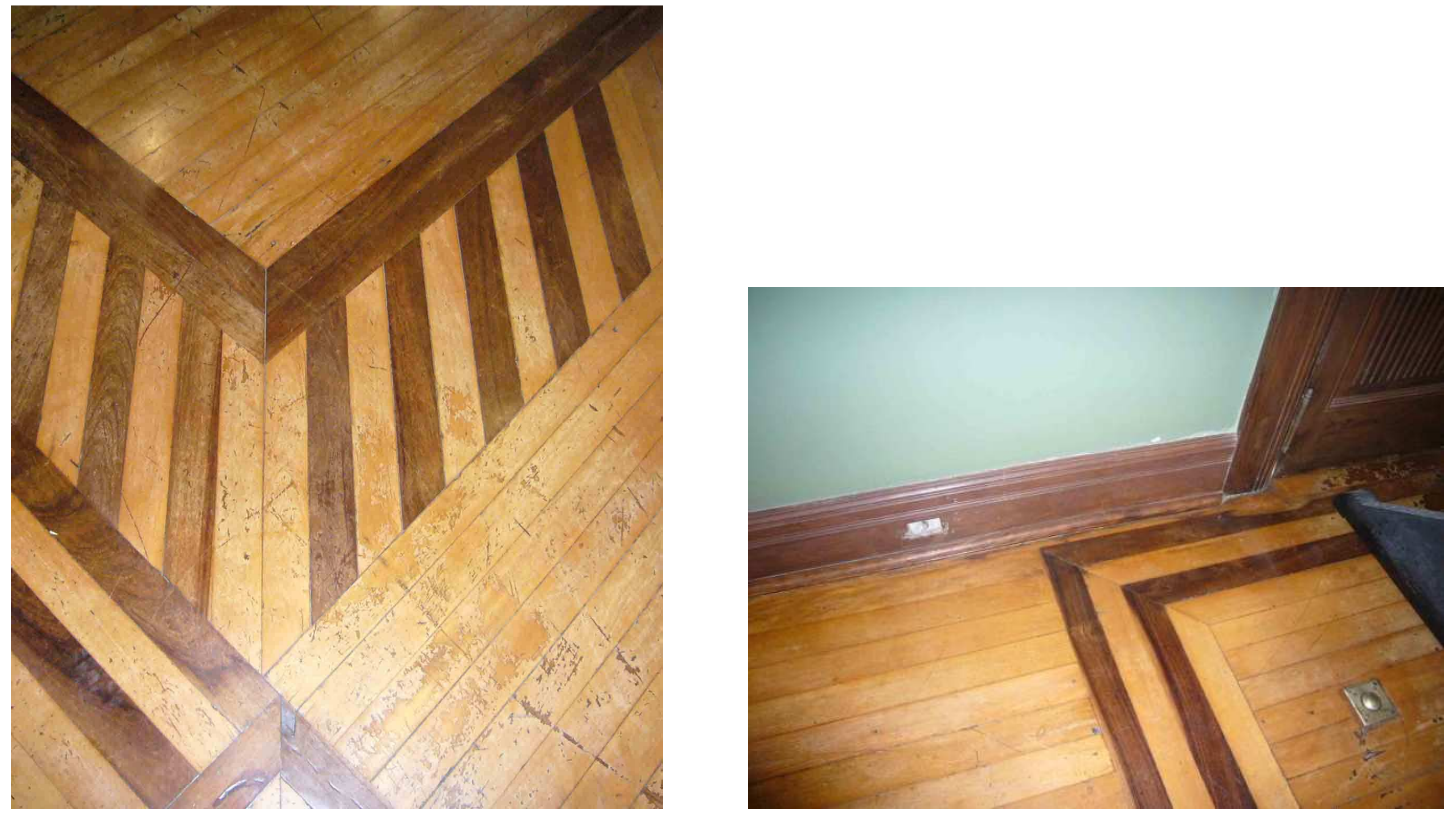

Figura 279 - Assoalho de madeira da Sala 12 Foto: Isis Roverso, abril de 2011.
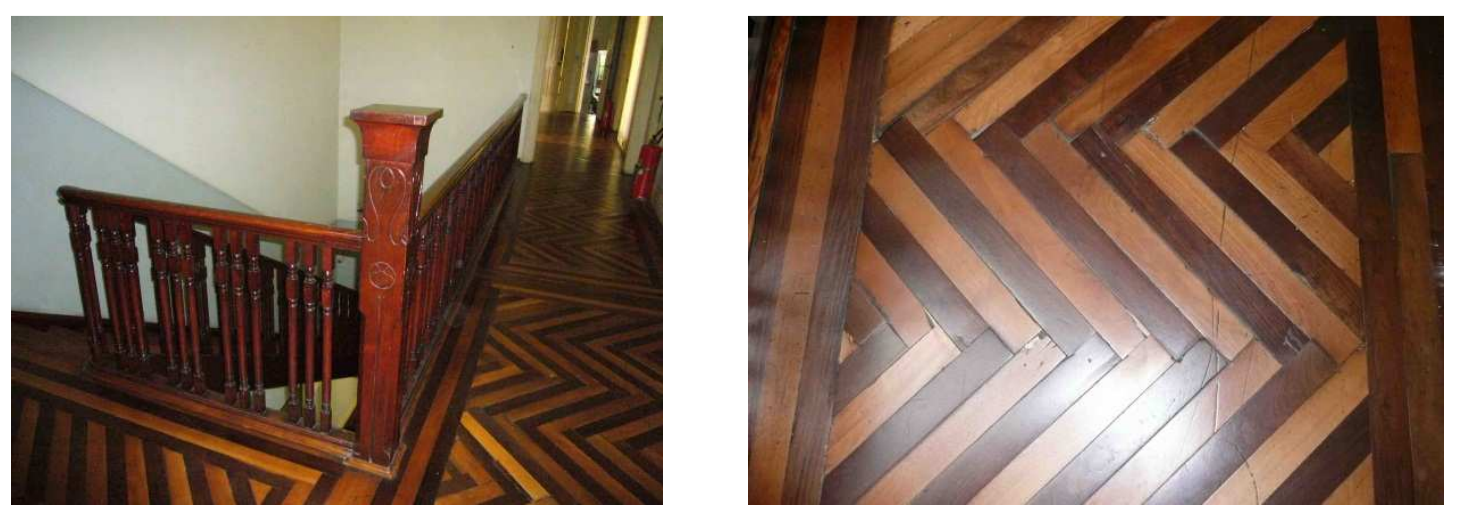

Figura 280 - Assoalho de madeira do Corredor em frente à Sala 57 Foto: Isis Roverso, abril de 2011.
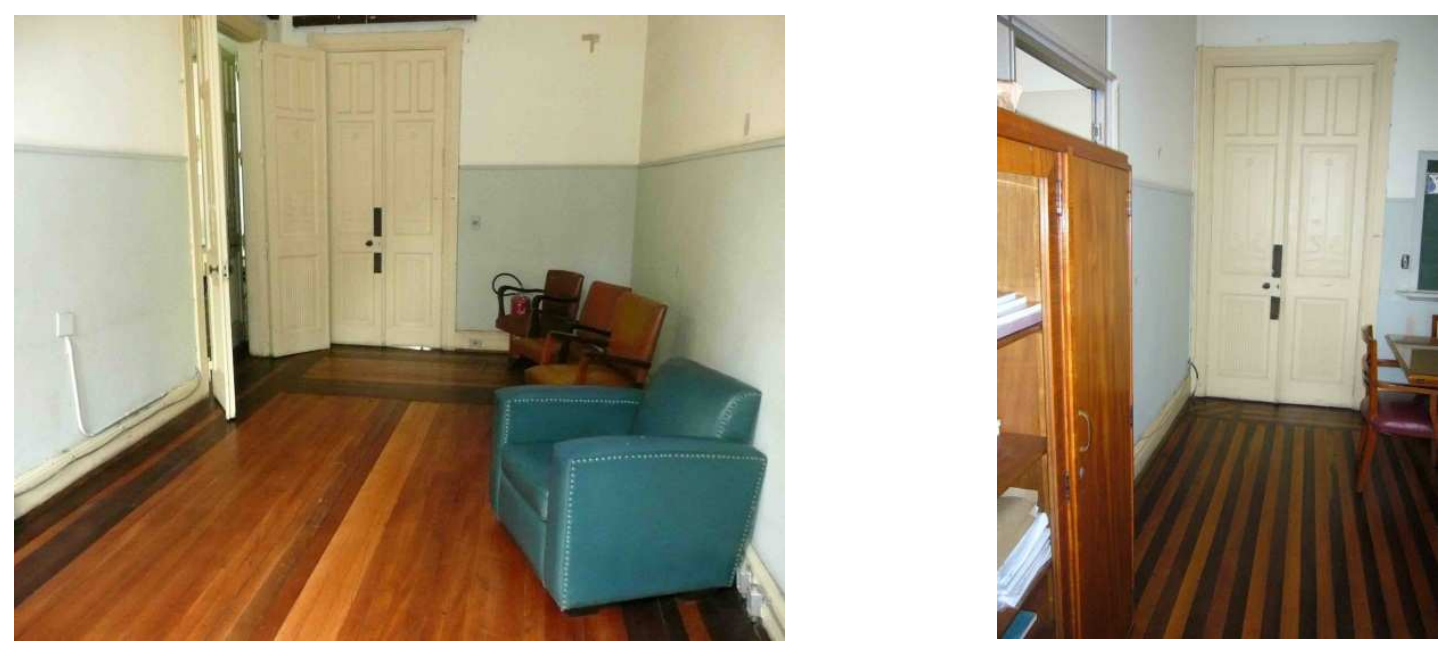

Figura 281 - Assoalho de madeira do Corredor S65 e da Sala da Diretoria S71 Foto: Isis Roverso, dezembro de 2010. 
Alguns assoalhos apresentam desgastes, especialmente nos locais onde há maior tráfego de usuários. A portaria apresenta um dos locais danificados pelo atrito constante provocado pela circulação de pessoas. $\mathrm{Na}$ foto da figura 282 , a área da entrada aparece protegida por um tapete.

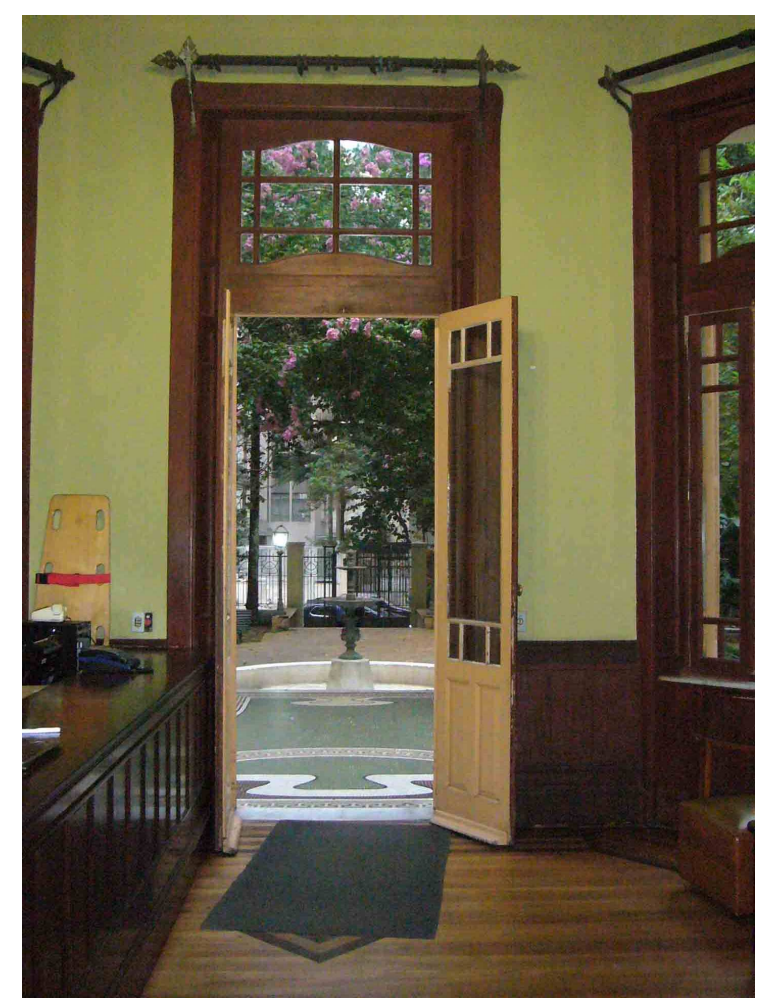

Figura 282 - Assoalho de madeira da Portaria Foto: Isis Roverso, abril de 2011.

A área localizada atrás do balcão de recepção contém um trecho de piso removível (área de inspeção).

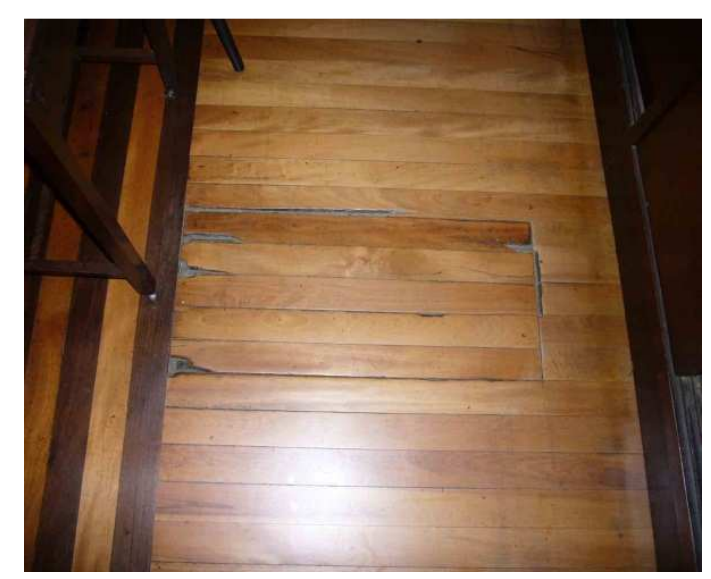

Figura 283 - Área de inspeção no assoalho de madeira da Portaria Foto: Isis Roverso, dezembro de 2010. 
Entre a área da Portaria, em assoalho de madeira, e a área do Saguão, em mosaico, há um trecho de piso intermediário, executado em mármore.

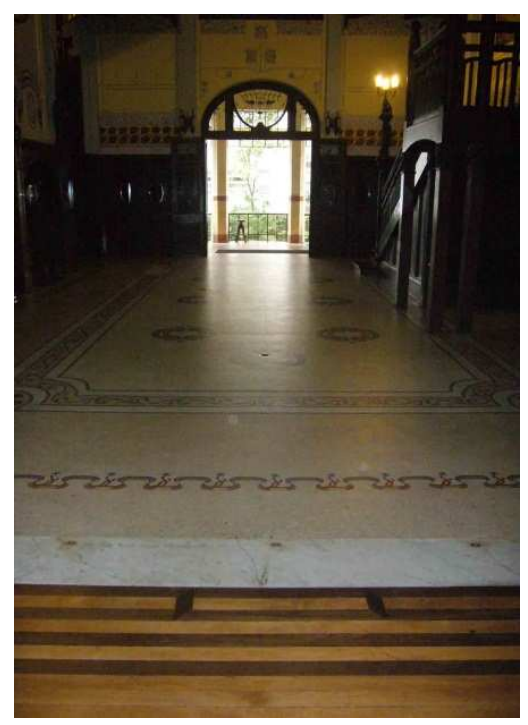

Figura 284 - Área intermediária entre o assoalho de madeira da Portaria e o mosaico do Saguão

Foto: Isis Roverso, abril de 2011.

Outras áreas de assoalho apresentam desgaste superficial (ver figuras $285 \mathrm{e}$ 286) e ainda há regiões onde a possibilidade de degradação é visível, como, por exemplo, a área de piso do mezanino que está sob o forro em estuque que ruiu devido a uma infiltração na cobertura em cobre (ver figura 287).

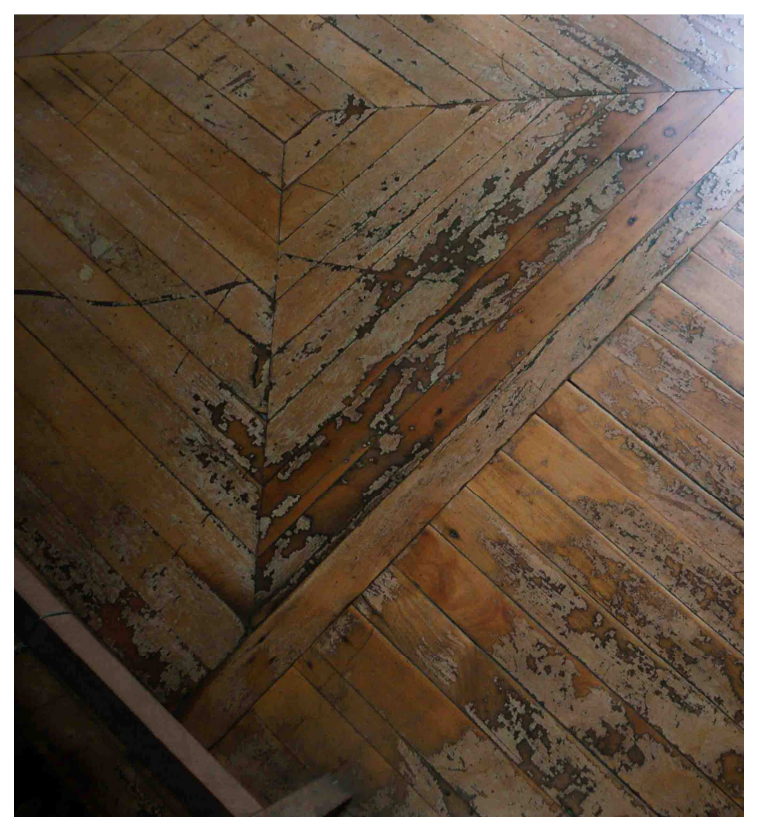

Figura 285 - Assoalho em madeira do hall da maquete Foto: Isis Roverso, dezembro de 2010. 


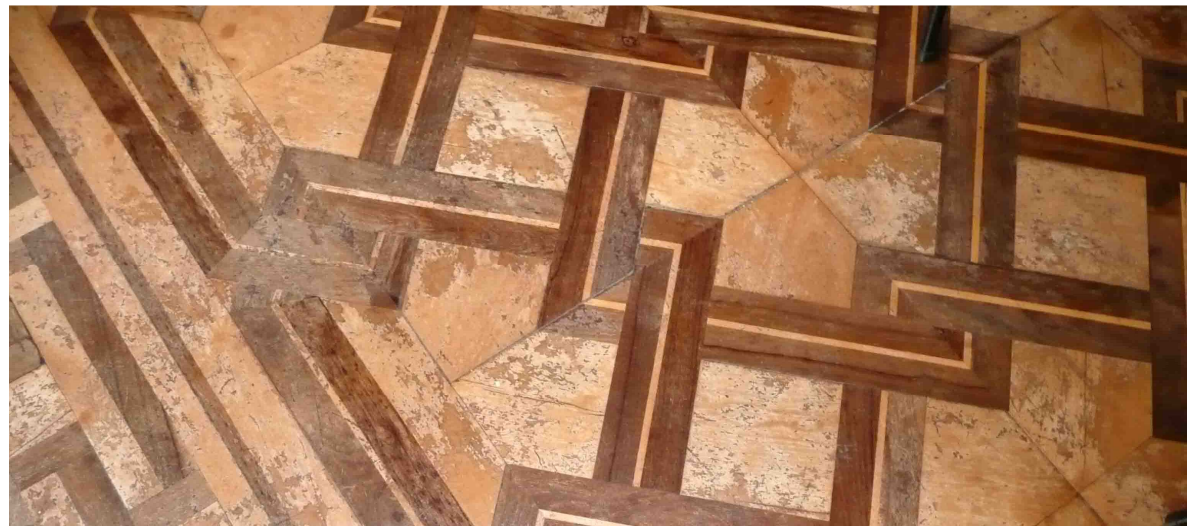

Figura 286 - Assoalho em madeira da Sala dos Espelhos Foto: Isis Roverso, dezembro de 2010.

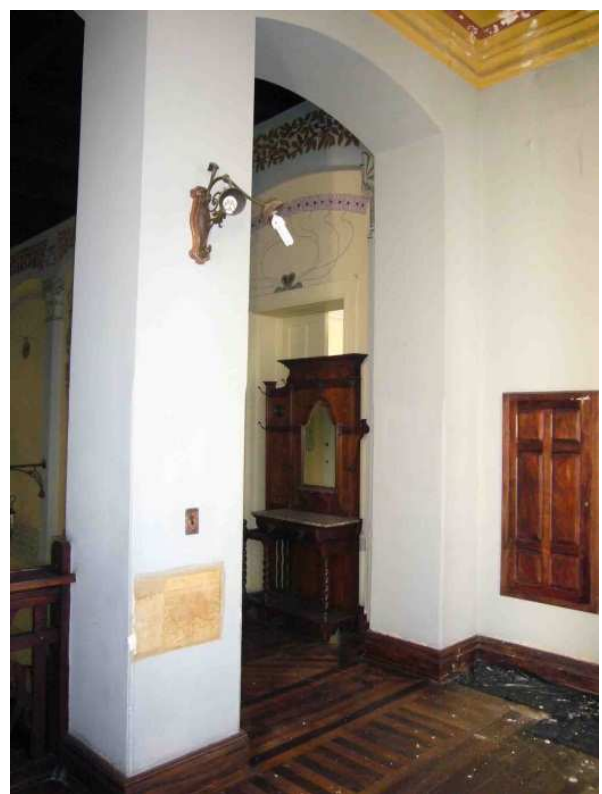

Figura 287 - Assoalho em madeira do Mezanino, sob a área do forro em estuque que ruiu

Foto: Isis Roverso, abril de 2011.
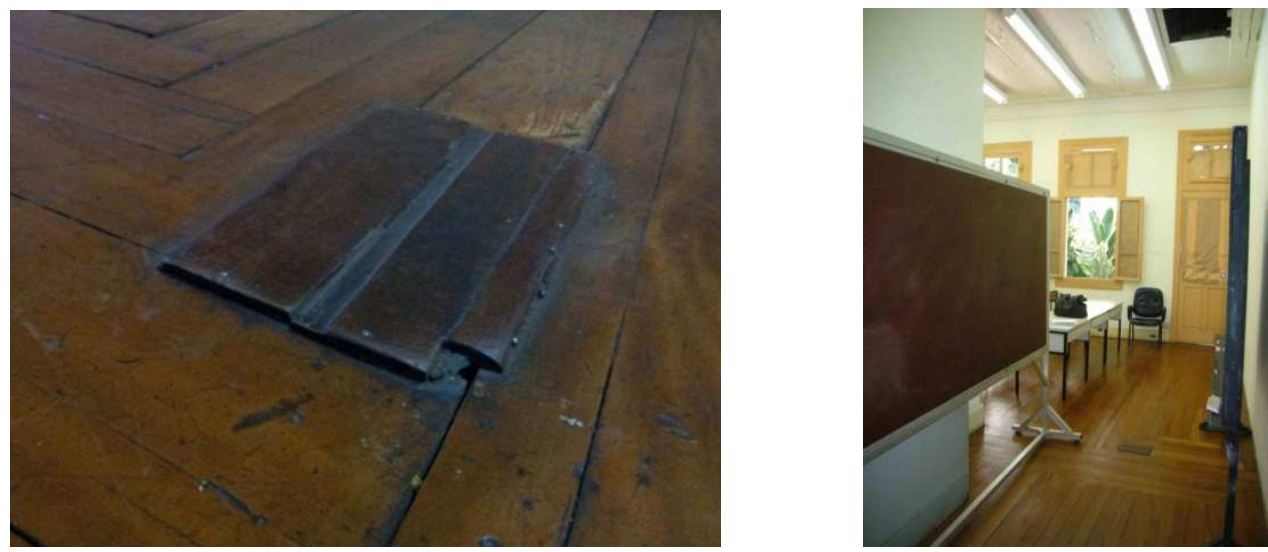

Figura 288 - Sala 44 com destaque para o remendo no assoalho Foto: Isis Roverso, outubro de 2011. 
A Sala 44 apresenta um pequeno trecho do assoalho com remendo saliente que expõe os usuários ao risco de tropeços, visto ficar na área de circulação da referida sala. Esse trecho, que pode ser verificado nas fotos da figura 288, deverá ser substituído por reparo onde o nível do assoalho deverá ser mantido.

Ainda na Sala 44, há um desnível no piso em relação ao corredor, portanto, logo na entrada da sala, há três degraus revestidos em madeira. O desnível dessa área, assim como o desnível da área do Laboratório de Informática, justifica-se pelo fato dessas áreas terem sido construídas somente em 1906, e alguns ajustes para propiciar essa ampliação foram necessários.
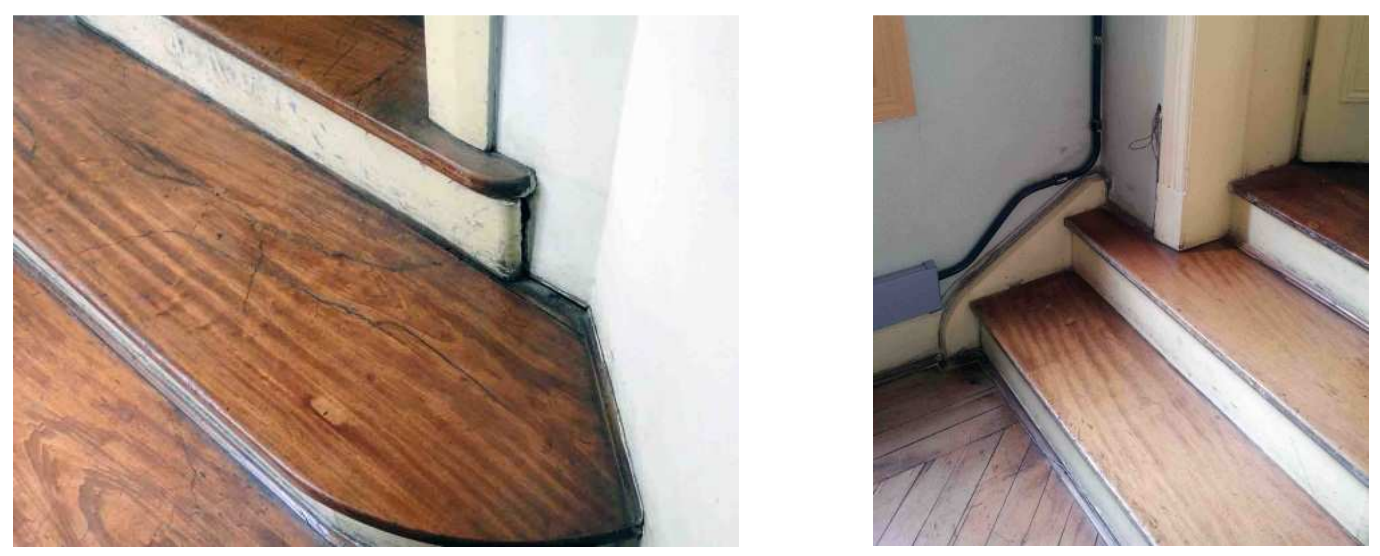

Figura 289 - À esquerda, degraus da Sala 44 e, à direita, degraus do Laboratório de Informática

Foto: Isis Roverso, janeiro de 2012 e novembro de 2011.

As principais escadas da Vila Penteado são feitas ou revestidas em madeira. A escada que interliga o Saguão ao pavimento superior é totalmente executada em madeira. As fotos das figuras 290 e 291 apresentam essa escadaria.
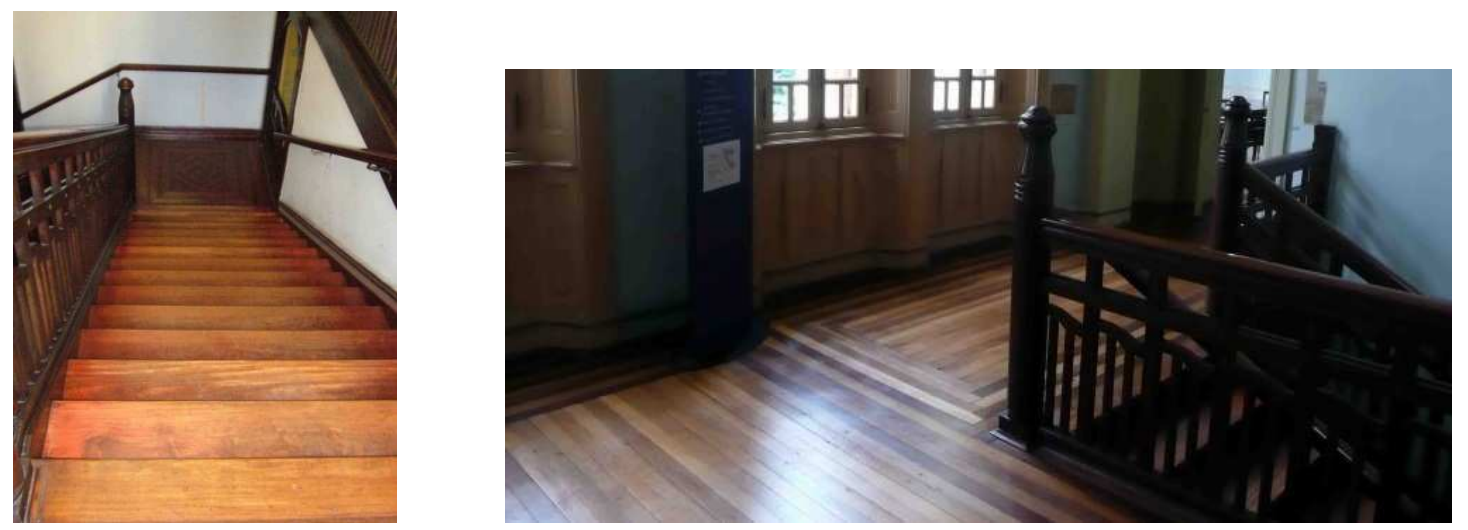

Figura 290 - Escada em madeira que interliga o Saguão ao pavimento superior Foto: Isis Roverso, abril de 2011 e dezembro de 2010. 

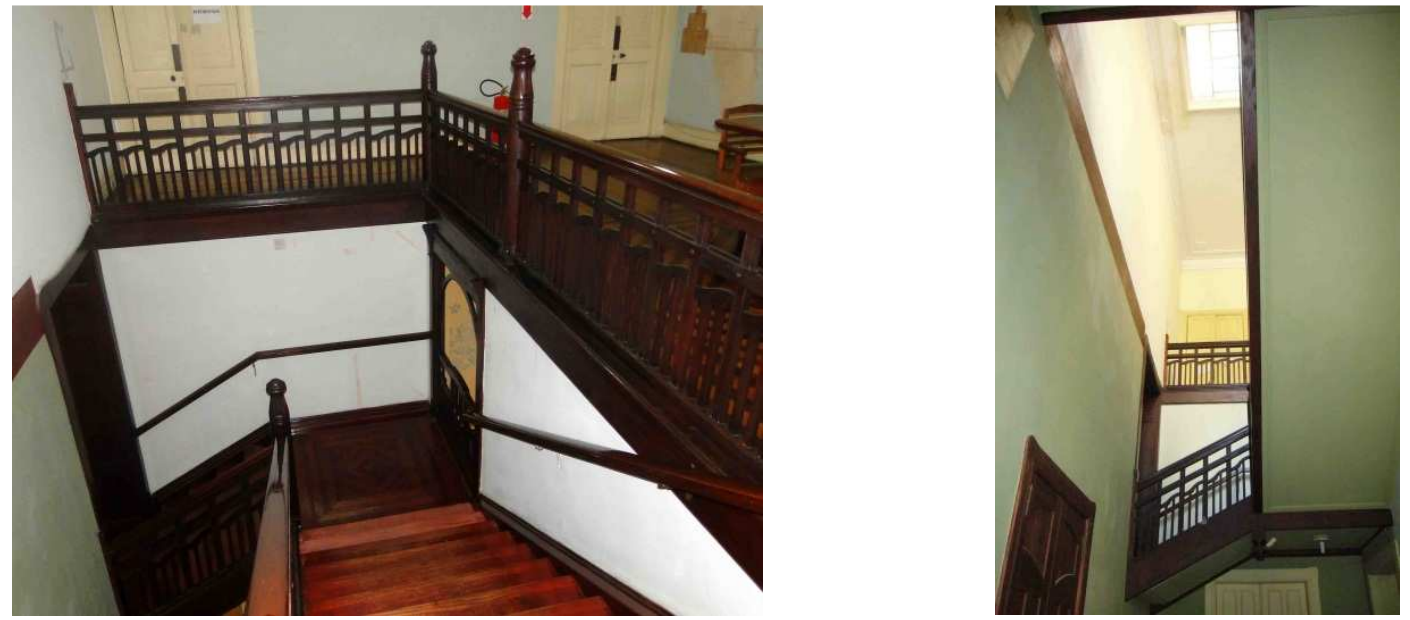

Figura 291 - Escada em madeira que interliga o Saguão ao pavimento superior Foto: Isis Roverso, novembro de 2011 e abril de 2011.

Um problema existente nas escadas com degraus em madeira refere-se a facilidade de escorregamento, em função da superfície lisa da madeira. O risco de haver acidente ocorre principalmente na escada que interliga o Saguão ao piso superior, visto ser essa a de maior tráfego. No período que a Vila Penteado abrigava o uso residencial, esse problema não existia porque havia uma passadeira instalada na escada, inclusive é possível verificar, ainda hoje, as marcar dos pinos de fixação do antigo tapete.

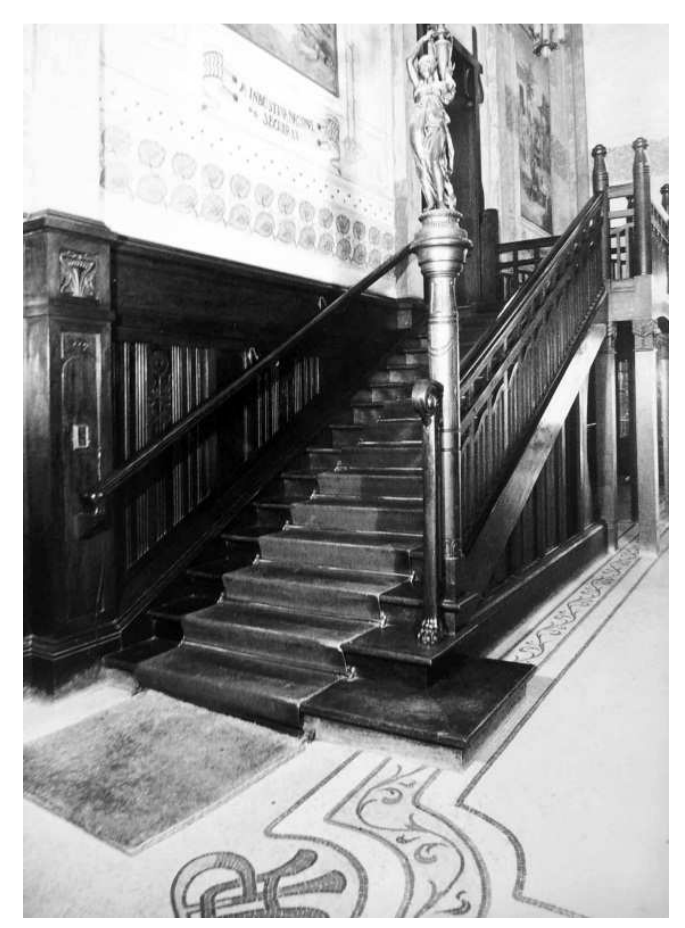

Figura 292 - Foto da escada com a antiga passadeira Fonte: PRADO, 1979. 

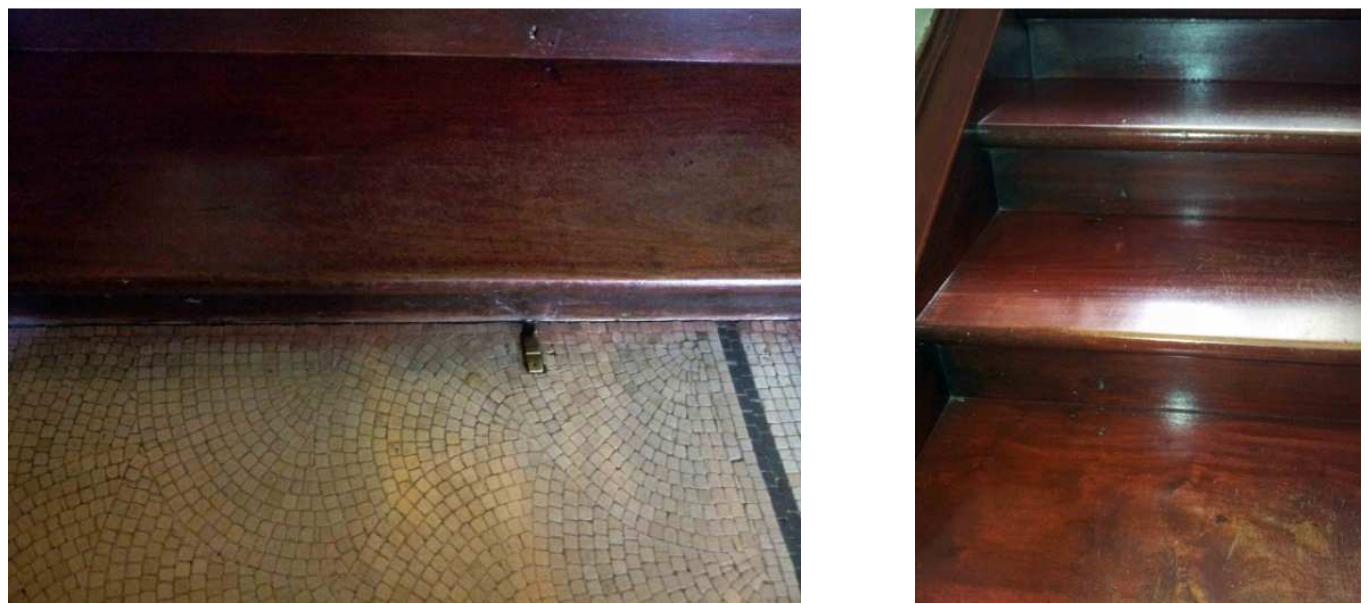

Figura 293 - escada principal: marcas dos suportes da antiga passadeira Fotos: Isis Roverso, janeiro de 2012.

A madeira também é empregada em outras escadas da Vila Penteado, como a escada que interliga os três pisos, próxima da Sala 8, e a escada que interliga o pavimento térreo com o superior, próxima a área da biblioteca.
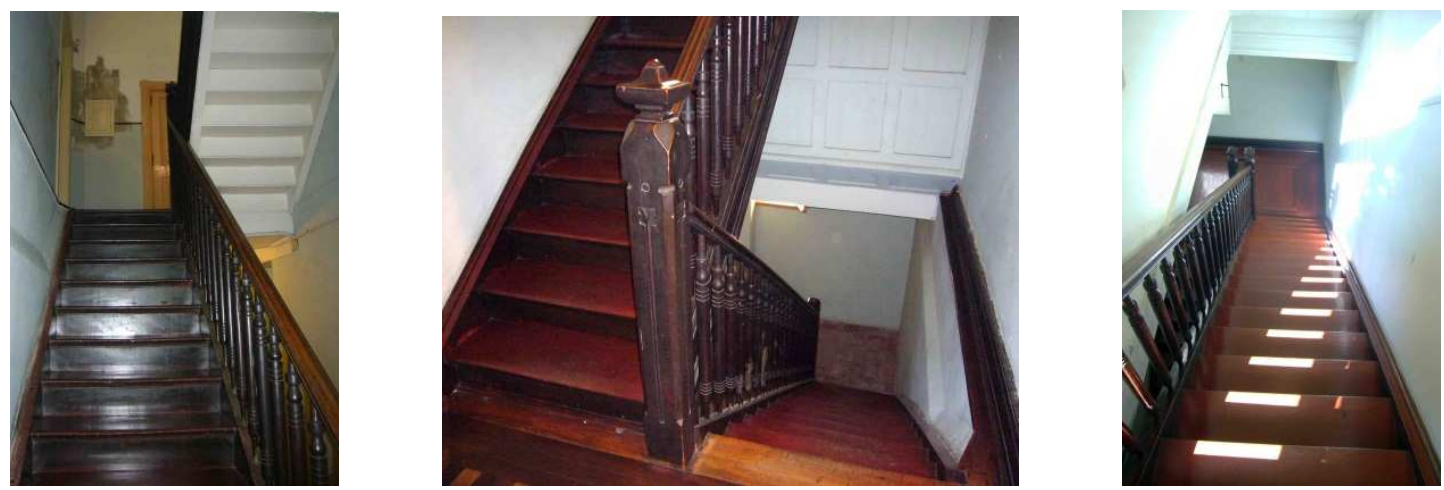

Figura 294 - Escada em madeira próxima a Sala 8 Foto: Isis Roverso, abril de 2011.
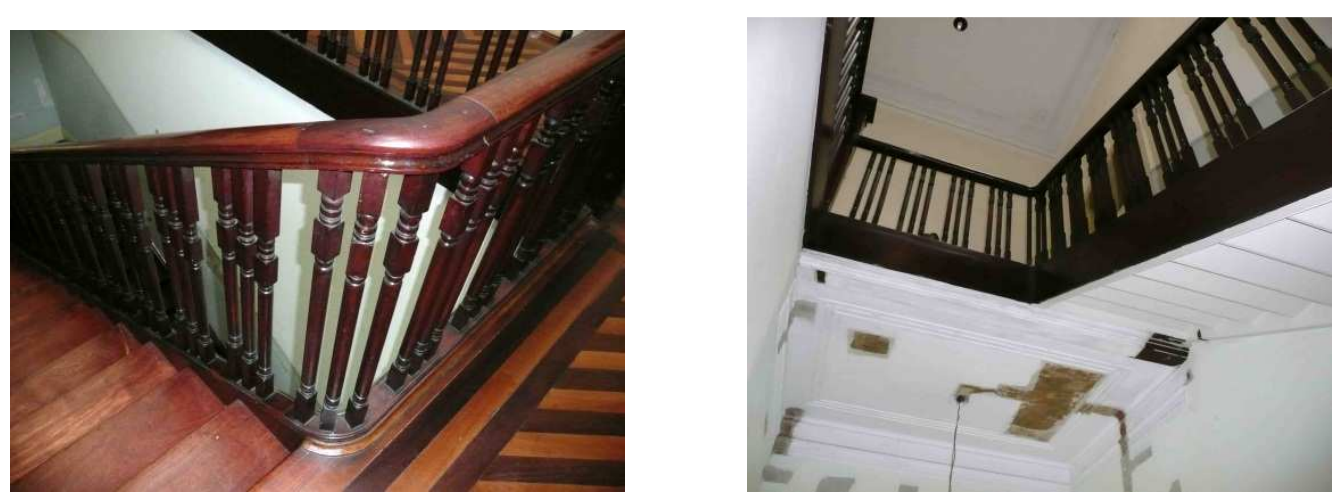

Figura 295 - Escada que interliga o pavimento térreo com o superior, próxima à Biblioteca

Foto: Isis Roverso, dezembro de 2010. 


\subsubsection{MOSAICOS}

Diversas áreas de piso da Vila Penteado apresentam como revestimento de piso o mosaico. Essas áreas correspondem aos acessos, ou seja, áreas de interface entre o ambiente interno e o externo, além da grande área do Saguão.

Para a execução dos mosaicos foram utilizadas peças em cores de diversas tonalidades com arranjos variados. Cada peça do mosaico é um elemento único, em função do seu corte artesanal. A variedade de desenhos e cores dos pisos em mosaico da Vila Penteado pode ser observada nas fotos das figuras 296 a 300.
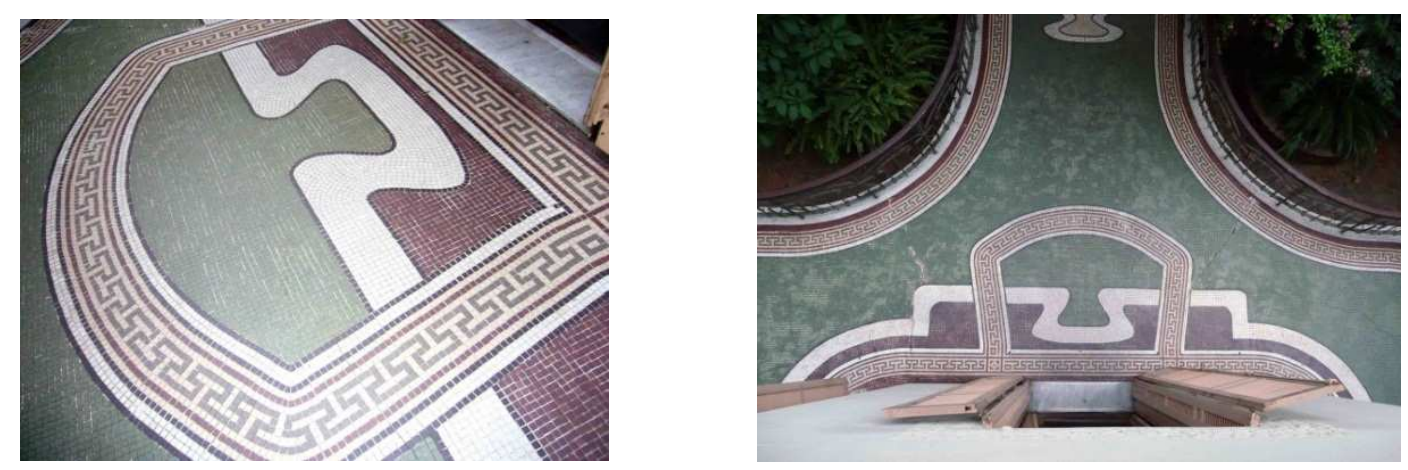

Figura 296 - Piso em mosaico do acesso principal (em frente à portaria) Foto: Isis Roverso, foto a esquerda de abril de 2011 e foto a direita de dezembro de 2010.
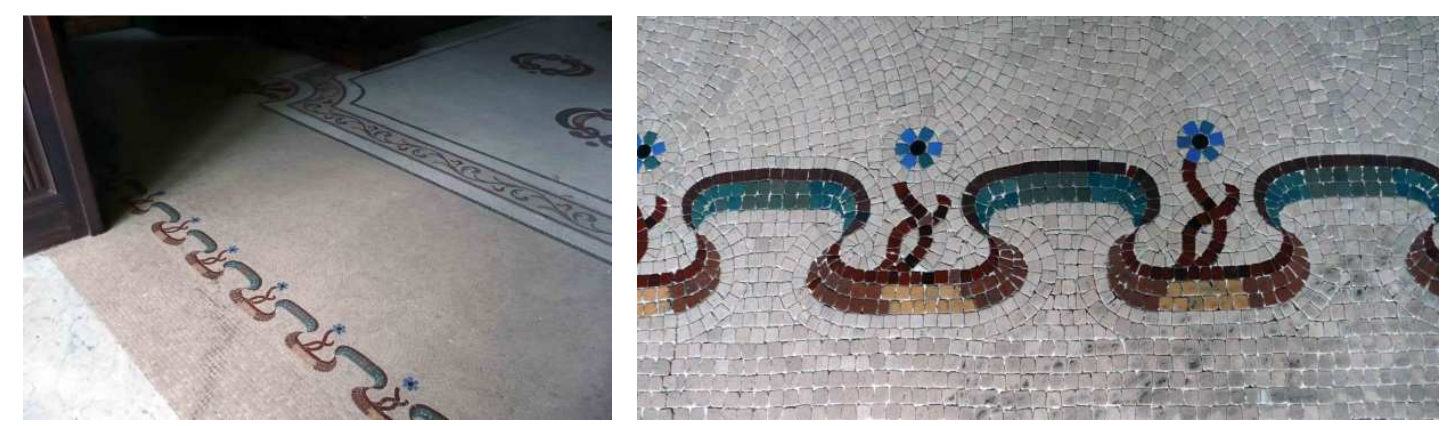

Figura 297 - Piso em mosaico do Saguão (área em frente ao acesso posterior) Foto: Isis Roverso, de dezembro de 2010.

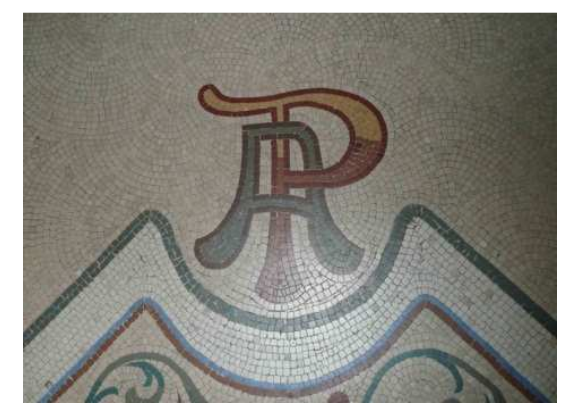

Figura 298 - Piso em mosaico do Saguão (área próxima à escada principal) Foto: Isis Roverso, de dezembro de 2010. 


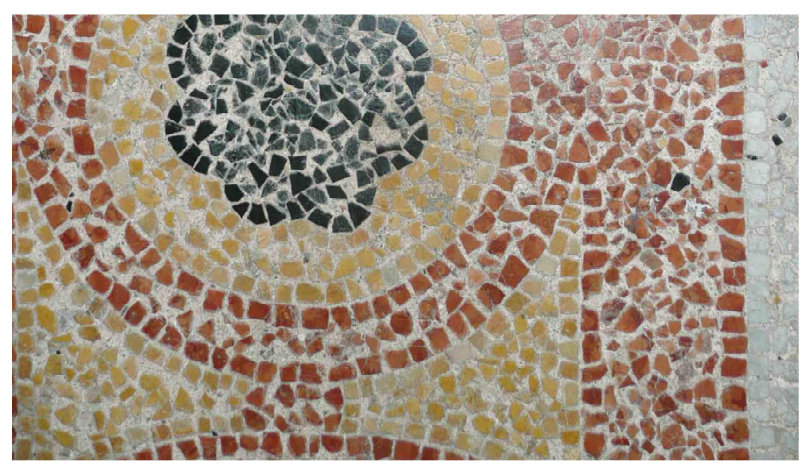

Figura 299 - Piso em mosaico da entrada lateral (hall próximo à Sala 12) Foto: Isis Roverso, de dezembro de 2010.

A foto da figura 300 apresenta um trecho do mosaico de piso na área externa, próxima à portaria. Com a ampliação desse trecho de piso é possível verificar a variedade de tons usados e o trabalho minucioso de corte das peças.

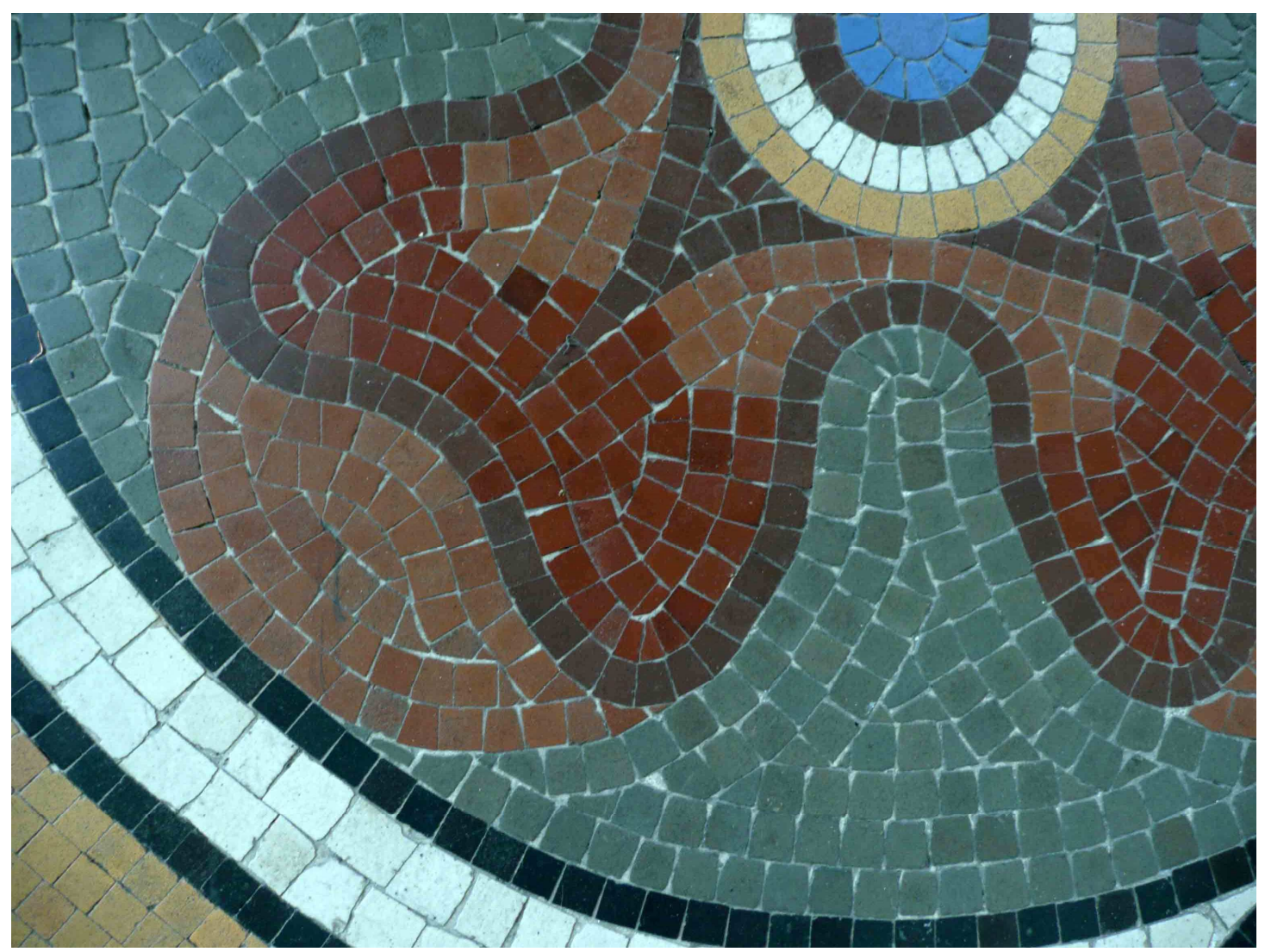

Figura 300 - Trecho do piso em mosaico - piso próximo à portaria Foto: Isis Roverso, dezembro de 2010.

O mesmo trecho da foto anterior é apresentado no desenho da figura 301. Através da análise feita pela observação e desenho das peças, desse trecho do piso em mosaico, é possível perceber que o corte de cada uma das peças de coloração 
diferente não é uniforme, ou seja, as tesselas claras, de cor quase branca, apresentam corte levemente arredondado, enquanto que as tesselas mais escuras, de cor terracota, apresentam corte angular, com laterais em linha reta. É possível estabelecer um padrão dentro de uma mesma coloração. As tesselas verde água apresentam corte angular com laterais irregulares, diferentemente das peças terracota. Fato que revela diferentes graus de dureza entre as cores das tesselas e sugere que a peças poderão sofrer desgaste irregular, em função da resistência ao tráfego também não ser idêntica para todas as peças do mesmo trecho de mosaico.

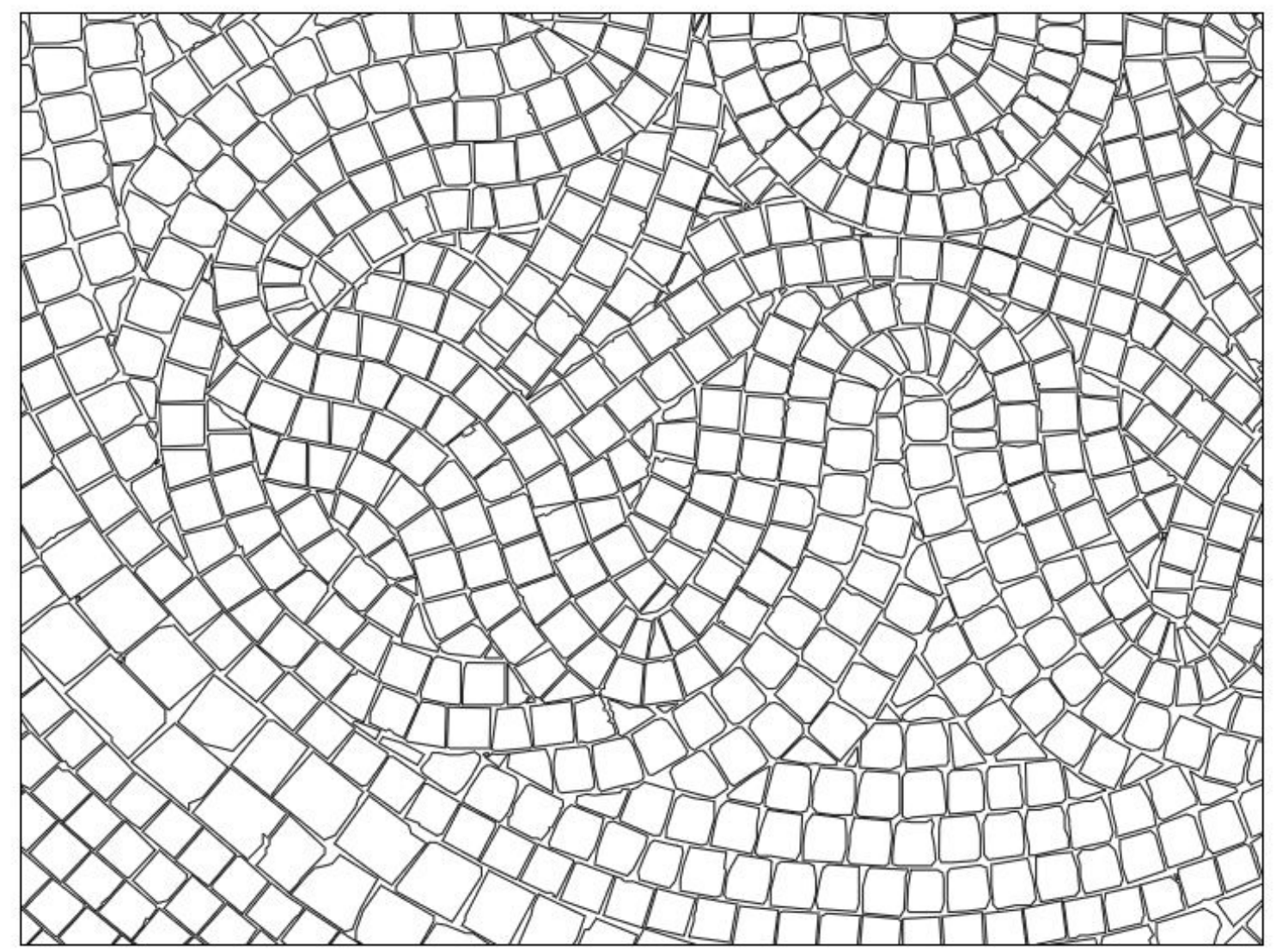

Figura 301 - Desenho do trecho do piso em mosaico - piso próximo à portaria Fonte: Desenho de Isis Roverso, a partir da foto de dezembro de 2010.

Em relação aos mosaicos, um problema construtivo aparente encontra-se no substrato: a base de apoio das áreas externas com revestimento em mosaico apresentam fissuras e desníveis provocados pela acomodação da base. As causas dessa acomodação devem ser investigadas. 

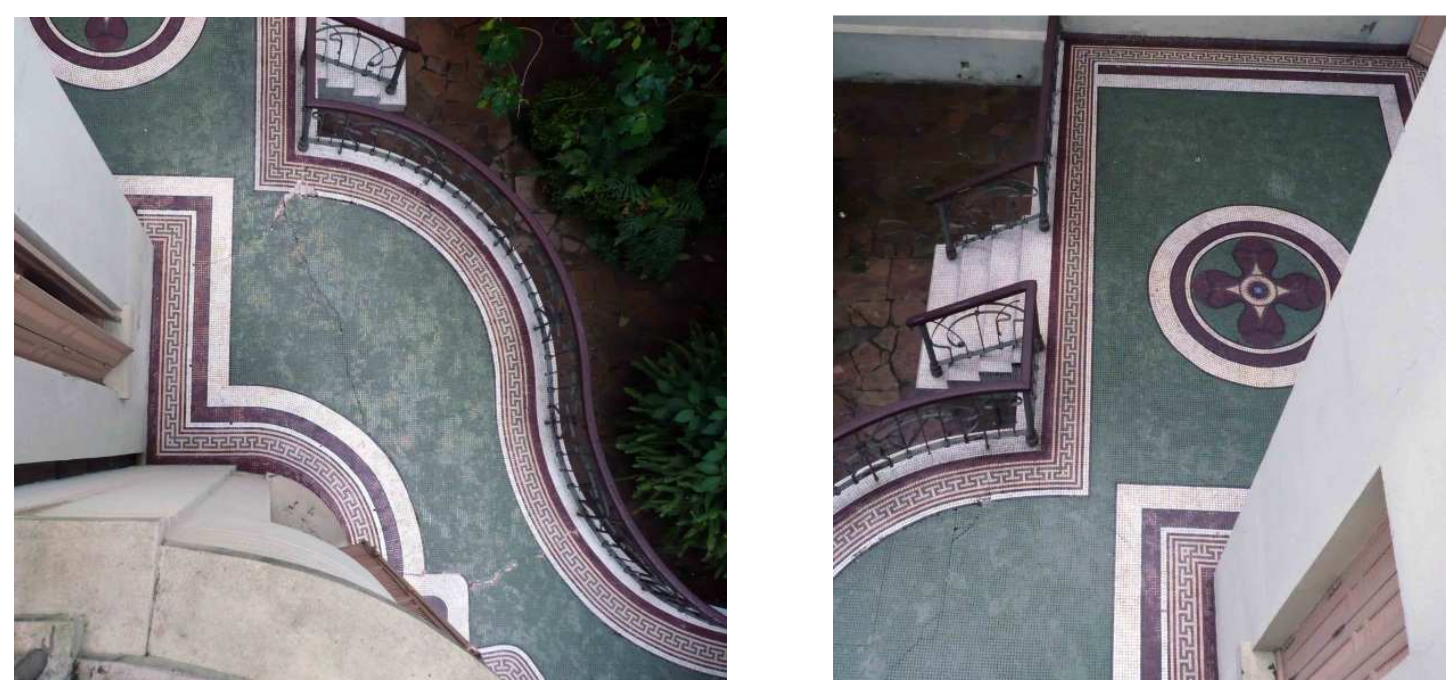

Figura 302 - Piso em mosaico: acesso à portaria Foto: Isis Roverso, dezembro de 2010.

Visando facilitar a visualização das fissuras existentes, a imagem da figura 303 apresenta-se duplicada, sendo que a imagem a direita apresenta o trajeto das fissuras destacado.
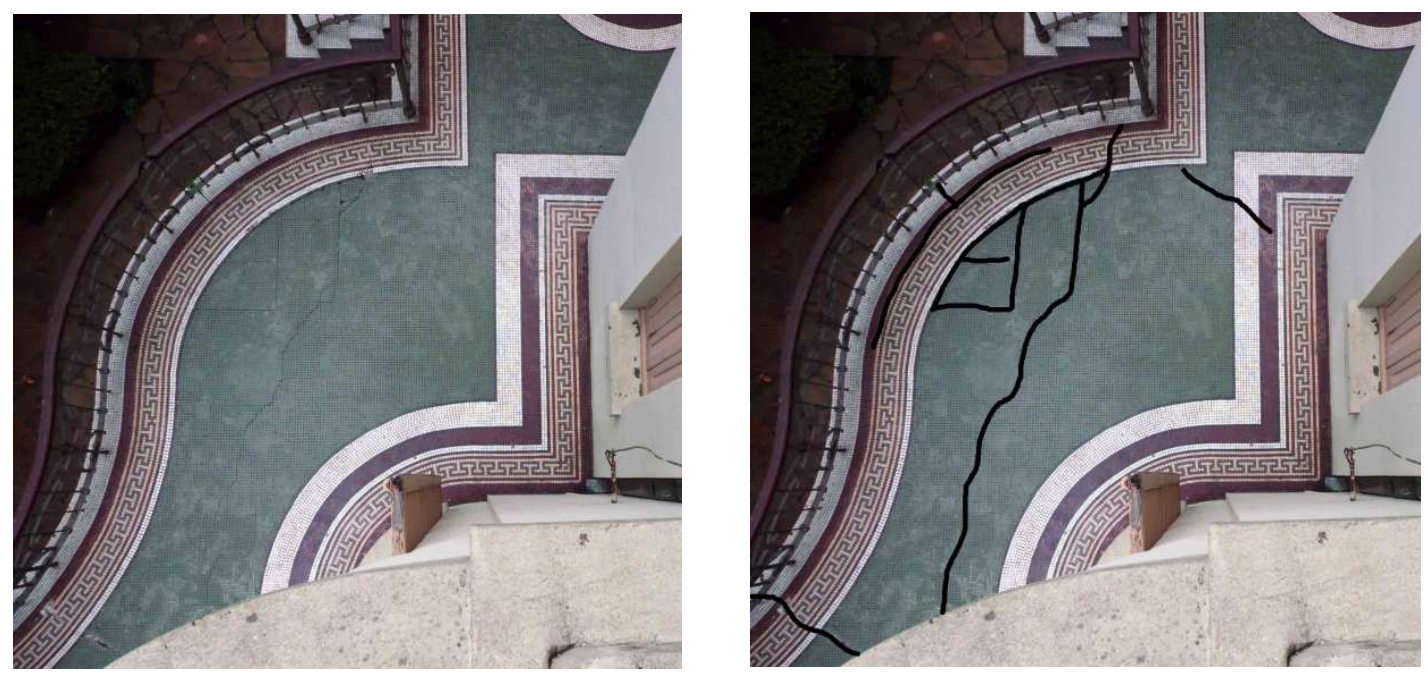

Figura 303 - Piso em mosaico: presença de fissuras Foto: Isis Roverso, dezembro de 2010.

Outra patologia construtiva encontra-se no desprendimento das tesselas do mosaico. Com a falta de uma tessela e com o constante tráfego de pessoas, a possibilidade de outras peças se soltarem é evidente. Em carta ${ }^{117}$ de Antonio Carlos

${ }^{117}$ Essa carta faz parte dos arquivos pessoais da professora Helena Ayoub Silva, gestora do edifício Vila Penteado. 
Alves de Carvalho ${ }^{118}$, antigo aluno da FAU, datada em 24 de outubro de 2003, há a constatação desse problema no mosaico externo próximo a entrada posterior. Nessa carta há inclusive uma tessela anexa. Na figura 304 é possível ver o trecho da carta que traz esse relato, a tessela colada à carta e ainda uma sugestão de controle do problema: preenchimento dos espaços onde as tesselas se soltaram com "argamassa leve de contenção".

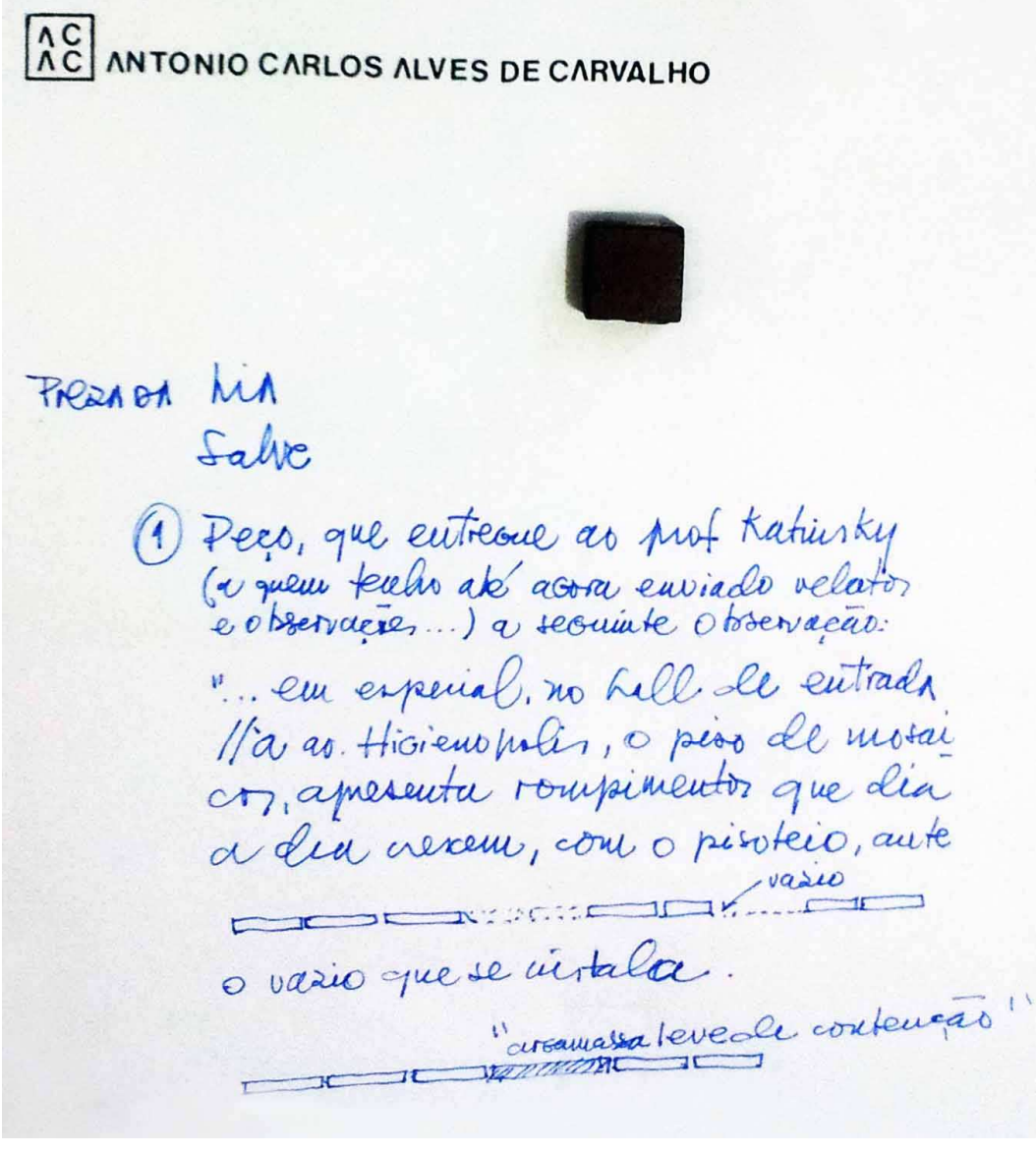

Figura 304 - Observação sobre rompimentos no mosaico

Fonte: Carta de Antonio Carlos Alves de Carvalho, datada de 24 de outubro de 2003.

\begin{abstract}
${ }^{118}$ A Revista Pós, v.16, n.25, São Paulo, junho de 2009, traz das páginas 27 a 32 um depoimento sob o título "O mago dos ladrilhos hidráulicos". Esse texto comenta sobre a arte do ladrilho hidráulico e destaca a figura do Sr. Antonio Carlos Alves de Carvalho "No prédio da FAU, onde funciona o curso de pós-graduação da Faculdade de Arquitetura e Urbanismo da USP, circulava, até há bem pouco tempo, um simpático senhor que parecia ser contemporâneo do nascimento da Vila Penteado. Mais ainda: ele parecia ter surgido com o próprio tempo. Assim como transitava pelos aposentos do velho casarão, transitava também entre professores, alunos, funcionários e vizinhos da rua Maranhão. Falo de Antônio Carlos Alves de Carvalho, o ACAC. Essa era sua grife pessoal com a qual marcava absolutamente tudo 0 que fazia. De cartões a coleções." Texto disponível em www.revistasusp.sibi.usp.br/pdf/posfau/n25/03.pdf, acessado em 12 de fevereiro de 2012.
\end{abstract}



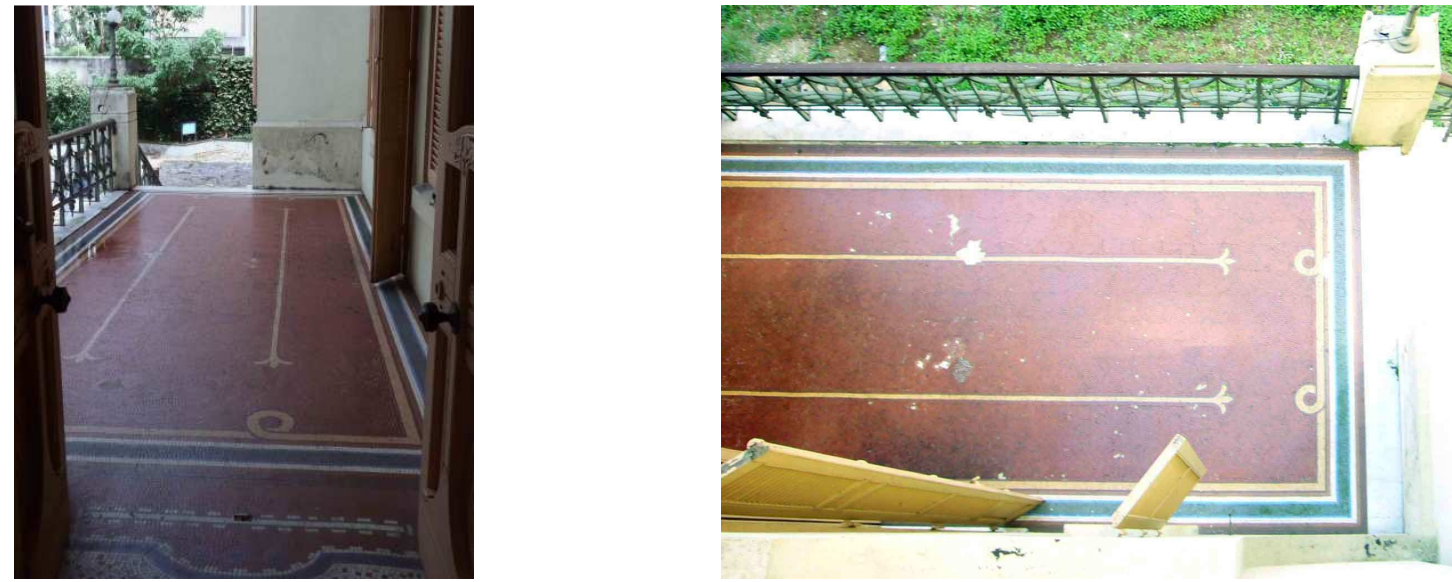

Figura 305 - Piso em mosaico da área de acesso posterior: áreas claras próximas as linha de tesselas de cor amarela apresenta peças faltando

Foto: Isis Roverso, foto a esquerda de dezembro de 2010 e foto a direita de abril de 2011.
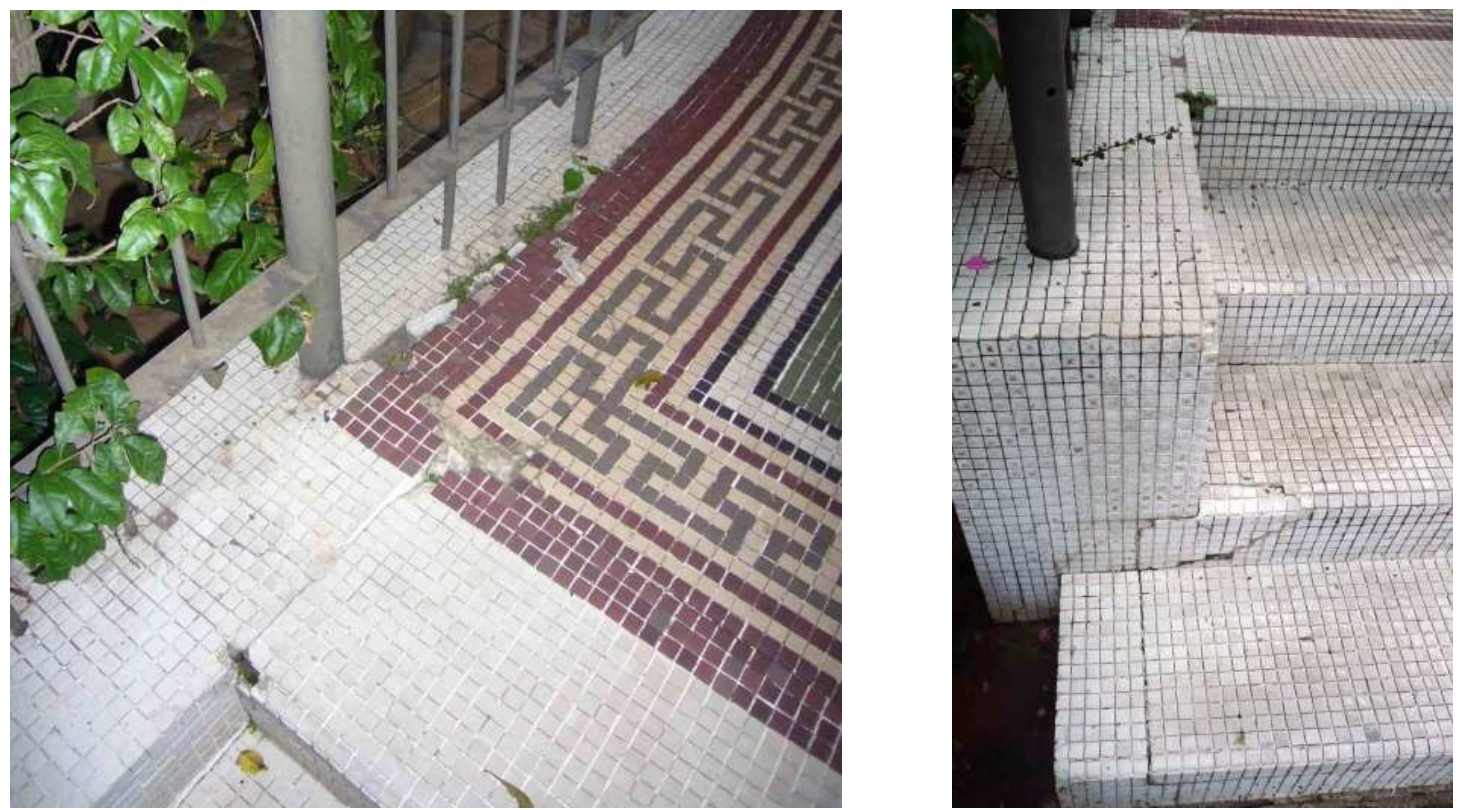

Figura 306 - Piso em mosaico com tesselas faltando (escada de acesso em frente à portaria)

Foto: Isis Roverso, abril de 2011.

A base do chafariz localizado no jardim frontal também é revestida em mosaico e apresenta ajuste preciso no corte das peças. Entretanto, o mosaico que reveste o chafariz, especialmente sua área de base, também apresenta peças soltas, como é visto na foto da figura 308. 

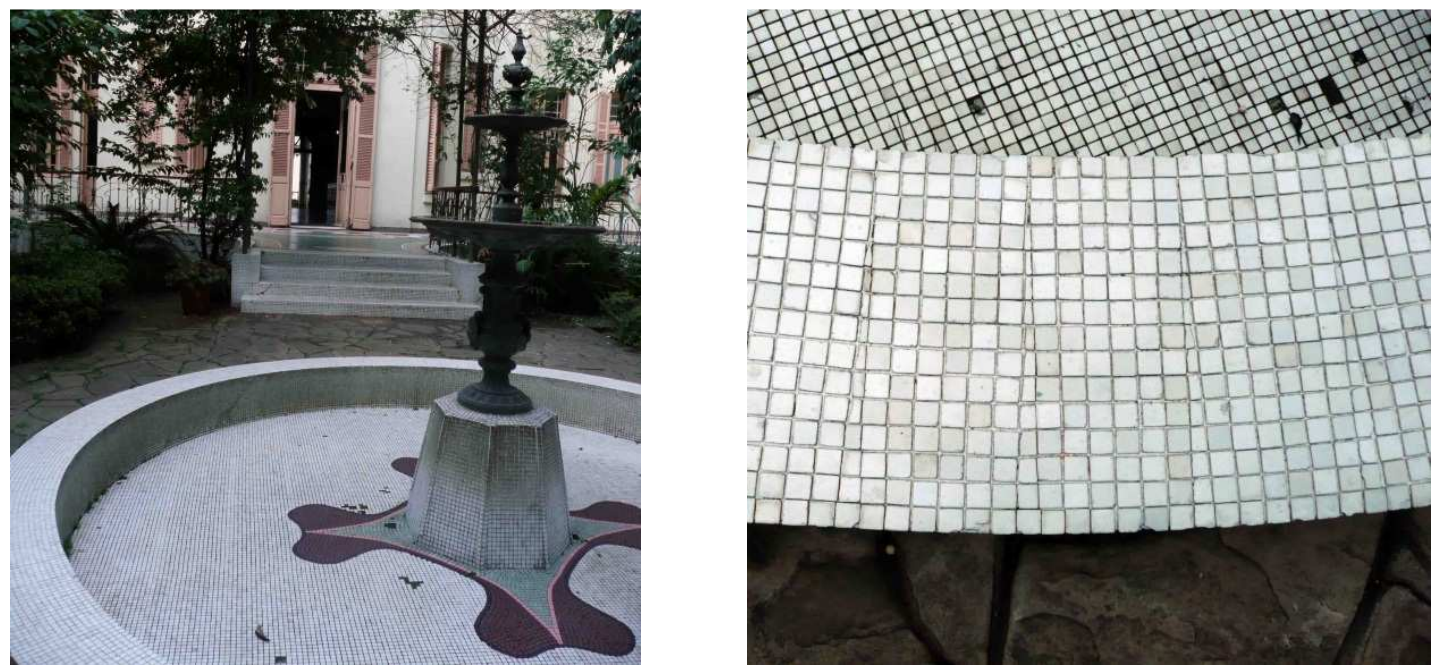

Figura 307 - Piso em mosaico da área do chafariz com destaque para o corte preciso das tesselas

Foto: Isis Roverso, dezembro de 2010.

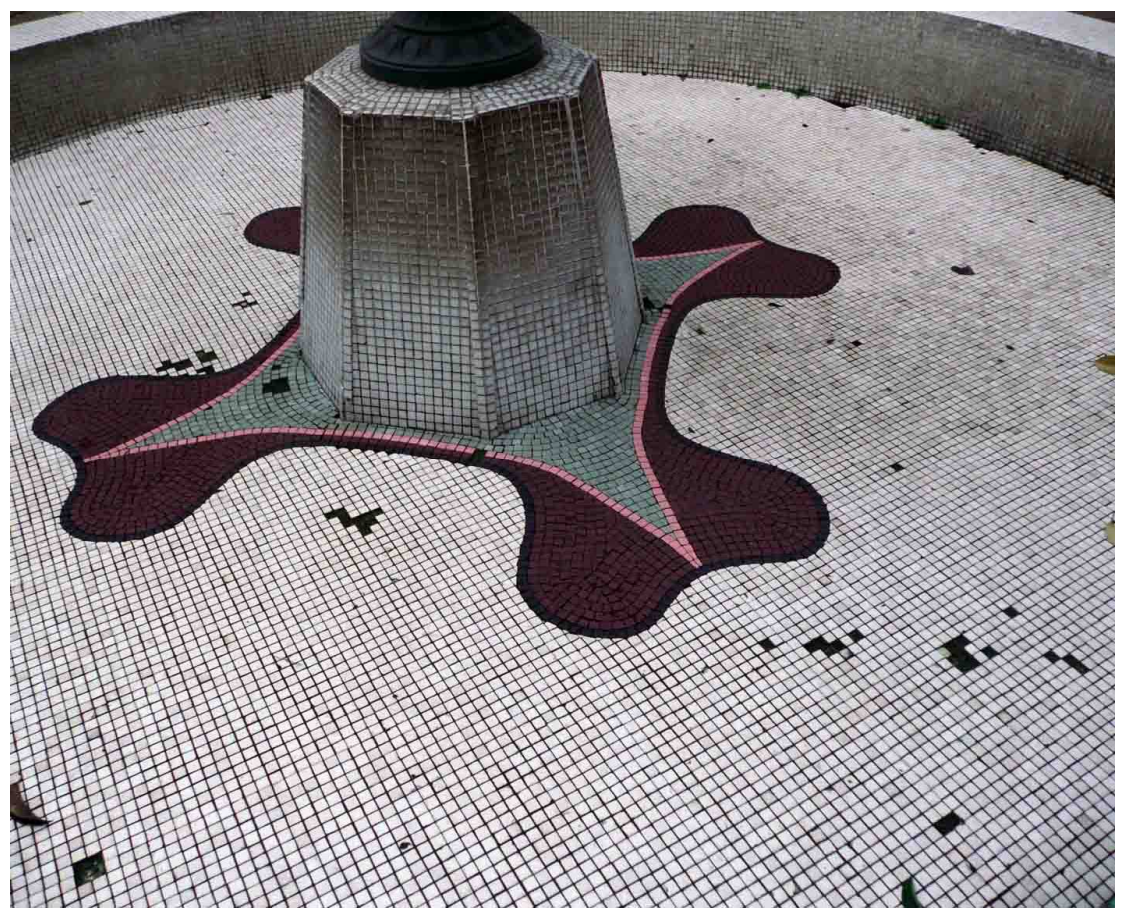

Figura 308 - Piso em mosaico da área do chafariz: algumas tesselas já se soltaram Foto: Isis Roverso, dezembro de 2010.

\subsubsection{PISOS EM PEDRA E GRANILITE}

A escada de acesso à entrada lateral (corredor S16) tem o piso revestido em mármore. A entrada lateral era, originalmente, usada pelos proprietários da residência em dias de chuva, pois fica protegida pelo piso do andar superior, permitindo o estacionamento de carros. O fato de essa escada não ser revestida em madeira e sim em pedra, evidencia a adequação do material em relação ao uso. 

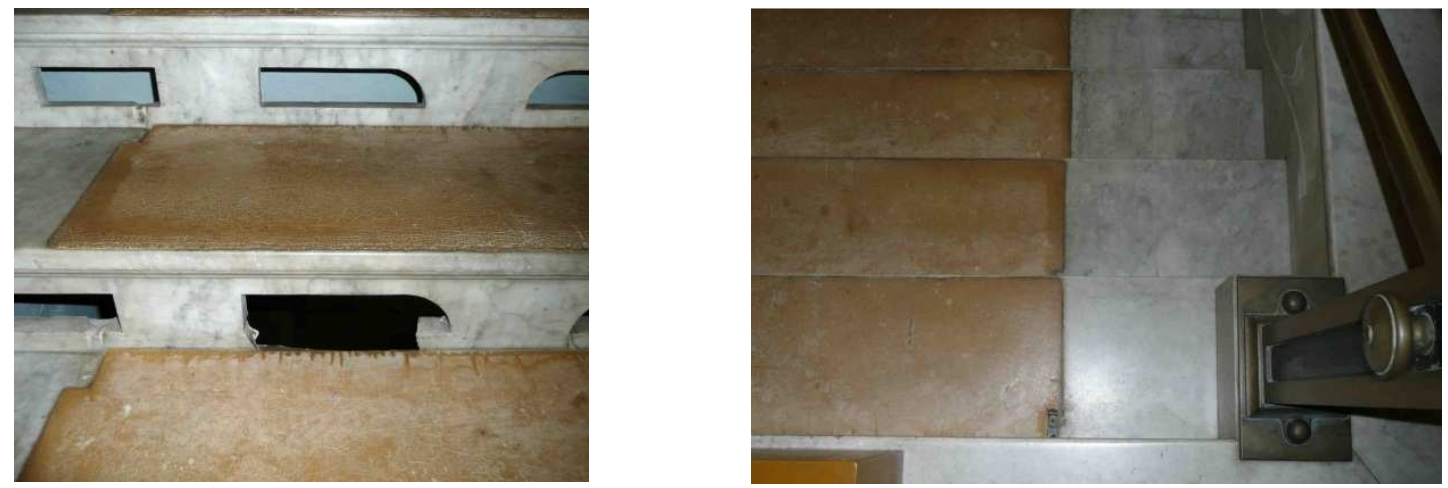

Figura 309 - Piso em mármore da escada de acesso a entrada lateral Foto: Isis Roverso, dezembro de 2010.

As escadas, que propiciam o acesso à fachada posterior da Vila Penteado, também são revestidas em mármore e apresentam desgaste em diversos pontos dos degraus.

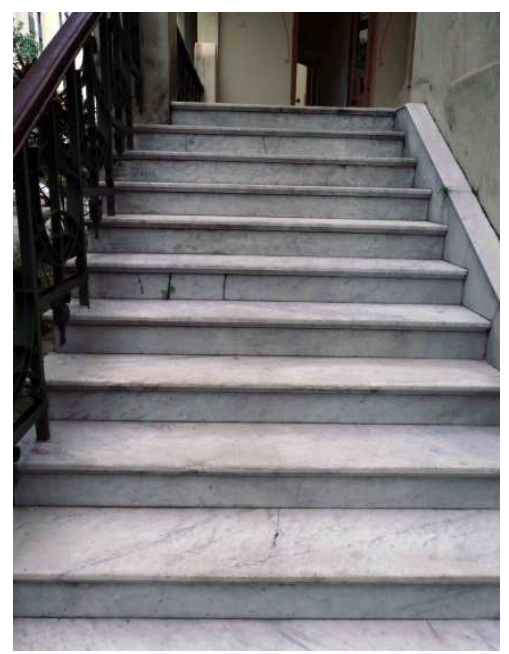

Figura 310 - Escada em mármore: acesso posterior da Vila Penteado Foto: Isis Roverso, dezembro de 2010.

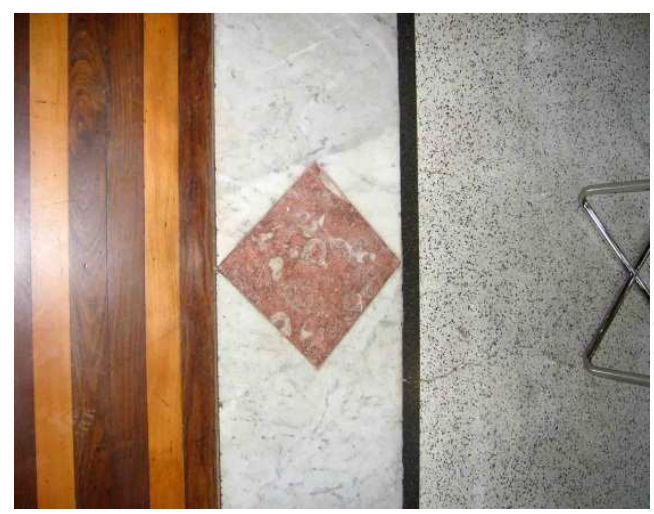

Figura 311 - Piso em mármore, entre assoalho e granilite, na Sala S37 da Biblioteca Foto: Isis Roverso, abril de 2011. 
A área S37, da biblioteca, apresenta três tipos de piso: assoalho em madeira, mármore (usado como uma soleira) e granilitite, sendo que o último reveste a área que, quando o edifício tinha uso residencial, era o hall de entrada da família do genro do conde Álvares Penteado.

As áreas externas da Vila Penteado são pavimentadas com pedras irregulares e a região de estacionamento recebeu pavimentação em concreto. As fotos das figuras 312 a 314 revelam a situação dos pisos externos da Vila, onde é possível notar algumas deformações, falhas construtivas relacionadas ao caimento dos pisos, gerando empoçamento das águas de chuva, e ainda dificuldade para a efetivação da limpeza rotineira, em virtude das irregularidades existentes.
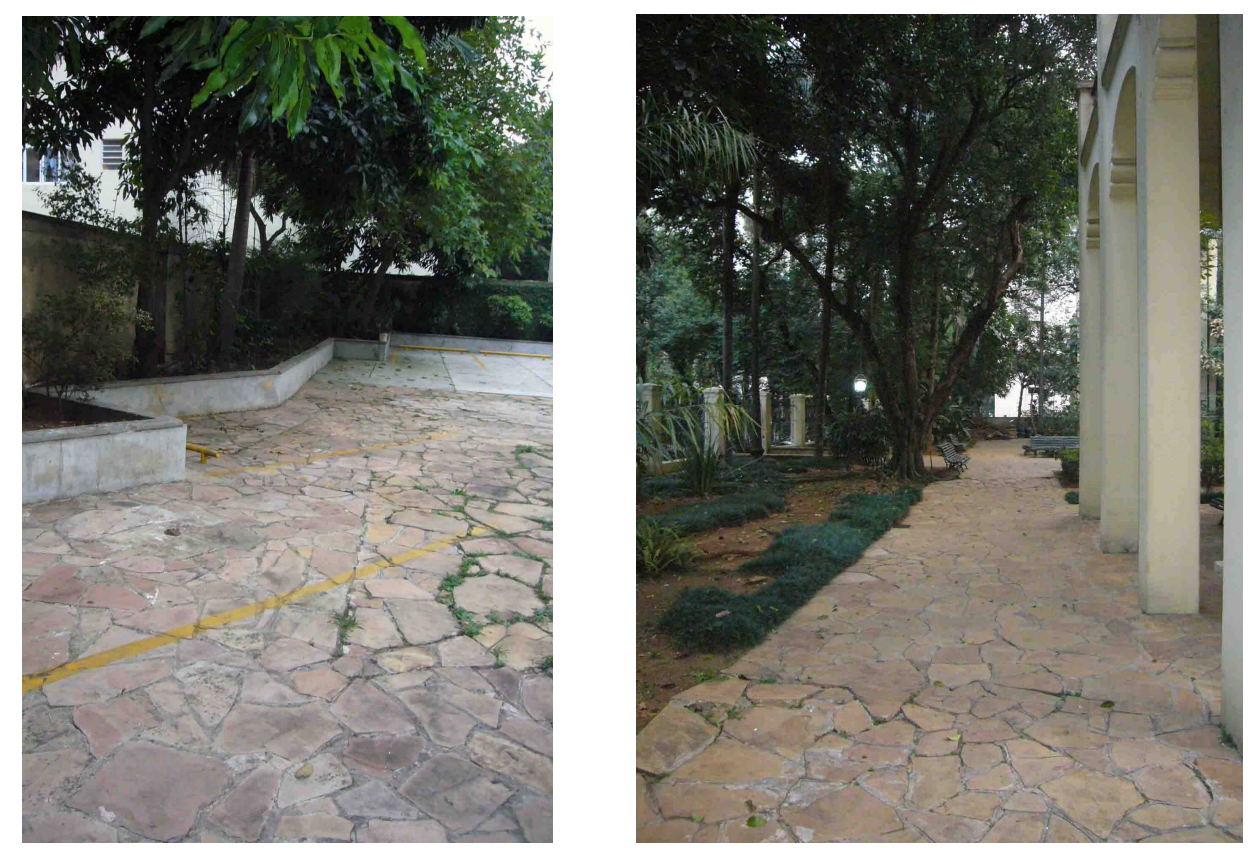

Figura 312 - Pisos externos da Vila Penteado: irregularidades na superfície Fotos: Isis Roverso, abril de 2011.

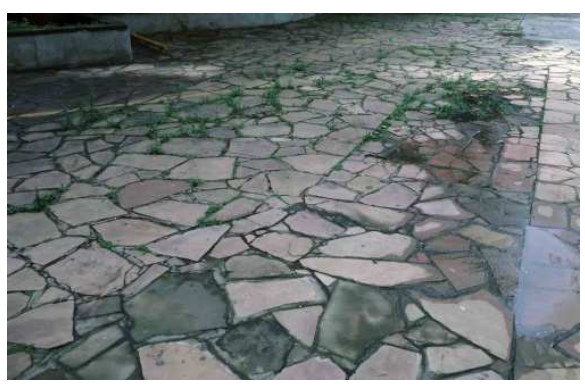

Figura 313 - Piso externo da Vila Penteado: empoçamento de águas pluviais Foto: Isis Roverso, dezembro de 2010. 

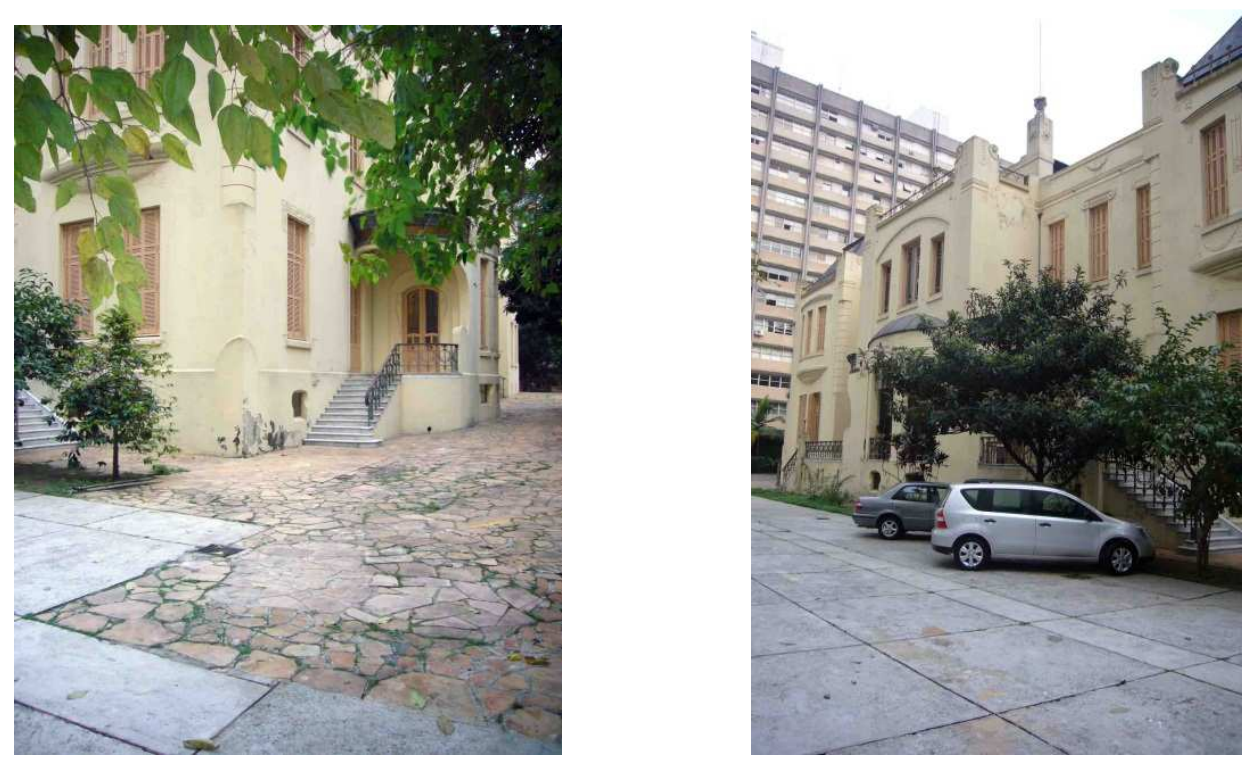

Figura 314 - Pisos externos da Vila Penteado: pavimentação em pedra e em concreto Fotos: Isis Roverso, abril de 2011.

\title{
4.1.8.4 LADRILHO HIDRÁULICO
}

A Vila Penteado possui algumas áreas revestidas em ladrilhos hidráulicos. Essas áreas, originalmente, correspondiam às áreas de serviço, onde o uso de um piso de maior resistência fazia-se necessário. Hoje, as áreas revestidas em ladrilho hidráulico continuam relacionadas às áreas de serviços, como o hall 10T e a Copa.

O texto "O mago dos ladrilhos hidráulicos" $" 119$ apresenta esse piso de pavimentação, afirmando sua alta resistência e durabilidade:

\begin{abstract}
O ladrilho hidráulico resulta da mistura de areia, água, cimento portland, pó de mármore e granito e mais os óxidos de ferro que expõem as cores. Usam-se secantes à base de pó de pedra e cimento seco. Cada peça possui duas camadas de argamassa e outra mais superficial (entre 5 e 7 $\mathrm{mm}$ ) que vai receber os pigmentos, em combinação dos tons básicos dos corantes. A palavra hidráulico surge da cura que é feita com água e não com fogo, como acontece com o azulejo.

[...]

Sua durabilidade é excepcional. Por possuírem desenho e cores estruturadas em boa espessura e não apenas em película fina, garantem as condições ideais de resistência. Exemplos de sua durabilidade são: 0 Museu Paulista, as Igrejas Santa Cecília, Nossa Senhora da Consolação, Imaculada Conceição, Santa Casa de Misericórdia, Colégio Sion e outras entidades que ainda possuem seu piso íntegro, prestando serviço, às vezes, por mais de um século.
\end{abstract}

119 BECKER, Angela Weingärtner e VUOLO, Cândida Maria. O mago dos ladrilhos Hidráulicos. Revista do programa de pós-graduação em arquitetura e urbanismo da FAUUSP. São Paulo: FAUUSP, 2009, n. 25, p. 27-32. 


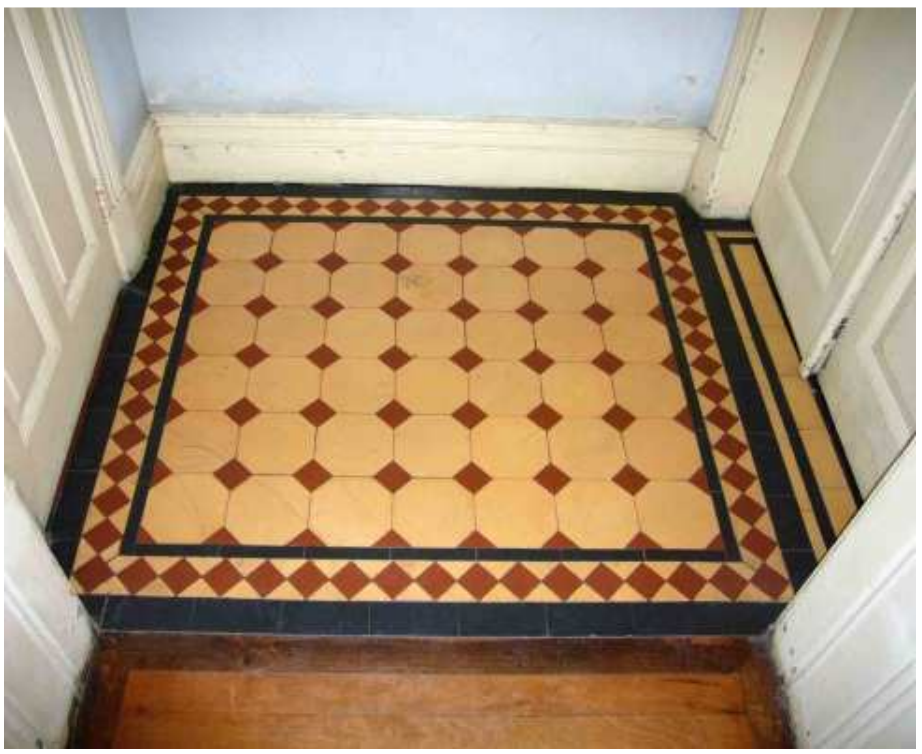

Figura 315 - Piso em ladrilho hidráulico do hall 7T Foto: Isis Roverso, abril de 2011.
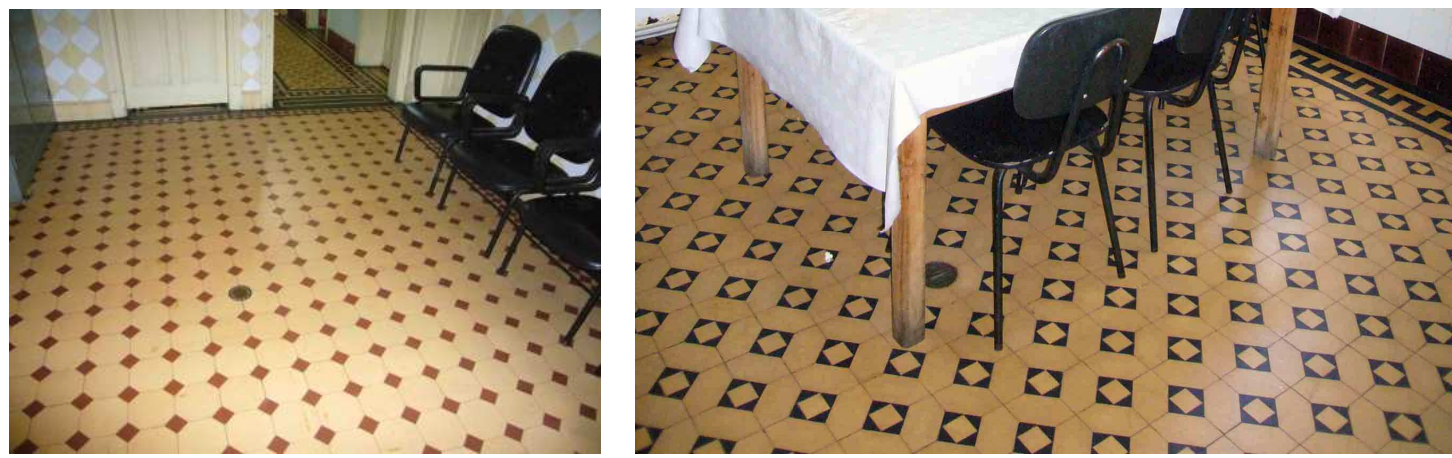

Figura 316 - Piso em ladrilho hidráulico da área 10T e da Copa Fotos: Isis Roverso, abril de 2011.
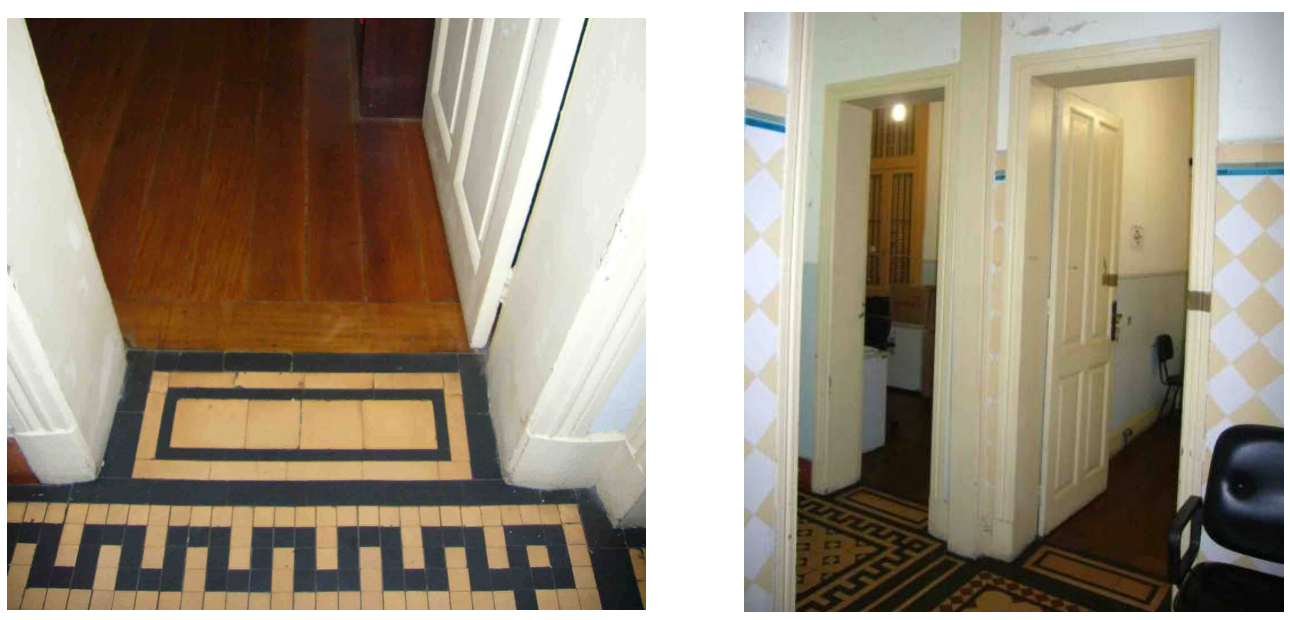

Figura 317 - Piso em ladrilho hidráulico do corredor conjugado a área 10T, terminando na soleira da Sala da Zeladoria (Sala 13T) e na soleira da Sala do Almoxarifado (Sala 10T)

Fotos: Isis Roverso, abril de 2011. 

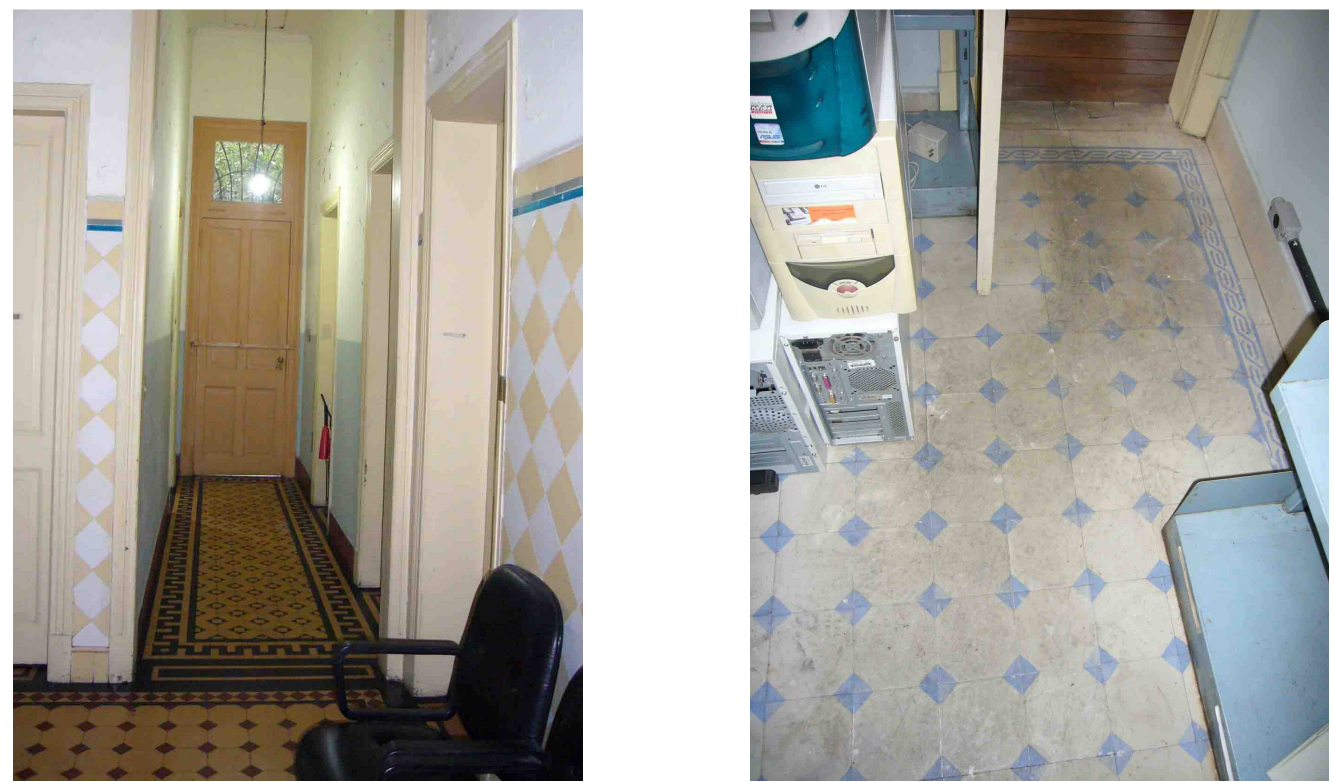

Figura 318 - Piso em ladrilho hidráulico do corredor conjugado a área 10T e da saleta S78B (saleta interligada com o Laboratório de Informática)

Fotos: Isis Roverso, abril de 2011.

Apenas duas das áreas em ladrilho hidráulico existentes na vila apresentam alguma falha construtiva: a primeira refere-se à saleta $578 \mathrm{~B}$, ligada ao Laboratório de Informática e a segunda refere-se ao hall externo de acesso às áreas de serviço $10 \mathrm{~T}$.

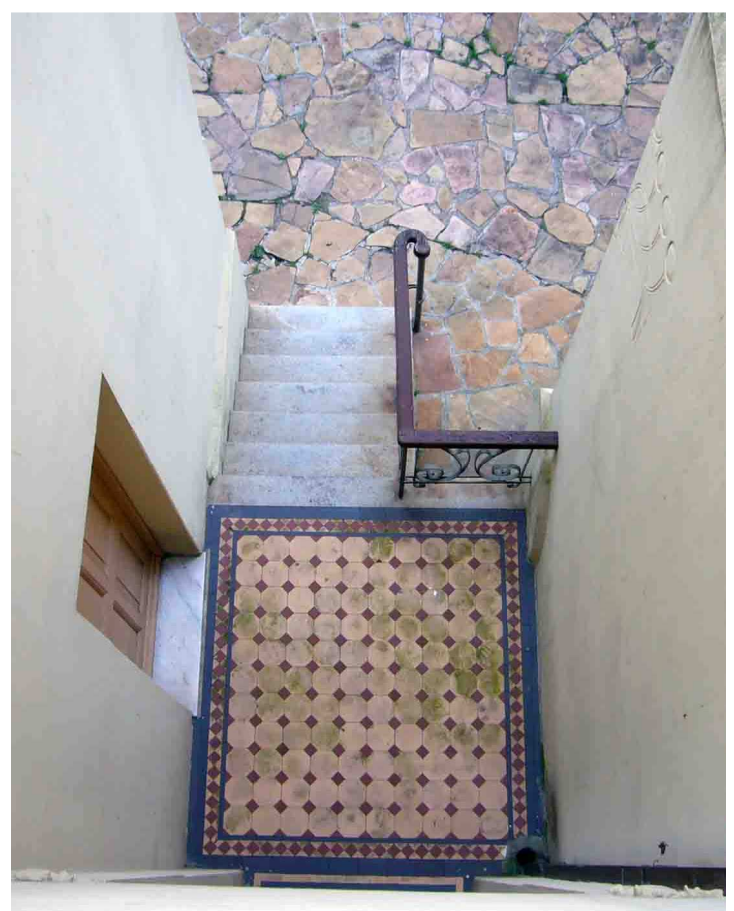

Figura 319 - Piso em ladrilho hidráulico do hall externo de acesso às áreas de serviço 10T

Fotos: Isis Roverso, abril de 2011. 
O hall externo, revestido em ladrilho hidráulico, apresentado na figura 319, contém áreas esverdeadas, resultantes do acúmulo de água das chuvas, que tornam esse piso úmido. Na foto apresentada, é possível perceber que um dos condutores de águas pluviais, em cobre, tem seu término exatamente nesse hall, ou seja, as águas das chuvas escoando da cobertura por essa tubulação e são despejadas sobre o piso em ladrilho hidráulico.

\subsubsection{CERÂMICA, CIMENTADO E TIJOLO}

Assim como às áreas revestidas em ladrilho hidráulico, as áreas com pavimentação em peças cerâmicas correspondem às antigas áreas de serviço da residência (cozinha), terraços e banheiros. Os pisos revestidos em cerâmica situamse, a maioria das áreas, na ala correspondente a residência do conde Álvares Penteado, enquanto que os em ladrilho hidráulico, situam-se na ala da residência de Antonio Prado Junior.

As peças cerâmicas encontram-se bem instaladas, mas é possível notar problemas com as áreas dos ralos. Por exemplo, na Sala 8, antiga cozinha, há ralos no meio da sala, o que provoca a queda dos pés de mesas e cadeiras, durante 0 período de aulas, visto que a Sala 8 hoje funciona como uma sala de aula. Essa situação pode provocar acidentes. As fotos da figura 320 correspondem a Sala 8.
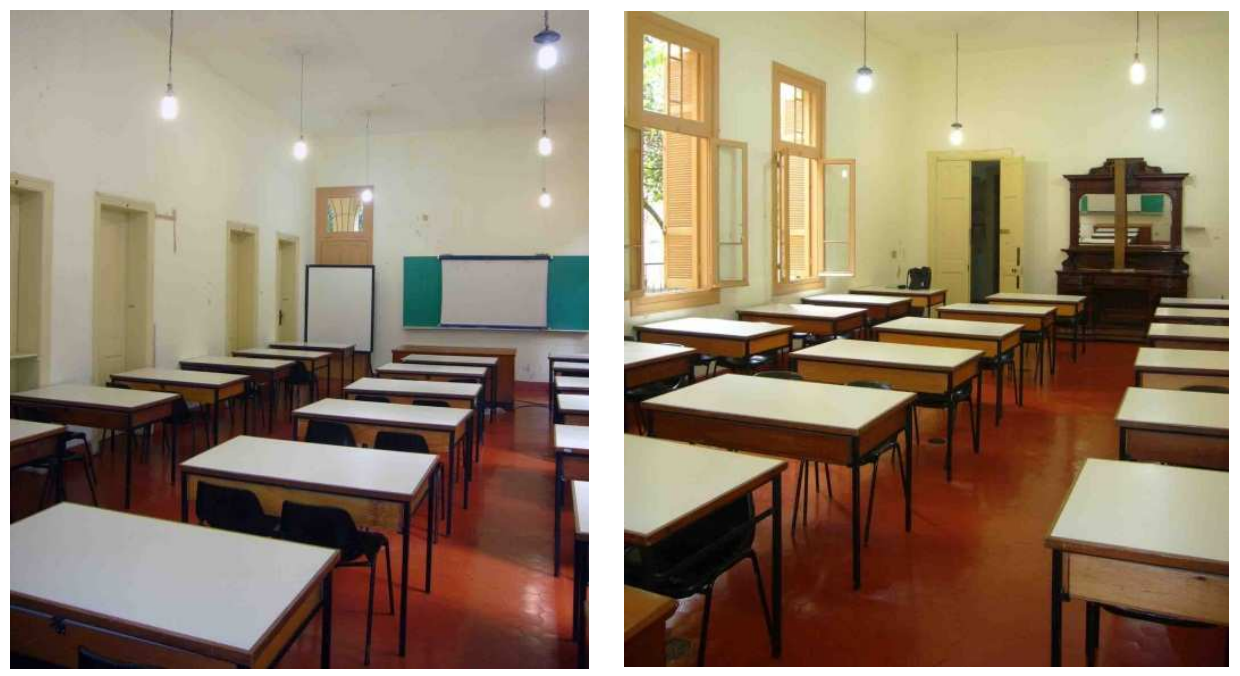

Figura 320 - Piso com revestimento em peças cerâmicas da Sala 8 Fotos: Isis Roverso, abril de 2011. 


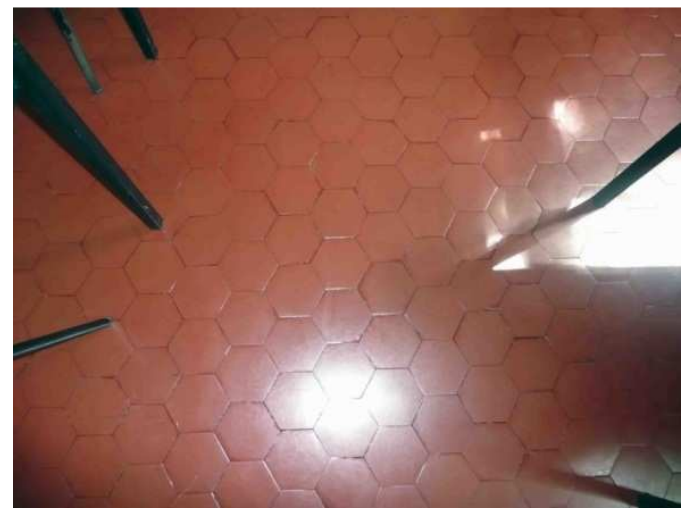

Figura 321 - Detalhe do piso com revestimento em peças cerâmicas da Sala 8 Fotos: Isis Roverso, dezembro de 2010.
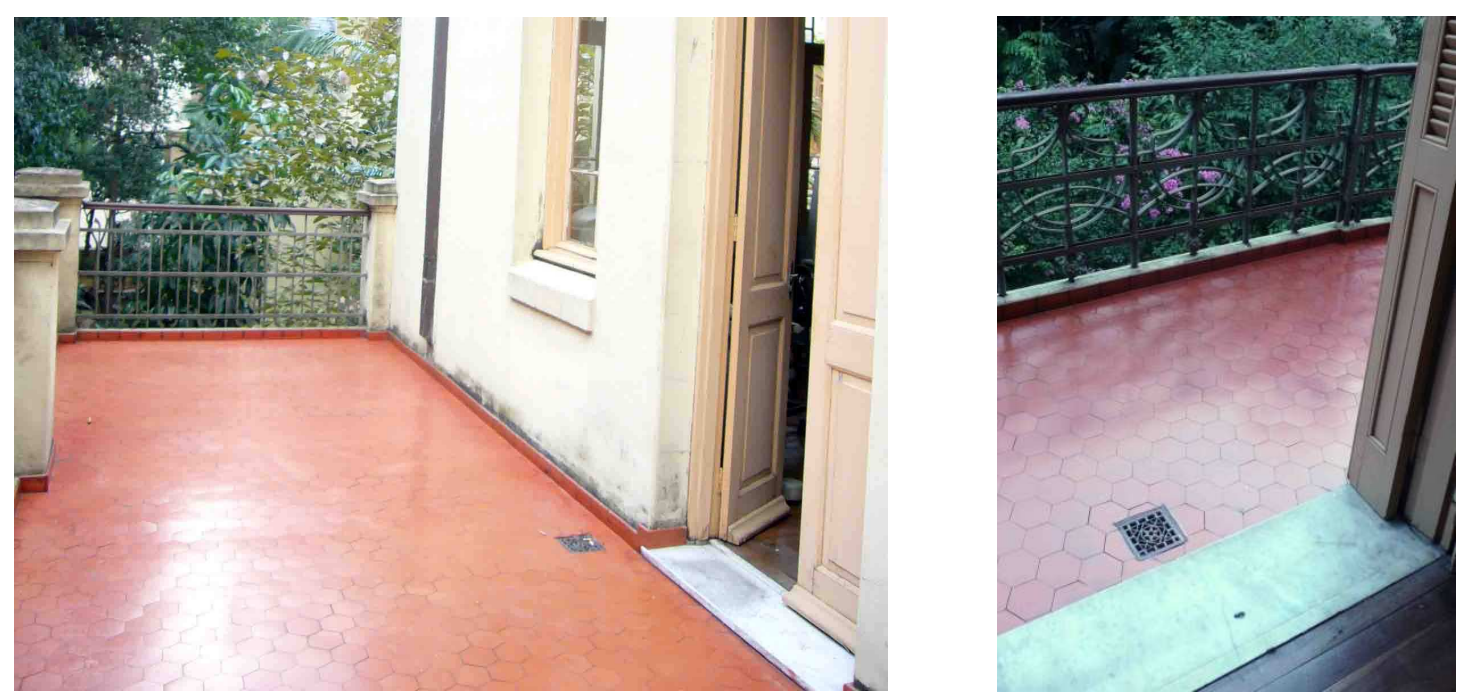

Figura 322 - Piso com revestimento em peças cerâmicas do terraço do Laboratório de Informática (S78) e do terraço da Sala 68

Fotos: Isis Roverso, abril de 2011 e dezembro de 2010.
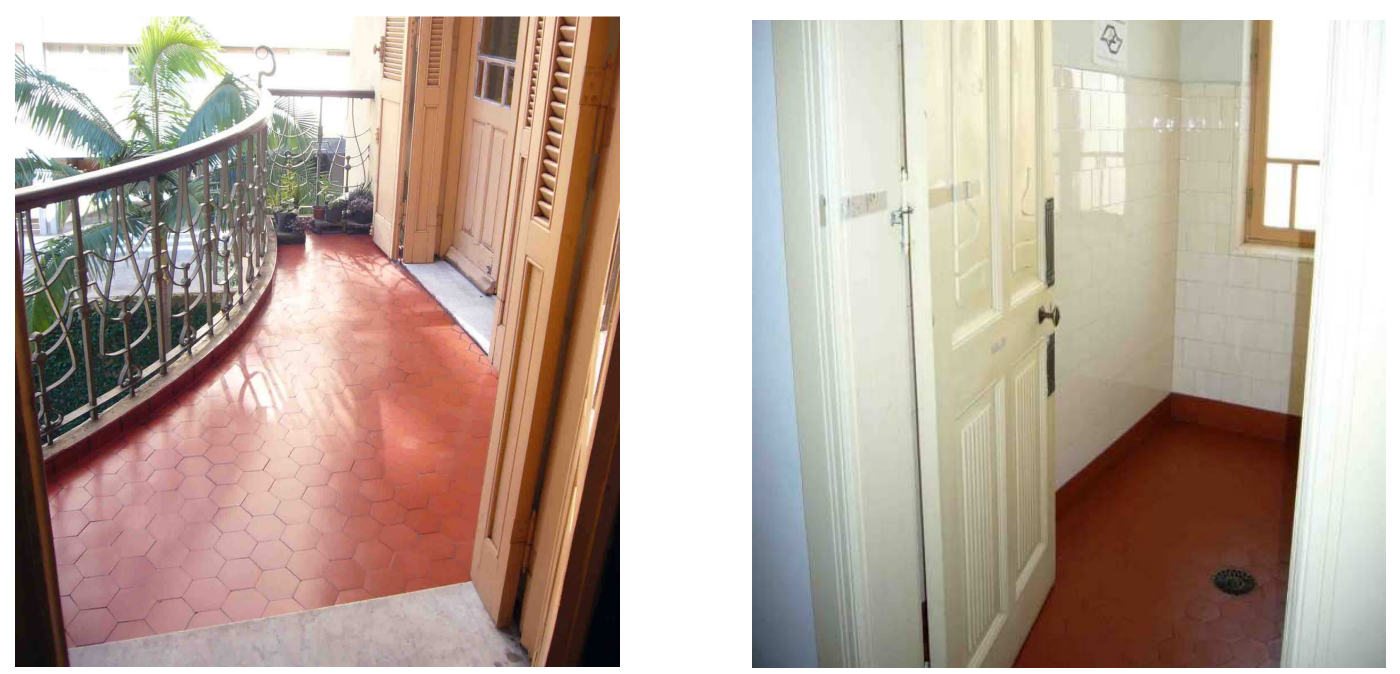

Figura 323 - Piso com revestimento em peças cerâmicas do terraço da Secretaria (S74) e do WC Feminino 547

Fotos: Isis Roverso, abril de 2011. 
Algumas áreas secundárias tem pavimentação simples, executada apenas com cimentado, é o caso de escadas de acesso ao porão e parte do piso do porão. Boa parte dos pisos cimentados encontra-se em condições adequadas de uso, entretanto outras áreas, como a escada de acesso externo a sala SUB-5, necessita de reparos. Cabe ressaltar que por muito tempo a sala SUB-5 sofreu com a entrada de águas pluviais em dias de chuva mais intensos, o que justifica o decréscimo de qualidade dos pisos dessa região.
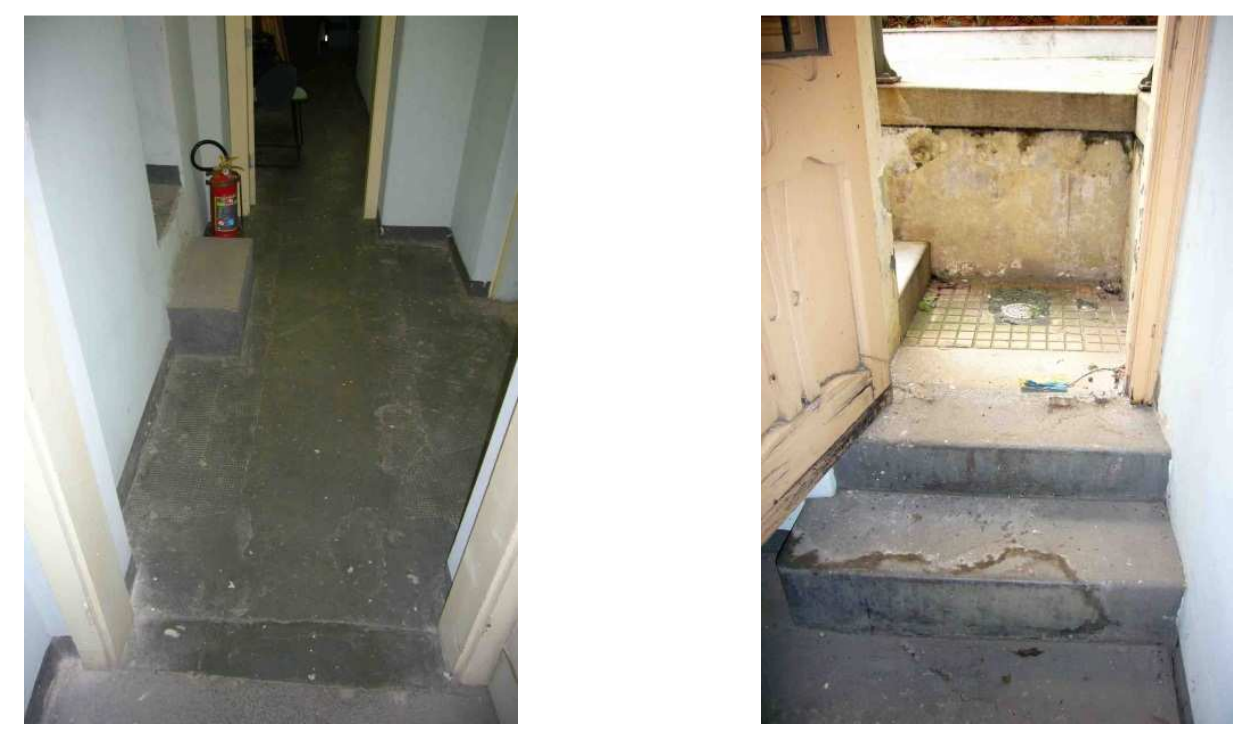

Figura 324 - Áreas do porão cimentadas.

À esquerda: piso cimentado do hall da área SUB-2 (local do quadro de entrada de luz $\mathrm{e}$ força). À direita: acesso à área SUB-5.

Fotos: Isis Roverso, abril de 2011.
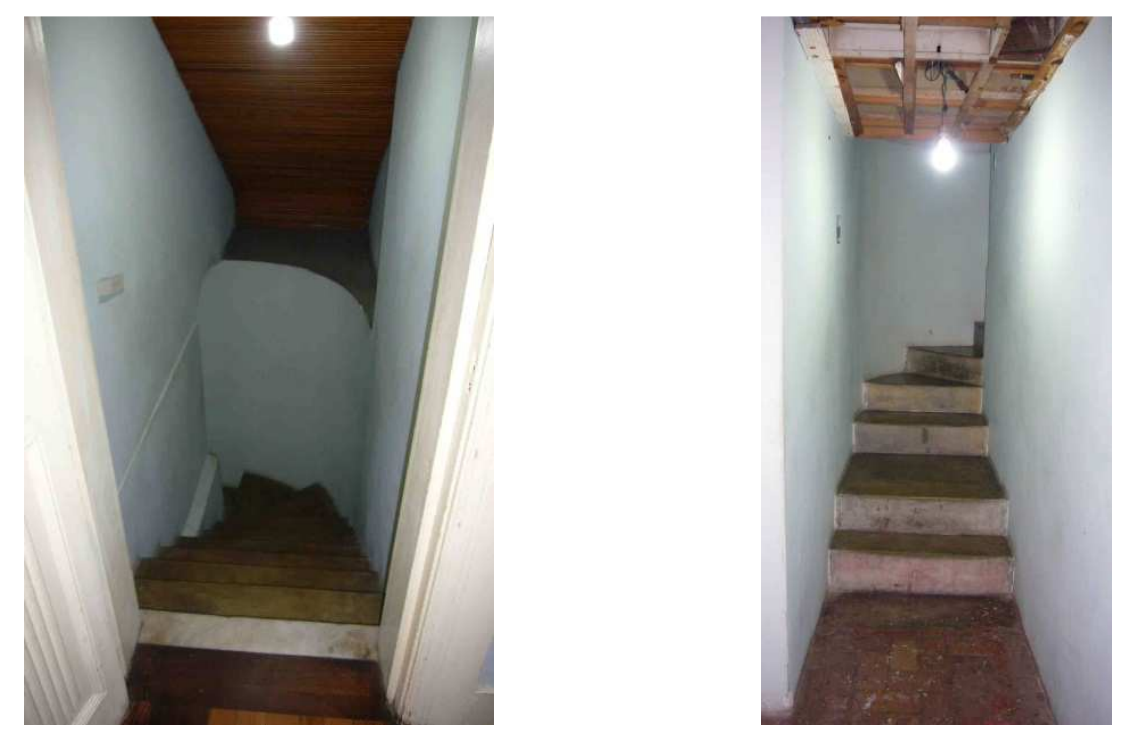

Figura 325 - Escada de acesso à área SUB-10 (Depósito) em cimento queimado Fotos: Isis Roverso, abril de 2011. 
A escada de acesso à área SUB-10 do porão encontra-se com excelente qualidade em sua pavimentação em cimento queimado.

O porão conta também com pavimentação executada em tijolos maciços. As áreas com esse tipo de piso apresentam condições adequadas de conservação. As figuras 326 e 327 apresentam essa situação.
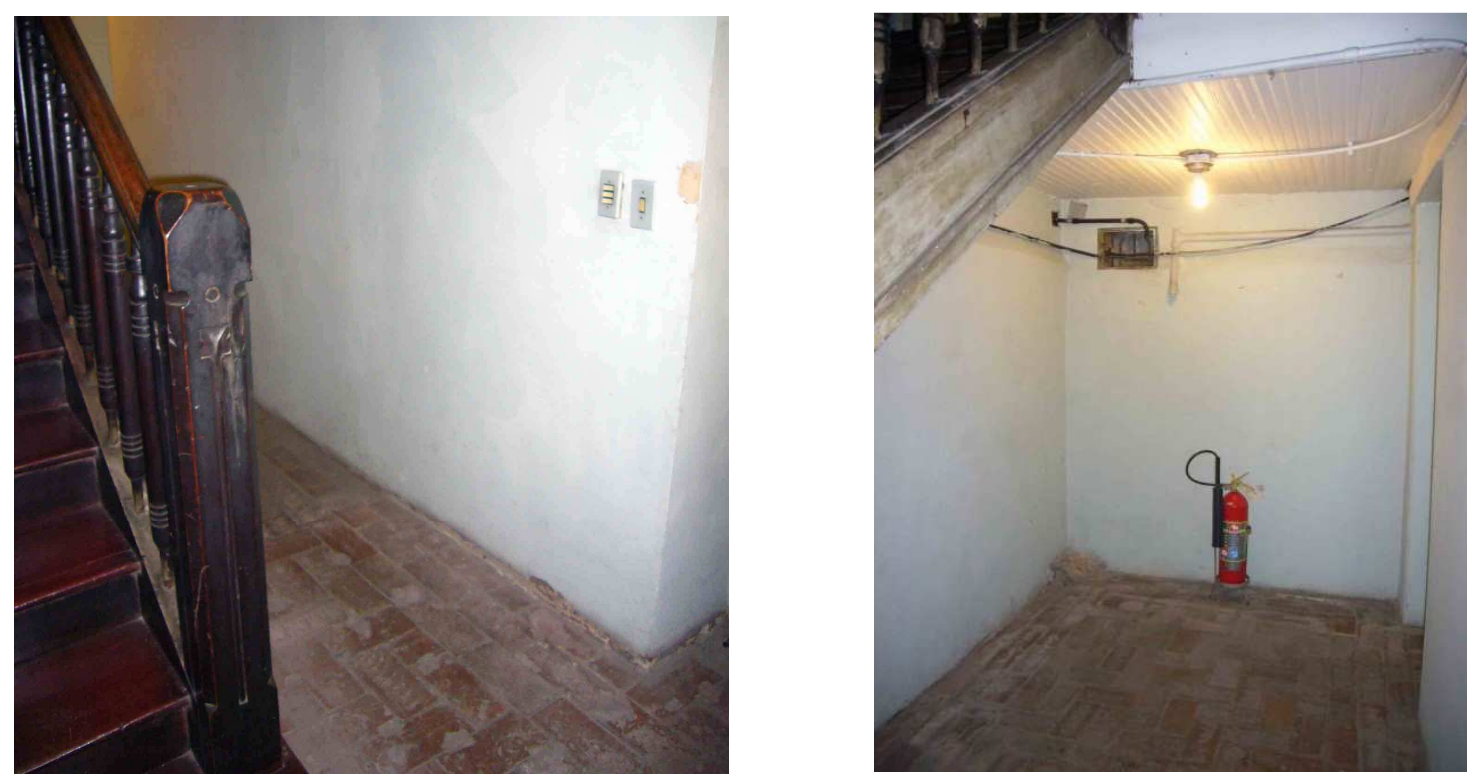

Figura 326 - Piso com revestimento em tijolos maciços da área de acesso a sala SUB-1 Fotos: Isis Roverso, abril de 2011.
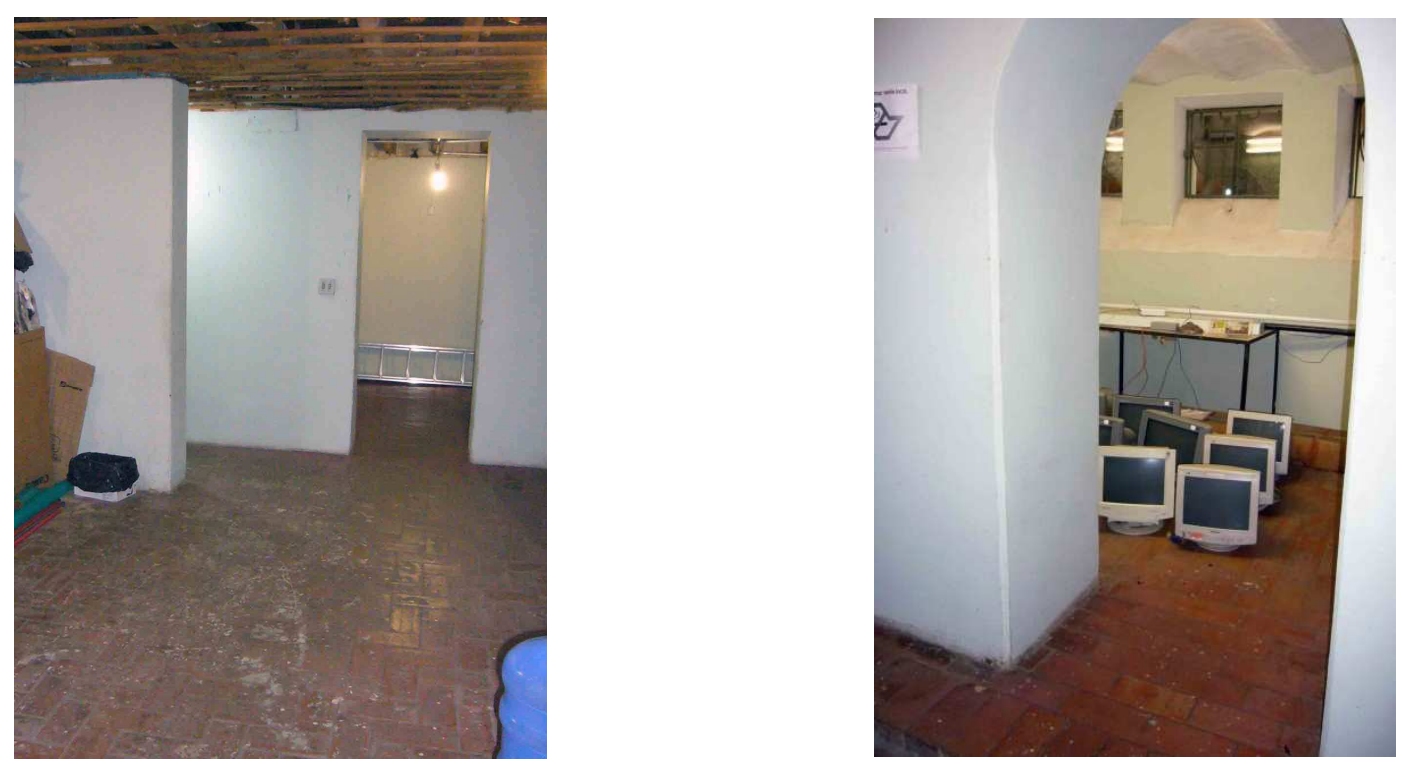

Figura 327 - Piso com revestimento em tijolos maciços da área SUB-10 do porão Fotos: Isis Roverso, abril de 2011. 


\subsubsection{INSTALAÇÕES ELETROMECÂNICAS}

As instalações eletromecânicas contemplam as instalações elétricas internas e externas, assim como as instalações telefônicas, de antenas e cabos para transmissão de dados.

Visto a Vila Penteado não contar com equipamentos para transporte vertical e de condicionamento térmico dos ambientes internos, as instalações necessárias a esses elementos não foram contempladas nesse item, entretanto, cabe ressaltar que há a necessidade de se prever a instalação de plataforma acessível, visando adequar o edifício as necessidades existentes em relação à acessibilidade.

Como já comentado nos itens 3.1.4 "O Edifício: Vila Penteado", 3.2.5 "Instalações Elétricas" e 3.4.3 "Projeto de Instalações Elétricas", as instalações elétricas da Vila Penteado encontram-se em nível inadequados de segurança e dimensionamento. O projeto de reforma dessas instalações foi elaborado e revisado, faltando apenas detalhar alguns itens, sendo eles:

1. Detalhamento da luminotécnica, incluindo modelos e tipos de lâmpadas e luminárias de acordo com as funções de cada ambiente, distinguindo a iluminação de uso geral, da iluminação de tarefa e da iluminação de destaque;

2. Detalhamento do sistema de réguas de instalações e dos perfilados para suporte da iluminação, com especificação dos modelos das peças e conectores.

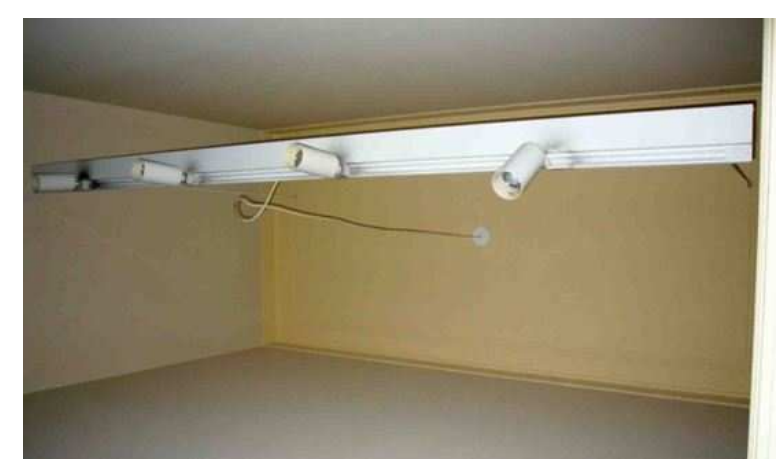

Figura 328 - Luminária instalada no hall de acesso a área de consulta da Biblioteca Fotos: Isis Roverso, abril de 2011.

A área da Biblioteca teve suas instalações elétricas reformadas (para detalhes dessa reforma consultar o item 3.2.6 "Intervenção na Área da Biblioteca") e foi privilegiado o uso de luminárias suspensas ou fixas no mobiliário. A figura 328 
apresenta o hall de acesso à área de consulta da Biblioteca, onde uma luminária suspensa foi instalada.

Para a reforma das instalações elétricas da Biblioteca, o trajeto dos eletrodutos foi facilitado pela possibilidade de ser usado o teto do porão (situação prevista também no projeto de reforma geral das instalações elétricas da Vila Penteado), entretanto, a altura de instalação desses eletrodutos acabou por prejudicar as vigas de madeira (detalhes dessa situação estão apresentados no item 3.1.3 "Estrutura").
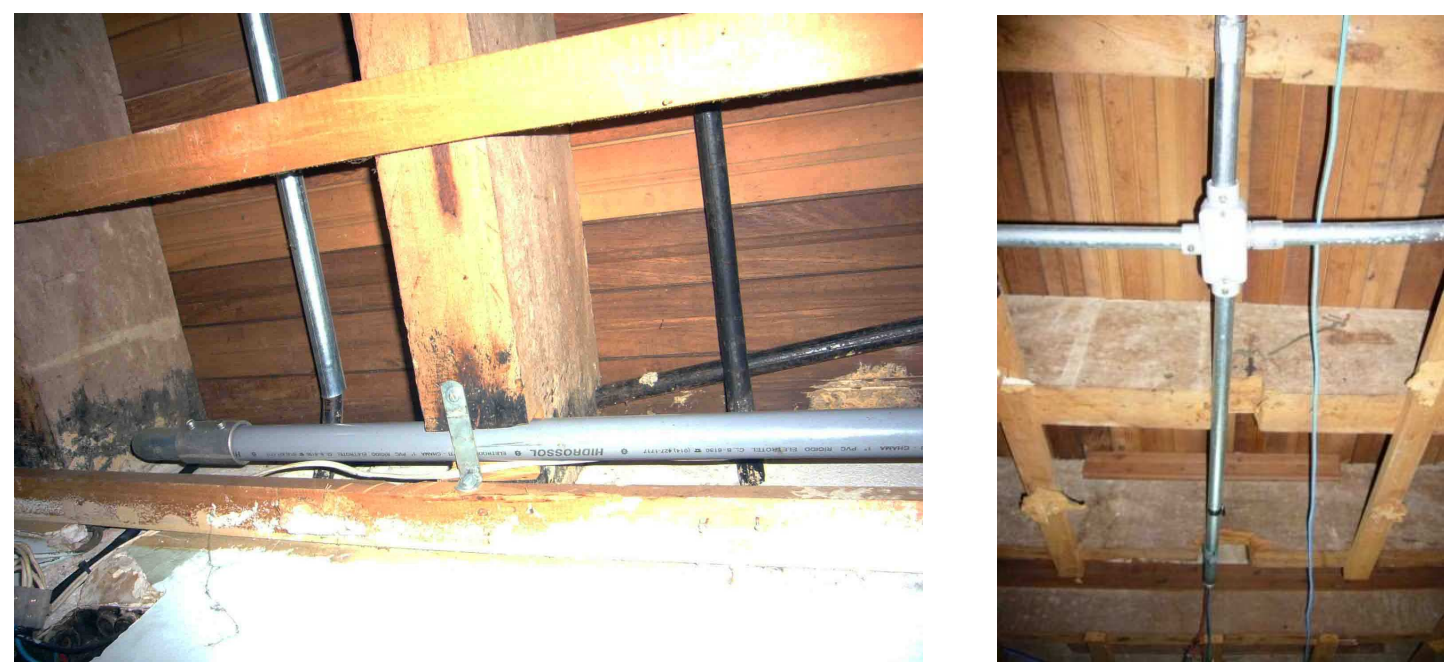

Figura 329 - Novos eletrodutos instalados para atender a Biblioteca Fotos: Isis Roverso, abril de 2011.
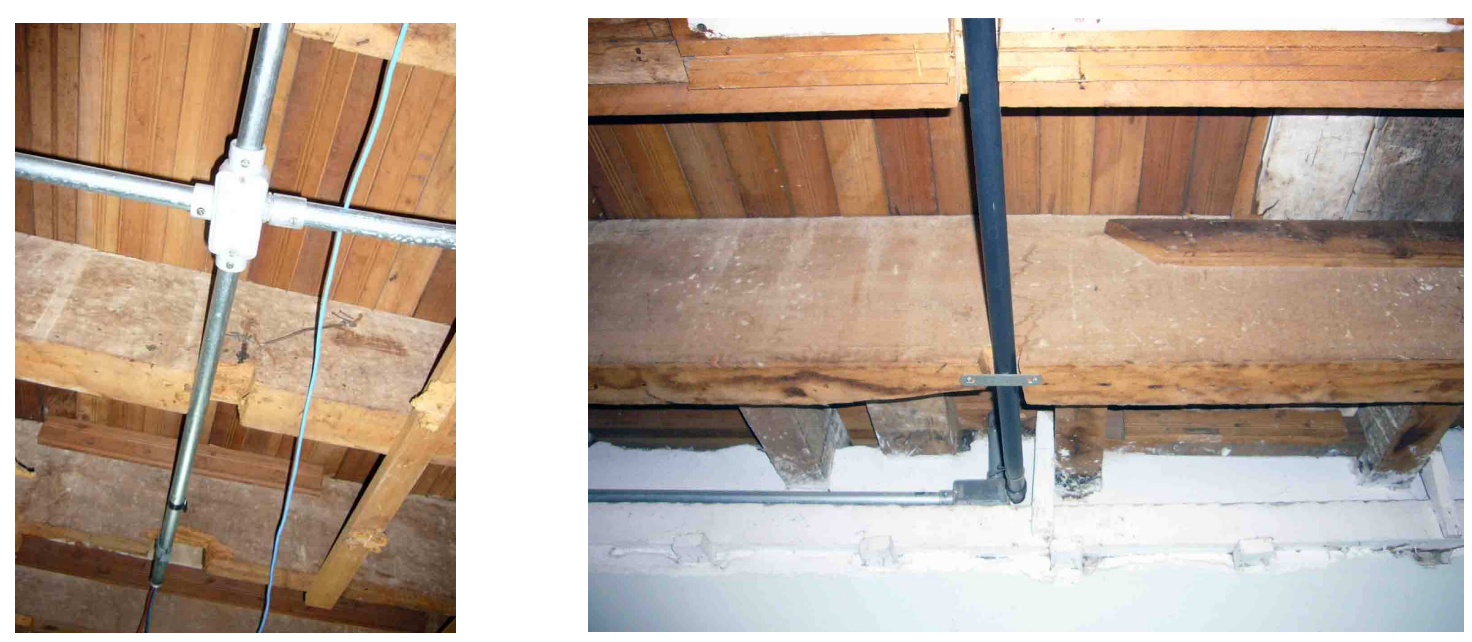

Figura 330 - Teto do porão com novos eletrodutos instalados para atender a Biblioteca Fotos: Isis Roverso, abril de 2011. 
Com excessão da biblioteca e, de forma parcial, das instalações do Laboratório de Informática, a situação do sistema elétrico da Vila Penteado é crítica. As fotos das figuras 331 a 339 apresentam claramente essa situação.

Em diversos corredores e salas é possível observar cabos instalados sem a devida proteção ou suporte. Essa situação revela a forma precária com que as instalações existentes foram executadas, instalações necessárias, motivadas pelas adaptações em função das alterações de uso dos ambientes.
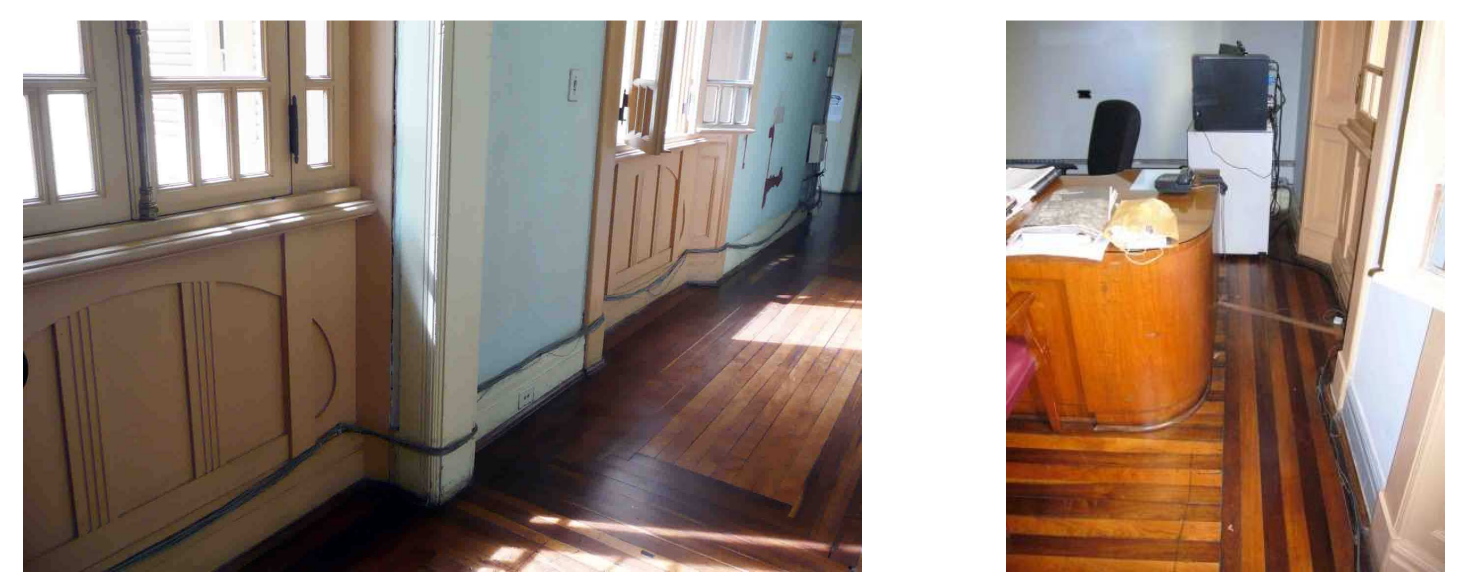

Figura 331 - Cabos expostos no Corredor S77 (trajetos sem suportes ou protetores) e Sala da Diretoria (cabos soltos pelo piso)

Foto: Isis Roverso, dezembro de 2010.
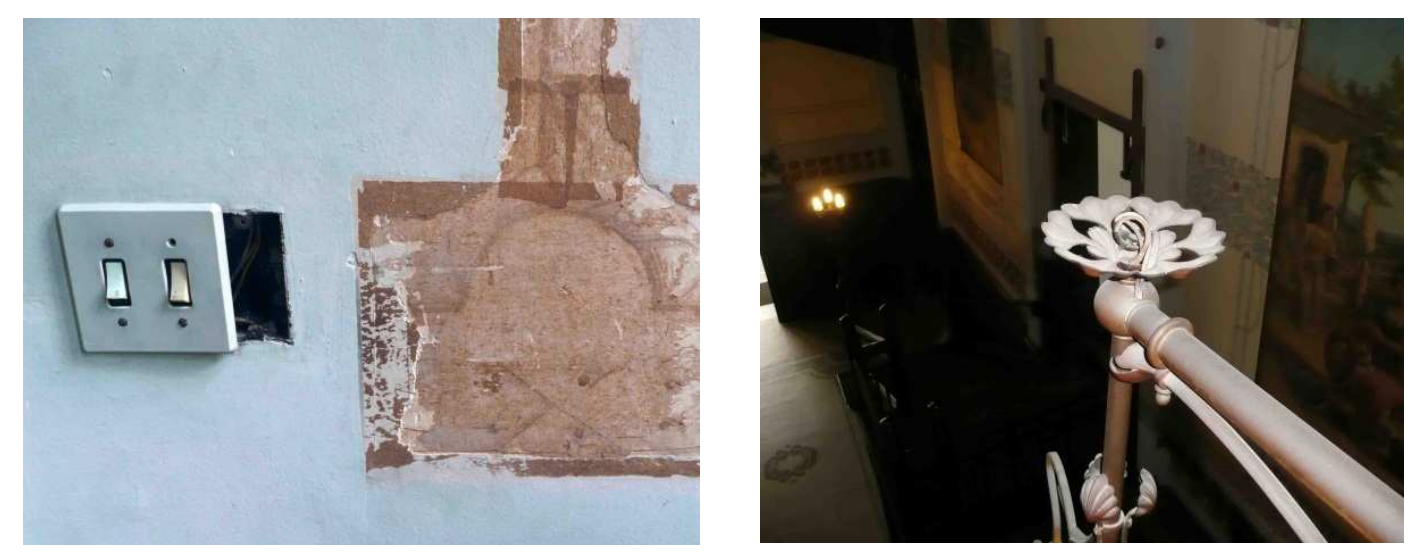

Figura 332 - Sala de Espera e Saguão: falha dos terminais das instalações elétricas Fotos: Isis Roverso, dezembro de 2010.

As áreas externas também apresentam instalações elétricas precárias. Por vezes é possível notar a fiação parcialmente exposta ao intemperismo. Em outras situações, as lâmpadas não recebem a proteção adequada: na sequência das fotos, da figura 334, é possível notar diferentes padrões de cúpula (revelando falta de 
critério na manutenção ordinária), cúpulas com remendo em fita adesiva (algo totalmente inadequado) e ainda a ausência da cúpula de proteção à lâmpada.

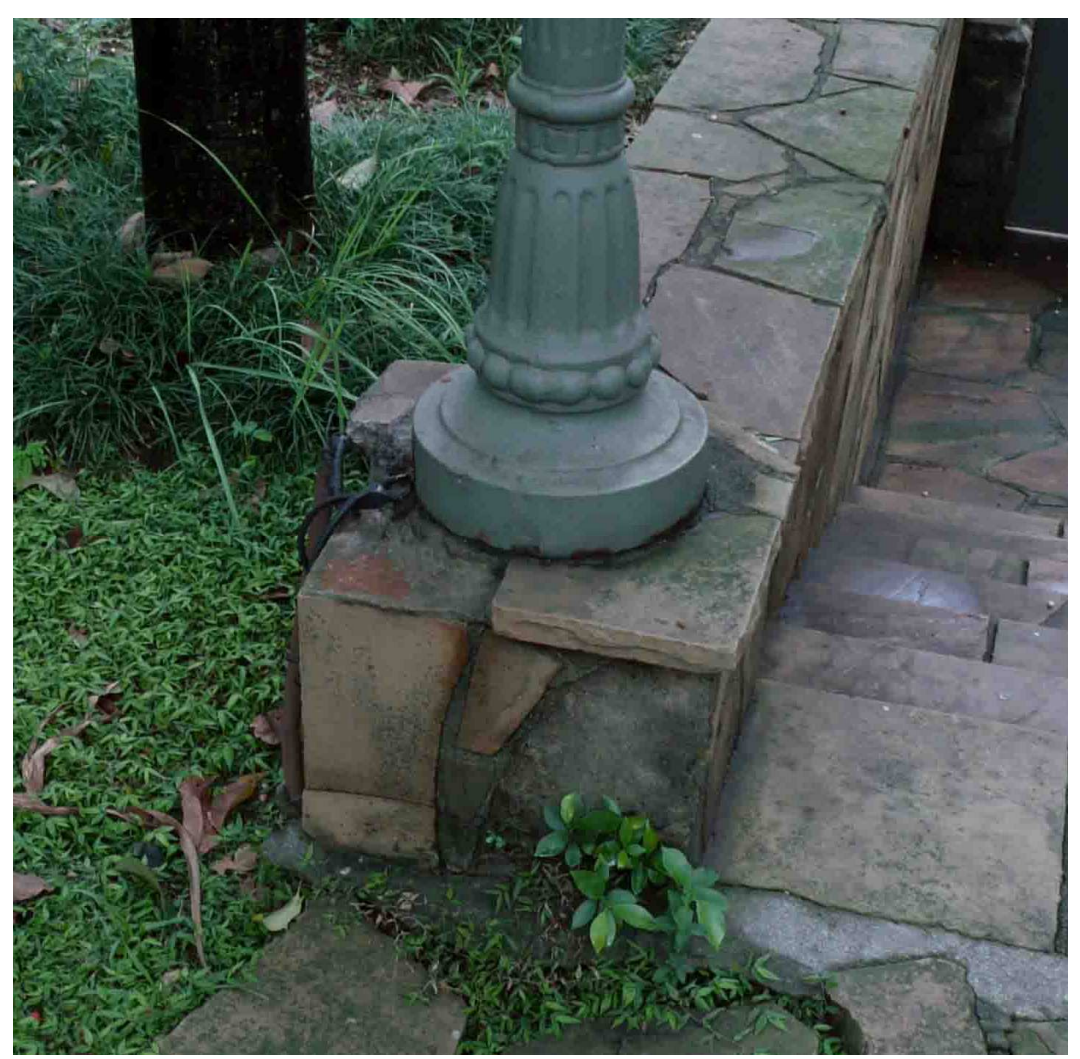

Figura 333 - Instalações elétricas da área externa da Vila Penteado Fotos: Isis Roverso, dezembro de 2010.
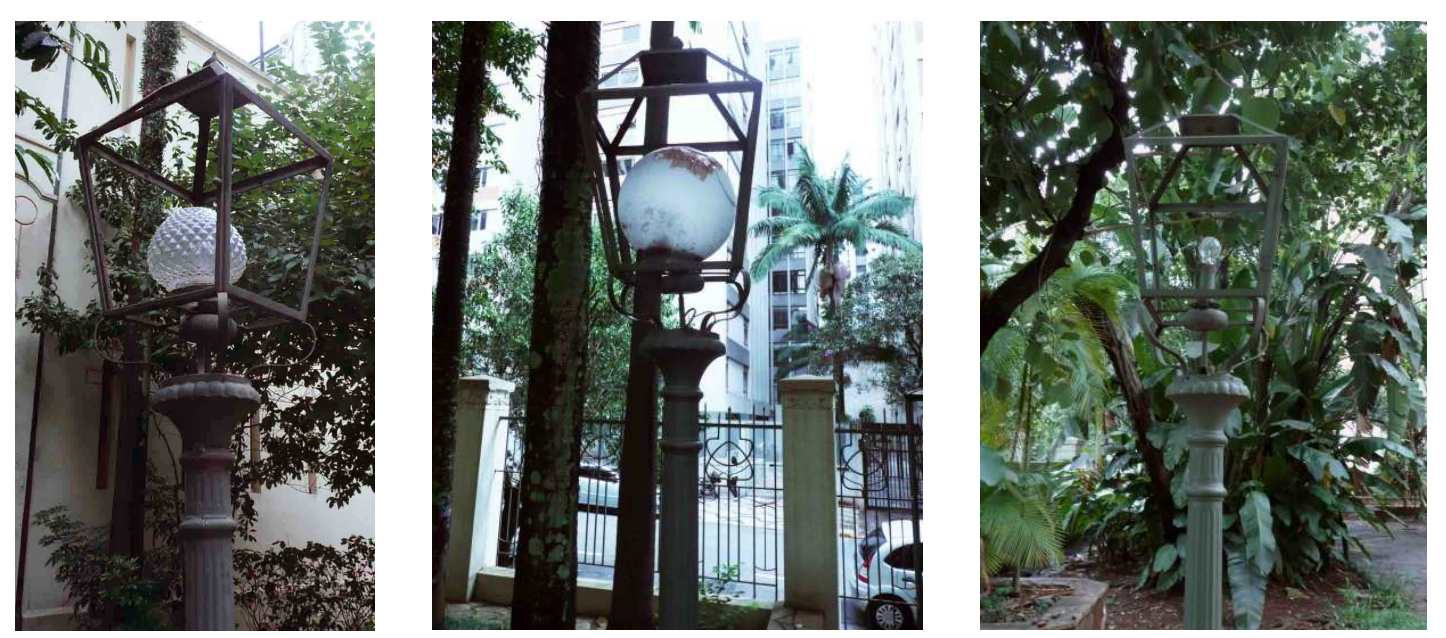

Figura 334 - Falhas nas cúpulas dos postes de iluminação dos jardins Fotos: Isis Roverso, dezembro de 2010.

No quadro de entrada de luz e força é notável a falta de proteção dos barramentos. 

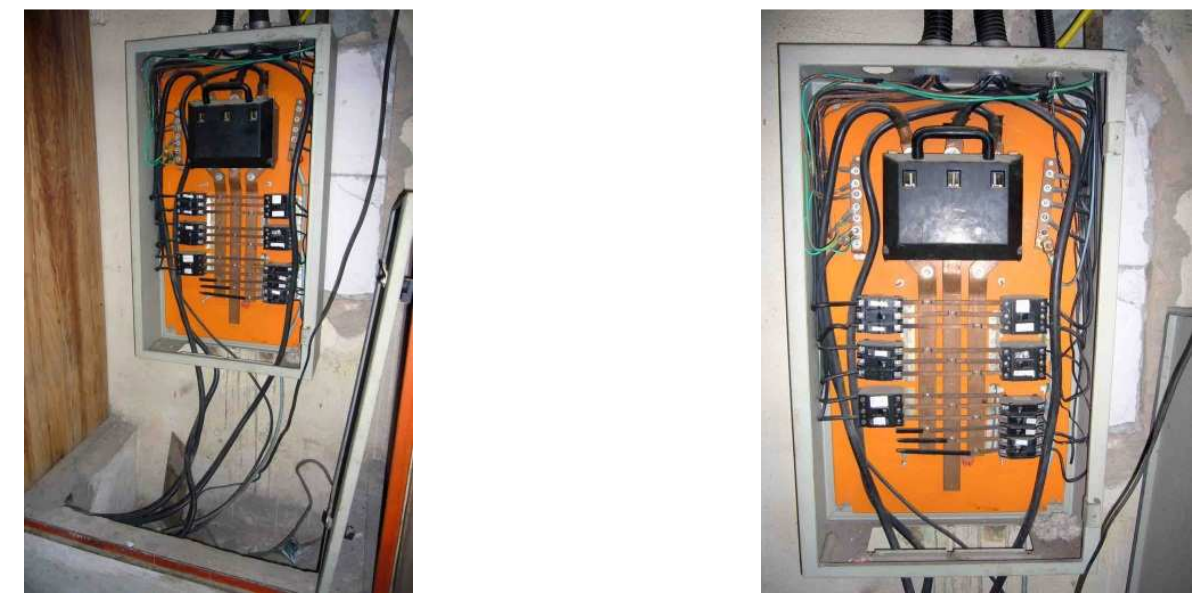

Figura 335 - Quadro de entrada de luz e força, instalado na sala SUB-2 do porão Fotos: Isis Roverso, abril de 2011.
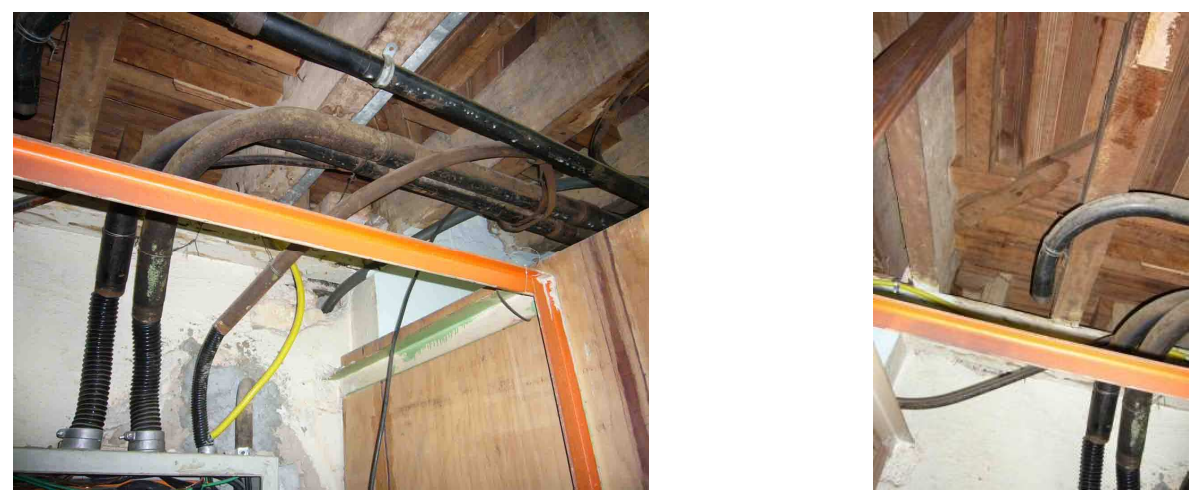

Figura 336 - Trajeto de encaminhamento dos cabos a partir do quadro de entrada de luz e força

Fotos: Isis Roverso, abril de 2011.

A área que inspira maiores cuidados é a do porão: fios e cabos estão expostos, o isolamento das emendas dos cabos é precário e a fiação encontra-se numa situação onde o aquecimento de uma das partes pode causa danos em todo o sistema.
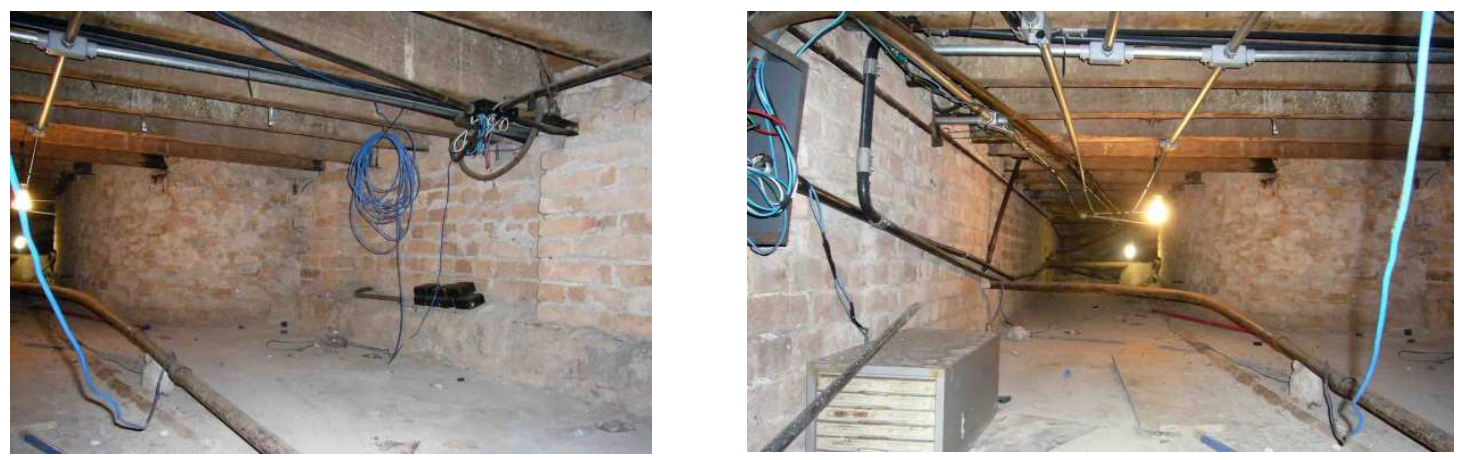

Figura 337 - Instalações elétricas na área do porão Fotos: Isis Roverso, abril de 2011. 

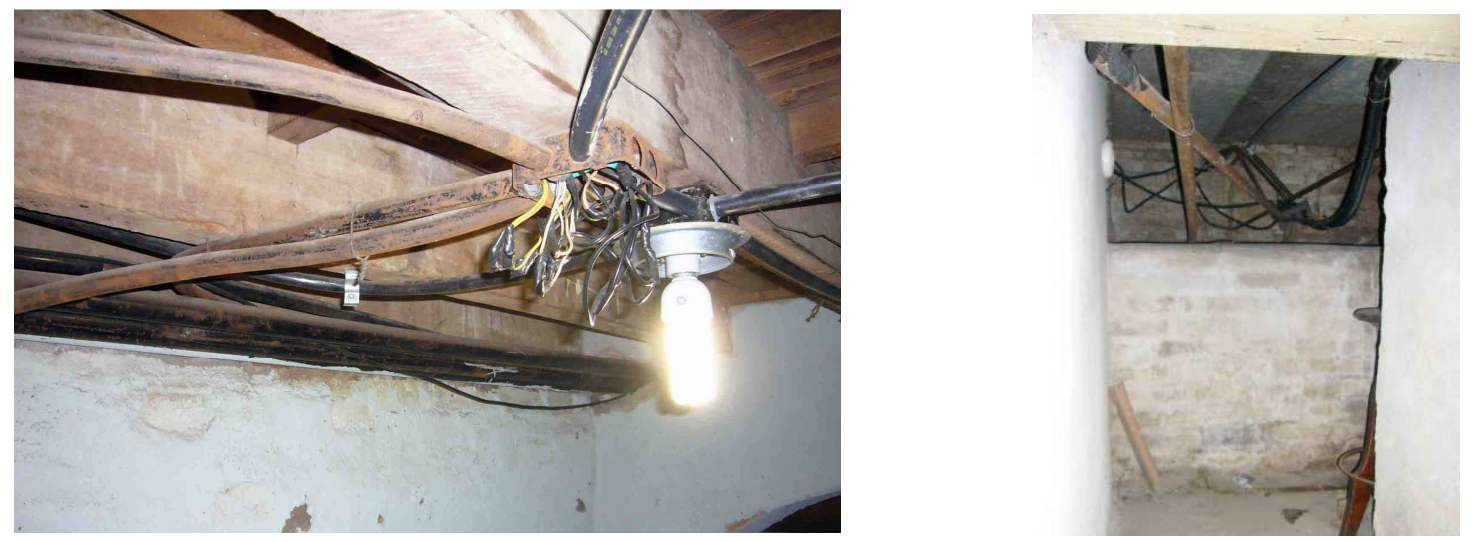

Figura 338 - Instalações elétricas na área do porão: caixas de passagem inadequadas Fotos: Isis Roverso, abril de 2011.
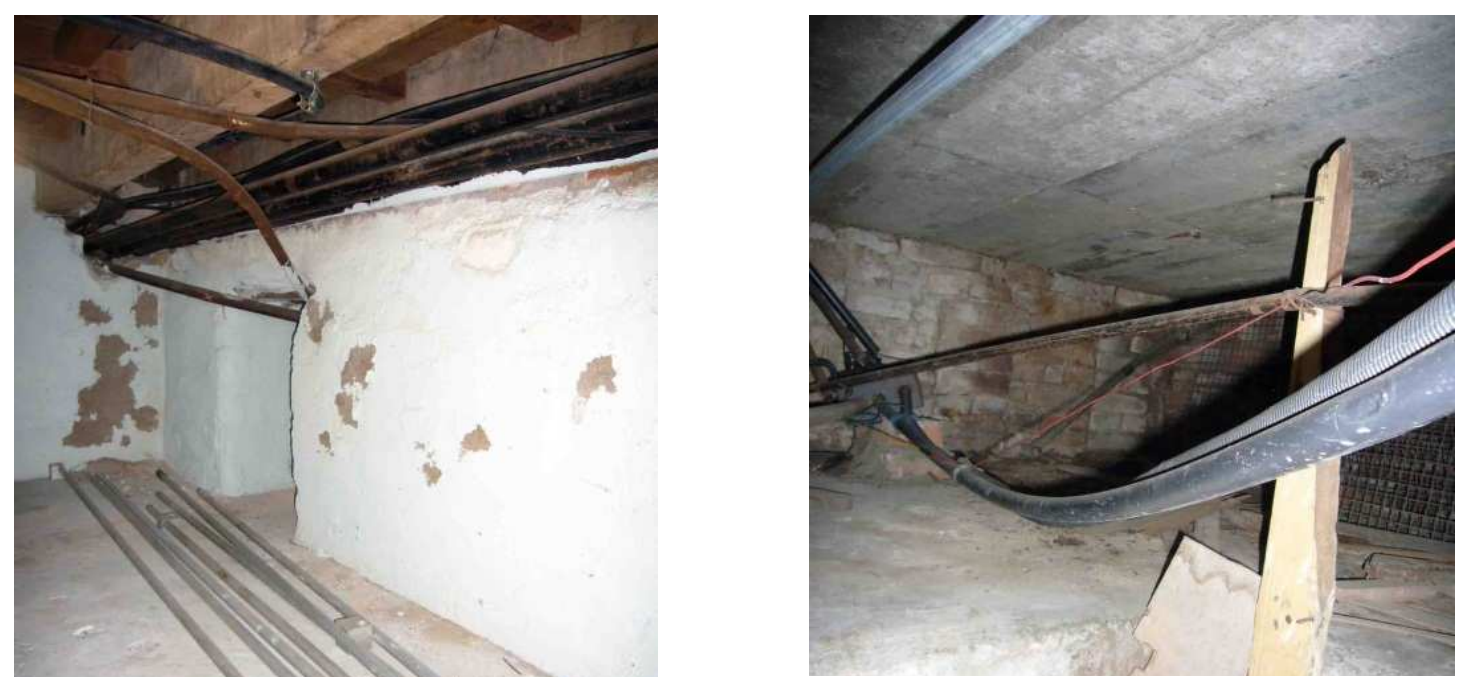

Figura 339 - Instalações elétricas na área do porão: trajetos desorganizados, com eletrodutos subdimensionados

Fotos: Isis Roverso, abril de 2011.

Associado às instalações elétricas, é necessário apresentar as qualidades e deficiências dos lustres da Vila Penteado. São diversos os modelos das peças originais ainda em uso, que apresentam qualidade satisfatória e ornamentação característica da época de construção da Vila, entretanto, várias peças encontramse amontoadas nos depósitos do porão, aguardando ações de restauro.

Alguns lustres recebem destaque e a figura 340 contém o pendente da portaria e um dos lustres do Saguão. 

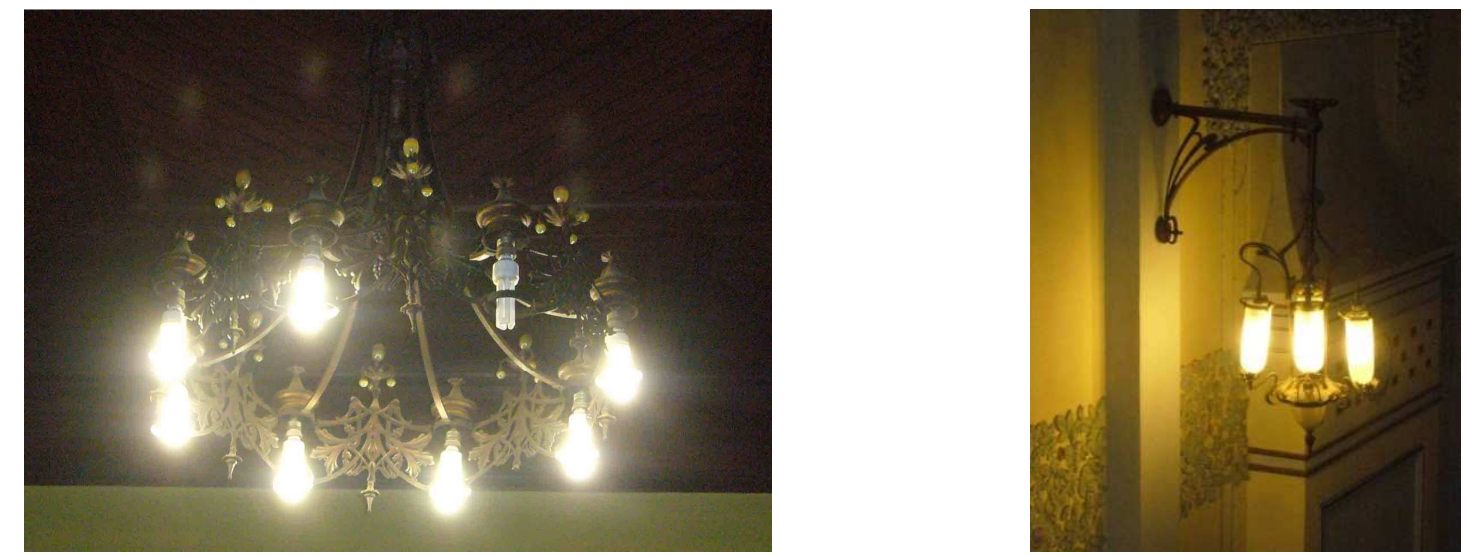

Figura 340 - Pendente da Portaria e Luminária do Saguão Fotos: Isis Roverso, abril de 2011.

Outros exemplares não se encontram em áreas de fácil acesso aos visitantes, é o caso do pendente dourado da Sala 65 (pavimento superior).

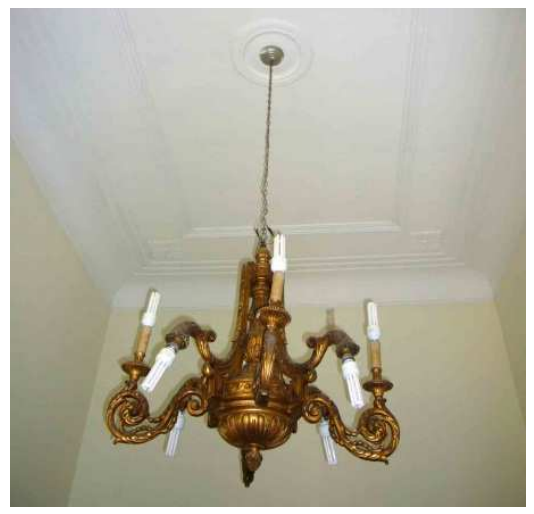

Figura 341 - Luminária pendente dourada da Sala 65 Foto: Isis Roverso, abril de 2011.

Diversas peças, representando vários períodos do casarão, encontram-se guardadas no porão, em função de estarem danificadas de alguma forma.
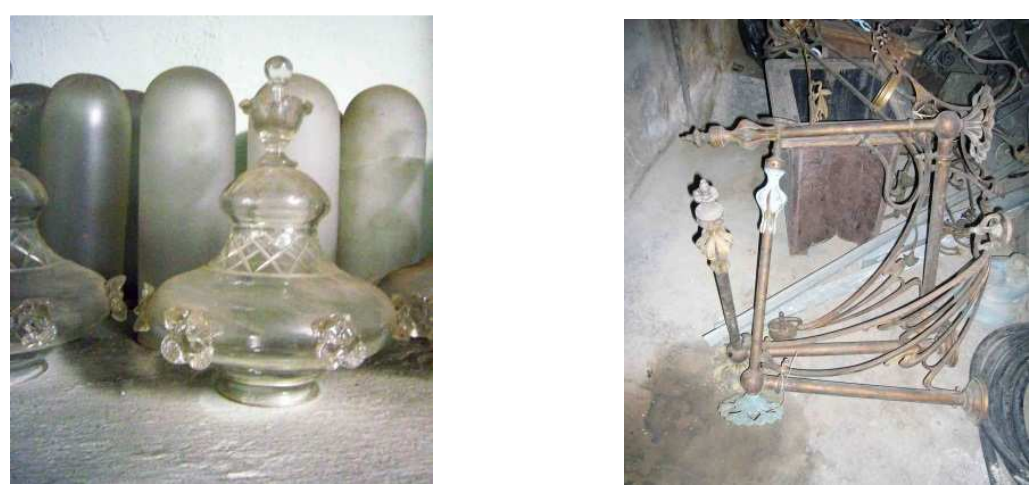

Figura 342 - Cúpulas e suportes ornamentados de diversas luminárias Fotos: Isis Roverso, abril de 2011. 

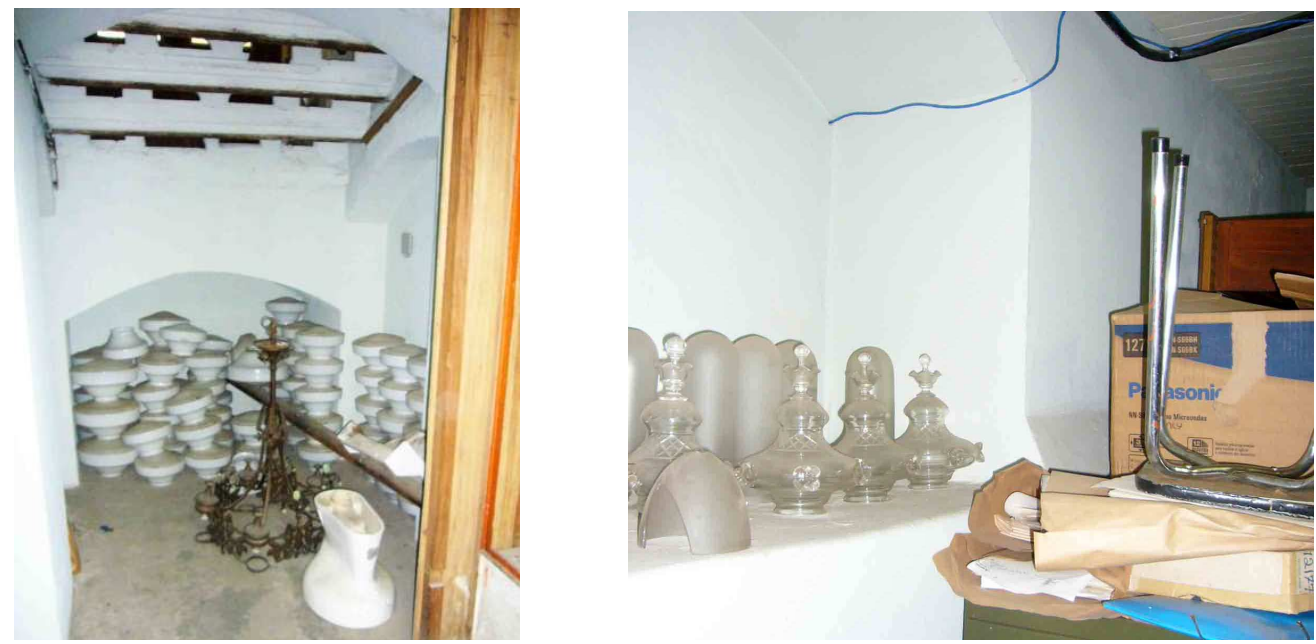

Figura 343 - Cúpulas e luminárias depositadas no porão Fotos: Isis Roverso, abril de 2011.

\subsubsection{INSTALAÇÕES ELÉTRICAS DO LABORATÓRIO DE INFORMÁTICA}

Em função das deficiências apresentadas pelo sistema de instalações elétricas do edifício Vila Penteado, o laboratório de informática foi interditado em 2007.

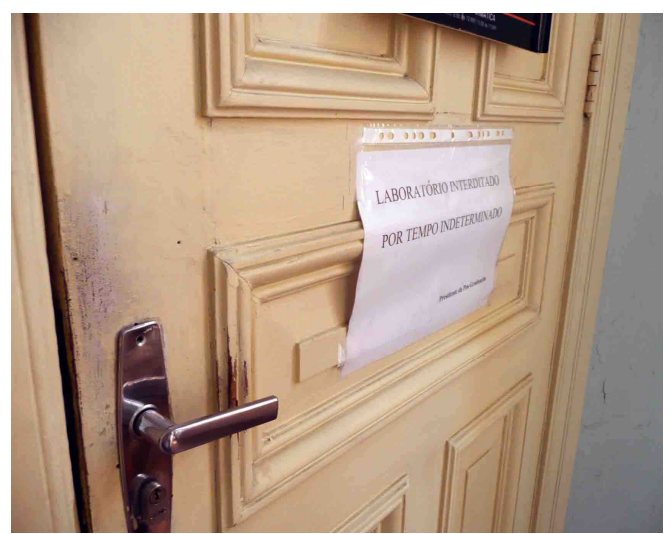

Figura 344 - Porta do Laboratório de Informática com aviso "Laboratório interditado por tempo indeterminado"

Fotos: Isis Roverso, dezembro de 2010.

Em outubro de 2011, motivado pela necessidade de liberar esse espaço para aulas específicas e acesso aos alunos da pós-graduação à rede de informática, as instalações elétricas desse laboratório foram parcialmente reformadas.

A reforma das instalações do Laboratório de Informática foi executada pela empresa Lumina, sob responsabilidade do eng. Marcio Urbani, com 
acompanhamento das arquitetas Eunice Bruno (do GEEF) e Isis Roverso (mestranda FAUUSP).

A iluminação foi mantida e as instalações das tomadas foram trocadas: foi instalada régua para instalações na parede longitudinal da sala e as mesas da sala foram deslocadas, sendo que as mesas ficaram encostadas na régua para alimentação direta (conforme diretriz já apontada pelo levantamento que motivou a revisão do projeto elétrico). Foi instalada nova alimentação para essa sala, derivada de forma direta do quadro geral.

O trajeto dessa alimentação é o seguinte: a partir do quadro de entrada (ver fotos da figura 345), a nova instalação caminha aparente pelo teto do porão até uma caixa existente sob a escada (ver figura 348).
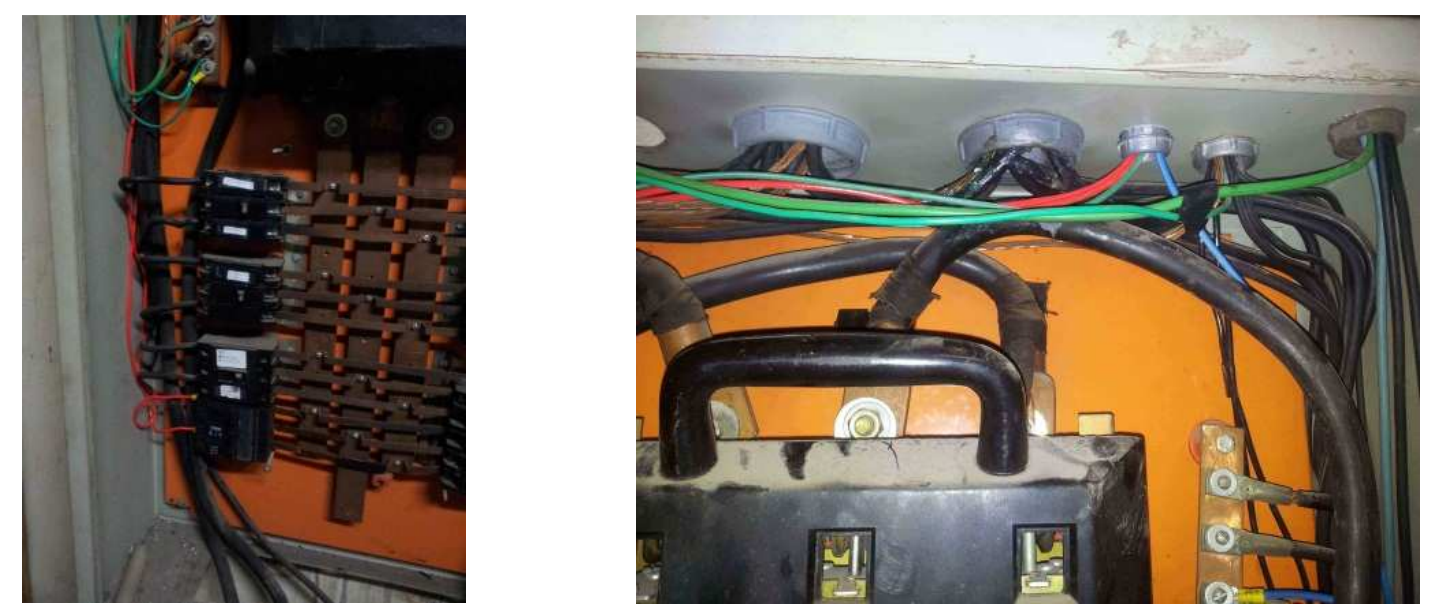

Figura 345 - Fotos do quadro geral, existente no porão, com novos disjuntores ligados ao novo circuito de alimentação do Laboratório de Informática

Fotos: Isis Roverso, outubro de 2011.

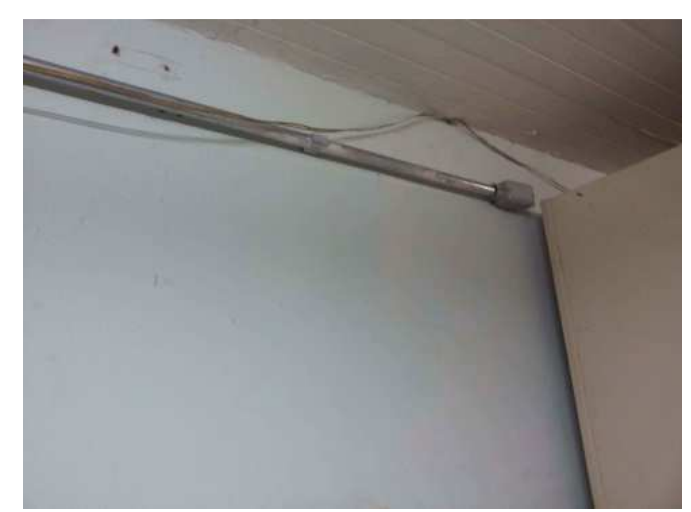

Figura 346 - Foto da saída dos cabos alimentadores por traz do quadro geral Foto: Isis Roverso, outubro de 2011. 

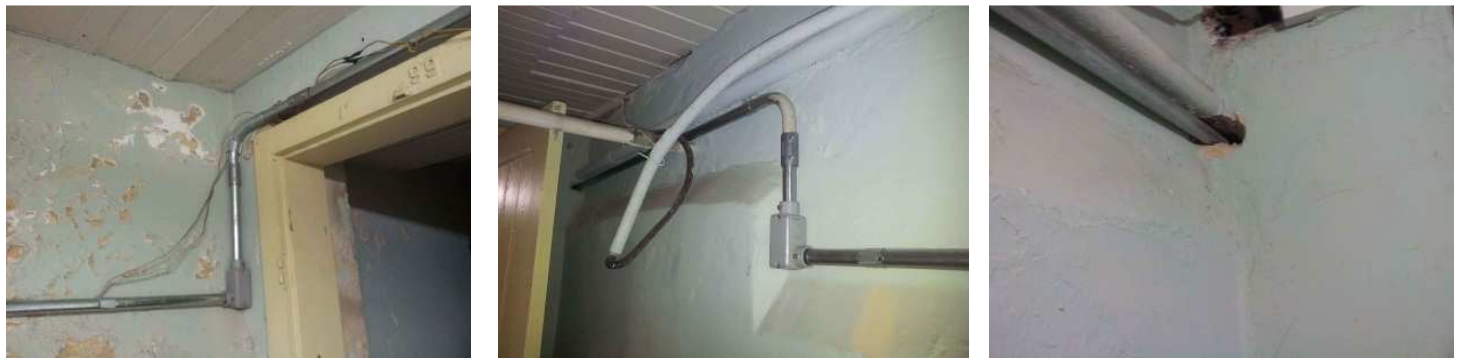

Figura 347 - Trajeto feito pelo porão dos novos cabos em eletroduto aparente Fotos: Isis Roverso, outubro de 2011.

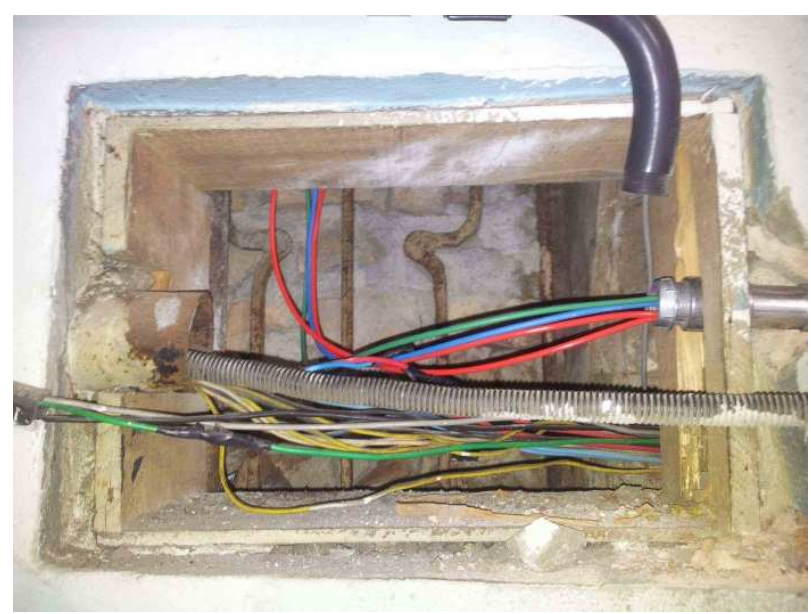

Figura 348 - Caixa existente sob a escada do porão com novos cabos para alimentação do Laboratório de Informática

Foto: Isis Roverso, outubro de 2011.

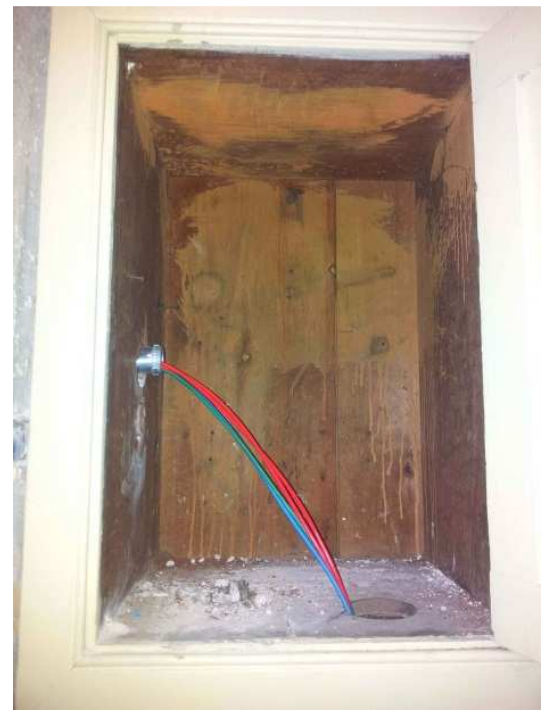

Figura 349 - Caixa existente no pavimento térreo ao lado da sala 08: serviu de passagem para os novos cabos de alimentação do Laboratório de Informática Foto: Isis Roverso, outubro de 2011.

A partir da abertura da caixa existente sob a escada do porão, a nova instalação chega ao quadro existente vazio no pavimento térreo (ver figura 349). No 
pavimento térreo, o trajeto é feito pela Sala 08 , passando pela saleta conjugada a Sala 08. Nessa saleta (Sala 03) foi feito um furo no teto que corresponde ao piso da saleta conjugada com o Laboratório de Informática. Nesse local foi instalado novo quadro elétrico (ao lado do quadro existente). A partir desse novo quadro, a alimentação da nova régua de tomadas foi distribuída pelo forro.
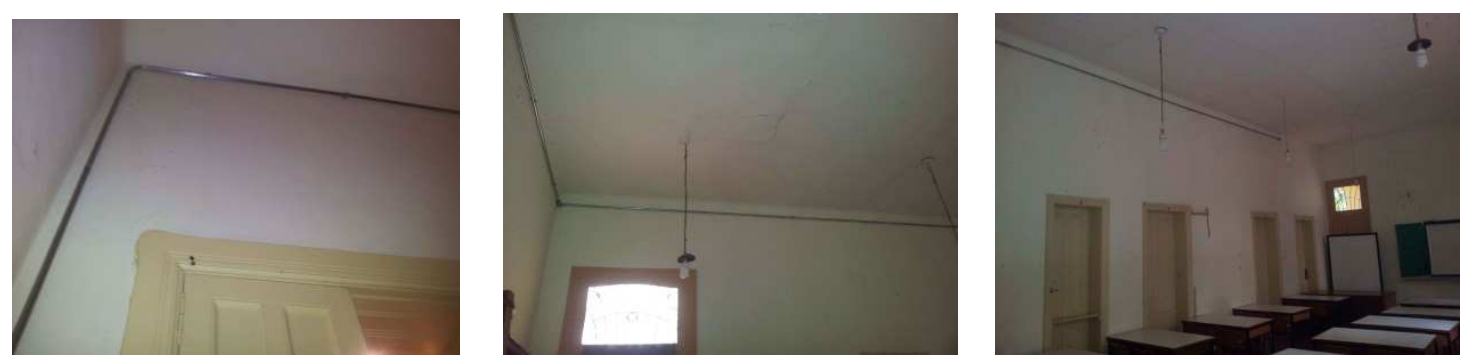

Figura 350 - Fotos do trajeto do novo eletroduto feito pela Sala 08 Fotos: Isis Roverso, outubro de 2011.

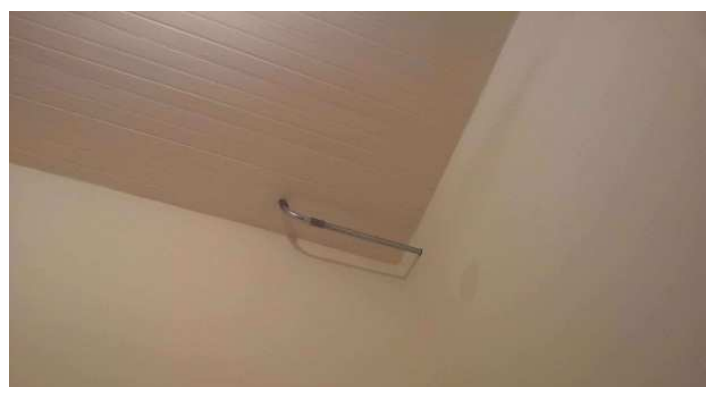

Figura 351 - Foto com passagem do eletroduto pela saleta conjugada a Sala 08 Nessa saleta (Sala 03) foi feito um furo no teto que corresponde ao piso da saleta conjugada com o Laboratório de Informática.

Foto: Isis Roverso, outubro de 2011.
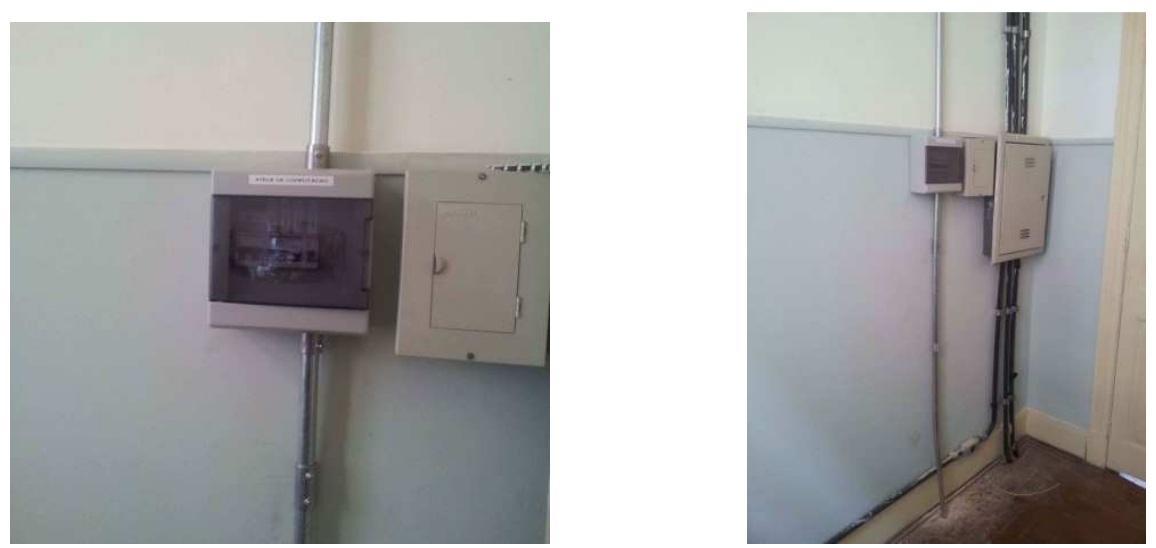

Figura 352 - Novo quadro elétrico instalado na saleta conjugada ao Laboratório de Informática (essa saleta fica sobre a Sala 03)

Fotos: Isis Roverso, outubro de 2011. 


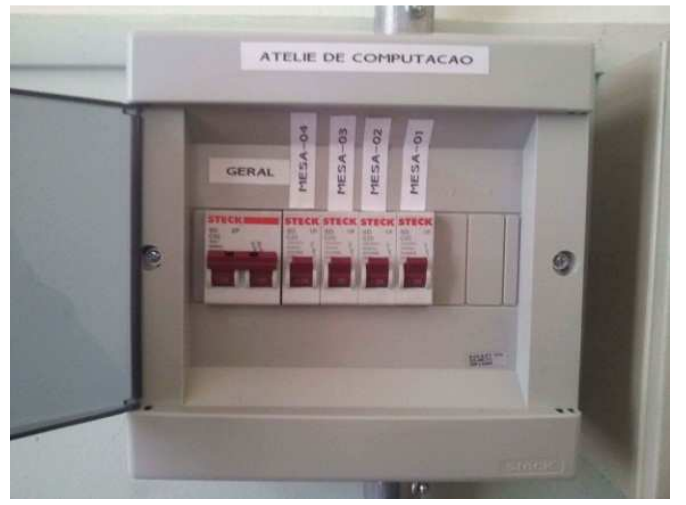

Figura 353 - Novo quadro elétrico para alimentação das tomadas do Laboratório de Informática

Foto: Isis Roverso, outubro de 2011.

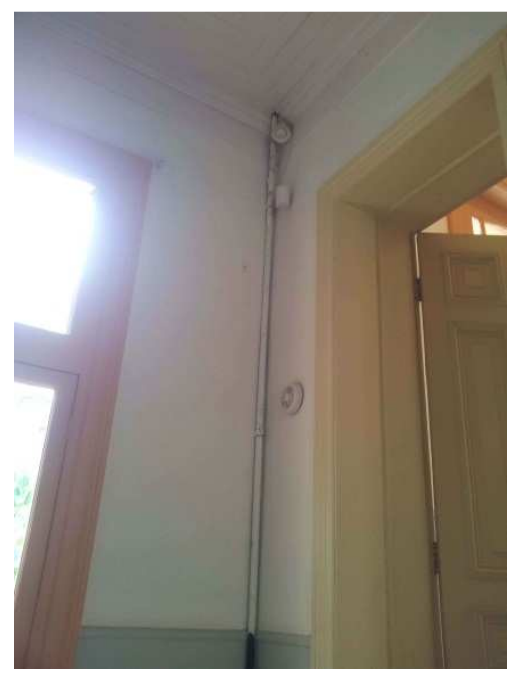

Figura 354 - A partir do novo quadro, a alimentação da nova régua de tomadas foi distribuída pelo forro

Foi usado o eletroduto vertical existente ao lado da porta de entrada do Laboratório de Informática.

Foto: Isis Roverso, outubro de 2011.

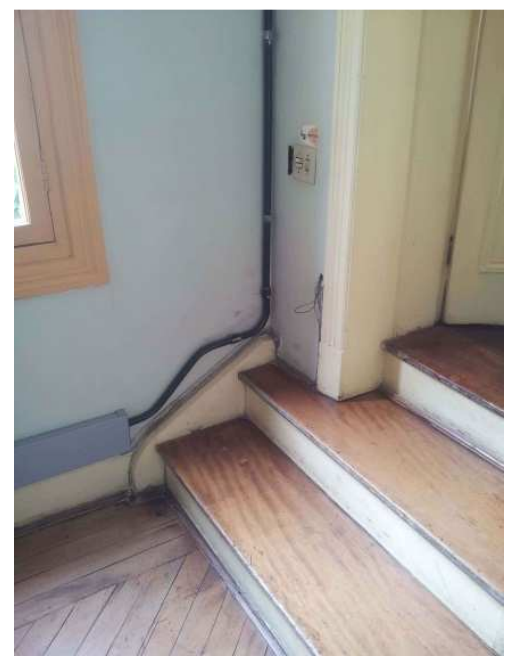

Figura 355 - Alimentação da nova régua de instalações elétricas Foto: Isis Roverso, outubro de 2011. 

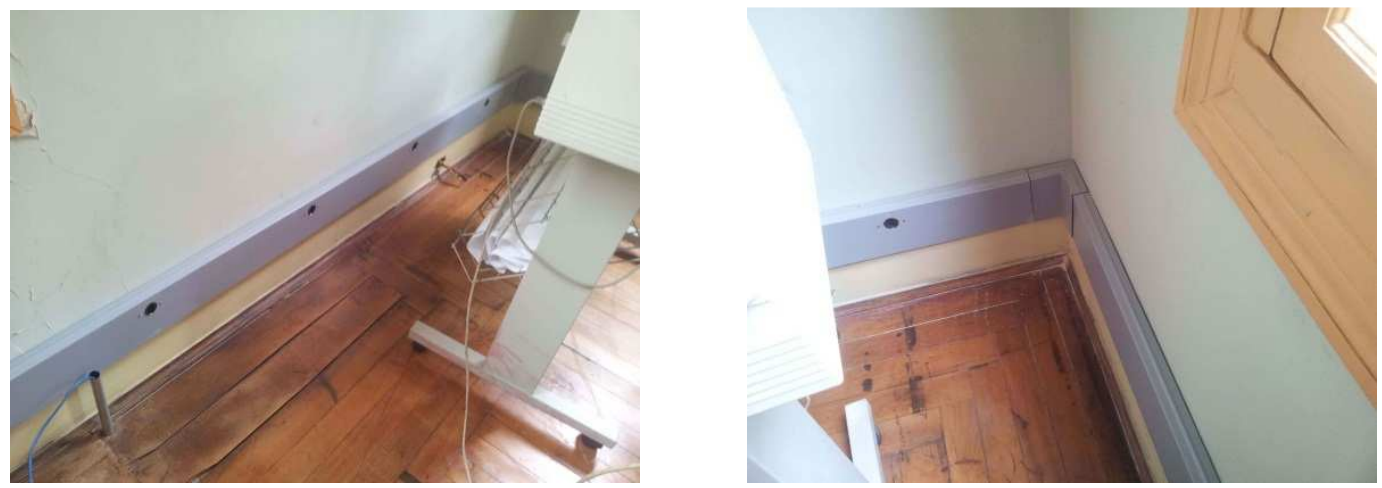

Figura 356 - Nova régua com tomadas para o Laboratório de Informática Fotos: Isis Roverso, outubro de 2011.

Foi feito um furo na parede da Sala 08, um furo entre a Sala 08 e a Sala 03 e um furo no teto da Sala 03, passando pelo piso da saleta conjugada ao Laboratório de Informática, para passagem da nova alimentação elétrica para o laboratório.

As instalações estão adequadas e podem ser observadas nas fotos das figuras 345 a 357.
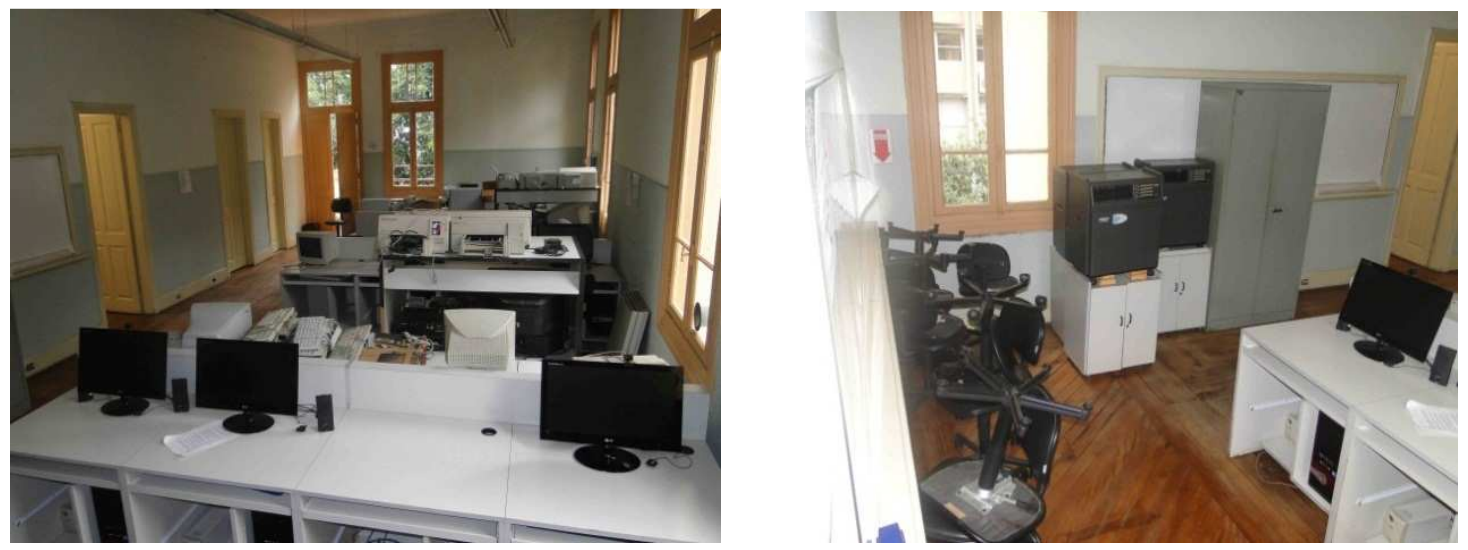

Figura 357 - Situação atual do Laboratório de Informática Fotos: Isis Roverso, novembro de 2011. 


\subsubsection{INSTALAÇÕES HIDROSSANITÁRIAS}

As instalações hidrossanitárias contemplam os sistemas de água fria e quente, esgoto, águas pluviais, combate a incêndios, gás combustível e demais fluídos, para edifícios com usos específicos.

No caso da Vila Penteado, as instalações de água e esgoto foram adequadas na década de 1940 para receber o curso de graduação da FAUUSP. E hoje apresentam diversas deficiências: os banheiros existentes não são acessíveis, as tubulações apresentam vazamentos e diversos trechos das instalações foram inutilizados visando evitar novos vazamentos.

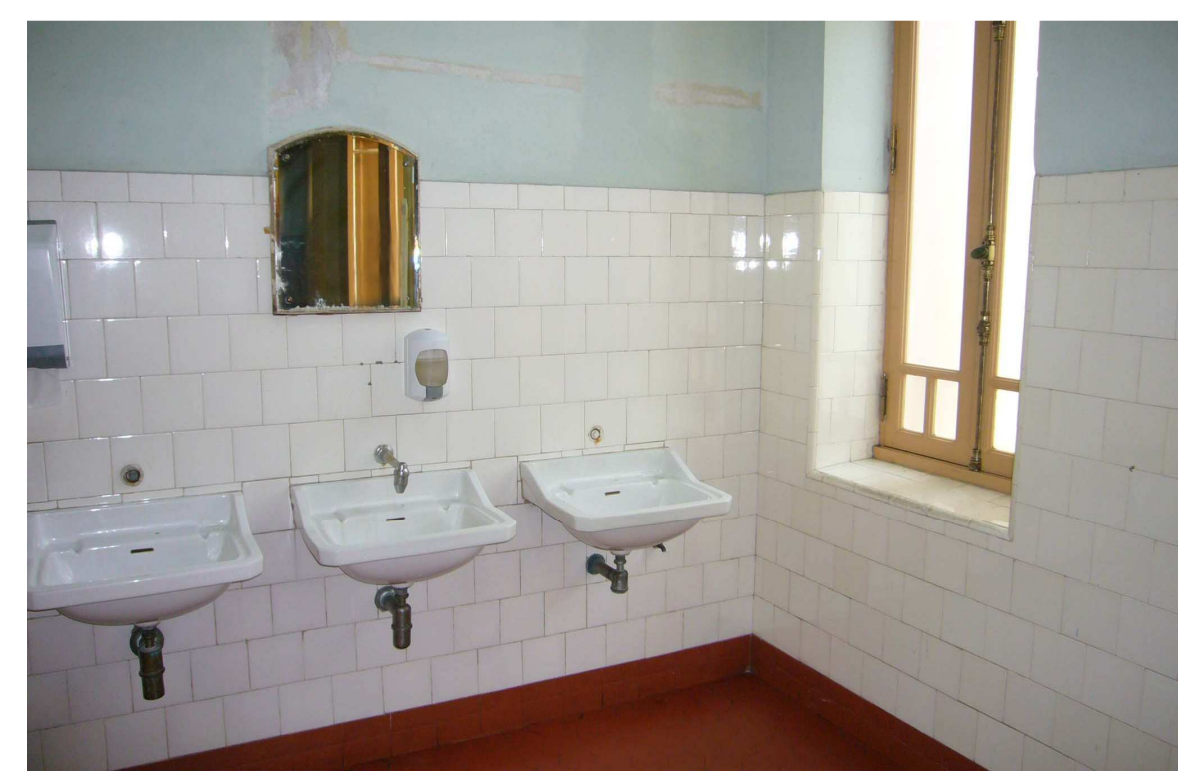

Figura 358 - Foto do Sanitário Masculino no Pavimento Térreo: destaque para a falta de duas torneiras

Foto: Isis Roverso, abril de 2011.

Faz-se necessário a realização de inspeção e reforma abrangente do sistema, visando a completa revisão da tubulação de distribuição de água fria, esgoto e ventilação. É importante ainda implementar recursos que visem a redução do consumo de água, evitando-se disperdícios, como é o caso da substituição das bacias sanitárias por bacias de volume de descarga reduzido (VDR) e a substituição das válvulas de descarga por válvulas econômicas.

As fotos das figuras 359 a 365 apresentam a situação atual do sistema hidrossanitário. 


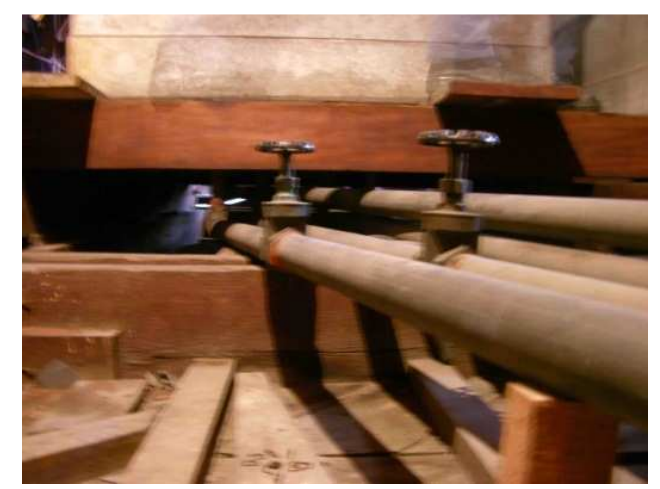

Figura 359 - Caixa d'água e tubulações na área do sótão da Vila Penteado Foto: Isis Roverso, junho de 2011.

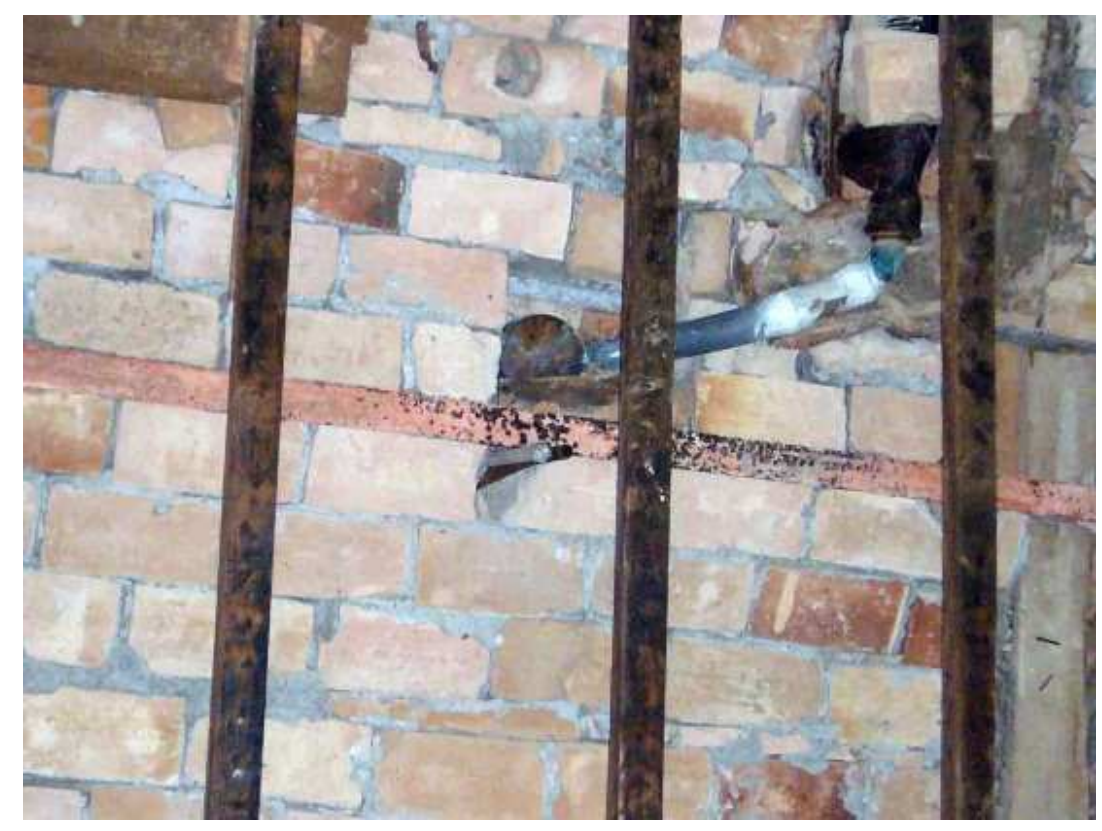

Figura 360 - Teto da Saleta S35

Foto: Isis Roverso, abril de 2011
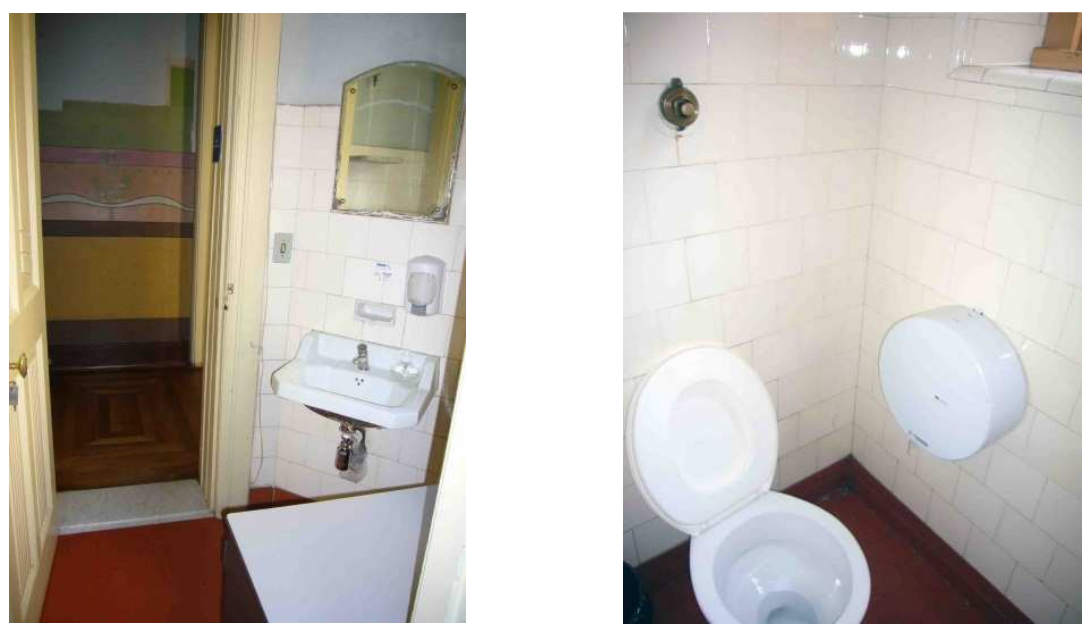

Figura 361 - Sanitário S21 e S22 (pavimento térreo) Fotos: Isis Roverso, abril de 2011. 

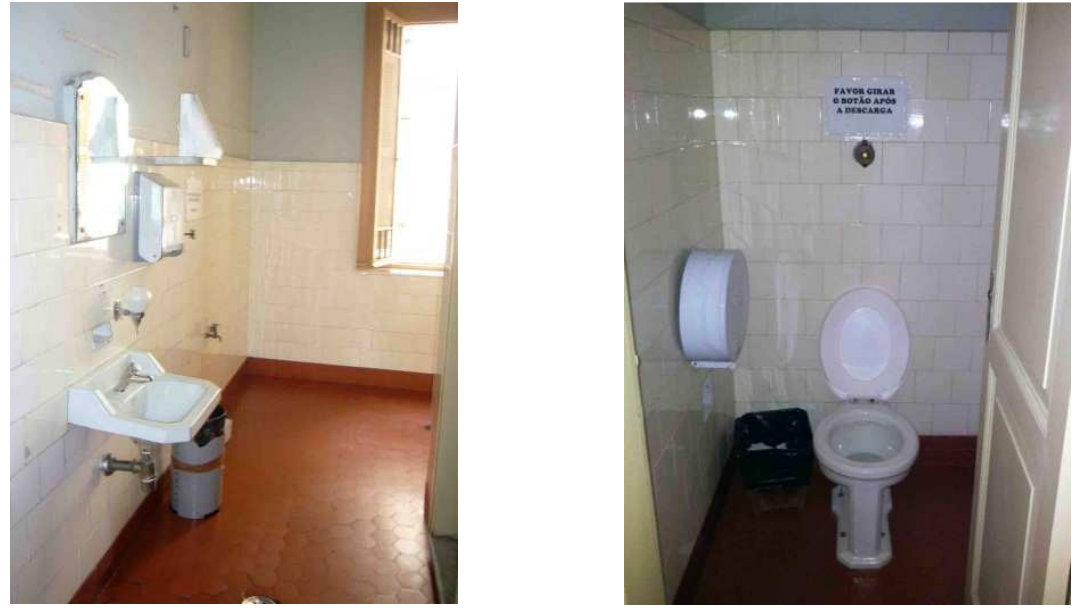

Figura 362 - Sanitário feminino (S75): aviso na válvula de descarga, indicando falha Fotos: Isis Roverso, abril de 2011 e janeiro de 2012.
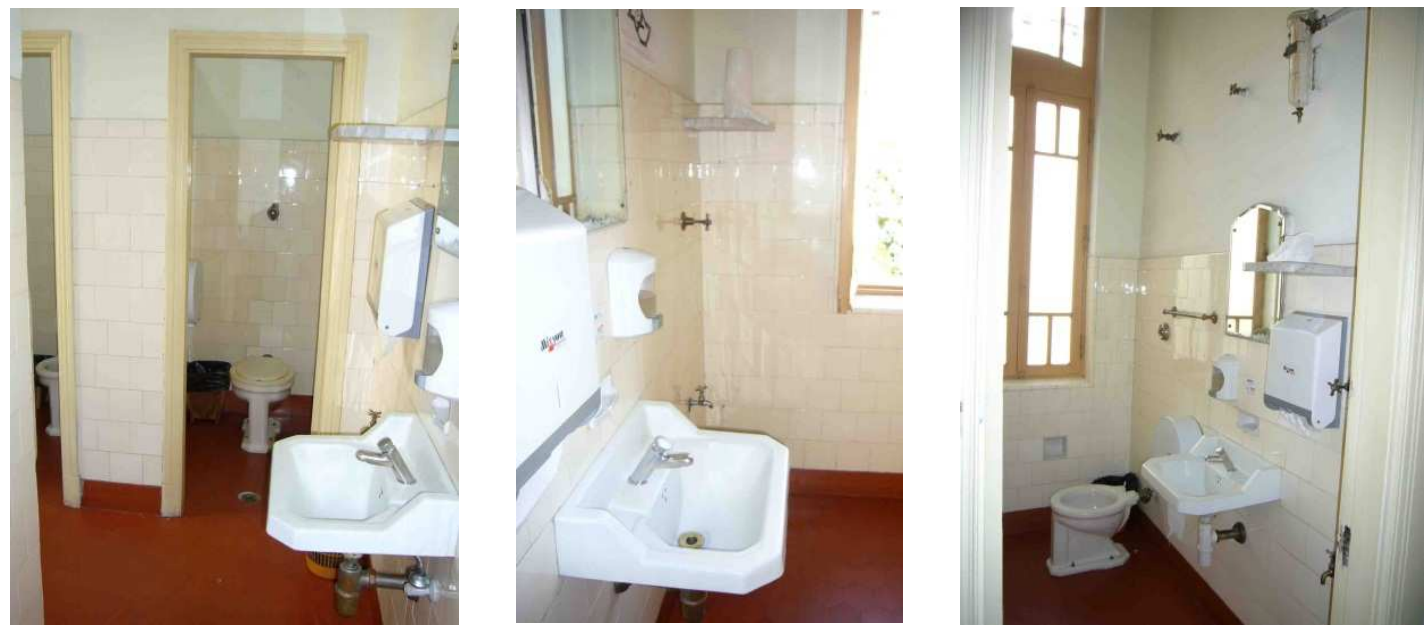

Figura 363 - Sanitários S45, S46 e S47 (pavimento superior) Foto: Isis Roverso, abril de 2011.

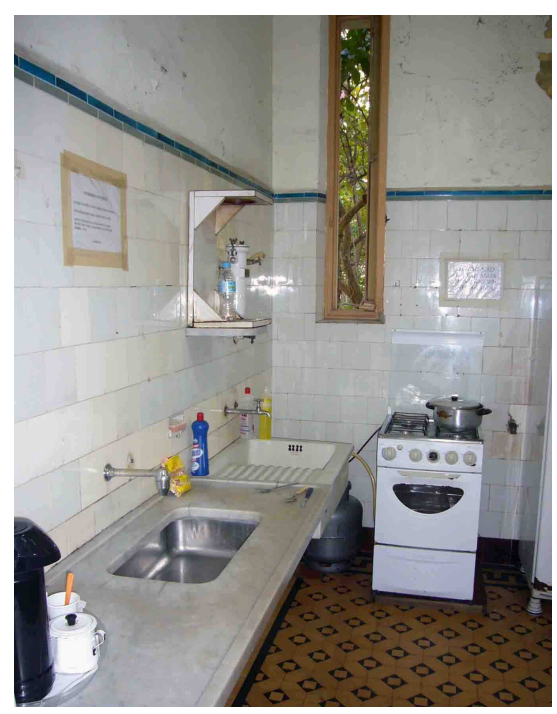

Figura 364 - Copa

Foto: Isis Roverso, abril de 2011. 

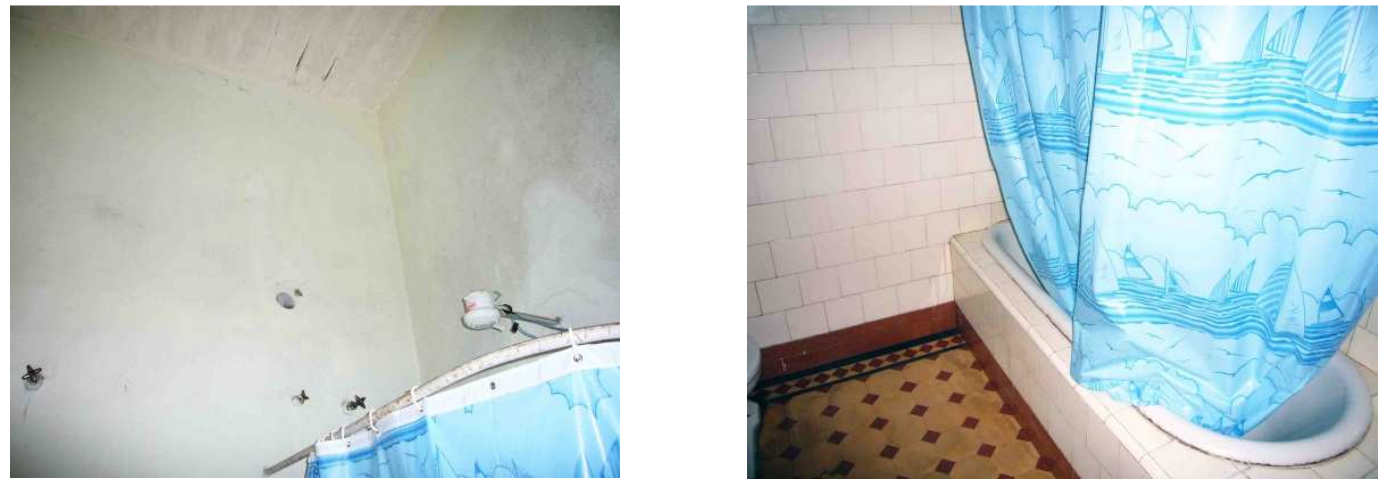

Figura 365 - Banheiro usado pelas funcionárias da Vila Penteado, em frente à área 10T Fotos: Isis Roverso, abril de 2011.

\subsubsection{INSTALAÇÕES DE CAPTAÇÃO DE ÁGUAS PLUVIAIS}

O sistema de captação de águas pluviais apresenta falhas construtivas, relacionadas ao desgaste do material e, principalmente, ao subdimensionamento das calhas e prumadas (para informações detalhadas sobre esse assunto, ver os itens 3.1.4 "O Edifício: Vila Penteado" e 3.2.1 "Documentos sobre a Cobertura").

A situação das calhas provoca infiltrações, que atingem os forros e estes vem apresentando degradação continuada. É necessário desenvolver, juntamente com o projeto de restauro da cobertura, o redimensionamento das calhas e prumadas de águas pluviais.

As figuras 366 a 368 apresentam detalhes desse sistema.
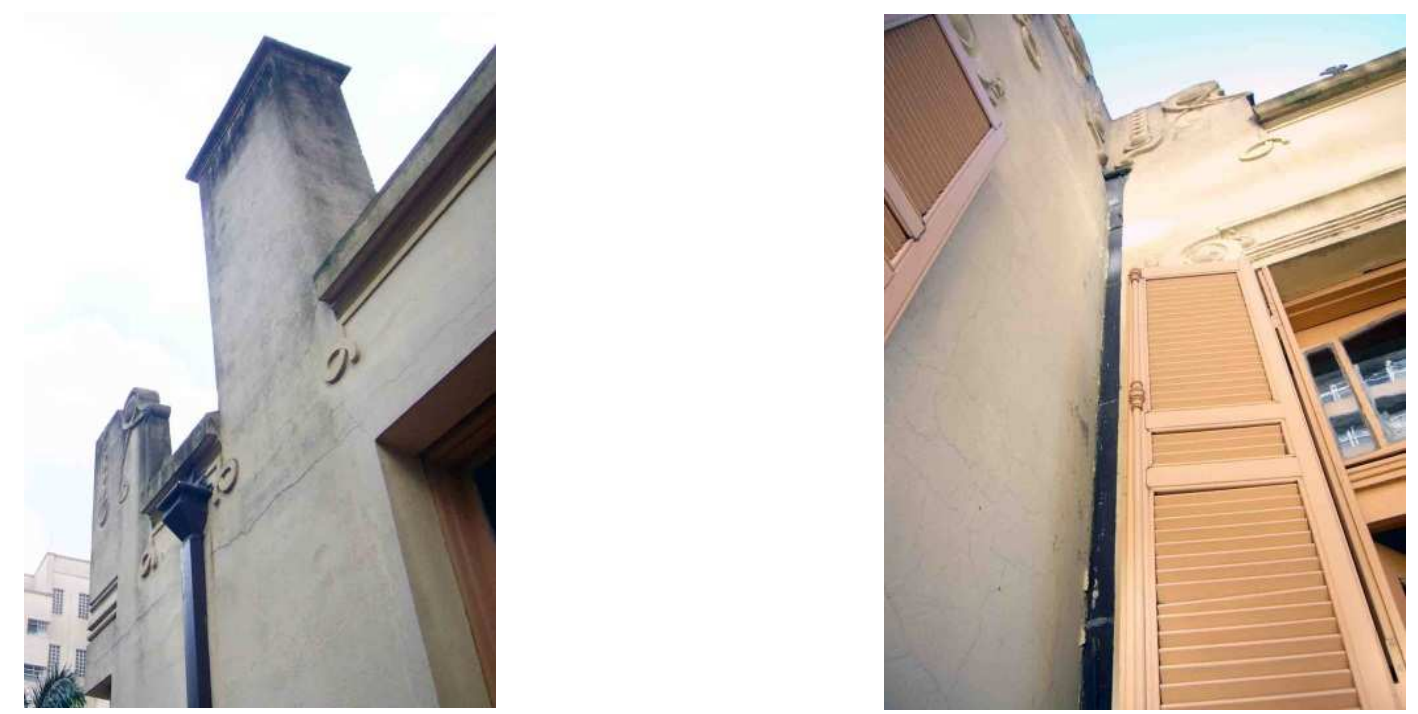

Figura 366 - Prumada de águas pluviais em cobre Fotos: Isis Roverso, abril de 2011. 

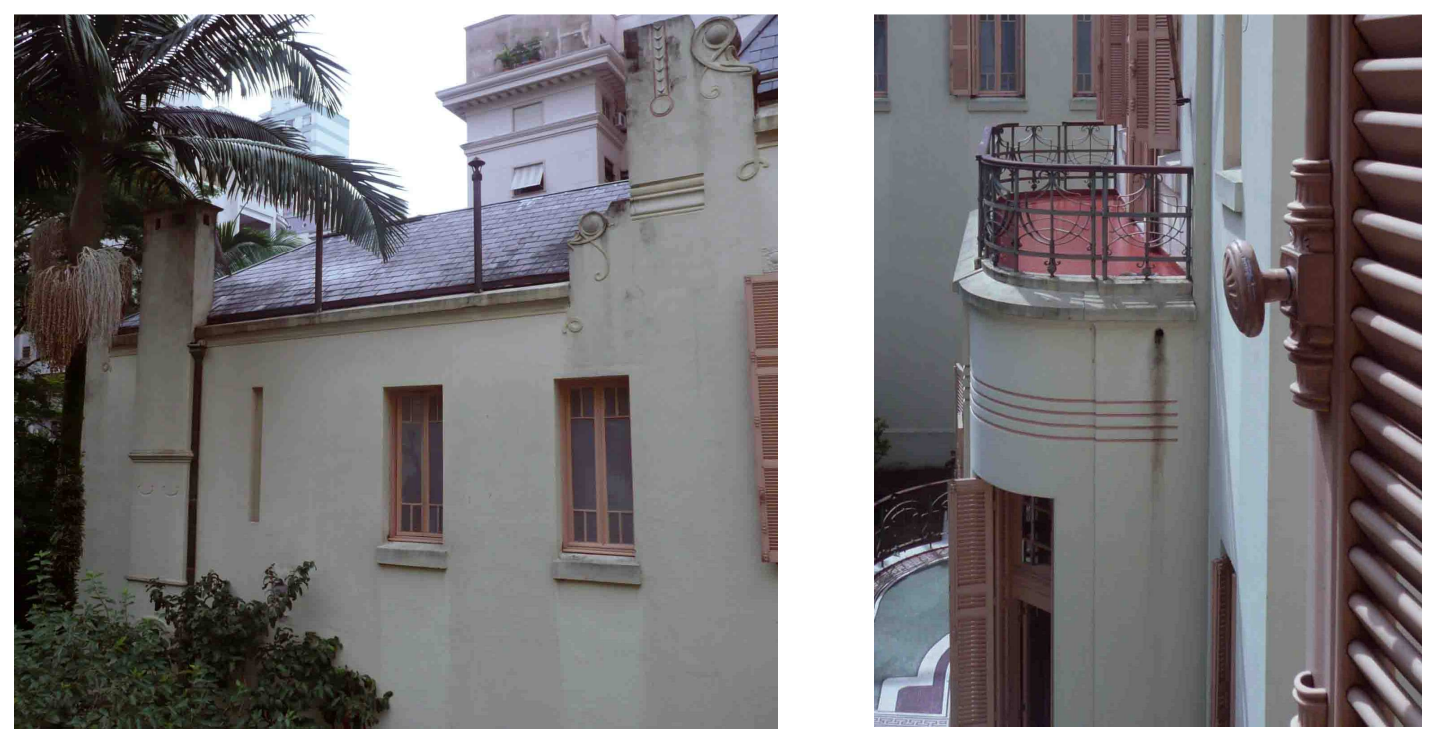

Figura 367 - Instalações de águas pluviais

$\mathrm{Na}$ foto à esquerda: fachada com prumada de águas pluviais a partir da cobertura. $\mathrm{Na}$ foto à direita, saída de águas diretamente pela lateral do terraço, provocando escurecimento do paramento

Fotos: Isis Roverso, dezembro de 2010.
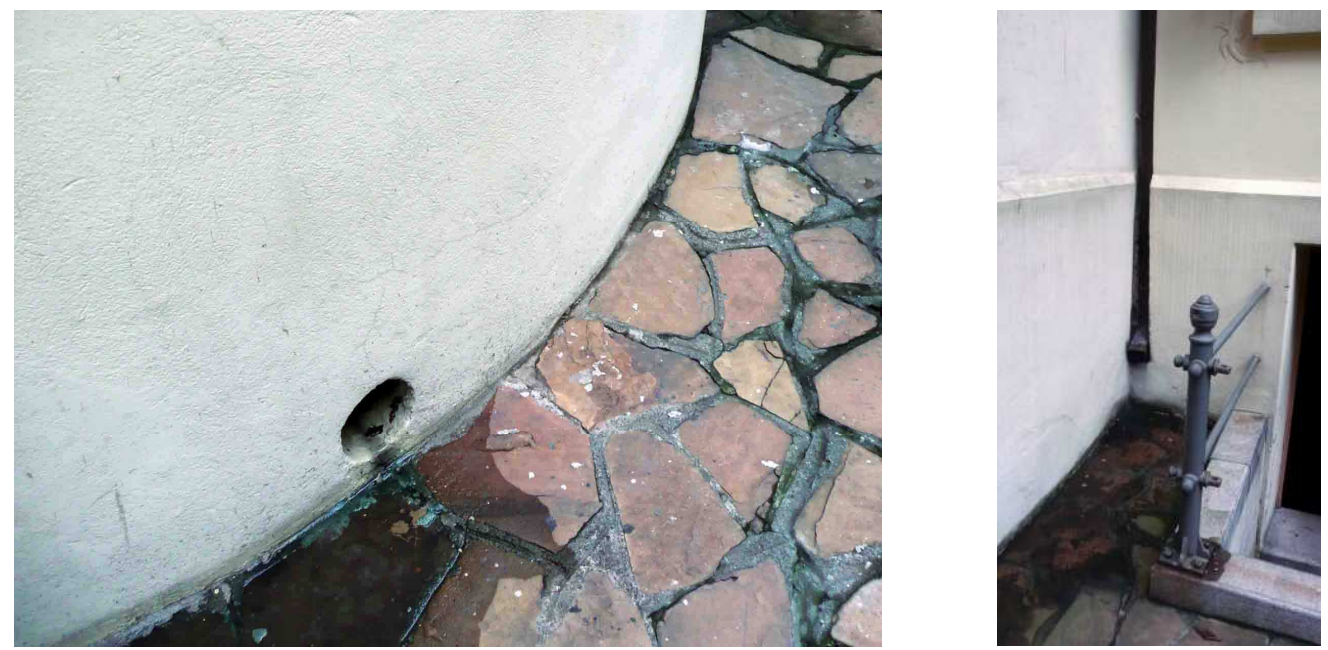

Figura 368 - Saída de águas pluviais em direção ao piso externo Fotos: Isis Roverso, dezembro de 2010. 


\subsubsection{INSTALAÇÕES DE PREVEnÇÃo E COMBATE A INCÊNDIOS}

Com relação à segurança contra incêndios, o $3^{\circ}$ Relatório sobre "Avaliação das condições de segurança contra incêndio e de uso dos edifícios da FAUUSP" é claro:

O edifício, construído em 1902, sofreu adaptações posteriores, ao ser ocupado como escola. Porém, não houve nenhum tipo de alteração física para a melhoria das condições de segurança ao longo dos anos, notando-se apenas a instalação de extintores portáteis de incêndio em várias áreas e reformas nas instalações elétricas prediais, do fim da década de $1980 .{ }^{120}$

Após esse relatório, houve apenas a inclusão, em 2011, de detectores de fumaça em pontos estratégicos do porão e do sótão do edifício. Dessa forma, a elaboração de um projeto de prevenção e combate a incêndios é algo necessário e urgente.

Em diversos locais na Vila Penteado é possível verificar a existência de extintores de incêndio, entretanto, falta à identificação desses equipamentos, assim como treinamento adequado, visando formar a brigada de incêndio.
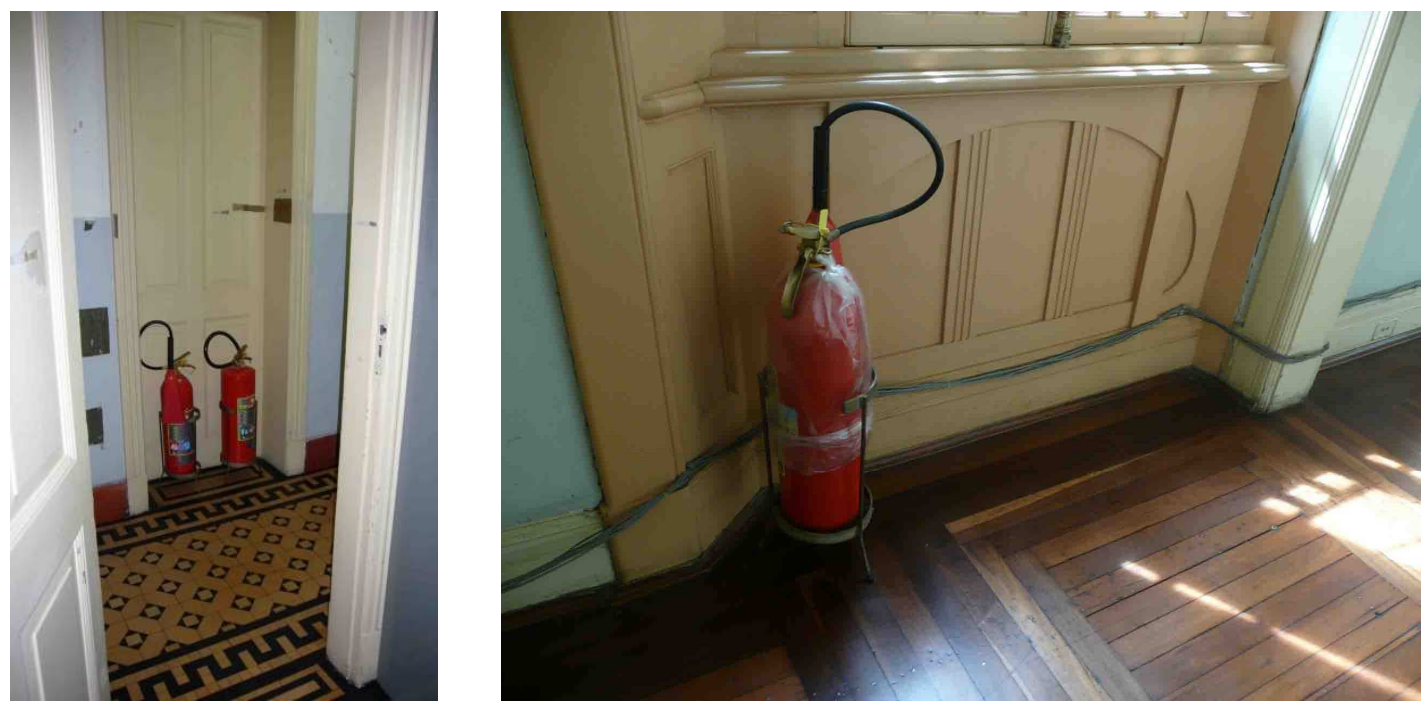

Figura 369 - Extintores de incêndio Fotos: Isis Roverso, abril de 2011 e dezembro de 2010.

${ }^{120}$ Avaliação das condições de segurança contra incêndio e de uso dos edifícios da FAUUSP - 3ํㅜ Relatório - Edifício Vila Penteado. NUTAU/USP Núcleo de Pesquisa em Tecnologia da Arquitetura e Urbanismo da Universidade de São Paulo, 22 de março de 2004. Equipe técnica: Prof ${ }^{\mathrm{a}}$ Dra. Rosaria Ono - FAUUSP e NUTAU/GSI - Coordenadora dos Trabalhos; Prof. Dr. Ualfrido Del Carlo - FAUUSP e NUTAU/GSI; Eng. Dr. Alexandre Itiu Seito - NUTAU/GSI; Cel. E Eng. Antonio Alfonso Gill NUTAU/GSI. 

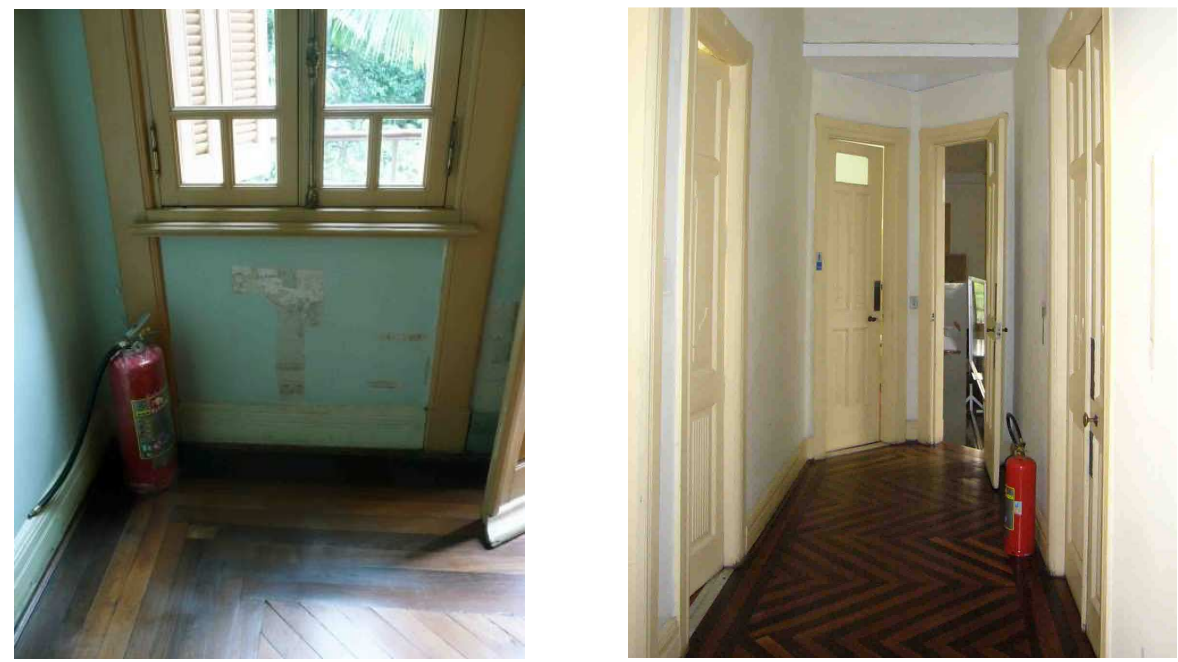

Figura 370 - Extintores de incêndio

Fotos: Isis Roverso, dezembro de 2010 e abril de 2011.

É necessário incluir sinalização identificando as rotas de fuga, assim como incluir um sistema de iluminação de emergência e alarme.

Em função dos materiais estruturais e de revestimentos empregados no edifício Vila Penteado, a carga combustível do mesmo é elevada. O acervo da Biblioteca, assim como os demais materiais armazenados, também constitui em elementos combustíveis. Visando diminuir a quantidade desse tipo de material e ainda facilitar os acessos, propiciando rotas para abandono do edifício, as áreas do porão deverão ter seu uso controlado. Disciplinar o uso do pavimento subterrâneo irá auxiliar o controle da carga de incêndio e melhorar as condições de rota de fuga pelas saídas de emergência.
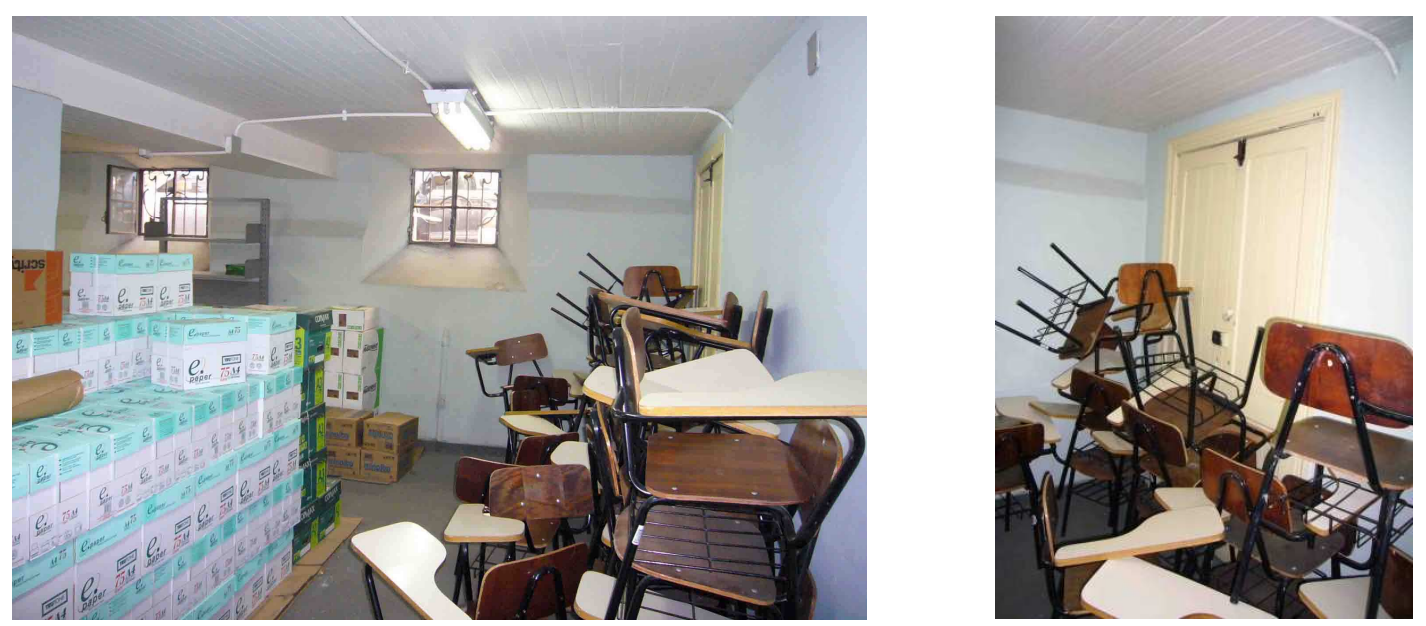

Figura 371 - Área do Porão com exceto de material combustível

Fotos: Isis Roverso, abril de 2011. 


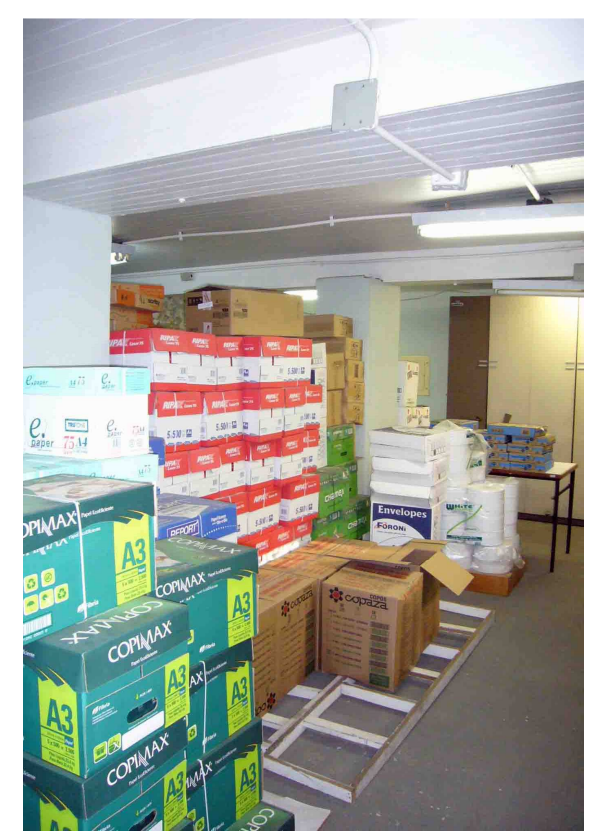

Figura 372 - Área do Porão com exceto de material combustível Fotos: Isis Roverso, abril de 2011.

Mas, não é apenas no porão que há guarda excessiva de material, diversos outros locais da Vila Penteado são usados como depósito. Essas pequenas salas guardam, principalmente, papéis na forma de documentos e publicações.
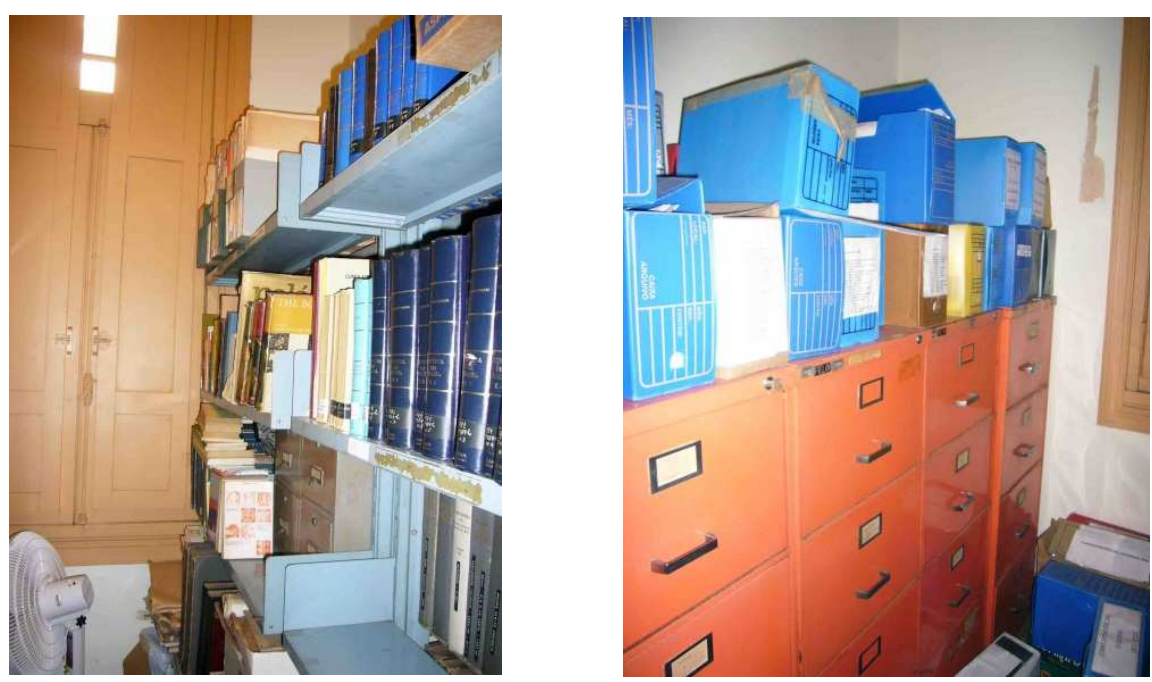

Figura 373 - Saleta 2, conjugada a Sala 8 e, à direita, Saleta 3, também anexa a Sala 8 Fotos: Isis Roverso, abril de 2011. 

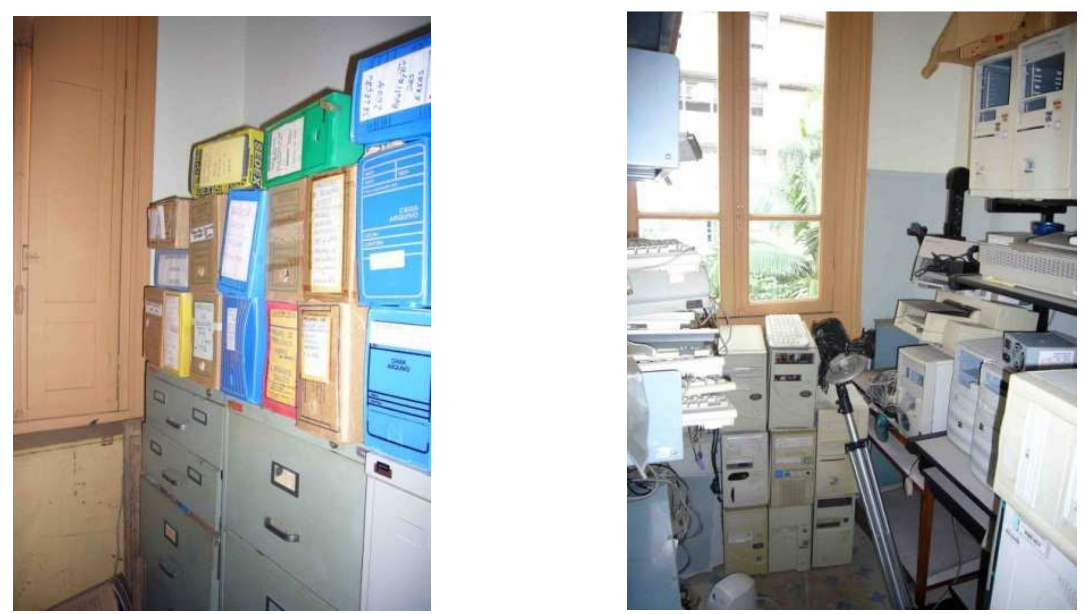

Figura 374 - Saleta 3, anexa a Sala 8 e Saleta S78b, conjugada ao Laboratório de Informática

Fotos: Isis Roverso, abril de 2011.

No porão, área SUB-1, há um antigo equipamento que servia para bombear água de uma cisterna, que se encontra abaixo dessa área. Após verificações do estado de conservação e implicações para a estrutura dessa região, essa cisterna poderá servir de reserva de água para incêndio, visando alimentar os hidrantes. Dessa forma, quando da instalação dos hidrantes, a reserva de incêndio não precisará ser alocada no sótão, gerando sobrecarga não prevista inicialmente.

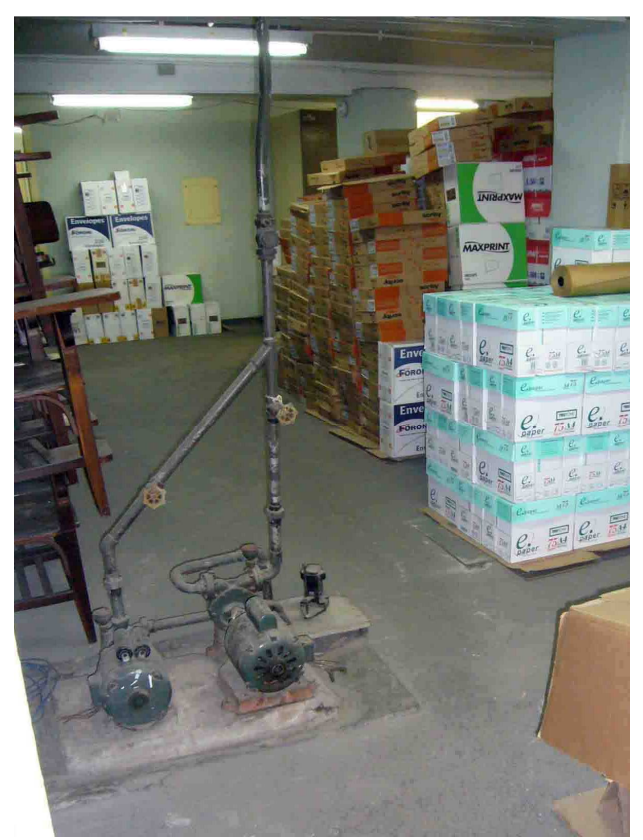

Figura 375 - Área SUB-1 do porão: equipamento obsoleto sem uso em primeiro plano e, abaixo do piso, antiga cisterna

Fotos: Isis Roverso, abril de 2011. 



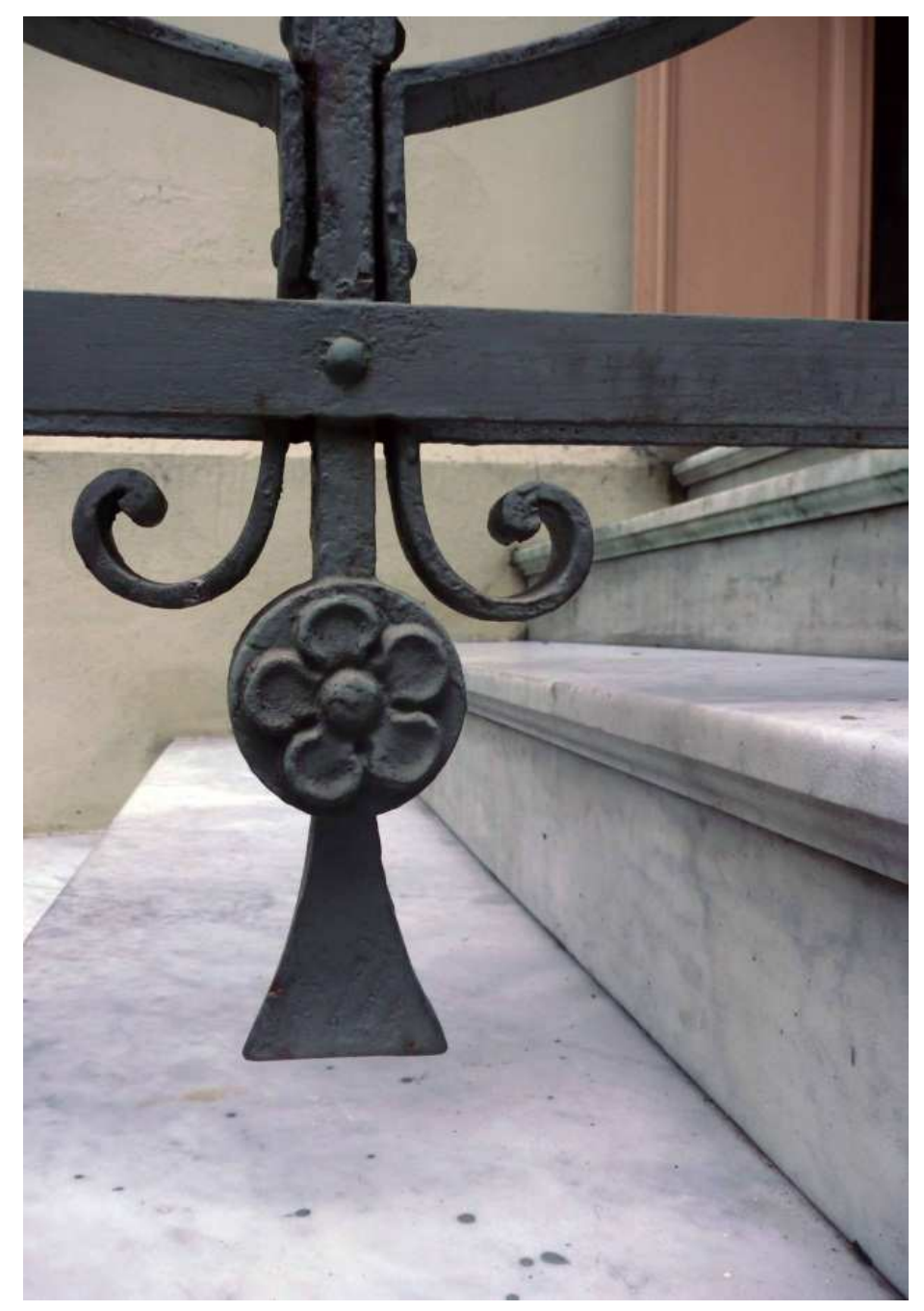

Figura 376 - Detalhe do guarda-corpo da escada externa Foto: Isis Roverso, dezembro de 2010.

\section{CAPÍTULO 5:}





\section{DIRETRIZES E OPERACIONALIZAÇÃO DA MANUTENÇÃO E CONSERVAÇÃO PREDIAL}

O quinto capítulo apresenta as diretrizes obtidas pela análise de desempenho técnico-construtivo, ponderada pelos princípios da preservação, com o objetivo de traduzir essas diretrizes em ações que viabilizem a operacionalização da manutenção programada de edifícios com restrições ao uso e ocupação.

No item 5.1 são apresentadas diretrizes gerais, que decorrem dos principais desafios e dificuldades enfrentadas para a manutenção e conservação de bens tombados, especialmente dos bens públicos. Embora algumas reflexões sejam baseadas nos estudos da Vila Penteado, essas diretrizes aplicam-se ao patrimônio arquitetônico de forma geral.

No item 5.2 são apresentadas diretrizes específicas, para a operacionalização da manutenção predial do edifício Vila Penteado. Essas diretrizes específicas visam recuperar o nível mínimo de desempenho, especialmente de requisitos relacionados à segurança patrimonial e dos usuários. As ações são propostas visando a extensão da intervenção necessária, organizadas em ordem de prioridade e ponderadas pelos princípios da preservação patrimonial.

\subsection{DIRETRIZES GERAIS}

Como já verificado no Capítulo 2, a ponderação da análise de desempenho pela preservação traz diretrizes claras, que podem ser resumidas nos itens a seguir:

a. A manutenção continuada é almejada ao invés da execução de maiores intervenções nas obras;

b. O patrimônio histórico condiciona a restauração, o que significa determinar limitantes para o uso do edifício, visando sua salvaguarda;

c. Os parâmetros (critérios e requisitos) de desempenho aplicados à preservação patrimonial alteram o sentido do desempenho, onde a plena funcionalidade do edifício é substituída por sua salvaguarda;

d. A análise sistêmica deve ser aprofundada nos aspectos históricos e documentais; 
e. A análise de desempenho em contrapartida com a qualidade das construções, revela os valores históricos e culturais específicos da obra a ser preservada.

As diretrizes resultantes da análise de desempenho, ponderada pela preservação, devem ser traduzidas em ações que viabilizem a operacionalização da manutenção predial. De forma prática, com auxílio do projeto de manutenção e das normas específicas, é possível traçar roteiros que subsidiem a manutenção.

A norma NBR 5674 (1999), no seu item 11, "Projeto e programação dos serviços de manutenção", traz as seguintes informações:

11.1 Os serviços de manutenção devem ser previamente projetados e programados.

11.2 O projeto de um serviço de manutenção deve incluir, entre outros:

a) especificações detalhadas dos materiais e procedimentos de execução;

b) desenhos e plantas, incluindo detalhes;

c) programação de atividades, incluindo, quando necessário, a previsão de estágios intermediários para o controle da qualidade dos serviços realizados;

d) dispositivos de sinalização e proteção dos usuários;

e) instruções para procedimento em caso de imprevistos;

f) o projeto deve prever acessos seguros a todos os locais da edificação onde sejam realizadas inspeções e serviços de manutenção.

Entre os desafios, para a implementação de ações de manutenção e conservação do patrimônio histórico, são destacados:

a. Execução de obras emergenciais;

b. Forma de contratação dos serviços pela administração pública;

c. Distanciamento das ações de intervenção prática em relação aos estudos pormenorizados do edifício e os conceitos teóricos;

d. Falta de valorização do orçamento necessário à manutenção predial, por parte da administração pública;

e. Indisponibilidade de mão-de-obra qualificada no mercado.

\subsubsection{PRESERVAÇÃO COMO FINALIDADE INSTITUCIONAL}

A definição da preservação do patrimônio arquitetônico, como atividade fim, notadamente das instituições de ensino, não deveria causar estranheza. $O$ respeito ao patrimônio deve ser ressaltado, afinal, os edifícios históricos são verdadeiras caixas únicas de conhecimento, são documentos únicos. 
"...Desafios como a habitação de interesse social, a interação entre a cidade, a paisagem e o meio-ambiente, a preservação e restauro do patrimônio construído, entre outros, constituem objeto de convergência tanto entre as humanidades, as artes e a tecnologia, que estruturam os departamentos da FAU, como entre as finalidades acadêmicas de ensino, de graduação e pós, de pesquisa e de cultura e extensão universitária...". 121"

Quando a manutenção e a conservação são preteridas pelo não reconhecimento da sua importância estratégica, os impactos são negativos. Principalmente, quando é necessário realizar obras emergenciais no patrimônio, para corrigir problemas que, quase sempre, estão associados a uma sucessão de falhas, que devem ser tratadas em conjunto.

Exemplos dos conflitos, entre a contratação de obras emergenciais e a forma de contratação de serviços pela administração pública, são descritos a seguir.

A análise dos processos relacionados com a Vila Penteado, processos arquivados na FAUUSP e COESF, demonstram, com grande frequência, pedidos para a contratação de serviços emergenciais. Esses pedidos, munidos pela urgência do problema a ser resolvido, acabam não dispondo de tempo adequado para a reflexão teórica, desenvolvimento e detalhamento de projeto e até mesmo para a realização do processo de licitação.

Essa situação pode ser observada, por exemplo, no Processo $\mathrm{N}^{0}$ 98.1.16.16.0, "Contratação de empresa prestadora de serviços de recuperação das tramas 3 e 4 dos telhados da FAUUSP, edifício a Rua Maranhão, $n^{\circ} 88$ Higienópolis". Quando da abertura desse processo, houve o preparo da documentação para licitação mediante carta convite. Entretanto, em função da urgência na contratação dos serviços de reparo nas tramas 3 e 4 dos telhados, foi feito pedido da dispensa de licitação, visando agilizar o início dos serviços de reparo:

Pelo presente solicito dispensa de licitação, em caráter de emergência, para
a contratação dos serviços de verificação, reparo e reposição na cobertura
da Vila Penteado, à Rua Maranhão 88 , sede de nossa Pós-Graduação.
Este pedido se funda no transbordamento das calhas, goteiras
generalizadas e sobrecarga nos forros de vários cômodos daquele edifício,
durante o temporal do último dia 03 e que se repetiram com o temporal de
ontem, dia 05 do corrente.

${ }^{121}$ Informação disponível em: http://www.usp.br/fau/cursos/index.html. Acesso em: 20 fev. 2012.

122 Of. GD/1298/FAU/060298 dirigido a Dr $^{\mathrm{a}}$ Nina Beatriz Stocco Ranieri (Chefe de Gabinete da Reitoria da Universidade de São Paulo), referente ao processo 98.1.16.16.0, datado em 06 de fevereiro de 1998, assinado pelo Vice-Diretor em exercício Murillo Marx. 
A esse pedido, com data de 06 de fevereiro de 1998, foi juntada justificativa técnica em 12 de fevereiro de 1998, sendo que o motivo é destacado a seguir:

[...] a cobertura da Vila Penteado de há muito necessita serviços de manutenção e substituição de peças e materiais danificados pelo tempo. As chuvas recentes em São Paulo deixaram a descoberto áreas razoáveis daquela cobertura, fazendo com que chova diretamente sobre o forro, que conduz a água da chuva para dentro do prédio, inviabilizando o seu uso parcial. ${ }^{123}$

Após a análise da situação por parte da assessoria jurídica, houve a dispensa de licitação, agilizando o processo de contratação da empresa prestadora de serviço, Qualimar Artmetal Engenharia e Gerenciamento Ltda.

Os trabalhos pontuais na cobertura foram realizados, e em seguida foi feita consulta pelo Prof. Dr. Júlio Roberto Katinsky (diretor da FAUUSP), para o Prof. Dr. Jacques Marcovitch (reitor da USP), sobre a possibilidade de ser autorizada a ampliação do contrato celebrado entre a FAUUSP e a empresa Qualimar, visando completar mais um trecho da cobertura danificada, baseado no que segue:

\begin{abstract}
Apesar do precaríssimo estado da cobertura, nossos recursos, no momento, em que foi solicitada a dispensa de licitação só cobriram $20 \%$ da cobertura do edifício constituindo-se em $50 \%$ do bloco central, justamente sob o qual desenvolveram-se 8 (oito) anos de trabalhos de restauro das pinturas parietais (e do forro mezanino norte) - restauro esse que pode-se dizer, único no Estado de São Paulo.

Atualmente, conseguimos os recursos para os outros $50 \%$ da cobertura, do bloco central, mas com a firma em trabalhos já em desenvolvimento, não será possível propor uma licitação para o restante dessa parte, a tempo de evitar as chuvas de outubro próximo. ${ }^{124}$
\end{abstract}

Sobre a consulta do Prof. Katinsky, a assessora jurídica, Maria Luiza Machado Granziera, apresentou amplos argumentos, baseados no artigo 24, inciso IV, da Lei 8.666/93 ${ }^{125}$ e no texto de Marçal Justen Filho ${ }^{126}$. A partir da Lei 8.666/93 é

${ }^{123}$ Carta do Prof. Dr. Augusto Mattei Faggin (AUH) para o Porf. Dr. Murillo Marx (Vice-diretor em exercício), datada em 12 de fevereiro de 1998.

${ }^{124}$ Texto constante da carta do Prof. Dr. Júlio Roberto Katinsky, diretor da FAUUSP, para o Prof. Dr. Jacques Marcovitch, Reitor da USP, datada em 29 de maio de 1998 , folha 60 do processo $n^{\circ}$ 98.1.16.16.0.

${ }^{125}$ Lei N ${ }^{\circ} 8.666$, de 21 de junho de 1993, Regulamenta o art. 37, inciso XXI, da Constituição Federal, institui normas para licitações e contratos da Administração Pública e dá outras providências. 
esclarecida a impossibilidade de um contrato feito por dispensa de licitação receber ampliação:

\begin{abstract}
Lei 8.666/93 estabelece, em seu artigo 24, as hipóteses de dispensa de licitação, estabelecendo o inciso IV que:

Art. 24

IV - nos casos de emergência ou de calamidade pública, quando caracterizada urgência de atendimento de situação que possa ocasionar prejuízo ou comprometer a segurança de pessoas, obras, serviços, equipamentos e outros bens, públicos ou particulares, e somente para os bens necessários ao atendimento da situação emergencial ou calamitosa e para as parcelas de obras e serviços que possam ser concluídas no prazo máximo de 180 (cento e oitenta) dias consecutivos e ininterruptos, contados da ocorrência da emergência ou calamidade, vedada a prorrogação dos respectivos contratos; ${ }^{127}$
\end{abstract}

E em relação ao entendimento das questões emergenciais e sua implicação no patrimônio a ser preservado, o texto de Marçal Justen Filho é citado pela assessora jurídica, na página 115, do Processo N 98.1.16.16.0: "Não basta alegar a existência da emergência, mas é necessário demonstrar que a contratação se afigura como instrumento efetivo de atendimento a tais carências"128. E na mesma página há ainda o destaque para o texto: "A contratação deve ser precedida de todas as justificativas não apenas sobre a emergência, mas sobre a viabilidade concreta de atender à necessidade pública." Ou seja, a contratação não pode ser baseada apenas da necessidade emergencial, é necessário garantir que a mesma seja adequada e que supra as reais necessidades da obra. O próprio texto de Marçal Justen Filho, constante na folha 113, do Processo $N^{0}$ 98.1.16.16.0 chama a atenção à finalidade da licitação:

A contratação administrativa pressupõe atendimento ao interesse público. Isso significa que a ausência da contratação representaria um prejuízo para o bem público. Se inexistisse um interesse público em risco, nem caberia intervenção do Estado. A atividade pública não pode ser suprimida ou

\footnotetext{
${ }^{126}$ Marçal Justen Filho, advogado formado pela UFPR em 1977 e doutor em Direito Tributário pela PUC-SP em 1985, é autor de diversos livros, dentre eles "Comentários à Lei de Licitações e Contratos Administrativos".

127 Trecho da Lei 8.666, de 21 de junho de 1993, constante no Parecer CJ.P.0834/98-RUSP, Consultoria Jurídica, 08 de julho de 1998, Assessora Jurídica Maria Luiza Machado Granziera, Parecer aprovado pelo Prof. Dr. João Alberto Schützer Del Nero, Procurador-Chefe, folhas 112 e 113 do processo $n^{\circ}$ 98.1.16.16.0.

${ }^{128}$ JUSTEN FILHO, Marçal. Comentários à Lei de Licitações e Contratos Administrativos. Rio de Janeiro: Dialetica, 1996, 4를 Ed, p. 152-154.
} 
diferia para o futuro. Afinal, essas são características inerentes à Administração Pública.

Na maioria dos casos em que o Estado vai contratar, há potencialidade de dano se inexistir contratação imediata. A contratação administrativa retrata a necessidade e a conveniência de uma atuação conjugada entre o Estado e terceiros. Uma interpretação ampla do inc. IV acarretaria, por isso, a dispensa de licitação como regra geral. $O$ argumento da urgência sempre poderia ser utilizado. ${ }^{129}$

Longe de apenas burocratizar as contratações, a licitação deve ser vista como instrumento que propicie a escolha adequada da empresa prestadora de serviços, ou de produtos e ainda mais,: deve conter, de forma clara e objetiva, a descrição pormenorizada dos serviços e materiais a ser contratados e comprados. A licitação deve estar integrada no planejamento global de ações que visam preservar o patrimônio público. Entretanto, fora de um contexto onde a visão sistêmica é empregada para nortear as ações, a licitação acaba sendo mais um transtorno ao processo.

No caso da cobertura da Vila Penteado, os serviços foram executados de forma parcial e até hoje o edifício sofre com os problemas apresentados pelo subdimensionamento das calhas, além de infiltrações e falta de suportes seguros, que viabilize o acesso de pessoas à cobertura, para a realização de inspeções e manutenções. O problema já era conhecido, mas não houve um projeto de restauro da cobertura organizado e executado antes das ações ocorridas nas áreas de forro. Esse descompasso das ações tem origens técnicas e administrativas, sendo que os problemas administrativos, por vezes, se sobrepõem as soluções técnicas.

$\mathrm{Na}$ consulta, já comentada, feita pelo Prof. Katinsky para o Prof. Dr. Jacques Marcovitch, sobre a possibilidade de ser autorizada a ampliação do contrato celebrado entre a FAUUSP e a empresa Qualimar, um grave problema administrativo é apresentado:

Apesar do precaríssimo estado da cobertura, nossos recursos, no momento, em que foi solicitada a dispensa de licitação só cobriram $20 \%$ da cobertura do edifício [...]

Atualmente, conseguimos os recursos para os outros $50 \%$ da cobertura, do bloco central [...]

Dessa forma, fica evidenciado que o problema já era conhecido, mas faltavam recursos para implementar as obras e, emergencialmente, foram iniciados os

${ }^{129}$ Ibidem, citado no Parecer constante do Processo № 98.1.16.16.0, folha 113. 
trabalhos, de forma inadequada (sem um projeto de restauro completo e sem instrumentos adequados para a contratação das obras) e em tempo inoportuno (analisando as datas dos documentos ${ }^{130}$, é notável que as obras se iniciaram logo após o período intenso de chuvas, o que deveria ter ocorrido antes desse período, evitando-se sérios danos aos sistemas do edifício).

Visando atender um problema pontual, grandes esforços são empreendidos, do ponto de vista operacional, financeiro e até em relação a recursos humanos (acompanhamento profissional), para a realização das obras emergenciais. Sem, no entanto, se obter os melhores resultados. Além disso, assim que as obras são feitas, os estudos são deixados de lado, por falta de perspectivas que indiquem sua continuidade, até o momento onde obras urgentes tem que ser executadas novamente.

Aprofundando um pouco mais a questão relacionada à administração pública, o texto do Dr. Antônio Carlos Cintra do Amaral ${ }^{131}$ explicita, de forma bem humorada, uma situação muito comum encontrada nos processos licitatórios e contratações:

\begin{abstract}
Permito-me contar uma antiga anedota, que ilustra bem esse aspecto do processo de contratação. Diz-se que, certa vez, um brasileiro foi a Lisboa e lá visitou um museu. Foi recebido por um guia, que passou a descrever o significado das peças que ali estavam expostas. Em determinado nicho, viu dois esqueletos, um grande e outro pequeno.

Perguntou: "De quem são esses esqueletos"? E o guia respondeu: "Este grande é de Camões". E o pequeno? "Este é de Camões quando era criança". No processo de contratação freqüentemente encontramos, na prática, uma situação semelhante. Este é o contrato que foi celebrado (Camões criança), este outro é o contrato que está sendo executado (Camões adulto). É claro que, muitas vezes, o contrato precisa ser alterado. Não estou dizendo que toda alteração contratual resulta de uma má gestão - seria absurdo dizê-lo -, mas que tem de haver muito cuidado com a juridicidade das decisões administrativas que alteram o contrato. Agora mesmo, no tocante às concessões de serviço público, costuma-se repetir um verdadeiro "slogan": "é indispensável cumprir os contratos para atrair
\end{abstract}

${ }^{130}$ O Processo $N^{\circ}$ 98.1.16.16.0 foi iniciado em 26 de janeiro de 1998, com a organização documental visando à licitação para contratação de empresa prestadora de serviços de recuperação dos telhados da FAUUSP, edifício à Rua Maranhão, 88. Quando as chuvas de início de ano provocaram agravamento dos problemas na cobertura e forro, foi feito o pedido de contratação com dispensa da licitação. Esse pedido ocorreu em 06 de fevereiro de 1998 e as obras foram iniciadas em 24 de abril de 1998 (com prazo de obras estabelecido em 70 dias corridos), conforme Contrato celebrado entre a Universidade de São Paulo, através da Faculdade de Arquitetura e Urbanismo e a empresa Qualimar Artmetal Engenharia e Gerenciamento Ltda., assinado pelo Prof. Dr. Júlio Roberto Katinsky, diretor da FAUUSP, pelo Eng. Jairo Abib Aiub, diretor técnico da empresa Qualimar, além das testemunhas.

${ }^{131}$ O Dr. Antônio Carlos Cintra do Amaral é Consultor e Parecerista em Direito Administrativo e Econômico, professor no Curso de Especialização em Direito Administrativo na PUC/SP (pós graduação 'latu sensu'), Diretor e Coordenador Geral do Centro de Estudos sobre Licitações e Contratos - CELC). 
investimentos da iniciativa privada". Costuma-se dizer que se precisa ter garantias de que os contratos não serão alterados. Mas isso não ocorre, nem irá ocorrer, é impossível que ocorra. Porque em contratos de duração, sobretudo nos de longa duração, como é que seus termos poderão manterse inalterados, abstraindo a dinâmica da realidade sócio-econômica na etapa de execução?

O que é intangível - e é isso que interessa à empresa privada contratada - é a equação econômico-financeira do contrato, ou seja, o equilíbrio econômico-financeiro do contrato. Essa equação deve ser respeitada, não mediante a imutabilidade do contrato - porque o princípio da mutabilidade é um dos princípios básicos dos contratos administrativos em geral - mas em nome do princípio do equivalente econômico [...]. ${ }^{132}$

O texto do Dr. Amaral deixa claro uma das dificuldades do processo, especialmente em relação à dinâmica da contratação. Mas esse descompasso entre as ações pode ser visualizado em diversas etapas do processo, por exemplo, quando o projeto (seja de reforma, restauro ou manutenção) de um sistema do edifício é detalhado, provavelmente o mesmo não é compatibilizado com os projetos dos demais sistemas, isso se deve, inicialmente, pela inexistência dos tais projetos. A falta da totalidade dos projetos necessários evidencia, inclusive, a inexistência do Programa de Necessidades, o que representa a carência dos princípios norteadores das ações. Supondo que os projetos estejam conceituados, detalhados e compatibilizados, o planejamento das obras esbarra com sérias dificuldades. A primeira delas diz respeito à ausência de recursos (realidade dos edifícios públicos) e ainda a falta de continuidade, constância, no recebimento dos recursos, quando eles existem. Estabelecendo que os recursos sejam resolvidos, para a concretização das obras, com a qualidade esperada, ainda é necessário superar os problemas relacionados à carência de mão-de-obra especializada (principalmente com relação ao desenvolvimento de obras em edifícios tombados) e a falta de acompanhamento adequado dos serviços.

\subsubsection{GESTÃO DAS INFORMAÇÕES}

A implantação de procedimentos e de um sistema de gestão das informações está associada aos desafios impostos pelo distanciamento das ações de intervenção prática e os estudos pormenorizados do edifício e os conceitos teóricos.

132 Trecho da palestra do Dr. Antônio Carlos Cintra do Amaral para o II Seminário de Direito Administrativo - TCMSP "Licitação e Contrato - Direito Aplicado", de 14 a 18 de junho de 2004. 
A transcrição dos conceitos teóricos para as pranchas dos projetos não é tarefa fácil. Da mesma forma que, entre as informações contidas nos projetos e a sua execução, diversos detalhes se perdem e com eles boa parte da qualidade das ações de intervenção. Isso se deve a diversos fatores, sendo que um deles refere-se à forma tradicional de apresentação gráfica dos sistemas usada até hoje, que não contempla, ou melhor, não evidencia as situações de conflito existentes, ou seja, nos desenhos em planta não é possível verificar as interferências tridimensionais, o que leva a uma simplificação das soluções e, no momento de execução das obras, diversos imprevistos surgem, imprevistos esses que poderiam ser identificados nos levantamentos cadastrais e documentação da obra.

Em relação aos projetos dos sistemas de instalações, a deficiência de entendimento do espaço é ainda maior, visto a prática apresentar um detalhamento extremamente simplificado, ou seja, os sistemas são representados com apenas um traçado em planta e algum desenho esquemático que, se bem construído, baseia-se numa perspectiva isométrica, mas por ser esquemático, esse desenho em perspectiva não carrega as interferências arquitetônicas dos espaços existentes edificados.

O conteúdo das normas relacionadas às instalações prediais e a formação do projetista de instalações, favorece o desenvolvimento de um projeto racional, objetivo e seguro, o que é bom e almejado, mas torna a visão do projetista limitada. Isso se deve ao fato do projeto tratar apenas do sistema em questão e acabar por deixar de lado o entendimento global do patrimônio arquitetônico.

Existem hoje diversas ferramentas que possibilitam o levantamento cadastral detalhado, como o uso, por exemplo, de equipamentos escâner a laser 3D. Em recente seminário de estudos sobre restauração arquitetônica, intitulado "Técnicas analíticas e de diagnóstico de bens culturais: experiências italianas recentes"133, 0 Prof. Dr. Nicola Santopuoli apresentou o papel das ciências na restauração, comentando sobre às técnicas analíticas e de diagnóstico, sobre os objetivos e desdobramentos dos estudos científicos, com destaque para as técnicas de termografia, refletografia e escâner a laser 3D. Entretanto, nem sempre é possível

${ }^{133}$ Nos dias 4 e 5 de novembro de 2010 esteve no programa de pós-graduação da FAUUSP o professor da Università degli Studi di Roma "Sapienza", Prof. Dr. Nicola Santopuoli, que conduziu o seminário intitulado "Técnicas analíticas e de diagnóstico de bens culturais: experiências italianas recentes", realizado na FAU-Maranhão. 
contar com equipamentos e recursos humanos para o diagnóstico do patrimônio arquitetônico, por meio das técnicas exemplificadas. Caso seja possível usufruir dessas técnicas, a análise dos resultados permanece indispensável, ou seja, a manipulação dos dados é imprescindível em qualquer levantamento, seja ele através de análise visual, medição manual e registro fotográfico ou através de equipamentos específicos. O trato com o material resultante deve ser criterioso e possibilitar 0 registro das questões teóricas. A tecnologia não dispensa a reflexão teórica, afinal os equipamentos não conseguem manipular as informações, para apresentar o entendimento da obra, tão necessário para tomada de decisões projetuais.

Mais do que obter informações, é necessário articular as mesmas, ou seja, para o cadastro de um edifício a ser preservado é necessário realizar o levantamento cadastral completo, desenhando todos os elementos com precisão, entretanto, a articulação arquitetônica dos elementos é tão, ou ainda mais importante do que a precisão dos detalhes. Inclusive a produção dos desenhos não deve ser algo automático, eles precisam ser projetados, afinal, até a altura de corte do desenho em planta é relevante para o cadastro correto do monumento histórico.

Resgatando algumas orientações, deixadas pelo Prof. João Carlos, na conferência "Tendências tradicionais de construção e conservação arquitetônica: alguns casos de estudo" ${ }^{34}$, para o trabalho com patrimônio arquitetônico, o edifício em questão deve ser estudado como se deve, onde uma lista de "sim" e de "não" orientam e limitam as possíveis intervenções. Essa lista deve ser justificada, favorecendo o processo guiado, que instruirá futuras intervenções.

Ainda é interessante ressaltar os comentários finais na conferência, onde o Prof. João Carlos mostrou certa indignação com o termo "requalificar", visto que os edifícios históricos têm suas qualidades próprias, e os projetistas atuais não tem o direito de dar novas qualidades aos mesmos. Com que direito a geração atual de profissionais pode agregar novos atributos a monumentos de valor tão amplo quanto o de escrever a história? É preciso trabalhar criticamente a fim de ser evitadas arbitrariedades.

Em todo o processo de análise e intervenção no patrimônio arquitetônico é possível cometer erros, entretanto, a análise criteriosa diminui muito essa

\footnotetext{
${ }^{134}$ A Conferência "Tendências tradicionais de construção e conservação arquitetônica: alguns casos de estudo", foi proferida pelo Prof. Dr. João Carlos de Oliveira Mascarenhas Mateus, do Centro de Estudos Sociais da Universidade de Coimbra e ocorreu na FAU Maranhão, no dia 13 de outubro de 2011.
} 
possibilidade, ou seja, tendo em mãos a documentação pormenorizada, as ações frequentes de manutenção podem ser programadas e os seus limites podem ser estabelecidos. As ações mais invasivas serão dotadas de crítica e caminharão ao largo da possibilidade de se cometer enganos. Dessa forma, as potencialidades do patrimônio são asseguradas e as intervenções passam a ter limites claros.

\subsubsection{GESTÃO DE RECURSOS}

A não valorização dos recursos orçamentários, destinados à manutenção predial e a dificuldade em identificar mão-de-obra qualificada no mercado, ou mesmo dentro das instituições, são reflexos da dificuldade, ou inexistência da gestão de recursos financeiros e humanos. E essas questões estão associadas à falta de planejamento que, por sua vez, é dependente de um profundo conhecimento do patrimônio para identificação das prioridades ao longo do tempo.

Segundo o documento que traça as diretrizes orçamentárias da USP, para o ano de 2012 (UNIVERSIDADE DE SÃO PAULO, 2011), devem ser destinados recursos para a manutenção predial na base de $\mathrm{R} \$ 20,00 / \mathrm{m}^{2}$. Aplicando os fatores de majoração proporcionais à idade (edifício com mais de 85 anos) e ao tipo de edifício (tombado pelo patrimônio histórico), o valor base para a Vila Penteado seria de $\mathrm{R} \$ 48,00 / \mathrm{m}^{2}$.

Há no documento citado - item 1.2.3 - instrução de que casos especiais de edifícios históricos tombados serão analisados especificamente pela Comissão de Manutenção Predial da Universidade. Porém a análise desses casos especiais apenas é viabilizada se houver uma argumentação consistente, fundamentada em estudos sistemáticos e orçamentos consistentes de curto, médio e longo prazo.

Analogamente, os recursos humanos devem ser qualificados e capacitados para atuar nas inspeções e ações rotineiras. E isso também requer investimento de tempo e recursos financeiros planejados para esse fim.

\subsection{DIRETRIZES ESPECÍFICAS}

Em relação ao edifício Vila Penteado, a operacionalização da manutenção predial pode ser organizada com a definição dos itens:

a. Frequência das inspeções e das ações de manutenção programada; 
b. Períodos de efetivação das ações de manutenção (em função das limitações específicas);

c. Infraestrutura necessária para a inspeção e execução dos serviços (equipamentos de suporte e segurança);

d. Verificação e registro das condições dos sistemas e das obras (visando documentar o monumento e alimentar $\mathrm{o}$ banco de dados sobre a cronologia e intervenções construtivas).

\subsubsection{FREQUÊNCIA DE INSPEÇÕES E AÇÕES DE MANUTENÇÃO}

A frequência ou periodicidade das inspeções deve ser específica para cada sistema do edifício, levando em consideranção, inclusive, as partes dos sistemas. As inspeções devem contar com formulários próprios, onde as listas de verificações devem ser claras e objetivas. A informação fotográfica é de grande valia para a alimentação do banco de dados.

Os níveis de inspeção, segundo a Norma de Inspeção Predial IBAPE/SP (2011), são os seguintes:

\section{CLASSIFICAÇÕES DAS INSPEÇÕES PREDIAIS}

7.1. QUANTO AO NÍVEL DA INSPEÇÃO

A Inspeção Predial poderá estar classificada de acordo com o nível pretendido do inspetor e da finalidade da mesma.

7.1.1 NÍVEL 1

Identificação das anomalias e falhas aparentes, elaborada por profissional habilitado.

\subsubsection{NÍVEL 2}

Vistoria para a identificação de anomalias e falhas aparentes eventualmente identificadas com o auxilio de equipamentos e/ou aparelhos, bem como análises de documentos técnicos específicos, consoante à complexidade dos sistemas construtivos existentes.

A Inspeção Predial nesse nível é elaborada por profissionais habilitados em uma ou mais especialidades.

\subsubsection{NÍVEL 3}

Equivalente aos parâmetros definidos para a inspeção de NíVEL 2, acrescida de auditoria técnica conjunta ou isolada de aspectos técnicos, de uso ou de manutenção predial empregada no empreendimento, além de orientações para a melhoria e ajuste dos procedimentos existentes no plano de manutenção.

As rotinas de inspeção podem estar pautadas na observação da evolução das falhas construtivas e, para casos mais graves, contar com a análise não destrutiva dos sistemas. Por exemplo, para obter-se conhecimento aprofundado da real 
situação das instalações elétricas da Vila Penteado é possível realizar a análise termográfica. Essa análise refere-se a uma técnica de inspeção, não destrutiva, realizada com a utilização de sistemas infravermelhos, para a medição de temperaturas ou observação de padrões diferenciais de distribuição de calor, com o objetivo de proporcionar informações relativas à condição operacional do sistema. Os objetivos das medições de termografia são os seguintes: identificar falha no contato nas emendas e conexões elétricas; identificar falhas internas dos componentes e equipamentos elétricos; identificar desequilíbrio de corrente no sistema; estabelecer o momento mais adequado para eventuais intervenções; aumentar a disponibilidade operacional dos equipamentos monitorados, reduzindo quebras não previstas e aumentar a confiabilidade operacional. A análise termográfica apresenta como resultado um relatório de dados que permite avaliar com maior rigor as instalações elétricas. No caso da Vila Penteado a necessidade de reforma geral do sistema elétrico é certa, entretanto, com a análise termográfica é possível conhecer melhor os problemas atuais do sistema, o que é útil para pautar as ações de manutenção emergencial.

A periodicidade das ações de manutenção corresponde às necessidades dos sistemas, conforme situação existente dos materiais, do risco a que submete o usuário e do risco ao patrimônio.

Traduzidas em termos práticos, as inspeções podem ser:

a. Realizadas por meio de observações dos usuários frequentes que, com o olhar apurado, reconhecem, nos mais simples detalhes, ameaças à integridade do patrimônio ou à segurança das pessoas; tais observações e o seu registro devem ser estimulados;

b. Realizadas visual e rotineiramente por funcionário da própria instituição, treinado para o monitoramento e documentação;

c. Realizadas de forma geral por funcionário treinado, nos principais sistemas do edifício (estrutura, cobertura, instalações etc) anualmente ou após eventos isolados, ou ocorrências que, pela experiência, trazem consequências sérias: chuvas intensas, ventos com velocidades acima da média local, granizo etc. Para as vistorias gerais recomenda-se, além da análise visual por funcionário treinado, o uso de técnicas de ensaio não destrutivo; 
d. Realizadas por meio de vistorias detalhadas, por funcionário treinado ou por técnicos especializados e acompanhadas por funcionário treinado, cuja frequência deve ser compatível com a expectativa da vida útil dos materiais, sobretudo dos materiais de acabamento; tais vistorias não devem ser superiores ao período de cinco anos.

\subsubsection{PERÍODOS DE EFETIVAÇÃO DAS AÇÕES DE MANUTENÇÃO}

Com relação aos períodos de efetivação das ações de manutenção, é necessário elencar as limitações específicas. As limitações correspondem aos períodos, meses ou ainda horários onde as obras de manutenção se tornam inviáveis, em função do uso do edifício, ou ainda em função de agendes externos, tais como: período de com chuvas intensas (obras internas no edifício devem ser executadas no início do ano, por ser o período chuvoso, enquanto que as obras externas devem ser realizadas no meio do ano, por ser período mais seco em São Paulo).

\subsubsection{INFRAESTRUTURA}

A infraestrutura necessária para a inspeção refere-se aos equipamentos de suporte e segurança e, no caso da Vila Penteado, estão relacionados, por exemplo, a compra ou locação de andaimes ou plataforma elevatória pantográfica, que possibilitem a verificação e manutenção programada da cobertura, e ainda a criação de pontos de apoio para a fixação de cintos de segurança. Além dos demais equipamentos de proteção individual obrigatórios.

\subsubsection{VERIFICAÇÃO E REGISTRO}

A partir da verificação e registro das condições dos sistemas, é possível estabelecer as prioridades das ações, onde a ordem de inscrição dos sistemas danificados deve ser decrescente, visando destacar os sistemas mais prejudicados ou ainda aqueles que, em função das falhas constatadas, oferecem maior risco aos usuários ou ao patrimônio. 
A Tabela 6 apresenta um exemplo, onde as prioridades das obras de conservação e restauro da Vila Penteado são registradas de forma prioritária, contendo sua justificativa em função da razão (finalidade) de sua execução.

\begin{tabular}{|c|c|c|c|}
\hline \multirow{5}{*}{ 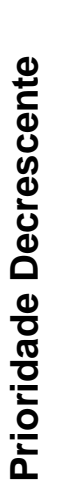 } & Conservação e Restauro & Risco & Finalidade \\
\hline & $\begin{array}{l}\text { Cobertura e Captação de } \\
\text { Águas Pluviais }\end{array}$ & $\begin{array}{l}\text { Ao patrimônio e } \\
\text { ao usuário }\end{array}$ & $\begin{array}{l}\text { Garantia da estanqueidade do edifício, } \\
\text { resguardando os demais sistemas }\end{array}$ \\
\hline & Instalações Elétricas & $\begin{array}{l}\text { Ao patrimônio e } \\
\text { ao usuário }\end{array}$ & $\begin{array}{l}\text { Adequar às necessidades do uso e } \\
\text { prevenir possíveis acidentes }\end{array}$ \\
\hline & $\begin{array}{l}\text { Esquadrias Externas, } \\
\text { Corrimãos e Guarda-corpos }\end{array}$ & $\begin{array}{l}\text { Ao patrimônio e } \\
\text { ao usuário }\end{array}$ & $\begin{array}{l}\text { Evitar perda dos materiais e conferir } \\
\text { segurança ao usuário }\end{array}$ \\
\hline & Instalações Hidráulicas & Ao patrimônio & Evitar perda dos materiais \\
\hline
\end{tabular}

Tabela 6 - Tabela de Prioridades das Obras de Restauro da Vila Penteado

Fonte: Isis Roverso, fevereiro de 2012

É importante ressaltar que os novos sistemas e materiais inclusos no edifício devem ter seus prazos de garantia registrados, assim como a estimativa de vida útil de projeto, fazendo com que os trabalhos de manutenção se organizem a partir dessas informações.

A operacionalização da manutenção é alimentada pela prática da verificação e inspeção constantes. A organização das informações traz grandes vantagens, como, por exemplo, a possibilidade de sanar o problema da escassez de recursos financeiros, para contratação de serviços e compra de materiais, visto que os processos podem ser iniciados e encadeados com a antecedência necessária.

Com a prática da manutenção rotineira e programada é possível superar as dificuldades provocadas pela sucessão de falhas construtivas. Por exemplo: se um vazamento ocorre numa tubulação e imediatamente é constatado e corrigido, o problema se extingue no sistema hidráulico do edifício, mas, se o mesmo problema ocorre e não há a prática da inspeção rotineira, até que o problema seja resolvido, outros sistemas podem estar comprometidos, tais como: sistema estrutural, vedos e paramentos.

É necessário buscar a superação da falta de entendimento sobre a continuidade das ações da manutenção: a manutenção deve ser permanente, ou seja, não é algo formado por obras e fatos estanques, isolados. 
Com um programa efetivo de manutenção, a preservação do patrimônio histórico é assegurada, indo muito além da estagnação das ações de preservação atuais que, não raras às vezes, se limitam ao tombamento do edifício.

A preservação, como ato de cultura, deve propiciar o entendimento do monumento, com toda a sua complexidade e abrangência.

O tombamento não é o único meio de salvaguardar o monumento. $O$ entendimento do patrimônio arquitetônico propicia ações de preservação, sendo que a mais ampla e eficaz é a disseminação da cultura patrimonial, onde a sociedade toma para si a defesa pela permanência dos bens culturais, algo que hoje lhe é negado, pela falta de conhecimento e entendimento histórico.

A Vila Penteado deveria ser cenário da divulgação cultural. Existem ações hoje, mas essas ações ainda não tornaram o casarão relevante para o bairro e para a cidade. É necessário, inclusive, rever a programação visual do edifício, fazendo com que as pessoas saibam que a Vila Penteado é um edifício aberto ao público e que há motivos, grandes e diversos, para a sua visitação. 


\subsection{CONSIDERAÇÕES}

Através do entendimento do monumento histórico, suas potencialidades são reveladas, sendo possível delimitar a área de intervenção e ainda assegurar sua salvaguarda. Nesse sentido, a análise de desempenho, desde que ponderada pelos conceitos da preservação patrimonial, mostra-se uma ferramenta de grande valia. Isso se dá pela possibilidade de operacionalização das ações, ou seja, pela facilitação da transição dos conceitos teóricos com as ações práticas.

O passado não pode ser restaurado. As pessoas não podem ser restauradas assim como o cotidiano e as características de uma época. Entretanto, é interessante notar o apego ao passado e até a necessidade de mantê-lo presente. A memória histórica da sociedade deve permanecer e a arquitetura torna-se o local adequado para guardar esse legado.

A Vila Penteado é um edifício que carrega muitos significados. Não é possível deixar de notar sua conformação espacial, as relações de volumes e os detalhes art nouveau. A singularidade é marcante, assim como a variedade de formas e detalhes. $O$ edifício destaca-se dentre os demais da região e da cidade.

Uma visita ao edifício Vila Penteado revela muitas questões. A primeira trata do entendimento do espaço que, apesar de antigo, torna-se novo aos olhares visitantes, em função do distanciamento estético, que mantém com os demais edifícios da cidade de São Paulo. A qualidade arquitetônica do espaço apresenta-se em sua grandiosidade (grandes aberturas, saguão generoso, etc.) e também na sua menor escala (detalhes singulares de pintura e ornamentos).

Os documentos, desenhos e projetos produzidos sobre e para o Edifício Vila Penteado demonstram a preocupação e entendimento de diversos profissionais, sobre o significado dessa obra. A motivação do tombamento também deixa claro o interesse cultural e histórico existente.

Os projetos recentes, ainda que incompletos, trazem conteúdo significativo para a organização e continuidade do processo de preservação da Vila Penteado. Se por um lado os estudos que motivam as intervenções precisam de tempo para reflexão e amadurecimento, por outro, esses estudos precisam se tornar ações práticas encadeadas, onde o tempo possa ser controlado, ou seja, os períodos entre as obras não devem comprometer as ações ordinárias de manutenção. Para tanto é necessário planejar a continuidade das obras e até tornar as ações de manutenção 
algo rotineiro, fruto de reflexão e aprofundamento teórico, refletido em ações práticas.

Com base no exposto, julgar que é possível manter as condições de segurança, habitabilidade e funcionalidade de um edifício, apenas contando com a boa vontade dos envolvidos, pode ser considerado praticamente um milagre. É necessário implantar um sistema de controle das ações, que visam à preservação patrimonial, contando com a visão sistêmica do processo, alimentada pela prática da verificação e inspeção constante. A operacionalização das ações facilita 0 desenvolvimento dos processos, identifica com antecedência as possíveis falhas nas ações, visa à preservação do patrimônio e valoriza o investimento público. 


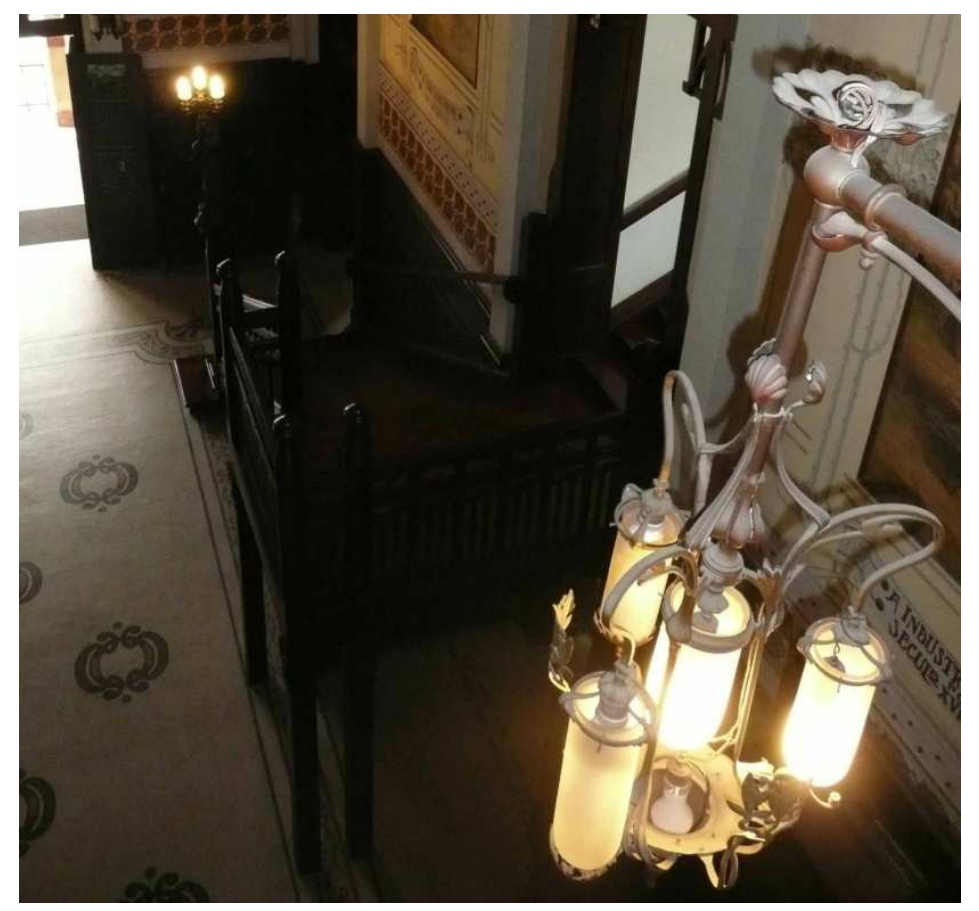

Figura 377 - Lustre do Saguão da Vila Penteado Foto: Isis Roverso, dezembro de 2010. 



\section{CONSIDERAÇÕES FINAIS}

A definição prévia, clara e cuidadosa do escopo dos serviços envolvidos na elaboração de projetos, é uma necessidade para o início de qualquer projeto em qualquer tipo de empreendimento, sendo que, as definições relacionadas à preservação arquitetônica, são ainda mais rigorosas. Dessa forma, os conceitos norteadores das ações práticas devem estar presentes de forma clara, ou seja, a reflexão teórica é indispensável e deve permear as soluções de projetos assim como direcionar a execução das obras.

No caso do edifício Vila Penteado, há três posturas possíveis em relação à preservação patrimonial, posturas essas que podem ser adotadas para a intervenção de outros monumentos patrimoniais, desde que contemplem a devida reflexão teórica.

A primeira postura refere-se ao encaminhamento gradual e pontual das soluções específicas, que visam sanar problemas existentes graves, ou seja, as ações estão relacionadas a intervenções que visam aliviar o edifício das falhas construtivas, ou problemas construtivos mais graves, com o objetivo de restaurar a segurança da edificação e a segurança dos usuários. As intervenções devem ser mínimas, tanto quanto possível, e partir do princípio da retrabalhabilidade (as ações não devem inviabilizar intervenções necessárias no futuro). Apesar de se tratar de intervenções para mitigar problemas graves e que, portanto, trazem riscos ao patrimônio e aos usuários, dependendo da disponibilidade de recursos, essa postura só é viável em médio ou longo prazo, devido à complexidade das ações envolvidas. Quando desprovida de uma compreensão sistêmica, um agravante desta situação é a falta de planejamento e de priorização das ações segundo uma escala de urgência.

A segunda postura configura-se a partir do entendimento do que é ideal para um projeto completo de preservação. Parte do levantamento pormenorizado do edifício, entendimento histórico e análise teórica aprofundada, com vistas ao traçado das diretrizes de preservação. Munidos dessas diretrizes, os projetos completos devem ser desenvolvidos, com o cuidado de tornar claros os conceitos teóricos, dentro das soluções adotadas. A partir do conjunto de projetos compatibilizados e comprometidos com a situação existente e a análise metodológica, as obras de intervenção podem ser planejadas, aqui um grande esforço deve ser feito no sentido 
de articular o acompanhamento profissional adequado das obras e ainda garantir a continuidade dos recursos.

A primeira situação apontada reflete as circunstâncias encontradas hoje, na Vila Penteado, e a segunda situação trata do que é almejado por todos. Em alguns momentos já houve tentativas de se organizar um projeto completo com vistas à preservação, mas a carga de trabalho envolvida, num projeto dessa magnitude, ultrapassa a boa vontade e requer a articulação de significativos recursos materiais e humanos, para ser planejada detalhadamente.

A terceira postura possível, que compreende a articulação de ações em curto prazo e longo prazo, é a que esse trabalho, apresentado em forma de dissertação, considera como ideal: conciliar as duas primeiras posturas apresentadas, ou seja, elencar as obras prioritárias e a extensão da intervenção imediata, ou, a curto prazo, estimular o monitoramento contínuo dos sistemas da edificação. Tais propostas visam dar fôlego às ações efetivas de reflexão teórica, projeto e planejamento das obras de restauro. Essa terceira postura tem como fundamento a revalorização da manutenção, como cuidado constante e permanente do edifício, como meio de prevenir intervenções que o descaracterizem.

Entre as obras prioritárias na Vila Penteado está a eliminação das infiltrações de água de chuva na cobertura, o que coloca em risco de ruína o forro do andar superior do edifício. Especial atenção deve ser dada às condições de acesso. 0 acesso seguro dos funcionários à cobertura permitirá a realização de consertos pontuais, limpeza e o monitoramento por meio de inspeções frequentes.

Outros sistemas que inspiram cuidados são os de instalações elétricas e prevenção e combate a incêndios. Visando mapear o real risco nesses sistemas, ou mesmo os riscos a que o edifício está submetido, quando da inexistência ou insuficiência de desempenho desses sistemas, recomenda-se como ação imediata, além das intervenções pontuais, a inspeção constante por meio de técnicas não destrutivas de análise e o monitoramento constante, por parte dos funcionários treinados e demais usuários do edifício. Para ações futuras, a readequação geral deve ser avaliada, visando à segurança do usuário e a salvaguarda do monumento.

Há sistemas com elementos emblemáticos a serem preservados e que requerem cuidados especiais, por estarem expostos ao intemperismo e à ação direta dos usuários: vãos (incluindo os corrimãos), paramentos e pavimentação. 
Sob a perspectiva técnica, as esquadrias e corrimãos externos merecem dedicação especial, visto que as falhas do seu desempenho comprometem a segurança patrimonial e a do usuário, em condições de uso normal e emergencial.

Para os materiais de acabamento nos paramentos, as marcas do tempo podem e devem ser consideradas com o respeito devido, ou seja, o "respeito pela matéria que carrega consigo o transladar da história" (KÜHL, 2010). Porém, os materiais de acabamento se prestam também à proteção dos substratos a que estão aplicados, além de serem os mais vulneráveis ao itemperismo e à ação dos usuários. Por essas razões também merecem atenção especial e cuidados constantes.

O sistema de pavimentação da Vila Penteado também precisa ser monitorado. Isso se deve ao fato de que as áreas externas de mosaicos apresentam fissuras e trincas, devido a deformação do substrato, e a área de assoalho da portaria não apresenta resistência adequada ao tráfego intenso, sofrendo desgaste acentuado, especialmente em dias chuvosos. As mesmas condições que aceleram a degradação dos pisos - águas da chuva, trincas e desníveis, resultantes da deformação - também comprometem a segurança na circulação dos usuários que, sobretudo em edifícios de acesso público, deve ser assegurada.

Como a programação da manutenção leva em consideração a vida útil dos materiais, e boa parte dos materiais empregados no edifício já está desfrutando da sua vida residual, é importante estabelecer para quais sistemas a vida residual dos materiais é satisfatória e para quais é necessário considerar ações de intervenções mais invasivas. Para tanto, as prioridades, riscos e consequências dos mesmos devem ser analisadas.

A manutenção do sistema de instalações hidráulicas requer cuidados, quanto ao monitoramento dos vazamentos. Como muitas das tubulações são embutidas em paredes estruturais, a detecção precoce e o conserto imediato de eventuais vazamentos, devem fazer parte das ações da manutenção permantente do edifício.

Para as fundações e a estrutura, quando consideradas estáveis, a manutenção deve ser compreendida por inspeções e relatórios periódicos, além do controle de uso, com o monitoramento dos limites de carregamentos dos elementos estruturais, sobretudo das lajes de piso e estrutura da cobertura.

Com relação ao projeto de restauro da Vila Penteado, a primeira ação referese ao traçado das diretrizes de preservação e, na sequência, os projetos dos 
sistemas podem ser desenvolvidos, tendo por base o projeto de ocupação do edifício, sendo eles: Projeto de Restauro da Cobertura; Projeto de Prevenção e Auxílio ao Combate a Incêndios; Projeto de Instalações Hidráulicas; Projeto de Acessibilidade e Projeto de Manutenção.

Tão importante quanto o desenvolvimento dos projetos é a compatibilização dos mesmos, visto se tratar de um conjunto que forma o Projeto de Restauro, único em concepção, desenvolvido a partir da compreensão integral do monumento histórico. Para obras novas, a compatibilização dos projetos é fundamental e, se não realizada de forma plena, revela equívocos durante a sua execução. No caso de Projetos de Restauro, os equívocos de entendimento das soluções ou ainda de tradução das soluções em ações de intervenção, podem resultar em grande perda para o patrimônio.

O planejamento detalhado das obras, a sua execução e acompanhamento também devem ser realizados de forma cuidadosa, contando com profissionais que tenham conhecimento no campo da preservação, algo que não é fácil de ser conseguido, mas é possível.

Encerrando a lista de projetos necessários, o Projeto de Manutenção visa manter as condições aceitáveis do edifício, rompendo com o ciclo de obras emergenciais, seguidas por períodos sem manutenção programada. Ainda mais importante do que reestabelecer as condições adequadas ao patrimônio histórico é manter essas condições, evitando-se assim intervenções que possam descaracterizar o edifício.

Com a falta da manutenção preventiva e programada, quando as ações de intervenção acontecem, as mesmas acabam tomando grandes proporções, o que, por vezes, mais prejudica do que agrega valor ao patrimônio arquitetônico. Portanto, é preciso dedicar especial atenção ao Projeto de Manutenção: a partir da conceituação teórica da preservação, limites das intervenções devem ser determinados de forma clara e objetiva, delimitando as ações de manutenção rotineira e manutenção programada.

É importante assegurar as condições mínimas de desempenho do edifício, através do Projeto de Restauro, para então ser possível instalar as práticas da manutenção programada, sendo que a operacionalização da manutenção proporciona a preservação do edifício, além da otimização dos recursos financeiros, físicos e humanos empenhados. 
Como sugestão para futuros trabalhos, é oportuno avançar nas pesquisas que visam à formação de banco de dados, contemplando o inventário das técnicas construtivas usadas no Brasil. A abrangência do inventário facilitará a caracterização pormenorizada dos sistemas, bem como a estimativa de vida residual dos materiais em uso, sendo que os critérios de avaliação da vida residual devem ser traçados.

O método e a forma de acesso às informações do banco de dados, também devem ser desenvolvidos, visando facilitar o uso de ferramentas específicas para as vistorias prediais.

A organização das informações sobre o patrimônio histórico alimenta a compreensão do mesmo e auxilia na tomada de decisão, com vistas à preservação.

Através do entendimento do monumento histórico, suas potencialidades são reveladas, sendo possível delimitar a área de intervenção e ainda assegurar sua salvaguarda. Nesse sentido, a análise de desempenho, desde que ponderada pelos conceitos da preservação patrimonial, mostra-se uma ferramenta de grande valia. Isso se dá pela possibilidade de operacionalização das ações, ou seja, pela facilitação da transição dos conceitos teóricos com as ações práticas.

Ao longo da história do casarão Vila Penteado, diversas pessoas dedicaram seu talento e energia para dar dignidade a esse patrimônio. Tantos estudos, levantamentos e reflexões foram feitas. $O$ trabalho abnegado e, por vezes, anônimo de inúmeras pessoas - funcionários docentes e não docentes da universidade, colaboradores e alunos - demonstra o respeito e a admiração que o edifício desperta. Que os próximos anos sejam dedicados à aproximação das reflexões teóricas com as práticas projetuais e que essas culminem em trabalhos de intervenção com excelência, pautados pela operacionalização das ações, e como forma de reconhecimento a todos os que já devotaram o seu trabalho à preservação desse edifício. 



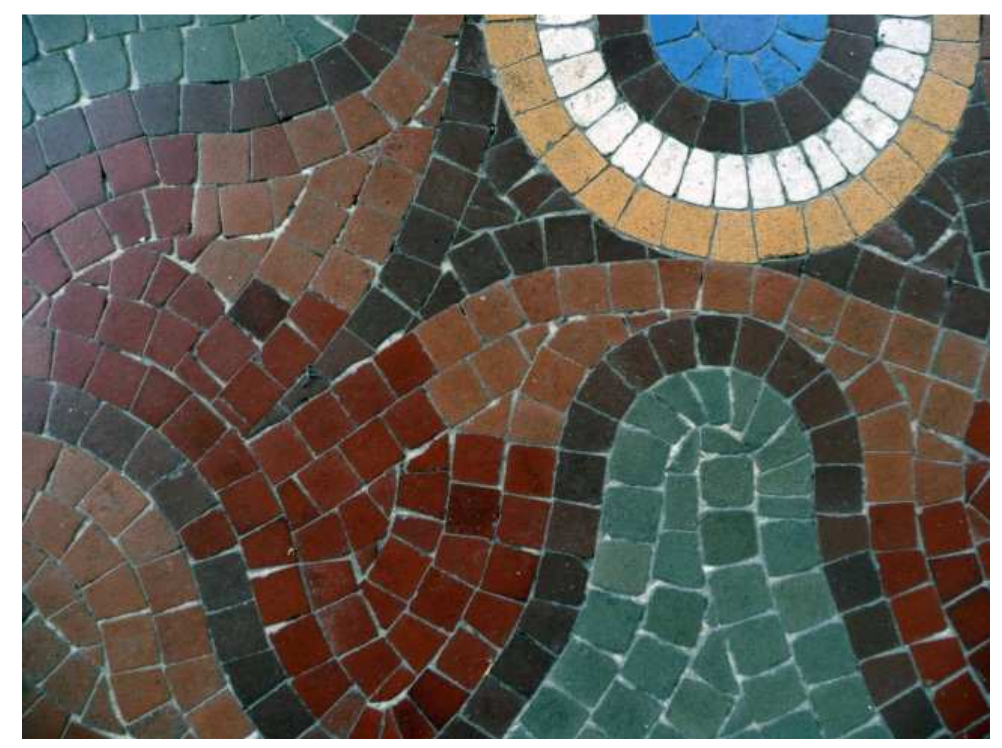

Figura 378 - Mosaico do terraço posterior da Vila Penteado Foto: Isis Roverso, dezembro de 2010. 



\section{REFERÊNCIAS}

ALLAN, George. Preventive Maintenance: the Way Forward? Informação acessada em 17 de fevereiro de 2012 e disponível em: http://www.maintainourheritage.co.uk/context_ga.htm.

ASSOCIAÇÃO BRASILEIRA DE NORMAS TÉCNICAS - ABNT. Edifícios habitacionais de até cinco pavimentos - Desempenho. Parte 1: Requisitos gerais. NBR 15.575-1. Rio de Janeiro: ABNT, 2008.

Janeiro: ABNT, 1999.

Manutenção de edificações - Procedimento. NBR 5674. Rio de - Manual de operação, uso e manutenção das edificações Conteúdo e recomendações para elaboração e apresentação. NBR 14037. Rio de Janeiro: ABNT, 1998.

Elaboração de projetos de edificações - Atividades técnicas. NBR 13531. Rio de Janeiro: ABNT, 1995.

AZEREDO JR, Hélio Alves de (Coord.). Manual Técnico de Manutenção e Recuperação. São Paulo: Fundação para o Desenvolvimento da Educação - FDE, 1990.

BECKER, Angela Weingärtner e VUOLO, Cândida Maria. O mago dos ladrilhos Hidráulicos. Revista do programa de pós-graduação em arquitetura e urbanismo da FAUUSP. São Paulo: FAUUSP, 2009, n. 25, p. 27-32.

BERTALANFFY, Ludwig von. Teoria general de los sistemas: fundamentos, dessarollo, aplicaciones. Trad. Juan Almela. 2ª ed. México: FCF, 2006.

BOITO, Camillo. Os Restauradores. São Paulo: Ateliê, 2002.

BRANDI, Cesare. Teoria da Restauração. São Paulo: Ateliê, 2004.

. Verbete: Concetto del Restauro. Enciclopedia Universale dell'Arte. Novara: Istituto Geografico de Agostini, 1983, 4ª edição (1를 ed. 1958).

BRASIL. Lei № 8.666, de 21 de junho de 1993. Regulamenta o art. 37, inciso XXI, da Constituição Federal, institui normas para licitações e contratos da Administração Pública e dá outras providências.

BRASIL. Lei № 11.228, de 25 de junho de 1992. Dispõe sobre as regras gerais e específicas a serem obedecidas no projeto, licenciamento, execução, manutenção e utilização de obras e edificações, dentro dos limites dos imóveis revoga a Lei no 
8.266, de 20 de junho de 1975, com as alterações adotadas por leis posteriores, e dá outras providências. Regulamentada pelo DM 32.329/92.

. Leis, decretos, etc. CASTRO, Sonia Rebello de (seleção e organização

de texto). Coletânia de Leis sobre preservação do patrimônio. Rio de Janeiro: IPHAN, 2006.

BIRKHOLZ, Lauro Bastos e NOGUEIRA, Brenno Cyrino Nogueira. A FAUUSP, sua Criação e Funcionamento na Vila Penteado. Sinopses Memória. São Paulo: Faculdade de Arquitetura e Urbanismo da Universidade de São Paulo, 1993, edição especial.

CAMBIAGHI, Silvana Serafino. Desenho universal: métodos e técnicas de ensino na graduação de arquitetos e urbanistas. Dissertação de mestrado. São Paulo: Faculdade de Arquitetura e Urbanismo da Universidade de São Paulo, 2004.

CARBONARA, Giovanni. Brandi e a restauração arquitetônica hoje. Desígnio. São Paulo: 2006, n. 6, p. 35-47

Carta de Veneza. Revista do Patrimônio Histórico e Artístico Nacional. Rio de Janeiro: 1987, n. 22, p. 106-107.

Carta do Restauro (1972), Disponível em:

<http://portal.iphan.gov.br/portal/montarDetalheConteudo.do?id=12430\&sigla=Legisl

acao\&retorno=detalheLegislacao >. Acesso em: 10 dez. 2010.

CHOAY, Françoise. A Alegoria do Patrimônio. São Paulo: UNESP, 2001.

CURY, Isabelle (Org.). Cartas Patrimoniais. Rio de Janeiro: IPHAN, 2004.

DAHER, Luiz Carlos. Aspectos da arquitetura no início do século XX. Vila Penteado: 100 anos. Revista do programa de pós-graduação em arquitetura e urbanismo da FAUUSP - número especial. São Paulo: FAUUSP, 2002, p. 39-49.

DVOŘÁK, Max. Catecismo da Preservação de Monumentos. Cotia: Ateliê, 2008.

EKMAN, Carlos. Recordações de minha vida. Exposição Vila Penteado. Catálogo. São Paulo: FAUUSP, 1976, p.44-49.

EKMAN, Domingos Ribeiro Jaguaribe. Vila Penteado: manuscrito inédito do arquiteto Carlos Ekman. Vila Penteado: 100 anos. Revista do programa de pósgraduação em arquitetura e urbanismo da FAUUSP - número especial. São Paulo: FAUUSP, 2002, p. 57-64.

FAGGIN, Carlos Augusto Matei. Projeto de restauro e recuperação do Edifício Vila Penteado. São Paulo: FUPAM, 2002. 
FERRETI, Luciano. B-10. Um Estudo de caso em HIS na Zona Leste de São Paulo. Dissertação de mestrado. São Paulo, Faculdade de Arquitetura e Urbanismo da Universidade de São Paulo, 2008.

FORSTER, Alan M.; KAYAN, Brit. Maintenance for historic buildings: a current perspective. Structural Survey. Vol. $27 \mathrm{~N}^{\circ} 3$, 2009, p. 210-229. Emerald Group Publishing Limited.

GHIRARDELLO, Nilson; SPISSO, Beatriz (Coord.). CARTILHA Patrimônio histórico: como e por que preservar. Bauru: Canal 6, 2008.

GIBSON, E. J. (Coord.) Working with the performance approach in building. INTERNATIONAL COUNCIL FOR RESEARCH AND INNOVATION IN BUILDING AND CONSTRUCTION - CIB, Rotterdam, Netherlands, 1982. (CIB State of Art Report nํ64, Working Commission W60).

GIOVANNONI, Gustavo. Verbete: Restauro dei Monumenti. Enciclopedia Italiana di Scienze. Lettere ed Arti, Roma: Istituto della Enciclopedia Italiana (Treccani), 1936 , v. 18 , p. 127-130.

GONZAGA, Armando Luiz. Madeira: uso e conservação. Brasília, DF: IPHAN/;MONUMENTA. 2006. 246p. (Cadernos Técnicos; 6).

GORDINHO, Margarida Cintra. Patrimônio da Metrópole Paulistana. São Paulo: Editora Terceiro Nome, 2010.

HERTZBERGER, H. Lições de Arquitetura. Martins Fontes: São Paulo, 1999.

HOMEM, Maria Cecília Naclério. Vila Penteado: Carlos Ekman, um inovador na arquitetura paulista. Boletim Técnico número 10. São Paulo: FAUUSP, 1993, p. 924.

(Coord) e MACHADO, Lucio Gomes. Exposição Vila Penteado. Catálogo. São Paulo: FAUUSP, 1976.

. Uma família paulista. Exposição Vila Penteado. Catálogo. São Paulo: FAUUSP, 1976, p. 58-65.

A "Vila Penteado" como residência. Exposição Vila Penteado. Catálogo. São Paulo: FAUUSP, 1976, p. 70-76.

HULTIN, Olof; et al. The complete guide to Architecture in Stockholm. $3^{\text {a }}$ edição (atualizada e revisada), Stockholm: Arkitektur Förlag AB, 2009.

Instituto Brasileiro de Avaliações e Perícias de Engenharia de São Paulo IBAPE/SP. Norma de Inspeção Predial. São Paulo: IBAPE, 2011. 
INSTITUTO DO PATRIMÔNIO HISTÓRICO E ARTÍSTICO NACIONAL (BRASIL). Patrimônio. 2006.

INTERNATIONAL COUNCIL ON MONUMENTS AND SITES - ICOMOS. Recommendations for the analysis, conservation and structural restoration of architectural heritage: Guidelines. 2003 Access: 21th July, 2011. Available at $<\mathrm{http}$ ://www.international.icomos.org/victoriafalls2003/iscarsah_guidelines.doc>.

INTERNATIONAL ORGANIZATION FOR STANDARDZATION (ISO) ISO6241. Performance standards in buildings: principles for their preparation and factors to be considered. London: ISO, 1984.

JUSTEN FILHO, Marçal. Comentários à Lei de Licitações e Contratos Administrativos. Rio de Janeiro: Dialetica, 1996.

KATINSKY, Júlio Roberto. Art Nouveau, Vila Penteado e o desejo de mudança em São Paulo. Vila Penteado: 100 anos. Revista do programa de pós-graduação em arquitetura e urbanismo da FAUUSP - número especial. São Paulo: FAUUSP, 2002, p. 130-146.

Vila Penteado: arquitetos e engenheiros estrangeiros em São Paulo na virada do século. Boletim Técnico número 3. São Paulo: FAUUSP, 1993, p. 9-31.

KÜHL, Beatriz Mugayar. Preservação do Patrimônio Arquitetônico da Industrialização - Problemas teóricos de restauro. Cotia: Ateliê / FAPESP, 2009.

Seminário de Estudos sobre Restauração Arquitetônica: "Técnicas Analíticas e de Diognóstico de Bens Culturais: Experiências Italianas Recentes". Revista do programa de pós-graduação em arquitetura e urbanismo da FAUUSP. São Paulo: FAUUSP, 2011, n. 29, p. 198-224.

Notas sobre a Carta de Veneza. Anais do Museu. Paulista. São Paulo: dez. 2010, v. 18, n. 2, p. 287-320. Disponível em: $<$ http://www.scielo.br/scielo.php?script=sci_arttext\&pid=S0101-

$47142010000200008 \&$ Ing $=p t \& n r m=$ iso $>$. Acesso em: 13 out. 2011.

- Cesare Brandi e a teoria da restauração. Revista do programa de pós-graduação em arquitetura e urbanismo da FAUUSP. São Paulo: FAUUSP, 2007(a), n. 21, p. 198-211.

- Restauração hoje: método, projeto e criatividade. Desígnio, São Paulo: 2007(b), v. 6, p. 19-34.

; SILVA, H. A. ; OLIVEIRA, C. T. A. FAU Maranhão: Considerações sobre uso e transformação. 2007. 
Preservação da arquitetura moderna e metodologia de restauro. Revista do programa de pós-graduação em arquitetura e urbanismo da FAUUSP. São Paulo: FAUUSP, 2006, v. 19, p. 198-201.

História e Ética na Conservação e na Restauração de Monumentos Históricos, Revista do programa de pós-graduação em arquitetura e urbanismo da FAUUSP. São Paulo: FAUUSP, 2005, v. 1, n. 1.

LE CORBUSIER. A Carta de Atenas. São Paulo: Hucitec / EDUSP, 1993.

LEMOS, Carlos A. C. A construção da Vila Penteado. Vila Penteado: 100 anos. Revista do programa de pós-graduação em arquitetura e urbanismo da FAUUSP - número especial. São Paulo: FAUUSP, 2002, p. 33-36.

LOURENÇO, Maria Cecília França. Vila Penteado: memória e futuro. Vila Penteado: 100 anos. Revista do programa de pós-graduação em arquitetura e urbanismo da FAUUSP - número especial. São Paulo: FAUUSP, 2002, p. 95-105.

; et al. Bens Imóveis Tombados ou em Processos de Tombamento da USP. São Paulo: Editora da Universidade de São Paulo - Imprensa Oficial do Estado de São Paulo, 1999.

MACEDO, Silvio Soares. Vila Penteado: significados paisagísticos. Vila Penteado: 100 anos. Revista do programa de pós-graduação em arquitetura e urbanismo da FAUUSP - número especial. São Paulo: FAUUSP, 2002, p. 106-117.

MACHADO, José Saporiti; CRUZ, Helena; NUNES, Lina. Mitos e factos relacionados com o desempenho de elementos de madeira em edifícios. In: $3^{\circ}$ ENCORE. Materiais e técnicas de conservação e de reabilitação. Lisboa: LNEC. 2003. p.1281-90. Disponível em http://mestradoreabilitacao.fa.utl.pt/disciplinas/jbastos/HCruzSaporitiHelenaLinaMitosMadeira.pdf.

Acesso em: 24 fev. 2012.

MOTTA, Flávio L. São Paulo e o Art nouveau. Exposição Vila Penteado. Catálogo. São Paulo: FAUUSP, 1976, p.88-93.

Art nouveau: um estilo entre a flor e a máquina. Rio de Janeiro: Cadernos Brasileiros, 1965, p. 54-63.

MOURA, Éride. Texto resumido a partir de reportagem Publicada originalmente na Revista Projeto Design, Ed. 275, jan. 2003, Disponível em: <http://www.arcoweb.com.br/arquitetura/jose-armenio-de-brito-cruz-biblioteca-da-2201-2003.html>. Acesso em: 23 abr. 2011.

MENESES, Ulpiano Bezerra de. Identidade Cultural e Arqueologia. Revista do Patrimônio Histórico e Artístico Nacional. Rio de Janeiro: 1984, n. 20, p. 33-36. 
Os Usos Culturais da Cultura. YAZIGI, E. (et. al.). Turismo, espaço, paisagem e cultura. São Paulo: Hucitec, 1996, p. 88-99.

NASCIMENTO, Cláudia Bastos. Deterioração de forro em estuque reforçado com ripas vegetais: o caso da Vila Penteado - FAUUSP. Dissertação de mestrado. São Paulo: Escola Politécnica da Universidade de São Paulo, 2002.

OLIVEIRA, C. T. A.; et al. O restauro do moderno: o caso do edifício Vilanova Artigas da FAUUSP. $7^{\circ}$ Seminário DOCOMOMO Brasil. Anais. Porto Alegre: DOCOMOMO. 22 a 26 out. 2007(a).

Projeto de restauração de sanitários do Edifício Vilanova Artigas da FAUUSP: Memorial encaminhado ao Conselho Municipal de Preservação do Patrimônio Histórico, Cultural e Ambiental da Cidade de São Paulo - Conpresp e ao Conselho de Defesa do Patrimônio Histórico, Arqueológico e Artístico e Turístico do Estado de São Paulo - Condephaat. Jul. 2007(b).

ORNSTEIN, Sheila Walbe. A Tecnologia de Recuperação do Telhado do Edifício Vila Penteado da Faculdade de Arquitetura e Urbanismo. Boletim Técnico número 3. São Paulo: FAUUSP, 1993, p. 9-24.

; ROMÉRO, Marcelo de Andrade (Colab.). Avaliação Pós-Ocupação

do Ambiente Construído. São Paulo: Studio Nobel/ Editora da USP, 1992 (a).

; ROMÉRO, Marcelo de Andrade (Coord.). Dossiê da Construção do Edifício. São Paulo: FAUUSP, 1992, 2ª edição (b).

PINHEIRO, Maria Lucia Bressan. A História da Arquitetura Brasileira e a Preservação do Patrimônio Cultural. Revista do programa de pós-graduação em arquitetura e urbanismo da FAUUSP, v. 1 n. 1 nov. 2005/ abr. 2006.

PRADO, Alberto da Silva. Vila Penteado: vida nova em velho prédio. Trabalho final de graduação - Faculdade de Arquitetura e Urbanismo. São Paulo: FAUUSP, 1979 , vol I e II.

PRUDON, Theodore H. M. Preservation of Modern Architecture. New Jersey: John Wiley \& Sons, Inc., 2008.

REIS FILHO, Nestor Goulart. O edifício da "Vila Penteado" em 1976. Vila Penteado: 100 anos. Revista do programa de pós-graduação em arquitetura e urbanismo da FAUUSP - número especial. São Paulo: FAUUSP, 2002, p. 20-23.

REITER, Ole Peter. Vila Penteado: ambiente arquitetônico sueco na época do arquiteto Carlos Ekman. Boletim Técnico número 2. São Paulo: FAUUSP, 1993, p. 9-17.

RUSKIN, John. A Lâmpada da Memória. Cotia: Ateliê, 2008. 
SILVA, H. A. A.; et al. A Consolidação dos Forros da Vila Penteado - em estuque estruturado por fasquias de juçara. Revista Brasileira de Arqueometria, Restauração e Conservação. 2007. Vol.1, n. 6, p. 305-308.

SIMÕES, J.R.L. Patologias - Origens e Reflexos no Desempenho TécnicoConstrutivo de Edifícios. Tese de Livre-Docência. São Paulo: FAUUSP, 2004.

A Vila Penteado: especificações técnicas das obras de preservação e restauro do edifício à rua Maranhão, 88 - FAUUSP. Boletim Técnico número 12. São Paulo: FAUUSP, 1993, p. 9-48.

SATO, Luana. Evolução das casas paulistanas: sete estudos de caso. Trabalho final de graduação. São Paulo: FAUUSP, 2007. CD-ROM.

A evolução das técnicas construtivas em São Paulo : residências unifamiliares de alto padrão. Dissertação de mestrado. São Paulo: Escola Politécnica da Universidade de São Paulo, 2011.

SILVA, Luiz Eduardo Pinheiro da (Coord.). Manual de Obras em Edificações Preservadas. Rio de Janeiro: Secretaria de Cultura, Turismo e Esportes/ Departamento Geral de Patrimônio Cultural, 1991, vol.1.

SOUZA, Roberto de. Avaliação de desempenho aplicada a novos componentes e sistemas construtivos para habitação. Tecnologia de Edificações. São Paulo: Pini - Instituto de Pesquisas Tecnológicas, divisão de edificações do IPT, 1988.

TAMAKI, Luciana. Vale o desempenho. Revista Téchne, São Paulo: Pini, Maio 2010, Ed. 158.

TIRELLO, Regina A. As Prospecções e Restaurações das Pinturas da Vila Penteado. Boletim Técnico número 11. São Paulo: FAUUSP, 1993.v.1, p. 9-28.

Depoimento: Redescobrindo e Restaurando as Pinturas Murais dos Edifícios da USP. Comissão de Patrimônio Cultural da USP (LOURENÇO, Maria Cecília França; et al org.). Bens Imóveis tombados ou em processo de tombamento da USP. São Paulo: EDUSP, IMESP, CPC, 1999, v. 1, p. 202-221.

O restauro dos murais art-nouveau da Vila Penteado e o canteiroescola da CPC-USP: uma experiência de formação qualificada. Vila Penteado: 100 anos. Revista do programa de pós-graduação em arquitetura e urbanismo da FAUUSP - número especial. São Paulo: FAUUSP, 2002, p. 148-171.

TOLEDO, Benedito Lima de. Vila Penteado: registros. São Paulo: FAUUSP, 2002.

Vila Penteado: Carlos Ekman: um arquiteto sueco no Brasil. Boletim Técnico número 9. São Paulo: FAUUSP, 1993, p. 9-22. 
UNIVERSIDADE DE SÃO PAULO. Diretrizes orçamentárias para 2012. São Paulo: USP. 2011. Disponível em:

http://www.usp.br/codage/files/diretrizescompleta2012.pdf. Acesso em: 24 fev. 2012.

UNIVERSIDADE DE SÃO PAULO. FACULDADE DE ARQUITETURA E URBANISMO. Vila Penteado 100 anos. Revista do programa de pós-graduação em arquitetura e urbanismo da FAUUSP - número especial. São Paulo: FAUUSP, 2002.

VIOLLET-LE-DUC, Eugène Emmanuel. Restauração. São Paulo: Ateliê, 2000. 


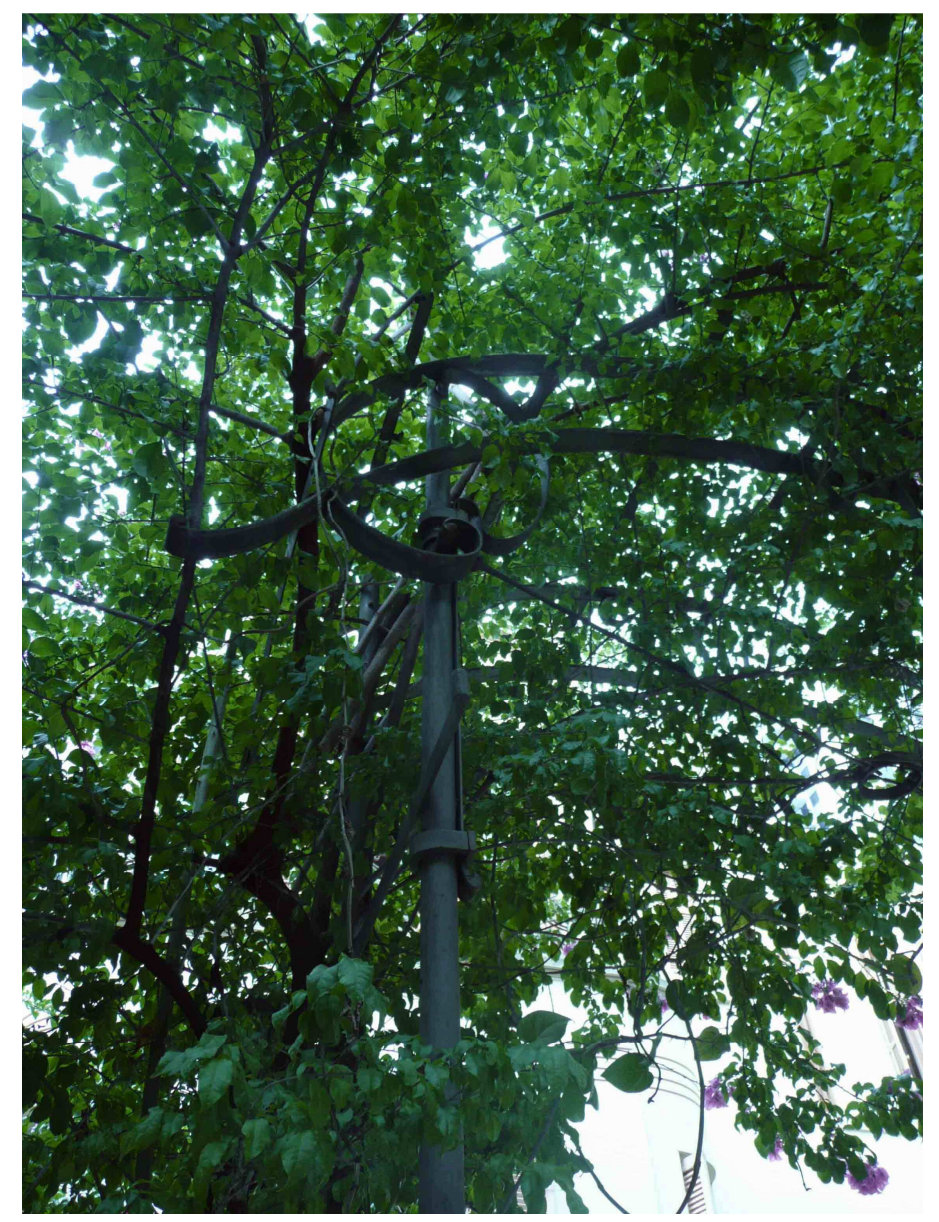

Figura 379 - Detalhe do caramanchão da Vila Penteado Foto: Isis Roverso, dezembro de 2010. 



\section{ANEXO A - Lista de processo e protocolos consultados sobre a Vila Penteado}

A tabela 6 refere-se à lista de processos e protocolos consultados da Faculdade de Arquitetura e Urbanismo de São Paulo - FAUUSP, arquivados e em andamento, que se encontram na FAUUSP e na COESF, referentes ao edifício Vila Penteado.

\begin{tabular}{|c|c|c|c|}
\hline & № do Processo & Assunto & Data \\
\hline 1 & 83.1 .22609 .51 .7 & $\begin{array}{l}\text { FUNDUSP. Encaminha relação e especificação referente a } \\
\text { reformas e adaptações da parte civil do edifício V. Penteado da } \\
\text { FAU. }\end{array}$ & 1983 \\
\hline 2 & 83.1.22618.51.6 & $\begin{array}{l}\text { FAU. Solicita a visita de um técnico para vistoriar a reforma e } \\
\text { restauração do edifício Vila Penteado. }\end{array}$ & 1983 \\
\hline 3 & 93.1 .00042 .49 .2 & Solicitações diversas feitas à PCO, durante o ano de 1993. & 1993 \\
\hline 4 & 93.1 .01024 .51 .0 & $\begin{array}{l}\text { Solicitando providências no sentido de serem sanados os } \\
\text { problemas de goteiras existentes no edifício Vila Penteado. }\end{array}$ & 1993 \\
\hline 5 & 93.5 .04068 .49 .3 & $\begin{array}{l}\text { Liberação de recursos para obras de barramento do quadro } \\
\text { geral no subsolo da FAU-Maranhão. }\end{array}$ & 1993 \\
\hline 6 & 94.1 .00457 .16 .2 & $\begin{array}{l}\text { Abertura de sindicância para apuração de fatos e } \\
\text { responsabilidades referentes a danificação das luminárias. }\end{array}$ & 1994 \\
\hline 7 & 94.1 .00660 .51 .0 & $\begin{array}{l}\text { Informa que foi interdito por segurança o prédio da FAU } \\
\text { Maranhão. }\end{array}$ & 1994 \\
\hline 8 & 94.1 .00660 .51 .0 & $\begin{array}{l}\text { FAU. Assunto a regularizar, informa que foi interdito por } \\
\text { segurança o prédio da FAU Maranhão. }\end{array}$ & 1994 \\
\hline 9 & 94.5 .00132 .49 .0 & $\begin{array}{l}\text { Solicita vistoria e avaliação das instalações hidráulicas da FAU- } \\
\text { Maranhão. }\end{array}$ & 1994 \\
\hline 10 & 94.5.00147.49.7 & $\begin{array}{l}\text { Execução de serviços de barramento do quadro geral no } \\
\text { subsolo da FAU-Maranhão. }\end{array}$ & 1994 \\
\hline 11 & 94.5 .00522 .49 .2 & $\begin{array}{l}\text { Solicita poda e limpeza dos jardins do edifício da FAU- } \\
\text { Maranhão. }\end{array}$ & 1994 \\
\hline 12 & 94.5 .00915 .51 .6 & $\begin{array}{l}\text { Relatório de avaliação do IPT realizada no edifício da FAU- } \\
\text { Maranhão. }\end{array}$ & 1994 \\
\hline 13 & 94.5 .01004 .49 .5 & $\begin{array}{l}\text { Solicita relatório de atividades realizadas nos reparos das } \\
\text { instalações elétricas da FAU-Maranhão. }\end{array}$ & 1994 \\
\hline 14 & 94.5 .01261 .51 .0 & $\begin{array}{l}\text { Solicita fornecimento de projetos e especificações técnicas, } \\
\text { orçamentos e contratos, serviços e pormenores. }\end{array}$ & 1994 \\
\hline 15 & 94.5 .01461 .49 .7 & $\begin{array}{l}\text { Avalia as instalações elétricas do edifício e solicita modificação } \\
\text { nos circuitos elétricos e na iluminação da biblioteca. }\end{array}$ & 1994 \\
\hline 16 & 94.5 .01673 .49 .4 & $\begin{array}{l}\text { Informa que foi interditado por segurança o prédio da FAU- } \\
\text { Maranhão. }\end{array}$ & 1994 \\
\hline
\end{tabular}




\begin{tabular}{|c|c|c|c|}
\hline 17 & 94.5 .01893 .49 .4 & $\begin{array}{l}\text { Relatório de inspeção técnica realizada no prédio da FAU- } \\
\text { Maranhão - referente ao desmoronamento do teto. }\end{array}$ & 1994 \\
\hline 18 & 94.5 .01921 .49 .8 & $\begin{array}{l}\text { Encaminha síntese da reunião s/ providências tomadas devido } \\
\text { desabamento de parte do forro da biblioteca. }\end{array}$ & 1994 \\
\hline 19 & 94.5 .02051 .49 .7 & $\begin{array}{l}\text { Informa providências tomada em relação ao desabamento de } \\
\text { parte do teto da FAU-Maranhão. }\end{array}$ & 1994 \\
\hline 20 & 95.1 .00578 .51 .3 & $\begin{array}{l}\text { Solicita providência para vistoria nas instalações elétricas na } \\
\text { FAU-Maranhão. }\end{array}$ & 1995 \\
\hline 21 & 95.1 .00652 .51 .9 & $\begin{array}{l}\text { Solicita vistoria na divisa do terreno daquela faculdade com o } \\
\text { ed. Lausanne (infiltração de água no muro). }\end{array}$ & 1995 \\
\hline 22 & 95.5 .00042 .51 .3 & $\begin{array}{l}\text { Solicita vistoria na divisa do terreno daquela faculdade com o } \\
\text { ed. Lausanne (infiltração de água no muro). }\end{array}$ & 1995 \\
\hline 23 & 95.5 .00838 .51 .2 & $\begin{array}{l}\text { Solicita reparos no forro de madeira do edifício da FAU- } \\
\text { Maranhão. }\end{array}$ & 1995 \\
\hline 24 & 95.5 .01288 .49 .4 & $\begin{array}{l}\text { Solicita recompor o revestimento dos muros na atual fase de } \\
\text { recomposição de fechos do terreno. }\end{array}$ & 1995 \\
\hline 25 & 96.1 .00307 .16 .2 & $\begin{array}{l}\text { Abertura de processo seletivo para contratação de um analista } \\
\text { de comunicação visual para a FAU-Maranhão. }\end{array}$ & 1996 \\
\hline 26 & 96.5 .02261 .49 .3 & Relatório técnico de vistoria das instalações elétricas. & 1996 \\
\hline 27 & 97.1 .00001 .16 .6 & $\begin{array}{l}\text { Consulta sobre a execução da colocação de brita e/ou } \\
\text { cascalho no terreno dos fundos do edifício. }\end{array}$ & 1997 \\
\hline 28 & 97.1 .00013 .16 .0 & $\begin{array}{l}\text { Solicitação de orçamento referente a poda de gramas e } \\
\text { gravetos do jardim da FAU-Maranhão. }\end{array}$ & 1997 \\
\hline 29 & 98.1 .00016 .16 .0 & $\begin{array}{l}\text { Contratação de empresa de serviços para recuperação das } \\
\text { tramas } 3 \text { e } 4 \text { dos telhados da FAU-Maranhão. }\end{array}$ & 1998 \\
\hline 30 & 98.1 .00124 .51 .5 & $\begin{array}{l}\text { Elaboração do Projeto para Reforma dos sistemas elétricos do } \\
\text { edifício da Rua Maranhão, } 88 \text {. }\end{array}$ & 1998 \\
\hline 31 & 98.1 .00314 .51 .9 & $\begin{array}{l}\text { Auxílio financeiro - execução de serviços nas calhas e } \\
\text { recolocação de ardósia no telhado da Vila Penteado. }\end{array}$ & 1998 \\
\hline 32 & 98.1.00315.16.7 & Recuperação dos telhados da FAU-Maranhão. & 1998 \\
\hline 33 & 98.1 .00316 .51 .1 & Assunto a regularizar - "as built" do edifício da FAU-Maranhão. & 1998 \\
\hline 34 & 98.1 .00625 .51 .9 & $\begin{array}{l}\text { Elaboração do Projeto para Reforma dos sistemas elétricos do } \\
\text { edifício da Rua Maranhão, } 88 \text { - convite } 03 / 98 \text {. }\end{array}$ & 1998 \\
\hline 35 & 98.5 .01021 .51 .4 & $\begin{array}{l}\text { Autorização para emissão de faturamento, correspondente ao } \\
\text { saldo dos projetos de reforma das instalações elétricas. }\end{array}$ & 1998 \\
\hline 36 & 98.5 .00379 .51 .0 & $\begin{array}{l}\text { Informa recebimento e encaminhamento do "as built" do } \\
\text { edifício da FAU-Maranhão. }\end{array}$ & 1998 \\
\hline 37 & 99.1 .00172 .16 .2 & $\begin{array}{l}\text { Solicitação de reparos dos condutores de águas pluviais no } \\
\text { edifício da FAU-Maranhão. }\end{array}$ & 1999 \\
\hline 38 & 99.1 .00319 .16 .3 & $\begin{array}{l}\text { Solicitação de licitação para venda da demolição do pavilhão } \\
\text { do prédio da Rua Maranhão. }\end{array}$ & 1999 \\
\hline
\end{tabular}




\begin{tabular}{|c|c|c|c|}
\hline 39 & 99.1 .00567 .51 .5 & $\begin{array}{l}\text { Obra e serviço. Reparos no forro da sala } 25 \text { da Biblioteca FAU } \\
\text { Maranhão. }\end{array}$ & 1999 \\
\hline 40 & 99.1 .00567 .51 .5 & $\begin{array}{l}\text { FAU. Reparos no forro da sala } 25 \text { da Biblioteca, FAU- } \\
\text { Maranhão. }\end{array}$ & 1999 \\
\hline 41 & 99.5 .00407 .70 .1 & Estudo das atuais instalações de rede local da FAU-Maranhão. & 1999 \\
\hline 42 & 99.5 .00434 .70 .9 & $\begin{array}{l}\text { Inclusão da Biblioteca no projeto da reestruturação da rede da } \\
\text { FAU-Maranhão. }\end{array}$ & 1999 \\
\hline 43 & 99.5 .00698 .51 .0 & $\begin{array}{l}\text { Obra e serviço - liberação de área para montagem de andaime } \\
\text { utilizados no reparo do forro. }\end{array}$ & 1999 \\
\hline 44 & 99.5 .01177 .16 .5 & $\begin{array}{l}\text { CPC. Encaminhamento do mapeamento esquemático do forro } \\
\text { da biblioteca da Vila Penteado. }\end{array}$ & 1999 \\
\hline 45 & 00.5 .00430 .51 .9 & $\begin{array}{l}\text { Relatório de vistoria - descrevendo condições técnicas do forro } \\
\text { em argamassa. }\end{array}$ & 2000 \\
\hline 46 & 00.5 .00474 .51 .6 & $\begin{array}{l}\text { Relação de pendências na execução - reunião com eng. } \\
\text { Fausto Tarran para definir reparos do forro. }\end{array}$ & 2000 \\
\hline 47 & 01.1 .00023 .49 .2 & Solicitações diversas feitas à PCO, durante o ano de 2001. & 2001 \\
\hline 48 & 01.1 .00504 .16 .8 & $\begin{array}{l}\text { Recurso financeiro para descupinização do edifício da FAU- } \\
\text { Maranhão. }\end{array}$ & 2001 \\
\hline 49 & 01.1 .00944 .51 .6 & $\begin{array}{l}\text { Auxílio financeiro - objetivando a execução de serviços } \\
\text { emergenciais na Vila Penteado. }\end{array}$ & 2001 \\
\hline 50 & 01.5 .00140 .51 .1 & $\begin{array}{l}\text { Obra e serviço - informa queda do forro junto a escadaria } \\
\text { principal no } 2^{0} \text { pavimento. }\end{array}$ & 2001 \\
\hline 51 & 01.5 .00186 .49 .0 & $\begin{array}{l}\text { Obra e serviço - recuperação das grades externas do prédio da } \\
\text { Vila Penteado. }\end{array}$ & 2001 \\
\hline 52 & 01.5 .00298 .51 .4 & $\begin{array}{l}\text { Relação de pendências na execução dos trabalhos de reforço } \\
\text { do forro do pavimento superior. }\end{array}$ & 2001 \\
\hline 53 & 01.5 .00372 .51 & $\begin{array}{l}\text { Obra e serviço - retomada de serviços no forro da sala } 25 \text { da } \\
\text { Biblioteca da FAU-Maranhão. }\end{array}$ & 2001 \\
\hline 54 & 01.5 .00443 .51 .4 & $\begin{array}{l}\text { Relatório de vistoria - constatado que alguns parafusos não } \\
\text { estão fixados nos barrotes de madeira da trama. }\end{array}$ & 2001 \\
\hline 55 & 02.1 .00221 .16 .7 & $\begin{array}{l}\text { Execução de serviços especializados de engenharia para } \\
\text { restauro das lâminas e/ou peças de cobre, cobertura da Vila } \\
\text { Penteado. }\end{array}$ & 2002 \\
\hline 56 & 02.1 .00388 .16 .9 & $\begin{array}{l}\text { Recuperação das argamassas externas e fornecimento e/ou } \\
\text { mão-de-obra para pintura das paredes externas da Vila } \\
\text { Penteado. }\end{array}$ & 2002 \\
\hline 57 & 02.1 .00492 .16 .0 & $\begin{array}{l}\text { Concessão de recursos do Fundo de Cultura/100 anos do } \\
\text { Edifício Vila Penteado. }\end{array}$ & 2002 \\
\hline 58 & 02.1 .00567 .16 .0 & $\begin{array}{l}\text { Contrato Júlio Moraes conservação e restauro SCL (esquadrias } \\
\text { externas). }\end{array}$ & 2002 \\
\hline 59 & 02.1 .00567 .16 .0 & $\begin{array}{l}\text { Contratação de serviço - convite. Serviço de recuperação, } \\
\text { restauro e pintura das esquadrias externas, } \ldots \text { Ed. Vila } \\
\text { Penteado. }\end{array}$ & 2002 \\
\hline 60 & 02.1 .00585 .51 .7 & $\begin{array}{l}\text { Memorial objetivando abertura de licitação para execução de } \\
\text { pintura interna das paredes, forros,... Vila Penteado. }\end{array}$ & 2002 \\
\hline
\end{tabular}




\begin{tabular}{|c|c|c|c|}
\hline 61 & 02.1 .00663 .16 .0 & $\begin{array}{l}\text { Aquisição de bens - compra direta. Serviços de restauração } \\
\text { dos vitrais das fachadas do Ed. Vila Penteado. }\end{array}$ & 2002 \\
\hline 62 & 02.1 .00731 .51 .3 & $\begin{array}{l}\text { Execução de serviço de pintura interna de paredes, forro e } \\
\text { esquadrias de ferro e madeira do Edifício Vila Penteado. }\end{array}$ & 2002 \\
\hline 63 & 02.1 .01292 .16 .5 & $\begin{array}{l}\text { Estúdio Artes Geraldo Martin Sarasá Ltda. Consulta à } \\
\text { CJ/serviços de restauro e conservação do edifício Vila } \\
\text { Penteado. }\end{array}$ & 2002 \\
\hline 64 & 02.1.01799.01.4 & $\begin{array}{l}\text { Auxílio Financeiro de } \mathrm{R} \$ 8.000,00 \text { para seminário novas áreas } \\
\text { do programa de pós e comemorações dos } 100 \text { anos do Vila } \\
\text { Penteado. }\end{array}$ & 2002 \\
\hline 65 & 02.1.07649.01.4 & $\begin{array}{l}\text { Recurso financeiro para restauração de forros e higienização } \\
\text { do acervo da biblioteca da FAU-Maranhão. }\end{array}$ & 2002 \\
\hline 66 & 02.5 .00414 .51 .5 & $\begin{array}{l}\text { Estimativas de custos para execução de serviços emergenciais } \\
\text { no Ed. Da Pós-Graduação, Vila Penteado. }\end{array}$ & 2002 \\
\hline 67 & 03.1 .00048 .51 .2 & $\begin{array}{l}\text { COESP. Relatório de vistoria de } 20 / 01 / 2003 \text {, onde se registrou } \\
\text { a existência de duas obras, contratadas pela FAU, Vila } \\
\text { Penteado. }\end{array}$ & 2003 \\
\hline 68 & 03.1.07097.01.2 & $\begin{array}{l}\text { CEUMA. Transferência patrimonial de bens para a FAU } \\
\text { Maranhão. }\end{array}$ & 2003 \\
\hline 69 & 03.5 .00014 .16 .0 & $\begin{array}{l}\text { FAU. Solicita a realização de Projeto de segurança } \\
\text { emergencial para a FAU Maranhão. }\end{array}$ & 2003 \\
\hline 70 & 03.5 .00032 .51 .6 & $\begin{array}{l}\text { SABESP. Relatório de vistoria e cadastro das redes externas } \\
\text { da EE, EC, FD, FAU Maranhão e Museu Paulista. }\end{array}$ & 2003 \\
\hline 71 & 03.5 .00155 .16 .2 & $\begin{array}{l}\text { FAU. Contratação de serviço. Termo de aditamento de serviços } \\
\text { para recuperação, no edifício Vila Penteado. }\end{array}$ & 2003 \\
\hline 72 & 03.5 .00536 .51 .4 & $\begin{array}{l}\text { COESF. Relatório de vistoria, de } 01 \text { a } 30 / 04 / 2003 \text {, referente a } \\
\text { execução de pintura no edifício Vila Penteado. }\end{array}$ & 2003 \\
\hline 73 & 03.5.01409.51.6 & $\begin{array}{l}\text { FAU. Esclarecimentos c/ relação à aditamento, empresa Julio } \\
\text { Moraes, ref. a execução de serviço de recup., restauro e } \\
\text { pintura. }\end{array}$ & 2003 \\
\hline 74 & 04.1 .01664 .82 .0 & $\begin{array}{l}\text { FAU. Execução de serviço de restauro dos forros do edifício } \\
\text { Vila Penteado, tomada de preços } n^{\circ} 21 / 2004 \text {. }\end{array}$ & 2004 \\
\hline 75 & 05.1 .01161 .82 .9 & $\begin{array}{l}\text { FAU. Execução de serviço de restauro dos forros do edifício } \\
\text { Vila Penteado, tomada de preços } n^{\circ} 43 / 2005 \text {. }\end{array}$ & 2005 \\
\hline 76 & 05.5.01162.82.2 & $\begin{array}{l}\text { COESF. Relatório de vistoria, de } 01 \text { a } 31 / 07 / 2005 \text {, inf. A } \\
\text { execução de trabalhos de limpeza,... restauro dos forros da Vila } \\
\text { Penteado. }\end{array}$ & 2005 \\
\hline 77 & 05.5.01285.82.7 & $\begin{array}{l}\text { COESF. Relatório de vistoria, de } 01 \text { a } 31 / 08 / 2005 \text {, referente a } \\
\text { execução de serviço de restauro dos forros da Vila Penteado. }\end{array}$ & 2005 \\
\hline 78 & 05.5.01345.82.0 & $\begin{array}{l}\text { Estúdio Sarasá. Relatório de vistoria, bim. e diário de obra, da } \\
\text { execução de serviço de restauro dos forros da Vila Penteado. }\end{array}$ & 2005 \\
\hline 79 & 05.5.01488.82.5 & $\begin{array}{l}\text { COESF. Relatório de vistoria, de } 01 \text { a } 30 / 09 / 2005 \text {, referente a } \\
\text { execução de serviço de restauro dos forros da Vila Penteado. }\end{array}$ & 2005 \\
\hline 80 & 05.5.01633.82.5 & $\begin{array}{l}\text { Informa que foram concluídas as primeiras etapas da execução } \\
\text { de serviço de restauro dos forros do edifício Vila Penteado. }\end{array}$ & 2005 \\
\hline 81 & 05.5.01770.82.2 & $\begin{array}{l}\text { Estúdio Sarasá. Composição de preços para execução de } \\
\text { serviços extras, restauro dos forros do edifício Vila Penteado. }\end{array}$ & 2005 \\
\hline
\end{tabular}




\begin{tabular}{|c|c|c|c|}
\hline 82 & 06.5 .00018 .16 .8 & $\begin{array}{l}\text { Referente aos serviços de consolidação dos forros da Vila } \\
\text { Penteado. }\end{array}$ & 2006 \\
\hline 83 & 06.5.00107.82.9 & $\begin{array}{l}\text { Estúdio Sarasá/ dilatação de prazo de } 30 \text { dias no restauro dos } \\
\text { forros do edifício da Vila Penteado. }\end{array}$ & 2006 \\
\hline 84 & 06.5.00209.82.6 & $\begin{array}{l}\text { COESF. Relatório de vistoria informando estar em fase de } \\
\text { conclusão o restauro dos forros da Vila Penteado, } 01 \text { a } \\
31 / 01 / 2006 \text {. }\end{array}$ & 2006 \\
\hline 85 & 06.5 .00365 .82 .8 & $\begin{array}{l}\text { COESF. Relatório de vistoria informando estar em fase de } \\
\text { conclusão o restauro dos forros da Vila Penteado, } 01 \text { a } \\
28 / 02 / 2006 \text {. }\end{array}$ & 2006 \\
\hline 86 & 06.5.00486.82.0 & $\begin{array}{l}\text { COESF. Relatório de vistoria informando estar em fase de } \\
\text { conclusão o restauro dos forros da Vila Penteado, } 01 \text { a } \\
30 / 03 / 2006 \text {. }\end{array}$ & 2006 \\
\hline 87 & 06.5.00946.82.0 & $\begin{array}{l}\text { Estúdio Sarasál certidão-Fazendas Municipal, Estadual, } \\
\text { Federal/referentes ao restauro dos forros do Edifício Vila } \\
\text { Penteado. }\end{array}$ & 2006 \\
\hline 88 & 07.1 .00841 .82 .8 & $\begin{array}{l}\text { Projeto para aprovação, objetivando a viabilização emergencial } \\
\text { para reforma das instalações elétricas da Vila Penteado. }\end{array}$ & 2007 \\
\hline 89 & 07.1.01416.01.2 & $\begin{array}{l}\text { Secr.de Ens. Sup. ESP/GR/2007/RUSP. Inform. fornecidas a } \\
\text { pedido s/ escritura e suas det. na doação do prédio da } \\
\text { FAU/USP. }\end{array}$ & 2007 \\
\hline 90 & 09.1 .00147 .16 .8 & $\begin{array}{l}\text { Levantamento completo da estrutura da cobertura da Vila } \\
\text { Penteado. }\end{array}$ & 2009 \\
\hline 91 & 09.1 .01083 .16 .3 & $\begin{array}{l}\text { Execução de reforma, projeto de adequação das instalações } \\
\text { elétricas no edifício Vila Penteado. }\end{array}$ & 2009 \\
\hline
\end{tabular}

Tabela 7 - Lista de processos e protocolos consultados na FAUUSP

Fonte: Isis Roverso, tabela elaborada a partir de lista inicial fornecida pela $\operatorname{Prof}^{\mathrm{a}} \mathrm{Dr}^{\mathrm{a}}$ Helena Ayoub e de consulta ao sistema de processos da USP, feita pela funcionária, da FAUUSP, Kênia Camargo. 